ISSN 2306-9716

МІНІСТЕРСТВО ЕКОЛОГІЇ ТА ПРИРОДНИХ РЕСУРСІВ УКРАЇНИ

ДЕРЖАВНА ЕКОЛОГІЧНА АКАДЕМІЯ ПІСЛЯДИПЛОМНОЇ ОСВІТИ ТА УПРАВЛІННЯ

\title{
ЕКОЛОГІЧНІ НАУКИ
}


Екологічні науки : науково-практичний журнал / Головний редактор О.І. Бондар. - К. : ДЕА, 2018. - № 4(23). - 160 c.

\section{Головний редактор:}

Бондар О.І., член-кореспондент НААНУ, д.б.н., проф.

\section{Заступник головного редактора:}

Нагорнева Н.А.

\section{Науковий редактор:}

Машков О.А., д.т.н., проф.

Відповідальний редактор:

Сікачина В.Г.

Відповідальний секретар:

Жук Ю.І.

\section{Редакційна колегія:}

Аверін Г.В., Д.т.н.; Азаров С.I., д.т.н.;

Азасков В.М., д.т.н.; Антонов А.В., д.т.н.;

Барабаш О.В., д.т.н.; Барановська В.С., к.е.н.;

Белецкий В.М., д.т.н. (Республіка Польща);

Білявський Г.О., д.г-м.н.;

Богдасаров М.А., д.г-м.н. (Республіка Білорусь);

Бондаренко О.А., д.б.н.; Будзяк О.С., д.е.н.;

Ващенко В.М., д.ф.-м.н.; Галушкіна Т.П., д.е.н.;

Гавриленко В.В., д.т.н.; Глушков О.В., д.ф.-м.н.;

Дутов О.І., д.с.-г.н.; Захматов В.Д., д.т.н.;

Зубова Л.Г., д.т.н.; Ільїн В.М., д.б.н.;
Ільїн О.Ю., д.т.н.; Іващенко Т.Г., к.т.н.;

Козелков С.В., д.т.н.; Коростіль Ю.С.

(Республіка Польща), д.т.н.;

Костишин С.С., д.б.н.; Кравченко Ю.В., д.т.н.;

Крайнов І.П., д.т.н.; Кутлахмедов Ю.О., д.б.н.;

Лапшин Ю.С., д.т.н.; Левченко О.М., д.е.н.;

Мальований М.С., д.т.н.; Машков В.А.

(Чеська Республіка), д.т.н.;

Машков О.А., д.т.н.; Мокін В.Б., д.т.н.;

Москаленко А.М., к.е.н.; Неділько С.М., д.т.н.;

Пашков Д.П., д.т.н.;

Пекло А.М., к.б.н.; Петриашвили Г., д.т.н.

(Республіка Польща);

Петрук В.Г., д.т.н.; Рудько Г.І., Д.т.Н., Д.Г.-м.Н., д.г.н.;

Соколов Ю.М., д.т.н.;

Тимошенко М.М., к.т.н.; Третяк А.М., д.е.н.;

Трофимчук О.М., д.т.н.; Тупкало В.М., д.т.н.;

Фінін Г.С., д.ф.-м.н.; Христо Атанасов Крагунов

(Республіка Болгарія), $\mathrm{PhD}$, професор;

Улицький О.А., д.т.н.;

Чумаченко С.М., д.т.н.; Шматков Г.Г., д.б.н.;

Prof.Dr. Clemens Walther (Німеччина);

Prof.Dr. Jan-Willem Vahlbruch (Німеччина);

Prof.Dr. Stefan Bister (Німеччина).

Науково-практичний журнал «Екологічні науки» входить до переліку наукових фахових видань із двох галузей наук: Біологічні науки (Наказ Міносвіти України № 153 від 14.02.2014), Технічні науки (Наказ Міносвіти № 642 від 16.05.2014).

Журнал публікує (після рецензування та редагування) статті, які містять нові теоретичні та практичні здобутки в галузі екологічних наук. 


\section{MICT}

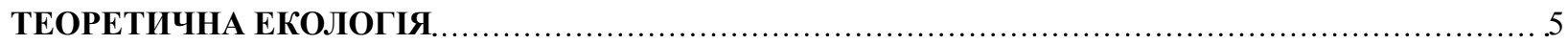

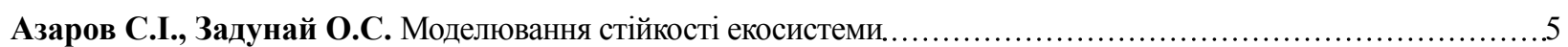

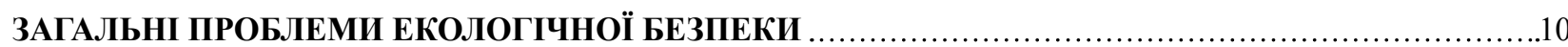

Шелудченко Л.С., Поліщук Д.В. Екологічна оцінка шумового забруднення міста,

спричиненого діяльністю автотранспортних засобів і стаціонарних джерел.......................................10

Барабаш О.В. Ефективність системи екологічного менеджменту як індикатор екологічної безпеки агломерацій

Григор'єва Л.І., Томілін Ю.А., Суха Н.О. Комплексна оцінка забруднення атмосферного повітря в місті Миколаєві.

Худов Г.В., Хижняк І.А., Соломоненко Ю.С., Маковейчук О.М. Ройовий метод тематичного сегментування зображень бортових систем екологічного моніторингу

Лук’янченко О.Ю., Лисенко М.В. Аналіз затримок транспортних засобів на нерегульованих пішохідних переходах

Хворов М.М., Гривківська О.В., Кургузенкова Л.А. Статистичні параметри радіаційного фону міста...........32

Ляшенко О.М. Моделювання й розроблення програмного комплексу для розв'язання завдань координаційного керування в умовах виникнення просторово-розподілених надзвичайних ситуацій.

ЕКОЛОГІЯ І ВИРОБНИЦТВО

Гурець Л.Л., Котолевець А.С., Котова І.І. Зниження рівня техногенного навантаження на довкілля під час використання відходів скла

Kuznyetsov S.I., Ischenko D.R. Absorption method for neutralization of sulfur dioxide...............................46

Glibovytska N.I., Plaksiy L.V. Efficiency of natural and artificial oil sorbents. ....................................52

Нечай М.М. Соціально-екологічні наслідки функціонування малих гідроелектростанцій для популяції форелі струмкової (Salmo trutta) в басейні річки Білий Черемош.

Тищенкова М.О., Филин В.Н., Селиванов В.В., Печений В.Л. Пылеподавление на золошлакоотвалах ТЭЦ с использованием водорастворимых полимеров.

Білецький О.О., Котовський В.Й. Енергетичні процеси в колах із суперконденсаторами та неідеальними джерелами постійної напруги в комбінованих системах живлення електромобілів.

Махиня О.М., Шабалтун А.М. Сучасний стан технології влаштування ін’єкційної відсічної гідроізоляції. ........67

ПРОБЛЕМИ ЕКОЛОГО-ЗБАЛАНСОВАНОГО РОЗВИТКУ .........................................73

Люльчик В.О., Русіна Н.Г. Підготовка фахівців з геодезії та землеустрою для сталого розвитку ...................73

Нєпєіна Г.В., Сербулова Н.А., Смирнов В.М., Смирнова С.М. Особливості застосування механізмів управління сталим туризмом, індикаторів та індексів його розвитку.

Патрушева Л.І. Розвиток екологічного туризму в приміському регіоні м. Миколаєва,.............................83

Якименко І.Л., Салавор О.М., Шаповалов С.Б. Стратегія сталого розвитку «Свропа 2020»: виклики для України.

Гребенюк Т.В., Науменко Д.П., Броницький В.О. Математичне моделювання перенесення марганцю у водному середовищі на прикладі річок Хомора і Случ

Іванець О.Р. Таксономічна структура кладоцероценозів Галичини та прилеглих теренів за матеріалами досліджень професора Бенедикта Дибовського. 
Скиба О.І., Грубінко В.В., Федонюк Л.Я. Запобігання забрудненню гідроекосистем важкими металами як одна з форм реалізації цілей сталого розвитку в Україні.

Федоровський О.Д., Зуб Л.М., Томченко О.В., Хижняк А.В., Ходоровський А.Я., Підгородецька Л.В. Оцінювання стану водних екосистем на основі методів системного аналізу аерокосмічної

й наземної інформації. ...

ЕКОЛОГІЯ ЗЕМЕЛЬНИХ РЕСУРСІВ ТА ГРУНТІВ.

Шевчик Л.3., Романюк О.І., Борсукевич Б.М. Рослинно-мікробні взаємовідносини обліпихи крушиновидної - основа ефективної фіторемедіації нафтозабруднених грунтів ...

Шпак Я.В., Баранов В.І., Терек О.І. Вміст макроелементів і важких металів

у породних відвалах і рослинах за впливу меліорантів

ЗБЕРЕЖЕННЯ БІОРІЗНОМАНІТТЯ

Нестеренко О.С., Маренков О.М. Сперматогенез сонячного окуня Lepomis gibbosus

(Linnaeus, 1758) в умовах Самарської затоки Запорізького водосховища.

БІОЛОГІЧНА БЕЗПЕКА

Gumeniuk I.I., Sherstoboeva O.V., Chabanyuk Ya.V. Dynamics of Bradyrhizobium japonicum

number on soybean seed.

РОЗВИТОК ПРИРОДНО-ЗАПОВІДНОГО ФОНДУ УКРАЇНИ

Покотилова К.Г. Екологічний і географічний аналіз дендрофлори штучних заповідних парків Рівненської області

ЕКОЛОГІЧНІ ПИТАННЯ В КОНТЕКСТІ ЄВРОІНТЕГРАЦЇ̈ УКРАЇНИ 140

Салавор О.М., Шаповалов Є.Б., Якименко І.Л. Порівняльний аналіз нормативної бази ЄС та України щодо захисту водних ресурсів.

Ложкін Р.С. Моделювання процесу координаційної взаємодії в системі оперативного управління в умовах виникнення надзвичайних ситуацій з використанням мультиагентної парадигми.

Глодова Л.М. Моніторинг екологічного стану річки Рибниця,

Національний природний парк «Гуцульщина».

БІБЛІОГРАФІЯ 


\title{
ТЕОРЕТИЧНА ЕКОАОГІЯ
}

\author{
УДК 049.3:574.4:581.526 \\ DOI https://doi.org/10.32846/2306-9716-2018-4-23-1
}

\section{МОДЕАЮВАННЯ СТІЙКОСТІ ЕКОСИСТЕМИ}

\author{
Азаров С.I. ${ }^{1}$, Задунай О.С. ${ }^{2}$ \\ ${ }^{1}$ Інститут ядерних досліджень Національної академії наук України \\ пр. Науки, 47, 03680, м. Київ \\ azarov@kinr.kiev.ua \\ ${ }^{2}$ Державний науково-дослідний інститут спеціального зв'язку та захисту інформації \\ вул. М. Залізняка, 6, 03142, м. Київ \\ a.zadunaj@gmail.com
}

\begin{abstract}
У другій половині XX ст. моделювання вийшло на якісно новий етап свого розвитку в результаті застосування ЕОМ. Істотно зросли можливості спільного аналізу систем рівнянь $з$ великим числом параметрів тощо. Однак успішність математичного моделювання залежить не тільки від досконалості математичного апарату й використовуваних обчислювальних можливостей, а й від того, наскільки науково обгрунтовані вихідні передумови. Процес пізнання завжди пов'язаний з абстрагуванням та ідеалізацією. Однак модель явища ідеальна тільки за визначенням і лише з якоюсь мірою наближення відповідає реальності. У статті авторами запропоновано математичну модель для оцінювання стійкості екосистем. Ключові слова: екосистема, екологічні моделі, математичне моделювання, стійкість, програма, нейронні мережі.
\end{abstract}

Моделирование устойчивости экосистемы. Азаров С.И., Задунай А.С. Во второй половине ХХ в. моделирование вышло на качественно новый этап своего развития в результате применения ЭВМ. Существенно возросли возможности совместного анализа систем уравнений с большим числом параметров и т. д. Однако успешность математического моделирования зависит не только от совершенства математического аппарата и используемых вычислительных возможностей, но и от того, насколько научно обоснованы исходные предпосылки. Процесс познания всегда связан с абстрагированием и идеализацией. Однако модель явления идеальная лишь по определению и только с какой-то степенью приближения соответствует реальности. В статье авторами предложена математическая модель для оценки устойчивости экосистем. Ключевые слова: экосистема, экологические модели, математическое моделирование, устойчивость, программа, нейронные сети.

Modeling of ecosystem sustainability. Azarov S., Zadunaj O. In the latter half of the 20th century, as a result of computers use, the modeling moved to a qualitatively new stage in its development. The possibility of joint analysis of equation systems increased significantly with a large number of parameters, etc. However, the success of mathematical modeling depends not only on the perfection of the mathematical apparatus and the computational capabilities used, but also on how scientifically grounded the initial conditions are. The process of cognition is always associated with abstraction and perfection. However, the phenomenon model is perfect only by definition, and corresponds to reality only in some way. In this article, the authors proposed a mathematical model for assessing the stability of ecosystems. Key words: ecosystem, ecological models, mathematical modeling, stability, program, neural networks.

Постановка проблеми. Жодне 3 досліджень, у тому числі й в екології, не може бути скільки-небудь точним, якщо воно не пов'язане 3 побудовою деякої досить прийнятної математичної моделі цього об'єкта або процесу. При цьому чим більш складними є об'єкти і процеси, якими займається наука, тим важче знайти математичні абстракції, які підходять для їх опису. Тут, як завжди, доводиться йти на компроміс між двома крайнощами: дуже просту модель легко побудувати математично, але вона занадто нереалістична, щоб їй можна було довіряти, а дуже складною моделлю, яка значно ближча до реальної дійсності, важко оперувати і її важче пояснити.

Серед найбільш актуальних проблем сучасності виділяється проблема 3'ясування причин i меж стійкості складних екосистем, що складаються 3 величезного числа компонентів. До таких систем належать організми й біосфера 3 іï екосистемами. В умовах планетарної екологічної кризи від нашого вміння розуміти й передбачати поведінку екосистем і самої біосфери залежить виживання людства.

Під екосистемою розуміється будь-яка система, що складається із живих істот і середовища їх проживання, об'єднаних у єдине функціональне ціле. Основні властивості екосистем - здатність здійснювати круговорот речовин, протистояти зовнішнім впливам, виробляти біологічну продукцію.

Аналіз останніх досліджень і публікацій. У роботах [1-3] обгрунтовано необхідність розроблення методики математичного моделювання стійкості екосистем. 
Багато вітчизняних і зарубіжних учених вивчають цю проблему з різних сторін на основі різних уявлень. Зокрема, робляться все більш численні спроби відходу від класичних консервативних (механістичних) моделей, які не враховують фундаментальні властивості живих систем.

Можна виділити два основні напрями досліджень.

Перший полягає в пошуку простих уявлень, що дасть можливість відображати найбільш значущі для авторів моделей властивості живих систем і спробувати на їх основі (із залученням математичної теорії катастроф тощо) спрогнозувати ключові процеси в екосистемах [1].

Другий, навпаки, акцентується на складності як найважливішій характеристиці живого й намагається запропонувати способи побудови моделей, що враховують цю складність і базові властивості екосистем, які з неї випливають [2].

Взаємна критика зводиться до такого [3]:

1. Прихильники першого напряму апелюють до неозорості і труднощів аналізу складних моделей.

2. Представники другого напряму вказують на надмірне спрощення та схематичність простих моделей, що приховує важливі властивості природних систем, що, у свою чергу, обмежує можливості їх розуміння й прогнозу.

Загалом два ці напрями доповнюють один одного, даючи різні перспективи (масштаби) граней реальності, що відображається. Разом із тим загальною складністю побудови класичних і неокласичних моделей $є$ необхідність детального вибудовування їх вручну, що вимагає великих зусиль і часу та не дає змоги виконувати швидкі мобільні перебудови за значної зміни умов або для завдань, що різняться.

Ці труднощі набувають не тільки технічного, а й фундаментального характеру під час переоцінювання ролі співвідношення структури та функції в природних системах у світлі сучасних знань. Так, на відміну від класичних уявлень, структура зв'язків і вид функцій в екосистемах (та інших природних системах) не статичні й можуть змінюватися при зміні зовнішніх умов (включаючи антропогенний вплив) не тільки завдяки утворенню нових видів, а й у силу адаптації до зміни особливостей взаємодій між видами.

Результатом таких змін $є$ динамічна перебудова атрактивного ландшафту екосистеми, на якому базується різноманіття іiі поведінки. Безліч квазістаціонарних станів (атракторів, інваріантних різноманіть) формують множинну стійкість екосистеми у відповідь на зміну зовнішніх умов (інваріантний портрет екосистеми).

Така організація дає змогу уникнути фундаментальних проблем, що виявляються в класичній методології моделювання складних природних систем, відомих як проблеми «розмірності й нестійкості». Саме їх наявність указує на глибоке протиріччя в розумінні й теоретичному описі кількісних зако- нів функціонування екосистем із реальністю, що спостерігається. Зокрема, відомо, що в більшості випадків стійкість екосистем зростає 3 підвищенням їх складності та видового різноманіття [4], а також у разі урахування в моделях адаптивного метаболізму [5; 6].

Мета й методи дослідження. Метою дослідження $\epsilon$ моделювання параметрів факторів, які впливають на стійкість екосистем. Об'єктом дослідження є екосистеми, що піддаються дигресії, а предметом дослідження $є$ показники факторів середовища цих екосистем. Метою моделювання адаптивної самоорганізації екосистем $\epsilon$ :

- з'ясування механізмів взаємодії елементів екосистеми;

- ідентифікація та верифікація параметрів моделі екосистеми за експериментальними даними;

- прогноз поведінки екосистеми при різних зовнішніх впливах.

Для розв'язання наведених вище завдань нами використано оригінальні методи моделювання стійкості екосистеми шляхом імітації механізмів зворотного зв'язку в екосистемі за допомогою нейронних мереж.

Виклад основного матеріалу. Для дослідження ефективності запропонованих адаптивних алгоритмів будемо використовувати модель екосистеми, яка містить замкнутий трофічний цикл (рис. 1).

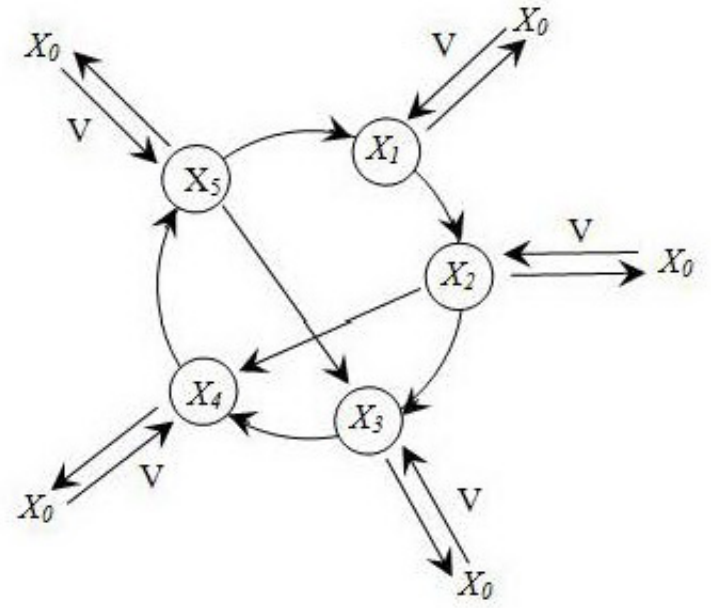

Рис. 1. Схема екосистеми із циилом по елементу, щуо лімітує, та множинними каналами обміну із зовнішнім середовищем

Позначення: $\mathrm{X}_{1}$ - субстрат; $\mathrm{X}_{2}$ - продуцент; $\mathrm{X}_{3}$ - консумент; $\mathrm{X}_{4}$ - детрит; $\mathrm{X}_{5}$ - редуцент.

Модель екосистеми описувалася такою системою рівнянь (рис. 1а):

де $\mu_{P}(S)=\frac{V_{P} S}{K_{P}+S}, \mu_{C}(S)=\frac{V_{C} S}{K_{C}+S}, \mu_{R}(S)=\frac{V_{R} S}{K_{R}+S}-$ питомі швидкості зростання продуцентів, консументів, редуцентів відповідно;

$\mathrm{k}_{\mathrm{R}}, \mathrm{k}_{\mathrm{e}}$ - питомі швидкості відмирання редуцентів і продуцентів; 


$$
\left\{\begin{array}{l}
\dot{X}_{1}=-\mu_{P}\left(X_{1}\right) X_{2}\left(X_{2}^{M A X}-X_{2}\right)+\left(\frac{1}{Y_{R}}-1\right) k_{R} X_{4} X_{5}+\left(\frac{1}{Y_{C}}-1\right) \mu_{C}\left(X_{2}\right) X_{3}+\left(\frac{1}{Y_{C}}-1\right) \mu_{R}\left(X_{5}\right) X_{3}+k_{S} X_{5}+V\left(X_{0}-X_{1}\right) \\
\dot{X}_{2}=\mu_{P}\left(X_{1}\right) X_{2}\left(X_{2}^{M A X}-X_{2}\right)-\frac{1}{Y_{C}} \mu_{C}\left(X_{2}\right) X_{3}-k_{e} X_{2}+V\left(X_{0}-X_{2}\right) \\
\dot{X}_{3}=\mu_{C}\left(X_{2}\right) X_{3}-k_{d} X_{3}+\mu_{R}\left(X_{5}\right) X_{3}+V\left(X_{0}-X_{3}\right) \\
\dot{X}_{4}=k_{d} X_{3}+k_{e} X_{2}-\frac{1}{Y_{R}} k_{R} X_{4} X_{5}+V\left(X_{0}-X_{4}\right) \\
\dot{X}_{5}=k_{R} X_{4} X_{5}-\frac{1}{Y_{C}} \mu_{R}\left(X_{5}\right) X_{3}-k_{S} X_{5}+V\left(X_{0}-X_{5}\right)
\end{array}\right.
$$

Рис. 1a.

$\mathrm{k}_{\mathrm{s}}, \mathrm{k}_{\mathrm{d}}$ - швидкості споживання субстрату й розкладання детриту;

$\mathrm{Y}_{\mathrm{R}}, \mathrm{Y}_{\mathrm{C}}$ - економічні коефіцієнти зростання редуцентів і консументів;

$\mathrm{V}_{\mathrm{P}}, \mathrm{V}_{\mathrm{C}}, \mathrm{V}_{\mathrm{R}}$ - інтенсивності взаємодії продуцентів, консументів і редуцентів із зовнішнім середовищем;

$\mathrm{K}_{\mathrm{p}}, \mathrm{K}_{\mathrm{C}}, \mathrm{K}_{\mathrm{R}}-$ значення коефіцієнтів чутливості продуцентів, консументів і редуцентів;

$\mathrm{V}$ - швидкість надходження в систему відповідного компонента;

$\mathrm{X}_{0}$ - концентрація речовини або чисельність організмів цього виду;

$\mathrm{X}_{2}^{\mathrm{MAX}}$ - максимально-можлива чисельність продуцентів.

Значення параметрів: $\mathrm{k}_{\mathrm{R}}=0,5 ; \mathrm{k}_{\mathrm{e}}=0,02 ; \mathrm{k}_{\mathrm{s}}=0,05$; $\mathrm{k}_{\mathrm{d}}=0,1 ; \mathrm{Y}_{\mathrm{R}}=0,2 ; \mathrm{Y}_{\mathrm{C}}=0,5 ; \mathrm{V}_{\mathrm{P}}=5 ; \mathrm{V}_{\mathrm{C}}=0,2 ; \mathrm{V}_{\mathrm{R}}=0,1 ;$ $\mathrm{K}_{\mathrm{P}}=0,4 ; \mathrm{K}_{\mathrm{C}}=0,4 ; \mathrm{K}_{\mathrm{R}}=0,5 ; \mathrm{V}=1 ; \mathrm{X}_{0}=1 ; \mathrm{X}_{2}{ }^{\mathrm{MAX}}=1$.

Проведення досліджень із чисельного моделювання адаптивної самоорганізації моделі екосистеми до стаціонарних станів виконано за допомогою комп'ютерної програми. Програма містила два взаємодіючі модулі [7]:

1) модуль рішення системи диференціальних рівнянь моделі екосистеми методом Рунге-Кутта 3 постійним кроком (рис. 2);

2) модуль нейронної мережі, що імітує адаптивний зворотний зв'язок в екосистемі й виконує динамічну корекцію параметрів (структури) моделі безпосередньо в процесі іiі функціонування («життедіяльності»).

На рисунках 3 і 4 представлений варіант динаміки адаптивної самоорганізації моделі екосистеми нейронною мережею.

3 рисунка 4 видно, що адаптивна самоорганізація екосистеми до стаціонарних станів безпосередньо в процесі функціонування екосистеми призводить до перебудови іiі структури, а отже, i до динамічної зміни структурно-функціональних відповідностей.

Під час запуску системи диференціальних рівнянь за одних і тих самих початкових умов відмінність досягається генерацією випадкових початкових значень ваги зв'язків нейронної мережі. Таким способом удається відобразити різноманітність поведінки живих організмів (видів) в екосистемі в зовнішньо схожих ситуаціях. Легко побачити, що різноманітність у поведінці видів не позначається на можливості досягнення екосистемою стаціонарного стану. Різниця полягає лише у формуванні різних атракторів (інваріантних різноманіть).

Нейронні мережі реалізували адаптивну самоорганізацію моделі екосистеми шляхом динамічної побудови відображень із 5-мірного простору змінних моделі екосистеми (системи диференціальних рівнянь) у 16-мірний простір іiі параметрів.

Специфічні особливості процесу моделювання стійкості екосистеми пов'язані з нестаціонарністю процесу вирішення задачі через постійні зміни параметрів (коефіцієнтів) системи диференціальних рівнянь (моделі), відмінність ієрархій часів для змінних і параметрів моделі й необхідність спільного вирішення систем диференціальних (модель) та алгебраїчних (нейромережа) рівнянь.

Завдяки нелінійності нейромережа функціонувала тільки по точках графіку (один раз у 10 обчислень похідних моделі), що на порядок скорочувало витрати часу обчислень щодо моделі екосистеми.

Нейромережа моделювала адаптивні процеси у взаємозалежній мережі організмів (видів) під час самоорганізації екосистеми до стаціонарного стану й функціонувала в замкнутому циклі так [7]:

1. На кожному кроці вирішення на вхід нейромережі подавалися п'ять значень змінних системи диференціальних рівнянь.

2. Система алгебраїчних рівнянь формальних нейронів у нейронній мережі функціонувала, генеруючи рішення нейронів у вигляді $\alpha_{i}^{\mathrm{k}+1}$.

3. Цільова функція Н оцінювала величину відхилення моделі від стаціонарного стану.

4. Обчислювалися нові значення величин зв'язків між елементами мережі $\mathrm{x}_{\mathrm{ij}}$, аналогічних за змістом силі зв'язків між організмами екосистеми (або в усередненому вигляді між видами).

5. Коригувалися значення параметрів моделі (системи диференціальних рівнянь) $\mathrm{p}_{\mathrm{i}}^{\mathrm{k}+1}=\mathrm{p}_{\mathrm{ik}}+\mathrm{c}_{\mathrm{i}}$ * $\alpha_{\mathrm{i}}^{\mathrm{k}+1}$, де $\mathrm{p}_{\mathrm{i}}$ - параметри моделі.

Потім цикл повторювався аж до досягнення моделлю стаціонарного стану (атрактора), що виражається в стабілізації чисельностей модельованих видів і припиненні змін параметрів.

Одним із важливих складників дослідження поведінки моделей є оцінювання їх стійкості. Зазвичай для цього використовують метод оцінювання за 


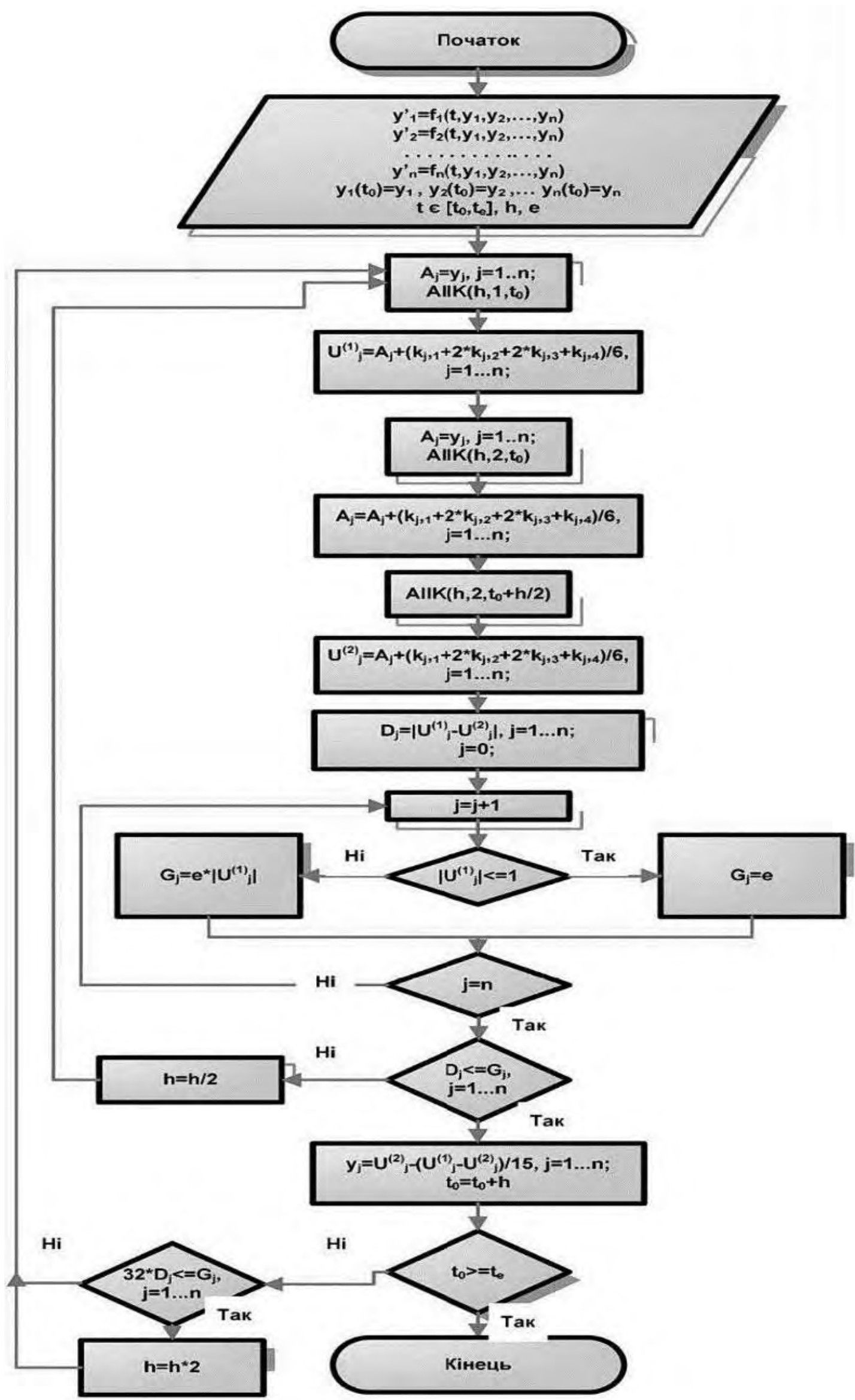

Рис. 2. Блок-схема методу Рунге-Кутта 


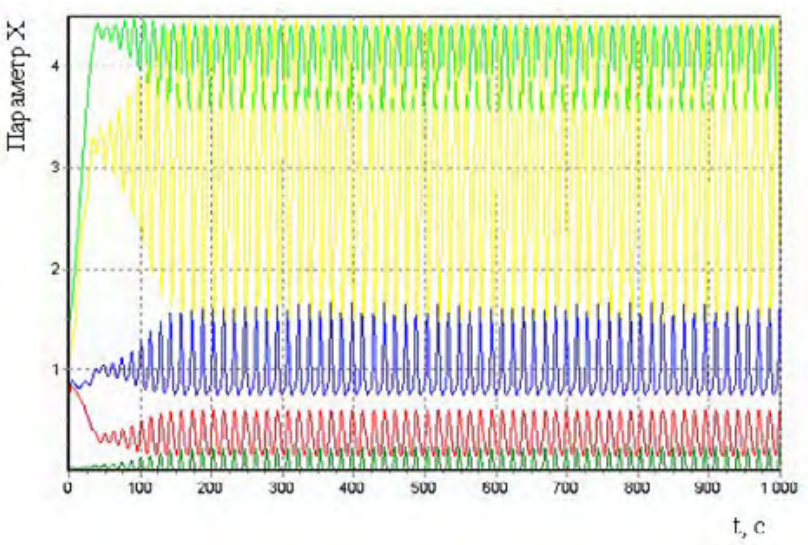

Рис. 3. Нестійка поведінка моделі екосистеми, що характеризується переходом ії зі стаціонарного стану в небезпечний (для реальної екосистеми) режим коливань

А.М. Ляпуновим [8]. Однак у цьому способі моделювання змінюється сам зміст поняття «стійкість». Спроба вивести таку систему з рівноваги активізуе механізми зворотного зв'язку між видами (живими організмами) в екосистемі, що намагаються повернути систему в стаціонарний стан. Якщо повернути iii не вдається, то формується новий стаціонарний стан. Число таких станів (атракторів) залежить від складності екосистеми (для моделі - числа рівнянь і коефіцієнтів) і з ускладненням зростає більше ніж з експоненціальною швидкістю. Відображення цієї властивості лавиноподібного збільшення інформаційної ємності екосистеми (потужності безлічі інваріантних різноманіть) з підвищенням іiї складності класичними методами практично неможливо. На відміну від класичних консервативних моделей екосистем [9], ці процеси точно відповідають процесам, що відбуваються в екосистемах і живих організмах.

Головні висновки. Ураховуючи викладене, можна резюмувати таке:

1. У роботі запропонований і реалізований метод вирішення фундаментальної проблеми «нестій-

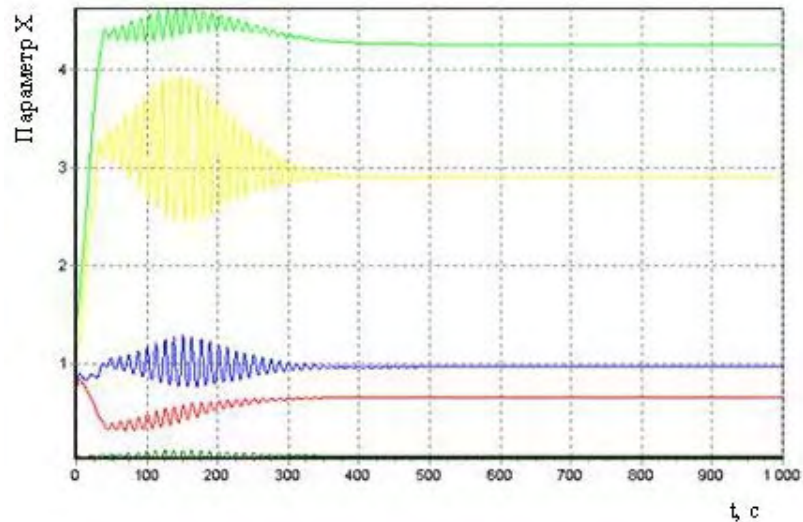

Рис. 4. Адаптивна самоорганізація структури моделі екосистеми, яка повертає ї̈ з режиму коливань до стачіонарного стану (формування атрактора)

кості» складних моделей екосистем. Ця проблема виникає поряд із проблемою «розмірності» в разі спроби досить детального опису поведінки і структури екосистем. Метод дає змогу відобразити нелінійні й важко передбачувані системні властивості, які не уловлюються в простих моделях екосистем.

2. Проаналізовано математичну модель для визначення динаміки адаптивної самоорганізації екосистеми.

3. На основі цієї моделі запропоновано математичні інструменти для оцінювання стійкості екосистеми.

4. У роботі запропоновано моделювати адаптивні зворотні зв'язки в екосистемах за допомогою штучних динамічних нейронних мереж, що дає змогу вести динамічну перебудову структури екосистеми в бік формування стаціонарних станів (атракторів, інваріантних різноманіть), які забезпечують множинну стійкість екосистеми 3 підвищенням іiі складності. На відміну від традиційних моделей, така методологія відповідає відомим фактам про зростання стійкості екологічних систем з підвищенням їх складності й видової різноманітності.

\section{Література}

1. Антомонов Ю.Г. Моделирование биологических систем. Киев: Наукова думка, 1977. 277 с.

2. Светлосанов В.А. Устойчивость и стабильность природных экосистем: модельный аспект. Москва: ВИНИТИ, 1990. T. $8.109 \mathrm{c}$.

3. Смит Дж.М. Модели в экологии. Москва: Мир, 1976. 184 с.

4. Стійкість екосистем до радіаційних навантажень / І.В. Матвеєва, С.І. Азаров, Ю.О. Кутлахмедов, О.В. Харламова. Київ: HAУ, 2016. 396 c.

5. Джефферс Д. Введение в системный анализ: применение в экологии. Москва: Мир, 1981. 256 с.

6. Уиттекер Р. Сообщества и экосистемы. Москва: Прогресс, 1980. 326 с.

7. Хайкин С. Нейронные сети: полный курс / пер с англ. Москва: Издат. дом «Вильямс», 2006. 1104 с.

8. Ляпунов А.М. Общая задача об устойчивости движения. Москва-Ленинград: ГИТТЛ, 1950. 471 с.

9. Пригожин И., Стэнгерс И. Порядок из хаоса: новый диалог человека с природой / пер. с англ.; под общ. ред. В.И. Аршинова, Ю.Л. Климонтовича, Ю.В. Сачкова. Москва: Прогресс, 1986. 432 с. 


\title{
ЗАГАМЬНІ ПРОБАЕМИ ЕКОАОГIЧНОї БЕЗПЕКИ
}

\author{
УДК 504.54:630 \\ DOI https://doi.org/10.32846/2306-9716-2018-4-23-2

\section{ЕКОАОГІЧНА ОЦІНКА ШУМОВОГО ЗАБРУДНЕННЯ МІСТА, СПРИЧИНЕНОГО ДІЯАЫНСТЮ АВТОТРАНСПОРТНИХ ЗАСОБІВ І СТАЦІОНАРНИХ ДЖЕРЕА}

\author{
Шелудченко Л.С. ${ }^{1}$, Поліщук Д.В. ${ }^{2}$ \\ ${ }^{1}$ Подільський державний аграрно-технічний університет \\ вул. Шевченка, 13, 32316, м. Кам'янець-Подільський \\ selucenkolesa@gmail.com \\ ${ }^{2}$ ТД ВО Машинобудівний завод \\ вул. Героїв України, 94, 27500, м. Світловодськ \\ mash-zavod@i.ua
}

\begin{abstract}
У статті наведені результати екологічної оцінки рівня екологічної небезпеки, які формують стаціонарні джерела шуму й автотранспортні засоби. Досліджені інструментальними способами параметри шумового забруднення збігаються з розрахунковими даними шуму, що створюється різними джерелами. За допомогою комп’ютерних програм із застосуванням електронної карти міста проведено дослідження ситуаційних шумових полів, на основі яких побудовано ізолінії сумарних рівнів шумового забруднення окремо взятих територій. На основі результатів досліджень побудовані карти шумових полів, спричинені діяльністю стаціонарних джерел та автотранспортних засобів. Розраховано сумарний вплив різних джерел шуму й визначено, що досліджені рівні шуму від автотранспортних засобів і стаціонарних джерел на територіях міст мають один порядок. При сумісній дії стаціонарних джерел та автотранспортних засобів у межах міської забудови рівень шуму перевищує допустимі норми внаслідок найбільшого внеску саме стаціонарних джерел, які представлені промисловими підприємствами. Ключові слова: екологічна оцінка, шумове забруднення, рівень шуму, джерело шуму, автотранспортні засоби.
\end{abstract}

\begin{abstract}
Экологическая оценка шумового загрязнения города, вызванного деятельностью автотранспортных средств и стационарных источников. Шелудченко Л.С., Полищук Д.В. В статье приведены результаты оценки состояний экологической опасности, которые формируют стационарные источники шума и автотранспортные средства. Исследованные инструментальными методами параметры шумового загрязнения совпадают с расчетными данными шума, который создается различными источниками. С помощью компьютерных программ с применением электронной карты городов Украины проведено исследование ситуационных шумовых полей, на основе которых рассчитаны изолинии суммарных уровней шумового загрязнения отдельно взятых территорий. Проанализированы и построены карты шумовых полей, вызванные деятельностью стационарных источников и автотранспортными средствами. Рассчитано суммарное влияние различных источников шума. Определено, что исследованные уровни шума от автотранспортных средств и стационарных источников на территориях городов имеют один порядок. При совместном действии стационарных источников и автотранспортных средств в пределах городских застроек уровень шума превышает допустимые нормы в результате приоритетного вклада именно стационарных источников промышленных предприятий. Для улучшения состояния экологической безопасности, учитывая нашу экологическую оценку, рекомендовано принять меры по изоляции стационарных источников шума. Приведена возможность экологической оценки отдельного взноса автотранспортных средств и стационарных источников в шумовое загрязнение в пределах городских застроек. Ключевые слова: экологическая оценка, шумовое загрязнение, уровень шума, источник шума, автотранспортные средства.
\end{abstract}

Environmental assessment of noise pollution of the city caused by the activities of motor vehicles and stationary sources. Sheludchenko L., Polishchuk D. The results of assessing the state of environmental hazards that form stationary noise sources and vehicles are given. The parameters of noise pollution are studied by instrumental methods coincide with the calculated data of noise, which is created by various sources. With the help of computer programs, using the electronic map of cities of Ukraine, a study was conducted of situational noise fields, on the basis of which the isolines of the total noise levels of individual territories were calculated. Analyzed and constructed maps of noise fields caused by the activities of stationary sources and vehicles. The total impact of various noise sources is calculated. It was determined that the investigated noise levels from motor vehicles and stationary sources in the territories of cities have the same order. With the joint action of stationary sources and motor vehicles, within urban development, the noise level exceeds the permissible norms as a result of the priority contribution of stationary sources of industrial enterprises. To improve the state of environmental safety, taking into account our environmental assessment, it is recommended to take measures to isolate stationary noise sources. The possibility of environmental assessment of a separate contribution of vehicles and stationary sources to noise pollution within urban buildings is given. Key words: environmental assessment, noise pollution, noise level, noise source, motor vehicles. 
Постановка проблеми. Автомобільний транспорт є причиною шумового забруднення близько $80 \%$ територій сучасних міст. Однією 3 причин перевищення наявних норм рівнів шуму в житловій забудові є близьке розташування автомобільних доріг безпосередньо поблизу житлових будинків [1], наслідком чого є збільшення чисельності населення, яке проживає в умовах шумового дискомфорту [3]. Ураховуючи наведене, проблема екологічної оцінки шумового забруднення територій міст, створеної різними джерелами шуму, є актуальною й потребує вирішення.

Актуальність дослідження. Збільшення кількості автотранспортних засобів у містах України призводить до перевантаження автомобільних доріг, ускладнення трафіку, збільшення кількості викидів забруднюючих речовин, вібраційного та шумового впливу тощо. Установлено, що автомобіль викидає понад 1200 шкідливих речовин [1]. Унаслідок використання 1 кг бензину з вихлопними газами виділяється 0,4 дм ${ }^{3}$ окислів вуглецю, 0,036 кг вуглеводнів, 0,003 кг сажі; а під час спалювання 1 кг дизельного пального - 0,02 кг оксидів азоту, 0,008 кг сірчистого ангідриду та 0,01 кг сажі [2]. У свою чергу, автомагістралі перетворилися на лінійні джерела викидів не лише хімічних речовин, а й шуму, які в комплексі підсилюють шкідливу дію забруднювачів на здоров'я населення [4]: ураження центральної нервової, імунної, серцево-судинної систем, ураження слуху, зменшення тривалості життя, порушення сну тощо. Шумове забруднення, яке створюють автотранспортні засоби в містах, часто накладається на шум, спричинений діяльністю стаціонарних джерел, що знаходяться в межах житлової забудови та не мають облаштованих санітарно-захисних зон. Саме тому екологічна оцінка спільної дії шумового забруднення транспортних і стаціонарних джерел є актуальною, а розроблення системи моніторингу й захисту підвищить рівень екологічної безпеки територій, які розташовані в межах постійного негативного впливу.

Зв'язок авторського доробку із важливими науковими та практичними завданнями. Проблема шумового забруднення $є$ актуальною для всіх великих міст України, яким притаманна наявність як стаціонарних, так i пересувних джерел забруднення. Для вирішення практичного завдання щодо зменшення шумового забруднення урбанізованих територій безпосередньо в межах житлових забудов основні акценти варто здійснювати на вивченні спільної дії точкових стаціонарних джерел шуму, які представлені стаціонарними джерелами й діяльністю автотранспортних засобів. У свою чергу, використання комп'ютерних програм на основі моніторингу дасть змогу моделювати ситуаційні електронні карти шумового забруднення території, а гнучкість алгоритму - адаптувати до різних умов досліджень.

Аналіз останніх досліджень і публікацій. Аналіз публікацій вітчизняних і закордонних нау- ковців установив, що більшість питань зосереджено на способах і методах оцінювання зниження рівнів шумового забруднення атмосферного повітря [13], побудовах карт шуму промислових підприємств [14], впливу автомобільного транспорту на стан шумового забруднення сельбищних територій [15], проведенні експрес-оцінки стану екологічної безпеки примагістральних територій сельбищних зон [16] тощо. Проте комплексна дія стаціонарних і пересувних джерел недостатньо вивчена, що підтверджує свою актуальність і необхідність дослідження

Виділення не вирішених раніше частин загальної проблеми, котрим присвячується означена стаття. Саме тому екологічна оцінка сумарного внеску в загальне шумове забруднення міста стаціонарними (точковими) джерелами шуму, які розташовані в межах житлової забудови міст, та автотранспортними засобами із застосуванням комп'ютерних програм для побудови ситуаційних шумових карт міст $з$ урахуванням усіх фіксованих джерел шуму $\epsilon$ необхідною для досягнення належного рівня екологічної безпеки.

Новизна. Проведено розрахунок шумових полів, що створює автомобільний транспорт на вулицях міста, основними джерелами шуму якого є система вихлопу (глушник) і двигун, що характеризуються незначними габаритними розмірами. Окрім того, для створення ситуаційних карт використано діаграми спрямованості шуму. Запропоновані алгоритми розрахунку шумових полів дають змогу враховувати рівень звукового тиску джерела шуму, його місцезнаходження на електронній карті міста й отримувати ізолінії сумарних рівнів шуму від різних джерел. Розроблена комп'ютерна програма дає змогу побудувати ситуаційні шумові поля, що створюються на досліджуваній території за одночасної дії стаціонарних і пересувних джерел.

Методологічне або загальнонаукове значення. Визначення шумової характеристики досліджуваних територій проводили згідно з ГОСТ 20444-85 «Шум. Транспортные потоки. Методы измерения шумовой характеристики» й БН В.2.3-4:2007 «Автомобільні дороги». Моніторинг шуму в навколишньому середовищі проводили 3 використанням шумоміра SVAN-943 на найбільш завантажених автотранспортом ділянках вулиць і доріг міста Кременчука Полтавська області [5-10].

Вимірювання шуму здійснювалося безпосередньо на автодорозі, на межі житлової забудови та безпосередньо на території житлової забудови на відстані не менше ніж 50 м від перехресть, площ i зупинок пасажирського громадського транспорту, а також світлофорів. Час проведення вимірювань відповідає періоду максимальної інтенсивності руху транспортних потоків. Вимірювальний мікрофон був направлений у бік транспортного потоку й на відстані витягнутої руки. Період вимірювання шумової характеристики транспортного потоку охо- 


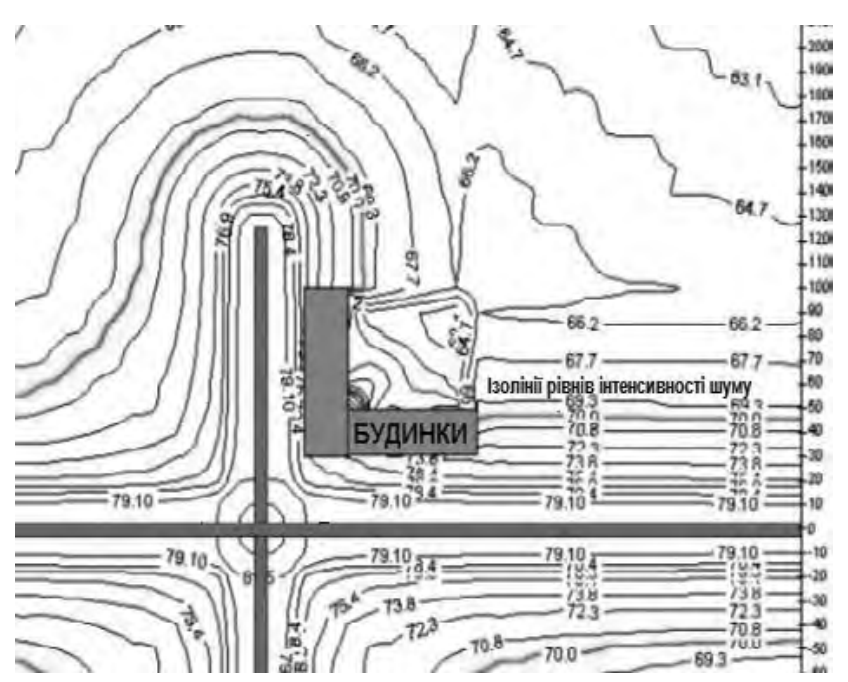

Рис. 1. Ізолінї̈ розповсюдження рівня звуку (дБА) на перехресті 2-х автомагістралей з урахуванням впливу забудови території

плював проїзд не менше ніж 200 транспортних одиниць в обох напрямках для оцінної характеристики ділянки або враховуючи відстань між автотранспортними засобами в 15 метрів для побудови ситуаційної карти.

Виклад основного матеріалу. Проведений аналіз завантаженості автодоріг міста Кременчука дав можливість визначити ділянки вулично-дорожньої мережі для оцінювання шумового забруднення 3 наявністю стаціонарних джерел шуму. В обраних точках розраховані еквівалентні рівні шуму й проведені його натурні виміри. Для проведення розрахунків визначено такі параметри, як інтенсивність руху на автодорозі, середня швидкість руху автотранспортного потоку, частка вантажного та громадського транспорту в потоці, наявність світлофорів на вибраній ділянці.

Отже, в результаті експериментальних досліджень визначено рівень інтенсивності шуму. Згідно 3 чинними нормами, еквівалентний рівень звуку на території, що безпосередньо прилягає до житлової забудови, не повинен перевищувати 55 дБА (3 7.00 год. до 23.00 год.) і 45 дБА (з 23.00 год. до 7.00 год.). Аналіз отриманих результатів виявив значні перевищення нормативу за всіма досліджуваними ділянками міста. У середньому по місту перевищення нормативного рівня шуму за даними фізичних вимірів становить $17 \%$, а за розрахунковими даними - 23\%. На нашу думку, такі відмінності між розрахунковими й експериментальними даними зумовлені тим, що під час розрахунку еквівалентного рівня звуку основним фактором є частка вантажного та громадського транспорту в потоці, при цьому не враховуються метеорологічні умови, міська забудова, наявність зелених насаджень.

На рис. 1 наведена карта шумового забруднення в районі перехрестя з урахуванням впливу забудови та побудовою ізоліній інтенсивності шуму. На основі

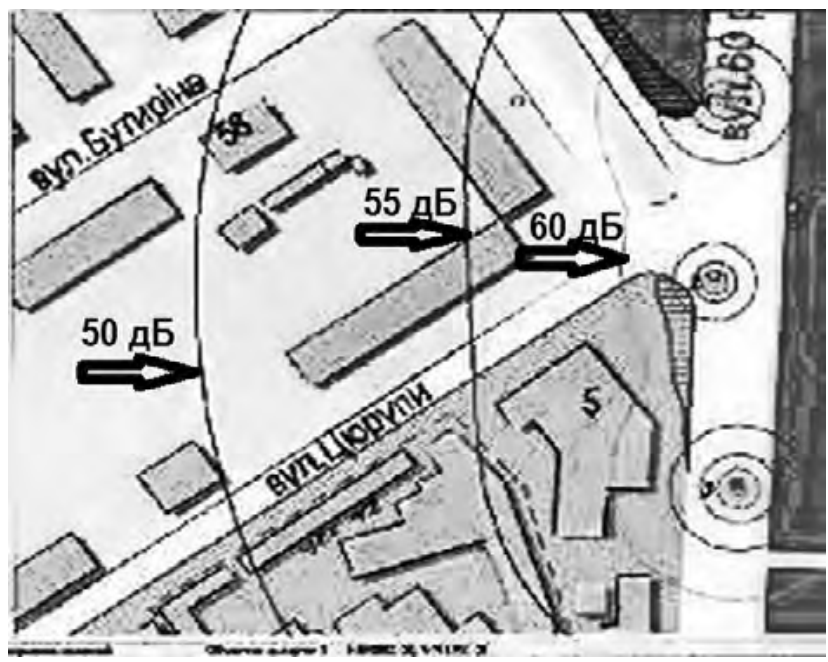

Рис. 2. Ситуачійна шумова карта в зоні досліджень за одночасного впливу 4 стаціонарних промислових джерел шуму иееху № 2 та автомагістралі

комп'ютерної програми MATLAB і цифрової карти міста Кременчука створені ситуаційні шумові карти в районі перехрестя з урахуванням стаціонарних джерел шуму Кременчуцької кондитерської фабрики «ROSHEN» у районі перехрестя вул. Майора Борищака (Цюрупи) і проспекту Свободи. Виявлено, що внесок у спільне шумове забруднення від стаціонарних джерел шуму, які знаходяться на даху цеху № 2 по вул. Майора Борищака (Цюрупи), $є$ незначним, порівняно з вантажним транспортом, що рухається проспектом Свободи.

На рис. 2 зображені ізолінії рівнів інтенсивності шуму від автотранспортних засобів і стаціонарних джерел шуму.

Отже, встановлено, що для покращення рівня екологічної безпеки в досліджуваному районі м. Кременчука необхідно знизити шумові показники до нормативних меж як від пересувних, так і від стаціонарних джерел забруднення в денний і нічний час.

Головні висновки. На основі розробленого алгоритму розрахунку ситуаційних шумових полів, програмного продукту й електронної карти міста Кременчука показана можливість проведення екологічної оцінки шумового забруднення сельбищної території міста 3 урахуваннями спільного внеску автотранспортних засобів і стаціонарних джерел i роздільного внеску цих джерел шуму. Установлено перевищення рівня шуму від автотранспорту на досліджуваній території як за розрахунковими даними, так і за результатами фізичних вимірювань. Окрім того, зниження рівня шуму та, як наслідок, зменшення його впливу на здоров'я населення, яке проживає в зоні його дії, можливе за рахунок озеленення території між житловою забудовою й автодорогою.

Перспективи використання результатів дослідження. Проведення екологічної оцінки шумового забруднення забезпечить прийняття інженерних та 
організаційних рішень для забезпечення достатнього рівня екологічної безпеки території міста 3 інтенсивним рухом автотранспортних засобів і наявними стаціонарними джерелами, які представлені фіксованими точками. Складання шумових карт сприятиме виявленню найбільш уразливих ділянок міста в акустичному стосунку, дасть змогу ранжувати транспортні магістралі за рівнями ризику, створюваного сумарним шумовим впливом пересувних джерел і стаціонарних джерел, що, у свою чергу, дасть можливість привести шумове забруднення до допустимих рівнів. До рекомендованих заходів варто зарахувати покращення конструкції дороги та iii стану, регулювання транспортних потоків, застосування захисних екранів і бар'єрів, у тому числі зелених насаджень, використання сучасного ефективного шумозахисного обладнання на об’ єктах стаціонарних джерел тощо.

\section{Література}

1. Гутаревич Ю.Ф. Запобігання забруднення повітря сажею. Київ: Урожай, 1982. 63 с.

2. Шило В.В. Автомобиль глазами эколога. Харьков: Торнадо, 2002. 159 с.

3. Микитин Д.П., Новиков Н.В. Окружающая середа и человек. Москва: Высшая школа, 1986. 415 с.

4. Штеренгарц Т.Я. Гигиена труда и профзаболевания. 1984. № 5. С. 40-42.

5. ДБН 360-92**. «Містобудування планування і забудова міських і сільських поселень».

6. ДБН В.2.3-5-2001 «Споруди транспорту. Вулиці та дороги населених пунктів».

7. БН В.2.3-4:2007 «Автомобільні дороги».

8. ГОСТ 12.1.023-80 «Система стандартов безопасности труда. Шум. Методы установления шумовых характеристик стационарных машин».

9. ГОСТ 17187-81 «Шумомеры. Общие технические требования и методы испытаний».

10. ГОСТ 27296-87 «Защиты от шума в строительстве. Звукоизоляция ограждающих конструкций. Методы измерений».

11. Основи акустичної екології / В.С. Дідковський, В.Я. Акименко, О.І. Запорожець, В.Г. Савін, В.І. Токарев. Кіровоград: Поліграфовидавничий центр ТОВ «Імекс ЛТД», 2001. 520 с.

12. Транспортна екологія: навчальний посібник / О.І. Запорожець, С.В. Бойченко, О.Л. Матвєєва, С.Й. Шаманський; МОН України, Національний авіаційний ун-т. Київ, 2017. 508 с.

13. Дейна І.П., Бахарєв В.С., Слізаров О.І. Способи та методи оцінки зниження рівнів шумового забруднення атмосферного повітря. Вісник КрНУ імені Михайла Остроградського. 2012. Випуск 2 (73). С. 154-156.

14. Саньков П.М., Ткач Н.О., Полторацька В.М. Визначення шумових характеристик і побудова карти шуму промислового підприємства. Вісник Придніпровської державної академії будівництва та архітектури. 2017. № 4. С. $231-232$.

15. Ткач Н.О. Оцінка та прогнозування впливу автомобільного транспорту на стан шумового забруднення сельбищ них територій: дис. ... канд. техн. наук. Кременчук, 2015. 181 с.

16. Гільов В.В. Експрес-оцінка стану екологічної безпеки примагістральних територій сельбищних зон: дис. ... канд. техн. наук. Кременчук, 2016. $161 \mathrm{c.}$

17. Поліщук Д.В., Шелудченко Л.С. Дослідження спільної дії шуму автотранспортних потоків і стаціонарних джерел шуму підприємств у межах селітебних зон. Проблеми екологічної безпеки: збірник матеріалів XVI Міжнародної науково-практичної конференції (Кременчук, 4-6 жовтня 2018 р.). Кременчук, 2018. С. 77.

18. Поліщук Д.В. Розробка засобів і способів підвищення рівня екологічної безпеки при дії шкідливих фізичних полів техногенного походження: дис. ... канд. техн. наук: спец. 504.05. Львів, 2005. 152 с. 


\title{
ЕФЕКТИВНІСТЬ СИСТЕМИ ЕКОАОГІЧНОГО МЕНЕДЖМЕНТУ ЯК ІНДИКАТОР ЕКОАОГІЧНОЇ БЕЗПЕКИ АГАОМЕРАЦІЙ
}

\author{
Барабаш О.В. \\ Національний транспортний університет \\ вул. Омеляновича-Павленка, 1, 01010, м. Київ \\ el_barabash@ukr.net
}

\begin{abstract}
У статті досліджено проблему застосування управлінських підходів для ефективного впровадження системи екологічного менеджменту (CEM) відповідно до вимог стандарту ДСТУ ISO 14001:2015. Проведено аналіз класичних підходів до управління системою екологічного менеджменту. Установлено, що на практиці необхідно комбінувати традиційні підходи управління для покращення ефективності системи екологічного менеджменту, що дасть змогу підвищити екологічну безпеку міських агломерацій України для забезпечення сталого розвитку держави. Ключові слова: система екологічного менеджменту, екологічна безпека, міська агломерація, стратегічний аналіз, процесний підхід, поведінковий підхід.
\end{abstract}

Эффективность системы экологического менеджмента как индикатор экологической безопасности агломераций. Барабаш Е.В. В статье исследована проблема применения управленческих подходов для эффективного внедрения системы экологического менеджмента (СЭМ) в соответствии с требованиями стандарта ДСТУ ISO 14001: 2015. Проведен анализ классических подходов к управлению системой экологического менеджмента. Установлено, что на практике необходимо комбинировать традиционные подходы управления для улучшения эффективности системы экологического менеджмента, что позволит повысить экологическую безопасность городских агломераций Украины и обеспечить устойчивое развитие государства. Ключевые слова: система экологического менеджмента, экологическая безопасность, городская агломерация, стратегический анализ, процессный подход, поведенческий подход.

The effectiveness of the environmental management system as an indicator environmental safety of agglomerations. Barabash O. Investigated the problem application of management approaches for effective implementation the environmental management system (EMS) according to requirements of standard DSTU ISO 14001: 2015. Analysed the classic approaches to managing EMS. It was found that in practice it is necessary to combine traditional management approaches to improve the efficiency of EMS which will improve the environmental safety of urban agglomerations of Ukraine and ensure state's sustainable development. Key words: environmental management system, environmental safety, urban agglomeration, strategic insight, process approach, behavioural approach.

Постановка проблеми. На шляху реалізації сталого розвитку держави виникла необхідність розроблення ефективної системи оцінювання екологічної безпеки агломерацій за допомогою не лише кількісних, а і якісних показників. Щоправда, сьогодні немає єдиного підходу до визначення як кількості індикаторів для ефективного оцінювання екологічної безпеки агломерацій, так і питань, які б вони мали охоплювати.

Ми пропонуємо здійснювати відбір індикаторів i їх показників з урахуванням особливостей екологічної ситуації й актуальних екологічних проблем у міських агломераціях України. Одним із таких індикаторів для визначення рівня екологічної безпеки агломерацій є оцінювання впровадження ефективної системи природоохоронних заходів на мікрорівні із застосовуванням нових підходів до управління підприємствами у сфері їх взаємодії з навколишнім середовищем [8, с. 411]. Одним із нетрадиційних рішень керівництва в цьому напрямі $\epsilon$ впровадження ефективної та результативної системи екологічного менеджменту (далі - CЕМ), яка стане частиною загального менеджменту й одним із напрямів виробничої діяльності підприємства [4, с. 294].
Актуальність дослідження. Поява ISO 14000 одна 3 найбільш значущих міжнародних природоохоронних ініціатив [9]. Основною функцією стандартів цієї серії є створення системи превентивних заходів щодо можливого впливу підприємства на стан навколишнього природного середовища та виконання вимог законодавства держави [7, с. 76]. Використання декількох підходів до управління на підприємстві під час розроблення й упровадження СЕМ стане результативним інструментом управління всією сукупністю впливів на навколишне середовище.

Зв'язок авторського доробку із важливими науковими та практичними завданнями. В Україні об'єктивно відбувається заглиблення процесів агломерування як особливої форми розміщення промислового виробництва, сфокусованої на обмеженій ділянці території, як неминучого етапу еволюційних процесів економічного розвитку країни та розселення населення на певній території. Одним із факторів розвитку агломерації є розміщення на іiі території промислових підприємств, які, з одного боку, позитивно позначаються на іiі зростанні, даючи можливості для працевлаштування і припливу насе- 
лення, а 3 іншого - в результаті своєї діяльності негативно впливають на стан навколишнього середовища. Тому основною метою в цьому випадку, що стоїть перед керівництвом, $є$ пошук досвідчених управлінців, дії яких будуть спрямовані не лише на збільшення прибутку, а й на усунення негативних впливів підприємства на довкілля. Управлінські рішення на підприємствах щодо зменшення негативного впливу на стан довкілля поділяються на два види: традиційні рішення, що неодноразово приймались, у цьому випадку потрібно вибирати один iз наявних варіантів, і нетрадиційні, нестандартні рішення, які пов'язані з пошуком нових альтернативних варіантів. Упровадження СЕМ на промислових підприємствах - це і є нетрадиційне й нестандартне рішення, яке потребує нової стратегії та концептуальних підходів [16, с. 298].

Аналіз останніх досліджень і публікацій. Серед науковців, які досліджують шляхи впровадження CЕМ на підприємствах, варто відмітити дослідження О.С. Безбородової [2-4], Л.М. Божко [7], О.І. Бородіна [8], А.В. Хорошавіна [16] та ін. Досить докладно розглядаються питання становлення й розвитку агломерацій, виділяються їх основні ознаки, показники, правовий статус у працях М.Ф. Аверкіної [1], С.В. Богачова [5], О.М. Ізарова [10] та ін. Багато науковців приділяють увагу дослідженням управлінського напряму 3 акцентом на нетрадиційні підходи й інструменти для впровадження СЕМ, серед них Ch. Gwen, M. Fetsko, Ch. Hendrickson [19], Jan Dul [21], Roger B. Mason [23] та ін.

Виділення не вирішених раніше частин загальної проблеми, котрим присвячусться означена стаття. Незважаючи на велику кількість досліджень у сфері територіального розвитку України, iii агломерацій і субрегіонів, їх правового статусу, а також публікацій, які розглядають особливості впровадження стандарту ISO 14001, варто зазначити, що розробок і пропозицій, що розглядали б як критерій екологічної безпеки агломерацій (далі - ЕБА) кількість підприємств, які впровадили СЕМ згідно з ISO 14001, а як індикатор ЕБА - показники ефективності й результативності впровадженої системи, нами не відмічено. 3 огляду на це, актуальним питанням залишається пошук критеріїв та індикаторів ЕБА.

Метою статті $\epsilon$ розроблення поетапного алгоритму застосування управлінських підходів для впровадження ефективної й результативної СЕМ промислових підприємств як індикатора екологічної безпеки агломерацій.

Новизна й методологічне або загальнонаукове значення. Для забезпечення ефективності та результативності СЕМ промислових підприємств розроблено алгоритм застосування підходів управління на всіх етапах іiі розроблення й упровадження.

Виклад основного матеріалу. У результаті трансформацій, що відбуваються в нашій державі в соціальній, економічній, правовій, а отже, і в екологічній сферах, необхідно акцентувати увагу на загостренні урбанізаційних процесів, які потребують негайного вирішення: стрімке зростання й посилення ролі міст у формуванні виробничо-господарського комплексу України, приуроченість господарських об'єктів до сировинних ресурсів, концентрація працюючого населення в містах, збільшення споживання готової продукції та розміщення продуктивних сил. Оскільки ці процеси є незворотними, одним із першочергових завдань, яке потрібно вирішувати на рівні держави, $\epsilon$ забезпечення збалансованого розвитку агломерацій шляхом кооперації місцевої та державної влади для оптимального співвідношення складників сталого розвитку: соціального, економічного й екологічного.

Останнім десятиліттям упровадження СЕМ на базі вимог міжнародного стандарту ISO 14001 набуло масового характеру [20]. На підставі звіту міжнародної організації зі стандартизації кількість сертифікованих організацій на відповідність стандарту ISO 14001 у всьому світі становить більше ніж 260000 [17]. Важливо, що останніми роками впровадження й сертифікація підприємств згідно 3 вимогами ISO 14001 найбільше зустрічається в країнах з економікою, що розвивається. Так, традиційних лідерів у впровадженні СЕМ (країни Свропи та Північної Америки) наздоганяють такі азіатські країни, як Китай, Південна Корея, Японія, Індія, Індонезія, Малайзія [16, с. 615].

Результативність та ефективність СЕМ на підприємствах відрізняється залежно від умов кожної окремо взятої країни. Це зумовлено різним рівнем розвитку законодавчої бази в галузі охорони навколишнього середовища, сформованістю нового покоління інструментів (адміністративно-контрольних, ринково-орієнтовних, добровільних угод), здатних створити умови переходу країни до стійкого соціо-еколого-економічного розвитку [13, с. 40-41]. Неабияку роль у процесі впровадження СЕМ відіграють стан природоохоронних технологій та інфраструктури, а також рівень обізнаності персоналу промислових підприємств про механізми досягнення результативної СЕМ. Крім цього, впровадження CEM відповідно до вимог ISO 14001 відбувається досить повільно з причин, які пов'язані зі значними фінансовими затратами підприємства на розроблення й сертифікацію. Потрібно відмітити, що переваги від ефективної СЕМ (умовно поділяються на внутрішні, які безпосередньо впливають на активність організації, та зовнішні - позитивні зміни, що полягають у зменшенні впливу діяльності підприємства на стан навколишнього середовища) перевершать усі сподівання й будуть більш значущими, ніж фінансові витрати організації на впровадження й сертифікацію СЕМ [22, с. 414].

Ефективне розроблення СЕМ пов'язано з визначеними підприємством цілями та чіткою стратегією керівництва, спрямованою на розподіл пріоритетів, що дасть змогу правильно розділити функції 
щодо розроблення, впровадження, функціонування й постійного покращення СЕМ. При цьому стратегія керівництва повинна постійно змінюватись у часі, так само як i змінюються умови навколишнього середовища [18, с. 69].

Уважається, що найбільш раціональним та ефективним варіантом упровадження CEM є застосування процесного підходу [16, с. 619], що повинен забезпечити інтегрування, налаштування і прозорість процесів на підприємстві, зосередити зусилля на їх результативності й ефективності, знизити витрати за рахунок раціонального використання ресурсів і надати більш чітке розуміння працівникам своєї відповідальності під час упровадження CEM. Така думка сформувалась на основі вимог стандарту ДСТУ ISO 14001:2015, які поєднують у цілісні процеси проходження певних етапів 3 підготовки та проведення змін на підприємстві із застосуванням методології покращення циклу Демінга (PDCA). На практиці ж виникає низка перешкод, що виявляють недоліки процесного підходу, які позначаються на неготовності до серйозних змін у структурі управління підприємством і його організаційній структурі, призводять до помилок під час створення системи показників роботи СЕМ, як результат, виникає елемент недосяжності на шляху підтримання системи постійного покращення процесів. Тому застосування процесного підходу управління на всіх етапах розроблення СЕМ буде оптимальним для підприємств 3 простою організаційною структурою, коли весь процес зосереджений у рамках однієї структурної одиниці [14, с. 102], а для складної ієрархічної системи такий підхід буде супроводжуватись зниженням ефективності [11, с. 98], оскільки визначається односпрямованістю до впровадження СЕМ. Отже, процесний підхід, з одного боку, дає чіткий результат у питаннях ідентифікації суттєвих екологічних аспектів, розроблення екологічної політики та програми екологічного менеджменту, а з іншого - супроводжується недоліками методологічного й методичного характеру під час використання [7, с. 78], оскільки пов'язаний із традиційним авторитарним, контрольно-орієнтованим стилем управління, що може призвести до дестабілізації відносин і поведінки в колективі [23, с. 14].

Виходячи з вищезазначеного, зауважимо, що для розроблення впровадження ефективної й результативної СЕМ потрібно використовувати декілька класичних підходів до управління: кількісний, поведінковий, процесний і стратегічний. Це дасть змогу розбудувати СЕМ у контексті перетворення виробництва та вмотивованості працівників.

Перший етап. Філософія змін (кількісний підхід $з$ елементами стратегічного аналізу). На цьому етапі впровадження СЕМ необхідно за допомогою математичних і статистичних методів, інженерних розрахунків установити залежності між різними показниками діяльності підприємства: техніко-ор- ганізаційними, економічними, якістю товару, витратами під час його виробництва й упровадженням природоохоронних технологій. При цьому буде доцільним застосувати методики типу Factor $\mathrm{X}$ [18, с. 18-25] і визначення екологічного матеріального балансу [18, с. 171]. Завдяки кількісному підходу із застосуванням вимірних показників і стратегічних інструментів, керівник підприємства зможе оцінити переваги СЕМ для розвитку організації, шляхи та етапи іiі створення, економічну рентабельність. У цьому випадку виникає необхідність організаційних змін на підприємстві й залучення працівників усіх підрозділів.

Другий етап. Учасники екологічних змін (поведінковий підхід з елементами стратегічного аналізу). Щоб упровадити ефективну й результативну СЕМ на підприємстві, потрібно змінити психологію працівників. «Трьома китами» нетрадиційного менеджменту з позицій поведінкового підходу є створення умов для розвитку та реалізації можливостей співробітників, стимуляція нових ідей і практичне впровадження новацій [12, с. 318]. На цьому етапі доцільним буде поєднати «мозковий штурм» із додаванням стратегічних інструментів SWOT і PESTLE-аналізу 3 методом Ішикави для можливості виявлення ключових параметрів процесів, що впливають на характеристики навколишнього середовища [24, с. 20; 25 , с. 56]. Застосування таких методів під час об'єднаних зборів і навчання працівників впливатиме на суб'єктів управління екологічними змінами, учасників екологічних змін, їхніх прибічників і на тих, хто зміни не підтримує, водночас дасть змогу збільшити мотивацію, цілеспрямованість, творче, стратегічне і трансформаційне мислення всіх співробітників організації [6, с. 17; 21, с. 5]. Керівництво має підтримувати й застосовувати лідерські якості персоналу для підвищення працездатності як окремого працівника, так всіх учасників, які забезпечують розроблення та впровадження СЕМ, адже розроблення, впровадження й ефективність СЕМ забезпечується працівниками підприємства - висококваліфікованими фахівцями у вузькому сегменті з постійним бажанням удосконалювати свої знання, реалізовувати свій творчий потенціал і отримувати за це відповідну винагороду. Працівників підприємства потрібно постійно мотивувати й навчати для того, щоб керівництво не перебувало в умовах постійного кругообігу проблем персоналу, які негативно позначатимуться на перебігу етапів упровадження CEM.

Tpeтій eman. Розроблення документації (процесний підхід). Після налагодження роботи та взаємозв'язків між працівниками підприємства керівництво має розробити й упровадити серію неперервних взаємопов’язаних дій на основі процесного підходу, оскільки наступними кроками впровадження СЕМ на підприємстві $є$ аналіз впливу діяльності підприємства на навколишнє природне середовище, ідентифікація екологічних аспектів і виділення 3 них 
найбільш суттєвих, вивчення вимог законодавчих документів.

Четвертий eman. Ефективна й результативна CEM (стратегічний підхід). Четвертий етап пов'язаний зі створенням стратегічних документів СЕМ. Розроблення екологічної політики та програми екологічного менеджменту підприємства має ввібрати в себе всі попередні напрацювання й забезпечити виконання головної мети - розвиток діяльності підприємства 3 дотриманням науково обгрунтованих екологічних вимог і постійне покращення екологічної результативності за рахунок підвищення ефективності людських ресурсів. Цей етап можна назвати безкінечним, оскільки він поєднує в собі попередні етапи, які є фундаментом для постійного покращення екологічно-орієнтованої діяльності підприємства.
Головні висновки. За результатами дослідження основні вимоги до системи екологічного менеджменту підприємства як індикатора ЕБА можна сформулювати так: поступова відмова від управлінського раціоналізму класичних шкіл менеджменту; застосування під час упровадження й функціонування СЕМ декількох підходів до управління; розгляд підприємства та навколишнього середовища агломерації як цілісної системи.

3 огляду на виявлені тенденції в застосуванні управлінських підходів до діяльності підприємств, відсутність переліку індикаторів ЕБА, зрештою, невизначеність правового статусу агломерацій, $\epsilon$ ще багато невирішених питань, які потребують подальших досліджень, пов'язаних із забезпеченням екологічної безпеки агломерацій і держави загалом.

\section{Література}

1. Аверкина М.Ф. Стратегічний набір в управлінні стійким розвитком агломерацій. Наукові записки Національного університету «Острозька академія». Серія «Економіка». 2017. № 5 (33). С. 47-51.

2. Безбородова О.Е., Вершинин Н.Н. Экологический менеджмент на предприятии. Наука и современность. 2014. Вып. 31. C. $100-105$.

3. Безбородова О.Е. Документация системы экологического менеджмента. Надежность и качество. 2011. Вып. 1. С. $356-357$.

4. Безбородова О.Е. Идентификация и оценка экологических аспектов деятельности предприятия. Молодежь. Наука. Инновации: сб. трудов III Международной научно-практической интернет-конференции Пензенский филиал РГУИТП (г. Пенза, 2011 г.). Пенза. 2011. С. 293-295.

5. Богачов С.В. Економіко-правові проблеми розвитку великих міст та агломерацій в Україні: монографія. Харків: HTMT, 2015. $247 \mathrm{c}$.

6. Божко Л.М. Современные подходы к управлению организационными изменениями. Экономика и управление предприятиями, отраслями и комплексами в условиях инновационного развития: сб. матер. Международной научно-практической конференции (Тверь, 21 октября 2013 г.). Тверь, 2013. С. 16-21.

7. Божко Л.М. Комбинированные научные подходы к управлению изменениями. Вестник Омского университета. Серия «Экономика». 2015. Вып. 2. С. 77-83.

8. Бородин А.И. Особенности формирования экологически приемлемого управления предприятием. Вестник Казанского технологического университета. 2003. Вып. 2. С. 411-416.

9. ДСТУ ISO 14001:2015 Системи екологічного управління. Вимоги та настанови щодо застосовування (ISO 14001:2015, IDT).

10. Ізаров О.М. Міські агломерації: пропозиції законодавчої ініціативи. Вісник Одеської державної академії будівництва та архітектури. 2017. № 66. С. 8-14.

11. Комиссарова М.А. Процессная модель системы стратегического управления угледобывающими предприятиями. Теrra Economicus. 2012. T. 10. № 1-2. C. 98-102.

12. Палей Т.Ф. Поведенческий подход к инновационному менеджменту как конструктивный процесс развития организации. Проблемы развития инновационно-креативной экономики. 2009. С. 316-330. URL: http://bgscience.ru/lib/10588 (дата звернення: 29.11.2018).

13. Пахомова Н.В., Рихтер К.К., Малышков Г.Б. Стратегия устойчивого развития и переход к зеленой экономике: обновление приоритетов и механизмов. Вестник СПбГУ. Серия 5. 2013. Вып. 4. С. 35-54.

14. Переверзев П.П. Стратегическое управление развитием промышленного комплекса на основе процессного подхода. Вестник Южно-Уральского государственного университета. Серия «Экономика и менеджмент». Серия 7. 2013. Вып. 3. C. 101-105.

15. Основы теории эко-эффективности: монография / под науч. ред. О. Сергиенко, Х. Рона. Санкт-Петербург: СПбГУНиПТ, 2004. $223 \mathrm{c}$.

16. Хорошавин А.В. Анализ проблем результативного внедрения систем экологического менеджмента. Применение процессного подхода в экологическом менеджменте. Научный журнал НИУ ИТМО. 2014. Вып. 3. С. 614-624.

17. Building Theory at the Intersection of Ecological Sustainability and Strategic Management / H. Borland, V. Ambrosini, A. Lindgreen, J. Vanhamme. Intersection of Ecological Sustainability and Strategic Management, Springer Science+Business Media Dordrecht. 2014. P. 293-307.

18. Dan Su. Review of Ecology-Based Strategy Change Theories. International Journal of Business and Management. 2009. Issue 4 (11). P. 69-72.

19. Gwen Ch., Fetsko M., Hendrickson Ch. Environmental Management Systems and ISO 14001. Certification for Construction Firms. Journal of construction engineering and management. 2004. P. 330-336.

20. ISO 14001 certifications reach new high. URL: http://www.environmentalistonline.com/article/2012-12-12/ iso-14001-certifications-reach-new-high (дата звернення: 21.11.2018).

21. Jan Dul. Human factors in business: creating people-centric systems. RSM Insight. 2011. Issue 5. P. 4-7. 
22. Matuszak-Flejszman A. Benefits of Environmental Management System in Polish Companies Compliant with ISO 14001. Polish J. of Environ. Stud. 2009. Issue 18 (3). P. 411-419.

23. Roger B. Mason. The external environment's effect on management and strategy. A complexity theory approach Management Decision. 2007. Issue 45 (1). P. 10-28.

24. Tarun Kanti Bose. Application of Fishbone Analysis for Evaluating Supply Chain and Business Process - a case study on the St. James Hospital. International Journal of Managing Value and Supply Chains (IJMVSC). 2012. Issue 3 (2). P. 17-24.

25. Watson G. The Legacy Of Ishikawa. Quality Progress. 2004. Issue 37(4). P. 54-47. 


\title{
КОМПАЕКСНА ОЦІНКА ЗАБРУДНЕННЯ АТМОСФЕРНОГО ПОВIТРЯ В МICTI МИКОААСВI
}

\author{
Григор'сва Л.І., Томілін Ю.А., Суха Н.О. \\ Чорноморський національний університет імені Петра Могили \\ вул. 68 Десантників, 10, 54003, м. Миколаїв
}

\begin{abstract}
За результатами екологічного моніторингу стану атмосферного повітря в м. Миколаєві здійснено комплексний аналіз забруднення полютантами повітряного простору міста. Представлено аналіз умісту основних екологічних полютантів атмосферного повітря в місті й аналіз комплексного індексу забруднення атмосферного простору в м. Миколаєві за 2015-2017 pр. Показано ймовірні причини екологічної небезпеки для атмосферного повітря в м. Миколаєві. Ключові слова: полютанти, атмосферне повітря, комплексний індекс забруднення атмосфери.
\end{abstract}

Комплексная оценка загрязнения атмосферного воздуха в городе Николаеве. Григорьева Л.И., Томилин Ю.А., Сухая Н.А. По результатам экологического мониторинга состояния атмосферного воздуха в г. Николаеве осуществлен комплексный анализ загрязнения поллютантами воздушного пространства города. Представлен анализ содержания основных экологических загрязнителей атмосферного воздуха в городе и анализ комплексного индекса загрязнения атмосферного пространства в г. Николаеве за 2015-2017 гг. Показаны вероятные причины экологической опасности для атмосферного воздуха в г. Николаеве. Ключевые слова: поллютанты, атмосферный воздух, комплексный индекс загрязнения атмосферы.

Comprehensive assessment of atmospheric air pollution in the Mykolayiv city. Grygoryeva L., Tomilin Y., Sukha N. According to the results of the environmental monitoring, atmospheric air in the city of Mykolaiv has been carried out a comprehensive analysis of pollutants polluting the airspace of the city. The analysis of the content of the main environmental pollutants of atmospheric air in the city and analysis of the integrated index of atmospheric pollution in Mykolaiv city for 2015-17 are presented. The probable reasons of the environmentally dangerous state of atmospheric air in Mykolaiv city are shown. Key words: pollutants, atmospheric air, comprehensive index of atmospheric pollution.

Постановка проблеми. Щороку в Україні в атмосферу виділяється близько 17 млн тонн шкідливих речовин. Обсяг шкідливих речовин, які потрапляють на один квадратний кілометр площі України, у 6,5 рази вищий, ніж у США, і в 3,2 рази - ніж у краінах Європи [4]. У територіальному розрізі найбільш високе забруднення атмосферного повітря характерне для Донецького й Придністровського регіонів України, а також навколо обласних центрів.

Основними забруднювачами повітря України $\epsilon$ підприємства чорної металургії (33\%), енергетики (30\%), вугільної промисловості $(10 \%)$, хімічної та нафтохімічної промисловості (7\%). Більше третини загального обсягу шкідливих викидів в атмосферу дає автотранспорт - 6,5 млн/тонн на рік. У великих містах України масова частка забруднення повітря від автомобільного транспорту становить 70-90\% від загальної маси забруднення.

Необхідність здійснення постійного екологічного моніторингу атмосферного повітря в міському середовищі очевидна й обгрунтована сучасними вимогами до якості навколишнього середовища. За даними спостережень гідрометеорологічної служби України, у першому півріччі 2018 р. в 13 містах України рівень забруднення повітря (за комплексним індексом забруднення атмосфери) оцінювався як високий (Маріуполь, Одеса, Луцьк, Кам'янське, Дніпро, Київ, Миколаїв, Слов'янськ, Кривий Ріг, Краматорськ,
Рубіжне, Лисичанськ, Запоріжжя) [6]. Тому комплексний аналіз забруднення атмосферного простору міста Миколаєва необхідний для розроблення відповідних контрзаходів.

Актуальність дослідження. Тривалий час у якості основних забруднювачів атмосфери у великих містах розглядалися промислові підприємства, які були джерелами надходження в навколишне середовище сірчистого газу, оксидів азоту, сажі й ін. Автомобільному транспорту як джерелу забруднення не приділялося належної уваги, хоча автотранспорт дає більше третини загального обсягу шкідливих викидів в атмосферу - 6,5 млн тонн на рік. У великих містах України масова частка забруднення повітря від автомобільного транспорту становить $70-90 \%$ від загальної маси забруднення. Один літр спалюваного бензину призводить до утворення приблизно 16 кубометрів вихлопних газів, які містять близько 200 шкідливих речовин. Небезпечно це тому, що в середньому один автомобіль за рік викидає близько 200 кг $\mathrm{CO}_{\mathrm{x}}, 60$ кг $\mathrm{N}_{\mathrm{x}} \mathrm{O}_{\mathrm{x}}, 40$ кг $\mathrm{C}_{\mathrm{x}} \mathrm{H}_{\mathrm{x}}, 3$ кг металевого й гумового пилу $[1 ; 5]$.

Метою дослідження $€$ комплексний аналіз забруднення небезпечними речовинами атмосферного повітря міста Миколаєва й транспортних потоків через місто. Використано результати екологічного моніторингу, проведеного Миколаївським обласним центром із гідрометеорології за станом 
атмосферного повітря у 2015-2017 pp. [2]; результати аналізу гідрофізичної лабораторії України [6]; результати власного наукового аналізу.

Виклад основного матеріалу. Постійний екологічний моніторинг за станом атмосферного повітря в м. Миколаєві здійснюється Миколаївським обласним центром із гідрометеорології. Спостереження в рамках моніторингу проводяться в 4-х контрольних пунктах спостереження (о 1, 7, 13, 19 годині в усі дні, крім неділі та святкових днів). Спостереження здійснюються за полютантами (забруднювачами): окис вуглецю (СО), пил, формальдегід $\left(\mathrm{H}_{2} \mathrm{CO}\right)$, фтористий водень (HF), двоокис азоту $\left(\mathrm{NO}_{2}\right)$, окис азоту (NO), двоокис сірки $\left(\mathrm{SO}_{2}\right)$.

Результати цього моніторингу свідчили про таке:

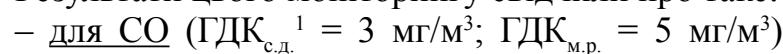
середньомісячні концентрації становили 2,0 \pm 1,1 мг $/ \mathrm{M}^{3} ;$ максимальні концентрації досягали 8-9 мг/м³ Перевищення ГДК с.д. мали постійний характер, а щодо перевищення ГДК щень навіть збільшилася у 2017 p.;

- для пилу $\left(Г Д К_{\text {с.д. }}=0,15 \mathrm{мг} / \mathrm{M}^{3} ;\right.$; ГДК середньомісячні концентрації становили 0,09 \pm $0,02 \mathrm{мг} / \mathrm{M}^{3}$; максимальні концентрації перевищували ГДК

- для $\mathrm{SO}_{2}\left(Г Д К_{\text {с.д. }}=0,05 \mathrm{M \Gamma} / \mathrm{M}^{3} ; \Gamma Д К_{\text {м.p. }}=0,5 \mathrm{M \Gamma} / \mathrm{M}^{3}\right)$ середньомісячні концентрації становили $0,006 \pm$ $0,002 \mathrm{Mг} / \mathrm{M}^{3} ;$ таким чином, не спостерігалося перевищень ГДК с.д., ГДК

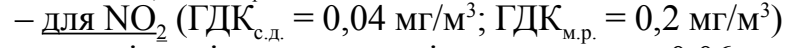
середньомісячні концентрації становили $0,06 \pm$ $0,02 \mathrm{M \Gamma} / \mathrm{M}^{3}$, таким чином, вони перевищували ГДК максимальні концентрації також перевищували ГДК

- для NO $\left(Г Д К_{\text {с.д. }}=0,06 \mathrm{м \Gamma} / \mathrm{M}^{3} ; \Gamma Д \mathrm{~K}_{\text {м.p. }}=0,1 \mathrm{мг} / \mathrm{M}^{3}\right)$ середньомісячні концентрації становили $0,015 \pm$ $0,002 \mathrm{Mг} / \mathrm{M}^{3}$; характерні щомісячні випадки досягнення ГДК

-дляНГприГДК середньомісячні концентрації становили $0,003 \pm$ $0,001 \mathrm{M \Gamma} / \mathrm{M}^{3}$; максимальні концентрації перевищували ГДК с.д., ГДК м..p, досягаючи 0,017-0,022 мг $/ \mathrm{M}^{3}$; перевищення ГДК. сячні випадки такого перевищення);

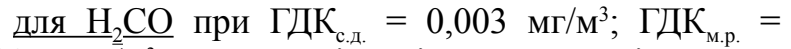
$0,035 \mathrm{мг} / \mathrm{M}^{3}$ середньомісячні концентрації становили $0,02 \pm 0,01 \mathrm{m \Gamma} / \mathrm{M}^{3}$; максимальні концентрації перевищували ГДК с.д., ГДК $0,07 \mathrm{мг} / \mathrm{M}^{3}$; перевищення ГДК с.д., ГДК м.р, мало стійкий характер (щомісячні випадки такого перевищення), особливо в період із квітня до жовтня.
Здійснено комплексну оцінку рівнів забруднення атмосферного повітря через визначення показників: індекс забруднення атмосфери (IЗА):

$$
\mathrm{I} \mathrm{A}_{\mathrm{i}}=\left(\frac{\mathrm{C}_{\mathrm{i}}}{\Gamma Д \mathrm{~K}_{\mathrm{i}}}\right)^{a_{i}},
$$

комплексний індекс забруднення атмосфери (KI3A):

$$
\text { КІЗА }=\sum_{\mathrm{i}=1}^{n}\left(\frac{\mathrm{C}_{\mathrm{i}}}{\Gamma Д \kappa_{\mathrm{i}}}\right)^{a_{i}},
$$

де $\mathrm{C}_{\mathrm{i}}$ - вміст екополютанта $i$ в атмосферному повітрі, мг $/ \mathrm{M}^{3} ;$ г ГК $\mathrm{K}_{\mathrm{i}}$ - гранично допустима концентрація екополютанта $i$ в атмосферному повітрі, мг $/ \mathrm{M}^{3} ; \mathrm{a}_{\mathrm{i}}$ - коефіцієнт, який залежить від класу небезпеки екополютанта.

Таблиця 1

Індекси забруднення атмосфери в м. Миколаєві

\begin{tabular}{|c|c|c|c|}
\hline Полютант & $\mathbf{2 0 1 5}$ p. & $\mathbf{2 0 1 6}$ p. & $\mathbf{2 0 1 7}$ p. \\
\hline $\mathrm{CO}$ & 0,83 & 0,85 & 1,40 \\
\hline $\mathrm{SO}_{2}$ & 0,03 & 0,03 & 0,03 \\
\hline пил & 0,89 & 0,72 & 0,77 \\
\hline $\mathrm{NO}_{2}$ & 0,97 & 1,10 & 1,00 \\
\hline $\mathrm{NO}$ & 0,44 & 0,44 & 0,18 \\
\hline $\mathrm{HF}$ & 4,64 & 4,30 & 5,06 \\
\hline $\mathrm{H}_{2} \mathrm{CO}$ & 2,96 & 4,98 & 4,59 \\
\hline
\end{tabular}

Як видно 3 таблиці 1 , підвищену увагу має викликати вміст у повітрі $\mathrm{CO}, \mathrm{NO}_{2}, \mathrm{HF}, \mathrm{H}_{2} \mathrm{CO}$.

Динаміка комплексного показника КІЗА за 20152017 рр. відображена на рис. 1.

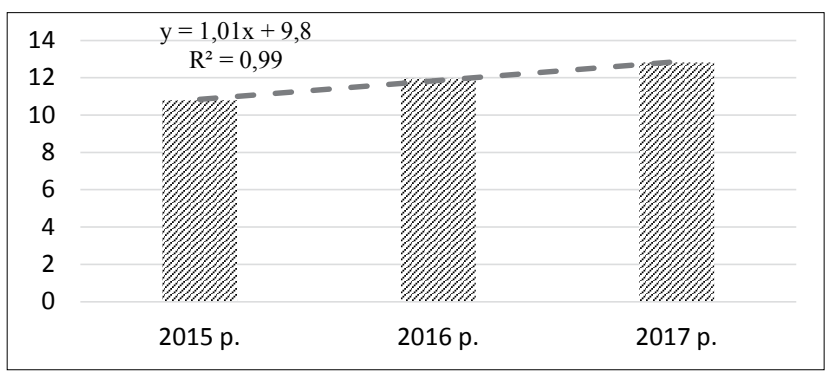

Рис. 1. Динаміка комплексного показника КIЗА в м. Миколаєві за 2015-2017 pp.

Рівень забруднення атмосферного повітря за показником КІЗА диференціюють так: при КІЗА $<5$ рівень забруднення є низьким; при $5 \leq \mathrm{KI} 3 \mathrm{~A}<8$ рівень підвищений; при $8 \leq K I 3 \mathrm{~A}<13$ рівень високий; при КІЗА $\geq 13$ рівень дуже високий. Показник КІЗА для атмосферного повітря м. Миколаєва у 2015-2017 pp. перевищив 10 одиниць. Апроксимація динаміки цього показника за ці роки вказала на наявність тен-

\footnotetext{
${ }^{1}$ Обмеження негативного впливу екологічних полютантів атмосферного повітря за законодавством України здійснюється через неперевищення нормативів:

ГДК с.д. - гранично допустима концентрація полютанта середньодобова - концентрація забруднювача в повітрі, яка не чинить прямого чи непрямого впливу на людину при цілодобовому диханні;

ГДК що не викликає рефлекторних реакцій в організмі людини (визначається 3 проб, які відбираються за 20-30-хвилинний інтервал часу).
} 


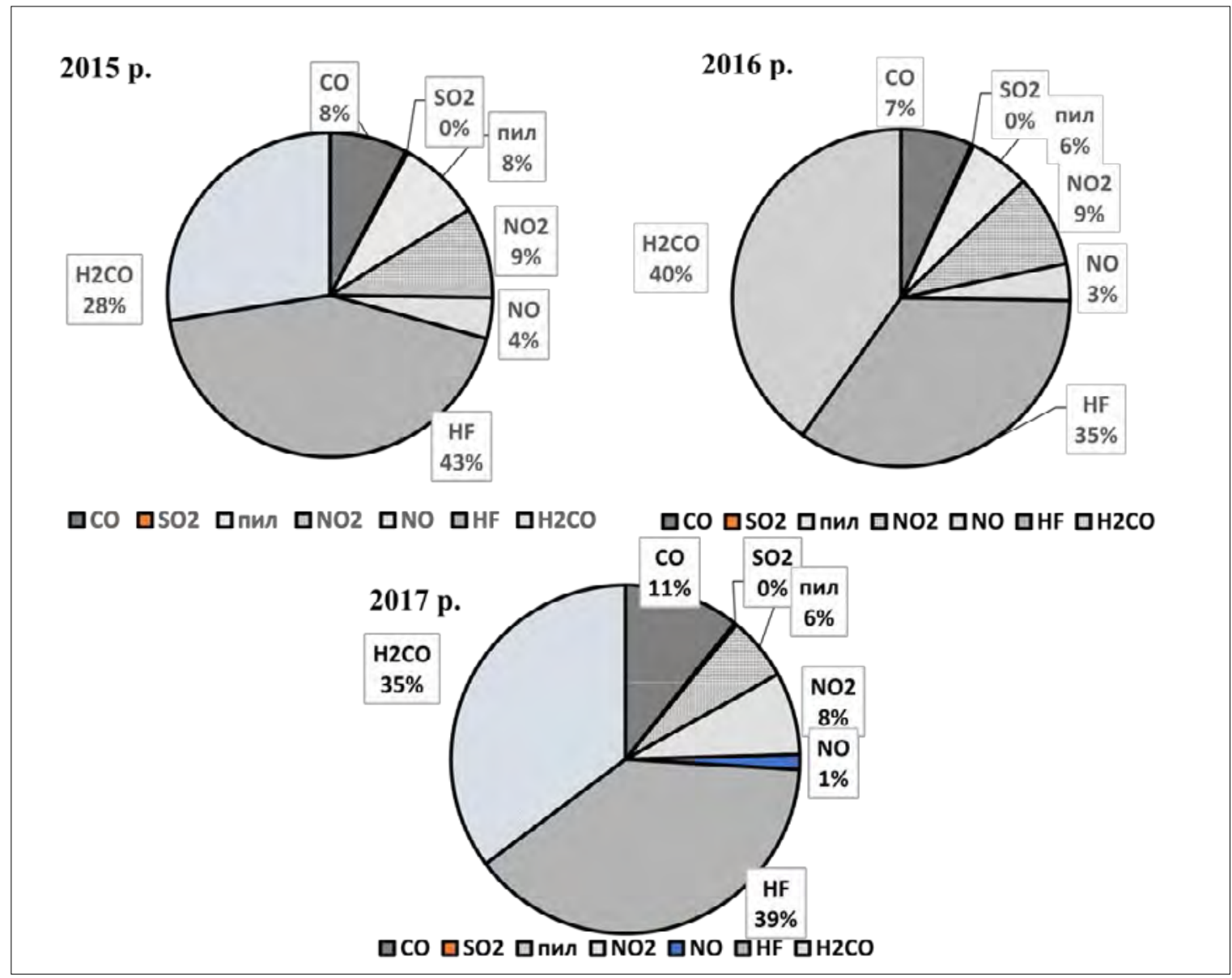

Рис. 2. КІЗА м. Миколаєва за внесками полютантів

денції до зростання із середньорічним темпом приросту, близьким до одиниці (рис. 1).

Внески кожного полютанта у формування КІЗА в м. Миколаєві відображені на рис. 2. Як видно 3 рисунку, найбільший внесок у формування комплексного рівня забруднення атмосферного повітря в м. Миколаєві здійснює формальдегід (від 28 до $40 \%$ ) і фтористий водень (від 35 до 43\%). Істотними $\epsilon$ також викиди двоокису азоту (8-9\%).

Потрібно зауважити, що екологічний моніторинг атмосферного повітря в м. Миколаєві, який здійснює Миколаївський обласний центр гідрометеорології, не включає вимірювання таких небезпечних токсикантів, присутність яких зазвичай $є$ характерною для великих міст: фенол і бензапірен. Тому величини КІЗА для м. Миколаєва можуть бути ще вищими.

Таким чином, типовий вигляд перевищення гранично допустимих концентрацій ГДК основних полютантів $i$ атмосферного повітря в м. Миколаєві має вигляд, який зображено на рис. 3.

Причини такого стану атмосферного простору в місті є зрозумілими. Миколаїв пов'язаний автодорогою Р-06 з автомагістраллю М-05 у районі м. Умань, що має вихід на Люблін-Варшаву-Гданськ (Польща). Довжина шляху Гданьск-Миколаїв становить 1530 км. Через Миколаїв проходить авто- магістраль М-14 (Рені-Ростов-на-Дону), пов'язана через автомагістраль М-05 (Одеса-Київ-Гомель) 3 автомагістраллю М-18 (Сімферополь-ХарківМосква) (рис. 4).

Протягом останніх років у м. Миколаєві спостерігається напружена ситуація з курсуванням магістралями міста великої кількості вантажного транспорту, який прямує в морські порти південного регіону; за різними даними, це від 15 до 50 тисяч вантажних автомобілів на рік. Більше тисячі авто накопичуються на вулицях міста в сезон перевезень без жод-

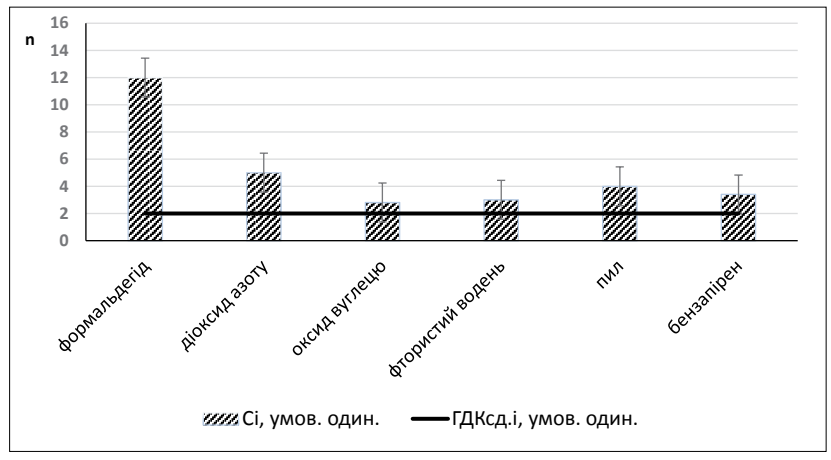

Рис. 3. Нормалізовані (на ГДК забруднювачів атмосферного повітря в м. Миколаєві (типовий вигляд) 


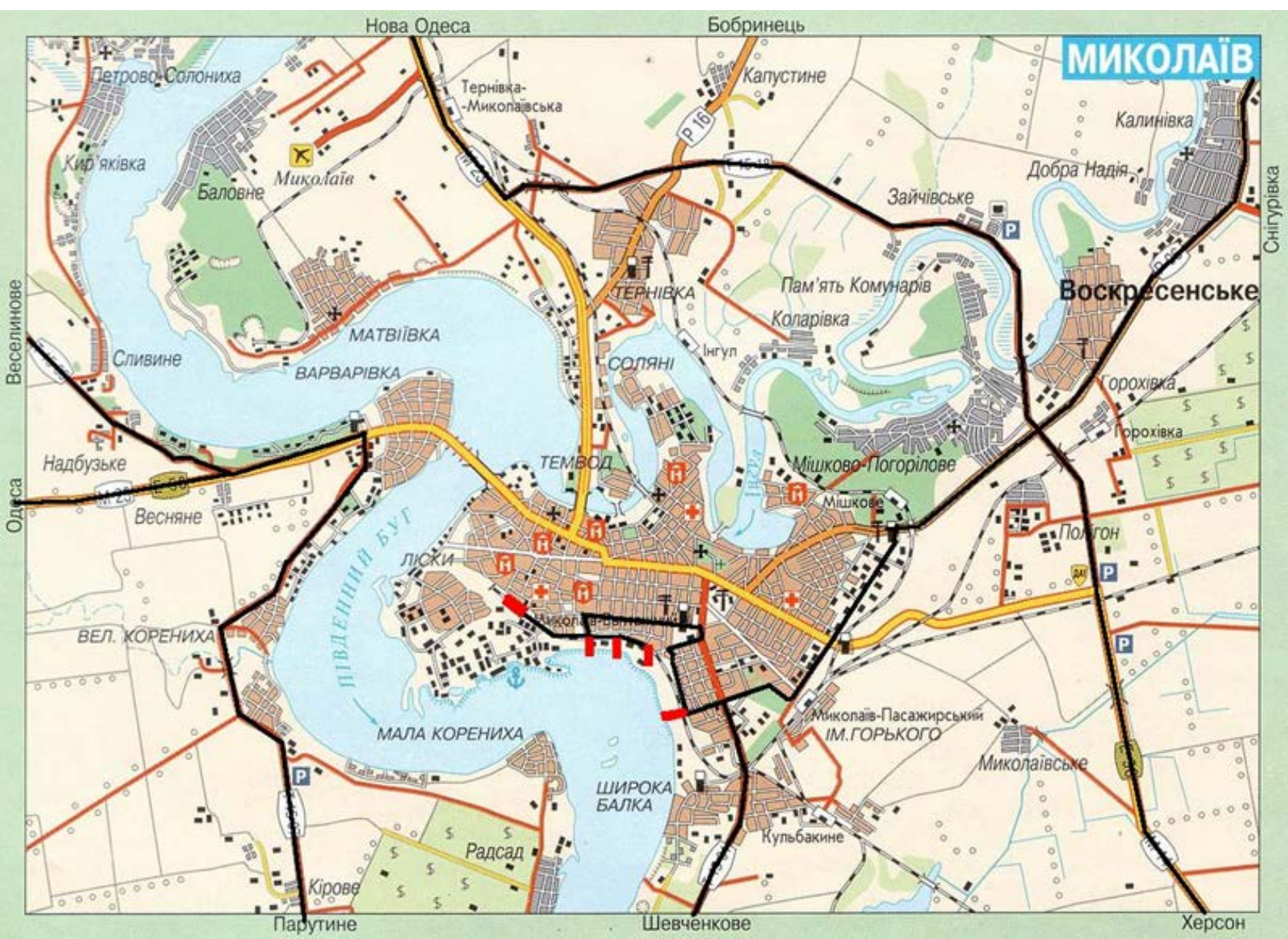

Рис. 4. Схема руху транспорту через м. Миколаӥв

ного контролю. Зрозуміло, що це спричиняє підвищення рівня формальдегіду й інших атмосферних полютантів в атмосферному просторі м. Миколаєва, а як відомо, формальдегід є генотоксичною речовиною, може викликати соматичні мутації, які можуть передаватися нащадкам; має мутагенну, ембріотоксичну та канцерогенну дії. До того ж діоксид азоту підсилює негативний вплив формальдегіду. Тому збільшення вмісту формальдегіду в атмосферному повітрі м. Миколаєва є суттєвим екологічним ризиком для населення.

Сьогодні доведене існування кореляції між збільшенням автотранспорту на газі й викидами формальдегіду: автомобіль, який працює на природному газі, дає вихлоп, у якому концентрація формальдегіду становить 0,177 мг/куб. м, що у 2-3 рази більше, ніж під час використання бензину [3]. Як відомо, кількість авто, що використовують газ у якості палива, постійно збільшується.

Розглядаючи кліматично-метеорологічні умови м. Миколаєва 3 позицій впливу на розсіювання викидів, зазначимо, що останні, особливо влітку, не характеризуються постійністю вітрів, що сприяло б розбавленню й перенесенню шкідливих домішок. Також потрібно зважати на те, що через фізикохімічні властивості формальдегіду збільшення вмісту останнього в повітрі відбувається в сонячну погоду та при високих температурах повітря. При цьому транзит багатотонажних вантажівок через місто також активізується у весняно-осінній сезон року. Отже, усі ці фактори сприяють підвищеним рівням формальдегіду й інших полютантів у повітрі міста.

\section{Головні висновки.}

1. Для повітряного простору м. Миколаєва характерне перевищення гранично допустимих концентрацій небезпечних полютантів (формальдегід, фтористий водень, двоокис азоту, вуглекислий газ, бензапірен, пил). Характерним $є$ не лише перевищення рівня середньодобових гранично допустимих концентрацій, а й максимально разових концентрацій. Особлива велика кратність перевищення ГДК с.д. (до 10 разів і вище) характерна для формальдегіду. Перевищення гранично допустимих концентрацій більш характерне для весняно-осіннього періоду.

2. Серед 7 полютантів, за якими ведеться моніторинг у м. Миколаєві, рейтинг їхніх місць у комплексному впливі на рівень забруднення атмосферного повітря міста такий: 1 місие $-\mathrm{H}_{2} \mathrm{CO}$; 2 місие - $\mathrm{HF}$; 3 місие - $\mathrm{NO}_{2}$; 4 місие - $\mathrm{CO} ; 5$ місие - пил. Через те, що при одночасній присутності в повітрі $\mathrm{NO}_{2} \mathrm{i} \mathrm{H}_{2} \mathrm{CO}$ кожний із них підсилює негативний вплив іншого, 
тобто вони діють синергічно, збільшення вмісту формальдегіду в атмосферному повітрі м. Миколаєва стає суттєвим екологічним ризиком для населення міста.

3. За комплексною оцінкою забруднення атмосфери (КІЗА) м. Миколаїв входить у першу десятку найбільш забруднених міст України. За величиною КІЗА рівень забруднення атмосферного повітря м. Миколаєва оцінюється як високий (КІЗА більше 10). Установлено тенденцію до зростання забруднення атмосферного повітря м. Миколаєва із середньорічним темпом зростання 1,0. Це свідчить про те, що вже у 2018-2019 рр. можемо отримати рівень забруднення атмосферного повітря м. Миколаєва не просто високий, а дуже високий (за показником КІЗА).
4. Щорічно магістралями міста курсує вантажний транспорт, який прямує в морські порти південного регіону, за різними даними, це від 15 до 50 тисяч вантажних автомобілів на рік. Кліматичнометеорологічні умови м. Миколаєва, особливо влітку, не характеризуються постійністю вітрів, що сприяло б розбавленню й перенесенню шкідливих викидних домішок. Через фізико-хімічні властивості формальдегіду, які призводять до збільшення його вмісту в атмосфері в сонячну погоду та при високих температурах повітря, і активізацію транзиту багатотонажних вантажівок через місто Миколаїв у весняно-осінні сезони року, останній несе серйозну екологічну небезпеку для міста.

\section{Література}

1. Авалиани С.Л., Буштуева К.А. Оценка вклада выбросов автотранспорта в интегральную характеристику риска загрязнений воздушной среды. Гигиена и санитария. 2002. № 6. С. 21-25.

2. Миколаївський обласний центр з гідрометереології. Структура. Хімічна лабораторія. URL: http://mcgm.mk.ua/structure/ laboratory/.

3. Мислюк О.О., Шейкіна О.Ю. Оцінка екологічної безпеки функціонування автотранспорту в умовах промислового міста. Вісник ЖДТУ. № 3 (46) Технічні науки. С. 1-9.

4. Сафранов Т.А. Антропогенне забруднення атмосферного повітря та його негативні екологічні наслідки. Екологічні основи природокористування: навчальний посібник для студ. вузів. Львів: Новий Світ-2000, 2003. 247 с.

5. Солошич І.О., Підліснюк В.В. Дослідження забруднення повітря транспортними потоками центральної частини м. Банська-Бистриця (Словацька республіка). Екологічна безпека - 4/2009(8) С. 43-48.

6. Ц Центральна геофізична обсерваторія імені Бориса Срезневського. Київ: ЦГО 2017-2018. URL: http://cgo-sreznevskyi.kiev.ua/ index.php?fn=u_zabrud\&f=ukraine. 


\title{
РОЙОВИЙ МЕТОД ТЕМАТИЧНОГО СЕГМЕНТУВАННЯ ЗОБРАЖЕНЬ БОРТОВИХ СИСТЕМ ЕКОАОГІЧНОГО МОНТТОРИНГУ
}

\author{
Худов Г.В. ${ }^{1}$, Хижняк І.А. ${ }^{1}$, Соломоненко Ю.С. ${ }^{1}$, Маковейчук О.М. ${ }^{2}$ \\ ${ }^{1}$ Харківський національний університет Повітряних Сил імені Івана Кожедуба, \\ вул. Сумська, 77/79, 61023, м. Харків \\ ${ }^{2}$ Харківський національний університет радіоелектроніки, \\ пр. Науки, 14, 61166, м. Харків \\ 2345kh_hg@ukr.net
}

\begin{abstract}
У статті запропоновано для тематичного сегментування зображень бортових систем екологічного моніторингу використання ройового методу штучної бджолиної колонії. Уведена цільова функція, що враховує дисперсії розподілу яскравості тематичних сегментів оптико-електронного зображення. Сформульована оптимізаційна задача, яка полягає в мінімізації цільової функції. Наведено результат тематичного сегментування оптико-електронного зображення. Розраховані значення помилок тематичного сегментування першого та другого роду. Ключові слова: екологічний моніторинг, оптико-електронне зображення, тематичне сегментування, ройовий метод, об'єкти інтересу.
\end{abstract}

Роевой метод тематического сегментирования изображений бортовых систем экологического мониторинга. Худов Г.В., Хижняк И.А., Соломоненко Ю.С., Маковейчук А.Н. В статье предложено для тематического сегментирования изображений бортовых систем экологического мониторинга использовать роевой метод искусственной пчелиной колонии. Введена целевая функция, которая учитывает дисперсии распределения яркости тематических сегментов оптико-электронного изображения. Сформулирована оптимизационная задача, которая заключается в минимизации целевой функции. Приведен результат тематического сегментирования оптико-электронного изображения. Рассчитаны значения ошибок тематического сегментирования первого и второго рода. Ключевые слова: экологический мониторинг, оптико-электронное изображение, тематическое сегментирование, роевой метод, объекты интереса.

Swarm method of thematic segmentation of images of on-board environmental monitoring systems. Khudov G., Khizhnyak I., Solomonenko Yu., Makoveychuk A. It is proposed to use the swarm method of artificial bee colony for thematic segmentation of images of on-board environmental monitoring systems. A target function was introduced that takes into account the dispersion of the brightness distribution of the thematic segments of the optoelectronic image. The optimization problem, which is to minimize the objective function, is formulated. The result of thematic segmentation of the optical-electronic image is given. The values of thematic segmentation errors of the first and second kind are calculated. Key words: environmental monitoring, optoelectronic image, thematic segmentation, swarm method, objects of interest.

Постановка проблеми. Процес дешифрування оптико-електронних зображень (далі- ОЕЗ) в інтересах екологічного моніторингу складається з декількох етапів, які ведуть дешифрувальника до розпізнавання об'єктів, а потім до їх загальної оцінки, визначення стану складного об’єкта й формування інформації про нього [2].

У статті основна увага приділяється етапу тематичного сегментування, від якості якого залежить результат обробки всього ОЕЗ. Результатом тематичного сегментування OE3 є розділення зображення на штучні об'єкти (об'єкти інтересу) та природні об' єкти (фон).

Актуальність дослідження. У ході ведення бойових дій на території Донецької та Луганської областей виникають численні екологічні проблеми, які в основному пов'язані із застосуванням озброєння й військової техніки. Як відомо, техногенні екологічні фактори (забруднення) класифікуються за механізмом, ступенем, рівнем, наслідками, масштабом впливу тощо. 3 погляду механізму впливу на навколишне природне середовище розрізняють три види забруднень: фізичної, хімічної та біологічної природи, а озброєння й військова техніка здатні генерувати найнебезпечніші типи всіх трьох видів [1].

Натепер грунтова поверхня десятків тисяч гектарів земель порушена воронками від мін і снарядів, пошкоджена гусеницями танків і важкою військовою технікою, а також забруднена нафтопродуктами, які у великому об'ємі можуть потрапити на грунт із пошкодженої військової техніки та нафтосховищ, а потім й у грунтові води. Уже сьогодні доцільно приступити до аналізу таких можливих техногенних катастроф 3 використанням бортових систем екологічного моніторингу. Значну частку серед таких даних, виходячи 3 їх наочності та придатності до точних вимірювань, займають дані, що отримані засобами оптико-електронного моніторингу повітряного й космічного базування [2-3]. 
Аналіз останніх досліджень і публікацій. Кількість робіт, що присвячені розробленню, модернізації й застосуванню методів сегментування ОЕ3, постійно зростає [4-6]. Це зумовлено значним впливом сегментування на кінцеву якість обробки та дешифрування зображення.

Відомі методи сегментування зображень [4-6] не можуть бути прямо застосовані до сегментування зображень бортових систем екологічного моніторингу. Однією 3 причини неможливості прямого застосування $\epsilon$ те, що ці методи не враховують особливості формування зображень з бортових систем екологічного моніторингу.

3 аналізу відомих методів сегментування ОЕЗ установлено, що їм властиві такі основні недоліки: більшість із них не визначають межі об'єктів, а лише підкреслюють їх і не проводять сегментування; проведення сегментування лише за критерієм рівня яскравості пікселя зображення, що не дає можливості визначати критерії гомогенності сегментів [4-5].

Для вирішення завдання тематичного сегментування зображень бортових систем екологічного

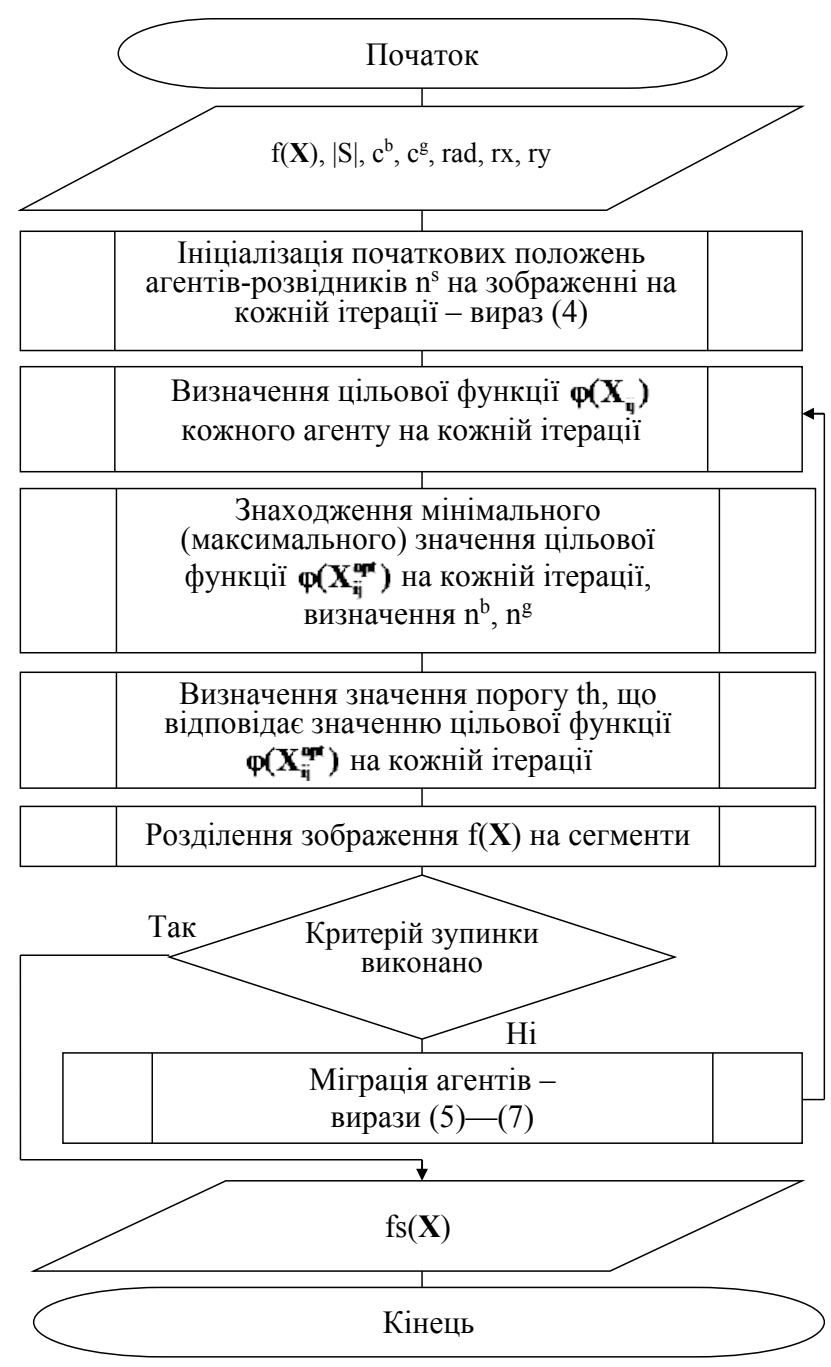

Рис. 1. Схема методу тематичного сегментування ОЕЗ бортових систем спостереження моніторингу можуть бути використані ройові методи, до яких належать метод штучної бджолиної колонії, мурашиний метод, метод рою частинок, метод зозулі тощо, які імітують соціальну поведінку живих істот [5].

Для тематичного сегментування ОЕЗ будемо використовувати метод штучної бджолиної колонії (АВС-метод (artificial bee colony)), який має такі переваги: несхильність до зациклення в локальних оптимумах; мультиагентність реалізації; здатність адаптуватися до змін навколишнього середовища; можливість використання для вирішення як дискретних, так і безперервних оптимізаційних задач; грунтування пошуку кращого рішення на рішеннях усіх агентів (бджіл) [6].

Виклад основного матеріалу. Сегментування вихідного розвідувального зображення $\mathrm{f}(\mathrm{x}, \mathrm{y})$ визначається виразом (1):

$$
\mathrm{f}(\mathrm{x}, \mathrm{y}) \rightarrow \mathrm{fs}(\mathrm{x}, \mathrm{y})
$$

де $\mathrm{f}(\mathrm{x}, \mathrm{y})$ - вихідне OE3; fs( $\mathrm{x}, \mathrm{y})$ - сегментоване зображення, та передбачає відображення пікселів (точок) вихідного зображення з координатами (x, y) у деякий простір ознак і введення метрики (міри близькості) на цьому просторі ознак. Як ознака використовується яскравість пікселів зображення та iii властивості - розривність та однорідність у деякому кольоровому просторі пікселів 3 координатами $(\mathrm{x}, \mathrm{y})$ на зображенні $\mathrm{f}(\mathrm{x}, \mathrm{y})$, метрикою є відстань між яскравостями пікселей у кольоровому просторі. Сегментування вихідного зображення, відповідно до (1), передбачає розбиття $\mathrm{f}(\mathrm{x}, \mathrm{y})$ на сегменти $\mathrm{B}_{\mathrm{i}}$, що задовольняє умовам (2):

$$
\left\{\begin{array}{l}
\bigcup_{\mathrm{i}=1}^{\mathrm{K}} \mathrm{B}_{\mathrm{i}}=\mathrm{B} ; \\
\mathrm{B}_{\mathrm{i}} \cap \mathrm{B}_{\mathrm{j}}=\varnothing, \text { для } \mathrm{i} \neq \mathrm{j} ; \forall \mathrm{i}, \mathrm{j}=\overline{1, \mathrm{~K}} ; \\
\mathrm{LP}\left(\mathrm{B}_{\mathrm{i}}\right)=1 ; \forall \mathrm{i}=\overline{1, \mathrm{~K}} ; \\
\mathrm{LP}\left(\mathrm{B}_{\mathrm{i}} \cap \mathrm{B}_{\mathrm{j}}\right)=0, \text { для } \mathrm{i} \neq \mathrm{j} ; \forall \mathrm{i}, \mathrm{j}=\overline{1, \mathrm{~K}} .
\end{array}\right.
$$

де $\mathrm{B}: \mathrm{B}=\left\{\mathrm{B}_{1}, \mathrm{~B}_{2}, \ldots, \mathrm{B}_{\mathrm{K}}\right\}-$ сегменти на зображенні fs $(\mathrm{x}, \mathrm{y})$;

$\mathrm{K}$ - кількість сегментів $\mathrm{B}_{\mathrm{i}},(\mathrm{i}=1,2, \ldots, \mathrm{K})$;

LP - предикат, що визначений на В та приймає значення «1»- істина тоді й тільки тоді, коли будьяка пара точок із кожного сегменту $\mathrm{B}_{\mathrm{i}}$ задовольняє деякому критерію однорідності - вираз (3):

$$
\operatorname{LP}\left(\mathrm{B}_{\mathrm{i}}\right)=\left\{\begin{array}{l}
1, \text { при } \mathrm{f}\left(\mathrm{x}_{1}, \mathrm{y}_{1}\right)=\ldots=\mathrm{f}\left(\mathrm{x}_{\mathrm{M}}, \mathrm{y}_{\mathrm{M}}\right) ; \\
0, \text { в іншому випадку, }
\end{array}\right.
$$

де $\left(\mathrm{x}_{\mathrm{m}}, \mathrm{y}_{\mathrm{m})} \in \mathrm{B}_{\mathrm{i}} ; \mathrm{m}=1,2, \ldots, \mathrm{M} ; \mathrm{M}\right.$ - кількість точок у сегменті $\mathrm{B}_{\mathrm{i}}$.

Для визначення оптимального порогу тематичного сегментування та розділення зображення на штучні об' єкти й фон удосконалено метод тематичного сегментування зображень бортових систем спостереження, схема якого наведена на рис. 1. На відміну від відомих, для тематичного сегментування застосовується ройовий метод штучної бджолиної 


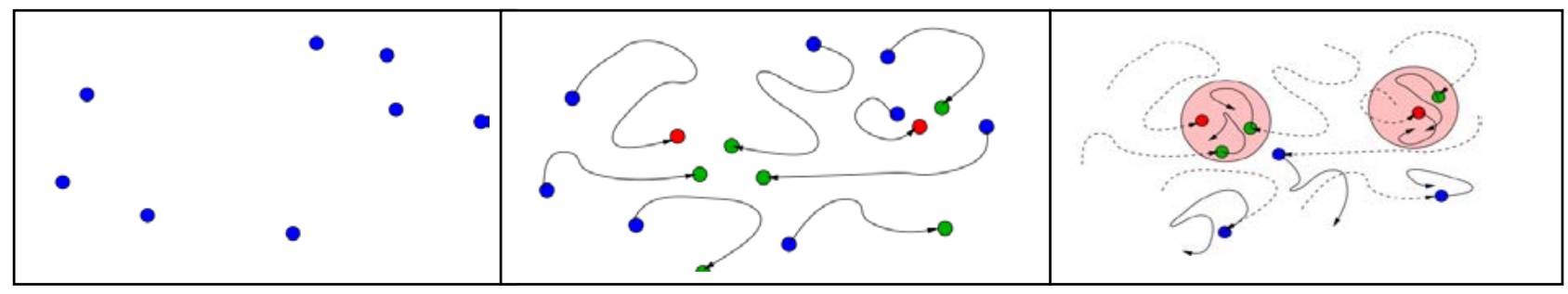

a)

б)

b)

Рис. 2. Положення агентів ройового методу тематичного сегментування:

а) інічіалізачія початкових положень, б) міграція, в) визначення оптимального положення

колонії, що передбачає визначення положень агентів (рис. 2а, вираз (4)), їх міграцію (рис. 2б, вирази (5)-(7)), умов зупинки ітераційного процесу за критерієм мінімуму фітнес-функції та визначення оптимального значення порогового рівня (рис. 2в):

$$
\mathbf{X}_{\mathrm{il}}=\operatorname{rand}(\mathrm{f}(\mathbf{X})) \text {, }
$$

де $\mathbf{X}=(\mathrm{x}, \mathrm{y})$ - вектор положень агентів;

$\mathbf{X}_{\mathrm{il}}=\left(\mathrm{x}_{\mathrm{il}}, \mathrm{y}_{\mathrm{i}}\right)-$ вектор положень агентів на першій ітерації;

$\operatorname{rand}(f(\mathbf{X}))$ - генератор випадкових чисел;

$\mathrm{n}^{\mathrm{s}}=1, \ldots, \mathrm{n}^{\mathrm{s}} ; \mathrm{n}^{\mathrm{s}} \cdot \mathrm{i}=1$ - кількість агентів-розвідників на першій ітерації;

$$
\mathbf{X}_{\left((\mathrm{i}-1) \mathrm{c}^{\mathrm{b}}+\mathrm{k}\right) \mathrm{j}}=\mathrm{N}_{\mathrm{i}(\mathrm{j}-1)}^{\mathrm{b}}+\mathrm{Rnd} \cdot \mathrm{rad},
$$

де $\mathbf{X}_{\left((\mathbf{i}-1) \mathbf{c}^{\mathbf{b}}+\mathbf{k}\right) \mathbf{j}}-$ вектор положень кращих агентів на ј-ій ітерації;

$\mathrm{N}_{\mathrm{ij}}^{\mathrm{b}}$ - краща позиція i-го агенту на $\mathrm{j}$-ій ітерації;

$\mathrm{i}=1, \ldots, \mathrm{n}^{\mathrm{s}}, \mathrm{k}=1, \mathrm{c}^{\mathrm{b}} ; \mathrm{n}^{\mathrm{b}},-$ кількість кращих позицій на ј-ой ітерації;

$\mathrm{c}^{\mathrm{b}}$ - кількість агентів, що відправляються (мігрують) до кращих позицій;

Rnd - випадкове число;

$\mathrm{rad}$ - коефіцієнт, що визначає розсіяння агентів при відправленні на кращі та перспективні позиції;

$$
\mathbf{X}_{\left(\mathrm{n}^{\mathrm{b}} \mathrm{c}^{\mathrm{b}}+(\mathrm{i}-1) \mathrm{c}^{\mathrm{b}}+\mathrm{k}\right) \mathrm{j}}=\mathrm{N}_{\mathrm{i}(\mathrm{j}-1)}^{\mathrm{g}}+\mathrm{Rnd} \cdot \mathrm{rad},
$$

де $\mathrm{N}_{\mathrm{ij}}^{\mathrm{g}}$ - перспективна позиція і-го агенту на ј-ій ітерації; $\mathrm{i}=1, \ldots, \mathrm{n}^{\mathrm{g}}, \mathrm{k}=1, \mathrm{c}^{\mathrm{g}} ; \mathrm{n}^{\mathrm{g}}$ - кількість перспективних позицій на ј-ій ітерації; $\mathrm{c}^{\mathrm{g}}$ - кількість агентів, що відправляються (мігрують) до перспективних позицій;

$$
\mathbf{X}_{\left(n^{b} c^{b}+n^{g} c^{g}+i\right) j}=\operatorname{rand}(f(X)),
$$

де, $\mathrm{i}=1, \ldots, \mathrm{n}^{\mathrm{s}}, \mathrm{n}^{\mathrm{s}}$ - кількість агентів-розвідників на ј-ій ітерації.

До цільової функції $\varphi\left(\mathbf{X}_{\mathrm{ij}}\right)$ висуваються такі вимоги: задоволення умови адекватності задачі; використання мінімуму обчислювального ресурсу; мінімум кількості локальних оптимумів; не повинна бути занадто «гострою». У як цільову функцію обрано суму дисперсії яскравості сегментів зображення (вираз (8)):

$$
\mathrm{D}(\text { th })=\mathrm{D}_{1}(\text { th })+\mathrm{D}_{2}(\text { th }),
$$

де $\mathrm{D}(\mathrm{th})$ - цільова функція;

th - значення порогу тематичного сегментування;
$\mathrm{D}_{1}($ th) - сума дисперсії яскравості пікселів тематичних сегментів, що мають яскравість вищу за пороговий рівень (штучні об'єкти);

$\mathrm{D}_{2}($ th) - сума дисперсії яскравості пікселів тематичних сегментів, що мають яскравість нижчу за пороговий рівень (фон).

У загальному вигляді оптимізаційна задача вибору оптимального порогу тематичного сегментування сформульована виразами (9)-(14) і полягає в мінімізації введеної цільової функції (9) з урахуванням визначень та обмежень (10)-(14):

$$
\begin{aligned}
& \mathrm{D}(\text { th })=\sum_{\mathrm{j}=1}^{\mathrm{K}} \mathrm{D}_{\mathrm{j}}(\text { th }) \rightarrow \min ; \\
& \mathrm{D}_{\mathrm{j}}(\text { th })=\frac{1}{\mathrm{~N}_{\mathrm{lj}}(\mathrm{th})-1} \sum_{\mathrm{k}=1}^{\mathrm{N}_{\mathrm{j}}(\text { th })}\left(\mathrm{U}_{\mathrm{kj}}-\mu_{\mathrm{j}}(\text { th })\right)^{2}-\text { для } \mathrm{U}_{\mathrm{kj}}>\text { th } ;(10) \\
& \mathrm{D}_{\mathrm{j}}(\text { th })=\frac{1}{\mathrm{~N}_{0 \mathrm{j}}(\text { th })-1} \sum_{\mathrm{k}=1}^{\mathrm{N}_{\mathrm{j}} \text { (th) }}\left(\mathrm{U}_{\mathrm{kj}}-\mu_{\mathrm{j}}(\text { th })\right)^{2}-\text { для } \mathrm{U}_{\mathrm{kj}} \leq \mathrm{th} \text {; } \\
& \mu_{\mathrm{j}}(\text { th })=\frac{1}{\mathrm{~N}_{\mathrm{lj}}(\mathrm{th})} \sum_{\mathrm{k}=1}^{\mathrm{N}_{\mathrm{j}} \text { (th) }} \mathrm{U}_{\mathrm{kj}}-\text { для } \mathrm{U}_{\mathrm{kj}}>\text { th } \text {; } \\
& \mu_{\mathrm{j}}(\text { th })=\frac{1}{\mathrm{~N}_{0 \mathrm{j}}(\text { th })} \sum_{\mathrm{k}=1}^{\mathrm{N}_{\mathrm{o}} \text { (th) }} \mathrm{U}_{\mathrm{kj}}-\text { для } \mathrm{U}_{\mathrm{kj}} \leq \text { th } ; \\
& 0 \leq \text { th } \leq \mathrm{U}_{\max },
\end{aligned}
$$

де $\mathrm{K}$ - кількість сегментів; $\mathrm{N}_{0 \mathrm{j}}$ - кількість пікселів в j-му сегменті, яскравість яких менша або дорівнює значенню порогового рівня th; $\mathrm{N}_{1 \mathrm{j}}-$ кількість пікселів в j-му сегменті, яскравість яких більша за значення порогового рівня th; $\mathrm{U}_{\mathrm{kj}}$ - яскравість k-го пікселя в j-му сегменті; $\mu_{\mathrm{j}}$ - математичне очікування яскравості в $j$-му сегменті; $U_{\max }$ - максимальне значення яскравості пікселів на зображенні.

Оптимізаційна задача (9) вирішується методом ітераційних розрахунків. Проведемо сегментування тонового зображення бортової системи спостереження, що отримано із зони ведення антитерористичної операції [6], удосконаленим методом тематичного сегментування зображень. Вихідне та сегментоване зображення наведені на рис. 3-4 відповідно.

Результати сегментування вихідного зображення (рис. 3) відомими методами [4-6] наведені на рис 5.

Порівняння результатів тематичного сегментування відомими методами (рис. 5) і запропонованим удосконаленим ройовим методом штучної бджолиної колонії (рис. 4) показують, що візуально об’єкти інтересу краще визначаються на рис. 4. Як об'єкти 


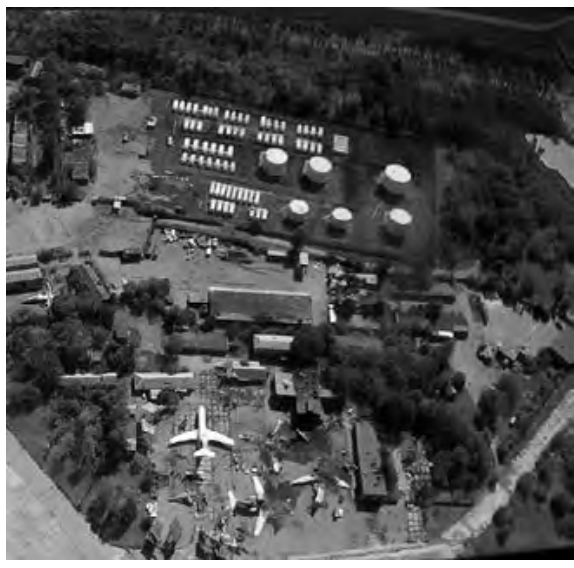

Рис. 3. Вихідне тонове ОЕ3

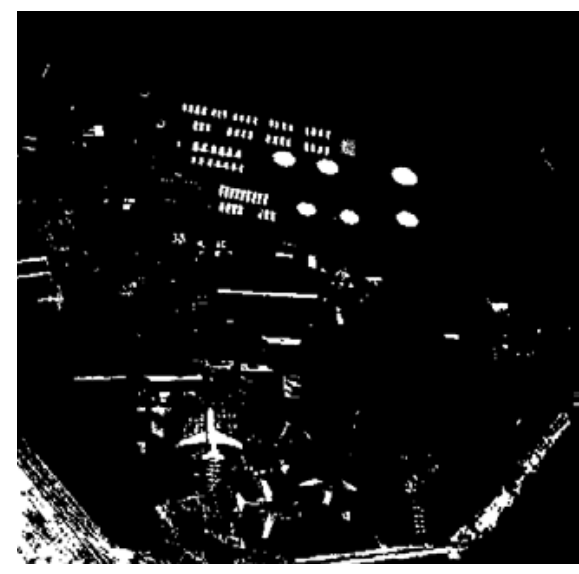

Рис. 4. Сегментоване тонове ОЕЗ

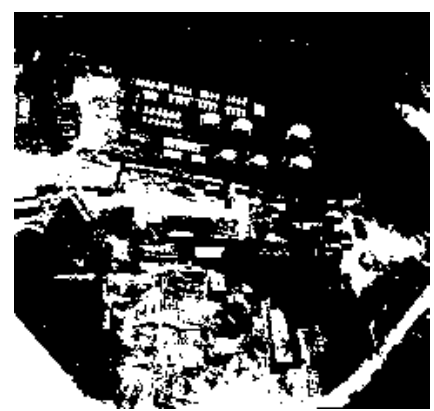

Метод Otsu

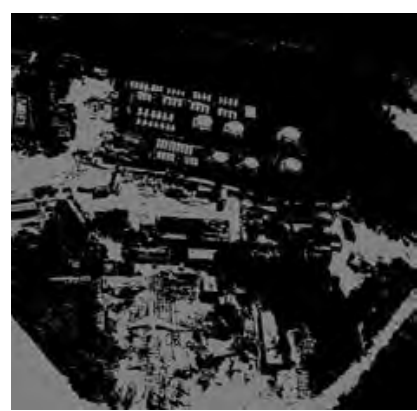

Метод k-means

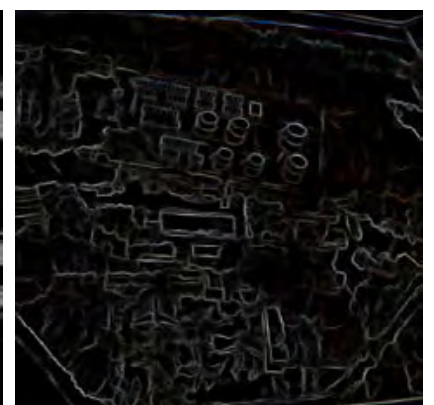

Метод Random forest

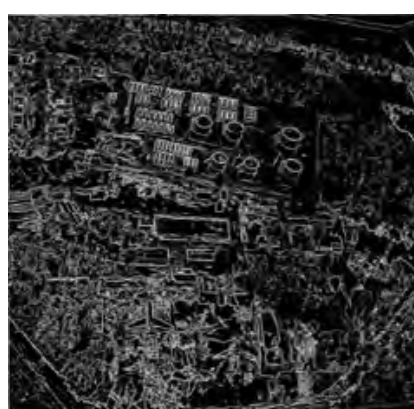

Мурашиний метод

Рис. 5. Результати тематичного сегментування ОЕЗ існуючими методами

Таблиця 1

Оцінка помилок першого та другого роду тематичного сегментування ОЕЗ різними методами

\begin{tabular}{|c|c|c|c|c|c|c|c|c|}
\hline $\begin{array}{c}\text { Методи } \\
\text { тематичного } \\
\text { сегментування }\end{array}$ & Otsu & Канні & $\begin{array}{c}\text { k-means } \\
\mathbf{( k = 2 )}\end{array}$ & $\begin{array}{c}\mathbf{k}-\mathbf{m e a n s} \\
\mathbf{( k = 3 )}\end{array}$ & $\begin{array}{c}\text { k-means } \\
(\mathbf{k}=\mathbf{4})\end{array}$ & $\begin{array}{c}\text { Random } \\
\text { forest }\end{array}$ & Мурашиний & ABC \\
\hline$\alpha_{1}, \%$ & 18,30 & 10,50 & 18,50 & 17,30 & 15,50 & 15,90 & 4,15 & 2,70 \\
\hline$\beta_{2}, \%$ & 25,70 & 14,30 & 25,80 & 23,70 & 20,30 & 17,76 & 6,84 & 4,55 \\
\hline
\end{tabular}

інтересу визначені вцілілий і пошкоджений літаки, сховища з нафтою, аеродромні споруди тощо.

Для кількісної оцінки якості тематичного сегментування зображень розраховуються класичні показники оцінки - ймовірності помилок тематичного сегментування першого $\left(\alpha_{1}\right)$ i другого $\left(\beta_{2}\right)$ роду [8-9]. Значення указаних помилок для різних методів тематичного сегментування наведено в таблиці 1.

Аналіз даних таблиці 1 свідчить про те, що впровадження вдосконаленого методу тематичного сегментування зображень бортових систем екологічного моніторингу в модернізацію наявних i розроблення перспективних систем обробки зображень дасть змогу підвищити якість обробки оптикоелектронних зображень, а саме знизити помилки сегментування першого та другого роду на величину від 4\% до $13 \%$.

Головні висновки. У статті проаналізовано основні недоліки відомих методів сегментування
OE3. Для тематичного сегментування OE3 бортових систем екологічного моніторингу запропоновано використання ройового методу штучної бджолиної колонії. Визначена цільова функція у вигляді суми дисперсії сегментів сегментованого зображення. Сформульована оптимізаційна задача, в якій як параметр, що оптимізується, обрано поріг сегментування, а оптимізація полягає в мінімізації цільової функції.

Наведені результати тематичного сегментування вихідного ОЕЗ відомими методами та запропонованим удосконаленим ройовим методом штучної бджолиної колонії. Візуальна оцінка якості тематичного сегментування дає змогу визначити об'єкти інтересу значно краще.

Розраховані значення помилок тематичного сегментування першого та другого роду. Застосування вдосконаленого ройового методу штучної бджолиної колонії дасть змогу підвищити якість обробки опти- 
ко-електронних зображень, а саме знизити помилки сегментування першого та другого роду на величину від 4\% до 13\% порівняно з іншими відомими методами сегментування.
Перспективи використання результатів дослідження. Отримані результати можуть бути використані під час модернізації наявних і розроблення перспективних систем екологічного моніторингу.

\section{Література}

1. Каракеян В.И. Мониторинг загрязнения окружающей среды. Москва: Юрайт, 2016. 397 с.

2. Шовенгердт Р.А. Дистанционное зондирование. Модели и методы обработки изображений. Москва: Техносфера, 2010. $560 \mathrm{c}$.

3. Попов М.О., Гринюк С.В. Стан і перспективи розвитку гіперспектральних систем аерокосмічної розвідки. Наука і оборона. Київ, 2012. № 2. С. 39-47.

4. Барталев С.А., Ховратович Т.С. Анализ возможностей применения методов сегментации спутниковых изображений для выявления изменений в лесах. Современные проблемы дистанционного зондирования Земли из космоса. 2011. Т. 8. № 1. C. 44-62.

5. Ayman El-Baz, Jiang X., Suru J.S. Biomedical image segmentation: advances and trends. US: CRC Press, 2016. 546 p.

6. Segmentation of the images obtained from onboard optoelectronic surveillance systems by the evolutionary method / I. Ruban, H. Khudov, V. Khudov, I. Khizhnyak, O. Makoveichuk. Eastern-European Journal of Enterprise Technologies. 2017. № 5/9 (89). P. 49-57.

7. Karaboga D. and Akay B. A comparative study of Artificial Bee Colony algorithm. Appl. Math. Computing. 2009. Vol. 214. P. $108-132$

8. Метод ройового інтелекту (штучної бджолиної колонії (АВC)) тематичного сегментування оптико-електронного зображення / І.А. Хижняк, О.М. Маковейчук, Р.Г. Худов, В.О. Подліпаєв, Г.В. Горбань, Г.В. Худов. Системи управління, навігації та зв'язку. 2018. № 2 (48). С. 91-96.

9. Худов В.Г., Маковейчук О.М., Хижняк І.А. Оцінка якості еволюційного методу сегментування зображення, що отримано з бортових систем оптико-електронного спостереження. Системи управління, навігації та зв'язку. 2017. № 4 (44). C. 133-137. 


\title{
АНАМІЗ ЗАТРИМОК ТРАНСПОРТНИХ ЗАСОБІВ НА НЕРЕГУАЬОВАНИХ ПІШОХІДНИХ ПЕРЕХОДАХ
}

\author{
Лук'янченко О.Ю., Лисенко М.В. \\ Черкаський державний технологічний університет \\ бул. Шевченка, 460, 18006, м. Черкаси \\ michae196@ukr.net \\ 111188@ukr.net
}

\begin{abstract}
У статті представлена методика збирання даних під час визначення транспортної затримки на нерегульованих пішохідних переходах. Виявлено фактори, які впливають на точність визначення транспортної затримки. Проаналізована зміна швидкості руху транспортного засобу під час проїзду нерегульованого пішохідного переходу. Ключові слова: транспортна затримка, навігаційна система, трек, інтенсивність транспорту, інтенсивність пішоходів.
\end{abstract}

Анализ задержек транспортных средств на нерегулируемых пешеходных переходах. Лукьянченко О.Ю., Лысенко М.В. В статье представлена методика сбора данных при определении транспортной задержки на нерегулируемых пешеходных переходах. Выявлены факторы, влияющие на точность определения транспортной задержки. Проанализировано изменение скорости движения транспортного средства при проезде нерегулируемого пешеходного перехода. Ключевые слова: транспортная задержка, навигационная система, трек, интенсивность транспорта, интенсивность пешеходов.

Analysis of vehicle delays at non-controlled pedestrian crossings. Lukianchenko O., Lysenko M. Technique of data collecting for determining transport delay at non-controlled pedestrian crossing is presented. The paper identifies the factors influencing the determination accuracy of transport delay, analyzes the change of vehicle speed when passing a non-controlled pedestrian crossing. Key words: transport delay, navigation system, track, intensity of traffic, intensity of pedestrians.

Постановка проблеми. Останнім часом спостерігається підвищення впливу нерегульованих пішохідних переходів на пропускну здатність ділянок вулично-дорожньої мережі. У зв'язку зі зростанням дисципліни водіїв нерегульовані пішохідні переходи значно збільшують затримки транспортних засобів, що має враховуватись під час вирішення питань щодо організації дорожнього руху $[1 ; 2]$. Тому актуальним $€$ завдання дослідження затримок транспортних засобів на зазначених ділянках, що пов'язано з:

- розробленням методики розрахунку затримок транспортних засобів на нерегульованих пішохідних переходах;

- уточненням ділянки значень інтенсивності руху пішоходів і транспортних засобів, які впливають на величину затримки транспорту.

Виклад основного матеріалу. Під час дослідження затримок транспортних засобів на нерегульованих пішохідних переходах із застосуванням відеозйомки виникають деякі складності:

- неточне визначення відстані, на якій зменшується і збільшується швидкість транспортного засобу;

- точність виміру часових характеристик має велику похибку;

- велика трудомісткість.

У зв'язку з цим вибрано поєднання цифрової зйомки транспортних і пішохідних потоків і треків навігаційних систем. При цьому пішохідні переходи поділені на два типи:
- зі штучними нерівностями;

- без штучних нерівностей.

Такий поділ зумовлений тим, що під час проїзду пішохідних переходів цих двох типів величина транспортної затримки значно відрізняється. На пішохідних переходах зі штучною нерівністю водій змушений завжди пригальмовувати, тому його транспортна затримка буде завжди більша за нуль. Пішохідні переходи без штучних нерівностей за відсутності пішоходів на них можуть бути пройдені без зниження швидкості транспортного засобу, тому їх транспортна затримка в деяких випадках дорівнює нулю або дуже близька до нього.

На цих переходах у ранковий (9:00-10:00) і вечірній (17:00-18:00) час проводилося збирання даних про інтенсивність транспортних і пішохідних потоків. Під час аналізу руху на переходах виявлені найбільш завантажені з них, на яких пішохідна інтенсивність досягає 362 і 190 піш./год. (рис. 2, 3), а інтенсивність транспорту - 2462 і 3951 авт./год. (рис. 4,5 ). Висока інтенсивність пішоходів спостерігається в районах шкіл, а висока інтенсивність транспорту відзначається на центральних вулицях.

Для вивчення швидкості руху транспортного засобу розглядається історія треку, яка дає змогу запросити інформацію про переміщення транспортного засобу в будь-який указаний проміжок часу (рис. 1).

Після обробки треків усі дані імпортуються в таблиці, при цьому відмічаються точки, які відпо- 


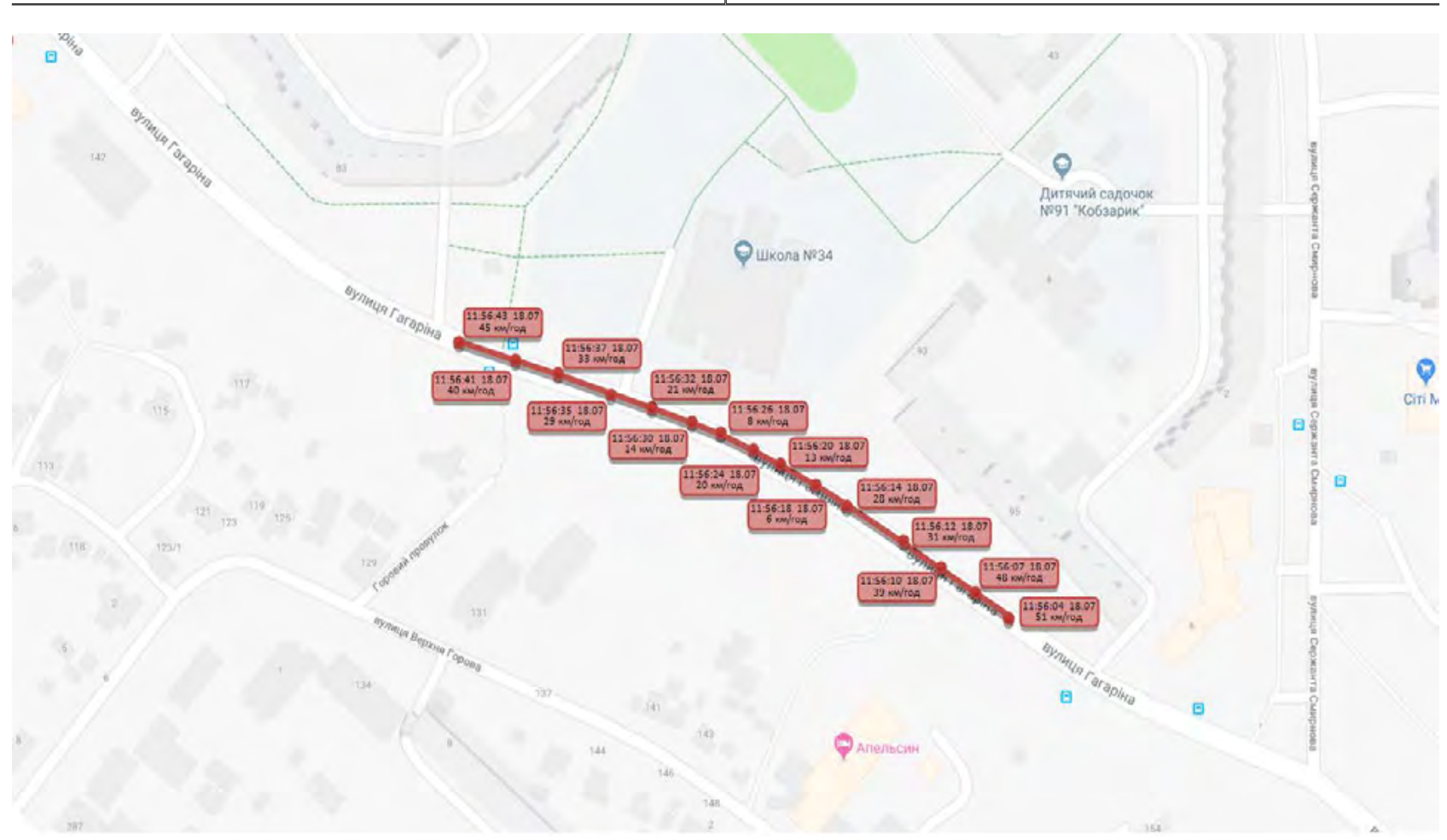

Рис. 1. Побудований трек по вул. Гагаріна з даними часу відстані і швидкості

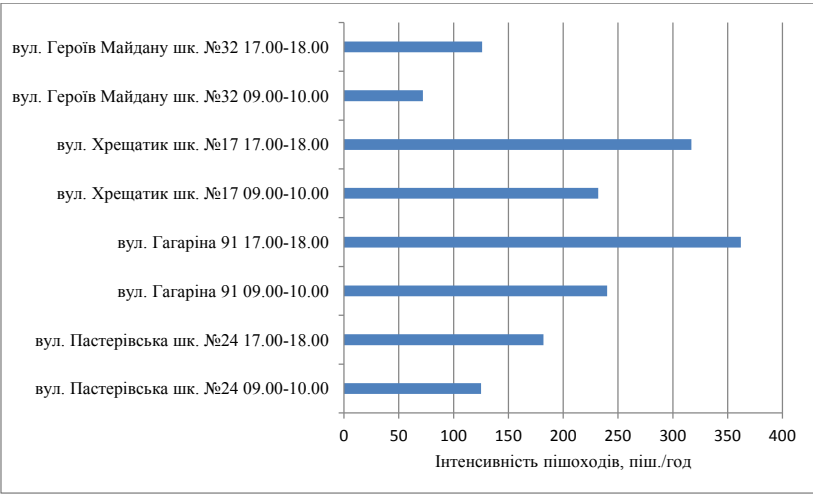

Рис. 2. Інтенсивність пішоходів на нерегульованих пішохідних переходах зі штучними нерівностями

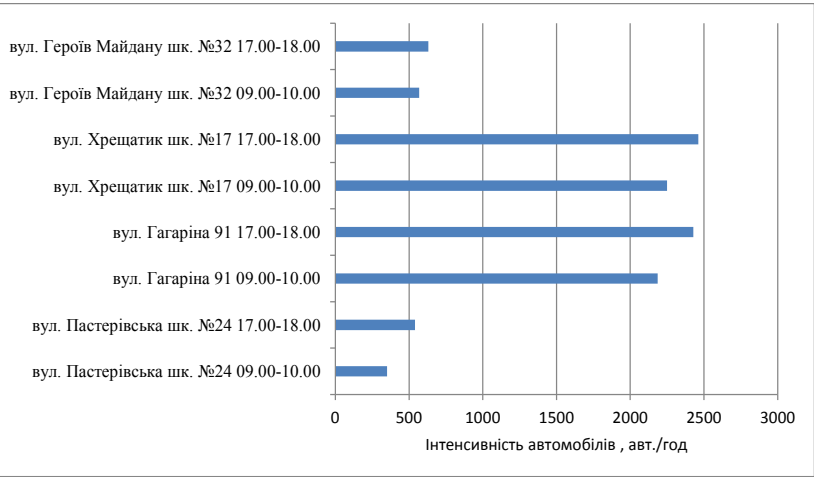

Рис. 4. Інтенсивність автомобілів на нерегульованих пішохідних переходах зі штучними нерівностями

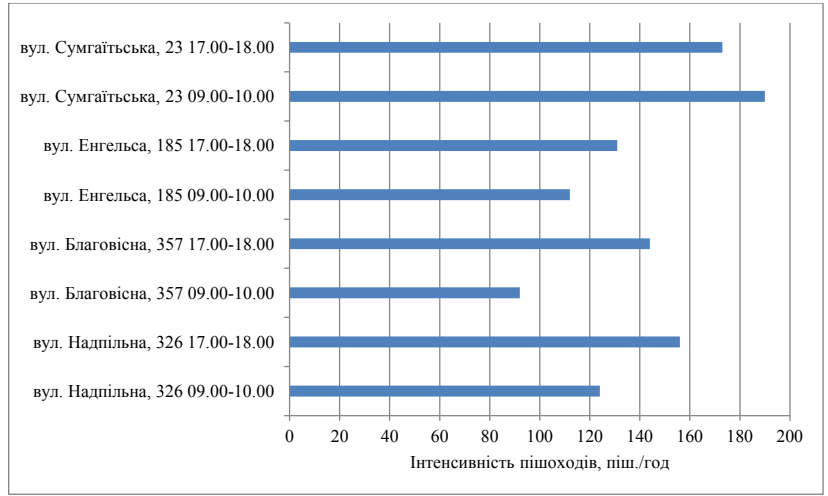

Рис. 3. Інтенсивність пішоходів на нерегульованих пішохідних переходах без штучних нерівностей

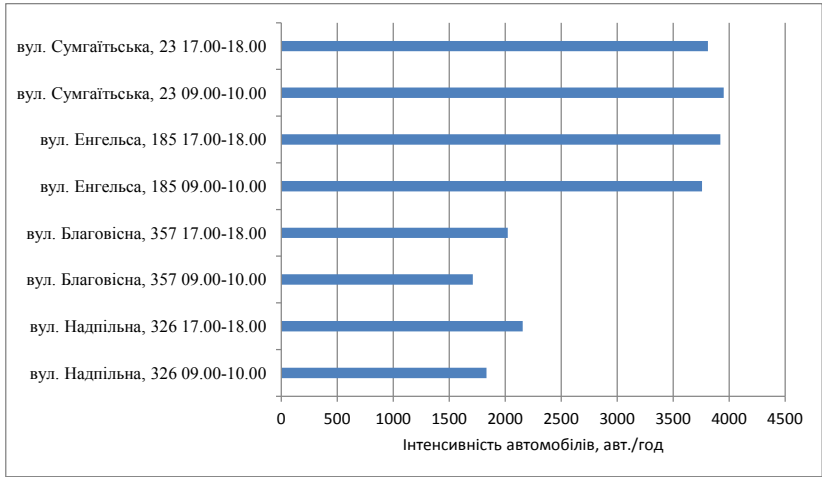

Рис. 5. Інтенсивність автомобілів на нерегульованих пішохідних переходах без штучних нерівностей 
Результати обробки треку

\begin{tabular}{|c|c|c|c|c|}
\hline $\begin{array}{c}\text { Відстань } \\
\text { між точками, м }\end{array}$ & $\begin{array}{c}\text { Сумарна відстань } \\
\text { між точками, м }\end{array}$ & $\begin{array}{c}\text { Швидкість, } \\
\text { км/год. }\end{array}$ & $\begin{array}{c}\text { Час між точками, } \\
\text { с }\end{array}$ & $\begin{array}{c}\text { Сумарний час } \\
\text { між точками, с }\end{array}$ \\
\hline 0 & 0 & 51 & 0 & 0 \\
\hline 43 & 43 & 48 & 3 & 3 \\
\hline 37 & 80 & 39 & 3 & 6 \\
\hline 20 & 100 & 31 & 2 & 10 \\
\hline 17 & 117 & 28 & 2 & 14 \\
\hline 20 & 137 & 6 & 4 & 20 \\
\hline 4 & 141 & 13 & 2 & 22 \\
\hline 22 & 163 & 20 & 4 & 26 \\
\hline 8 & 171 & 8 & 2 & 31 \\
\hline 7 & 178 & 14 & 4 & 33 \\
\hline 10 & 188 & 21 & 2 & 37 \\
\hline 21 & 209 & 29 & 3 & 39 \\
\hline 18 & 227 & 33 & 2 & 42 \\
\hline 42 & 269 & 40 & 4 & 2 \\
\hline 24 & 293 & 45 & 3 & \\
\hline 41 & 334 & 50 & & \\
\hline
\end{tabular}

відають положенню пішохідних переходів. На основі отриманих даних будується графік зміни швидкості транспортного засобу (рис. 6). У кожній точці графіка перша цифра позначає відстань від початкової точки до тієї, яка розглядається, друга цифра - швидкість транспортного засобу в цій точці.

Результати обробки даних дають змогу зробити такі головні висновки:

- затримки транспортних засобів на нерегульованих переходах варіюються в діапазоні від 0 до 60 с (за відсутності пішоходів зниження швидкості руху транспортного засобу було незначним, тому транспортна затримка в такому випадку ухвалювалася рівною 0);

- довжина зони впливу пішохідного переходу варіюється від 90 до 350 метрів (більші значення - випадки утворення транспортних черг на підході до нерегульованого переходу).

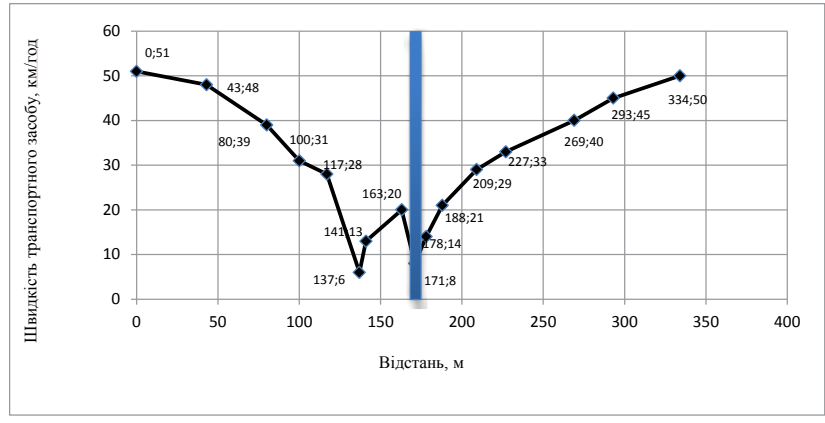

Рис. 6. Графік зміни швидкості руху транспортного засобу під час проїзу нерегульованого пішохідного переходу

Перспективи використання результатів дослідження. Дослідження можна використати під час розрахунку залежності затримки транспортних засобів від інтенсивності пішоходів на пішохідних переходах зі штучною нерівністю й без неї.

\section{Література}

1. Мовчан М.І., Собко Ю.М. Проектування автомобільних доріг: навчальний посібник. Львів: Видавництво Львівської політехніки, 2012. $116 \mathrm{c.}$

2. Лобанов Е.М. Транспортная планировка городов. Москва: Транспорт, 1990. 240 с.

3. Бабков В.Ф. Дорожные условия и безопасность движения: учебник для вузов. Москва: Транспорт, 1993. 271 с.

4. Клинковштейн Г.И., Афанасьев М.Б. Организация дорожного движения: учебник для вузов. 5-е изд., перераб. и доп. Москва: Транспорт, 2001. 247 с.

5. Системологія на транспорті: підручник: у 5 кн. / за заг. ред М.Ф. Дмитриченка, Е.В. Гаврилов, М.Ф. Дмитриченко, В.К. Доля та ін. Київ, 2005. 452 с. С. 447-448. 


\title{
СТАТИСТИЧНІ ПАРАМЕТРИ РАДІАЦІЙНОГО ФОНУ МІСТА
}

\author{
Хворов М.М., Гривківська О.В., Кургузенкова Л.А. \\ Європейський університет \\ бульвар Академіка Вернадського, 16в, 03115, м. Київ \\ m_khvorov@ukr.net
}

\begin{abstract}
У статті проведено вимірювання і статистичну обробку параметрів радіаційного фону об'єктів міста Києва. Зазначено, що в межах допустимої норми радіаційного фону спостерігаються значні коливання, які зумовлені внеском техногенного складника. Ключові слова: радіаційний фон, статистична обробка результатів вимірювання, гістограми частотного розподілу.

Статистические параметры радиационного фона города. Хворов М.М., Грывкивская О.В., Кургузенкова Л.А. В статье проведены измерения и статистическая обработка параметров радиационного фона объектов города Киева. Отмечено, что в пределах допустимой нормы радиационного фона наблюдаются значительные колебания, обусловленные вкладом техногенной составляющей. Ключевые слова: радиационный фон, статистическая обработка результатов измерений, гистограммы частотного распределения.
\end{abstract}

Statistical parameters of the radiation background of the city. Khvorov M., Hryvkivska O., Kurhuzenkova L. Measurement and statistical processing of radiation background parameters of the city of Kiev was carried out. It is noted that within the allowable radiation background there are significant fluctuations that are due to the contribution of the technogenic component. Key words: radiation background, statistical processing of measurement results, frequency distribution histograms.

Постановка проблеми. Одним із головних складників екологічної безпеки міста є радіаційна безпека, яка визначається як дотримання допустимих меж радіаційного впливу на персонал, населення та навколишнє природне середовище, встановлених нормами, правилами і стандартами з безпеки [1]. Оцінювання радіаційної небезпеки урбанізованої території є важливим складником аналізу й управління екологічним ризиком. Сучасні міста характеризуються підвищеною густиною населення, яка безперервно зростає, i, відповідно, значними масштабами антропогенної діяльності. Така діяльність включає використання радіаційних технологій передусім у медицині й техніці. Дослідження шкідливого впливу радіаційного випромінювання стають особливо важливими і складними в умовах дії ефекту синергізму - одночасної дії спектру негативних факторів антропогенного походження - промислових і комунальних хімічних забруднень, викидів транспорту та енергетики. Складниками радіаційного фону (порядку 3,0 м3в/рік) є природний радіаційний фон - доза опромінення, створювана космічним випромінюванням, а також природними радіонуклідами в землі, воді, повітрі, інших елементах біосфери, харчових продуктах та організмі людини; внесок у формування глобальної середньої річної ефективної дози - 2,4 м3в/рік; і техногенно змінений фон - доза опромінення, що створюється в результаті діяльності людини, в основному за рахунок медичних джерел випромінювання, глобальних випадінь радіонуклідів, будматеріалів, телебачення, авіації; це природний радіаційний фон, змінений у процесі діяльності людини; його внесок у форму- вання глобальної середньої річної ефективної дози 0,6 мЗв/рік.

Виклад основного матеріалу. Відносно новим джерелом радіаційного випромінювання є сучасна техніка мобільного зв'язку, а саме система тоталітарного охоплення всієї території країни та їі міст мережею потужних передавачів сигналу стільникового зв'язку. Прибутки від мобільного зв'язку вже зараз перевищують прибутки від міжнародного зв'язку в стаціонарних телефонних мережах, а в майбутньому ця різниця обіцяє зрости ще більше. У деяких країнах ємність мереж стільникового зв'язку вже перевищила аналогічний показник для стаціонарних мереж. Високі темпи розвитку стільникових мереж спостерігаються в Україні, випереджаючи темпи зростання в Західній Європі, яка вже зараз практично наближається до 100-відсоткового насичення ринку [2], у зв'язку з чим темпи приросту мобільних абонентів останніми роками знижуються (рис. 1). За результатами проведених за останні десять років вимірювань, рівні електромагнітного випромінювання на території житлової забудови, в приміщеннях житлових і громадських будинків у зоні можливого впливу передавальних антен базових станцій коливались у межах від 0,32 до 1,6 мкВт/см² при гранично допустимому рівні для населення 2,5 мкВт/ $\mathrm{cm}^{2}$.

Під час роботи мобільного телефону електромагнітне випромінювання сприймається не лише приймачем базової станції, а й тілом користувача, насамперед його головою. Відмінною особливістю стільникового телефону як джерела електромагнітного випромінювання $є$ його максимальне набли- 
ження до голови користувача на відстань два-п'ять сантиметрів у неконтрольованих умовах. Впливу зазнають головний мозок, периферичні рецепторні зони вестибулярного, слухового аналізаторів, сітківка очей. Негативної дії випромінювання стільникового телефону зазнають також і люди, які його оточують, коли він розмовляє по телефону.

Саме базові станції покривають усю зону дії стільникового зв'язку техногенним електромагнітним полем. Базові станції частіше за все розташовуються в місцях постійного перебування людини, тобто відбувається цілодобовий вплив на людину низькоінтенсивного електромагнітного поля радіочастотного діапазону.

Біологічний ефект дії електромагнітного випромінювання формується залежно від дальності абонента від базової станції й тривалості дії (частоти і тривалості телефонної розмови); вихідного стану об'єкта дії (вік, стать, стан здоров'я, індивідуальна чутливість тощо); розподілу енергії в біологічних тканинах (вид тканин, глибина проникнення високочастотного поля в організм).

В Україні діють Державні санітарні норми і правила захисту населення від впливу електромагнітних випромінювань [3], які узгоджені зі світовими стандартами [4]. Ці санітарні норми разом із методичними вказівками до них дають змогу регламентувати умови експлуатації й розміщення засобів випромінювання стосовно житлової забудови й тим самим забезпечити охорону здоров'я населення від впливу електромагнітних полів, що виникають у навколишньому середовищі.

Метою роботи $є$ експериментальне дослідження рівня радіаційного фону низки об'єктів м. Києва та математична обробка результатів, зважаючи на принципово статистичний характер показників. Вимірювання проводили за допомогою індикаторів

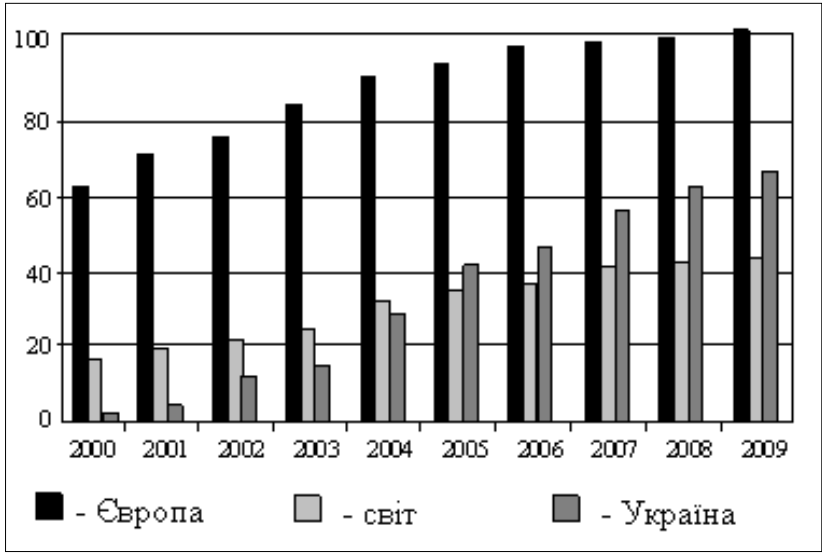

Рис. 1. Темпи приросту мобільних абонентів в Украӥні й Західній Європі [2]

радіоактивності Soeks-01M i РАДЕКС РД503, які проводять оцінювання радіаційного фону об'єкта за величиною потужності іонізуючого випромінювання (гама, бета, рентгенівський діапазони). Діапазон вимірювань потужності експозиційної дози - 0,059,99 мкЗв/год. (5-999 мкР/год.), випадкова похибка при довірчій достовірності - 0,95 (відтворюваність показників), \% - +/- (15+6/P), де Р - потужність дози в мкЗв/год. Вибірка кількості вимірювань фону на кожному об'єкті - 50 із кратністю 2 двома приладами.

Математична обробка експериментальних даних включала розрахунки в програмі Excel параметрів [5]:

математичне сподівання випадкової величини радіанного фону кожного об'єкта як суми попарних добутків величини потужності дози фону $\mathrm{x}_{\mathrm{i}}$ на ймовірність пї появи $\mathrm{p}_{\mathrm{i}}$

$$
M(X)=\sum_{i=1}^{\infty} x_{i} p_{i}
$$

дисперсія (середнє арифметичне квадратів відхилень кожного значення величини фону від загальної середньої величини, або середній квадрат відхилень)

Статистичні параметри радіаційного фону об'єктів м. Києва

\begin{tabular}{|c|c|c|c|c|c|c|}
\hline \begin{tabular}{|c|}
$№$ \\
$3 /$ II
\end{tabular} & $\begin{array}{c}\text { Об'скт } \\
\text { спостереження }\end{array}$ & 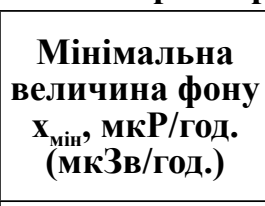 & $\begin{array}{c}\text { Максимальна } \\
\text { величина фону } \\
\text { x }_{\text {макс }}, \text { мкР/год. } \\
\text { (мкЗв/год.) }\end{array}$ & \begin{tabular}{|c|} 
Математичне \\
сподівання \\
мкР/год. \\
(мкЗв/год.) \\
М(х) \\
\end{tabular} & $\underset{\mathbf{S}^{2}}{\text { Дисперсія }}$ & $\begin{array}{c}\text { Середнс } \\
\text { квадратичне } \\
\text { відхилення } \\
\text { мкР/год. } \\
\text { (мкЗв/год.) S }\end{array}$ \\
\hline 1 & Цегляний будинок & $14(0,14)$ & $19(0,19)$ & $11(0,11)$ & 1,1 & $1,0(0,01)$ \\
\hline 2 & Бетонний будинок & $12(0$ & 21( & $15(0,15)$ & 13 & $1,1(0,01)$ \\
\hline 3 & $\begin{array}{l}\text { Площа «Майдан } \\
\text { незалежності» }\end{array}$ & $13(0,13)$ & $20(0,20)$ & $17(0,17)$ & 2,5 & $1,6(0,02)$ \\
\hline 4 & $\begin{array}{l}\text { Станція метро } \\
\text { «Майдан } \\
\text { незалежності» }\end{array}$ & $5(0,05)$ & $11(0,11)$ & $9(0,09)$ & 5,5 & $2,3(0,02)$ \\
\hline 5 & $\begin{array}{l}\text { Станція метро } \\
\text { «Арсенальна» }\end{array}$ & $11(0,11)$ & $16(0,16)$ & $13(0,13)$ & 8,9 & $3,0(0,03)$ \\
\hline 6 & $\begin{array}{l}\text { Станція метро } \\
\text { «Гідропарк» }\end{array}$ & $16(0,16)$ & $27(0,27)$ & $21(0,21)$ & 10,7 & $3,3(0,03)$ \\
\hline 7 & Бульвар Вернадського & $10(0,10)$ & $18(0,18)$ & $14(0,14)$ & 6,2 & $2,2(0,02)$ \\
\hline 8 & Лісопарк «Феофанія» & $8(0,08)$ & $19(0,19)$ & $12(012)$ & 9,0 & $3,0(0,03)$ \\
\hline
\end{tabular}



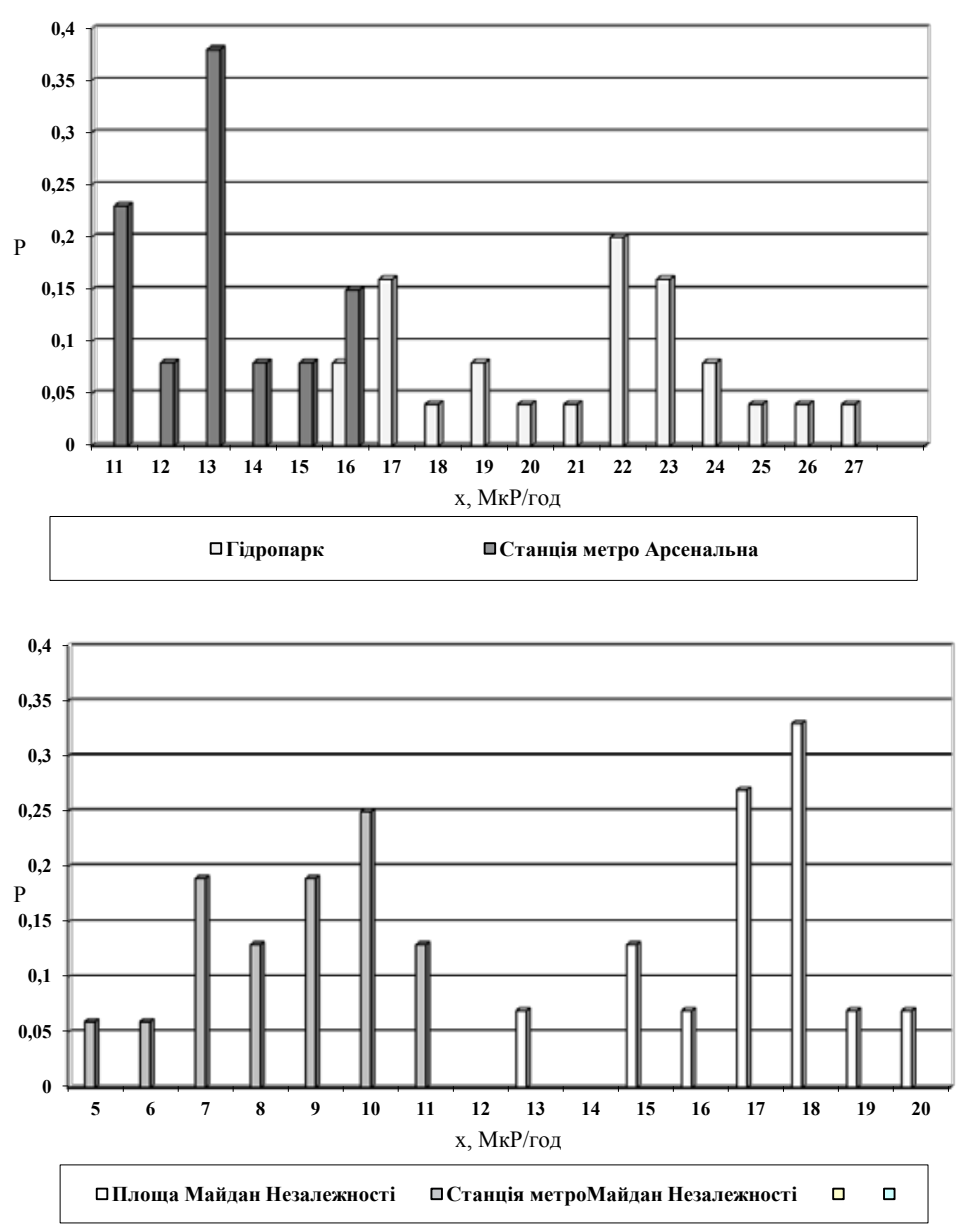

Рис. 2. Гістограми частотного розподілу радіаційного фону деяких об'єктів Києва

$$
S^{2}=\frac{\sum\left(x_{i}-\bar{x}\right)^{2} n_{i}}{\sum n_{i}}
$$

середнє квадратичне відхилення

$$
S=\sqrt{\frac{\sum\left(x_{i}-\bar{x}\right)^{2} n_{i}}{\sum n_{i}} .}
$$

Середнє квадратичне відхилення (мкР/год. або мкЗВ/год.) - це узагальнена характеристика абсолютних розмірів варіації величин фону в іiі сукупності.

Вибір об'єктів дослідження статистичного радіаційного фону зумовлений потребою охоплення території з максимальним рівнем антропогенного навантаження (площа «Майдан незалежності», станція метро «Гідропарк») з порівняно з приміською зоною (лісопарк «Феофанія»). Гістограми частотного роз- поділу (рис. 2) наглядно демонструють статистичний характер параметрів радіаційного фону.

Головні висновки. Представлені експериментальні дані та результати їх статистичної обробки свідчать, що радіаційний фон об'єктів Києва знаходиться в межах чинних норм і не перевищує величину 30 мкР/год. (0,3 мкЗв/год.). У зазначених межах спостерігаються значні коливання величини фону та дисперсії (таблиця 1), причиною яких є різний рівень антропогенного складника, зокрема, за рахунок внеску впливу електромагнітного випромінювання систем мобільного зв'язку. Так, на відкритій місцевості (станція метро «Гідропарк») величини фону й дисперсія даних значно вищі, ніж на глибоких станціях метро («Арсенальна»). У сучасних умовах постійного зростання антропогенного впливу необхідно регулярне проведення радіаційного моніторингу.

\section{Література}

1. Про використання ядерної енергії та радіаційну безпеку: Закон України від 8 лютого 1995 року № 40/95-ВР.

2. Бойко А.Б. Оцінка сучасного стану галузі зв’язку та інформатизації в Україні. Економіка. Управління. Інновації. 2015 . № 1.

3. Основні санітарні правила забезпечення радіаційної безпеки України: Наказ Міністерства охорони здоров'я України від 2 лютого 2005 року № 54.

4. Attix F.H. Introduction to radiological physics and radiation dosimetry. John Wiley \& Sons, Inc, 2008. 607 c.

5. Сеньо П.С. Теорія ймовірностей та математична статистика. Київ: Знання, 2007. 556 с. 


\title{
МОДЕАЮВАННЯ Й РОЗРОБАЕННЯ ПРОГРАМНОГО КОМПАЕКСУ ДАЯ РОЗВ'ЯЗАННЯ ЗАВДАНЬ КООРДИНАЦІЙНОГО КЕРУВАННЯ В УМОВАХ ВИНИКНЕННЯ ПРОСТОРОВО-РОЗПОДІАЕНИХ НАДЗВИЧАЙНИХ СИТУАЦІЙ
}

\author{
Ляшенко О.М. \\ Херсонський національний технічний університет \\ Бериславське шосе, 4, 73008, м. Херсон \\ olenakntu@gmail.com
}

\begin{abstract}
У дослідженні поставлено та вирішено науково-прикладну проблему моделювання й розроблення програмного комплексу для розв'язання завдань координаційного керування в умовах виникнення просторово-розподілених надзвичайних ситуацій. Запропоновані програмні засоби й технології забезпечать підвищення якості прийняття рішень завдяки використанню координаційних стратегій під час ліквідації надзвичайних ситуацій; зменшення тривалості ліквідації надзвичайних ситуацій завдяки використанню оперативної інформації про обстановку в зоні надзвичайних ситуацій; мінімізацію ресурсних і матеріальних витрат завдяки своєчасному коректуванню й уточненню планів дій з ліквідації наслідків надзвичайних ситуацій. Ключові слова: координаційне керування, програмний комплекс, просторово-розподілені надзвичайні ситуації.
\end{abstract}

Моделирование и разработка программного комплекса для решения задач координационного управления в условиях возникновения пространственно-распределенных чрезвычайных ситуаций. Ляшенко Е.Н. В исследовании сформулирована и решена научно-прикладная проблема моделирования и разработки программного комплекса для решения задач координационного управления в условиях возникновения пространственно-распределенных чрезвычайных ситуаций. Предложенные программные средства и технологии обеспечат повышение качества принятия решений благодаря использованию координационных стратегий при ликвидации чрезвычайных ситуаций; уменьшение продолжительности ликвидации чрезвычайных ситуаций благодаря использованию оперативной информации об обстановке в зоне чрезвычайных ситуаций; минимизацию ресурсных и материальных затрат благодаря своевременной корректировке и уточнению планов действий по ликвидации последствий чрезвычайных ситуаций. Ключевые слова: координационное управление, программный комплекс, пространственно-распределенные чрезвычайные ситуации.

Modeling and developing a software complex to solve tasks of coordinating control under conditions of spatially-distributed emergencies. Liashenko $\mathbf{O}$. The applied scientific research on the problems of modeling and developing a software complex to solve tasks of coordinating control under conditions of spatially-distributed emergencies, has been formulated and solved. The proposed software and technologies will provide: improving the quality of decision-making by using the coordination strategies in emergency response; reducing the duration of emergency response by using the operational information about the situation in the emergency zone; minimization of resource and material costs by timely adjustment and clarification of emergency response plans. Key words: coordinating control, software complex, spatially-distributed emergencies.

Постановка проблеми. Аналіз статистичних даних про виникнення надзвичайних ситуацій (далі - НС) в Україні впродовж останніх п’яти років показує тенденцію постійного зростання їх кількості й масштабності $[1 ; 2]$. В умовах виникнення НС необхідна чітка координація дій органів управління, а також ефективне координаційне керування силами та засобами Державної служби з надзвичайних ситуацій України (далі - ДСНС), що залучаються для локалізації зон і ліквідації наслідків НС, з метою порятунку життя, збереження здоров'я людей, зниження екологічних і матеріальних збитків, завданих природному середовищу, а також припинення дії характерних для $\mathrm{HC}$ небезпечних факторів.

Отже, науково-прикладною проблемою дослідження $є$ моделювання та розроблення програмного комплексу для функціонування в умовах виникнення НС різного походження, що забезпечить підвищення обгрунтованості, оперативності й ефективності рішень, які приймаються під час виконання основних завдань координаційного керування в режимах повсякденної готовності, підвищеної готовності (у разі загрози виникнення НС) і надзвичайної ситуації (у разі виникнення та ліквідації НС).

Актуальність дослідження підтверджується тим, що в результаті розв'язання науково-прикладної проблеми буде сформовано й обгрунтовано наукові підходи до розв'язання завдань координації в складних просторово-розподілених динамічних системах, до яких можна зарахувати $\mathrm{HC}$, в умовах невизначеності, наявності динамічних збурень різної природи та дефіциту часу на прийняття рішень.

Зв'язок авторського доробку із важливими науковими та практичними завданнями. 
Дослідження виконано відповідно до пріоритетних цілей, сформульованих у Стратегії державної екологічної політики України на період до 2030 року. Також тема дослідження $є$ складником науково-дослідних робіт (далі - НДР), що проводяться в Херсонському національному технічному університеті в рамках держбюджетних НДР «Розробка теоретичних та методологічних основ формування системи управління лісовими ресурсами регіону» (№ 0113U007939) і «Моделювання процесів координаційного керування та прийняття рішень в умовах виникнення надзвичайних ситуацій природного характеру» (№ 0117U007290).

Аналіз останніх досліджень і публікацій. Аналіз робіт [2-6] показав, що досить широка аудиторія дослідників ставила перед собою завдання 3 розроблення програмних комплексів, що забезпечать можливість інформаційної підтримки процесу оперативного координаційного керування 3 ліквідації наслідків НС.

Так, у роботі [2] набули подальшого розвитку інформаційна технологія побудови просторової структури техногенних систем із потенційно небезпечними об'єктами (далі - ПНО), яка завдяки використанню мультимедійного подання аварійної ситуації забезпечує можливість синтезу процедур і стратегій оперативного координаційного керування процесом ліквідації НС; метод побудови процедури інтеграції структур ДСНС України в АСУ техногенними комплексами з ПНО, який на основі координаційних стратегій забезпечує мінімізацію ризиків виникнення аварій і скорочує час їх ліквідації.

У праці [3] розглянуто стан і проблеми впровадження системи моніторингу безпеки в Україні та іiі відмінності від систем розвинутих країн. Сутність i призначення системи моніторингу безпеки і прогнозування полягають у спостереженні, контролі та передбаченні небезпечних процесів і явищ природи, техносфери, зовнішніх дестабілізуючих та інших факторів, які є джерелами НС, а також визначенні масштабів НС 3 метою вирішення завдань щодо мінімізації їх поширення.

У роботі [4] розроблено систему, метою якої є підтримка процесів прийняття рішень на етапах підготовки, запобігання та планування системи захисту від природних та інших катастроф. Основою системи $є$ географічна інформаційна підсистема області з усіма необхідними даними про регіон, де сталася НС.

У праці [5] розроблено й упроваджено динамічну інтегровану модель, яку призначено для оперативного керування процесом ліквідації НС. На основі моделі створено прототип системи підтримки прийняття рішень (далі - СППР) в умовах виникнення НС.

У роботі [6] запропоновано модель СППР, яка дає змогу координувати дії сил, що залучаються для ліквідації НС транскордонного характеру. Запропонована технологія дала можливість закласти основи для створення інтегрованих інформаційних
СППР із керування аварійно-рятувальними роботами в умовах виникнення НС транскордонного характеру.

За результатами аналізу останніх досліджень i публікацій можна зробити висновок, що в більшості робіт для вирішення поставлених завдань використовувалися методи: системного аналізу, теорії ймовірності, теорії ієрархічних систем, теорії прийняття рішень. Недоліком використання таких методів є висока обчислювальна складність, що перешкоджає досягненню необхідної швидкості роботи програмних систем, які призначені для функціонування в умовах виникнення НС.

Це й зумовлює актуальність подальших дослідження з обраної теми.

Виділення не вирішених раніше частин загальної проблеми, котрим присвячується означена стаття. Важливу роль у зниженні тяжкості наслідків від НС різного походження відіграє правильність та обгрунтованість рішень 3 оперативного керування, що приймаються в процесі ліквідації НС.

Однією $з$ важливих функцій керування в умовах виникнення просторово-розподілених НС є координація дій сил і засобів ДСНС України.

Варто зазначити, що чим вищі складність і масштабність поширення НС, тим важче забезпечувати ефективну координацію особливо на початкових стадіях їх виникнення та розвитку.

Отже, виникає необхідність у моделюванні та розробленні програмних комплексів для розв'язання завдань координаційного керування в умовах невизначеності й неповноти інформації про параметри поширення НС, необхідні темпи ліквідації, необхідний обсяг ресурсів, а також рівні складності робіт 3 ліквідації НС.

Новизна. У дослідженні поставлено та вирішено науково-прикладну проблему моделювання й розроблення програмного комплексу для розв'язання завдань координаційного керування в умовах виникнення просторово-розподілених НС. Для вирішення поставленої науково-прикладної проблеми використано моделі координації динамічних систем, моделі та методи прийняття рішень, методи інтелектуального аналізу даних і методологію об'єктна-орієнтованого проектування програмних систем.

Методологічне або загальнонаукове значення. Запропоновані програмні засоби й технології забезпечать підвищення якості прийняття рішень завдяки використанню координаційних стратегій у режимах повсякденної готовності, підвищеної готовності (у разі загрози виникнення НС) і надзвичайної ситуації (у разі виникнення та ліквідації НС); зменшення тривалості ліквідації НС завдяки використанню оперативної інформації про обстановку в зоні НС; мінімізацію ресурсних і матеріальних витрат завдяки своєчасному коректуванню й уточненню планів дій з ліквідації наслідків НС та оперативній мобілізації підрозділів ДСНС України. 
Виклад основного матеріалу. Розглянемо питання координації в складних ієрархічних системах (далі - IC), що утворюються органами керування в процесі їхньої спільної діяльності 3 ліквідації наслідків НС.

Нехай існує ієрархічна система $\Theta 3 n$ рівнями ієрархії керування [7].

Задамо множину об'єктів: $A=\left\{A_{i j}\right\}$, де $i-$ рівень керування, $i \in[1 . . n]$, який містить $m_{i}$ об'єктів; $j$ - індекс конкретного об'єкта рівня $i, j \in\left[1 . . m_{i}\right]$.

Побудуємо ієрархію Y у вигляді трійки: $\mathrm{Y}=\langle\perp, A, \prec\rangle$, де $A-$ множина об'єктів ієрархії; $\prec-$ відношення несуворого порядку, що задане над $A ; \perp-$ найменший елемент для $\prec$.

Відношення порядку $\prec \epsilon$ відношенням підпорядкованості: $A_{i j} \prec A_{k l}$ означає, що орган керування $A_{i j}$ підпорядкований органу керування $A_{k l}$. Відповідно, $A_{i j} \in$ керованим об'єктом, а $A_{k l}$ - керуючим об'єктом, що формує для $A_{i j}$ (й інших підлеглих об'єктів) керуючі впливи.

У рамках IC функція керування будь-яким об'єктом $A_{i j}$ реалізується керівником відповідного органу з ліквідації наслідків НС, який цілеспрямовано (шляхом постановки мети, визначення завдань і вибору сил, засобів і ресурсів для їх реалізації) здійснює прийняття рішень.

Відповідно, керівник кожного з об'єктів $A_{i j}$ приймає рішення відповідно до наявної установки $Z_{i j}=\left\langle G_{j}, Q_{j}, R_{j}\right\rangle$, що включає цілі $G_{i j}$, критерії $Q_{i j}$ та обмеження $R_{i j}$ (наприклад, на множині доступних ресурсів або за часом). Виконання прийнятих керівником $A_{i j}$ рішень передбачає реалізацію деякої послідовності керуючих впливів $\left[u_{i j}, \ldots, u_{i j l}\right]$, які є планом $P_{i j}$ (програмою, процедурою, алгоритмом) досягнення мети $G_{i j}$, оптимальним із погляду суб'єктивних установок $Z_{i j}$. При цьому керуючий вплив $u_{i j k}$ можна розглядати як множину одночасно (в момент часу $t_{k}$ ) виконуваних дій $\left\{a_{1 k}, \ldots, a_{m k}\right\}$, кожна 3 яких змінює певний параметр стану об'єкта.

Відповідно, процес координації можна розглядати як координацію рішень, координацію дій [7].

За об'єктом координації рішень розрізняють:

1) координацію в просторі цілей, яка передбачає узгодження приватних цілей $G_{i j}$ взаємодіючих об'єктів $A_{i j}$ для досягнення спільної мети $G_{(i+1) k}$, що встановлюється керуючим об'єктом $A_{(i+1) k}$;

2) координацію в просторі обмежень (ресурсів), яка передбачає узгодження множини обмежень $R_{i j}$ взаємодіючих об'єктів $A_{i j}$ так, що $R_{(i+1) k}=\cup_{j=1}^{m(i+1)} R_{i j}$;

3) координацію в просторі критеріїв, яка передбачає узгодження множини критеріїв прийняття рішень $Q_{i j}$ взаємодіючих об'єктів $A_{i j}$;

4) координацію планів, що передбачає узгодження планів $P_{i j}$ взаємодіючих об'єктів $A_{i j}$ керуючим об'єктом $A_{(i+1) k}$.

Координація дій, як правило, зводиться до такого:
1) координації керуючих впливів, яка передбачає узгодження виконуваних взаємодіючими об'єктами $A_{i j}$ конкретних керуючих впливів у рамках плану $P_{i j}$;

2) координації за часом, що передбачає узгодження в часі моментів застосування керуючих впливів для різних взаємодіючих об'єктів $A_{i j}$.

Для розв'язання завдань координаційного керування побудовано програмний комплекс (далі - ПК), призначення якого полягає в забезпеченні керівників органів управління в умовах виникнення НС інформаційною підтримкою під час виконання основних завдань з ліквідації наслідків НС, а саме [8; 9]:

1) визначення зони $\mathrm{HC}$ i зони можливого ураження;

2) аналітичного опрацювання інформації про обстановку в зоні НС;

3) ведення робочої карти (схеми) зони НC;

4) постійного моніторингу оперативної обстановки в зоні НС з метою регулярних спостережень і прогнозу змін метеорологічних, ландшафтних, радіологічних та інших факторів, що впливають на процес ліквідації наслідків НС;

5) створення сховища даних про НС, а також резерви матеріальних і фінансових ресурсів, необхідних для запобігання НC і реагування на НC;

6) обліку залучених сил і засобів для проведення невідкладних робіт з ліквідації наслідків НC;

7) розроблення, своєчасного коректування й уточнення планів дій щодо запобігання виникненню та ліквідації наслідків НС;

8) розроблення інструкцій 3 координації дій між різними підрозділами ДСНС України;

9) прогнозування й оцінювання соціально-економічних наслідків НС, визначення на основі прогнозу потреби в силах, засобах, матеріальних і фінансових ресурсах;

10) розроблення маршрутів i розрахунок часу прибуття на місце виникнення НС підрозділів, що входять до складу ДСНС України.

ПК складається 3 чотирьох взаємопов'язаних підсистем: підсистеми завантаження та зберігання даних, підсистеми інтелектуального аналізу даних (Data Mining), підсистеми координації рішень і підсистеми візуалізації просторової інформації (рис. 1).

Основою підсистеми завантаження та зберігання даних є сховище даних (далі - СД). СД - предметно-орієнтований, інтегрований, незмінний набір даних, що підтримує хронологію й організований для цілей підтримки прийняття рішень. В основі концепції СД полягає ідея поділу даних, що використовуються для оперативного оброблення та вирішення завдань аналізу. Такий поділ дає змогу оптимізувати як структури даних оперативного зберігання (оперативні БД, файли, електронні таблиці тощо) для виконання операцій уведення, модифікації, видалення та пошуку, так і структури даних, що використовуються для аналізу (для виконання аналітичних запитів) [10]. 


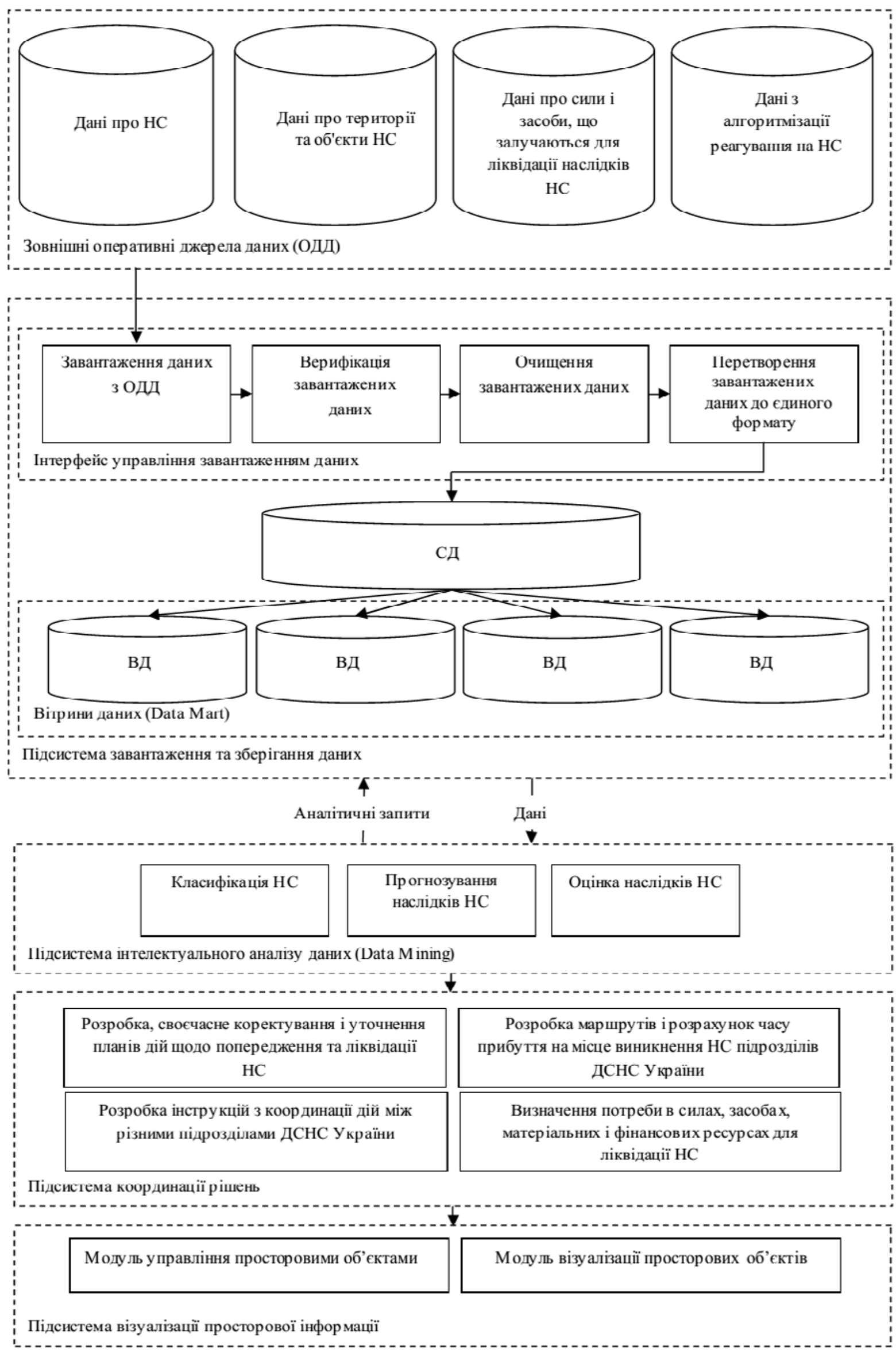

Рис. 1. Концептуальна структура програмного комплексу 
У СД за допомогою інтерфейсу управління завантаженням даних завантажуються дані із зовнішніх оперативних джерел даних (далі - ОДД).

До ОДД належать такі реляційні бази даних (далі - БД): «Дані про НС» (адреса, дата й час виникнення, площа НС, час прибуття підрозділів до місця виникнення НС, кількість поранених, кількість загиблих, матеріальні збитки); «Дані про території та об'єкти НС» (регіон, вид об'єкта, опис об'єкта); «Дані про сили й засоби, що залучаються для ліквідації наслідків НС» (належність сил і засобів до формування, кількість особового складу, кількість пожежної техніки); «Дані з алгоритмізації реагування на НС» (плани дій щодо запобігання НC і ліквідації наслідків НС, інструкції з координації дій між різними підрозділами ДСНС України).

При завантаженні інформації з ОДД в СД дані проходять етапи верифікації, очищення та перетворення. Багато даних не потрапляє в СД, оскільки вони позбавлені сенсу з погляду використання в процедурах аналізу.

Далі очищені дані завантажуються в цільові вітрини даних (далі - ВД) і стають доступними користувачеві для аналізу і звітності. Отже, кінцеві користувачі мають можливість доступу до детальних даних СД для отримання більш повної інформаційної картини про НС.

Основне завдання підсистеми інтелектуального аналізу даних - надати керівникам інструмент для виконання аналізу даних. Підсистема не генерує правильні рішення, а тільки надає дані у відповідному виді (звіти, таблиці, графіки тощо) для вивчення й аналізу.

За ступенем «інтелектуальності» обробки даних під час аналізу можна виділити три класи завдань, які вирішуються підсистемою: інформаційно-пошукові - підсистема здійснює пошук необхідних даних; оперативно-аналітичні - підсистема виробляє групування даних у будь-якому вигляді, необхідному керівникам; інтелектуальні - підсистема здійснює пошук функціональних і логічних закономірностей у накопичених даних, здійснює побудову моделей i правил, які пояснюють знайдені закономірності (прогнозування наслідків НС, класифікація НС, оцінювання наслідків НС) [10].
У підсистемі координації рішень на основі даних, отриманих із підсистеми інтелектуального аналізу даних, здійснюються розроблення, своєчасне коректування й уточнення планів дій щодо запобігання виникненню НС і ліквідації наслідків НС; розроблення інструкцій з координації дій між різними підрозділами ДСНС України; розроблення маршрутів i розрахунок часу прибуття на місце виникнення НС підрозділів ДСНС України й визначається потреба в силах, засобах, матеріальних і фінансових ресурсах, які необхідні для ліквідації НС.

Підсистема візуалізації просторової інформації складається 3 двох модулів: модуля управління просторовими об'єктами та модуля візуалізації просторових об'єктів.

Модуль управління просторовими об'єктами дає керівникам змогу здійснювати такі операції: операції векторизації (розроблення додаткових векторних шарів мапи), вимірювальні операції, операції буферизації (виділення зон НС), просторові запити (наприклад, пошук відповідної ділянки місцевості за іiі номером), відновлення об'єктів за координатами.

Модуль візуалізації просторових об'єктів дає керівникам змогу здійснювати роботу з векторними шарами мапи. Ці шари відображають географічні особливості території, на якій сталася НС, розташування сил і засобів, що залучаються для ліквідації $\mathrm{HC}$, площу НС і плани ліквідації НС.

Головні висновки. У статті розроблено програмний комплекс для функціонування в умовах виникнення НС різного походження, використання якого забезпечить підвищення обгрунтованості, оперативності й ефективності рішень, що приймаються під час виконання основних завдань координаційного керування в режимах повсякденної готовності, підвищеної готовності (у разі загрози виникнення НС) і надзвичайної ситуації (у разі виникнення та ліквідації НС).

Сформовано й обгрунтовано наукові підходи до розв'язання завдань координації в складних просторово-розподілених динамічних системах, до яких можна зарахувати НC, в умовах невизначеності, наявності динамічних збурень різної природи та дефіциту часу на прийняття рішень.

\section{Література}

1. Інформаційно-аналітична довідка про виникнення НС в Україні упродовж 9 місяців 2018 року. URL: http://www.dsns.gov.ua/ua/Dovidka-za-kvartal/83622.html.

2. Рак Т.Є. Ієрархічні моделі та інформаційні технології оперативного управління в умовах надзвичайних ситуацій: автореф. дис. ... докт. тех. наук: спец. 05.13.06 «Інформаційні технології» / Національний університет «Львівська політехніка». Львів, 2013. 39 с.

3. Кропотов П.П., Бєгун В.В., Гречанінов В.Ф. Створення сучасної системи моніторингу безпеки - актуальна державна та наукова задача. Системи обробки інформації. 2015. Вип. 11 (136). С. 199-206.

4. Buzolic J., Mladineo N., Knezic S. Decision support system for disaster communications in Dalmatia. International Journal of Emergency Management. 2009. Vol. 1 (2). P. 191-201.

5. Asghar S., Alahakoon D. \& Churilov L. A Dynamic Integrated Model for Disaster Management Decision Support Systems. International Journal of Simulation. 2006. Vol. 6 (10-11). P. 95-114.

6. Бердашев Б.Ж. Модель адаптивной системы информационной поддержки управления ликвидацией чрезвычайных ситуаций трансграничного характера: дисс. ... канд. техн. наук: спец. 05.13.10. Москва: Академия Государственной противопожарной службы МЧС России, 2014. 155 с. 
7. Ляшенко Е.Н., Шерстюк В.Г. Разработка модели координации сил и средств в иерархической системе гражданской защиты населения. Технологический аудит и резервы производства. 2015. № 4/2 (24). С. 4-10.

8. Ляшенко О.М., Кирийчук Д.Л. Комп’ютерна програма «Система координації дій з попередження виникнення та ліквідації надзвичайних ситуацій природного характеру «DM SYSTEM FOR CANES». Авторське право на твір, свідоцтво № 69379 від 26.12.2016. Зареєстроване в Державній службі інтелектуальної власності України.

9. Ляшенко О.М. Інформаційна система підтримки прийняття координаційних рішень під час ліквідації наслідків надзвичайних ситуацій. Теорія і практика гасіння пожеж та ліквідації надзвичайних ситуацій: матеріали VIII Міжнародної науково-практичної конференції. Черкаси: ЧІПБ ім. Героїв Чорнобиля НУЦЗ України, 2017. С. 56-58.

10. Методы и модели анализа данных: OLAP и Data Mining / А.А. Барсегян, М.С. Куприянов, В.В. Степаненко, И.И. Холод. Санкт-Петербург: БХВ-Петербург, 2004. 336 с. 


\title{
ЗНКЖЕННЯ РІВНЯ ТЕХНОГЕННОГО НАВАНТАХЕННЯ НА ДОВКІМАЯ ПІД ЧАС ВИКОРИСТАННЯ ВІДХОДІВ СКАА
}

\author{
Гурець Л.Л., Котолевець А.С., Котова I.I. \\ Сумський державний університет \\ вул. Римського-Корсакова, 2, 40007, м. Суми \\ kotolevets.a@gmail.com
}

\begin{abstract}
У статті проведений аналіз системи поводження з відходами склобою в Україні та країнах Європи, розглянуті напрями використання склобою в промисловості, розроблені пропозиції щодо впровадження системи збирання, сортування та підготовки скла. Ключові слова: поводження з відходами, тверді побутові відходи, склобій, система збирання відходів, утилізація.

Снижение уровня техногенной нагрузки на окружающую среду при использовании отходов стекла. Гурец Л.Л., Котолевец А.С., Котова И.И. В статье проведен анализ системы обращения с отходами стеклобоя в Украине и странах Европы, рассмотрены направления использования стеклобоя в промышленности, разработаны предложения по внедрению системы сбора, сортировки и подготовки стекла Ключевые слова: обращение с отходами, твердые бытовые отходы, стеклобой, система сбора отходов, утилизация.
\end{abstract}

Reducing the level of anthropogenic environmental impact due to the use of glass waste. Hurets L., Kotolevets A., Kotova I. The analysis of the waste glass treatment system in Ukraine and European countries is carried out. Considered the use of cullet in industry, developed proposals for the implementation of a system for collecting, sorting and preparing glass. Key words: waste management, municipal solid waste, cullet, waste collection system, recycling.

Постановка проблеми. Світовий технічний прогрес закономірно призвів до того, що існування людини стало екологічно небезпечним передусім через утворення та накопичення величезної кількості відходів виробництва і споживання. За даними національної стратегії управління відходами в Україні, обсяги утворення твердих побутових відходів (далі ТПВ) у 2016 році становили близько 11 млн. тонн [1]. Незважаючи на те що протягом останніх 20 років чисельність населення України постійно скорочується, обсяги утворення відходів збільшуються. Показник утворення відходів в Україні в середньому становить 250-300 кілограмів на рік на людину й має тенденцію до зростання. Як правило, внаслідок недостатнього рівня контролю або відсутності належної системи поводження з побутовими відходами, за офіційними даними, щороку утворюється понад 27 тис. несанкціонованих сміттєзвалищ [1].

Багато видів відходів добре піддаються знешкодженню й переробці $з$ метою їх подальшої утилізації, проте рівень використання таких відходів залишається все ще низьким. Проблеми, що перешкоджають розвитку ринку вторинних матеріальних ресурсів з відходів споживання, можна розділити на техніко-технологічні, організаційно-управлінські, економічні й інформаційні.
У складі ТПВ $12 \%$ - склобій. Основний обсяг відходів скла утворюється за рахунок різних видів склотари. 3 погляду екології скло вважається досить важко утилізованим відходом. Якщо органічні відходи здатні повністю розкладатися протягом 1-3 років, полімерні матеріали розкладаються через 5-20 років, то скло може зберігати свої властивості більше ніж 100 років [2]. Зменшити обсяги відходів і зберегти близько 10000 гектарів землі щорічно можливо шляхом вторинної переробки скла. Сьогодні скло $€$ одним із найважливіших матеріалів, який відіграє ключову роль як у традиційних секторах промисловості (будівельна, автомобільна, пакувальна), так і в більш інноваційних (медицина, оптика, телекомунікації, авіація високі технології й космонавтика) [3]. Воно також відіграє одну з пріоритетних ролей в економії енергетичних ресурсів і первинної сировини на підприємствах $[4 ; 5]$. У зв'язку з цим необхідно виявити основні проблеми, з якими доводиться стикатися в Україні, для досягнення найголовніших цілей щодо рециркуляції скла.

Основна мета роботи - оцінити продуктивність скляної промисловості з погляду переробки склобою, дослідити проблему та напрями утилізації відходів скла в Україні порівняно з іншими країнам світу й обгрунтувати доцільність утилізації скляних виробів. 
Виклад основного матеріалу. Скляні вироби посідають особливе місце в круговій економіці, оскільки скло визначається як «постійний матеріал», тому що він повністю й нескінченно переробляється без будь-якого погіршення його властивостей [6]. Перша згадка про «постійні матеріали» в європейському законодавстві датується 2012 роком у резолюції ресурсоефективності Європи. 3 погляду сталого розвитку можемо подати таке визначення: «Постійно доступні матеріали - це ті, які повторно використовуються, або перероблюються без утрати якості незалежно від того, скільки разів матеріал переробляється» [6].

Виробництво скла - високотемпературний процес, у ході якого споживається значна кількість невідновлюваних ресурсів та енергії (паливо, електроенергія), що сприяє постійному збільшенню екологічного навантаження на навколишнє середовище. Скляна промисловість потребує переходу до більш високих рівнів енерго- й ресурсоефективності, а також упровадження комплексних заходів для зменшення навантаження на довкілля.

До екологічних проблем виробництва скла насамперед належать такі:

- утворення твердих відходів (склобій, сировинні матеріали підготовки шихти у вигляді пилу);

- суспензії та шлами (шлами й осади систем підготовки шихти та очищення стічних вод);

- газоподібні викиди (гази скловарних печей, що містять оксиди азоту, сірки й вуглецю, димові гази сушильного цеху, газова фаза та повітря зі стадій відпалу й обробки скловиробів).

Переробка склобою відіграє одну з пріоритетних ролей в економії ресурсів і первинної сировини на підприємствах, а також сприяє збереженню навколишнього середовища. Так як склобій - це високоякісний сировинний матеріал, його використання у виробництві скла призводить до такого:

- скорочення споживання первинної сировини (кварцовий пісок, сода, доломіт тощо),

- зменшення викидів $\mathrm{CO}_{2}$, який утворюється під час плавлення сировини,

- продовження терміну служби до 30\% і збільшення потужності печі через більш низьку температуру і скорочення тривалості часу плавлення,

- використання меншої кількості палива, що також сприяє зниженню викидів $\mathrm{NO}_{\mathrm{x}}, \mathrm{SO}_{2}$ в навколишнє середовище,

- збереження ділянок землі за рахунок збирання й утилізації, замість поховання,
- 100\% вторинна переробка [7].

За даними Державної служби статистики України (таблиця 1), можна помітити збільшення утворення скляних відходів останніми роками, але утилізація або видалення відходів залишається незначною [8].

Унаслідок значних обсягів неутилізованого склобою з кожним роком зростає площа земель, виведених із господарського обороту під полігони ТПВ. Процес вимивання окремих компонентів зі склобою під впливом атмосферних опадів призводить до забруднення грунтових вод. Пил склобою розноситься вітром і негативно впливає на стан атмосферного повітря поблизу полігонів ТПВ [9].

Першим етапом раціонального поводження зі скляними відходами є збирання й сортування. Практика правильного сортування сміттєвих відходів уже не одне десятиліття застосовується за кордоном. Вона $є$ не тільки добровільним рішенням окремих компаній і громадян, а й справжньою державною програмою, яка впроваджується на законодавчому рівні.

Наприклад, у багатьох промислово розвинених країнах 3 початку 70-х років XX ст. проводиться робота щодо створення системи селективної заготовки відходів скла. Для збирання склобою і склотари встановлюються контейнери в спеціально відведених для цього місцях. Використовувалися й контейнери спеціальної конструкції, наприклад, із трьома відсіками для склобою різного кольору. Таке сортування сприяє виробленню із вторинної сировини продукції відмінної якості. Ініціаторами такої заготовки, як правило, є фірми - виробники скла.

Хорошим прикладом розумного підходу в цій сфері може слугувати Німеччина, де всі відходи суворо класифікуються залежно від можливості їх повторного використання, а підприємства, що допускають утворення сміттєзвалищ, змушені платити додаткові внески в державну казну. Із цих штрафних сум потім оплачується розбирання й сортування сміттєвих звалищ [10].

Швейцарія з моменту заборони змішаного викиду відходів на громадські звалища 2000 року досягла високих показників переробки в 50-80\%. Тут практикується використання спеціальних побутових пакетів або контейнерів, що дають змогу розділити батарейки, пробки від пляшок, скло, папір, старий одяг та інші види сміття [11].

У Німеччині, Франції, Італії, Бельгії, Данії, Австрії, Нідерландах сортування побутових відходів населенням матеріально стимулюється. Там кожну

Таблиця 1

Обсяги утворення скляних відходів і поводження 3 ними, тис. т.

\begin{tabular}{|l|c|c|c|c|c|}
\hline \multicolumn{1}{|c|}{ Рік утворення } & $\mathbf{2 0 1 3}$ & $\mathbf{2 0 1 4}$ & $\mathbf{2 0 1 5}$ & $\mathbf{2 0 1 6}$ & $\mathbf{2 0 1 7}$ \\
\hline Утворення відходів & 40,1 & 23,5 & 22,3 & 25,8 & 34,3 \\
\hline Утилізація відходів & 14 & 1,8 & 2,1 & 1,8 & 3,4 \\
\hline Видалення у спеціально відведені місця & 0,1 & 0,3 & 0,3 & 1,0 & 0,3 \\
\hline
\end{tabular}


групу відходів вивозять окремо за певними графіками. Мешканці будинків кладуть відходи до контейнерів або пакетів, різних за кольорами чи емблемами-позначками. Придатні для утилізації компоненти транспортуються до сортувальних установок, де їх доводять до кондиції, яка відповідає технічним умовам приймання на промислові підприємства як вторинної сировини [12].

За рахунок використання роздільного збирання й сортування багато розвинених країн світу практично повністю вирішують проблему поводження зі скляними відходами, про що свідчить дані таблиці 2 $[13 ; 14 ; 15 ; 16 ; 17]$.

Таблиця 2

Обсяги утворення та перероблення скляних відходів у країнах світу, тис. т.

\begin{tabular}{|l|c|c|c|}
\hline \multicolumn{1}{|c|}{ Країна } & Отримано & Утилізовано & \% \\
\hline США & 11470 & 3030 & 26 \\
\hline Фінляндія & 84815 & 76975 & 90,7 \\
\hline $\begin{array}{l}\text { Велика } \\
\text { Британія }\end{array}$ & 2399 & 1609 & 67,1 \\
\hline Австрія & 252,8 & 234 & 93 \\
\hline Данія & 150,408 & 146,926 & 98 \\
\hline Німеччина & 2483,2 & 2183,2 & 88 \\
\hline Франція & 2712 & 1992 & 73 \\
\hline Свропа & 16575,479 & 11825,477 & 71 \\
\hline
\end{tabular}

Утилізація скла може проходити по замкнутому циклу, це означає, що скло переробляється назад у той самий тип продукту. Процеси із замкнутим циклом забезпечують найвищу фінансову й екологічну віддачу. Однак для цього потрібно скло з низьким рівнем забруднення й у стані, придатному для кольороподілу, що має труднощі під час збирання [18]. Поряд із використанням власного склобою, який утворюється на окремих стадіях процесу, застосовується вторинний або привізний бій, що подається пунктами прийому склотари, базами вторсировини.

У Швейцарії працює скловарна піч, яка виробляє 200 т/добу зеленого скла. Шихта містить 80-85\% склобою, економія палива при цьому становить 0,25\% на 1\% переробленого скла. У деяких випадках у печах використовується до 100\% скляних відходів. Процентний уміст склобою під час виробництва скляних виробів у різних країнах світу наведений у таблиці 3 [19].

Середня питома витрата склобою у виробництві тари за кордоном

\begin{tabular}{|c|c|}
\hline Країна & Склобій, \% \\
\hline США & $30-60$ \\
\hline Швейцарія & $80-85$ \\
\hline Німеччина & 30 \\
\hline Нідерланди & 40 \\
\hline Чехія & 24 \\
\hline Угорщина & 20 \\
\hline
\end{tabular}

На скловарних заводах використовуються різні технологічні схеми, які відрізняються складом шихти, співвідношенням шихта/склобій, способом ïx помелу й завантаження в піч, температурним режимом скловаріння печей і способом формування виробів, але при будь-якому технологічному процесі використання склобою необхідно [19].

Скло після споживача зазвичай містить суміш прозорого та пофарбованого матеріалу й часто забруднюється іншими відходами, що вимагає великих витрат. Тому доцільно використовувати процес утилізації з відкритим циклом. Це процес, у якому скло переробляється в інший продукт, який зазвичай має обмежені можливості для подальшої переробки. Існує можливість використовувати перероблене скло як основи матеріалу для будівництва дорожніх покриттів. Наявність скла в суміші асфальтобетону покращує іï здатність утримувати тепло, так можна отримати більш щільне дорожнє покриття, ніж у разі застосування звичайного асфальту. Такий спосіб утилізації може бути рентабельним і виключає необхідність сортування [20].

Відходи скла можуть бути використані у виробництві будівельних матеріалів. Енергозберігаюча технологія виробництва матеріалів на основі склобою дуже проста, вона не вимагає спеціального обладнання й дає змогу вести виробництво на вільних площах діючих об'єктів будіндустрії без особливих матеріальних вкладень. Після операцій сортування, дроблення, помелу й поділу на фракції скло стає повністю готовою сировиною для отримання будівельних матеріалів і виробів. Фракції склобою більше ніж 5 мм застосовують у бетонах як великий заповнювач, дрібні фракції - як дрібний заповнювач, а тонкомолотий порошок - як зв'язувальну речовину [2].

У Гонконгському політехнічному університеті проведена велика дослідницька робота 3 пошуку практичних способів утилізації відпрацьованого скла для виробництва різних бетонних виробів, таких як бетонні блоки, бетон, який самоущільнюється, й архітектурний бетон [21].

Широко застосовується склобій також у виробництві оздоблювальних матеріалів. Битим склом можна обробляти зовнішні стіни будівель, робити художнє оформлення вестибюлів, ванних кімнат та інших приміщень. Усе більше застосовуються облицювальні плитки, виготовлені з використанням склобою. Серед облицювальних плиток особливе місце посідає склокерамічна плитка, яка відрізняється своєю довговічністю, морозо- й атмосферостійкістю i здатністю підтримувати нормальний мікроклімат усередині будівель. 3 неї можна набирати «килими», що надають будівлям оригінального вигляду. Плитка $\epsilon$ дешевим облицювальним матеріалом, причому виготовлення облицьованих нею панелей може бути механізовано на всіх стадіях виробництва [22].

Ще одним напрямом використання склобою $є$ виробництво скловолокна. Кількість скляного бою 
у вихідній сировині для виробництва скловолокна може становити до 90\% загального обсягу, що дає змогу знизити його собівартість.

Отже, останніми роками накопичений значний досвід використання склобою в різних галузях господарювання, однак через відсутність системи перероблення (у тому числі системи роздільного збирання) Україна втрачає мільйони тонн ресурсоцінних матеріалів. Розвиток роздільного збирання $€$ невід'ємною частиною використання склобою як вторинної сировини.

Відходи скла можуть збиратися або окремо, або через муніципальне господарство обробки, після цього відправляються на очисні споруди, де скло відділяється від домішок (папір, метал, пластик, дрібні фракції скла).

На рис. 1 запропонована основна схема сортування та утилізації [6].

Для очищення від домішок склобій засипається в бункер, потім у привідному барабані транспортера електромагнітом відокремлюються металеві включення. Оброблений склобій, отриманий методом селективної заготовки або виділений із побутових відходів, може бути підданий додатковій обробці 3 метою видалення 3 нього алюмінієвих, керамічних та інших включень, а також сортування за кольором. Така додаткова обробка й сортування дає змогу підвищити якість продукції, що виготовляється з його використанням, і розширити сферу застосування склобою. Отриманий продукт піддається подрібненню для забезпечення потрібного розміру частинок. За допомогою вагового дозування шихти і склобою забезпечується задане співвідношення вихідних матеріалів.

Усе вищенаведене свідчить, що головною причиною низького рівня залучення склобою в повторне використання $є$ відсутність необхідної інфраструктури. Збирання, транспортування й особливо сортування відходів скла є дорогими статтями утиліза- ції відходів [7]. Рівнем цих витрат значною мірою визначається економічна доцільність вторинного використання склобою. У зв'язку з цим необхідно надавати велике значення питанням удосконалення методів збирання та сортування відходів скла.

Спираючись на досвід інших країн, Україна може вибрати найбільш оптимальний варіант 3 переробки та утилізації відходів скла. Це може бути:

- селективна заготовка, яка передбачає збирання й сортування відходів на місці їх утворення;

- централізована заготівля, що передбачає виділення скла зі змішаних відходів на спеціалізованих підприємствах.

Ще однією проблемою є відсутність вітчизняного обладнання для механізованого очищення склобою від сторонніх домішок і бруду, а також для поділу його за кольорами, що практично виключає використання склобою. Змішаний же склобій для виготовлення світлої склотари й багатьох інших виробів не підходить через різний хімічний склад.

Іншою проблемою, що перешкоджає залученню відходів у господарський оборот, $є$ те, що собівартість захоронення відходів набагато нижча за собівартість їх переробки. У сфері поводження 3 відходами є також низка структурних проблем, викликаних недосконалістю чинного законодавства в цій сфері: відсутність координації між муніципальними утвореннями та владою різного рівня під час здійснення ними повноважень у сфері поводження 3 відходами; відсутність контролю з боку держави за транспортними потоками відходів; відсутність ефективних важелів спонукання учасників діяльності щодо поводження 3 відходами до дотримання вимог екологічної безпеки та мінімізації негативного впливу відходів на навколишнє середовище.

Головні висновки. Переробка склобою - це одна 3 пріоритетних ролей в економії ресурсів і первинної сировини на підприємствах. Завдяки вторинному

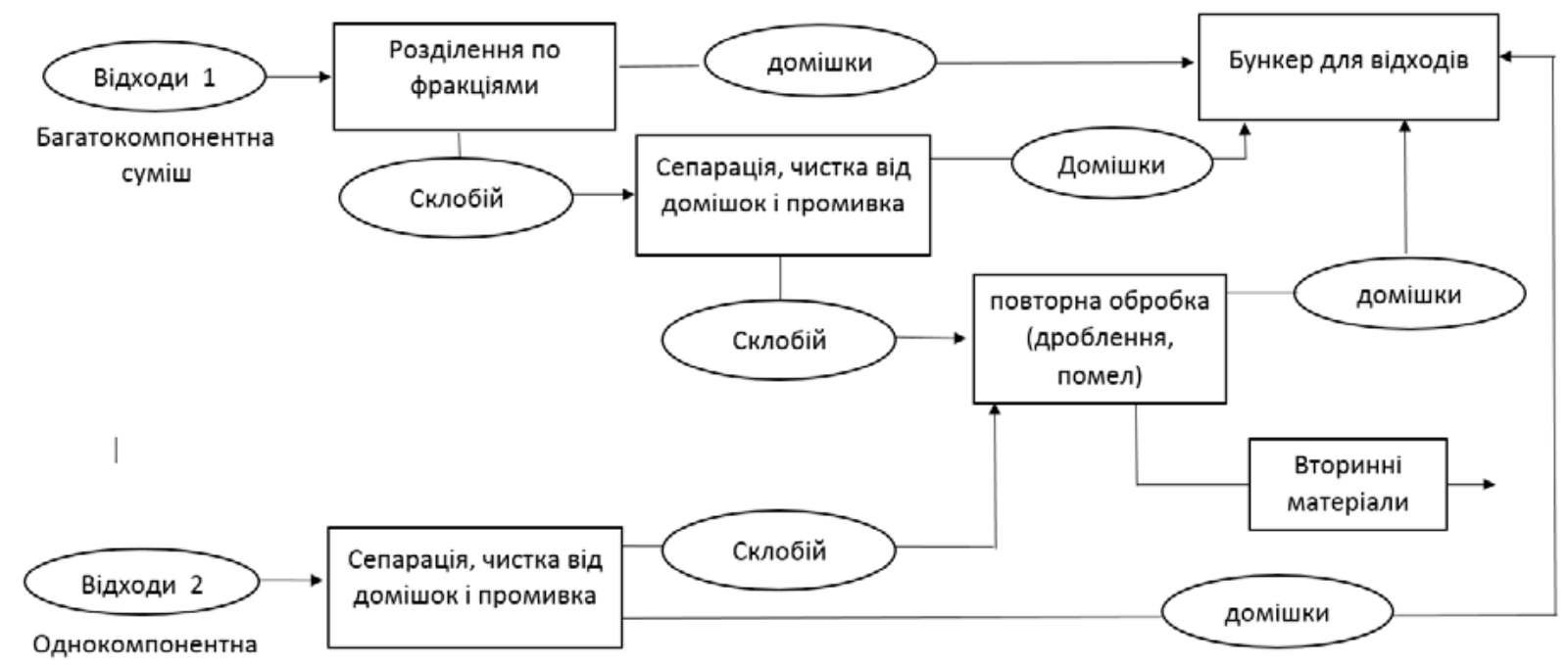

Рис. 1. Основна схема сортування й утилізації скляних відходів 
використанню скла можна зменшити негативний вплив на довкілля та знизити енергоспоживання.

Але сучасні способи управління відходами в Україні орієнтовані на полігонне захоронення, їх розміщення на сміттєзвалищах, більшість із яких не відповідають вимогам екологічної безпеки. Через низькі тарифи на послуги із захоронення відходів не впроваджуються інноваційні технології й системи щодо утилізації та переробки.

Запобігання накопиченню відходів, повторне використання та краще управління відходами загалом мають вирішальне значення для мінімізації впливу на довкілля. Отже, для зростання рівня використання склобою потрібно:

- створити систему збирання від населення й виділення склобою 3 побутових відходів, так як відсоток потрапляння його в побутові відходи значний;

- велику увагу приділяти впровадженню різних схем збирання, включаючи галузеві відмінності й колір скла;

- ефективному використанню склобою може сприяти організація спеціалізованих підприємств щодо його обробки, на яких буде здійснюватися його подрібнення, очищення й сортування;

- розвивати раціональні напрями використання склобою, що дають змогу економити первинну сировину;

- підвищувати обізнаність серед населення та інші цілі за допомогою комунікації й освітніх кампаній. Успіх системи заготівлі пояснюється насамперед активністю населення.

\section{Література}

1. Національна стратегія управління відходами в Україні до 2030 року: Розпорядження Кабінету Міністрів України від 08.11.2017 № 820-р. Офіційний вісник України. 2017. № 94. Ст. 2859.

2. Chung S., Elrahman M., Sikora P. et al. Evaluation of the Effects of Crushed and Expanded Waste Glass Aggregates on the Material Properties of Lightweight Concrete Using Image-Based Approaches. Materials. 2017. doi: 10.3390/ma10121354.

3. A touch of glass for extra-large multi-touch screens. AGC Glass Europe. URL: http://www.agc-glass.eu/ru/news/story/ innovacionnoe-steklo-dla-sirokoformat nyh-multisensornyh-ekranov (дата звернення: 15.11.2018).

4. Testa M., Malandrino O., Sessa M. R. et al. Long-Term Sustainability from the Perspective of Cullet Recycling in the Container Glass Industry: Evidence from Italy. Sustainability. 2017. doi:10.3390/su9101752.

5. Supino S., Malandrino O., Testa M., Sica D. Sustainability in the EU cement industry: the Italian and German experiences. Cleaner Production. 2016. doi: 10.1016/j.jclepro.2015.09.022.

6. Tiozzo S. Permanent Materials in the framework of the Circular Economy concept: review of existing literature and definitions, and classification of glass as a Permanent Material. Murano. 2016. URL: http://feve.org/wp-content/uploads/2016/ 09/SSV-Report-onGlass-as-Permanent-Material.pdf.

7. Kovacec M., Pilipovic A., Stefanic N. Impact of Glass Cullet on the Consumption of Energy and Environment in the Production of Glass Packaging Material. URL: http://www.wseas.us/e-library/conferences/2011/Montreux/COMICI CBIO/COMICICBIO-30.pdf.

8. Державна служба статистики України. URL: http://www.ukrstat.gov.ua.

9. Пузанов С.И. Оценка комплексного воздействия стеклобоя на окружающую среду и совершенствование технологий его вторичного использования: дисс. ... канд. техн. наук: спец. 03.00.16. Пермь, 2010. 184 с.

10. Артуганова А.И. Проблема отходов в России. Санкт-Петербург: Частное образовательное учреждение дополнительного образования «Лингвистический центр «Тайкун», 2018.

11. Акопов С.Е. Питання поводження з твердими побутовими відходами в Україні та країнах Європи. Вісник Донбаської державної машинобудівної академії. 2016. № 1 (37). С. 116.

12. Наумовська О. Шляхи вирішення утилізації і переробки побутового сміття сільських територій. Національний університет біоресурсів і природокористування України. 2013. С. 335-340.

13. Glass: Material-Specific Data. United States Environmental Protection Agency. URL: https://www.epa.gov/ facts-and-figures-about-materials-waste-and-recycling/glass-material-specific-data.

14. UK Statistics on Waste. Department for environment Food and Rural Affairs. URL: tps://www.stat.fi/til/jate/2015/ jate_2015_2016-12-20_en.pdf.

15. Waste statistics 2015. Environment and Natural Resources. 2016. URL: https://assets.publishing.service.gov.uk/government/ uploads/system/uploads/attachment_data/file/746642/UK_Statistics_on_Waste_statistical_notice_October_2018_FINAL.pdf.

16. Statistics of the glass recycling industry. European Federation of Glass Recyclers. URL: http://www.ferver.eu/en/statistics.

17. Чупрова Л.В. Экологические и экономические аспекты утилизации отходов стекла. Международный журнал прикладных и фундаментальных исследований. 2016. № 11-2. С. 222-225.

18. Исследование возможностей переработки стеклобоя и энергоэффективности производства стекла в Российской Федерации: Краткое содержание отчета для обсуждения с заинтересованными сторонами / по заказу Европейского банка реконструкции и развития. Контракт С21162/САТС-2010-10-07. 2012. С. 36.

19. Чупрова Л.В. Отходы производства и потребления стекла как сырье для получения качественной продукции. Международный журнал прикладных и фундаментальных исследований. 2016. № 12-4. С. 640-644.

20. Imteaz M., Ali M., Arulrajah A. Possible environmental impacts of recycled glass used as a pavement base material. Waste Manag Res. 2012. doi: $10.1177 / 0734242 X 12448512$.

21. Linga T., Poona C., Wonga H. Management and recycling of waste glass in concrete products: Current situations in Hong Kong. Resources, Conservation and Recycling. 2013. Vol. 70. P. 25-31. doi: 10.1016/j.resconrec.2012.10.006.

22. Производство плитки из стекла. Мир стекла. URL: https://www.mirstekla-expo.ru/ru/article-about-glass/ proizvodstvo-plitki-iz-stekla/. 


\title{
ABSORPTION METHOD FOR NEUTRALIZATION OF SULFUR DIOXIDE
}

\author{
Kuznyetsov S.I., Ischenko D.R. \\ Kherson National Technical University \\ Beryslavske highway, 24, 73008, Kherson \\ ksieko@rambler.ru \\ mnenflint@gmail.com
}

\begin{abstract}
A method is proposed for cleaning waste gas from heat-and-power enterprises from sulfur dioxide. The influence of various physicochemical factors on the absorption process has been studied. Optimal parameters were determined and a mathematical model of the process was obtained. In parallel, some parameters of wastewater neutralization were investigated. Key words: absorption, purification of waste gases, neutralization of sulfur dioxide.
\end{abstract}

\begin{abstract}
Абсорбційний метод нейтралізації двооксиду сірки. Кузнєцов С.І., Іщенко Д. У статті запропоновано метод очищення відведених газів теплоенергетичних підприємств від двооксиду сірки. Вивчено вплив різних фізико-хімічних факторів на процес абсорбції. Визначено оптимальні параметри й отримано математичну модель процесу. Паралельно досліджено деякі параметри нейтралізації стічних вод. Ключові слова: абсорбція, очищення відведених газів, нейтралізація двооксиду сірки.

Абсорбционный метод нейтрализации диоксида серы. Кузнецов С.И., Ищенко Д. В статье предложен метод очистки отходящих газов теплоэнергетических предприятий от диоксида серы. Изучено влияние различных физико-химических факторов на процесс абсорбции. Определены оптимальные параметры и получена математическая модель процесса. Параллельно исследованы некоторые параметры нейтрализации сточных вод. Ключевые слова: абсорбция, очистка отходящих газов, нейтрализация диоксида серы.
\end{abstract}

All human life passes in the air. A person continuously consumes about $15-20 \mathrm{~m}^{3}$ of air per day [1]. Air pollution even in small doses can cause serious damage to people's health. Polluted air can destroy ecological bonds in nature. This leads to heavy and unforeseen consequences.

Worldwide emissions of sulfur dioxide to the atmosphere amount to 190 million tons per year [2]. It is a colorless gas with a strong odor, which is formed during the combustion of sulfur-containing fossil fuels. Prolonged exposure to sulfur dioxide in humans leads to loss of taste, cramped breathing, inflammation or pulmonary edema. It contributes to interruptions in cardiac activity, impaired blood circulation and respiratory arrest [3].

Combining in an atmosphere with water vapor, sulfur oxides form sulfuric, sulfurous acid [4]. Then, acid rain in the soil makes it acidic, reducing the yield of agricultural crops. Acid rain affects the leaves of plants and there are "burns" in the form of brown spots. Trees lose some foliage and become defenseless against frost and disease. As a result of chemical reactions, the soil loses some trace elements and becomes less nutritious. Restoration of fertility of acidic soils requires large material costs.

Acid rain has a negative effect on reservoirs - lakes, rivers, bays, ponds - increasing their acidity. Algae grow best in water with a $\mathrm{pH}$ between 7 and 9.2. With an increase in acidity, they die, depriving other animals of the reservoir of food. With a $\mathrm{pH}$ of 6 , freshwater shrimp die. When the acidity rises to $\mathrm{pH} 5.5$, bottom bacteria die, which decompose organic matter and leaves, and organic debris begins to accumulate at the bottom. Then plankton perishes, which forms the basis of the food chain of water bodies and feeds on substances formed during the decomposition of organic substances by bacteria. When the acidity reaches a $\mathrm{pH}$ of 4.5 , all fish, most frogs and insects, die [5].

As organic matter accumulates at the bottom of water bodies, toxic metals begin to leach out of them. The increased acidity of water contributes to a higher solubility of such dangerous metals as aluminum, cadmium, mercury, and lead from bottom sediments and soils. These heavy metals are hazardous to human health.

A great damage to the economy is caused by the corrosion of metals, which is accelerated under the action of air containing sulfur dioxide. Due to corrosion, millions of tons of ferrous metals are lost every year, of which complex and expensive engineering structures are complex: bridges, towers for energy transmission, pipelines. And under the influence of atmospheric pollution, the destruction of buildings, monuments of architecture and art occurs. Acid rain can dissolve the mortar in the masonry of buildings, damage structures made of natural stone, especially limestone, which in turn can lead to loss of strength of structures.

For industrial purification of waste gases from sulfur dioxide, it is advisable to use absorption methods. Of great importance is the correct choice of the absorption solution. 
Absorption is the process of selective absorption of gas by a liquid. Two phases are involved in absorption processes - liquid and gas. When this occurs, the transition of the substance from the gas phase to the liquid. Absorption processes are one of the types of mass transfer.

There are physical absorption and chemisorption. During physical absorption, the gas is retained in the liquid due to mechanical (physical) bonds and it is not accompanied by a chemical reaction. During chemisorption, a chemical reaction takes place between the components [6].

The basis of absorption is diffusion processes of transition of a substance from the gaseous phase to the liquid through the interface. The driving force of absorption is the difference between the initial and equilibrium pressures of the interacting components:

$$
\Delta \mathrm{Pcp}=\frac{\left(\mathrm{P}_{\mathrm{r}}^{\prime}-\mathrm{P}_{\mathrm{p}}^{\prime}\right)-\left(\mathrm{P}_{\mathrm{r}}^{\prime \prime}-\mathrm{P}_{\mathrm{p}}^{\prime \prime}\right)}{2,3 \lg \frac{\mathrm{P}_{\mathrm{r}}^{\prime}-\mathrm{P}_{\mathrm{p}}^{\prime}}{\mathrm{P}_{\mathrm{r}}^{\prime \prime}-\mathrm{P}_{\mathrm{p}}^{\prime \prime}}},
$$

where $\mathrm{P}_{r}^{\prime}, \mathrm{P}_{\mathrm{r}}^{\prime \prime}$ - the partial pressure of the absorbed component in the gas phase at the entrance to the apparatus and exit from the apparatus;

$\mathrm{P}_{\mathrm{p}}{ }^{\prime}, \mathrm{P}_{\mathrm{p}}{ }^{\prime \prime}$ - equilibrium partial pressure of the absorbed component above the liquid.

The greater the difference between the pressures, the greater the driving force of the process and the faster the absorption takes place.

Water, as well as organic and inorganic solvents, are used as absorption solutions. For a more complete extraction of the harmful component from the gas mixture, it is necessary to use the principle of countercurrent with a continuous supply of fresh solution to the absorber.

The waste waters of textile enterprises, which will be considered by us as absorbents, are complex physicochemical multicomponent systems containing insoluble impurities, suspensions, molecular solutes of mineral and organic origin. They have a specific color. Chemical oxygen demand (COD) is significantly higher than biological oxygen demand (BOD), which indicates the presence of difficult to oxidize compounds in wastewater. The concentration of synthetic surfactants and certain drugs is in the range of $10-140 \mathrm{mg} / \mathrm{dm}^{3}$.

A significant predominance of alkaline reagents over acidic and neutral (75-80\%), leads to an increase in alkalinity of wastewater with an increase in the activity of the reaction $\mathrm{pH}$ to $11-12.5$.

High alkalinity of wastewater creates certain difficulties in their treatment in the system of city-wide sewage treatment plants, where the main method is biological treatment. The $\mathrm{pH}$ value of wastewater significantly affects the vital activity of microorganisms of activated sludge aerotanks. Studies have shown that with the help of unadapted (active) sludge of aerotanks it is possible to successfully purify wastewater within the limits of the active reaction $\mathrm{pH} 6.5-9.2$ at a temperature of $20^{\circ} \mathrm{C}$. The increase in alkalinity of wastewater above $\mathrm{pH}$ 9.2 causes the death of microorganisms.
In industry, alkaline type absorbers $\left(\mathrm{NaOH}, \mathrm{Na}_{2} \mathrm{CO}_{3}\right.$, $\left.\mathrm{Ca}(\mathrm{OH})_{2}, \mathrm{MgO}\right)$ are used to clean flue gases [7]. For the most cost-effective operation of sewage treatment plants, they are designed taking into account local conditions and the presence of those components that could be used as $\mathrm{SO}_{2}$ absorption solutions. At present, a huge amount of alkaline waste water is discharged into industrial sewage systems.

In wastewater treatment plants, the alkalinity of wastewater is neutralized by mineral acids $\left(\mathrm{HCl}, \mathrm{H}_{2} \mathrm{SO}_{4}\right.$, etc.), which is very expensive. Recently, in many countries, the possibility of using alkaline waste water as a neutralizing agent has been investigated.

Sulfurous anhydride contained in waste gases creates an acidic environment and can be neutralized with alkaline waste water. As a result of the absorption of sulfur dioxide, an acid is formed, which is necessary to neutralize the alkali. Wastewater becomes discolored with ash, which is formed during the combustion of coal in a steam boiler. Fly ash, due to its large surface area and high carbon content (over $40 \%$ ), is a good adsorbent.

An analysis of the emissions of harmful substances entering the atmosphere during the operation of the CHP revealed that the maximum surface concentration of sulfur dioxide in them is $1.37 \mathrm{mg} / \mathrm{m}^{3}$. This is 2.74 times the maximum allowable concentration for populated areas.

To study the process of neutralization of waste gases containing sulfur dioxide by sewage, a laboratory installation was created. The studies were conducted on the basis of natural wastewater of a cotton mill and an air mixture containing sulfur dioxide. The task of laboratory research included the study of the influence of various physicochemical factors on the process of cleaning waste gases from $\mathrm{SO} 2$. And also, the identification of optimal neutralization parameters and obtaining a mathematical model of the process

The degree of purification of waste gases from sulfur dioxide depends on many different parameters. The data are shown in table 1.

In order to verify the data obtained in the laboratory, as well as to further simulate the process of neutralizing waste gases with sewage, studies were carried out at a pilot plant using natural gases and sewage.

The main apparatus of the installation is the tore absorber-neutralizer, the design of which is similar to that used in the pilot installation.

The installation consists of an absorber 3, made in the form of a torus apparatus with a diameter of $3 \mathrm{~m}$ and a height of $1.5 \mathrm{~m}$ which has a flat roof and a conical bottom. A central tube 5 is installed in the center of the absorber with a gas outlet 2 . The gas enters the absorber via fitting 6 , which is tangentially welded to the outer side surface of the apparatus. Centrifugal atomizers 4 interconnected by a common collector 7 are placed on the flat roof of the apparatus. Absorbent (wastewater) is supplied to the collector by means of a centrifugal pump 10 with a capacity of $6 \mathrm{~m}^{3} / \mathrm{h}(\mathrm{N}=3.2 \mathrm{~kW})$. 
The scheme adopted a closed irrigation cycle with a continuous supply of fresh solution to the system and the exit from the system of the same amount of neutralized wastewater. Collecting the fluid circulating in the system is carried out in collection 8 , from where part of it goes to the irrigation of the absorber, and part of it is removed from the system and discharged into neutral sewage as neutral wastewater. The flow rate of the liquid supplied for irrigation was carried out using a diaphragm and a differential pressure gauge 9 .

The contact between the liquid and the gas in the absorber was made by spraying the liquid with centrifugal sprays. The atomizer consists of a vertical rotating shaft, on the lower part of which a centrifugal atomizer with blades is mounted. The shaft is driven by an electric motor $\mathrm{N}=0.12 \mathrm{~kW}, \mathrm{n}=2800 \mathrm{~min}^{-1}$. Liquid falling on the blades under the action of centrifugal force is sprayed into small droplets, creating a developed contact surface. The advantage of this method of spraying is the high reliability of operation of the nozzle centrifugal nozzles without clogging them with solid particles (ash). For uniform irrigation of the entire volume of the absorber, it has five centrifugal nozzles with a capacity of $165 \mathrm{~m}^{3} / \mathrm{h}$ each. The purified gases through the central pipe 5 are emitted into the atmosphere. In the pipe, there are drop eliminators 6 in the form of a layer of Rashig rings.

Wastewater was placed in a container 8 and their composition was analyzed. After turning on the centrifugal atomizers and the centrifugal pump 10, gas was supplied to the absorber. After neutralization and settling, sewage was discharged into the sewage system, and the purified gas was released into the atmosphere.

Table 1

Dependence of the degree of gas purification on $\mathrm{SO}_{2}(\beta)$ and degree of neutralization of the absorbent ( $\alpha$ ) on the volume of gas passing through the absorbent

\begin{tabular}{|c|c|c|c|c|c|c|c|c|c|}
\hline \multirow{2}{*}{ № } & \multirow{2}{*}{$\begin{array}{l}\text { Absorption } \\
\text { time, } \\
\text { min }\end{array}$} & \multirow{2}{*}{$\begin{array}{c}\text { Gas } \\
\text { consumption, } \\
\mathbf{d m}^{3} / \mathbf{m i n}\end{array}$} & \multirow{2}{*}{$\begin{array}{c}\text { Volume } \\
\text { of gas, } \mathbf{d m}^{3}\end{array}$} & \multirow{2}{*}{\multicolumn{2}{|c|}{$\begin{array}{c}\text { Concentration } \\
\mathrm{SO}_{2}, \%\end{array}$}} & \multirow{2}{*}{$\begin{array}{l}\text { Alkalinity } \\
\text { of the } \\
\text { absorbent, } \\
\text { mg-eq/dm }\end{array}$} & \multirow{2}{*}{$\begin{array}{c}\text { pH } \\
\text { absor- } \\
\text { bent }\end{array}$} & \multicolumn{2}{|c|}{$\begin{array}{c}\text { Cleaning } \\
\text { degree }\end{array}$} \\
\hline & & & & & & & & $\begin{array}{c}\alpha \\
(\%)\end{array}$ & $\begin{array}{c}\beta \\
(\%)\end{array}$ \\
\hline 1 & 0 & & & 0.04 & & 8 & 11.01 & & \\
\hline 2 & 1 & 25 & 25 & 0.04 & 0.0080 & 7 & 10.00 & 83 & 80 \\
\hline 3 & 2 & 25 & 50 & 0.04 & 0.0081 & 7 & 9.50 & 84 & 80 \\
\hline 4 & 3 & 25 & 75 & 0.04 & 0.0083 & 7 & 9.02 & 85 & 79 \\
\hline 5 & 4 & 25 & 100 & 0.04 & 0.0086 & 6 & 8.5 & 86 & 78 \\
\hline 6 & 5 & 25 & 125 & 0.04 & 0.0091 & 6 & 8.05 & 87 & 77 \\
\hline 7 & 6 & 25 & 150 & 0.04 & 0.0096 & 6 & 7.95 & 88 & 76 \\
\hline 8 & 7 & 25 & 175 & 0.04 & 0.0099 & 5 & 7.55 & 89 & 75 \\
\hline 9 & 8 & 25 & 200 & 0.04 & 0.0100 & 5 & 7.10 & 90 & 75 \\
\hline 10 & 9 & 25 & 225 & 0.04 & 0.0105 & 5 & 6.05 & 90 & 74 \\
\hline 11 & 10 & 25 & 250 & 0.04 & 0.0109 & 4 & 6.01 & 91 & 73 \\
\hline 12 & 11 & 25 & 275 & 0.04 & 0.0110 & 4 & 5.55 & 91 & 72 \\
\hline 13 & 12 & 25 & 300 & 0.04 & 0.0115 & 4 & 5.51 & 92 & 71 \\
\hline 14 & 13 & 25 & 325 & 0.04 & 0.0117 & 4 & 5.47 & 92 & 71 \\
\hline 15 & 14 & 25 & 350 & 0.04 & 0.0124 & 4 & 5.41 & 93 & 68 \\
\hline 16 & 15 & 25 & 375 & 0.04 & 0.0131 & 4 & 5.35 & 93 & 67 \\
\hline 17 & 16 & 25 & 400 & 0.04 & 0.0135 & 3 & 5.29 & 94 & 66 \\
\hline 18 & 17 & 25 & 425 & 0.04 & 0.0137 & 3 & 5.15 & 94 & 66 \\
\hline 19 & 18 & 25 & 450 & 0.04 & 0.0141 & 3 & 5.03 & 95 & 64 \\
\hline 20 & 19 & 25 & 475 & 0.04 & 0.0151 & 3 & 5.01 & 95 & 62 \\
\hline 21 & 20 & 25 & 500 & 0.04 & 0.0157 & 3 & 4.94 & 95 & 60 \\
\hline 22 & 21 & 25 & 525 & 0.04 & 0.0161 & 2 & 4.93 & 96 & 59 \\
\hline 23 & 22 & 25 & 550 & 0.04 & 0.0167 & 2 & 4.93 & 96 & 58 \\
\hline 24 & 23 & 25 & 575 & 0.04 & 0.0171 & 2 & 4.92 & 97 & 57 \\
\hline 25 & 24 & 25 & 600 & 0.04 & 0.0174 & 2 & 4.92 & 98 & 56 \\
\hline 26 & 25 & 25 & 625 & 0.04 & 0.0175 & 2 & 4.91 & 99 & 56 \\
\hline 27 & 26 & 25 & 650 & 0.04 & 0.0184 & 2 & 4.91 & 99 & 55 \\
\hline 28 & 27 & 25 & 675 & 0.04 & 0.0185 & 2 & 4.90 & 99 & 54 \\
\hline 29 & 28 & 25 & 700 & 0.04 & 0.0186 & 2 & 4.90 & 100 & 53 \\
\hline 30 & 29 & 25 & 725 & 0.04 & 0.0187 & 2 & 4.90 & 100 & 53 \\
\hline 31 & 30 & 25 & 750 & 0.04 & 0.0189 & 2 & 4.90 & 100 & 53 \\
\hline
\end{tabular}


When conducting research on the installation, the following analytical control was carried out:

in gases, the content of sulfuric anhydride at the inlet and outlet by the iodometric method once an hour, the ash content is episodic;

in wastewater - the content of $\mathrm{NaOH}$, total alkalinity, $\mathrm{pH}$ (every 15 minutes), the total analysis of wastewater (occasionally), ash content (1 time per shift). The temperature of the gas and waste water at the inlet and outlet was constantly monitored. The degree of gas purification was determined by the formula:

$$
\beta \%=\frac{C_{\text {in }}-C_{\text {out }}}{C_{\text {in }}} \cdot 100,
$$

where $\mathrm{C}_{\text {in }}-\mathrm{SO}_{2}$ concentration at the entrance to the apparatus, $\%$ vol.;

$\mathrm{C}_{\text {out }}-\mathrm{SO}_{2}$ concentration at the exit of the apparatus, $\%$ vol.

Acceptable $\mathrm{pH}=6.5-8.5$. Therefore, a 100\% degree of neutralization can be considered if the $\mathrm{pH}$ of the medium is lowered to $\mathrm{pH}=8.5$ and lower, however, not lower than $\mathrm{pH}=6.5$. In studies, the degree of neutralization was assumed to be $100 \%$ in the case when the total alkalinity in the solution was zero.

As a result of the calculations, an equation was obtained describing the process of purifying gases from sulfuric anhydride (implicit form).

$$
\begin{gathered}
y=84,47-0,97 X_{1}+4,97 X_{2}+1,28 X_{3}+2,47 X_{4}+3,03 X_{1} X_{2}+0,094 X_{1} X_{3}- \\
3,59 X_{1} X_{4}-1,59 X_{2} X_{3}+3,09 X_{2} X_{4}-3,34 X_{3} X_{4} .
\end{gathered}
$$

Using the transition formulas, we obtain the equation in its natural form:

$\beta \%=37.84+2.39 \tau-0.86 \mathrm{H}+0.86 \mathrm{t}^{\circ}+29.1 \cdot 10^{-3} \mathrm{~W}+$

$0,14 \tau \mathrm{H}+1.1 \cdot 10-{ }^{3} \mathrm{HW}+1.79 \cdot 10^{-3} \tau \mathrm{t}^{\circ}-2.99 \cdot 10^{-3} \tau \mathrm{W}-$

$12.9 \cdot 10^{-3} \mathrm{Ht}^{\circ}-0.477 \cdot 10^{-3} \mathrm{t}^{\circ} \mathrm{W}$

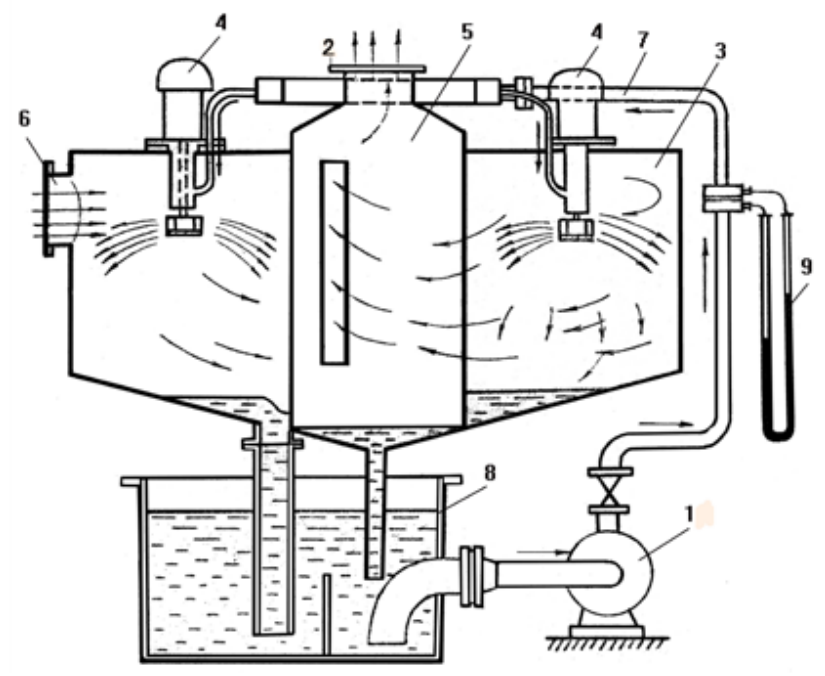

Picture 1. Absorber

1 - pump; 2 - outlet fitting; 3 - absorber; 4 - centrifugal atomizers; 5 - central tube; 6 - input tangential choke;

7 - collector; 8 - water collection; 9 - pressure gauge.

Rejecting the insignificant terms of the equation, we arrive at the desired mathematical model of the process of gas purification from sulfur dioxide in the laboratory setup:

$$
\begin{gathered}
\beta \%=37.84+2.39 \tau-0.86 \mathrm{H}+0.86 \mathrm{t}^{\circ}+ \\
29.1 \cdot 10^{-3} \mathrm{~W}+0.14 \tau \mathrm{H}-2.99 \cdot 10^{-3} \tau \mathrm{W}+ \\
1.1 \cdot 10^{-3} \mathrm{HW}-0.477 \cdot 10^{-3} \mathrm{t}^{\circ} \mathrm{W}
\end{gathered}
$$

Based on the experimental data, the influence of var-

\begin{tabular}{|c|c|c|c|c|c|c|c|}
\hline \multirow{3}{*}{$\begin{array}{c}\text { № } \\
\text { experience }\end{array}$} & \multicolumn{4}{|c|}{ Factors } & \multirow{2}{*}{\multicolumn{3}{|c|}{ Degree of gas cleaning }} \\
\hline & $\mathbf{X}_{1}$ & $\mathbf{X}_{2}$ & $\mathbf{X}_{3}$ & $\mathbf{X}_{4}$ & & & \\
\hline & $\mathbf{t}$ & H, sm & $t,^{\circ}$ & $\mathbf{W}, \mathbf{h}^{-1}$ & $\mathrm{y}_{1} \%$ & $\mathbf{y}_{2} \%$ & $\mathbf{y}_{3} \%$ \\
\hline 1 & 1 & 3 & 25 & 1000 & 71 & 67 & 69 \\
\hline 2 & 7 & 3 & 25 & 1000 & 75 & 72 & 73.5 \\
\hline 3 & 1 & 17 & 25 & 1000 & 81 & 79 & 80 \\
\hline 4 & 7 & 17 & 25 & 1000 & 90 & 84 & 87 \\
\hline 5 & 1 & 3 & 60 & 1000 & 83 & 85 & 84 \\
\hline 6 & 7 & 3 & 60 & 1000 & 96 & 92 & 94 \\
\hline 7 & 1 & 17 & 60 & 1000 & 85 & 84 & 84.5 \\
\hline 8 & 7 & 17 & 60 & 1000 & 81 & 87 & 84 \\
\hline 9 & 1 & 3 & 25 & 1800 & 93 & 95 & 94 \\
\hline 10 & 7 & 3 & 25 & 1800 & 67 & 73 & 70 \\
\hline 11 & 1 & 17 & 25 & 1800 & 93 & 95 & 94 \\
\hline 12 & 7 & 17 & 25 & 1800 & 99 & 97 & 98 \\
\hline 13 & 1 & 3 & 60 & 1800 & 90 & 84 & 87 \\
\hline 14 & 7 & 3 & 60 & 1800 & 66 & 63 & 64.5 \\
\hline 15 & 1 & 17 & 60 & 1800 & 92 & 90 & 91 \\
\hline 16 & 7 & 17 & 60 & 1800 & 98 & 96 & 97 \\
\hline
\end{tabular}
ious factors on the degree of purification of waste gases and the degree of neutralization of wastewater has been established.

Table 2

The working matrix of the process of neutralizing gases from sulfuric anhydride 
Calculated matrix for determining the coefficients of the equation for the process of gas purification from sulfuric anhydride

\begin{tabular}{|c|c|c|c|c|c|c|c|c|c|c|c|}
\hline \multirow{2}{*}{$\begin{array}{c}\text { № } \\
\text { experience }\end{array}$} & \multicolumn{10}{|c|}{ Estimated coefficients } \\
\cline { 2 - 14 } & $\mathbf{B}_{\mathbf{0}}$ & $\mathbf{B}_{\mathbf{1}}$ & $\mathbf{B}_{\mathbf{2}}$ & $\mathbf{B}_{\mathbf{3}}$ & $\mathbf{B}_{\mathbf{4}}$ & $\mathbf{B}_{\mathbf{1 2}}$ & $\mathbf{B}_{\mathbf{1 3}}$ & $\mathbf{B}_{\mathbf{1 4}}$ & $\mathbf{B}_{\mathbf{2 3}}$ & $\mathbf{B}_{\mathbf{2 4}}$ & $\mathbf{B}_{\mathbf{3 4}}$ \\
\hline 1 & 69 & -69 & -69 & -69 & -69 & 69 & 69 & 69 & 69 & 69 & 69 \\
\hline 2 & 73.5 & 73.5 & -73.5 & -73.5 & -73.5 & -73.5 & -73.5 & -73.5 & 73.5 & 73.5 & 73.5 \\
\hline 3 & 80 & -80 & 80 & -80 & -80 & -80 & 80 & 80 & -80 & -80 & 80 \\
\hline 4 & 87 & 87 & 87 & -87 & -87 & 87 & -87 & -87 & -87 & -87 & 87 \\
\hline 5 & 84 & -84 & -84 & 84 & -84 & 84 & -84 & 84 & -84 & 84 & -84 \\
\hline 6 & 94 & 94 & -94 & 94 & -94 & -94 & 94 & -94 & -94 & 94 & -94 \\
\hline 7 & 84,5 & $-84,5$ & $-84,5$ & 84,5 & $-84,5$ & $-84,5$ & $-84,5$ & 84,5 & 84,5 & $-84,5$ & $-84,5$ \\
\hline 8 & 84 & 84 & 84 & 84 & -84 & 84 & 84 & -84 & 84 & -84 & -84 \\
\hline 9 & 94 & -94 & -94 & -94 & 94 & 94 & 94 & -94 & 94 & -94 & -94 \\
\hline 10 & 70 & 70 & -70 & -70 & 70 & -70 & -70 & 70 & 70 & -70 & -70 \\
\hline 11 & 94 & -94 & 94 & -94 & 94 & -94 & 94 & -94 & -94 & 94 & -94 \\
\hline 12 & 98 & 98 & 98 & -98 & 98 & 98 & -98 & -98 & -98 & 98 & -98 \\
\hline 13 & 87 & -87 & -87 & 87 & 87 & 87 & -87 & -87 & -87 & -87 & 87 \\
\hline 14 & 64,5 & 64,5 & $-64,5$ & 64,5 & 64,5 & $-64,5$ & 64,5 & 64,5 & $-64,5$ & $-64,5$ & 64,5 \\
\hline 15 & 91 & -91 & 91 & 91 & 91 & -91 & -91 & -91 & 91 & 91 & 91 \\
\hline 16 & 97 & 97 & 97 & 97 & 97 & 97 & 97 & 97 & 97 & 97 & 97 \\
\hline $\mathrm{B}_{\mathrm{i}}$ & 84.47 & -0.97 & 4.97 & 1.28 & 2.47 & 3.03 & 0.094 & -3.59 & -1.59 & 3.09 & 3.34 \\
\hline
\end{tabular}

The effect of volumetric rate on the degree of gas purification and degree of neutralization of wastewater. Under the volumetric rate, we take the volume of gas passing through $1 \mathrm{~m}^{3}$ of the volume of the apparatus. With increasing volumetric rate, the degree of gas purification decreases. This is due to the decrease in the residence time of the gas in the apparatus, i.e. reducing the time of contact of the gas with the liquid. To achieve a high degree of gas purification (within $90 \%$ ), the gas volumetric rate should not exceed $500-750 \mathrm{~h}^{-1}$.

Influence of irrigation density on the degree of gas purification and the degree of neutralization of wastewater.Irrigation density shows the volume of irrigating fluid passing through $1 \mathrm{~m}^{2}$ of the apparatus cross-section per unit time $\mathrm{P}, \mathrm{m}^{3} / \mathrm{m}^{2} \cdot \mathrm{h}$.

A change was also made in the amount of fluid supplied for irrigation into the apparatus. The wastewater flow rate at the installation varied in the range from $2.4 \mathrm{~m}^{3} / \mathrm{h}$ to $7.7 \mathrm{~m}^{3} / \mathrm{h}$, which corresponds to the irrigation density, $0.6-1.91 \mathrm{~m}^{3} / \mathrm{m}^{2} \cdot \mathrm{h}$.

With an increase in the irrigation density, the degree of gas purification increases, and this dependence is most pronounced with a short circulation time (15 min). When the irrigation density doubles, from 1 to $2 \mathrm{~m}^{3} / \mathrm{m}^{2} \cdot \mathrm{h}$, the degree of gas purification increases from 72 to $90 \%$, i.e. by $18 \%$. Therefore, in production processes, for a more complete purification of gases, it is necessary to increase the density of irrigation. A high degree of gas purification cannot be achieved with a simultaneous high degree of neutralization of wastewater.

The influence of the circulation time of the solution on the degree of gas purification and the degree of neu- tralization of wastewater. Circulation time is the time of the solution, without adding to it a fresh solution and removal of used.

At the beginning of the research, wastewater has the highest alkalinity and maximum $\mathrm{pH}$. As the solution circulates, the alkaline components of the wastewater react with $\mathrm{SO}_{2}$ and their content gradually decreases to complete conversion to sulfite-sulphate salts. At the same time, the $\mathrm{pH}$ of these solutions also decreases.

Alkaline wastewater absorbs $\mathrm{SO}_{2}$ from waste gases better than those solutions that have been in circulation for 30 or 40 minutes. The common alkalinity decreases to zero already after about 15 minutes of circulation, after which the absorption of $\mathrm{SO}_{2}$ occurs already in a weakly alkaline or weakly acidic medium. When $\mathrm{SO}_{2}$ is absorbed by sewage having an initial $\mathrm{pH}=11.75$, when the circulation time is 15 minutes, the degree of gas purification reaches $90 \%$, but after 30 minutes it decreases to $85 \%$ and after 60 minutes to $70 \%$. The study shows that full $100 \%$ neutralization occurs at the circulation time for wastewater with $\mathrm{pH}=10.1$ after 32 minutes, and with $\mathrm{pH}=11.0$ after 48 minutes.

It should be noted that for $100 \%$ degree of neutralization the conditions were accepted, when the total alkalinity of the wastewater was zero, while the $\mathrm{pH}$ of the wastewater was in the range of 5-6. This indicates that wastewater has a weakly acidic environment. Therefore, in practical terms, it is sufficient to carry out neutralization by $70-80 \%$, which will comply with the MPC (Maximum permissible concentration) standards. Thus, the circulation time of the solution should be 15-25 minutes, after which the wastewater can be discharged into the reservoir. 
The effect of the initial concentration of $\mathrm{SO}_{2}$ on the degree of gas purification. Thermal power plant exhaust gases have non-constant $\mathrm{SO}_{2}$ concentration. Usually the concentration of $\mathrm{SO}_{2}$ in the exhaust gas ranges from 0.04 to $0.08 \%$. The data show that with increasing concentration, the degree of gas purification increases.

To study the process of neutralization of waste gases with sewage, studies have been conducted at a pilot plant using natural gases and sewage. In waste gases, the was degreed of neutralization of sulfurous anhydride and ash is determined, and in wastewater - the $\mathrm{NaOH}$ content, total alkalinity, and $\mathrm{pH}$.

Was make matrices for determining the coefficients of the equation have been compiled and an equation has been obtained that describes the process of cleaning gases from sulfuric anhydride.

The influence of various factors on the degree of purification of waste gases and the degree of neutralization of wastewater has been established.

\section{References}

1. ASHRAE 62-1999 "Ventilation for Acceptable Indoor Air Quality".

2. URL: https://ru.wikipedia.org/wiki/Загрязнение_атмосферы_Земли.

3. URL: http://www.eco.nw.ru/lib/data/04/4/030404.htm.

4. Васильев Б.Т., Отвагина М.И. Технология серной кислоты. Москва, 1985.

5. URL: https://moodle.ggau.by/mod/page/view.php?id=2923.

6. Young D.M., Crowell A.D. Physical adsorption of gases. L., 1962. 


\title{
EFFICIENCY OF NATURAL AND ARTIFICIAL OIL SORBENTS
}

\author{
Glibovytska N.I., Plaksiy L.V. \\ Ivano-Frankivsk National Technical University of Oil and Gas, \\ Karpatska street, 19, 76000, Ivano-Frankivsk \\ nataly.glibovytska@gmail.com
}

\begin{abstract}
The prospect of using the most widespread in the industry and national economy natural and synthetic materials in the purification of the environment from oil is considered. The maximum absorption capacity of cotton as a natural material is identified, that quickly absorbs oil components and does not require the use of additional resources to combat water contamination. It is found that natural charcoal absorbent is inefficient in comparison with other methods of water purification from oil and requires a long time and additional pollution catchers, which is economically unprofitable. Synthetic polymer foam and white coal absorb oil in a short time, but in the latter case, nevertheless, small spots remain on the surface of the water. According to the efficiency of oil absorption by natural and synthetic materials, we can distinguish the following series of investigated materials: black coal $\rightarrow$ foam $\rightarrow$ white coal $\rightarrow$ cotton. Key words: oil, pollution, water resources, purification, methods, sorbents.
\end{abstract}

Ефективність природних і штучних сорбентів нафти. Глібовицька Н.І., Плаксій Л.В. У статті розглянуто перспективність використання найпоширеніших у промисловості й народному господарстві природних і синтетичних матеріалів в очищенні довкілля від нафти. Виявлено максимальну поглинальну здатність бавовни як природного матеріалу, який швидко абсорбує компоненти нафти й не вимагає використання додаткових ресурсів для боротьби з контамінацією води. 3'ясовано, що природній абсорбент чорне вугілля малоефективне порівняно з іншими методами очищення води від нафти та вимагає тривалого часу й додаткових уловлювачів забруднення, що є економічно невигідним. Синтетичний полімер пінопласт і біле вугілля поглинають нафту за короткий час, однак в останньому випадку на поверхні води залишаються незначні плями. За ефективністю поглинання нафти природними та синтетичними матеріалами можна виділити такий ряд досліджених матеріалів: чорне вугілля $\rightarrow$ пінопласт $\rightarrow$ біле вугілля $\rightarrow$ бавовна. Ключові слова: нафта, забруднення, водні ресурси, очищення, методи, сорбенти.

Эффективность естественных и искусственных сорбентов нефти. Глибовицкая Н.И., Плаксий Л.В. В статье рассмотрена перспективность использования самых распространенных в промышленности и народном хозяйстве природных и синтетических материалов в очистке окружающей среды от нефти. Выявлена максимальная поглощающая способность хлопка как природного материала, который быстро абсорбирует компоненты нефти и не требует использования дополнительных ресурсов для борьбы с контаминацией воды. Выяснено, что естественный абсорбент черный уголь малоэффективен по сравнению с другими методами очистки воды от нефти и требует длительного времени и дополнительных ловушек загрязнения, что экономически невыгодно. Синтетический полимер пенопласт и белый уголь поглощают нефть за короткое время, однако в последнем случае на поверхности воды остаются незначительные пятна. По эффективности поглощения нефти естественными и синтетическими материалами можно выделить следующий ряд исследованных материалов: черный уголь $\rightarrow$ пенопласт $\rightarrow$ белый уголь $\rightarrow$ хлопок. Ключевые слова: нефть, загрязнение, водные ресурсы, очистка, методы, сорбенты.

Formulation of the problem. Oil is one of the main and most dangerous pollutants in water ecosystems, which leads to the death of their inhabitants. Each year more than 3 million tons of oil comes into the water areas of the seas and oceans as a result of accidents on drilling rigs and platforms, mainly on gas and oil pipelines. Construction and technological defects and corrosion of the pipelines lead to breakthrough and destruction of equipment with the subsequent emergency oil spill (V.F. Kablov, Yu.P. Ioschenko, 2004; V.A. Vladimirov, 2014).

On the water surface oil can form a film, be in the form of substances dissolved or emulsified in water, or settle down to the bottom of the reservoir. Toxic influence of oil components on water inhabitants leads to their death and poisoning of organisms that are at the higher trophic levels of the food pyramid. Low molecular weight aliphatic, naphthenic, aromatic hydrocarbons, as well as heavy metals present in oil are harmful to the circulatory, nervous systems of a man (L.V. Plaksiy, 2016). That is why the search of ways to defeat the problem of environmental oil pollution is very important.

Connection of the author's work with important scientific and practical tasks. The highest levels of oil pollution are observed in the Mediterranean and the Baltic seas, respectively, 17 and $14 \%$ of all pollution of the world's oceans. The highest concentrations of oil are recorded mainly in the water surface, bottom layer and in the coastal zone. The main components of oil hydrocarbons of various classes - have low solubility in water, which decreases with an increase in the length of the carbon chain in their molecules (N.N. Brakorenko, T.V. Korotchenko, 2016).

As an insoluble in water mixture, the oil forms an emulsion of the next types - "oil in water" and "water in oil". Particular hazards are aggregates - oil lumps in 
the size of 1-20 $\mathrm{mm}$ - since they can be stored for a long time in water, move the flow and settle on the bottom of the reservoir. The aggregates are formed as a result of the combination of high molecular weight hydrocarbons such as resins and asphaltenes in a single mixture that is a trap for water inhabitants - invertebrates and lower plants (M.R. Tsibulnikova et al., 2015).

In Ukraine, where more than 0.5 million tons of oil comes into the aquatic ecosystems every year, the following gradation to determine the mass of oil on the surface of the water is used (Table 1) (V. Maksimov, 2004).

Analysis of recent researches and publications. To combat oil pollution, the following methods are used (O.V. Pogharnitskaya et al., 2016; N.I. Glibovytska, L.V. Plaksiy, 2018):

- mechanical - use of equipment, in particular separators, for the purification of oil-contaminated water;

- biological - decomposition of petroleum products by microorganisms of Calanus, Penicillium, Candida types, capable to metabolizing toxic components of oil and detoxifying them to harmless compounds. This method, also known as bioremediation, is environmentally safe and can be used to restore the abiotic medium transformed under the influence of oil (T.M. Yatsyshyn, N.I. Glibovytska, 2016);

- dispersant - the use of dispersants brands DN-75 and EPN-5, which emulsify the oil film to individual droplets, subjected to further biochemical decomposition;

- sorption - is the use of natural or synthetic porous materials that can effectively absorb oil - coal, perlite, wood sawdust, bentonite clay, cotton, peat, polystyrene, foam, aluminosilicates, sapropel.

Relevance of research. It is the sorbent method that is one of the most promising ways to clean water-contaminated water, since it is least cost-effective and fastest in dealing with pollution problems compared to others. Therefore, the purpose of this work is to assess the effectiveness of natural and artificial sorbent materials in purifying water from oil pollution.

The allocation of previously unsettled parts of the general problem to which this article is devoted. Among all the methods known today for purifying the environment from oil, the sorption method is least studied. Therefore, analysis of materials' properties that would help to cope with environmental oil pollution is extremely important. The problem of methods combating the oil contamination of natural resources lies in their expensiveness and labor-intensiveness. Each method has both advantages and disadvantages, but the first reason to choose the method is its environmental safety. In this context, there is a wide range of substances that possess adsorbing properties, help to get rid of pollution of various origins. Therefore studies of oil absorption by materials, widely used in everyday life and in various areas of industry, are of great practical importance.

Novelty. For the first time, the comparative effectiveness of simple and affordable natural and artificial materials that can be used as adsorbents of oil in the case of its entry into water resources is evaluated. These economically advantageous and low-cost products do not pollute the environment, do not threaten the safety of living organisms and quickly cope with this problem.

Methodological or general scientific significance. Under laboratory conditions an oil was added to the water with the aid of a dispenser and formed an oil spot with a diameter of 50-70 $\mathrm{mm}$ on the surface of the water. The sorbent was added to the surface in an amount that would provide a full coverage of the formed spot and the time of the oil absorption was determined. The repetition of the experiment is threefold.

As sorbents, foam, cotton, white and black coal were used.

Cotton today is one of the main types of raw materials of the textile industry. This natural material is extracted from an annual bush plant - cotton. By chemical composition $95 \%$ of cotton consists of cellulose, and also contains a small amount of natural waxes, proteins and neutral fats. Cotton fibers are characterized by durability, flexibility, softness, clarity, heat-shielding properties.

Polyfoam is a synthetic material with a porous structure, obtained by foaming polystyrene granules. It is characterized by low density, high thermal insulation characteristics. Polyfoam has advantages over other artificial materials used in different branches of industry.

Visual indicators for determining the oil mass on the water surface

Table 1

\begin{tabular}{|c|l|c|}
\hline \multicolumn{1}{|c|}{$\begin{array}{c}\text { Determination of the mass of oil per } \mathbf{1} \mathbf{~ m}^{\mathbf{2}} \text { of water surface } \\
\text { on the appearance of film oil (average data) }\end{array}$} & $\begin{array}{c}\text { Mass of oil per } \mathbf{1} \mathbf{~ m}^{\mathbf{2}} \\
\text { of water surface (g) }\end{array}$ \\
\hline 1 & Pure water surface without signs of coloring under various lighting conditions & 0 \\
\hline 2 & $\begin{array}{l}\text { Lack of film and stains, individual rainbow strips, which can be seen under the } \\
\text { most favorable conditions and calm condition of the water surface. }\end{array}$ & 0,1 \\
\hline 3 & $\begin{array}{l}\text { Separate stains and gray films of silver on the surface of the water, which are } \\
\text { visible at a calm condition of the water surface, the appearance of the first signs } \\
\text { of coloration }\end{array}$ & 0,2 \\
\hline 4 & Spots and films with bright colored stripes that can be seen with minor waving & 0,4 \\
\hline 5 & $\begin{array}{l}\text { Oil in the form of spots and films that cover significant areas of the surface of the } \\
\text { water that do not burst during agitation }\end{array}$ & 1,2 \\
\hline 6 & $\begin{array}{l}\text { The surface of the water is covered with a solid layer of oil, well visible in waving, } \\
\text { the color is dark, dark brown }\end{array}$ & 1,5 \\
\hline
\end{tabular}


Features of the oil absorption by sorbents

\begin{tabular}{|c|c|c|c|c|c|c|c|}
\hline \multirow{2}{*}{ № } & \multirow{2}{*}{$\begin{array}{c}\text { Type of } \\
\text { sorbent }\end{array}$} & $\begin{array}{c}\text { Experiment 1 } \\
\text { The time } \\
\text { of sorption, } \\
\text { sec. }\end{array}$ & $\begin{array}{c}\text { The spot } \\
\text { diameter, } \\
\text { cm }\end{array}$ & $\begin{array}{c}\text { The time } \\
\text { of sorption, } \\
\text { sec. }\end{array}$ & $\begin{array}{c}\text { The spot } \\
\text { diameter, } \\
\text { cm }\end{array}$ & $\begin{array}{c}\text { The time } \\
\text { of sorption, } \\
\text { sec. }\end{array}$ & $\begin{array}{c}\text { The spot diam- } \\
\text { eter, } \\
\text { cm }\end{array}$ \\
\hline 1 & Black coal & 8.26 & 5.0 & 9.12 & 6.5 & 8.45 & 5.7 \\
\hline 2 & White coal & 3.02 & 5.3 & 1.56 & 5.5 & 1.76 & 5.4 \\
\hline 3 & Polyfoam & 6.26 & 5.1 & 3.56 & 7.0 & 5.22 & 5.3 \\
\hline 4 & Cotton & 1.49 & 5.5 & 0.18 & 5.5 & 1.48 & 5.4 \\
\hline
\end{tabular}

One of the advantages is its waterproofness, which is especially important in case of its application in the fight against oil pollution. Another advantage is the low cost of raw materials and foam production technology.

Black coal is a natural substance with a porous carbon structure with high adsorption properties and hydrophobicity. Due to its effective absorbing properties, black coal is widely used in medicine, chemistry, food industry and everyday life.

White coal - a natural inorganic substance - silicon dioxide - has a high dispersion and sorption properties. The commercial name "white coal" the preparation received by analogy with black coals due to known sorption characteristics, but its composition does not contain coal. Sorbent properties of white coal significantly exceed the same indicators for black coal. However, whether this property of white coal allows us to cope better with oil pollution, the experiment has shown.

Presentation of the main material. In the case of the use of black coal, there is a process of thickening of the oil spill (Table 2). The process of sorption is slow, part of the sorbent with sorbed petroleum products formed a precipitate.

As a result of the use of white coal, the process of thickening of the oil spot takes place quite intensively. The big part of the sorbent that entered the reaction fell into the precipitate.

In the case of foam there is a process of adhesion (sticking to the bottom of the foam). Oil is closely linked with foam, which indicates the passage of the process of sorption (absorption) of oil.

As a result of the use of cotton as a sorbent, the process of adhesion is observed when the oil spot adheres very quickly to the surface, after which it is possible to separate water pollution easily.

Main conclusions and prospects for using research results. According to the type of sorbent used to clean water from oil pollution, the time and quality of oil absorption depends.

Experimental research has shown that cotton is the most optimal option for water purification from oil. In this case, it is not necessary to use additional sediment traps. Cotton is the fastest way to absorb oil. The water remains clean as a result. This is the fastest and most effective way.

Absorption of oil by white coal is carried out in a small amount of time, part of the sorbent falls into the precipitate. Since not all of the mass of white coal has come into contact with oil, on the surface partly there are minor spots.

Polyfoam absorbs oil in a short time, but inferior to the efficiency of absorption of white coal and cotton natural materials.

Absorption of oil by black coal requires a considerable amount of time and traps, since coal is largely dispersed and quickly precipitates. This method of purifying water from oil is most economically disadvantageous and requires more time to reach the goal.

\section{References}

1. Brakorenko N.N., Korotchenko T.V. Impact of petroleum products on soil composition and physical-chemical properties. IOP Conf. Series: Earth and Environmental Science. 2016. № 33. H. 1-6. doi:10.1088/1755-1315/33/1/012028.

2. Glibovytska N.I., Plaksiy L.V. Methods of water treatment from oil contamination. Ecological education and ecological culture of the population: materials of the VI international scientific conference on February 25-26, 2018. Prague. P. 44-45.

3. Kablov V.F., Ioschenko Yu.P. Oil spills and the issue of oil removal. Fundamental Research. 2004. № 6. P. 64.

4. Maksimov V., Dinyak S., Dinyak O. Analysis of systemic losses of petroleum products at enterprises of oil and gas complex of Ukraine. Ecology of environment and life safety. 2004. № 5. P. 41-44.

5. Plaksiy L.V. Methodology of estimation of surface water in the places of influence of objects of oil pipeline transport. Ecological safety and balanced resource use. Ivano-Frankivsk: IFNTUNG, 2016. № 2 (14). 5 p.

6. Pogharnitskaya O.V. et al. Treatment of petroleum-contaminated water resources: modern techniques. IOP Conf. Series: Earth and Environmental Science. 2016. № 43. P. 1-6. doi.org/10.1088/1755-1315/43/1/012026.

7. Tsibulnikova M.R. et al. Economic assessment of environmental impact in the course of oil field development and production. IOP Conf. Series: Earth and Environmental Science. 2015. № 27. P. 1-5. doi:10.1088/1755-1315/27/1/012076.

8. Vladimirov V.A. Oil spills: causes, scales, effects. Civil safety strategy: issues and research. 2014. № 1. $217 \mathrm{p}$.

9. Yatsyshyn T.M., Glibovytska N.I. Influence of oil and gas extraction on the environment and prospects of phytodynamics and phytothermization of technogenotransformed territories. Ecological safety and balanced resource use. 2016. № 1. P. $22-29$. 


\title{
СОЦІААЬНО-ЕКОАОГІЧНІ НАСАІДКИ ФУНКЩІОНУВАННЯ МАИИХ ГІДРОЕАЕКТРОСТАНЦІЙ ДАЯ ПОПУАЯЦІї ФOPEAI CTPУМКОВОÏ (SALMO TRUTTA) В БАСЕЙНI РІЧКИ БІАИЙ ЧЕРЕМОШ
}

\author{
Нечай М.М. \\ Національний природний парк «Верховинський» \\ пр. Печіще, 3А, 78712, с. Верхній Ясенів, Івано-Франківська обл. \\ nppverhovuna@ukr.net
}

\begin{abstract}
У статті висвітлено проблеми будівництва низки міні-ГЕС на гірських річках Карпат через їх вплив на аборигенну, типову іхтіофауну, водну екосистему і традиційне раціональне природокористування. Досліджено можливості розвитку Карпатського регіону як туристичного об'єкта за умови забудови гірських річок міні-ГЕС. Ключові слова: міні-ГЕС, іхтіофауна, руйнування, водна екосистема, річка Білий Черемош, екологічні збитки.
\end{abstract}

\begin{abstract}
Социально-экологические последствия функционирования малых гидроэлектростанций для популяции форели ручьевой (Salmo trutta) в бассейне реки Белый Черемош. Нечай М.М. В статье освещены проблемы строительства ряда мини-ГЭС на горных реках Карпат через их влияние на аборигенную, типичную ихтиофауну, водную экосистему и традиционное рациональное природопользование. Исследованы возможности развития Карпатского региона как туристического объекта при условии застройки горных рек мини-ГЕС. Ключевые слова: мини-ГЭС, ихтиофауна, разрушения, водная экосистема, река Белый Черемош, экологический ущерб.
\end{abstract}

Socio-ecological consequences of functioning of small hydroelectric power stations) for the population of trout stream (Salmo trutta) in the basin of the White Cheremosh. Nechay M. The problems of the construction of a number of mini-hydroelectric power stations on the mountain rivers of the Carpathians are explored due to their influence on aboriginal, typical ichthyofauna, water ecosystem and traditional rational nature management. The possibilities of development of the Carpathian region as a tourist object under conditions of development of mountain rivers by mini-HESs are explored. Key words: mini-HPP, ichthyofauna, destruction, aquatic ecosystem, river Bely Cheremosh, ecological losses.

Постановка проблеми. За останні декілька років на гірських річках Карпат, зокрема в басейні Білого Черемошу, почали з'являтися міні-гідроелектростанції, які викликають супротив не тільки в місцевого населення, а й у науковців-екологів. Під час будівництва цих гідроспоруд виникає комплекс екологічних проблем: порушення гідрологічного режиму русла та природного характеру течії річки, втрати води від водозабору; погіршення якості води під час ії проходження через систему труб і турбін; порушення природного нересту риб, зміна циклів міграції живих організмів. Це призводить до незворотних змін у гірській водній екосистемі [2]. Малі гідроспоруди катастрофічно впливають на якісний і кількісний склад іхтіофауни водойм, зокрема форель струмкову (Salmo trutta), яка є одним із основних видів риби, тісно пов'язаного з побутом місцевого населення.

Якість води визначали лабораторними методами, а вплив різних чинників на популяцію форелі струмкової (Salmo trutta) в басейні Білого Черемошу в місцях розміщення міні-ГЕС - власними польовими дослідженнями й узагальненням результатів праць провідних дослідників.
Виклад основного матеріалу. Протягом сотень років форель струмкова (Salmo trutta) давала змогу горянам збагачувати їхній одноманітний харчовий раціон, який переважно складався 3 м'ясо-молочної продукції. У сучасних соціально-економічних умовах України необхідно зробити все можливе, щоб зберегти і примножити цей цінний вид риб для наступних поколінь [6], адже форель струмкова $\epsilon$ одним із важливих харчових об'єктів для багатьох тварин, у тому числі й раритетних. Наприклад, раціон видри річкової (lutra lutra (L.)) у верхів'ях рік Білого та Чорного Черемошу, Перкалаби й Сарати переважно складається $з$ форелі струмкової. Крім видри, таким «делікатесом» охоче можуть поласувати норка європейська (Mustela lutreola (L.)), куниця лісова (Martes martes (L.)), куниця кам'яна (Martes foina (Erxl.)), кіт лісовий (Felis silvestris Schreb.), рись звичайна (Felis lynx (L.)), окремі хижі птахи, деякі плазуни, зокрема вуж звичайний (Natrix natrix (L.)). Ведмідь бурий (Ursus arctos) також полює на форель струмкову, особливо в період іï нересту, i, за словами місцевих жителі, він «нагулює» на цій рибі значну частину свого жиру, що дає йому змогу без пробуджень провести всю зиму в барлогу [6]. 


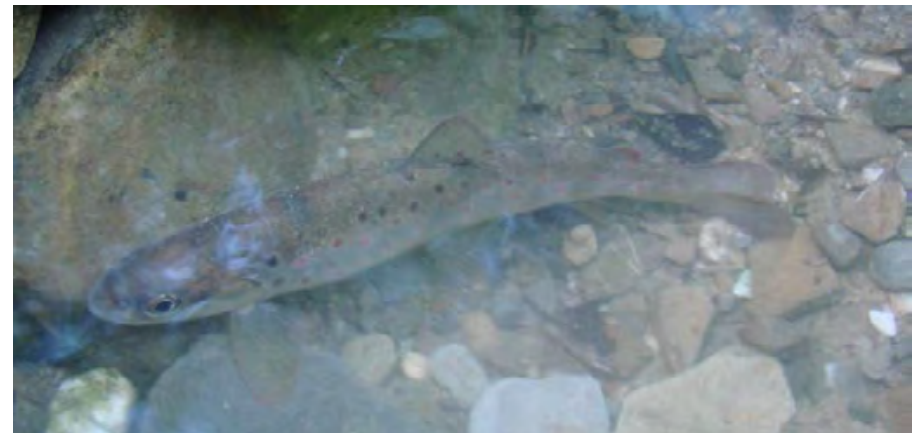

Pис. 1. Струмкова форель (Salmo trutta (L.) - басейн р. Черемош, 19.07.2013

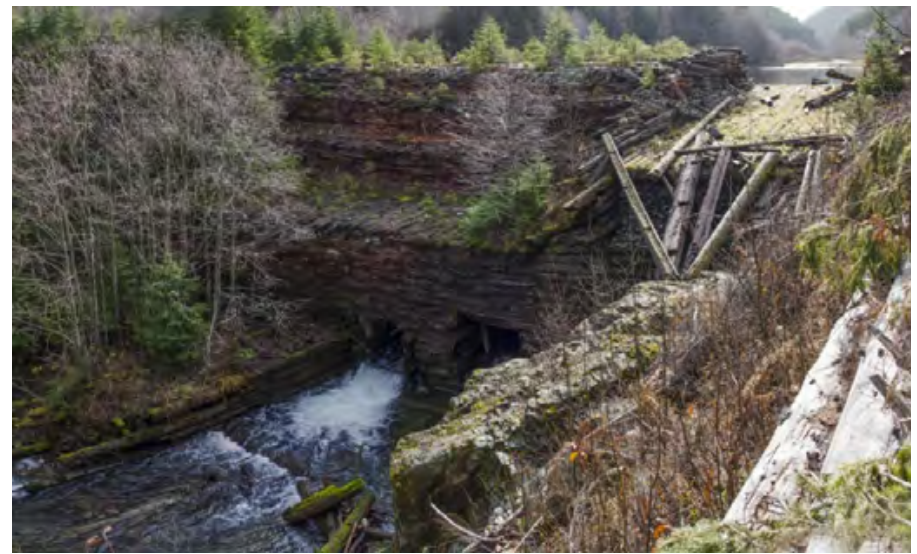

Рис. 2. Залишки кляузи кронпринца Рудольфа на території НПП «Верховинський» ур. Перкалаба

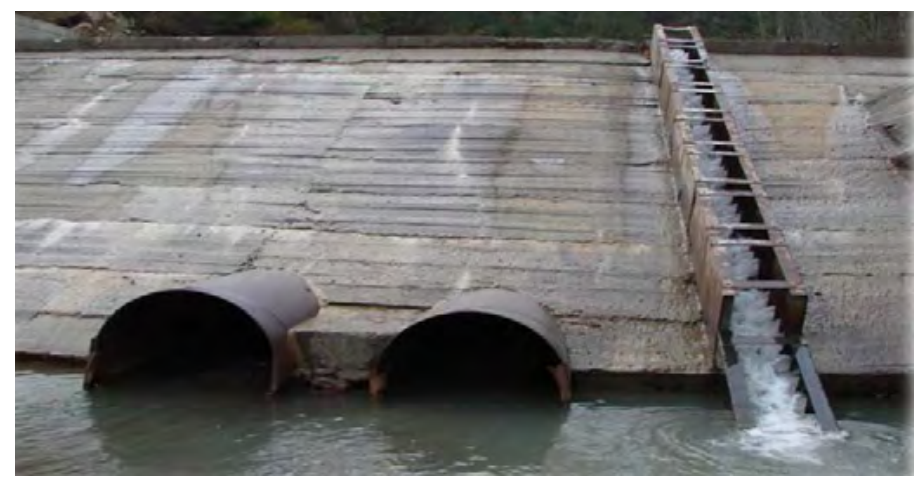

Рис. 3. Міні-ГЕС на річиі Пробійна в с. Пробійнівка Верховинського району Івано-Франківської області

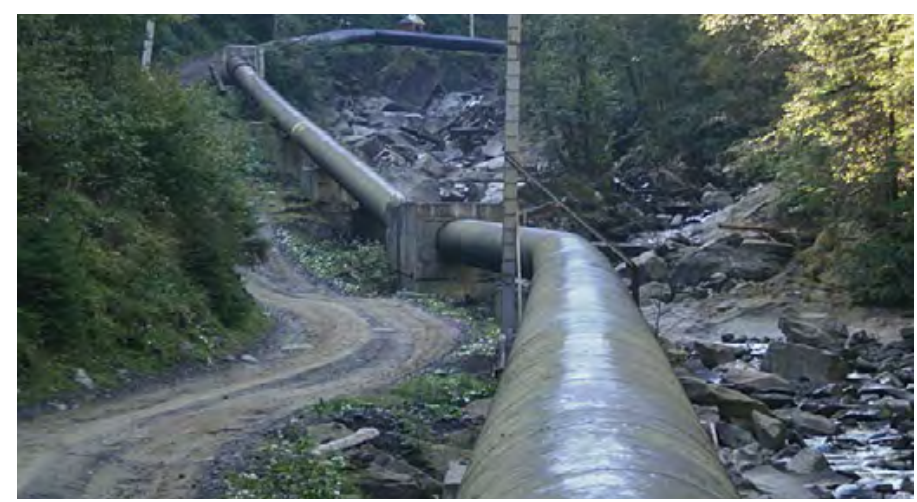

Рис. 4. Деривачійні споруди міні-ГЕС у с. Пробійна
Черемош із його притоками Путилка, Білий Черемош і Чорний Черемош поряд із Прутом і Тисою $є$, без сумніву, однією з найголовніших річок Гуцульщини [1].

Річка Білий Черемош $є$ важливим складником екосистеми Карпат, є не лише їі окрасою, а й має велике репродуктивне значення для збереження різноманіття гірської іхтіофауни. Зі своїми холодними та чистими притоками річка здавна відома своїм багатством рибних запасів [5]. У прохолодних струменях кришталево чистої води басейну Черемошу водиться багато видів риб: форель струмкова (Salmo trutta (L.)) (рис. 1), форель райдужна (Parasalmo mykiss (Walb.)), лосось дунайський (Hucho hucho (L.)), минь річковий (Lota lota (L.)), марена середземноморська (Barbus petenyi (Heck.)), підуст (Chondrostoma nasus (L.)), головень (Squalius cephalus (L.)), щука (Esox lucius (L.)), в’юн звичайний (Misgurnus fossilis (L.)), бистрянка (Alburnoides bipunctatus (Bloch.)), карась сріблястий (Carassius gibelio (Bloch.)), карась звичайний (Carassius carassius (L.)), пічкур карпатський (Gobio carpathicus (Vladykov.)), гольян звичайний (Phoxinus phoxinus (L.)), щипавка дунайська (Cobitis elongatoides (Bacescu et Maier), бабець строкатоплавцевий (Cottus poecilopus (Heck.)) тощо [8].

Щодо основних причинзменшення популяції форелі струмкової (Salmo trutta) як реофільного виду риб, то в басейні Черемошу мають місце:

- браконьєрський вилов протягом багатьох років 3 використанням електричної напруги, хлору, остів, сітей тощо;

- знищення середовищ існування (плес, перекати, місця нересту) під час забору з дна річки піщано-гравійної суміші та річкового каменю;

- відсутність якісних очисних споруд;

- весняний льодохід і періодичні паводки, які є частим явищем на гірських річках;

- проведення берегоукріплювальних та інших робіт без урахування умов життєдіяльності іхтіофауни й унеможливлення шляхів руху малакофауни в невеликі потоки, струмки басейну Черемошу (занадто високо встановлені труби на автомобільних переїздах тощо);

- забруднення струмків під час промислових лісорозробок;

- трелювання деревини руслами гірських струмків і річок;

- підвищення температури води внаслідок прогрівання іiі на відкритих ділянках, які утворюються під час вирубування дерев по берегах річок і струмків.

Проте одним із катастрофічних видів діяльності, яка знищує популяцію форелі і загалом аборигенної іхтіофауни, є будівництво й функ- 
ціонування відновлених і новостворених міні-гідроелектростанцій дериваційного типу на гірських річках Карпат. Наочним прикладом негативних наслідків на якісний і кількісний склад іхтіофауни головних карпатських річок є будівництво на них кляуз-гатей (рис. 2), призначених для транспортування деревини. Багаторічне функціонування в басейні Черемошу гідротехнічних споруд гребельного типу, наслідком чого є осідання паводкових наносів протягом десятків років, створило несприятливий режим для реофільних видів риб [6, с. 13]. Також за такої експлуатації водойм нищівних наслідків зазнавала й прибережна заплавна рослинність, яка відіграє ключову роль у функціонуванні типової природної екосистеми [2].

Отже, карпатський регіон уже має негативний досвід такого використання гірських річок, що спричинило виникнення екологічних проблем у регіоні.

Якщо розглянути роботу вже наявних міні-ГЕС на Карпатських річках, зокрема тих, що розташовані у Верховинському районі на р. Білий Черемош, у с. Пробійнівка (Пробійна 1 і Пробійна 2) та с. Яблуниця, й міні-ГЕС, які з різних причин так i не були введені в експлуатацію, очікувані економічні результати супроводжуються екологічними збитками [13]. Крім того, знищується загальна естетика регіону, що призводить до втрати популярності цієї території для туристів і відвідувачів, що знижує соціально-економічний стан місцевого населення, основою доходів якого переважно є розвиток рекреації й туризму [7]. Фото (рис. 3-6) наведених гідротехнічних споруд, на нашу думку, не відбивають історико-культурну, етнічну, соціально-економічну та екологічну ситуацію району. Крім того, відповідно до Закону України «Про оцінку впливу на довкілля», не ГЕС залежно від потужності підлягають оцінюванню впливу на довкілля [11].

Досліджувані міні-ГЕС є переважно гребельними та дериваційними. Під час будівництва греблі річку фактично поділяють на дві по-різному видозмінені частини, якщо річка бурхлива та швидкоплинна, то в ній вище греблі вода вже застоюється, а нижче греблі річка майже знищена [2]. Чим вища гребля, тим глибше штучно утворене водосховище, де повністю змінюється характер річки. Вона стає схожою на ставок iз тихою спокійною течією, коли вода починає замулюватися, змінюється рівень кисню, біохімія, фізичні властивості. Пізніше вода «цвіте», починає «булькати» через початок гнилісних процесів, а це означає, що природна екосистема гірської річки вже знищена [3].

Дослідження впливу міні-ГЕС на якість води розпочаті Т. Микитчаком і Я. Ільчинським ще у 2009 р. в с. Грамотне на злитті потоків Грамотний і Пробійна (ліва притока Білого Черемошу). Детальніше методику дослідження висвітлено в праці «Порівняння стану якості вод верхів'я річки Прут та Чорний Черемош» [10]. Біоіндикація (біологічний аналіз вод) дає змогу об'єктивно оцінити навіть найменші зміни чи коливання якості води у водному середовищі. Дослідженнями встановлено незначне забруднення, зменшення показників індексів якості води (TBI й EBI) на 1,5-2,0 бали нижче по течії за станцією. Також у процесі дослідження станцій у с. Довгопілля (Білий Черемош) і с. Дземброня (Чорний Черемош) зафіксовано зниження показників якості води на 1 бал, що в типових природних умовах на такій короткій відстані (до 1 км) неможливе. Унаслідок спорудження каскаду міні-ГЕС відбудеться істотне зниження якості води, на відновлення якої необхідне не одне десятиліття. Стік води (витрата води) - активний чинник, динаміка й розмір якого зумовлюють хід фізико-хімічних і біотичних процесів, що, відповідно, впливає на розвиток ерозійно-зсувних (акумулятивних) процесів і призводить до зміни русла ріки й гідрологічного режиму. Вплив водного стоку на якість води найвиразніше виявляється в характері розподілу розчинених речовин у річці, ефективності процесів самоочищення й мінливості гідробіологічних показників [2].

Відповідно, змінюється й кількість мешканців уже в різних водоймах. Там почнуть виникати інвазійні види, які ніколи б не мали жити там, а ті, що жили, аборигенні види зникнуть через утворення зовсім іншої нетипової екосистеми [4]. Тобто вже про еталон не може бути мови, а більшість карпатських річок є природними без невтручання людини, що видозмінювало б ї. Тому в карпатських річках ще збереглися автентичні види риб, які зараз зане-

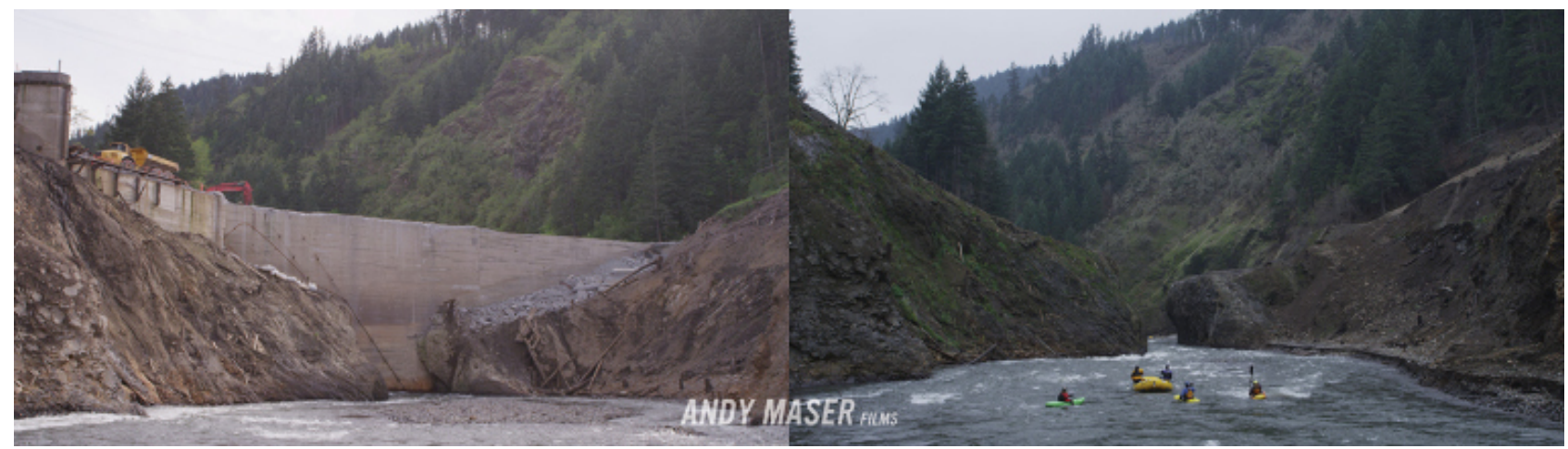

РИс. 5. Демонтаж ГЕС у США 
сені до Червоної книги України, це їхнє природне середовище. Після будівництва міні-ГЕС екосистема часто кардинально змінюється, і це призводить до зникнення деяких видів, особливо аборигенних видів і тих, які занесені до Червоної книги України.

Уся річкова система дуже сильно пов'язана, для тутешньої іхтіофауни вона єдина. Наприклад, iз Черемошу вся риба на нерест іде у верхів'я ріки та її притоки. Але якщо на річці побудували греблю, нересту фактично не буде, як наслідок - катастрофічна ситуація стану популяції. Басейн Черемошу $€$ вкрай важливим для збереження таких видів, як лосось дунайський, форель струмкова й низка інших коропоподібних, занесених до Червоної книги України, які фактично залишилися тільки в деяких карпатських ріках.

Щоб гребля була функціональна й там могла пересуватися риба, роблять рибоходи - це відповідні пристрої, які допомагають рибі пройти вгору і спуститися вниз. Але на ріці не повинно бути греблі взагалі, тому що для кожного виду риби має бути свій рибохід. Наприклад, у рибохід для лососевих коропові риби не підуть, їх лякає надто бурхлива та швидка вода. Тому для такої річки майже неможливо спроектувати правильного рибоходу, бо риба різна й те, що прийнятне для одного виду, не підходитиме для іншого.

Проте, з огляду на те, як саме на наших ріках виглядають і функціонують ГЕС-споруди, рибохід або взагалі відсутній, або такий інколи абсурдний, що не може бути придатним ні для одного з видів, які мешкають у тому водотоці. Практика наочно показує поступове знищення аборигенної ендемічної іхтіофауни та заміщення її екологічної ніші зовсім іншими видами, нетиповими для цього регіону, часом навіть «агресивними видами», що призводить до руйнування еталонного водного об'єкта, який є «візитною карточкою» карпатського регіону [4].

На прикладі форелі струмкової практичні натурні спостереження протягом кількох років показують, що ця риба, яка рухається вгору по течії до витоків і струмків Білого Черемошу на нерест, зустрічається 3 такою непереборною перешкодою, як гребля чи дериваційні споруди, і гине, так і не діставшись місця нерестилищ. Унаслідок цього популяція цього виду різко зменшилася, що негативно впливає не тільки на водну екосистему, а й на якість життя місцевого населення. Форель струмкова $є$ популярним делікатесом, який користується попитом у місцевих i гостей регіону. Тому створення низки форельних господарств матиме позитивний ефект, буде позитивною альтернативою використання карпатських природних ресурсів і вписуватиметься в традиційне господарювання з позитивним впливом на розвиток регіону без шкоди природним екосистемам [9].

Існують переконливі економічно обгрунтовані докази ефективності малих ГЕС на гірських річках. Проте на ліквідацію наслідків екологічної катастрофи витрачаються значні кошти, що спричиняє безповоротні зміни в екосистемі природи.

Світовий досвід свідчить про низку недоліків у використанні малих ГЕС на гірських річках. 3 метою відтворення природних екосистем і припинення їх знищення практикують демонтаж таких споруд (рис. 5).

Водною рамковою директивою $С С$ запроваджено принципово новий підхід до системи управління водними ресурсами - це інтегроване управління водними ресурсами за басейновим принципом, яким, зокрема, передбачено, що основною одиницею управління є басейн водного об'єкта [14]. Заслуговує на увагу наукова позиція багатьох учених щодо необхідності впровадження охорони цінних природних територій за басейновим принципом.

Головні висновки. Одним із впливових методів боротьби з досліджуваної проблеми є роз'яснювальна робота серед населення. Оскільки, за Законом України «Про регулювання містобудівної діяльності», жоден містобудівний документ не може бути прийнятий без громадських слухань, забудовники повинні надати пропонований проект місцевій громаді з оцінюванням негативу й позитиву [12]. Отже, науковцям-екологам та управлінцям на місцях варто проводити обгрунтовану пропагандистську діяльність щодо шкідливості та нерентабельності будівництва ГЕС на гірських річках, адже певне стихійне протистояння місцевого населення вже існує, що вимагає дотримання чинного законодавства 3 проектування, будівництва й безпосередньо функціонування міні-гідроелектростанцій на карпатських ріках.

Стосовно наявних на гірських річках міні-ГЕС уважаємо за необхідне вимагати проведення реконструкції старих і створення нових рибоходів на греблях, які б відповідали біології тих видів іхтіофауни, що перебувають у відповідних водотоках. Доцільно проводити очисні роботи від замулення та інші роботи на греблях у місцях утворення водосховища, дотримуватися правил у будівництві дериваційних споруд і забору води.

Водні артерії є основними об'єктами збереження екосистем території. Отже, необхідно надати річці Білий Черемош охоронного статусу для запобігання незаконним діям і посилення відповідальності за порушення природоохоронного законодавства, що призводить до знищення унікальних гірських екосистем. 


\section{Література}

1. Друкман С.Л. По Черемошу і Пруту: Путиводитель. Ужгород: Карпати, 1985. 214 с.

2. Ільчишин Я.Т. Екологічні загрози будівництву каскаду міні-ГЕС на території басейну р. Черемош. Вісник Львівського університету ім. Івана Франка. Серія «Географічна». Випуск 45. Львів, 2014. С. 403-407.

3. Ільчишин Я.Т. Про дослідження екологічного стану якості вод гірських рік Українських Карпат за методикою біоіндикації (на прикладі річки Прут). Гідрологія, гідрохімія, гідроекологія. 2012. Т. 1. С. 156-166.

4. Коляджин I.I. Поява чужорідного виду звичайної щуки (Esox lucius) та іiї вплив на іхтіофауну у верхів 'і басейну Черемошу. Регіональні аспекти флористичних і фауністичних досліджень: матер. II Міжн. наук. конф. (24-25 квітня 2015 року, смт. Путила, Чернівецької обл., Україна). Чернівці: ДрукАрт, 2015. С. 286-288.

5. Мовчан Ю.В. Риби України (Визн. довідник). Київ, 2011. 444 с.

6. Нечай M.M. Сучасний стан популяції та перспективи збільшення чисельності струмкової форелі (Salmo trutta (L.)) в басейні Черемошу. Регіональні аспекти флористичних і фауністичних досліджень: матер. I Міжн. наук. конф. (10-12 квітня 2014 року, м. Хотин). Чернівці: ДрукАрт, 2014. С. 195-200.

7. Рожко І.М. Рекреаційна оцінка гірських природо-територіальних комплексів для потреб туризму (на прикладі Українських Карпат): дис. ... канд. географ. наук. Львів, 2000.

8. Скільський I.В., Зеленчук Я.І., Киселюк О.І. Фауна хребетних національного природного парку «Верховинський»: загальний огляд. Прагматичні аспекти діяльності національних природних парків у контексті збалансованого розвитку: матер. Міжнар. конф., присвяч. 20-річчю Нац. прир. парку «Вижницький» (17-19 вересня 2015 року, смт. Берегомет Чернівецької обл., Україна). Чернівці: ДрукАрт, 2015. С. 165-181.

9. Шнаревич І.Д., Шиліна Л.М. Матеріали з екології форелі і перспективи розвитку форелівництва в річках Чернівецької області. Праці експед. з компл. вивч. Карпат і Прикарпаття. Серія «Біологічна» / Чернів. держ. унів. Львівськ. ун-т. 1956. Т. П. С. $145-155$.

10. Ilczyszyn Y., Lenko O. Stan ekologiczny objektów wodnych Czarnohory. Homo Naturalis: мat. konf. Katowice, 2009. S. $156-165$.

11. Про оцінку впливу на довкілля: Закон України від 23 травня 2017 року № 2059-19. Відомості Верховної Ради України. 2017. № 29. С. 315.

12. Про регулювання містобудівної діяльності: Закон України від 17 лютого 2011 року № 3038-VI. Відомості Верховної Ради України. 2011. № 34. С. 343.

13. Рамкова конвенція про охорону та сталий розвиток Карпат, ратифікована Законом України від 7 квітня 2004 року № $1672-\mathrm{IV}$.

14. Про встановлення рамок діяльності Співтовариства в галузі водної політики: Директива 2000/60/ЄС Європейського парламенту та Ради від 23 жовтня 2000 року. 


\title{
ПЫИЕПОДАВАЕНИЕ НА ЗОАОШААКООТВАМАХ ТЭЦ С ИСПОАЬЗОВАНИЕМ ВОДОРАСТВОРИМЫХ ПОАИМЕРОВ
}

\author{
Тищенкова М.О. ${ }^{1}$, Филин В.Н. ${ }^{2}$, Селиванов В.В. ${ }^{3}$, Печений В.Л. \\ ${ }^{1} \mathrm{OOO}$ «НПО «Экоальянс» \\ ул. Кирилловская, 6-А, 04080, г. Киев \\ mtyshenkova@ecoalliance.com.ua; \\ ${ }^{2} \mathrm{OOO} \mathrm{«Экология-Днепр} \mathrm{2004»}$ \\ бул. Независимости, 13, кв. 92, 51928, г. Каменское \\ filin_v@i.ua \\ ${ }^{3} \mathrm{OOO}$ «Евро-Реконструкция», г. Киев \\ ул. Панаса Мирного, 28, оф. 20, г. Киев, 01011 \\ kanc@euro.tec4. kiev.ua \\ ${ }^{4}$ Государственная экологическая академия \\ последипломного образования и управления \\ ул. Митрополита Василия Липковского, 35, корп. 2, 03035, Киев \\ pressdei@ukr.net
}

\footnotetext{
В статье проведен анализ опубликованных источников по использованию водорастворимых полимеров для пылеподавления на золошлакоотвалах ТЭЦ-4 и других пылящих поверхностях. Представлены варианты запатентованных пылеподавляющих композиций. Ключевые слова: пыль, золошламонакопитель, водорастворимый полимер, полиакрилаты.
}

Пилопригнічення на золошлаковідвалах ТЕЦ із використанням водорозчинних полімерів. Тіщенкова М.О., Філін В.М. Селіванов В.В., Печений В.Л. У статті проаналізовано опубліковану інформацію щодо використання водорозчинних полімерів для пилопригнічення на золошлаковідвалах ТЕЦ та інших поверхнях, що пилять. Наведено варіанти запатентованих пилоприбивних композицій. Ключові слова: пил, золошламонакопичувач, водорозчинний полімер, поліакрилати.

Dust-oppression on ash slag from CHP using water-soluble polymers. Tishchenkova M., Filin V., Selivanov V., Pechenyy V. Desk research has been conducted on the use of water-soluble polymer for dust suppression at ash-slag disposal area at combined heat and power (CHP) and others dusty surfaces. The options for patented dust suppression compositions are being presented. Key words: dust, ash sludge tank, water-soluble polymer, acrylic plastics.

Постановка проблемы. Большинство теплоэлектростанций (далее - ТЭС/ТЭЦ), использующих уголь в качестве топлива, вынуждены иметь рядом золошламонакопители, в которых концентрируются частицы золы и шлака, направляемые туда по системе гидрозолоудаления. В летний период, когда отдельные участки золошламонакопителей пересыхают, возникает угроза пыления, что негативно влияет на санитарное состояние окружающей территории с учётом сложного химического состава золы. По данным ВНИИ гидротехники им. Веденеева, с одного гектара подсушенной поверхности золошламонакопителей при скорости ветра 5-6 м/с уносится в сутки $2-5$ т зольной пыли. За год за пределы некоторых золоотвалов с 1 га может поступать до 1000 т мелкодисперсной золы [1].

Анализ последних исследований и публикаций. Анализ научных публикаций по пылеподавлению на золошлакоотвалах ТЭЦ показывает, что основными способами пылеподавления являются рекультивация и мелиорация золошлакоотвала (без перспективы использования золошлаков в качестве техногенного сырья) [2; 3], а также обработка золошлаков раствором водорастворимых полимеров для упрочнения мелкодисперсного пылевидного слоя золы и образования устойчивой защитной пленки на поверхности золошлакоотвала [4-7]. Частичное снижение пыления на золошлакоотвалах можно также обеспечить гранулированием золы в местах её складирования [8].

Изложение основного материала. К пылеподавляющим композициям предъявляются следующие основные требования:

- возможность распыления при помощи как пневматических распылителей, так и распылителей высокого давления;

- водорастворимый состав должен сохранять свои эксплуатационные и технологические характеристики при температуре окружающего воздуха от 5 до $40{ }^{\circ} \mathrm{C}$;

- покрытие должно обладать водо-, атмосферо- и химстойкостью в течение всего срока эксплуатации.

До 70-х годов прошлого века для стабилизации почв в дорожном строительстве и сельском хозяй- 
стве использовали лигнин, гуминовые кислоты, битумы, смоляные и торфяные клеи. Затем стали использовать преимущественно частично гидролизованные (на 20-30\%) полиакрилонитрил или полиакриламид с концентрацией в водном растворе 0,05-0,5\%, а также другие полимеры, что позволило снизить расход стабилизаторов почвы в 10-20 раз [7, с. 9-11]. Склеивающая способность полиэлектролитов на почвах с различными значениями $\mathrm{pH}$ и содержания солей различна [7]. Это полимеры, содержащие в боковых цепях только ионогенные группы (соли акриловой, метакриловой, малеиновой кислоты и др.) или вообще не содержащие их (поливиниловый спирт, метилцеллюлоза) и малоэффективные. Эффективными являются полимеры, содержащие как ионогенные, так и неионогенные группы (например, частично гидролизованный полиакриламид). В настоящее время наряду с крилиумами (линейными водорастворимыми полимерами акриловой, метакриловой и других кислот) в качестве структурообразователя почвы используются так называемые суперабсорбенты - полимеры сетчатой структуры, образующие устойчивый гидрогель. Они характеризуются большой молекулярной массой (в 100 и более раз превосходящей молекулярную массу крилиумов), что позволяет снизить дозу их применения в 100 и более раз [12].

В последнее время активно апробируются поликомплексы - связующие препараты с участием полианионов и поликатионов. В качестве полиани- онов используют полиакриловую кислоту (ПАК), препарат К-4, гидролизованный полиакрилонитрил (ГИПАН), карбоксиметилцеллюлозу (КМЦ), а в качестве поликатионов - полиэтиленимин (ПЭИ), мочевиноформальдегидную смолу и др. Поликомплексы относятся к органическим соединениям типа целлюлозы и медленно разрушаются в почве. Хотя в состав поликомплексов входят водорастворимые полимеры, при нанесении на поверхность почвы их разбавленных растворов они быстро реагируют друг с другом, образуя эффективное связующее вещество, которое не растворяется в воде. Внесение поликомплекса в дозе 75-200 кг/га предотвращало эрозию при интенсивности дождевания до 2 мм/мин и обеспечивало устойчивость к выдуванию при скорости ветра $25 \mathrm{M} /$ сек [12].

В таблице 1 представлены варианты запатентованных пылеподавляющих композиций.

Для предотвращения распространения радиоактивной пыли с пылящих поверхностей в окружающее пространство разработаны специальные пылеподавляющие составы АК-501 и СКС-501, образующие устойчивую полимерную пленку. Оба состава применяли при проведении работ по дезактивации в условиях ликвидации последствий аварии на Чернобыльской АЭС. Характеристики составов АК-501 и СКС-501 приведены в таблице 2.

Анализ данных таблиц 1 и 2, а также опубликованных данных источников показывает, что одним из основных компонентов пылеподавляющих соста-

Состав отдельных пылеподавляющих композиций.

Таблица 1

\begin{tabular}{|c|c|c|c|c|}
\hline $\begin{array}{c}\text { № } \\
\text { ПI/II }\end{array}$ & $\begin{array}{c}\text { Компоненты пылеподавляющего состава, } \\
\text { \% мас. }\end{array}$ & Вид пыли & \begin{tabular}{|c|} 
Рабочая \\
$\begin{array}{c}\text { концентрация } \\
\text { состава, } \\
\% \text { мас. }\end{array}$ \\
\end{tabular} & Источник \\
\hline 1 & $\begin{array}{l}\text { - Лигносульфонат }-5-10 \\
\text { - Полиакриламид - 0,2-0,5 } \\
\text { - Отходы производства хромовых солей }-2,5-5,0 \\
\text { - Гидросульфит натрия }-0,2-0,5 \\
\text { Вода - остальное }\end{array}$ & $\begin{array}{l}\text { Пыль карьеров, } \\
\text { шахт, отвалов, } \\
\text { хвостохранилищ } \\
\text { ТЭС, почвы }\end{array}$ & & [13] \\
\hline 2. & $\begin{array}{l}\text { - Лигносульфонат - 1-2,5 } \\
\text { - Полиакриламид - 0,25-0,75 } \\
\text { - Карбамид - } 1-3 \\
\text { - } \mathrm{Ca}(\mathrm{OH}) 2-0,3-0,5 \\
\text { - } \mathrm{CaCl} 2-0,02-0,05 \\
\text { Вода - остальное } \\
\end{array}$ & Почва, зола & & {$[5]$} \\
\hline 3 . & $\begin{array}{l}\text { - Полиакриламид -0,003-0,3 } \\
\text { - Жидкое стекло - 0,03-0,6 } \\
\text { - Вода - остальное }\end{array}$ & $\begin{array}{l}\text { Золоотвалы ТЭС, } \\
\text { почва }\end{array}$ & & [14] \\
\hline 4. & $\begin{array}{l}\text { - Полиакриламид - 2,5-3,0 } \\
\text { - Диметилдиаллиламмонийхлорид - 1,1-1,3 } \\
\text { - Вода - остальное }\end{array}$ & Золоотвалы ТЭС & & [6] \\
\hline 5. & $\begin{array}{l}\text { - Акриламид - 98,37 } \\
\text { - Метилен-бис-акриламид - 1,63 }\end{array}$ & Угольная пыль & $1,5-2,7$ & [15] \\
\hline 6. & $\begin{array}{l}\text { - Полиакрилат - 0-20 } \\
\text { - Поливинилацетат - 0-20 } \\
\text { - Глицерин - 40-95 } \\
\text { - Вода - 0-40 }\end{array}$ & $\begin{array}{c}\text { Пыль грунта } \\
\text { и гравия }\end{array}$ & & [16] \\
\hline
\end{tabular}


Характеристики составов АК-501 и СКС-501

\begin{tabular}{|c|c|c|}
\hline Показатель & AK-501 & CKC-501 \\
\hline Состав & $\begin{array}{c}\text { Водная дисперсия } \\
\text { силоксан-акрилатного } \\
\text { связующего, комплексо- } \\
\text { образователей и ПАВ }\end{array}$ & $\begin{array}{c}\text { Водная дисперсия } \\
\text { латексной смеси, } \\
\text { пластификаторов и } \\
\text { комплексообразователей }\end{array}$ \\
\hline $\begin{array}{l}\text { Время защитного действия пленок } \\
\text { (не менее месяца) }\end{array}$ & $\begin{array}{c}\alpha \text { и } \beta \text {-активные } \\
\text { загрязнения }-6\end{array}$ & $\begin{array}{c}\alpha \text {-активные загрязне- } \\
\text { ния }-24, \beta \text {-активные } \\
\text { загрязнения }-12\end{array}$ \\
\hline Расход составов на один слой, г/м² & 500 & 500 \\
\hline Толщина одного слоя пленки, мм & 0,2 & 0,2 \\
\hline Степень окомкования, \% & $\geq 80$ & $\geq 80$ \\
\hline $\begin{array}{l}\text { Условная вязкость составов по вискозиметру типа } \\
\text { В3-246 с диаметром сопла } 4 \text { мм при } \mathrm{t}=25 \pm 10^{\circ} \mathrm{C} \\
\text { (ГОСТ 8420-74), не менее с }\end{array}$ & $10-24$ & $10-24$ \\
\hline $\begin{array}{l}\text { Стойкость пленок на пылеподавление, } \\
\text { не менее мес. }\end{array}$ & 6 & 6 \\
\hline Концентрация водородных ионов составов (рН) & $7-8$ & $7-8$ \\
\hline Доля нелетучих веществ, \% мас. & $10-12$ & 15 \\
\hline $\begin{array}{l}\text { Прочность при ударе } \\
\text { (ГОСТ 4765-73), см }\end{array}$ & $40-50$ & $40-50$ \\
\hline $\begin{array}{l}\text { Твердость при пылеподавлении (ГОСТ 5233-89), } \\
\text { усл. ед. }\end{array}$ & $\geq 0,2$ & $\geq 0,2$ \\
\hline $\begin{array}{l}\text { Адгезия при пылеподавлении (ГОСТ 15140-78) } \\
\text { не более, баллы }\end{array}$ & 2,0 & 2,0 \\
\hline Срок хранения составов со дня изготовления, мес. & $\geq 6$ & $\geq 6$ \\
\hline Срок годности составов со дня изготовления, мес. & $\geq 6$ & $\geq 6$ \\
\hline
\end{tabular}

вов являются полиакрилаты в той или иной форме (акриловые сополимеры, полиакриламид и др.).

Главные выводы. Дальнейшие исследования по подбору качественного пылеподавляющего состава для золошлаков будут связаны с оптимизацией таких факторов, как экономическая целесообразность применения и эффективность эксплуатационных характеристик.

\section{Литература}

1. Лисненко В.Г., Щелоков Я.М., Ладыгичев М.Г. Топливо. Рациональное сжигание, управление и технологическое использование. Справ. издание: в 3 кн. Москва: Теплотехник, 2004. Кн. 3.545 с.

2. Щиренко А.И. Технология растительных мелиораций рекультивируемых золоотвалов на примере второй секции золоотвала Новочеркасской ГРЭС: автореф. дисс. ... канд. техн. наук. Новочеркасск: Новочеркасская государственная мелиоративная академия, 2010.

3. Белозёрова Т.И. Рекультивация золоотвалов тепловых электростанций в условиях Севера: автореф. дисс. ... канд. тех. наук. Архангельск: Институт экологических проблем Севера Уральского отд. РАН, 2006.

4. Байбурдов Т.А., Шиповская А.Б. Синтез, химические и физико-химические свойства полимеров акриламида. Саратов: ФГБОУ ВПО «Саратовский гос. ун-т», 2014. С. 39-44.

5. Авторское свидетельство СССР № 1371965. Состав для ликвидации пыления золоотвалов / Т.А. Прозорова, А.М. Сафарбаков. Опубл. 07.02.1988, бюл. № 3.

6. Патент 16671 РК. Способ пылеподавления золоотвалов / А.Г. Зайков. Опубл. 15.12.2005.

7. Николаев А.Ф., Охрименко Г.И. Водорастворимые полимеры. Ленинград: Химия, 1979. С. 73-74, 86-87.

8. Вишня Б.Л., Платонов В.К. Технологии грануляции золы. Перспективы применения на угольных TЭЦ. URL: coaleco.ru/ wp-content/uploads/2016/10/12-vishnya-fenix-coaleco2016.pdf.

9. Химические средства защиты почв от эрозии / И.А. Романов и др. Земледелие. 1989. № 11. С. 55-57.

10. Михайлина В.И. Меры борьбы с ветровой эрозией в США. Растениеводство. 1973. № 6. С. 31-38.

11. Габай В.С. Полиакриламид и закрепление подвижных песков. Вестн. с/х науки. 1965. № 7. С. 10-16.

12. Куценко Е.В. Применение поликомплексов для закрепления подвижных песков и борьбы с дефляцией легких почв. Вестн. МГУ. 1981. Сер. 17. № 2. С. 58-61.

13. Патент 4743 РК. Состав для пылеподавления / Н.Ж. Жалгасов и др. Опубл. 16.06.1997.

14. Патент 13034 РК. Состав для пылеподавления золоотвалов / А.Г. Зайков. Опубл. 15.05.2003.

15. U.S. Pat. № 4417992. Dust control / Bhattacharyya, et.al. 29.11.1983.

16. U.S. Pat. № 20100284741A1. Dust suppression agent / R.W. Vitale, C.L. Detloff, D.A. Thomson. 31.03.2009. 


\title{
ЕНЕРГЕТИЧНI ПРОЦЕСИ В КОААХ ІЗ СУПЕРКОНДЕНСАТОРАМИ ТА НЕІДЕААЬНИМИ ДЖЕРЕААМИ ПОСТІЙНОЇ НАПРУГИ В КОМБІНОВАНИХ СИСТЕМАХ ЖИВАЕННЯ ЕАЕКТРОМОБIАIВ
}

\author{
Білецький О.О., Котовський В.Й. \\ Національний технічний університет України \\ «Київський політехнічний інститут імені Ігоря Сікорського» \\ пр. Перемоги, 37, 03056, м. Київ \\ biletsky27@gmail.com
}

\begin{abstract}
У роботі розглянуто енергетичні процеси в колах коливального заряду суперконденсаторів від неідеальних джерел постійної напруги в комбінованих системах живлення електромобілей. При коливальному заряді суперконденсаторів від неідеальних джерел постійної електрорушійної сили за умови великої добротності зарядного контуру запропоновано заряджати суперконденсатори до напруг, що перевищують напругу на джерелі енергії. Дослідним шляхом підтверджено, що в разі зменшення початкової напруги на клемах суперконденсаторів від додатних до від'ємних значень максимальна напруга заряду суперконденсаторів нелінійно змінюється до значень, що можуть перевищувати в 1,7 рази напругу на джерелі. Ключові слова: енергетичні процеси, суперконденсатор, джерело постійної напруги, комбінована система живлення, електромобіль.

Энергетические процессы в цепях с суперконденсаторами и неидеальными источниками постоянного напряжения в комбинированных системах питания электромобилей. Белецкий О.А., Котовский В.И. В работе рассмотрены энергетические процессы в цепях колебательного заряда суперконденсаторов от неидеальных источников постоянного напряжения в комбинированных системах питания электромобилей. При колебательном заряде суперконденсаторов от неидеальных источников постоянной электродвижущей силы при условии большой добротности зарядного контура предложено заряжать суперконденсаторы до напряжений, превышающих напряжение на источнике энергии. Опытным путем доказано, что при уменьшении начального напряжения на клеммах суперконденсаторов от положительных до отрицательных значений максимальное напряжение заряда суперконденсаторов нелинейно меняется до значений, которые могут превышать в 1,7 раза напряжение на источнике. Ключевые слова: энергетические процессы, суперконденсатор, источник постоянного напряжения, комбинированная система питания, электромобиль.
\end{abstract}

Energy processes in circuits with supercapacitors and nonideal sources of constant voltage in the combined power supply systems of electric vehicles. Biletskyi O., Kotovskyi V. In this paper, the energy processes in the circuits of the oscillatory charge of supercapacitors from nonideal sources of constant voltage in the combined power supply systems of electric vehicles are considered. With the oscillatory charge of supercapacitors from nonideal sources of constant electromotive force, under the condition of a large Q-factor of the charging circuit, it is proposed to charge supercapacitors to voltages exceeding the voltage at the source of energy. It is confirmed experimentally that when the initial voltage is suppressed on supercapacitor terminals from positive to negative values, the maximum voltage of supercapacitor charge changes nonlinearly to values which may exceed 1.7 times the voltage at the source. Key words: energy processes, supercapacitor, constant voltage source, combined power supply system, electric vehicle.

Постановка проблеми. У новітніх електротехнічних комплексах усе більше застосовуються комбіновані системи живлення, в яких використовуються суперконденсатори (далі - СК) та акумуляторні батаpeї (далі - АБ). Поєднуючи високу питому потужність СК з високою питомою енергією АБ, можна реалізувати комбіновану електротехнічну систему, яка може забезпечити високу вихідну потужність при динамічних режимах електромобіля (далі - EM) і при цьому забезпечувати споживання енергії з АБ протягом тривалого періоду часу [1-5]. У наукових роботах [2; 6] проводилось дослідження, в якому підтверджено, що використання комбінованих систем живлення може суттєво збільшити термін служби АБ й реалізує можливість працювати з високим коефіцієнтом передачі енергії як при аперіодичному, так і при коливальному заряді СК від АБ.
Актуальність дослідження. У низці робіт [4; 7; 8] під час аналізу енергетичних процесів заряду звичайного (лінійного) конденсатора приведено шляхи підвищення енергетичних характеристик за допомогою застосування ненульових початкових умов по напрузі на клемах лінійних конденсаторів.

Метою роботи було дослідження варіантів підвищення напруги коливального заряду СК від неідеального джерела постійної напруги (на прикладі АБ) при довільних початкових умовах по напрузі на затискачах СК та різноманітних добротностях зарядного контуру.

Виклад основного матеріалу. Під час коливального заряду СК від неідеального джерела постійної напруги процес заряду СК переривається, завдяки напівпровідниковому ключу (біполярному транзистору з ізольованим затвором), тоді як струм у заряд- 
ному колі міняє полярність (рис. 1). Відповідно до схеми зарядного контуру комбінованої системи живлення ЕМ (рис. 1), СК заряджається від літій-іонної АБ через сумарний активний опір зарядного кола $R_{\Sigma}=R_{\text {АБ }}+R_{1}+R_{\text {ПР }}$, котушку індуктивності $L$ і біполярний транзистор PWM1 . Біполярний транзистор з ізольованим затвором у новітній електроніці частіше називається IGBT транзистором. IGBT транзистор є гібридом полього й біполярного транзистора. Таке вдале поєднання транзисторів дало змогу використати їх позитивні властивості в IGBT транзисторі.

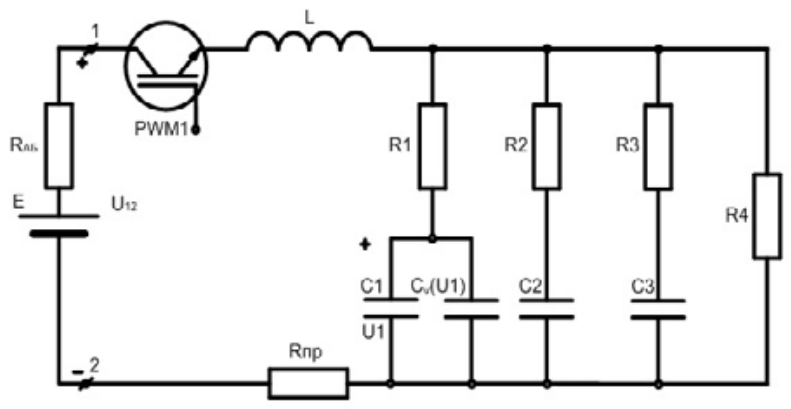

Рис. 1. Схема електричного кола заряду суперконденсатора

Велика добротність контуру заряду $Q\left(U_{H}\right)$ дає змог заряджати СК до напруг, що можуть суттєво перевищувати напругу на АБ.

У схемі електричного кола заряду СК (рис. 1) використовується АБ з напругою $U_{\text {н }}=2,3$ (В) та опором $R_{\text {АБ }}=0,012$ (Ом). СК представлений схемою заміщення $з$ трьома паралельними гілками, які мають, відповідно, різні сталі часу $\tau=R C$, також ураховано опір проводів $R_{\text {ПР }}=0,01$ (Ом). Опір першої гілки становить $R_{1}=0,025$ (Ом), а ємність складається з паралельного з'єднання постійної ємності $C_{1}=270(\Phi)$ i ємності $C_{\mathrm{v}}\left(U_{1}\right)=k U$, яка залежить від напруги (коефіцієнт $k=190$ (Ф/В)). У другій гілці опір і ємність становлять $R_{2}=0,9$ (Ом) i $C_{2}=100(\Phi)$, параметри третьої гілки мають значення $R_{3}=5,2$ (Ом) i $C_{3}=220(\Phi) .3$ метою врахування саморозряду СК в схемі на рис. 1 використано опір $R_{4}=9000$ (Ом) $[2 ; 9 ; 10]$. Біполярний транзистор як комутатор допомагає зафіксувати максимальну напругу на клемах СК у момент часу $d U_{\mathrm{CK}}(t) / d t=0.3$ метою дослідження енергетичних процесів у комбінованій системі електроживлення ЕМ необхідно провести аналіз енергетичних характеристик у процесі коливального заряду СК від літій-іонної АБ при ненульових початкових умовах по напрузі на клемах СК в діапазоні $-U_{\mathrm{AБ}}<U_{0 \mathrm{CK}}<+U_{\mathrm{AБ}}$.

При цьому під час дослідження початкові й кінцеві умови для струму в контурі заряду були однакові: $i(t=0)=i(t=\infty)=0$. Проведено аналіз дози енергії, яка надходить в СК; дози енергії, яка відбирається від АБ; енергії втрат у колі заряду СК й коефіцієнта передачі енергії від АБ при заряді від джерела постійної напруги (АБ). Досліджено точки: $-U_{\mathrm{H}},-0,9 \cdot U_{\mathrm{H}}, \ldots,+U_{\mathrm{H}}$.
Загальна ємність СК представлялась сумою незмінної ємності $C_{1}=$ const і ємності $C_{\mathrm{v}}(U)=k \cdot|U|$, яка лінійно залежить від величини напруги $U[2 ; 4 ; 10]$ :

$$
C(U)=C_{1}+k \cdot|U|
$$

Щоб відбувався коливальний заряд СК від АБ, параметри кола вибираються так, щоб виконувалась умова для добротності $Q$. Ураховуючи вираз (1), маємо:

$$
\mathrm{Q}=\frac{1}{\mathrm{R}_{\Sigma}} \cdot \sqrt{\frac{\mathrm{L}}{\mathrm{C}(\mathrm{U})}}>0,5 .
$$

3 урахуванням виразів (1)-(2), добротність також являє собою функцію від напруги на клемах СК в процесі заряду $Q(U)$.

Необхідно визначити характер зміни добротності $Q(U)$ на всьому діапазоні зміни напруги на клемах СК $\left(-U_{\mathrm{AБ}}<U_{0 \mathrm{CK}}<+U_{\mathrm{AБ}}\right)$. Для дослідження цієї залежності візьмемо два різні значення індуктивності $L_{1}=1,697$ (Гн) та $L_{2}=42,438$ (Гн) і сумарний опір зарядного кола $R_{\Sigma}=$ $R_{\mathrm{AБ}}+R_{1}+R_{\text {ПР }}=0,0245$ (Ом), за яких добротності коливального зарядного контуру (рис. 1) становлять, відповідно, $Q_{1}\left(U_{\text {н }}\right)=2$ та $Q_{2}\left(U_{\text {н }}\right)=10$. На рис. 2 зображені функціональні залежності добротностей від напруги на клемах СК: $Q_{1}(U)$ - суцільна крива, $Q_{2}(U)$ - штрих-пунктирна крива.

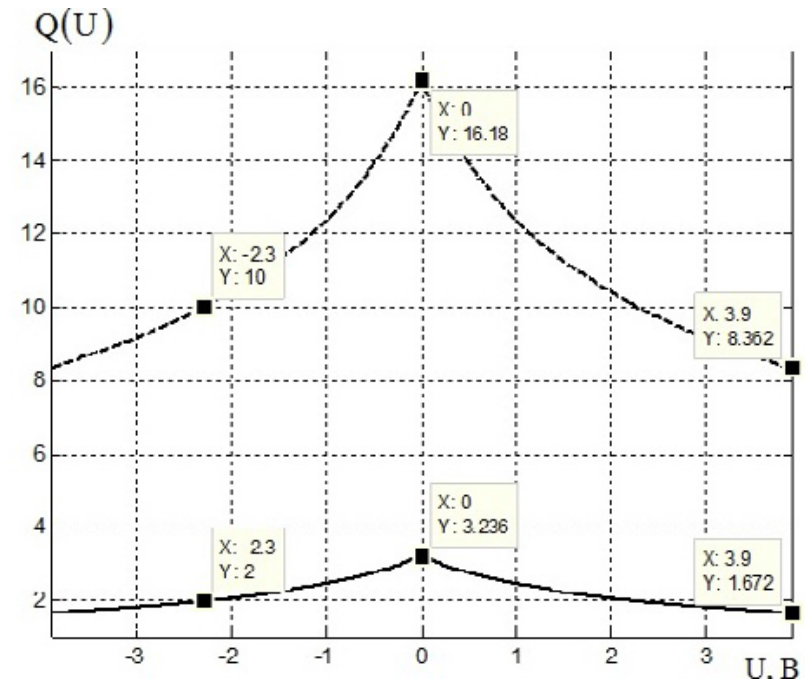

Рис. 2. Залежність добротності кола коливального заряду суперконденсатора від напруги на клемах

Проаналізуємо зміну добротностей $Q_{1}(U)$ та $Q_{2}(U)$, які зображені на рис. 2. При номінальній напрузі на $C K\left|U_{\mathrm{H}}\right|$ добротності становлять $Q_{1}\left(\left|U_{\mathrm{H}}\right|\right)=2$ та $Q_{2}\left(\left|U_{\mathrm{H}}\right|\right)=10$ для цих параметрів зарядного кола. Проведений аналіз показав, що при напрузі на клемах $U=3,9$ (В) добротність становить $Q_{1}=1,672$, а при напрузі $U=1$ (В) це значення становитиме $Q_{1}=2,479$. Максимальне значення добротності $Q_{1}=3,236$ буде при нульовій напрузі на клемах СК, відповідно, при цій напрузі $Q_{2}=16,18$. Для контуру з індуктивністю $L_{2}=42,438\left(\Gamma_{\mathrm{H}}\right)$ добротність при $U=3,9$ (В) дорівнює $Q_{2}=8,362$, а при напрузі 
$U=1$ (В) добротність $Q_{2}$ зростає в 1,48 рази. У разі зміни напруги в діапазоні від $U=-3,9$ (В) до 0 (В) добротності $Q_{1}(U)$ та $Q_{2}(U)$ збільшуються на $93 \%$. Цю залежність добротності зарядного контуру від напруги необхідно враховувати під час дослідження комбінованих електротехнічних систем електроживлення в ЕМ.

Проведемо дослідження залежностей максимальної напруги коливального заряду СК, приведеної до величини $\left.U_{\mathrm{AБ}}(U)_{\text {СК } \max }=U_{\text {СК } \max } / U_{\mathrm{AБ}}\right)$, від початкової напруги СК, приведеної до величини $U_{\mathrm{AБ}}\left(U_{0 \mathrm{CK}} / U_{\mathrm{AБ}}\right)$, для двох різних величин добротності контуру $Q_{1}\left(U_{\mathrm{H}}\right)=2$ (суцільна лінія) та $Q_{2}\left(U_{\mathrm{H}}\right)=10$ (пунктирна лінія) при коливальному заряді СК від АБ (рис. 3).

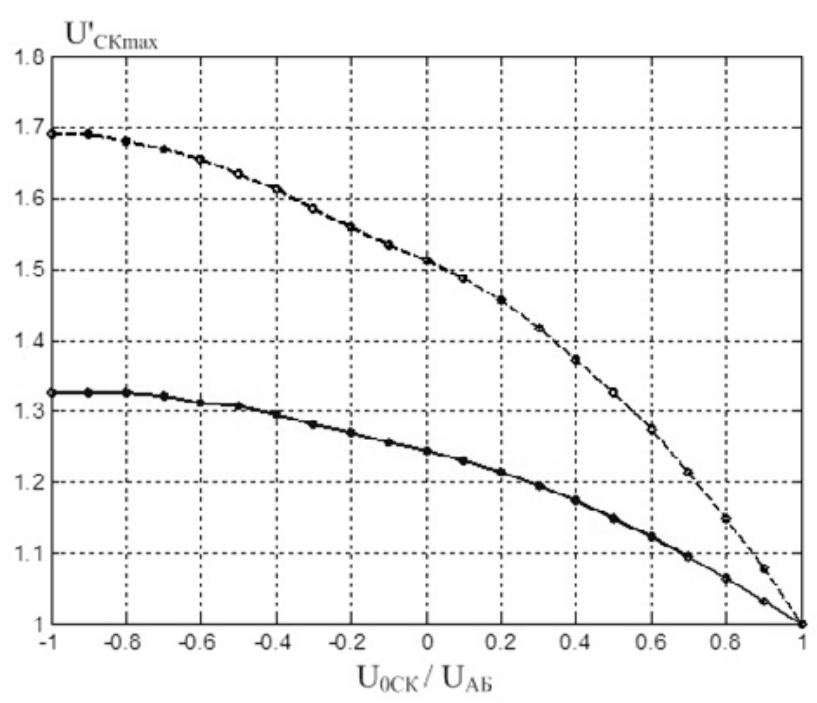

Рис. 3. Залежність максимальної напруги заряду СК, приведеної до величини $U_{\mathrm{AБ}}$, від початкової напруги $C K$, приведеної до величини $U_{\mathrm{AБ}}$, для двох значень добротності

$$
Q_{1}\left(U_{\mathrm{H}}\right)=2 \mathrm{ma}_{2}\left(U_{\mathrm{H}}\right)=10
$$

Аналіз цих функціональних залежностей максимальної напруги заряду СК, приведеної до величини напруги, на клемах АБ $U /_{\text {СКmax }}\left(U_{\text {OСК }} / U_{\mathrm{AБ}}\right)$ на рис. 3 підтверджує, що в міру зменшення початкової напруги в діапазоні від $U_{0 \mathrm{CK}}=U_{\mathrm{AБ}}$ до $U_{0 \mathrm{CK}}=-U_{\mathrm{AБ}}$ величина максимальної напруги коливального заряду CK $U /_{\text {СКmax }}$ нелінійно змінюється в діапазоні від значень $U_{\mathrm{AБ}}$ до значень, які можуть перевищувати майже в 1,7 рази значення напруги на АБ (при $Q\left(U_{H}\right)>10$ ).

При добротності контуру заряду СК від АБ $Q_{1}\left(U_{\mathrm{H}}\right)=2$ та початковій напрузі на клемах СК $U_{\text {оск }} / U_{\mathrm{AБ}}=0,8$ максимальне значення напруги на затискачах СК буде становити $U / /_{\text {СКах }}=1,07$, а при подальшому зменшенні початкової напруги до $U_{\text {оск }} / U_{\mathrm{AБ}}=0$ ця величина становитиме $U /_{\text {СКmax }}=$ 1,24. При від'ємних початкових напругах на клемах СК максимальне значення напруги на клемах підвищуватиметься й при величині $U_{0 С K} / U_{\mathrm{AБ}}=-0,8$ становитиме $U /_{\text {СКmax }}=1,32$.

Варто підкреслити, що при добротності коливального контуру заряду $Q_{2}\left(U_{\mathrm{H}}\right)=10$ (рис. 2 - пунктирна лінія) за один цикл заряду СК максимальна величина напруги на клемах СК $U /$ СКmax буде підвищуватися більше. Так, при початковій напрузі на затискачах СК $U_{0 \mathrm{CK}} / U_{\mathrm{AБ}}=0,8$ величина максимальної напруги становить $U / /_{\text {СКmax }}=1,15$, а при нульовій початковій напрузі $-U /{ }_{\text {С̆max }}=1,52$. При подальшому зменшенні початкової напруги на клемах СК до $U_{\text {оск }} / U_{\mathrm{AБ}}=-0,8$ величина максимальної напруги на клемах становитиме $U /_{\text {СКmax }}=1,68$.

При збільшенні значення добротності контуру заряду СК від джерела постійної напруги (АБ) може бути реалізоване більше значення максимальної напруги на затискачах СK $U /$ СКmax (при добротності $Q_{1}\left(U_{\mathrm{H}}\right)=2-U /_{\text {СКтаx }}=1,32$, а при $Q_{2}\left(U_{\mathrm{H}}\right)=10$ ця величина становитиме $U /$ СКmax $=1,69$, при початковій напрузі на затискачах СК $-U_{\text {оск }}=-U_{\mathrm{Ab}}[2 ; 6]$.

Головні висновки. Отже, з огляду на викладене вище, можемо резюмувати таке:

1. Під час коливального заряду СК від неідеального джерела постійної напруги (АБ) при великій добротності зарядного контуру $Q\left(U_{\mathrm{H}}\right)$ можна реалізувати заряд СК до напруг, які можуть суттєво перевищувати напругу на джерелі енергії.

2. Дослідження показали, що при зменшенні початкової напруги в діапазоні від $U_{\text {оск }}=U_{\text {АБ }}$ до $U_{\text {оск }}=-U_{\mathrm{AБ}}$ величина максимальної напруги заряду CK $U /$ СКтах нелінійно міняється в межах від величини $U_{\mathrm{AБ}}$ до величин, які перевищують майже в 1,7 рази значення напруги на неідельному джерелі напруги (АБ) (при високих добротностях контуру $\left.Q\left(U_{\mathrm{H}}\right)>10\right)$.

3. Визначено, що при більшій величині добротності коливального зарядного контуру може реалізуватися більша величина максимальної напруги на затискачах СК $U /{ }_{\text {СКmax }}$ (при добротності $Q_{1}\left(U_{\mathrm{H}}\right)=2$ $U /$ СКmax $=1,32$, а при $Q_{2}\left(U_{\mathrm{H}}\right)=10$ це значення становить $U /_{\text {СКmax }}=1,69$, при початковій напрузі на затискачах суперконденсатора $-U_{0 \mathrm{cK}}=-U_{\mathrm{AE}}$ ).

4. Цей спосіб дає змогу збільшувати максимальну напругу на затискачах СК $U /{ }_{\text {CKmax }}$ та в низці випадків реалізує можливість обходитись без підвищувального трансформатора.

\section{Лiтература}

1. Burke A. Present and future supercapacitors: technology and applications. Presented at the supercapacitor USA. Santa Clara. California, 2014.

2. Білецький О.О. Енергетичні процеси в колах заряду суперконденсаторів зі змінними початковими напругами: дис. ... канд. техн. наук: спец. 05.09.05. Київ, 2016. 195 с.

3. Burke A. Ultracapacitors alone and in combination with batteries in hybrid- electric vehicles: system considerations and performance. Encyclopedia of Sustainability Science and Technology. Springer Publishing. 2011. 
4. Білецький О.О., Супруновська Н.І., Щерба А.А. Залежність енергетичних характеристик кіл заряду суперконденсаторів від їх початкових і кінцевих напруг. Технічна електродинаміка. 2016. № 1. С. 3-10.

5. Burke A., Miller M., Zhao H. Lithium batteries and ultracapacitors alone and in combination in hybrid vehicles: fuel economy and battery stress reduction advantages. JSR. 2010. 21.23: 15.

6. Білецький О.О., Котовський В.Й. Енергетичні характеристики кіл коливального заряду суперконденсатора. Вінниця: ВНТУ, 2017. С. 10-11.

7. Шидловский А.К., Щерба А.А., Супруновская Н.И. Энергетические процессы в электроимпульсных установках с емкостными накопителями энергии. ИЭД НАНУ. 2009. 207 с.

8. Щерба А.А., Супруновская Н.И., Белецкий О.А. Энергетические характеристики суперконденсаторов при их заряде от источника напряжения и разряде на резистивную нагрузку. Праці Інституту електродинаміки Національної академії наук України. 2014. № 39. С. 65-73.

9. Zubieta L., Bonert R. Characterization of double-layer capacitors for power electronics applications. IEEE Trani. on Ind. Appl. 2000. Vol. 36. № 1. P. 199-205.

10. Білецький О.О., Щерба А.А., Супруновська Н.І. Енергетичні характеристики кіл аперіодичного заряду суперконденсаторів від акумуляторних батарей. Вісник Нац. техн. ун-ту «ХПІ»: зб. наук. пр. Темат. вип.: Проблеми автоматизованого електропривода. Теорія і практика. 2015. № 12 (1121). С. 379-383. 
УДК 699.82

DOI https://doi.org/10.32846/2306-9716-2018-4-23-15

\title{
СУЧАСНИЙ СТАН ТЕХНОАОГІї ВААШТУВАННЯ ІН'ЄКЦІЙНОї ВІДСІЧНОї ГІДРОІЗОАЯЦІї
}

\author{
Махиня О.М., Шабалтун А.М. \\ Київський національний університет будівництва і архітектури \\ пр. Повітрофлотський, буд. 31, 03680, м. Київ
}

Tbv_arc@ukr.net

\begin{abstract}
У статті проаналізовано сучасний стан технології влаштування ін'єкційної відсічної гідроізоляції. Наведено ії класифікацію. Розглянуто різновиди, характеристики та галузь застосування ін'єкційних сумішей, структуру, параметри й особливості технології влаштування ін'єкційної відсічної гідроізоляції. Ключові слова: ін'єкційна відсічна гідроізоляція, ін'єкційна суміші, шпур, пакер.
\end{abstract}

Современное состояние технологии устройства инъекционной отсечной гидроизоляции. Махиня А.Н., Шабалтун А.Н. В статье проанализировано современное состояние технологии устройства инъекционной отсечной гидроизоляции. Рассмотрено ее классификацию, разновидности, характеристики и область применения инъекционных смесей, структуру, параметры и особенности технологии устройства инъекционной отсечной гидроизоляции. Ключевые слова: инъекционная отсечная гидроизоляция, инъекционные смеси, шпур, пакер.

The current state of technology of placement of the injecting waterproofing. Makhynia O., Shabaltun A. In this article was analyzed the current state of technology of placement of the injecting waterproofing. There are the classifications of it. The variety, the characteristics and the application areas of the injecting mixture; a structure, the parameters and the peculiarities of technology of placement of the injecting waterproofing were reviewed. Key words: the injecting waterproofing, the injecting mixture, blast hole,packer.

Постановка проблеми. Підйом капілярної вологи загрожує руйнуванню фундаментів i конструкцій, що 3 ними сполучаються. Частинки вологи, які проникають у тіло фундаментів та інших конструкцій, розширюють у них мікротріщини, підвищують вологість, зменшують морозостійкість, призводять до більш інтенсивної корозії матеріалів i біологічного їх руйнування. Особливо це небезпечно для пам'яток історичної й культурної спадщини, що може стати причиною їх утрати.

В умовах ремонту, реконструкції чи реставрації будинків і споруд, коли немає можливості влаштовувати традиційну відсічну гідроізоляцію, все ширшого застосування набуває ін'єкційна відсічна гідроізоляція. Різноманітність матеріалів та особливостей їх застосування вимагає більш глибшого розгляду сучасної технології влаштування ін'єкційної відсічної гідроізоляції, спробу чого зроблено в статті.

Аналіз останніх досліджень і публікацій. Питаннями теорії i практики захисту підземних частин будинків і споруд від впливу води та влаштування гідроізоляційних покрить займались С.Н. Алєксєєва, В.О. Афанасьєва, В.І. Бабушкіна, А.П. Баглай, В.В. Бойко, Ю.М. Баженова, Р. Вуйцик [1; 2], О.С. Гончаров, Д.Ф. Гончаренко, Л.П. Зарубіна [3], В.А. Івахнюк, В.С. Іскріна, С.К. Карапузов [4], В.М. Кирнос, О.В. Коваленко [5], В.В. Козлова, Т.С.Кравчуновська,С.І.Кривоносов,В.В.Савйовський, В.А. Таранов, В.I. Терновий, В.I. Торкатюк, Р.Б. Тян, І.А. Риб'єва, С.Н. Попченко, К. Хільмер, В.К. Черненко, Т.М. Штоль, М.Г. Ярмоленко.
Метою роботи є огляд сучасного стану технології влаштування ін'єкційної відсічної гідроізоляції, виявлення іiі переваг і недоліків.

Виклад основного матеріалу. Сутність технології влаштування ін'єкційної відсічної гідроізоляції полягає в нагнітанні до конструкції та іiі просочуванні спеціальними гідроізоляційними сумішами, які в подальшому створюють водонепроникний монолітний масив, що запобігає проникненню вологи. Захист від зволоження конструкцій здійснюють за рахунок зменшення радіусу капілярів чи їх ущільнення, гідрофобізації поверхні або комбінованих впливів на матеріал конструкції [2].

Сучасну ін'єкційну відсічну гідроізоляцію можна класифікувати за:

- матеріалом ін'єкційної суміші: видом в'яжучого (мінеральні: цементні; на основі лужних силікатів (рідкого скла); мінерально-полімерні: полімер-цементні; суміші силікатів і лужних метил силікатів; полімерні: кремній-органічні; на основі поліуретанових, епоксидних чи акрилових, акрилатних смол; лужних пропілсилікатів; силанів і низькомолекулярних силоксанів; силіконових емульсоїдів SMK; асфальтові емульсії, асфальтові емульсії в органічних розчинах; термопластичні емульсії; парафіни, компоненти гасових восків; за складом суміші (однокомпонентні чи багатокомпонентні);

- технологічними параметрами: способом нагнітання суміші до конструкиї (під тиском, самопливом, із застосуванням ефекту електроосмосу чи пульсуючого струменю, одноетапне чи багатоетапне 
нагнітання); способом розміщення шпурів $і$ пакерів (однорядна чи багаторядна (двохрядна) (рис. 1, 2); однобічна чи двобічна (рис. 3)); способом термічної підготовки (з підігріванням суміші, основи, чи того й іншого або без нього) виду ін'єкиійної речовини (рідини, піни чи аерозолю), виду підготовки поверхні (з попереднім осушенням чи без нього).

Швидкість капілярного піднімання води пропорційна до величини радіуса пор, а тому застосування сумішей, які зменшують радіус пор, зумовлює зменшення швидкості капілярного всмоктування. Прикладами таких матеріалів є суміші на основі мінеральних в'яжучих: цементів, рідкого скла. Такі матеріали загальнодоступні й мають невелику собі-

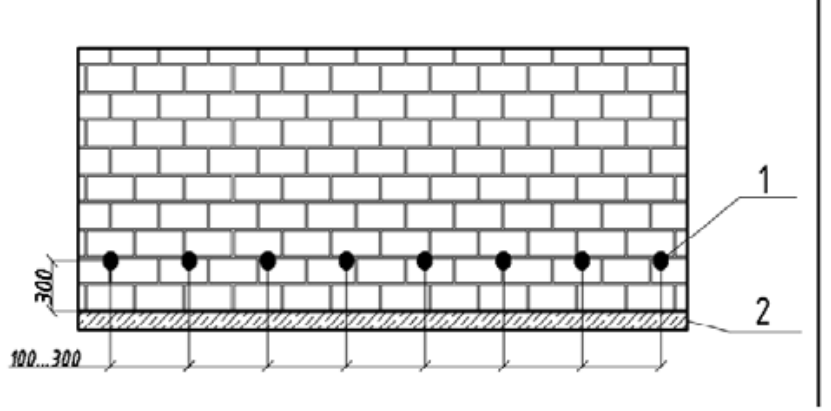

a)

Рис. 1. Способи розміщення шпурів і пакерів для ін'єкції: a-однорядне; б - багаторядне (дворядне); 1 - шпур; 2 - рівень підлоги вартість, але вони не забезпечують надійного перекриття руху капілярної вологи, внаслідок усадки, утворення шкідливих побічних продуктів (під час застосування силікатів) чи пористості (під час застосування цементів).

Застосування полімерцементних сумішей із високоміцних цементів, піску та активних хімічних домішок дає змогу частково усунути недоліки цементних сумішей, наприклад, Лахта ${ }^{\circledR}$ [8]. Усе ширше також застосовують цементні суміші 3 меншим розміром заповнювачів (до 0,08..0,95 мм), так звані мікроцементні суміші (наприклад, Sika@) InjectoCem-190 [7; 13], Maxgrout Injection ${ }^{\circledR}$ [9], Liakor® ISB [15]). При цьому захист від зволоження

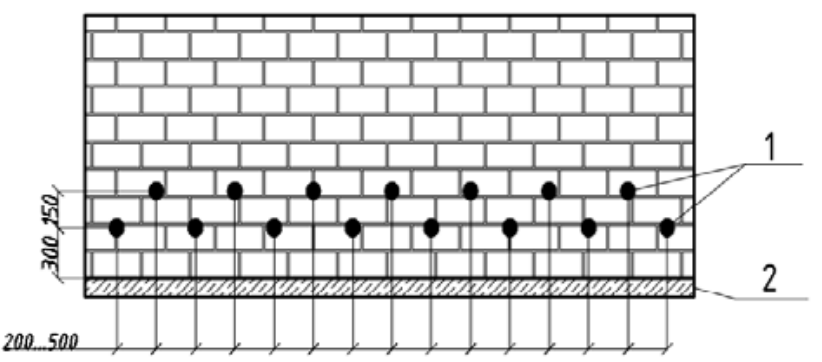

б)

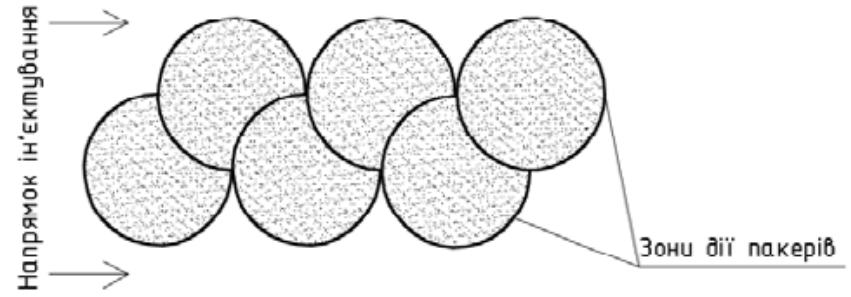

a)

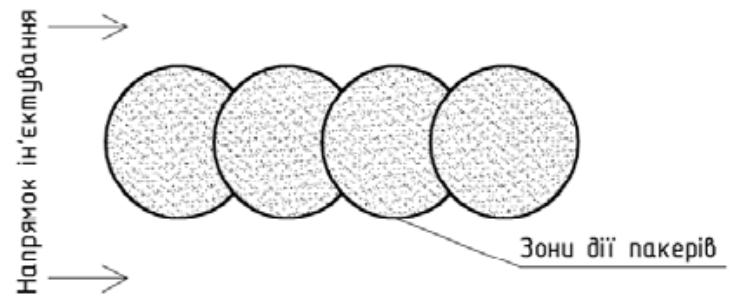

б)

Рис. 2. Схеми взаємного перекриття зон ін'єктування, при розміщені шпурів і пакерів: $а$ - однорядному; б-двохрядному

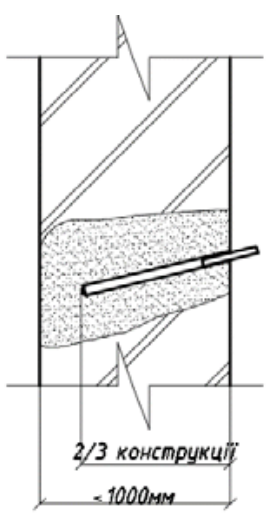

a)

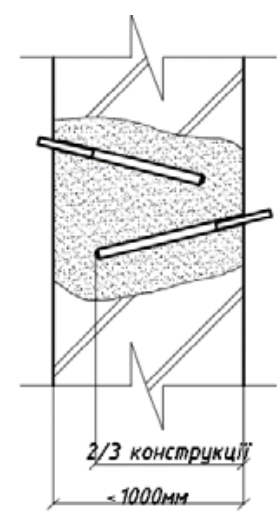

б)

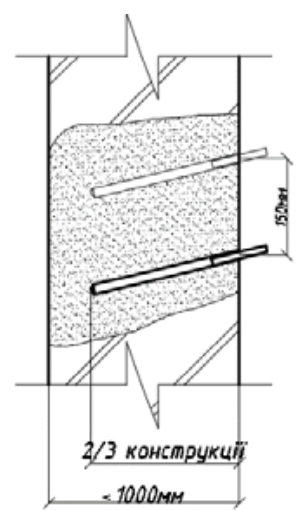

в)

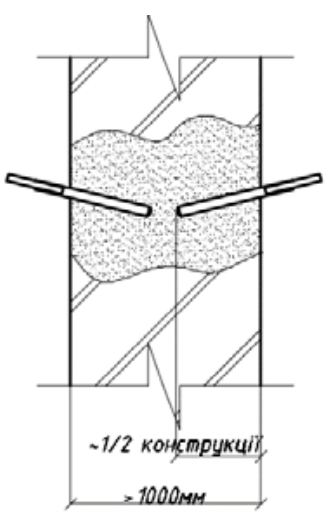

2)

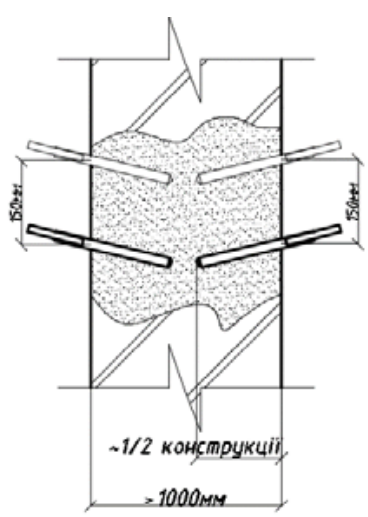

d)

Рис. 3. Варіанти розмішення шпурів і пакерів:

$a$-однобічне однорядне; б-двобічне однорядне в різних рівнях; в - однобічне дворядне в шаховому порядку;

г-двобічне однорядне в одному рівні; д-двобічне дворядне в шаховому порядку 
конструкцій здійснюють за рахунок комбінованого впливу (зменшення радіусу капілярів і їх ущільнення). Мікроцементні суміші утворюють непроникний для води бар'єр унаслідок процесів кристалізації, який може відновлюватись у разі потрапляння води. Порівняно з полімерцементними сумішами в них менша в'язкість та осідання, більше проникнення до матеріалу конструкції, але при цьому зменшується її паропроникність (таблиця 1).
Гідрофобізуючі суміші на основі силікатів і кремнійорганічних сполук (наприклад, Ceresit ${ }^{\circledR}$ CO 81 [4; 17], Remmers@ Kiesol® [11]) під час взаємодії 3 водою утворюють нерозчинні солі, що заповнюють пори й мікротріщини конструкціï, при цьому проходить гідрофобізація поверхні. Вони добре проникають до пор і мікротріщин завдяки в'язкості, що наближається до в'язкості води, навіть при зволоженій поверхні

Характеристики ін'скційних сумішей

Таблиця 1

\begin{tabular}{|c|c|c|c|c|c|c|c|}
\hline \multirow{4}{*}{ Назва параметра } & \multirow{4}{*}{ 昰 } & \multicolumn{6}{|c|}{ Значення параметра ін'скційних сумішей } \\
\hline & & 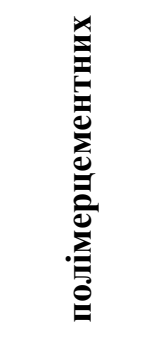 & : & 氙 & 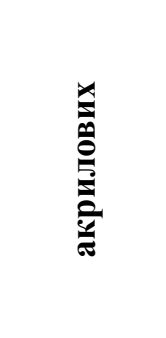 & 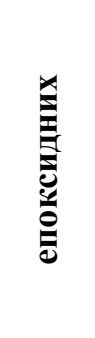 & 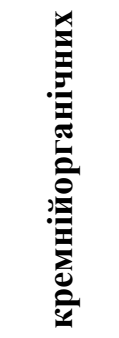 \\
\hline & & \multicolumn{6}{|c|}{ промислового виготовлення торгової марки } \\
\hline & & 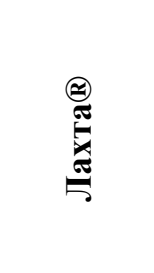 & 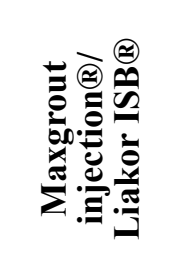 & 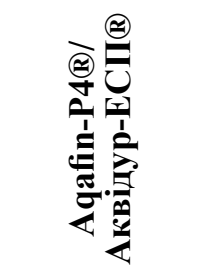 & 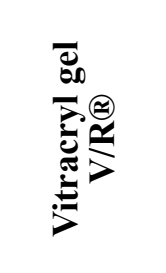 & 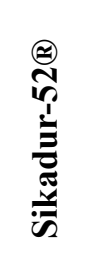 & 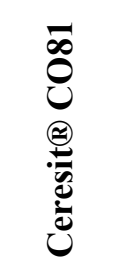 \\
\hline Густина & кГ/ $\mathrm{M}^{3}$ & 947 & $960 / 1000$ & $985 / 70-140$ & 1050 & 1100 & 1180 \\
\hline В'язкість & $\mathrm{m} \Pi \mathrm{a} \cdot \mathrm{c}$ & 2,19 & $2,1 / 2,13$ & $150 / 650$ & $2,46-2,66$ & 430 & 1,08 \\
\hline $\begin{array}{l}\text { Час життя/ } \\
\text { тужавлення }\end{array}$ & хв. & $\sim 30$ & $\sim 20-30$ & $\sim 25-35 / 30$ & $\sim 2-30$ & $\sim 25$ & - \\
\hline Осідання & $\mathrm{cm}$ & $\begin{array}{c}0,5 \div \\
0,8\end{array}$ & 0,3 & - & - & - & 0,3 \\
\hline Витрати & Кг/л & $\sim 1,6$ & $\sim 1,33 / 1,67$ & $\begin{array}{c}\sim 1 / \text { не } \\
\text { нормується }\end{array}$ & $\sim$ & 1 & $10 \div 15$ \\
\hline Збільшення в об’ємі & $\%$ & - & - & $\geq 100$ & $\sim 60$ & - & - \\
\hline $\begin{array}{l}\text { Проникнення } \\
\text { до конструкції }\end{array}$ & MM & $\leq 60 \ldots 70$ & $\leq 100$ & $\leq 80$ & $\leq 60$ & $\leq 60$ & $\leq 120$ \\
\hline $\begin{array}{l}\text { Попереднє вису- } \\
\text { шення конструкції }\end{array}$ & & + & \pm & - & - & + & - \\
\hline $\begin{array}{l}\text { Наявність активного } \\
\text { напору води }\end{array}$ & & - & - & + & + & - & - \\
\hline Паропроникність & мг/(м·год Па) & $\leq 0,027$ & $\leq 0,012$ & $\leq 0,005$ & $\sim 0$ & $\sim 0$ & $\leq 0,02$ \\
\hline
\end{tabular}

Галузь застосуванням ін'єкційних сумішей

\begin{tabular}{|l|c|c|c|c|c|}
\hline \multirow{2}{*}{$\begin{array}{c}\text { Різновид ін'скційної } \\
\text { суміші }\end{array}$} & \multicolumn{5}{|c|}{ Різновид конструкції за матеріалом } \\
\cline { 2 - 6 } & $\begin{array}{c}\text { кам'яна } \\
\text { (цегляна) }\end{array}$ & бетонна & залізобетонна & бутова & $\begin{array}{c}\text { пористого } \\
\text { бетону }\end{array}$ \\
\hline полімерцементні & + & + & + & + & - \\
\hline мікромецентні & + & + & + & + & \pm \\
\hline поліуретанові & \pm & + & - & - & - \\
\hline акрилові & \pm & + & - & + & - \\
\hline епоксидні & - & + & - & \pm & \pm \\
\hline кремнійорганічні & \pm & + & + & \pm \\
\hline
\end{tabular}


(таблиця 1). Їх недоліком є поява шкідливих сторонніх речовин i часткове осідання розчину.

Безперечною перевагою поліуретанових матеріалів (наприклад, Aquafin $®-P 4$ [14], Аквідур®-ЕСП [16]) $€$ їх гідрореактивність, що усуває потребу у видаленні вологи із зони пошкоджень, а їі, навпаки, використовують для полімеризації, тому такий матеріал не рекомендують наносити на суху поверхню (таблиця 1).

Під час полімеризації утворюється піна та збільшується об'єм матеріалу (від 3 до 25 разів) 3 підвищенням його внутрішнього тиску (до 30 бар), що обмежує його використання в кам'яних конструкціях.

Акрилові суміші на основі акрилатів і метакрилатів (наприклад, Vitracryl Gel®V/R [10]), що за властивостями схожі до води, проникають у дрібні капіляри, які закупорюють гумоподібною речовиною, що збільшується в об'ємі (таблиця 1). Проте для ін'єктування армованих бетонних конструкцій їх використання обмежене через корозійну дію на металеву арматуру.

Суміші на основі епоксидних смол (наприклад, Sika@ Sikadur®-52 Injection N/LP [7; 12]) мають високу механічну міцність при стисканні й підвищену стійкість до атмосферних впливів. Епоксидні матеріали характеризуються високою проникною здатністю й адгезією до бетону, але їх застосування потребує видалення вологи з ремонтної зони. Крім того, до їх недоліків необхідно зарахувати невисоку вогнестійкість та утворення шкідливих речовин.

До переваг сумішей із полімерних матеріалів необхідно зарахувати відсутність усадки при твердінні (таблиці 1).

За галуззю застосування (таблиця 2) найбільш універсальні полімерцементні, мікроцементі та кремнійорганічні суміші.

Загалом процес влаштування традиційної ін'єкційної відсічної гідроізоляції складається 3 таких операцій:

- niдготовчі операщіï: видалення опоряджувального шару в місцях свердління шпурів; виправлення дефектів конструкції в зоні ін'єктування та їі просушування (за потреби); очищення поверхні; розмітка i свердління шпурів; очищення їх від продуктів свердління; встановлення пакерів (ін'єкційних трубок) у шпури; герметизація місць установлення пакерів;

- основні операціï: приєднання й налаштування системи нагнітання розчинів; підготовка ін'єкційних розчинів; ін'єктування конструкції (нагнітання ін'єкційного розчину); від'єднання системи нагнітання розчинів; закриття отворів пакерів; а після технологічної перерви на твердіння розчину виймання пакерів і замазування шпурів.

Трудомісткість виконання гідроізоляції значною мірою залежить від параметрів шпурів, які влаштовують у стіні (їх діаметр, глибина, кут нахилу, крок,

Таблиця 2

Галузь застосуванням ін'скційних сумішей

\begin{tabular}{|c|c|c|c|c|c|}
\hline \multirow{2}{*}{$\begin{array}{c}\text { Різновид ін'єкційної } \\
\text { суміші }\end{array}$} & \multicolumn{5}{|c|}{ Різновид конструкції за матеріалом } \\
\hline & $\begin{array}{c}\text { кам'яна } \\
\text { (цегляна) }\end{array}$ & бетонна & залізобетонна & бутова & $\begin{array}{c}\text { пористого } \\
\text { бетону }\end{array}$ \\
\hline полімерцементні & + & + & + & + & - \\
\hline мікромецентні & + & + & + & + & \pm \\
\hline поліуретанові & \pm & + & - & - & - \\
\hline акрилові & \pm & + & - & + & - \\
\hline епоксидні & - & + & - & + & - \\
\hline кремнійорганічні & \pm & + & + & \pm & \pm \\
\hline
\end{tabular}

Технологічні параметри розташування отворів для ін'єктування

Таблиця 3

\begin{tabular}{|c|c|c|c|c|c|c|c|}
\hline \multirow[b]{2}{*}{$\begin{array}{c}\text { Торгова марка } \\
\text { ін'скційної суміші }\end{array}$} & \multicolumn{3}{|c|}{ Технологічні параметри отворів } & \multicolumn{4}{|c|}{ Схема розташування отворів } \\
\hline & $\underset{\text { мм }}{\text { Діаметр, }}$ & $\underset{\text { Мм }}{\text { Крок, }}$ & $\begin{array}{c}\text { Кут } \\
\text { нахилу, } \\
\text { град }\end{array}$ & 究 & 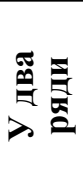 & 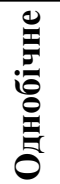 & 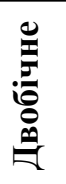 \\
\hline Лахта $®$ & $25 \ldots 30$ & $120 . .200$ & $30 \ldots 60$ & + & + & + & + \\
\hline Maxgrout Injection $\AA$ & $16 \ldots 18$ & $150 \ldots 500$ & 30 & + & + & + & + \\
\hline Vitracryl Gel@ V/R & $17 \ldots 18$ & до 150 & 45 & \pm & + & + & \pm \\
\hline Liakor $\AA$ ISB & $25 \ldots 30$ & $100 \ldots 120$ & 45 & + & + & + & \pm \\
\hline Sikadur $(-52$ Injection N/LP & 20 & $200 \ldots 250$ & $30 \ldots 60$ & \pm & + & + & + \\
\hline Aquafin $®-P 4$ & 20 & $200 \ldots 300$ & 45 & + & + & + & + \\
\hline Аквідур®-ЕСП & 20 & $150 \ldots 900$ & 45 & \pm & + & + & \pm \\
\hline Kiesol® & 12 & 120 & $45 \ldots 60$ & \pm & + & + & \pm \\
\hline Ceresit $\AA$ CO 81 & $12 \ldots 18$ & 120 & $30 \ldots 45$ & + & + & + & + \\
\hline
\end{tabular}


Технологічні параметри влаштування ін'скційної відсічної гідроізоляції

\begin{tabular}{|c|c|c|c|c|c|}
\hline \multicolumn{2}{|c|}{$\begin{array}{l}\text { Параметри } \\
\text { ін'єктування }\end{array}$} & \multicolumn{2}{|c|}{ Параметри конструкції } & \multicolumn{2}{|c|}{ Вид ін'єкційного розчину } \\
\hline спосіб & $\begin{array}{l}\text { тиск, } \\
\text { МПа }\end{array}$ & $\begin{array}{c}\text { розкриття } \\
\text { тріщин, мм }\end{array}$ & $\begin{array}{l}\text { максимальна } \\
\text { вологість, \% } \\
\end{array}$ & склад & торгова марка \\
\hline \multirow{8}{*}{ 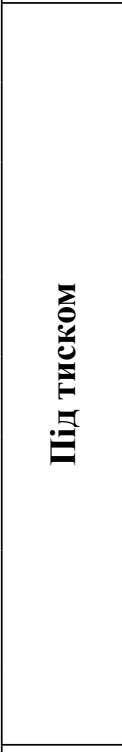 } & 0,5 & $\leq 0,3$ & $\begin{array}{c}\geq 100 \text { (активний } \\
\text { напір води) }\end{array}$ & $\begin{array}{l}\text { Однокомпонентний, } \\
\text { полімерцементний }\end{array}$ & Лахта® \\
\hline & 0,3 & $\leq 0,5$ & $\leq 70$ & $\begin{array}{l}\text { Однокомпонентний, } \\
\text { мікроцементний }\end{array}$ & Maxgrout Injection ${ }^{\circledR}$ \\
\hline & $0,2 \ldots 0,24$ & $\leq 0,2$ & $\begin{array}{c}\geq 100 \text { (активний } \\
\text { напір води }\end{array}$ & $\begin{array}{c}\text { Двохкомпонентний, на } \\
\text { основі акрилатів } \\
\text { i метакрилатів }\end{array}$ & Vitracryl Gel@ V/R \\
\hline & $0,05 \ldots 0,3$ & $\leq 0,2 \ldots 0,3$ & $\leq 8 \ldots 10$ & $\begin{array}{l}\text { Однокомпонентний, } \\
\text { полімерцементний }\end{array}$ & Liakor® ISB \\
\hline & 0,2 & $\leq 0,5$ & $\leq 40$ & $\begin{array}{c}\text { Двохкомпонентний, на } \\
\text { основі епоксидної смоли }\end{array}$ & $\begin{array}{c}\text { Sikadur }{ }^{\circledR-52 ~ I n j e c t i o n ~} \\
\text { N/LP }\end{array}$ \\
\hline & $0,5 \ldots 1,5$ & $\leq 0,2 \ldots 0,5$ & $\leq 80$ & $\begin{array}{l}\text { Двохкомпонентний, на } \\
\text { основі поліуританової } \\
\text { смоли } \\
\end{array}$ & Aquafin ${ }^{\circledR}-\mathrm{P} 4$ \\
\hline & $0,5 \ldots 0,8$ & $\leq 0,3$ & $50 \ldots 100$ & $\begin{array}{c}\text { Однокомпонентний, } \\
\text { на основі поліуританової } \\
\text { смоли } \\
\end{array}$ & Аквідур®-ЕСП \\
\hline & $0,2 \ldots 0,7$ & $\leq 0,3 \ldots 0,5$ & $\leq 80$ & $\begin{array}{l}\text { Однокомпонентний, на } \\
\text { основі кремнієвих кислот }\end{array}$ & Ceresit ${ }^{\circledR}$ CO 81 \\
\hline \multirow{3}{*}{ 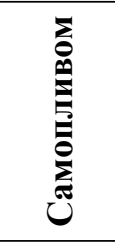 } & \multirow{3}{*}{ 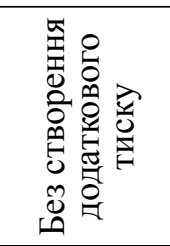 } & $\leq 0,5$ & $\leq 95$ & $\begin{array}{l}\text { Однокомпонентний, } \\
\text { на силановій основі }\end{array}$ & Kiesol ${ }^{\circledR}$ \\
\hline & & $\leq 0,3 \ldots 0,5$ & $\leq 80$ & $\begin{array}{l}\text { Однокомпонентний, на } \\
\text { основі кремнієвих кислот }\end{array}$ & Ceresit ${ }^{\circledR}$ CO 81 \\
\hline & & $\leq 0,2 \ldots 0,3$ & $\leq 8 \ldots 10$ & $\begin{array}{c}\text { Однокомпонентний, } \\
\text { полімерцементний }\end{array}$ & Liakor® ISB \\
\hline
\end{tabular}

кількість рядів, розташування шпурів щодо підлоги і боків стін), що, у свою чергу, приймають залежно від виду й матеріалу конструкції; виду гідроізоляційних матеріалів; ступеня зволоження конструкції; технічного стану конструкції та суміжних елементів; способу нагнітання розчину; параметрів технічного оснащення [2]. Для сучасних товарних ін'єкційних сумішей влаштовують шпури 3 діаметром отвору від 12 до 30 мм, з кроком 120...900 мм і кутом нахилом $30 \ldots 60^{\circ}$ (таблиця 3 ).

На трудомісткість і собівартість влаштування гідроізоляції впливає також стан основи. Сучасні товарні ін'єкційні суміші застосовують при розкритті тріщин до 0,5 мм і максимальній вологості конструкції від 8 до 100\%, а окремі суміші можуть бути застосовані при активному опорі води (таблиця 4). Суміші нагнітають до конструкції самопливом чи під тиском від 0,2 до 1,5 МПа (таблиця 4).

Головні висновки. Аналіз технології влаштування ін'єкційної відсічної гідроізоляції виявив такі iii переваги [6]:

- можливість виконання робіт у стислих умовах без додаткового розбирання конструкцій;

- відсутність потреби в зміні розмірів попередніх перерізів конструкцій;

- можливість збільшення монолітності й міцності конструкції;
- можливість висушування та зменшення вологості вище розташованих конструкцій;

- поліпшення санітарно-гігієнічних та екологічних умов у приміщеннях.

- До недоліків цієї технології необхідно зарахувати такі:

- застосування тільки в непошкоджених, слабо- чи середньопошкоджених конструкціях, при максимальному зниженні несучої здатності до $25 \%$;

- відсутність доступного точного методу визначення внутрішнього стану конструкції (наявності порожнин і їх розташування) до влаштування гідроізоляції й після іï влаштування;

- відсутність методики розрахунку технологічних параметрів влаштування ін'єкційної відсічної гідроізоляції з урахуванням стану конструкції;

- відсутність комплексних досліджень щодо довговічності та взаємодії гідроізоляції з конструкцією 3 плином часу.

Актуальним науковим завданням подальших досліджень є виявлення факторів і взаємозв'язків, що впливають на технологію влаштування ін'єкційної відсічної гідроізоляції, а також уточнення технологічних параметрів і режимів, рецептур розчинів 3 урахуванням стану конструкції, іiі подальшої довговічності й екологічної безпеки. 


\section{Література}

1. Вуйцик Р. Механические методы устройства горизонтальной гидроизоляции в исторических зданиях. Строительные материалы. 2006. № 9. С. 58-59.

2. Вуйцик Р. Восстановление горизонтальной гидроизоляции в зданиях инъекционным методом. Строительные материалы. 2006. № 10. С. 84-87.

3. Зарубина Л.П. Гидроизоляция конструкций, зданий и сооружений. Санкт-Петербург: БХВ-Петербург, 2011. 155 с.

4. Карапузов С.К., Соха В.Г., Остапченко Т.С. Матеріали і технології у сучасному будівництві: підручник. Київ: Вища освіта, 2004. $416 \mathrm{c}$.

5. Коваленко О.В., Крученюк В.Д. Ін'єкційна гідроізоляція - ефективний метод усунення активних протікань води через конструкції гідротехнічних споруд / Інститут водних проблем і меліорації НААН. Меліорація і водне господарство. 2013. Вип. 100. С. 138-147.

6. Гетун Г.В., Румянцев Б.М., Жуков А.Д. Системи ізоляції будівельних конструкцій. Дніпро: Журфонд, 2016. 676 с.

7. Брошура від виробника / Sika building trust; «Waterproofing leak sealing solutions with Sika injection systems, for concrete, masonry and natural stone structures». $19 \mathrm{c}$.

8. Инструкция по применению сухой смеси ЛАХТА проникающая гидроизоляция. URL: http://www.rastro.ru/catalogue/ gidroisoliatsia/gidroisoliatsia 21.html.

9. Инструкция по применению Максгроут Инжекшн. URL: https://www.gydrozo.ru/upload/iblock/280/TO\%20Максгроут\% 20Инжекшн\%20ред\%20151.03.pdf.

10. Инструкция по применению Витракрил Гель B/P. URL: http:/gdps.ru/katalog-produktsii/item/ vitrakril-gel-v-vitracryl-gel-v\#загрузить.

11. Техническое описание артикул 0727 Kiesol C. URL: http://remmers.net.ua/catalog/detail/id/287.

12. Техническая карта материала Sikadur-52 Injection Тип N и LP. URL: http://www.aquaproof.com.ua/epoksidnaya-smolaSikadur-52-Injection-A-B-N-d288.htm.

13. Технічний опис матеріалу Sika®injectoCem-190. URL: https://idn.sika.com/dms/getdocument.get/1c563c01-5028-38a1-bc4b5908236b0ebd/sika-injectocem-190_pds-en.pdf.

14. Техническое описание Aquafin-P4. URL: http://www.aquaproof.com.ua/dvykhkomponentnaya-inektsionnaya-elastichnayasmola-AQUAFIN-r4-d1021.htm.

15. Технічна карта Liakor ISB. URL: http://liakor.ua/materialy-budivelnoi-khimii/iniektsiina-hidroizoliatsiia/117-liakor-isb-3.html.

16. Техническое описание Аквидур-ЭСП. URL: http://strim.su/uploads/files/pdf/Аквидур\%20ЭС-П.pdf.

17. Технічний опис Ceresit CO 81. URL: http://ceresit.ua/ru/categoryproducts/products/show?id=182. 


\title{
ПРОБАЕМИ ЕКОАОГО-ЗБАМАНСОВАНОГО POЗBИTKY
}

\author{
УДК 528; 378.09 \\ DOI https://doi.org/10.32846/2306-9716-2018-4-23-16
}

\section{ПІДГОТОВКА ФАХІВЦІВ З ГЕОДЕЗІї ТА ЗЕМАЕУСТРОЮ ДАЯ СТАМОГО РОЗВИТКУ}

\author{
Люльчик В.О., Русіна Н.Г. \\ ВСП «Рівненський коледж \\ Національного університету біоресурсів і природокористування України» \\ вул. Коперника, 44, 33001, м. Рівне \\ midaff80@ukr.net \\ RusinaN@i.ua
}

У статті розкрито зміст підготовки фахівців з геодезії та землеустрою для сталого розвитку з урахуванням головних виробничих функцій і типових завдань діяльності. Надано характеристику основних проблем і проведено аналіз навчальних планів фахових дисциплін, інноваційних методів і технологій навчання, компетенцій для сталого розвитку. Ключові слова: сталий розвиток, компоненти освіти, зміст, навчання, теоретико-методологічні засади, компетенції.

Подготовка специалистов геодезии и землеустройства для устойчивого развития. Люльчик В.А., Русина Н.Г. В статье раскрыто содержание подготовки специалистов геодезии и землеустройства для устойчивого развития с учетом главных производственных функций и типовых задач деятельности. Охарактеризованы основные проблемы и проведен анализ учебных планов специальных дисциплин, инновационных методов и технологий обучения, компетенций для устойчивого развития. Ключевые слова: устойчивое развитие, компоненты образования, содержание, обучение, теоретико-методологические основы, компетенции.

Training of specialists in Geodesy and Land Management for Sustainable Development. Liulchyk V., Rusina N. The content of training of specialists in geodesy and land management for sustainable development with the consideration of the main production functions and typical tasks of activity is revealed. The description of the main problems is given and the analysis of curricula of professional disciplines, innovative methods and technologies of training, competence for sustainable development is conducted. Key words: sustainable development, components of education, content, training, theoretical and methodological principles, competencies.

Постановка проблеми. Поняття сталого розвитку в його сучасному значенні - це розвиток, який забезпечує збалансоване вирішення соціально-економічних завдань, а також проблем сприятливого навколишнього середовища та природно-ресурсного потенціалу з метою задоволення потреб сучасного й наступних поколінь людства. Основне завдання сталого розвитку України полягає в забезпеченні динамічного соціально-економічного зростання, збереженні довкілля та раціональному використанні природно-ресурсного потенціалу 3 метою задоволення потреб нинішнього й майбутніх поколінь через побудову високоефективної економічної системи, яка стимулює продуктивну працю, науково-технічний прогрес, має соціальну спрямованість [5, с. 376].

У зв'язку з цим виникла потреба формування нової парадигми землекористування в Україні концепції сталого землекористування, яка могла б забезпечити підвищення добробуту людей, вирішити проблеми, пов’язані 3 деградацією навколиш- нього середовища, поліпшення екологічного стану земель [7]. Основою практичної реалізації концепції сталого використання земель $є$ освіта для сталого розвитку, адже освіта для збалансованого розвитку вважається одним із основних чинників становлення гармонійного суспільства, засобом удосконалення й ефективної організації виробництва, споживання ресурсів біосфери з позиції її можливостей.

Актуальність дослідження. Науково-методологічною основою сучасного землеустрою $є$ вчення про географічну оболонку Землі, закони розвитку природних систем, принципи та механізми досягнення сталого розвитку землекористування й територій. Саме землевпорядна освіта повинна бути спрямована на формування фахівців для суспільства, орієнтованого на сталий розвиток, вирішення проблем збалансованого розвитку земельних ресурсів. Її базові положення зазначені в Указі Президента України «Про Національну стратегію розвитку освіти в Україні на період до 2021 року», Постанові 
Кабінету Міністрів України від 05.11.2008 № 974, Національній парадигмі сталого розвитку України та Концепції регіональної системи освіти для сталого розвитку.

Відзначимо, що в рекомендаціях Стратегії ЄЕК ООН з освіти для сталого розвитку [11] підкреслюється, що потрібно «особливу увагу ... приділяти країнам Східної Свропи, Кавказу та Центральної Азії і Південно-Східної Європи у вирішенні іх основних проблем в галузі екологічної освіти та освіти для сталого розвитку». До таких проблем належать «нестача задовільних навчально-методичних матеріалів, недовикористання можливостей вищої освіти і науково-дослідних інститутів, нестача кваліфікованих педагогів і недостатня інформованість, а також недостатній розвиток міжвідомчого i багатостороннього співробітництва 3 питань ОСР» [9]. Для вирішення означеної проблеми проведено дослідження 3 обгрунтування змістових модулів і змісту навчально-методичних матеріалів для вдосконалення навчального процесу професійної підготовки майбутніх землевпорядників.

Аналіз останніх досліджень i публікацій. Формуванню освітньої політики стосовно освіти для сталого розвитку присвячено роботи Г. Білявського, О. Бондаря, М. Згуровського, Н. Касимова, М. Моісеєва, Т. Шакирова, В. Шевчука, А. Урсула та ін. При цьому встановлено недостатній рівень обгрунтування як змісту, форм і методів формування освітньої політики, так і шляхів оптимізації змісту й засобів викладання відповідних дисциплін у вищих навчальних закладах (ВН3) України під час переходу суспільства до сталого розвитку [1]. Питанням змісту землевпорядної та геодезичної освіти в Україні присвячено досить багато праць вітчизняних дослідників, зокрема Д. Гнатковича, О. Панчука, А. Третяка, В. Кривова, О. Лозового, М. Ступеня, Р. Гулька, Р. Таратули, Й. Дороша, 3. Флекея, Д. Добряка та інших, вони акцентують переважно на проблемах відповідності змісту освіти актуальним завданням тривалої в Україні земельної реформи [6, с. 34].

Варто відмітити наукові доробки А. Мартина. Науковець, розмірковуючи над майбутнім топографо-геодезичної та землевпорядної галузі, змоделював головні тренди розвитку геодезії та картографії, землеустрою, геоінформатики, дистанційного зондування Землі, кадастрово-реєстраційної діяльності й оцінної діяльності, а також управління в галузі земельних відносин, які обумовлюють напрями модернізації геодезичної та землевпорядної освіти [6, с. 36]: не менше ніж $80 \%$ навчання має бути присвячене тому, що буде завтра, а не тому, що було вчора, хоча це й позбавляє більшість викладачів їхньої «зони комфорту»; навчальні програми мають бути безжально очищені від застарілого та непотрібного матеріалу, який не має практичного застосування; найкраще, що університет може дати студенту, - це вміння критично мислити, не довіряти догмам, бути інтелектуально мобільними; під час навчання студент має «доторкнутися» до всіх найбільш прогресивних технологій, які визначатимуть майбутнє галузі в середньостроковій перспективі, аби бути готовим до їх практичного застосування; практичне навчання має бути побудоване так, щоб студент без «доучування» зміг одразу самостійно працювати в галузі.

У дослідженні «Землевпорядна освіта і наука в контексті реалізації цілей сталого розвитку України» Т. Калина й О. Константінова відзначають, що землевпорядна освіта і наука для сталого розвитку спрямовані на набуття знань і навичок, виконання наукових досліджень у галузі раціонального використання та охорони земель, управління земельними ресурсами, ведення Державного земельного кадастру, спрямованих на формування нового світогляду, позицій, цінностей, що сприяють розвитку, який $є$ соціально бажаним, економічно життєздатним та екологічно збалансованим [4].

Науковці Харківського національного аграрного університету ім. В.В. Докучаєва виділяють шість основних фахових ознак вищої землевпорядної освіти: уміння систематично інтегровано мислити на основі набуття міждисциплінарних знань і можливості їх застосування в конкретних виробничих ситуаціях; здатність діяти в комплексних виробничих ситуаціях із різними економічними, екологічними та соціально-культурними складниками; розуміння економічних процесів у суспільстві; соціальна адаптивність і компетентність; психологічні здібності й комунікабельність під час роботи з людьми й вирішення конфліктних ситуацій; уміння застосовувати соціально-економічну етику, бути відповідальним фахівцем [5].

Землевпорядний факультет сучасного вищого навчального закладу вже не має бути лише навчальним центром. Він має стати інтелектуальним та експертно-аналітичним осередком галузі, платформою для відпрацювання і практичної адаптації передових технологічних рішень, майданчиком для фахових дискусій і практичного навчання. Лише такий підхід дасть змогу зберегти вітчизняну землевпорядну освіту в середньостроковій перспективі та розраховувати в перспективі на міжнародне визнання [6].

\section{Виділення не вирішених раніше частин} загальної проблеми, котрим присвячусться означена стаття. Незважаючи на кількісне зростання досліджень, присвячених проблемі професійної підготовки майбутніх землевпорядників в умовах переходу до сталого розвитку, в Україні на рівні системи досі не розглядались концептуальні підходи до формування їхньої професійної компетентності, на відміну від країн Європейського Союзу [5; 6]. Актуальність проблеми формування професійної компетентності майбутніх фахівців геодезії та землеустрою в умовах переходу до сталого розвитку й необхідність ії дослідження зумовлені низкою супе- 
речностей між [1] об'єктивними вимогами суспільства до висококваліфікованих фахівців-землевпорядників 3 високим рівнем професійної компетентності й недостатньо гнучкою реакцією системи професійної освіти; традиційною системою підготовки майбутніх землевпорядників у вищих навчальних закладах України й недостатньою розробленістю їі теоретичного та методичного забезпечення практичної діяльності під час вивчення фахових дисциплін; потребами студентів закладів вищої освіти в освоєнні сучасних професійних компетенцій і відсутністю науково обгрунтованої системи й технології підготовки майбутніх землевпорядників до професійної діяльності для цілей сталого розвитку.

Отже, відсутність концептуально системних i фундаментальних досліджень проблеми підготовки майбутніх землевпорядників, а також наявність низки суперечностей у реальному процесі цієї підготовки у вищих навчальних закладах України зумовили вибір теми дослідження.

Новизна. Освіта для сталого розвитку потребує рівнозначного розвитку екологічного, соціального та економічного складників і є новою комплексною системою освіти, яка суттєво впливає на підготовку фахівців геодезії та землеустрою. Особливе місце в освітньому аспекті сталого розвитку посідають теоретико-методологічні засади освіти для сталого розвитку. Тому елементи освіти для сталого розвитку $€$ обов'язковим компонентом програм підготовки здобувачів освіти різного рівня вищої освіти спеціальності «Геодезія та землеустрій», що відображено у відповідних державних стандартах вищої освіти.

Методологічне або загальнонаукове значення. Для досягнення поставленої мети необхідно було проаналізувати основні виробничі функції і професійні компетенції майбутнього землевпорядника з урахуванням положень Стратегії СЕК ООН освіти для сталого розвитку [1].

Виклад основного матеріалу. Узагальнюючи положення концепції формування теоретичних знань 3 теорії сталого розвитку в майбутніх землевпорядників, можна виокремити в системі навчання необхідність формування:

- теоретико-методологічної основи, яка б грунтувалась на аналізі тенденцій походження й розвитку теоретичного пізнання загальних закономірностей процесу розвитку складних систем, здатних до самоорганізації та саморозвитку;

- дидактичних принципів структурування змісту базових нормативних навчальних дисциплін: «Землеустрій», «Державний земельний кадастр», «Моніторинг довкілля», «Організація та управління в природоохоронній діяльності», «Планування територій населених пунктів», «Раціональне використання та охорона земель», «Інвестиційний аналіз», «Ландшафтознавство», «Технології відтворення продуктивності земель» та «Управління земельними ресурсами»-з урахуванням аспектів сталого розвитку;
- педагогічних умов забезпечення інноваційності навчального процесу формування знань у галузі сталого розвитку в майбутніх землевпорядників.

Стратегія СЕК ООН, маючи на меті заохочення держав до включення в системи формальної освіти елементів ОСР, одним із першочергових завдань визначає розроблення програм відповідних навчальних дисциплін. Також стратегією передбачається введення в навчальний процес нетрадиційних тем, підходів і методів, щоб навчити ставити завдання й вирішувати комплексні соціально-екологічні проблеми. Національні стратегії освіти для сталого розвитку мають акцентувати увагу на забезпеченні можливості міждисциплінарного аналізу ситуацій, характерних для реального життя, шляхом зміни як структури навчальних планів i програм, так і методів викладання [8].

Сучасні тенденції й відповідні міжнародні рекомендації щодо інноваційних методів і технологій навчання передбачають такі зміни в організації навчального процесу $[1 ; 7]$ :

- лекції для великих потоків повинні поступитися місцем заняттям у малих групах (семінари, проекти), при цьому акценти робляться на проблемно-(або проектно-)орієнтовану систему навчання (problem/ project-based learning) і на оволодіння студентами практичних навиків (що є проблематичним за наявного, досить обмеженого фінансування державних вищих навчальних закладів);

- технології навчання повинні бути максимально зорієнтовані на інформаційно-комунікаційні технологіï (e-learning), онлайн-освіту, зокрема ширше використовувати наявні в Інтернеті навчальні засоби (open educational resources), ГІС-технологіï, революційні технології: супутникові радіонавігаційні системи (GNSS), лазерне 3D-сканування (лідарна зйомка) та оперативне картографування з використанням безпілотних літальних апаратів (БПЛА) тощо;

- необхідно змінити підходи до організації роботи викладача в бік збільшення обсягу самостійної роботи під керівництвом викладача, збільшення кількості індивідуальних занять, широкого впровадження проектних технологій тощо (орієнтація на аудиторні години вважається неадекватною сучасним умовам навчання).

Такий підхід до організації навчального процесу поряд із модернізацією системи оцінювання міг би суттєво змінити ситуацію з професійної підготовки майбутніх фахівців, у тому числі й фахівців-землевпорядників. В умовах переходу суспільства до сталого розвитку в меті й завданнях професійної діяльності майбутніх землевпорядників відбуваються суттєві зміни у зв'язку з необхідністю, що все зростає, стримувати споживацьке ставлення людини до природи, адже призначенням землеустрою є забезпечення реалізації державної політики щодо використання та охорони земель, наукового обгрунтування розподілу земель за цільовим призначенням 3 ура- 
хуванням державних, громадських і приватних інтересів, формування раціональної системи землеволодіння й землекористування, створення екологічно сталих агроландшафтів тощо; прогнозування, планування й організації раціонального використання та охорони земель на національному, регіональному, локальному й господарському рівнях; розроблення і здійснення системи заходів із землеустрою для збереження природних ландшафтів, відновлення та підвищення родючості грунтів, рекультивації порушених земель і землювання малопродуктивних угідь, захисту земель від ерозії, підтоплення, висушення, зсувів, вторинного засолення, закислення, заболочення, ущільнення, забруднення промисловими відходами й хімічними речовинами тощо, консервації деградованих і малопродуктивних земель, запобігання іншим негативним явищам; організації території підприємств, з метою створення умов сталого землекористування у використанні та охороні земель несільськогосподарського призначення.

Відповідно до освітньо-професійної програми першого рівня вищої освіти галузі знань 19 «Архітектура та будівництво» спеціальності 193 «Геодезія та землеустрій», на рівні обов'язкових компонентів циклу професійної підготовки еколого-управлінські функції розглядаються тільки в таких дисциплінах, як «Землеустрій», «Моніторинг довкілля», «Технології відтворення продуктивності земель», «Планування територій населених пунктів», «Раціональне використання та охорона земель» $\mathrm{i}$ «Державний земельний кадастр». Ці самі еколого-управлінські функції розглядаються у 2-му модулі дисципліни «Організація управління в екологічній діяльності» [2], який включає, окрім теоретичних знань у галузі природоохоронного менеджменту, ще цілий блок нормативно-правового забезпечення (форми заяв, терміни подачі, розгляду й повернення документів тощо). На нашу думку, розвиток проектних компетентностей щодо сталого розвитку територій, сталого землекористування необхідно здійснювати під час викладу фахових дисциплін «Планування територій населених пунктів» (розроблення генеральних планів населених, зонінгу територій), «Раціональне використання та охорона земель» (правові аспекти охорони земель, природоохоронного законодавства), «Інвестиційний аналіз» (програми економічного й соціального розвитку територіальних громад, залучення інвестицій, аналіз інвестиційної привабливості території), «Ландшафтознавство» (ландшафтне планування території), «Технології відтворення продуктивності земель» (контурно-меліоративна, ландшафтна організація території, стале землекористування, еколого-економічна ефективність використання земель) та «Управління земельними ресурсами» (наукове обгрунтування механізму їх розвитку, що передбачає визначення й конкретизацію сукупності інструментів і методів регулювання суспільних відносин щодо збалансованого землекористування й охорони довкілля).

Варто зазначити, що Барселонська декларація об'єднує орієнтири щодо інтеграції елементів сталого розвитку до інженерної освіти. Інженериземлевпорядники сьогодення повинні бути здатними розуміти, як саме їхня робота взаємодіє із суспільством і навколишнім середовищем на локальному та глобальному рівнях 3 метою ідентифікації ймовірних викликів, ризиків і впливів; розуміти вклад їхньої роботи в різні культурні, соціальні та політичні контексти й ураховувати ці відмінності; працювати в міждисциплінарних групах з метою адаптування сучасних технологій до вимог сталого розвитку, енергоефективності, запобігання забрудненням та управління відходами; застосовувати цілісний і системний підхід до вирішення проблем i бути здатними виходити за межі традицій розбиття реальності на низку роз'єднаних частин; брати активну участь у обговоренні та визначенні економічних, соціальних і технологічних політик з метою переспрямування суспільства до більш сталого розвитку; застосовувати професійний досвід відповідно до життєвих принципів та універсальних цінностей, етичних імперативів; чітко відслідковувати вимоги громадян та інших зацікавлених сторін і надавати їм право висловитись стосовно розроблення нових технологій та інфраструктурних об'єктів.

Відповідно до цього, компетенції в галузі сталого розвитку пов'язані з таким [3]: 1. Критичним мисленням - умінням здійснювати інтелектуально впорядкований процес активного й умілого аналізу, концептуалізації, застосування, синтезування та/ або оцінювання інформації, отриманої чи породженої спостереженням, досвідом, роздумами або комунікацією.

2. Системним мисленням - умінням виконувати дослідження об'єкта як цілісної множини елементів у сукупності відношень і зв'язків між ними (розглядати об'єкт як систему).

3. Міждисциплінарністю - умінням колективно працювати над вирішенням завдань як разом iз фахівцями в різних галузях, так і разом із різними зацікавленими особами.

4. Цінностями й етикою, що лежать в основі метакогнітивного набору компетенцій, вони показані як головна сила зміни ставлення діяти особисто і професійно для досягнення цілей сталого розвитку.

Головні висновки. Отже, вища освіта з геодезії та землеустрою повинна бути контекстною, інноваційною й конструктивною, орієнтованою та експансивною, цілісною й соціальною, міждисциплінарною, заохочувати до участі, критичною, збалансованою, системною, етичною, цільовою, продовжуватись протягом усього життя. Вибір змісту дисциплін для сталого розвитку визначають ключові компетенції майбутнього бакалавра-землевпорядника. Під час уведення елементів сталого розвитку до землевпо- 
рядних дисциплін рекомендується послуговуватись такими настановами: розуміння основних принципів стабільності, сталого землекористування; з'ясування значення освіти для сталого розвитку; виявлення та використання педагогічних підходів у поєднанні 3 хорошою навчальною практикою; розвиток і поглиблення навчання для сталого розвитку; здобуття студентами вмінь і навичок для сталого розвитку; робота в стійкому навколишньому середовищі.

Перспективи використання результатів дослідження. Зазначимо, що особливе місце в освітньому аспекті сталого розвитку посідають теоретико-методологічні засади екологічної освіти й освіти для сталого розвитку. Отже, елементи освіти для сталого розвитку $\epsilon$ обов'язковим компонентом програми підготовки здобувачів освіти землевпорядного спрямування. Тому необхідно включити до нормативної частини циклу професійно-орієнтованої гуманітарної та соціально-економічної підготовки вказаної спеціальності дисципліну «Стратегія сталого розвитку», а розроблення змістового наповнення $є$ перспективою подальших досліджень.

\section{Література}

1. Боголюбов В.М. Проблеми формування змісту навчально-методичних матеріалів при підготовці майбутніх екологів. Восточноевропейский журнал передовых технологий. 2014. № 4/10 (70). С. 8-13.

2. Вольська А.О. Щодо проблем використання земельних ресурсів в Україні. Інноваційна економіка. 2013. № 1. С. $25-27$.

3. Свропейський досвід підготовки інженерів для сталого розвитку: монографія. Д.: Дріант, 2016. $92 \mathrm{c.}$

4. Калина Т., Константінова О. Землевпорядна освіта і наука в контексті реалізації цілей сталого розвитку України. URL: http://mx.ogasa.org.ua/handle/123456789/6060 (дата звернення: 03.12.2018).

5. Кошкалда I., Князь О., Тишковець В. Використання світового досвіду підготовки інженерів-землевпорядників для сталого розвитку аграрної освіти в Україні. Agricultural and Resource Economics: International Scientific E-Journal. 2015. Vol. 1. № 2. C. $40-50$.

6. Мартин А. Вища освіта з геодезії та землеустрою: час змінювати пріоритети навчання? Землевпорядний вісник. 2018. № 2. C. 30-36.

7. Освіта для сталого розвитку: національна доповідь. URL: http://dea.gov.ua/training/1215.html (дата звернення: 03.12.2018).

8. Пашков I.А. Системні основи сталого землекористування в Україні. URL: http://www.nbuv. gov.ua/ portal/ natural/vznu/ eco/2009_1/149.pdf.

9. Програма дій «Порядок денний на 21 століття» / пер. 3 англ.; ВГО «Україна. Порядок денний на 21 століття». Київ: Інтелсфера, 2000. 360 с.

10. Підготовка фахівців-екологів для сталого розвитку у вищих навчальних закладах України / Т.А. Сафранов, О.Р. Губанова, Т.П. Шаніна, В.Ю. Приходько. Науковий вісник НЛТУ України. 2014. Вип. 24.11. С. 376-379. URL: http://nbuv.gov.ua/ UJRN/nvnltu_2014_24.11_62.

11. Стратегія СЕК ООН освіти для сталого розвитку / пер. з англ. Одеса: Екологія, 2005. 44 с. 


\title{
ОСОБАИВОСТІ ЗАСТОСУВАННЯ МЕХАНІЗМІВ УПРАВАІННЯ СТАИИМ ТУРИЗМОМ, ІНДИКАТОРІВ ТА ІНДЕКСІВ ЙОГО РОЗВИТКУ
}

\author{
Нєпєіна Г.В. ${ }^{1}$, Сербулова Н.А. ${ }^{1}$, Смирнов В.М. ${ }^{2}$, Смирнова С.М. ${ }^{1}$ \\ ${ }^{1}$ Чорноморський національний університет імені Петра Могили, \\ вул. 68 Десантників, 10, 54003, м. Миколаїв \\ annanep.dan@gmail.com \\ leto0412leto@gmail.com \\ ${ }^{2} \mathrm{TOB}$ «ТД «АННОНА»» \\ площа Заводська, 1, 54050, м. Миколаїв \\ vnsmirnov79@gmail.com
}

\begin{abstract}
У статті проаналізовано визначення й подано характеристику поняття «сталий туризм»; визначено сутність і принципи сталого розвитку туризму; наведено показники, що використовуються як індикатори сталого розвитку туризму. Ключові слова: туризм, сталий розвиток, сталий туризм, сталий розвиток туризму, Всесвітня туристична організація, ресурсний потенціал, туристична діяльність.
\end{abstract}

Особенности применения механизмов управления устойчивым туризмом, индикаторов и индексов его развития. Непеина А.В., Сербулова Н.А., Смирнов В.Н., Смирнова С.М. В статье проанализировано определение и изложена характеристика понятия «устойчивый туризм»; определены сущность и принципы устойчивого развития туризма; приведены показатели, которые используются в качестве индикаторов устойчивого развития туризма. Ключевые слова: туризм, устойчивое развитие, устойчивый туризм, устойчивое развитие туризма, Всемирная туристическая организация, ресурсный потенциал, туристическая деятельность.

Features of application of sustainable tourism management mechanisms, indicators and indicators of its development. Niepieina A., Serbulova N., Smirnov V., Smirnova S. The definition and description of the concept of "sustainable tourism" are analyzed, the essence and principles of sustainable development of tourism are defined, indicators of sustainable tourism development are given. Key words: tourism, sustainable development, sustainable tourism, sustainable development of tourism, the World Tourism Organization, resource potential, tourist activity.

Постановка проблеми. На початку третього тисячоліття туризм став невід'ємним складником сучасного життя. У всьому світі він $\epsilon$ визнаним і вагомим економічним чинником, який допомагає ринковому розвитку відносин і міжнародному співробітництву, створюючи передумови для поліпшення платіжного балансу країни, стабільного й динамічного збільшення надходжень до бюджету. Туристична галузь залишається головним складником доходу та працевлаштування на національному, регіональному й місцевому рівнях. Розвиток туризму відіграє також важливу роль у вирішенні соціальних проблем, сприяе підвищенню зайнятості, підвищенню рівня життя та освіти населення.

Попит на відпочинок і туризм зростає дуже швидко, особливо в країнах, що розвиваються. Він стимулюється більшою доступністю туристичних місць, а також зростанням мобільності, доходу і збільшенням кількості вільного часу туриста-споживача.

Основна ідея багатьох міжнародних документів, які прийняті останнім часом світовою спільнотою, полягає в тому, що розвиток туризму заснований на принципах сталості - це туризм, екологічно орієн- тований у довгостроковій перспективі, економічно життєздатний, а також той, що відповідає етичним і соціальним інтересам місцевих громад.

Сьогодні, коли в українському туризмі домінує конкурентне середовище, необхідна наявність достатньої кількості наукових праць, які б допомагали здійснювати стійке управління в цій сфері діяльності.

Актуальність дослідження. Останнім часом спостерігається підвищений інтерес до такої форми туристичної діяльності, як екологічний туризм, який упевнено займає відповідну нішу в туристичній індустрії України.

Екологічний туризм - порівняно нове поняття в туристичній діяльності. Основна причина виникнення екологічного туризму полягає в недостатній урегульованості відносин у системі «суспільство - природа». Сьогодні все більше туристів прагне відпочивати в екологічно комфортних умовах, спілкуватися 3 природою в процесі туристичних подорожей. Головна цінність екологічного туризму - унікальна можливість пережити почуття єдності з природою [9]. 
Нині надзвичайно актуальним є також питання наукового обгрунтування ролі сталого туризму в системі соціально-економічних пріоритетів регіонального й місцевого розвитку, вироблення теоретичних основ формування регіональної туристичної політики та механізмів іiі практичної реалізації, а також розроблення індексів та індикаторів сталого розвитку і сталості туристичного потенціалу.

Зв'язок авторського доробку із важливими науковими та практичними завданнями полягає в дослідженні, узгодженні й порівнянні прийнятих за основу визначень, понять, термінів у галузі туризму; розкритті значення та зв'язку двох груп понять: по-перше, «подорож», «рекреація» й «туризм», а по-друге, «м'який туризм», «екологічний туризм» $\mathrm{i}$ «сталий туризм», а також розробленні індексів та індикаторів сталості туристичного потенціалу.

Аналіз останніх досліджень і публікацій. Туризм - одна з галузей світової економіки, що найбільш динамічно розвиваються. Туризм - це багатовимірна, багатогранна економічна діяльність із сильним соціальним елементом. У 1991 році Світова організація туризму (COTOH) запропонувала таке визначення: «Туризм включає відпустку, основну або додаткову, одноденні подорожі, ділові поїздки, відвідування друзів або родичів, поїздки освітні, спортивні, оздоровчі або релігійні. Це - рух людей у межах своєї країни та поїздки від одної країни до іншої» [5].

Визначенням понять «подорож» $\mathrm{i}$ «туризм» займалися В. Квартальнов, Г. Папірян та інші науковці, а також деякі міжнародні організації. Що стосується поняття «рекреація», то в перекладі з латині це означає «відновлення сил», «відпочинок» [7]. Саме ця точка зору існувала у вітчизняній (в основному радянській) літературі. Розробленням понятійного апарату й методологічних питань, що стосуються рекреації, вчені почали займатися із 70-80-х років минулого століття [2].

Відомо понад 14 визначень терміна «рекреація» залежно від мети, яку переслідує дослідник, а також від його суб'єктивного сприйняття цього явища: «рекреація» вживається в розумінні галузі народного господарства (Р. Гусейнов), використовується для означення одного з видів природокористування (В. Павлов, Л. Черчик), процесу відпочинку (М. Нудельман), господарської діяльності (П. Гудзь), функції туризму (I. Зорін) тощо [2].

У сучасній літературі, виданій останніми роками, спостерігається перехід до нового бачення рекреації (В. Квартальнов, І. Смаль, В. Смаль, В. Новіков та інші).

Розробленням концепції «м'якого туризму» займався Дітер Крамер. Ї̈̈ використовували в Німеччині, Швейцарії, Австрії. У контексті цієї концепції «м'який туризм» передбачає не лише успішний туристичний бізнес, а й дбайливе ставлення до природи, культури і традицій місцевого населення. Сутність цього виду туризму - гуманізація традиційного туризму [9].

Термін «екологічний туризм» - порівняно нове поняття в туристичній галузі. Уперше його запропонував у 1980 р. мексиканський економіст Гектор Цебаллос Ласкурейн. На його думку, екологічний туризм означає поєднання подорожі 3 дбайливим ставленням до природи, дає змогу поєднати радість знайомства 3 нею та вивчення зразків флори й фауни 3 можливістю сприяти їх захисту [9]. Проблемою визначення поняття «екологічний туризм» займалися I. Петрасов, А. Бабкін, В. Новіков та інші, а поняття «стійкий туризм» вивчали В. Новіков, I. Петрасов, В. Квартальнов, а також низка міжнародних організацій.

Розробленням показників, індексів та індикаторів сталого розвитку займалися П. Мунін, С. Бобильов, С. Бойко, О. Попов, С. Краснокутський, С. Артюх, Н. Тарасова, Є. Кручина, Л. Мельник, В. Прадун та інші.

Різноманітність досліджень із питань туристичної галузі підтверджує складність, актуальність і неоднозначність цієї теми. Однак варто зазначити, що ціла низка аспектів державного регулювання розвитку туризму в Україні ще адекватно й усебічно не відображена в науковій літературі.

Виділення не вирішених раніше частин загальної проблеми, котрим присвячується означена стаття. Питання наукового обгрунтування ролі сталого туризму в системі соціально-економічних пріоритетів регіонального й місцевого розвитку, а також вироблення теоретичних основ формування регіональної туристичної політики та механізмів іiі практичної реалізації залишаються сьогодні відкритими. Застосування механізмів управління сталим туризмом у практичній площині й обгрунтування індикаторів та індексів його розвитку становить не вирішену раніше частину цієї загальної проблеми.

Новизна дослідження пов'язана 3 тим, що зараз у нашій країні спостерігається недостатня розробленість економічних, екологічних та управлінських аспектів туризму. У зв'язку з цим достатньо слабо розроблено й більшість прикладних питань організації та інформації у сфері туризму. Тому на сучасному етапі розвитку України, особливо в умовах адміністративної реформи, що триває, актуальними стають питання щодо створення ефективних індикаторів та індексів стійкості туристичної галузі на всіх рівнях, децентралізації й деконцентрації влади 3 чітким визначенням повноважень кожного іiі рівня.

Методологічне або загальнонаукове значення авторського доробку полягає в подальшому розвитку теоретико-методологічних підходів до визначення сутності екологічного туризму, аналізі основних методів управління сталим туризмом, визначенні основних індексів та індикаторів сталості туризму.

Виклад основного матеріалу. Сьогодні туризм $€$ найбільш динамічним сектором у світовій еконо- 
міці, який виконує економічну, соціально-культурну, політичну й інші функції. Туризм - висококонкурентна галузь. Це означає, що ті, хто залежить від стабільності або зростання попиту на туризм, мають постійно докладати зусиль для підтримання високої якості їхнього «продукту», його ефективного маркетингу та пристосування до змін у попиті [5].

Підвищення життєвих стандартів збільшує час відпочинку працюючого населення, звільняючи більше часу для пізнання багатої й різноманітної природної та історико-культурної спадщини. Водночас у результаті швидкого поширення індустрії туризму виникла проблема зростання антропогенного навантаження на природні й культурно-історичні ресурси традиційних і нових місць відвідування туристів. Тому натепер розвиток цієї галузі економіки пов'язаний із низкою екологічних проблем, що потребують негайної уваги та пошуку шляхів їх вирішення. Одним із таких шляхів є сталий напрям розвитку туристичної діяльності [1].

Саме цей напрям обрала Всесвітня туристична організація (далі - ВТО, а 32003 року - ЮНВТО) за підтримки ООН. Із середини 90-х років минулого століття сталий розвиток туризму є пріоритетним напрямом для більшості країн світу. Такі міжнародні документи, як Конвенція 3 питань біологічного різноманіття, Порядок денний на XXI століття, прийняті в 1992 році на Конференції ООН з питань довкілля та розвитку в Ріо-де-Жанейро, підкреслили необхідність додати туризм до складників міжнародної політики захисту довкілля [6].

Концепція сталого туризму 3'явилась у відповідь на дві проблеми: $з$ одного боку, потреби розвивати прибутковий туризм, а $з$ іншого - враховувати обмеження щодо наявних природних ресурсів і їх збереження.

Визначення сталого туризму розроблене ВТО в 1996 році, Відповідно до цього визначення, сталий туризм - це «туристична діяльність, за якої управління всіма ресурсами проходить таким чином, що економічні, соціальні, естетичні потреби задовольняються та зберігається культурна складова, екологічні процеси, біологічне різноманіття та системи підтримки життя» [6]. Також розвиток сталого туризму описується як «процес, який задовольняє потреби сучасних туристів та місцевостей, які їх приймають, і водночас зберігає та розвиває можливості для майбутнього» (ВТО, 1996 рік). За цим визначенням, розвиток сталого туризму має задовольняти потреби сьогодення та майбутнього, потреби туристів і приймаючої сторони, має слугувати інтересам людей у сфері економіки, соціуму й екології.

На додаток до створення можливостей для зайнятості в місцевій громаді сталий туризм має допомогти зменшити вплив на природну та культурну спадщину, сприяти використанню місцевих продуктів. У Хартії зі сталого туризму (1995 рік) написано: «Сталий туризм базується на критерії сталості, що означає, що він має бути екологічно нешкідливим в довготривалій перспективі, економічно доцільним та соціально рівним для місцевих громад» [6].

Сталий розвиток туризму базується на доктрині сталого розвитку, яка спрямована на зміну стосунків людини й природи задля розширення можливостей економічного зростання та на створення скоординованої глобальної стратегії виживання людства, орієнтованої на збереження й відновлення природних спільнот у масштабах, необхідних для повернення до меж господарської місткості біосфери.

Згідно з Порядком денним на XXI століття, принципи сталого розвитку туризму такі: 1) сприяння утвердженню повноцінного і здорового життя людини в гармонії з природою; 2) внесок у збереження, захист і відновлення екосистем Землі; 3) розроблення й застосування сталих моделей виробництва та споживання як основа для подорожей i туризму; 4) співпраця народів у сфері відкритої економічної системи; 5) скасування тенденцій протекціонізму у сфері надання послуг туристичного характеру; 6) обов'язків захист довкілля як невід'ємний складник процесу розвитку туризму, повага відповідних законів; 7) участь громадян країни в розв'язанні проблем, пов'язаних із розвитком туризму, в тому числі тих, що стосуються їх безпосередньо; 8) забезпечення локального характеру прийняття рішень щодо планування туристичної діяльності; 9) обмін досвідом і впровадження найефективніших технологій туризму; 10) урахування інтересів місцевого населення [8].

На сучасному етапі сутність сталого розвитку туризму розглядається як найважливіший фактор сталого розвитку суспільства загалом. Це положення чітко зафіксовано в Глобальному етичному кодексі туризму, ухваленому ВТО в 1999 році. У ньому проголошено зобов'язання всіх учасників туристичного процесу зберігати природне середовище 3 метою стійкого і збалансованого розвитку. Вагоме місце належить ролі органів центральної, регіональної та місцевої влади, які мають підтримувати найбільш сприятливі для природного середовища форми туризму. 3 метою зміни негативного впливу великих туристичних потоків варто застосовувати заходи рівномірного розподілу туристів і відвідувачів, зменшуючи так дію фактору сезонності. Планування нових об'єктів туристичної інфраструктури потрібно здійснювати 3 урахуванням особливостей місцевості, гарантування збереження звичного способу життя населення. Сталий розвиток територій, залучених для туристичної діяльності, забезпечують шляхом створення об'єктів інфраструктури туризму, організації нових робочих місць, залучення до нової діяльності у сфері туристичного обслуговування місцевого населення. У результаті цього підвищується життєвий рівень мешканців периферійних регіонів, відбувається їх закріплення на історичній території проживання. Природоохоронний характер туризму 
натомість полягає в обов' язковості збереження біорізноманіття рекреаційних територій і центрів. Вагоме значення в охороні та відновленні рекреаційних територій мають також схеми фінансування і кредитування природоохоронної діяльності в їх межах [8].

Значну роль у такому контексті відіграє формування екологічного світогляду як населення рекреаційних регіонів, так і туристів, а саме: усвідомити рекреаційну привабливість природного ландшафту, його еколого-естетичну цінність, що може приносити економічну вигоду, а тому потребу охорони і дбайливого ставлення до рекреаційних ресурсів. Розуміння місцевим населення того факту, що хижацьке використання ресурсів призведе до того, що його територія залишиться за межами сфери рекреаційного використання, може бути значним стимулом для дбайливого й раціонального користування ресурсами. Від туристів необхідно таке: згода поступитися певною часткою свого комфорту; надання переваги продукції, виробленій у цьому регіоні; інтерес і повага до місцевих звичок, традицій і прийнятого способу життя; згода користуватися лише громадським транспортом; ентузіазм щодо активного захисту довкілля, мінімізація негативних наслідків від рекреаційної діяльності; збільшення часу перебування на відпочинку за рахунок зменшення частоти подорожей. Отже, за сталого розвитку туризму всі рекреаційні ресурси використовують і спрямовують так, щоб задовольняти економічні, соціальні й естетичні потреби під час одночасного збереження культурної ідентичності, екологічної рівноваги, біологічного різноманіття та систем життєзабезпечення регіону відпочинку [8].

Варто наголосити, що в Україні основи теорії, наукові принципи й методи сталого туризму ще формуються.

Сьогодні як індикатори сталого розвитку туризму використовуються такі показники, запропоновані ЮНВТО:

- для державної реалізації концепції сталого розвитку (наявність місцевої політики зі сталого розвитку в районі, реєстру місць, що становлять культурну цінність, реєстру місць, що становлять природну цінність, кількість туристичних комплексів, які мають екоярлик або які беруть участь у програмі з управління природокористуванням (EMAS або ISO 14000));

- для аналізу антропогенної діяльності (туристичні перевезення - транспортування до й від місця відпочинку, внутрішні перевезення; несуча місткість - використання землі, біорізноманітність і туристична діяльність, використання енергії, використання води, поводження з твердими відходами);

- соціальний i культурний показник (співвідношення працівників, які не проживають у цьому місці, до загальної кількості працюючих у туризмі; середня тривалість контрактів для туристського пер- соналу; відсоток території, що займають працівники, які не проживають у цьому місці; кількість зареєстрованих крадіжок; співвідношення населення турист/господар);

- економічний показник (сезонні коливання занятості в туристичній сфері, сезонні коливання оренди житла, середня тривалість ночівель, загальна житлова місткість на представника місцевого населення) [10].

В Україні з метою забезпечення гармонійного розвитку туризму, Стратегію розвитку туризму i курортів [4] узгоджено з наявними державними стратегіями, передусім із Державною стратегією регіонального розвитку на період до 2020 року, затвердженою Постановою Кабінету Міністрів від 6 серпня 2014 року № 385 .

Відповідно до Державної стратегії регіонального розвитку на період до 2020 року, основною метою регіональної політики є створення умов для підвищення конкурентоспроможності регіонів, забезпечення їх сталого розвитку на сучасній технологічній основі, високої продуктивності виробництва та зайнятості населення. Виконання стратегічних завдань регіональної політики дасть можливість забезпечити динамічний збалансований розвиток країни загалом, наблизити рівень життя до європейських стандартів і створити умови для посилення економічної активності в усіх регіонах країни, що сприятиме поступовому пом'якшенню міжрегіональних диспропорцій, зменшенню ризиків утворення депресивних територій і захистить суспільство від значних витрат на відновлення належних умов його життедіяльності [3].

Головні висновки. Викладене свідчить, що в Україні основи теорії, наукові принципи й методи сталого туризму ще формуються. Згідно 3 Державною стратегією регіонального розвитку на період до 2020 року, першим стратегічним завданням регіональної політики є підвищення конкурентоспроможності регіонів і зміцнення їхнього ресурсного потенціалу. Реалізація цього напряму дасть змогу підвищити продуктивність сфер економіки i регіонах і підтримати нові види діяльності, що сприятиме підвищенню рівня зайнятості населення. Але ситуація, яка склалась, фактично призводить до зриву реалізації заходів Державних програм, тому що методи державного управління розвитком туризму недостатньо вивчені, особливо механізми управління туристичної сферою в сучасних умовах, а системи індексів та індикаторів сталого розвитку недостатньо розроблені й обгрунтовані як для регіонального, так і для локального рівнів.

Перспективи використання результатів дослідження. Отримані наукові результати мають бути спрямовані на дослідження механізмів державного управління соціалізацією, екологізацією та інформатизацією туризму. 


\section{Література}

1. Гулевська Н.М. Передумови формування стійкого туризму. Вісник СумДУ. Серія «Економіка». 2007. № 2. С. $130-134$.

2. Кравченко Н.О. Рекреаційне господарство Полісся: сучасний стан та перспективи розвитку. URL: http://tourlib.net/ books_ukr/kravchenko1-1.htm (дата звернення: 08.12.2018).

3. Про затвердження Державної стратегії регіонального розвитку на період до 2020 року: Постанова Кабінету Міністрів України від 6 серпня 2014 року № 385 / Кабінет Міністрів України. URL: http://zakon.rada.gov.ua/laws/show/ 385-2014-\%D0\%BF (дата звернення: 09.12.2018).

4. Про Стратегію розвитку туризму та курортів до 2026 року: Схвалено Розпорядженням Кабінету Міністрів України від 16 березня 2017 року № 168-p. URL: https://www.kmu.gov.ua/ua/npas/249826501 (дата звернення: 09.12.2018).

5. Розвиток сталого сільського туризму: Тематичний довідник / Видано Асоціацією Євроакадемія та Карпатським фондом в Україні у рамках проекту «Розвиток сталого сільського туризму - зміцнення спроможності лідерів сільського розвитку» за підтримки Сврокомісії, EuropeAid, TACIS, Програми розбудови інституційного партнерства (IBPP). Ужгород, 2007.88 с.

6. Сербулова Н.А., Нєпєіна Г.В. Теоретичні основи й практичні аспекти застосування механізмів управління сталим туризмом та індикаторів і індексів його розвитку. Наукові праці: науково-методичний журнал. 2012. Вип. 194. Т. 206: Екологія. C. $86-90$.

7. Смаль I.В., Смаль В.В. Рекреація, туризм і дозвілля: тлумачення і співвідношення понять. URL: http://tourlib.net/statti ukr/ smal.htm (дата звернення: 08.12.2018).

8. Смирнов І.Г. Логістика туризму: навчальний посібник. Київ: Знання, 2009. 444 с.

9. Сорокіна Г.О. Екологічний туризм: навчальний посібник. Луганськ: Вид-во ДЗ «ЛНУ імені Тараса Шевченка», 2013. 206 с.

10. Ярімчук О.Я. Системний підхід до планування, прогнозування і прийняття рішень в туризмі. URL: http://sait.kpi.ua/ eproc/2011/1/1140.pdf (дата звернення: 08.12.2018). 
УДК 338.482(477.73)

DOI https://doi.org/10.32846/2306-9716-2018-4-23-18

\title{
РОЗВИТОК ЕКОАОГІЧНОГО ТУРИЗМУ В ПРИМIСЬКОМУ РЕГIOHI М. МИКОААЕВА
}

\author{
Патрушева Л.І. \\ Чорноморський національний університет імені Петра Могили \\ вул. 68 Десантників, 10, 54003, м. Миколаїв \\ lpatruseva2@gmail.com
}

\begin{abstract}
У статті автором обрано критерії оцінювання ключових точок екотуристичного маршруту: інформативний, естетичний, активний, економічний і комфортний. Результати оцінювання представлені в балах від 1 до 30 . За результатами аналізу закладена мережа екологічних і туристичних маршрутів. Вони заплановані на 2-5 днів. У кожному з маршрутів активні дії чергуються 3 відпочинком під час зупинок. Розвиток екологічного туризму в сільській місцевості дасть змогу зберегти сфери незайманого характеру за рахунок коштів, отриманих від туристичного доходу туризму. Ключові слова: соціальний запит, екологічний туризм, визначне місце, екотуристичний маршрут.
\end{abstract}

Развитие экологического туризма в пригородном регионе г. Николаев. Патрушева Л.И. В статье автор выбрал критерии оценки ключевых точек екотуристического маршрута: информативный, эстетический, активный, экономичный и удобный. Результаты оценки представлены в баллах от 1 до 30. По результатам анализа проложена сеть экологических и туристических маршрутов. Они запланированы на 2-5 дней. На каждом из маршрутов активные действия чередуются с отдыхом на остановках. Развитие экологического туризма в сельской местности позволит сохранить районы девственной природы за счет средств, полученных от туристического дохода от туризма. Ключевые слова: социальный запрос, екологический туризм, выдающееся место, екотуристический маршрут.

Development of environmental tourism in Mykolayev's suburban region. Patrusheva L. In modern conditions of financial restrictions of residents, recreation in the suburbs is most in demand. Recreational needs can be met without leaving far from the city. The author chose criteria for estimating the route: informative, aesthetic, active, economical, and comfortable. The results of the evaluation are presented in scores from 1 to 30 . Based on the results of the analysis, a network of ecological and tourist routes was laid. They are scheduled for 2-5 days. In each of the routes, active actions alternate with rest during stops. The development of ecological tourism in rural areas will preserve the areas of virgin nature, at the expense of the funds received from the tourism income of tourism. Key words: social request, ecological tourism, tourist attraction, recreation, ecotourism route.

Постановка проблеми. Інтенсивний ритм життя, невпинний потік зайвої інформації й зазвичай незадовільний стан середовища існування змушують міських мешканців шукати недоторкані куточки природи, аби відновити моральні та духовні сили. Тому вони починають звертати увагу на місця 3 уповільненим ритмом життя, гарними краєвидами, чистим повітрям і смачною й корисною їжею. Саме таким вимогам відповідають території з недоторканою природою, що залишилась здебільшого в межах об'єктів природно-заповідного фонду (далі - ПЗФ). Крім того, створені там природоохоронні установи мають достатні засоби для задоволення пізнавальних та естетичних потреб відпочиваючих. А навколишня сільська місцевість, яка $є$ дещо несподіваною та екзотичною для сучасної людини, що живе в місті, додасть незабутніх вражень у повсякденних потребах. Саме в селі $є$ можливість змінити шалений темп на спокій. Але, крім тихого, розваженого відпочинку, в українському селі можна отримати цікаву, різноманітну інформацію про історико-архітектурну спадщину, автентичну культуру, унікальний побут, старовинні гастрономічні рецепти.
Актуальність дослідження. Задовольнити соціальне замовлення та попит відпочиваючих можливо за умов визначення їхніх уподобань, а отже, і ресурсного потенціалу території, придатної для рекреації. Актуальність організації мереж еколого-туристичних маршрутів сьогодні полягає в їх потенційному економічному та природоохоронному зиску, а також у тому, що вони $є$ чи не єдиним дієвим механізмом забезпечення найбільш цікавої й масової форми екологічної просвіти. Залучити до активного пізнання навколишнього світу різні соціальні групи міських мешканців стане можливим за умови створення різноманітних маршрутів, які за своєю складністю, естетикою та інформативністю мають відповідати бажанням будь-яких категорій населення.

Метою дослідження визначено таке: оцінити можливі ключові пункти, виділити найбільш цікаві 3 них і на основі отриманих результатів розробити мережу туристичних маршрутів.

Досягнення поставленої мети вимагає вирішення таких завдань:

- ознайомитись із досвідом дослідження потреб міського населення в екологічному відпочинку;

- окреслити регіон дослідження; 
- визначити методику оцінювання ключових, каркасних точок у приміському регіоні;

- провести оцінювання еколого-туристичної привабливості приміського регіону;

- розробити й обгрунтувати мережу еколого-туристичних маршрутів.

Зв'язок авторського доробку із важливими науковими та практичними завданнями. Стратегічне планування розвитку туризму в регіоні є складником Стратегії розвитку Миколаївської області на період до 2020 року та забезпечує цільову спрямованість на поліпшення якості життя населення як основного показника оцінювання сталого розвитку суспільства.

Аналіз останніх досліджень і публікацій. Питання розвитку рекреації на приміських територіях представлені в дослідженнях О. Бабчинської, О. Бейдика [1], Й. Гілецького, А. Голода [2], В. Данильчука [3], О. Любіцевої, В. Шуляка [4] та ін. Зважаючи на зростання соціального запиту на бюджетний, короткочасний насичений відпочинок, дослідження в цьому напрямі потребують подальшого розвитку й теоретико-методологічного обгрунтування.

Виділення не вирішених раніше частин загальної проблеми, котрим присвячусться означена стаття. Інформація щодо розвитку туризму в Миколаївській області подана в роботах T. Козаченко, Т. Чичкалюк, В. Кулакова, М. Романенко, А. Іванова та інших, проте окремо приміський регіон не досліджувався. У сучасних умовах фінансових обмежень мешканців саме він має найбільший попит, тому представлене дослідження є актуальним і своєчасним, має велике прикладне значення.

Новизна дослідження полягає в удосконаленні методики оцінювання ключових пунктів екотуристичних маршрутів і застосування іii на території поблизу м. Миколаєва.

Методологічне або загальнонаукове значення. Проведене оцінювання може слугувати підгрунтям для оцінювання доцільності розвитку екологічного туризму на приміських територіях.

Виклад основного матеріалу. Туристично привабливою вважається територія, яка користується популярністю у відвідувачів. Приїхати туди їх заохочує наявність специфічних туристичних ресурсів, зручність транспортно-географічного положення й доступна для кожного інформація. Найбільш привабливими є території, де соціально-економічні, історико-культурні, етнографічні об'єкти поєднуються в комплекс із надзвичайними краєвидами, водоймами, придатними для купання та рибної ловлі, лісами, комфортними для прогулянок [5].

Аналіз сучасної ситуації щодо соціально-економічних потреб і можливостей міських мешканців, для яких проводилась представлена робота, довів, що є велике бажання отримати нову інформацію, естетичне задоволення, ексклюзивні вироби тощо протягом невеликого часового проміжку -
1-2 дні - та 3 мінімальними витратами на транспорт. Ці потреби можна задовольнити не від'іжджаючи далеко від міста. Тут доводиться враховувати сучасний стан транспортної інфраструктури. Тому для нас стало актуальним детально вивчити приміський регіон, а особливо ту його частину, що традиційно залишалася поза увагою фахівців у сфері туризму. Вибір регіону дослідження зумовлений запитом потенційних користувачів маршрутів. Відповідно до їхніх побажань і виходячи з туристичної логістики, ми сформулювали для маршрутів такі вимоги:

1. Екологічність - максимальний час перебування на природі, наявність об'єктів ПЗФ, пересування екологічними видами транспорту (пішки, велосипедом, на байдарках, яхтах тощо).

2. Інформативність - спостереження за цікавими об'єктами живої природи, відвідування історико-культурних та археологічних пам'яток, знайомство з етнографічними особливостями.

3. Естетичність - постійне знаходження в естетично привабливому місці, зупинки на оглядових майданчиках.

4. Активність - використання транспорту, що потребує певних фізичних зусиль, участь у квестах і майстер-класах.

5. Економічність - мінімізація транспортних витрат, проживання в сільських садибах і наметах.

6. Комфортність - оптимальна швидкість проходження, що врахує можливості кожного учасника, вибір найбільш сприятливого сезону, забезпечення якісного харчування та побутових потреб.

Маршрути прокладено, відповідно до перелічених вимог, по об'єктах, що отримали найвищий бал, за підсумками проведеного оцінювання. У ньому враховано як позитивні, так і негативні сторони кожного окремо взятого об'єкта [6]. Оцінка містить інформацію про їх кількісні та якісні характеристики, а саме:

- наявність цікавих для мандрівника природних та антропогенних об'єктів фортеці, костьоли, скелі, печери, об'єкти ПЗФ тощо;

- дорога (комфортність доїзду до об'єкта, наявність дерев, покриття, мальовничість);

- наявність оглядових майданчиків (краєвид на кожному 3 майданчиків, що потребує окремої оцінки);

- місця ночівлі (наметовий табір, приватний сектор - агрооселі, готелі);

- водні об'єкти (зручний підхід до води, безпечний рельєф дна, сприятливий грунт);

- наявність джерел і якість питної води;

- туристичні «родзинки» (можливість спостерігати за представниками рідкісних та унікальних видів рослинного і тваринного світу, музеї, автентичні ремесла, ферми, фестивалі, розважальні комплекси);

- пункти харчування (можливість скоштувати неповторні, традиційні, місцеві вироби); 
- можливість збирання лікарських трав, грибів, рибальство.

Усі вищеперелічені характеристики є позитивними, відповідно, наявність кожної з них збільшує привабливість об'єкта. Проте є також і негативні риси, які можуть привабливість зменшувати:

- наявність небезпечних тварин (плазунів, комах);

- активна фаза впливу алергенних рослин.

Для кожної характеристики визначалась кількість балів. У підсумку обчислювалась їх загальна кількість [6; 7]. Відрізки між населеними пунктами оцінювались разом із наступним населеним пунктом. Максимально можлива оцінка становила 30 балів, отримані результати подано на рисунку 1.

Під час оцінювання ми також ураховували кліматичні особливості регіону. Аналіз привабливості проводився лиш для теплого сезону року з 1 квітня до 15 жовтня, проте цей період за погодними умовами також є неоднорідним, тому залежно від умов руху маршрутом ураховані такі особливості, як спека влітку, квітнення цікавих рослин, привабливість краєвиду з урахуванням кольорової гами по сезонах, купання у водоймах тощо.

За підсумками проведеного аналізу нами прокладено мережу еколого-туристичних маршрутів. Наприклад, деякі з них:

- пішохідні: Ковалівка - Андріївка - Варюшине - Покровка, Криворіжжя - Підлісне Новосафронівка - Богодарівка - Кам'янка;

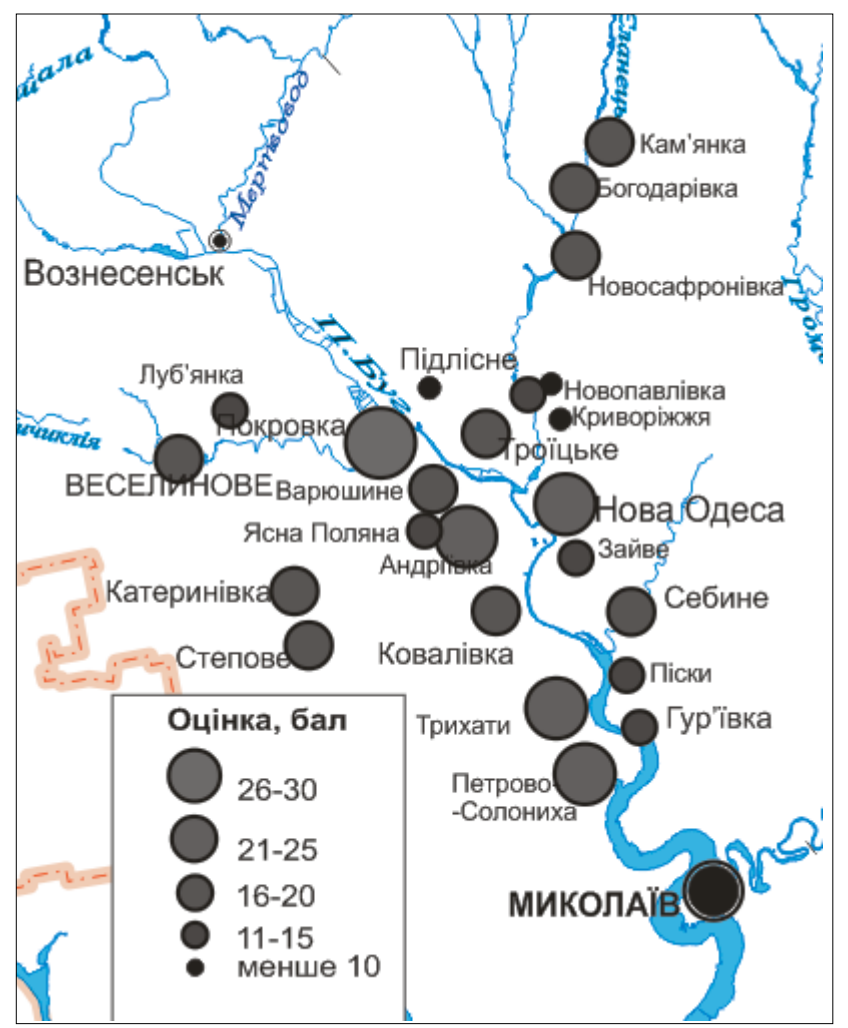

Рис. 1. Очінка ключових пунктів екотуристичних марирутів приміського регіону
- велосипедні: Петрово-Солониха - Трихати Ковалівка - Андріївка - Варюшине - Покровка, Троїцьке-Криворіжжя-Підлісне-НовосафронівкаБогодарівка - Кам'янка;

- водний: Петрово-Солониха - Трихати - Пєски Себіне - Ковалівка - Андріївка - Варюшине Покровка;

- мішаний, що складається 3 двох частин: водної - Миколаїв - Петрово-Солониха - Трихати Ковалівка - та пішохідної - Ковалівка - Андріївка Варюшине - Покровка.

Маршрути розраховані на 2-5 днів. У кожному 3 маршрутів активні дії чергуються 3 відпочинком під час зупинок, де обов'язковою є екскурсія, центральним елементом кожної екскурсії має бути історико-культурний, археологічний або природний об'єкт, наприклад, турецька фортеця в с. Покровка, музеї німецьких колоністів у с. Катеринівка, католицький костьол у с. Степове тощо.

Позитивні емоції під час проходження маршрутів будуть формуватись завдяки необтяжливому фізичному навантаженню в подоланні незначних відстаней в умовах рівнинного рельєфу, зміні різних типів рослинності (степові та лісові масиви), а також гарантованими гарними краєвидами протягом усього маршруту [7].

Головні висновки. Розвиток екотуризму в регіоні зумовить таке:

- розвиток сільського туризму, що дасть змогу вирішити соціальні питання самозайнятості, відповідно, і матеріального забезпечення місцевих мешканців. Бажання залучити більшу кількість відпочиваючих стимулюватиме підвищувати комфортність умов проживання господарів садиб;

- проведення комплексу природоохоронних заходів 3 метою покращення екологічної ситуації в регіоні, здійснення постійного моніторингу природних територій;

- облаштування місць для відпочинку у виділених мальовничих лісових ділянках, на берегах річок та озер; створення в області мережі доріг, стежок, спеціальних маркованих туристичних, спортивних, екологічних маршрутів;

- розвиток мережі малих приватних готелів сімейного типу уздовж туристичних маршрутів сільського (зеленого) й екологічного туризму;

- будівництво й реконструкцію під'їзних шляхів до сільських і віддалених населених пунктів, що визнані перспективними 3 погляду рекреаційного й туристичного продукту;

- проведення рекламних кампаній у пресі 3 метою формування іміджу Миколаївської області для відпочинку;

- створення рекреаційних сайтів і порталів у мережі Інтернет (надання необхідної та різнопланової інформації про об' єкти й послуги рекреаційної сфери області з можливостями вибору та замовлення потрібних послуг); 
- стимулювання створення громадських організацій та об’єднань туристичних підприємств для захисту колективних інтересів виробників туристичного продукту;

Покращення інфраструктури й обслуговування по кожному із зазначених вище компонентів екотуристичної індустрії в Миколаївській області в подальшому призведе до зростання показників розвитку туристичного комплексу регіону.

Перспективи використання результатів дослідження. Екологічний туризм, що базується на сільських населених пунктах, дає додаткову можливість для загального розвитку навколишніх територій, не вимагаючи надвеликих капіталовкладень, і ство- рення облаштованих робочих місць. Для сільських мешканців розвиток екологічного туризму є одним зі шляхів вирішення низки соціальних проблем: зайнятості населення, розвитку інфраструктури, покращення комфортності побутових умов, реалізації продуктів сільськогосподарського виробництва, підвищення загального культурного рівня та патріотичного виховання місцевих мешканців, прибирання сміття тощо.

Екологічний туризм, розвинений на сільських територіях, дасть змогу зберегти куточки незайманої природи, сприятиме примноженню природних цінностей за допомогою екологічної просвіти й за рахунок коштів, спрямованих із прибутків від туризму.

\section{Література}

1. Бейдик О.О. Пріоритети регіонального розвитку туризму і рекреації в Україні. Україна: географічні проблеми сталого розвитку: зб. наук. праць: у 4 т. Київ: ВЛГ Обрії, 2004. Т. 2. С. 167-168.

2. Голод А.П. Рекреаційно-туристичні об’єкти приміської зони м. Львова: компонентна та територіальна структура. Проблеми активізації рекреаційно-оздоровчої діяльності населення: матер. VI Всеукр. наук.-практ. конф. 3 міжнар. участю. Львів: Вид-во ЛДУ ФК, 2008. С. 11-14.

3. Данильчук В.Ф. Методология сравнительной оценки объектов и территорий туристического назначения. Культура народов Причерноморья. 2006. № 74. С. 36-39.

4. Шуляк В.В. Про сучасний стан і проблеми розвитку сфери відпочинку і туризму в Україні. Містобудування та територіальне планування. Київ: КНУБА, 2006. Вип. 23. С. 358-361.

5. Патрушева Л.І., Сербулова Н.А. Перспективи розвитку екологічного туризму в Миколаївській області. Ольвійський форум - 2014: Стратегії країн Причорноморського регіону в геополітичному просторі. Миколаїв: Вид-во ЧДУ ім. Петра Могили, 2014. С. 81-83.

6. Патрушева Л.І. Різнорівнева оцінка туристичної привабливості регіонів. Могилянські читання - 2014: Всеукраїнська науково-методична конференція «Досвід та тенденції розвитку суспільства в Україні: глобальний, національний та регіональний аспекти». Миколаїв: Вид-во ЧДУ ім. Петра Могили, 2014. С. 127-128.

7. Патрушева Л.І., Маркач Н.М. Оцінка еколого-туристичних ресурсів Миколаївської області. Миколаїв: Вид-во ЧдУ ім. Петра Могили, 2015. С. 54-59. 


\title{
СТРАТЕГІЯ СТАМОГО РОЗВИТКУ „ЕВРОПА 2020»: ВИКАИКИ ДАЯ УКРАЇнИ
}

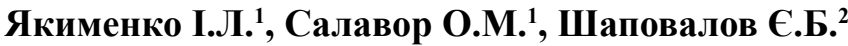 \\ ${ }^{1}$ Національний університет харчових технологій \\ вул. Володимирська, 68, 01601, м. Київ \\ iyakymen@gmail.com \\ ${ }^{2}$ Національний центр «Мала академія наук України» \\ вул. Дегтярівська, 38-44, 04119, м. Київ
}

\begin{abstract}
Стратегія сталого розвитку «Європа 2020» є стратегічним документом Європейського Союзу, прийнятим у 2010 р., що визначає стратегію розвитку Європейського Союзу до 2020 р. на засадах розумного економічного зростання (smart growth) i3 пріоритетами низьковуглецевої, енерго- та ресурсозберігаючої, соціально орієнтованої економіки. Стратегія визначає чіткі цілі й кількісні індикатори їх досягнення. У 2015 р. Україна прийняла стратегічний документ «Україна 2020», який значною мірою націлений на виклики, що стоять перед країною на шляху євроінтеграції та подолання труднощів нинішньої соціально-економічної й екологічної ситуації в країні. У статті проводиться порівняльний аналіз двох документів, визначаються слабкі місця стратегії «Україна 2020» порівняно зі стратегією «Європа 2020» та обгрунтовується висновок, що повномасштабне і своєчасне виконання Україною взятих на себе зобов'язань згідно з Угодою про асоціацію між Україною та Європейським Союзом може бути дієвим інструментом у просуванні України на шляху сталого розвитку. Ключові слова: стратегія, smart growth, peформа.
\end{abstract}

Стратегия устойчивого развития «Европа 2020»: вызовы для Украины. Якименко И.Л., Салавор О.М., Шаповалов Е.Б. Стратегия устойчивого развития «Европа 2020» является стратегическим документом Европейского Союза, принятым в 2010 г., который определяет стратегию развития Европейского Союза до 2020 г. на основе разумного экономического роста (smart growth) с приоритетами низкоуглеродной, ресурсо- и энергосберегающей, социально ориентированной экономики. Стратегия определяет четкие цели и количественные показатели их достижения. В 2015 г. Украина приняла стратегический документ «Украина 2020», в значительной мере направленный на вызовы, которые стоят перед страной на пути евроинтеграции и преодоления трудностей нынешней социально-экономической и экологической ситуации в стране. В статье проводится сравнительный анализ двух документов, определяются слабые места стратегии «Украина 2020» по сравнению со стратегией «Европа 2020» и обосновывается вывод, что полномасштабное и своевременное выполнение Украиной взятых на себя обязательств согласно Договора об ассоциации между Украиной и Европейским Союзом может быть действенным механизмом в продвижении Украины по пути устойчивого развития. Ключевые слова: стратегия, smart growth, peформа.

Sustainable development strategy Europe 2020: Challenges for Uraine. Yakymenko I., Salavor O., Shapovalov E. Sustainable development strategy Europe 2020 is a strategic document of the EU adopted in 2010 on the smart economy growth, low-carbon, resource- and energy-efficiency, and socially inclusive economy. The strategy determines clear goals and precise numerical indicators of their achieving. Ukraine adopted national sustainable development strategy Ukraine 2020 in 2015 as a response to challenges of Eurointegration and for improving current socio-economic and environmental situation in the country. The article provides a comparative analysis of the two strategies, indicates weak points of Ukraine 2020 strategy as compared to Europe 2020, and draws the conclusion that full-scale implementation of obligations of Ukraine in term of the EU-Ukraine Association Agreement may be an effective mechanism in promotion of Ukraine's sustainable development. Key words: strategy, smart growth, reform.

Постановка проблеми. Стратегія сталого розвитку стала базовим світоглядним орієнтиром для світової спільноти завдяки активній діяльності Організації Об'єднаних Націй $(\mathrm{OOH})$ щодо формуванні стратегії, починаючи 3 Доповіді Комісії Брундтланд 1987 р. [1] і завершуючи прийняттям «Плану дій 2030» 3 визначення оновлених глобальних цілей сталого розвитку у 2015 р. [2]. Ключовою ідеєю стратегії є принципова необхідність постійного узгодження трьох взаємопов'язаних складників успішного розвитку людства - економічного зростання, захисту й збереження довкілля та соціального захисту/комфорту всіх членів суспільства [3]. При цьому стратегія наголошує на обмежених фізичних можливостях планети (межі планети), які мають бути враховані в усіх сферах і проявах людської діяльності [4].

Актуальність дослідження. Тією чи іншою мірою стратегія сталого розвитку взята на озброєння й використовується як практичний дороговказ для ефективної внутрішньої та зовнішньої політики в багатьох країнах світу. Але одним із регіонів, де ця стратегія знаходить найбільшу підтримку й розуміння, $\epsilon$, ймовірно, країни Європейського Союзу (далі - СС). Як неодноразово наголошувалося лідерами $\mathrm{CC}$, стратегія сталого розвитку в певному розумінні лягла в саму основу створення $Є \mathrm{C}$ і охоплює всі сфери його діяльності. Від Маастрихтського договору про утворення Свропейського Союзу (1993 р.) стратегія сталого розвитку стає наріжним 
каменем інтегрованих політик СС, спрямованих на добробут громадян ЄС за рахунок економічного зростання, узгодженого 3 можливостями планети в соціально орієнтованому суспільстві. Стратегія сталого розвитку ЄС закріплена у відповідних рішеннях Європейської комісії (2006 та 2009 рр.) [5] і більш пізньому стратегічному документі СС «Європа 2020» (2010 р.) [6]. Євростат (центральний орган статистичної звітності (С) кожні 2 роки готує статистичні звіти щодо відповідності політики ЄС стратегії сталого розвитку [7; 8]. Тобто значною мірою ЄС є світовим лідером і прикладом для наслідування щодо запровадження стратегії сталого розвитку в практику.

Виклад основного матеріалу. Україна сьогодні проходить складний процес соціально-економічних трансформацій і вкрай важливим є усвідомлення на рівні політикуму та суспільства загалом, що ці трансформації мають базуватися саме на стратегії сталого розвитку, що має об'єднати суспільство у вирішенні трьох базових взаємопов'язаних викликів - економічного, соціального й екологічного. У статті ми проводимо аналіз ключових складників стратегії сталого розвитку «Європа 2020» і викликів, що ця стратегія ставить перед Україною, зокрема в аспекті євроінтеграційних прагнень нашого суспільства.

Стратегія сталого розвитку «Свропа 2020». Упродовж останніх років СС упровадив цілі сталого розвитку в широкий спектр своїх політик. Зокрема, як наголошується в комюніке Свропейської коміciï (Сом (2009) 400) «Про перегляд стратегіï сталого розвитку Свропейського Союзу - 2009» [5], Євросоюз став міжнародним лідером у боротьбі проти змін клімату й у впровадженні низьковуглецевої, високотехнологічної, ресурсозберігаючої економіки. У цьому ж комюніке, яке було значною мірою відповіддю Сврокомісії на глобальну економічну та фінансову кризу 2008 р., наголошувалося на важливості підтримки й розвитку реального сектору економіки для скорочення негативних соціальних наслідків кризи, забезпечення економічно сталого та соціально орієнтованого розвитку суспільства. Тобто бачимо, що в основу запропонованої Сврокомісією стратегії виходу з економічної кризи 2008 р. покладені ключові тези класичної стратегії сталого розвитку. Одним із останніх стратегічних документів ЄС щодо сталого розвитку стала стратегія «Європа 2020», розроблена Європейською комісією та прийнята Європейською радою у 2010 р. [6].

Стратегія визначає три чіткі взаємопов'язані пріоритети розвитку СС до 2020 р.:

- розумне зростання (smart growth): розвиток економіки, що базується на знаннях та інноваціях;

- стале зростання (sustainable growth): розвиток ресурсозберігаючої, зеленої й конкурентної економіки;

- соціально орієнтоване зростання (inclusive growth): розвиток економіки, що забезпечує високу зайнятість населення, соціальний захист і розвиток територій.

Для забезпечення цих пріоритетів стратегія «Європа 2020» визначає 5 основних цілей, що мають бути досягнуті ЄС до 2020 р.:

- 75\% населення у віці 20-64 роки мають бути забезпечені роботою;

- 3\% ВВП ЄС мають бути інвестовані в науку;

- мета «клімат/енергія - 20/20/20» передбачає, що до 2020 р. ЄС має скоротити викиди $\mathrm{CO}_{2}$ на 20\% (порівняно 31990 р.), отримувати 20\% усієї енергії 3 відновлюваних джерел; збільшити енергоефективність виробництва на 20\%;

- шкільну освіту мають отримувати не менше ніж 90\% дітей, не менше ніж 40\% молоді мають отримувати університетську освіту;

- 20 мільйонів громадян ЄС мають бути виведені за межі бідності [6].

Як бачимо, стратегія «Європа 2020» ставить чіткі пріоритети й кількісно означені цілі. Більше того, стратегія дає порівняльний аналіз цілей і стану ЄС на момент прийняття документа. Зокрема, вказується, що у 2010 р. рівень зайнятості населення у віці 20-64 роки в СС був на рівні 69\% (мета - 75\%). СС витрачало менше ніж 2\% (1,83\% у 2008 р.) на науку (мета - 3\%; на рівні США та Японії). Мета - скоротити викиди парникових газів у межах ЄС на 20\% від рівня 1990 р. для запобігання глобальному потеплінню - в обговоренні стратегії підсилена за можливості до 30\%. Ця мета досягнута вже у 2015 р., коли викиди парникових газів у СС скоротилися на 22,1\% порівняно з 1990 р. [8]. Розвиток відновлюваної енергетики, зокрема вітро- та сонячної енергетики, розвивається в СС надзвичайно швидкими темпами, і мета - отримувати $20 \%$ енергії з відновлювальних джерел також, імовірно, буде досягнута. У 2015 р. відновлювана енергетика вже забезпечувала 16,7\% енерговитрат СС [8]. Крім позитивного впливу на довкілля, вирішення проблеми енергетичної незалежності (передусім від Росії), ці цілі також позитивно вплинуть на ринок робочої сили ЄС. Стратегія оцінює, що за рахунок розвитку сектору відновлювальної енергетики до 2020 р. у СС буде створено понад 600 тис. робочих місць, ще понад 1 млн. робочих місць буде створено за рахунок упровадження енергозберігаючих технологій [6].

Що стосується рівня освіти молоді, Стратегія визначила за цілі скоротити кількість дітей, що не закінчують навчання в початковій/середній школі $315 \%$ до 10\%. Частка молоді, яка отримує вищу освіту, має зрости в ЄС з 31\% до 40\%. Що стосується боротьби з бідністю, за оцінками Стратегії, 80 млн. громадян ЄС (iз 500 млн. усіх громадян) перебували у 2010 р. під загрозою бідності. Відповідно, Стратегія визначила за мету скоротити до 2020 р. категорію бідного населення СС на 25\%, або на 20 млн. осіб. Показово, що Стратегія визначає межу бідності для кожної країни ЄС як 60\% від 
середнього доходу громадян цієї країни. Як бачимо, у цьому випадку мова йде зовсім не про визначені ООН 2 долара США в день на людину, а скоріше про різницю в доходах між громадянами певної країни ЄС. Тобто якщо у 2015 р. в Німеччині номінальний ВВП на душу населення становив понад 41 тис. доларів США (а середній дохід у країні зазвичай близький до ВВП на душу населення), то в Німеччині «бідними» будуть уважатися громадяни, чий дохід становить менше ніж 24,5 тис. доларів на рік.

Індикатори сталого розвитку ЄС. Як відзначив у вступі до звіту Євростату щодо сталого розвитку ЄС 2015 р. віце-президент Сврокомісії, відповідальний за сталий розвиток $\mathrm{CC}$, ви не можете керувати тим, чого ви не можете виміряти [7]. Отже, кількісна оцінка сталого розвитку СС є як важливим чинником для самого СС, так і яскравим прикладом для наслідування. Сьогодні ЄС аналізує свій прогрес у сталому розвитку за 10 основними напрямами i 100 індикаторами. Для кожного з напрямів визначено один головний індикатор, який, на думку експертів ЄС, найбільш повно відбиває стан справ за цим напрямом. Відповідні напрями та головні індикатори сталого розвитку ЄС є такими (першим іде напрям, за ним відповідний індикатор) [7]:

- соціально-економічний розвиток/реальний ВВП на душу населення;

- стале споживання та виробництво/ресурсозбереження (оцінює витрати ресурсів на одиницю виробленої продукції);

- соціальна захищеність/кількість населення, що зазнає ризику бідності;

- демографічні зміни/рівень зайнятості старшого покоління;

- громадське здоров'я/середня тривалість життя і тривалість життя в здоровому стані;

- зміни клімату й енергія/викиди парникових газів та енергоспоживання;

- сталий транспорт/енергоспоживання транспорту порівняно з рівнем ВВП;

- природний капітал/загальний індекс диких птахів;

- глобальне партнерство/офіційна підтримка розвитку бідних країн;

- гарне управління/(головний індикатор не визначено).

Ці напрями й індикатори виписані та кількісно проаналізовані у звіті Свростату 2015 р. як по Союзу загалом, так і по кожній країні-члену СС окремо [7]. У звіті наглядно представлена короткострокова (останні 5 років) і довгострокова (останні 15 років) динаміка відповідних показників у вигляді метеорологічних символів - від «ясне сонце», коли динаміка індикатора виражено позитивно, до «грозові хмари», коли динаміка виражено негативно. Наприклад, соціально-економічний розвиток і в короткостроковій, i ву довгостроковій перспективі позначено як такий, що має позитивну динаміку. I пояснюється це тим, що головний індикатор за цим напрямом - реальний ВВП на душу населення - зріс у СС з 2000 р. на 13\% (попри економічну кризу 2008 р.). Так само позитивно оцінено стан громадського здоров'я в $\mathrm{CC}$, що підтверджується зростанням середньої тривалості життя серед громадян СC із 2004 по 2013 р., відповідно, на 1,8 року в жінок і на 2,6 року в чоловіків. У 2013 р. середня тривалість життя в СС у жінок становила 83,3 року і в чоловіків 77,8 року.

Гарну позитивну динаміку, згідно 3 аналізом Євростату, показали такі напрями, як «демографічні зміни» та «зміни клімату й енергія». Натомість напрям «природний капітал», що відбиває стан дикої природи, оцінено як такий, що знаходиться в СС у загрозливому стані. Негативна динаміка, за оцінкою Свростату, виявлена й у довготривалому вимірі соціальної захищеності населення. За даними експертів, кількість населення, ураженого тією чи іншою формою бідності, перевищила в СС у 2012 р. 100 млн., тобто становила близько 20\% населення Союзу [7].

Отже, статистичний аналіз динаміки сталого розвитку СС виявляє як успішні, так і проблемні сторони розвитку європейського співтовариства й дає змогу керівним органам ЄС і громадянському суспільству визначити пріоритети на майбутнє. I суворий кількісний аналіз процесу, безумовно, є вагомою перевагою країн ЄС на шляху до сталого розвитку.

Виклики для України. Україна перебуває в цей момент у складному становищі з огляду на всі три складники сталого розвитку: економічні показники розвитку країни не тільки суттєво відстають від рівня розвинених країн, а і $є$ навіть значно нижчими за середньосвітові. Упродовж останніх років номінальний ВВП на душу населення в Україні становив 2-2,5 тис. доларів США на рік, тоді як середньосвітовий показник сьогодні сягає 10 тис. доларів США в рік на людину [9]. Екологічний стан в Україні, за оцінками неупереджених експертів, оцінюється як кризовий [10]. I, як наслідок, соціальний розвиток населення в країні аж ніяк не можна назвати задовільним.

Для аналізу поточних проблем країни, що гальмують іï соціально-економічний розвиток i руйнують довкілля, можемо звернутися до Проекту Концепції сталого розвитку України, розробленої Національною академією наук України ще у 2012 р. [10]. Документ містить конкретний аналіз ключових проблем національної економіки та екологічних негараздів країни.

Зокрема, у документі відзначається таке:

- Україна посідає одне 3 перших місць у світі за рівнем споживання енергії, води й інших ресурсів на одиницю ВВП, обсяги промислових відходів на душу населення перевищують аналогічні показники багатьох країн світу;

- маючи обмежені природні ресурси, Україна вкрай неефективно та витратно споживає більшість із них, енергоємність ВВП України у 2,6 рази перевищує середньосвітову; 
- сільськогосподарські угіддя займають 68,9\% території країни, з них 78\% припадає на ріллю. Показник розораності території України в 5 разів перевищує середньосвітовий, однак ефективність використання земель є надзвичайно низькою;

- рівень водоємності національної економіки у 2,5 рази перевищує середньосвітовий рівень;

- на світових ринках за Україною закріплюється роль сировинного регіону, оскільки основу їі товарного експорту становить продукція природоємних, екологічно шкідливих, низькотехнологічних галузей;

- в Україні через надзвичайно високий рівень зношеності основних виробничих засобів зростає загроза техногенних аварій зі значними негативними екологічними наслідками. Найбільше зношені основні засоби і галузях транспорту і зв'язку (83,9\%), промисловості $(61,8 \%)$, освіти $(62,4 \%)$;

- в Україні триває практика прийняття економічних, соціальних, технологічних та екологічних рішень без необхідного поєднання їх у єдину комплексну систему на основі стратегії сталого розвитку.

Очевидно, у відповідь на виклики, що стоять перед нашим суспільством, у 2015 р. підписано Указ Президента «Про Стратегії сталого розвитку «Україна 2020». Безумовно, назва документа наголошує на його аналогії зі стратегією «Європа 2020» [11]. У документі прямо наголошується на тому, що стратегія «Україна 2020» має на меті наближення України до стандартів ЄС. Стратегія виділяє 4 основні вектори розвитку країни, 10 основних реформ і програм і 25 стратегічних індикаторів реалізації стратегії.

Зокрема, першочерговими визначені такі реформи і програми:

- реформа системи національної безпеки й оборони;

- оновлення влади та антикорупційна реформа;

- судова реформа;

- реформа правоохоронної системи;

- децентралізація й реформа державного управління;

- дерегуляція та розвиток підприємництва;

- реформа системи охорони здоров'я;

- податкова реформа;

- програма енергонезалежності;

- програма популяризації України у світі.

Очевидно, що повномасштабна реалізація запропонованої стратегії буде сприяти просуванню України по шляху сталого розвитку. Але, на жаль, під час порівняння стратегій «Європа 2020» і «Україна 2020» впадає в око один принципово важливий момент. Стратегія «Свропа 2020» першим пріоритетом визначає «розумне економічне зростання» (smart growth), що базується на знаннях та інноваціях. I однією $з$ основних цілей стратегії «Європа 2020» визначено доведення витрат на наукові дослідження до 3\% ВВП країн СС. I вже за перші 3 роки реалізації Стратегії цей показник зріс у ЄС з 1,85\% до 2,01\% ВВП [7]. Тобто європейська стратегія повною мірою передбачає економічне зростання на основі наукового прогресу й технологічного лідерства. Ці підходи повністю відсутні в стратегії «Україна 2020». Тобто залишається незрозумілим, за рахунок чого Україна має будувати конкурентну економіку та піднімати ВВП до 16 тис. доларів США в рік на людину (як це визначено в стратегії) після подолання корупції, судової та податкової реформи. Очевидним $є$ те, що треба визнати: подолання корупції на всіх рівнях, особливо у вищих ешелонах влади, наведення ладу із судочинством і податковою політикою - це вкрай необхідні, але недостатні умови для сталого розвитку країни. Адже нашій слабкій, ресурсовитратній економіці треба конкурувати 3 політико-економічними системами розвинених країн, де проблеми на кшталт корупції та неефективного оподаткування давно вирішені. Отже, ми маємо думати не тільки про це, а й про наступні кроки розвиток наукоємних технологій, сучасних інформаційних сервісів, конкурентних за світовими мірками енерго- та ресурсоефективних виробництв. А для цього маємо стрімкими темпами розвивати (або спочатку відродити, а потім розвивати) науку й технології конкурентного рівня. Нам потрібні ефективні науковці та грамотні інженери-технологи хоча б для того, щоб стати ефективною країною - наслідувачем, спроможною впроваджувати вже розроблені в інших країнах ефективні технології світового рівня [12]. При наших нинішніх 0,6-0,8\% ВВП на науку (при цьому дуже низького ВВП) країна просто не зможе бути конкурентною в сьогоднішньому світі.

На жаль, стратегія «Україна 2020» надзвичайно мало уваги приділяє екологічному складнику сталого розвитку. Показово, що серед пріоритетних програм і стратегічних індикаторів реалізації Стратегії, наведених у документі, жодна програма і жоден індикатор (!) не пов'язані зі станом довкілля в країні. Безумовно, це йде в розріз зі Стратегією $Є С$, що прямо наголошує на сталій/зеленій економіці як одному з трьох пріоритетів Свросоюзу до 2020 р. і де контроль якості довкілля включено до основних індикаторів, за якими Свростат аналізує ефективність виконання Стратегії.

У цій ситуації варто наголосити, що підписання Угоди про асоціацію між Україною та СС може стати дієвим інструментом для просування України на шляху сталого розвитку й системного покращення стану довкілля в країні, оскільки Україна взяла на себе зобов'язання привести національне законодавство в усіх сферах і в галузі охорони довкілля зокрема у відповідність до нормативно-правової бази ЄС. Проте цей процес іде важко. За нещодавньою оцінкою незалежних експертів громадського об'єднання «Український Центр європейської політики», за останні 4 роки Україна виконала тільки $13 \%$ узятих на себе на цей період зобов'язань щодо 
імплементації норм СС у сфері охорони довкілля в національне законодавче поле [13]. I це при тому, що в цій галузі таки проводиться значна робота щодо наближення законодавства України до норм ЄC (дивіться, наприклад, аналіз [14; 15]). Слабкою втіхою $\epsilon$ те, що в деяких інших секторах показники виконання зобов'язань України ще нижчі (транспорт - 7\%, енергетика - 6\%, громадське здоров'я $0 \%)$. До речі, серед «євроінтеграційних лідерів» звіт називає такі напрями, як публічні закупівлі - 100\%, технічні бар'єри в торгівлі - 87\%, оподаткування $67 \%$ (відсоток імплементованих правових норм СС у законодавство України від запланованих).

Головні висновки. Стратегія сталого розвитку «Європа 2020» є стратегічним документом ЄС, що визначив стратегію розвитку Союзу до 2020 р. на засадах розумного економічного зростання (smart growth) iз пріоритетами низьковуглецевої, енерго- та ресурсозберігаючої, соціально орієнтованої економіки. Стратегія визначає чіткі цілі й кількісні індикатори їх досягнення. Зокрема, «розумне зростання» економіки ЄС передбачає збільшити інвестиції в науку до 3\% ВВП Союзу. Стратегія «Свропа 2020» визначає захист і збереження довкілля одним із пріоритетних напрямів і передбачає відстежування стану довкілля як обов'язкового елемента успішної реалізації стратегії. Зокрема, виконання цілі «клімат/енергія 20/20/20» повною мірою поєднує як економічний, так й екологічний складники сталого розвитку. Й аналіз Свростату показує, що, найімовірніше, ця мета буде виконана в повному обсязі.

Стратегічний документ «Україна 2020» значною мірою націлений на виклики, що стоять перед країною на шляху євроінтеграції, та подолання труднощів складної соціально-економічної й екологічної ситуації в країні. Проте в документі неповною мірою визначені механізми досягнення успіху на шляху сталого розвитку. Також документ не визначає пріоритетних програм і стратегічних індикаторів екологічного складника сталого розвитку.

Дісвим механізмом просування України на шляху сталого розвитку в тому числі в галузі охорони та збереження/відновлення довкілля може бути повномасштабна імплементація Угоди про асоціацію між Україною та СС, зокрема в частині дотримання Україною взятих на себе зобов'язань щодо приведення національного законодавства у відповідність до нормативно-правової бази СС. При цьому контроль з боку громадянського суспільства за процесом імплементації є важливим складником успіху.

\section{Література}

1. Brundtland G.H. Our common future - Call for action. Environmental Conservation 1987; 14: 291-294.

2. Cf O d D S. Transforming our world: The 2030 agenda for sustainable development. 2015.

3. Sachs J D, The age of sustainable development. 2015: Columbia University Press.

4. Steffen W., Richardson K., Rockström J., Cornell S.E., Fetzer I., Bennett E.M., Biggs R., Carpenter S.R, De Vries W., et al. Planetary boundaries: Guiding human development on a changing planet. Science 2015; 347.

5. Mainstreaming sustainable development into EU policies: 2009 Review of the European Union Strategy for Sustainable Development. Brussels, 24.7.2009. COM (2009) 400 final.

6. Europe 2020. A strategy for smart, sustainable and inclusive growth. Brussels, 3.3.2010. COM (2010) 2020.

7. Sustainable development in the European Union. 2015 monitoring report of the EU Sustainable Development Strategy. Eurostat. 2015.

8. Sustainable development in the European Union. Monitoring report on progress towards the SDGS in an EU context. Eurostat. 2017.

9. World Economic Outlook Database, April 2016. URL: https://www.imf.org/external/pubs/ft/weo/2016/01/weodata/index.aspx.

10. Концепція переходу України до сталого розвитку. Проект. 2012 p. URL: http://old.mon.gov.ua/images/files/gromad_obg/2012/ koncepcia.doc.

11. Про Стратегію сталого розвитку «Україна - 2020»: Указ Президента України від 12 січня 2015 року № 5/2015.

12. Якименко І.Л. Стратегія сталого розвитку: європейський вимір. Київ: НУХТ, 2017.

13. Україна та Угода про асоціацію: моніторинг виконання 2014-2018 / ГО «Український центр європейської політики». Київ, 2018.

14. Шаповалов С.Б, Салавор О.М., Якименко І.Л. Порівняльний аналіз законодавства ЄС та України в галузі охорони атмосферного повітря. Екологічні науки. С. 192-197.

15. Салавор О.М, Шаповалов Є.Б, Якименко І.Л. Порівняний аналіз нормативної бази ЄС та України щодо захисту водних ресурсів. Екологічні науки (стаття в друці). 


\title{
ЕКОАОГІЯ ВОДНИХ РЕСУРСІВ
}

УДК 504.45:556

DOI https://doi.org/10.32846/2306-9716-2018-4-23-20

\section{МАТЕМАТИЧНЕ МОДЕАЮВАННЯ ПЕРЕНЕСЕННЯ МАРГАНЦЮ У ВОДНОМУ СЕРЕДОВИЩІ НА ПРИКААДІ РІЧОК ХОМОРА I САУЧ}

\author{
Гребенюк Т.В., Науменко Д.П., Броницький В.О. \\ Київський політехнічний інститут імені Ігоря Сікорського \\ вул. Борщагівська, 115,03056, м. Київ \\ t.hrebeniuk07@gmail.com \\ dasha.nmnk@gmail.com \\ vadim.bronytskyy@gmail.com
}

\begin{abstract}
У статті розглянуто одновимірну математичну модель трансформації й перенесення забруднюючих речовин у водному середовищі на прикладі р. Хомора Хмельницької області, що дало змогу виконати прогнозування поширення марганцю у водному середовищі. Проаналізовано особливості зв'язування іонів марганцю з тіоловими сполуками в живих організмах і їх біологічну дію. Ключові слова: моделювання, самоочищення, гранично допустима концентрація, турбулентна дифузія, метод різницевої апроксимації, марганець.
\end{abstract}

Математическое моделирование переноса марганца в водной среде на примере реки Хомора и Случ. Гребенюк Т.В., Науменко Д.П., Броницкий В.О. В статье рассмотрена одномерная математическая модель трансформации и переноса загрязняющих веществ в водной среде на примере р. Хомора Хмельницкой области, что позволило выполнить прогнозирование распространения марганца в водной среде. Проанализированы особенности связывания ионов марганца с тиоловыми соединениями в живых организмах и их биологическое действие. Ключевые слова: моделирование, самоочистка, предельно допустимая концентрация, турбулентная диффузия, метод разностной аппроксимации, марганец.

Mathematical modeling of the transfer of manganese in the water environment by the case of river Khomor and Sluch. Hrebeniuk T., Naumenko D., Bronytskyi V. One-dimensional mathematical model of transformation and transfer of pollutants in an aqueous environment is considered on the example of the Khomor River of the Khmelnitsky region, which allowed to carry out the forecasting of the distribution of manganese in the aquatic environment. The peculiarities of binding of manganese ions with thiol compounds in living organisms and their biological effects are analyzed. Key words: modeling, self-purification, maximum permissible concentration, turbulent diffusion, method of difference approximation, manganese.

Постановка проблеми. Унаслідок роботи целюлозно-паперових підприємств загострюється екологічна ситуація, зумовлена хімічним забрудненням стічними водами природних водойм, у які відбувається скид. Неповні або відсутні певні ступені очищення вод перед скиданням у природні водойма провокують потрапляння в них хімічних небезпечних речовин.

Для прогнозування якості води річок, у які відбувається скид стічних вод, використовують низку методів, за допомогою яких можна запобігти зниженню якості води й передбачити розміри забруднених територій.

Актуальність дослідження зумовлена потребою людства в чистій прісній воді, адже якість питної води тепер $\epsilon$ чи не найбільшою екологічною проблемою.

У статті розглянуто вміст у стічних водах такого металу, як марганець (II), який уважається «від- носно» нетоксичним. Але його здатність легко змінювати ступінь окиснення й широкий спектр коливань вмісту в прісних водоймах викликає інтерес до вивчення його дії на гідробіонтів. Досліджено, що марганець спричиняє токсичну дію на ссавців, це пов'язано зі специфічним його впливом на тіоли, що $€$ похідними вуглеводнів, у молекулах яких один або декілька атомів гідрогену заміщені меркаптогрупою -SH (тіольною, сульфгідрильною). Тіоли, в яких меркаптогрупа сполучена 3 аліфатичним радикалом, називають тіоспиртами, з ароматичним тіофенолами [1].

Для виявлення універсальних і видових характеристик тіолових сполук організму за дії іонів важких металів постає інтерес розглянути їх вплив на представників, що належать до одного біотопу, але різних за екологічними вимогами. Значення обраних для дослідження видів визначається тим, що короп $\epsilon$ промисловою рибою, а беззубка лебедина - одним 
iз найпоширеніших на території України видів прісноводних двостулкових молюсків, які можуть ефективно концентрувати метали - забруднювачі.

Прісноводні тварини мають здатність зв'язувати надлишок марганцю за широкого діапазону його концентрації у воді узгоджено зі значною активацією антиоксидантних факторів організму. Надлишок металів у тканинах не акумулюється металотіонеїнами й викликає найзначніші ознаки токсичності.

У печінці коропа за дії всіх доз іонів марганцю його вміст у термостабільних компонентах істотно зростає, причому це відбувається навіть за умови його зменшення в тканині. Специфічною ознакою дії марганцю на тіоли в коропа є значне збільшення вмісту білкових тіолів за незмінного вмісту небілкових тіолів. Вплив марганцю на антиоксидантно-прооксидантну систему (далі - АПС) у печінці коропа має антиоксидантну спрямованість, що відповідає найвищому вмісту вільної форми марганцю в тканині.

У беззубки дія іонів марганцю викликає істотні зміни показників АПС, хоча загалом зміни показників АПС у тканинах беззубки збалансовані.

Марганець виявляє схильність до акумуляції в низькомолекулярних сполуках в обох організмів. Однак тоді як у коропа він у великому діапазоні доз акумулюється в металотіонеїни й активує антистресові системи організму, то в беззубки він накопичується в небілковому розчині та пригнічує антиоксидантний захист [2].

Важливим науковим i практичним завданням є дослідження впливу марганцю на флору і фауну річок Хомора і Случ за допомогою даних прогнозування розповсюдження забруднюючих речовин за течією.

Аналіз останніх досліджень і публікацій. У науковій літературі питання Понінківської картонно-паперової фабрики - «Україна» (далі - ПКПФ-Україна) та іiі вплив на річки Хомора і Случ розглядається лише як загальний вплив таких підприємств на водні об'єкти [3].

Аналіз попередніх публікацій виявив, що екологічний стан річок Хомора і Случ недостатньо вивчено, а саме вплив паперової фабрики на водне середовище.

Розглянуто перенесення марганцю по водотоку річок Хомора і Случ, що дає можливість зробити прогнозування масштабів їх забруднення на певні відстані від місця скидання стічних вод.

Метою статті $\epsilon$ внесення пропозиції щодо використання одновимірної моделі трансформації й перенесення забруднюючих речовин на прикладі річки Хомора.

Виклад основного матеріалу. У води річки Хомора під час аварійних скидів потрапляють забруднюючі речовини з ПКПФ-Україна. Щоб передбачити розміри забруднення водної екосистеми розглянуто математичну модель трансформації й перенесення [4].
За умови поширення забруднювальних речовин у річках (одновимірний випадок) рівняння в частинних похідних має такий вигляд:

$$
\begin{gathered}
\frac{\partial U}{\partial t}=a^{2} \frac{\partial^{2} U}{\partial x^{2}}+\lambda(t, x) U-V \frac{\partial U}{\partial x}+ \\
+f(t, x)+\eta(t, x)
\end{gathered}
$$

де $\eta(t, x)$ - випадкова величина, для якої

$$
\begin{gathered}
E \eta(t, x) \eta(\tau, s)=Q(t, x, s) \delta(\tau-t) \\
E \eta(t, x)=0
\end{gathered}
$$

3 крайовими умовами:

$$
\begin{aligned}
& U\left(t, x_{0}\right)=\xi x_{0}(t) \\
& U\left(t, x_{N}\right)=\xi x_{N}(t)
\end{aligned}
$$

Тут $U=U(t, x)$ - концентрація забруднювальної речовини; $f(t, x)$ - функція потужності джерела викидів, що лежить у початку координат

$$
f(t, x)=\left\{\begin{array}{cc}
\mathrm{g}(t) & \text { при } x=0 \\
0 & \text { при } x>0 ;
\end{array}\right.
$$

$V(x, t)$ - швидкість потоку; $\lambda(t, x)$ - величина, що характеризує швидкість розпаду речовини (самоочищення потоку); $\alpha$ - коефіцієнт турбулентної дифузії.

Розіб' ємо відрізок $\left[x_{0}-x_{N}\right]$ на $N$ рівних частин точками $x_{k}=k h_{k}+x_{0}$, де $h_{x}=\left(x_{N}-x_{0}\right) / N$, і виберемо крок по $t$, що дорівнює $\tau$. Відомі різні методи побудови різницевих схем вихідного диференціального оператора залежно від структури розв'язання, неперервності або розривності коефіцієнтів, які дають змогу побудувати різницевий аналог у вигляді співвідношення концентрації речовини забруднення у вузлах схеми (шаблону).

Так, якщо припускається гладкість точного розв'язку, можна розкласти в ряд:

$$
\begin{gathered}
U_{k, n+1}=U_{k, n}+\tau\left(\frac{\partial U}{\partial t}\right)_{k, n}+O\left(\tau^{2}\right) \\
U_{k, n+1}=U_{k, n} \pm h_{x}\left(\frac{\partial U}{\partial t}\right)_{k, n}+\frac{1}{2} h_{x}^{2}\left(\frac{\partial^{2} U}{\partial x^{2}}\right)_{k, n} \pm \\
\pm \frac{1}{6} h_{x}^{2}\left(\frac{\partial^{3} U}{\partial x^{3}}\right)_{k, n} \pm O\left(h_{x}^{4}\right) .
\end{gathered}
$$

Замінивши в рівнянні (1) похідні різницями, дістанемо його різницевий аналог:

$$
\begin{array}{r}
\frac{U_{k, n+1}-U_{k, n}}{\tau}=a \frac{U_{k+1, n}-2 U_{k, n}+U_{k-1, n}}{\Delta x^{2}}- \\
-V \frac{U_{k+1, n}-U_{k-1, n}}{2 \Delta x}+\lambda U_{k, n}+f\left(x_{n}, t_{n}\right)+\eta\left(x_{n}, t_{n}\right)
\end{array}
$$

Підставляючи формулу (5) у рівняння (6), переконаємося, що вихідне диференціальне рівняння апроксимується 3 точністю до $O\left(x^{4}, \tau^{2}\right)$. Крім, умов апроксимації, для збіжності розв'язку задачі (6) до розв'язку задачі, що описується неперервним оператором (1), перевіряється ще умова стійкості різницевої схеми.

Метод різницевої апроксимації дає змогу легко скласти схему першого або другого порядків апрокси- 
мації на прямокутній сітці для рівнянь із неперервними (й досить гладкими) коефіцієнтами. Однак цей метод важко або навіть неможливо застосовувати в складних випадках: для рівнянь із розривними коефіцієнтами, для рівнянь високого порядку тощо.

Задача ідентифікації різницевого рівняння (6) знаходження числових значень (оцінок) коефіцієнтів $a, V$, $\lambda$. Якщо коефіцієнт дифузії $a$, швидкість перенесення забруднень $V$ ще піддаються оцінці, то $\lambda(t, x)$ - функція, що характеризує розпад забруднень за рахунок механічних і біологічних перетворень, визначається в природних умовах надто складно.

Поставимо задачу, що має на меті запобігання зниженню якості питної води нижче від санітарно-гігієнічних нормативів.

Підприємство ПКПФ-Україна розташоване в точці $A$ (місце випуску стічних вод) (рис. 1). За умови неправильного режиму роботи очисних споруд, коли порушується технологія або режим випуску стічних вод, у районі устя $B$ спостерігається екологічно небезпечна ситуація.

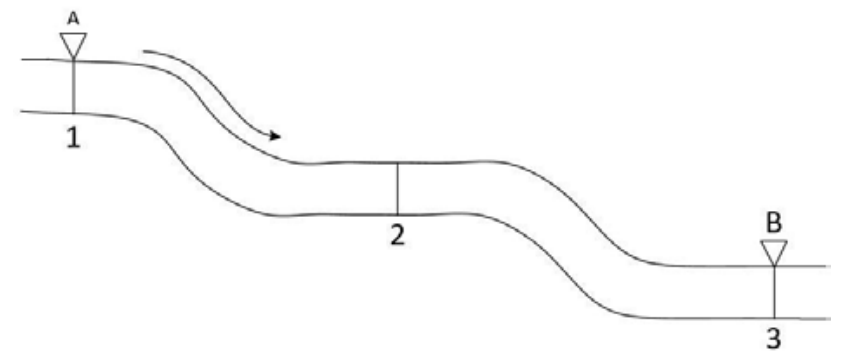

Рис. 1. Схема спостережень і розташування гідрохімічних постів на річиі Хомора

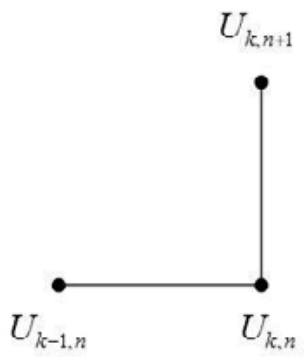

Рис. 2. Розрахункова комірка (шаблон) для побудови моделей

Необхідно скласти систему локального моніторингу, яка б базувалась на мінімально можливому числі гідрохімічних постів спостережень і результатах аналізу гідрохімічної обстановки в річці з використанням математичних моделей.

Тимчасова схема спостережень, яка організовується для збирання даних натуральних спостережень за концентрацією забруднювальних речовин з метою ідентифікації моделей прогнозу, добирається в такий спосіб.

Здійснюється спостереження за скидом стічних вод у точці $A$ безпосередньо на підприємстві (об’єм скиду, час, концентрація стічних вод тощо).
У точці 1 (повного перемішування стічних вод), а також у точках 2, 3 здійснюються синхронні вимірювання концентрацій забруднювальних речовин 3 інтервалом часу $\tau$. Відстань $\Delta x$ між точками краще брати постійною (рівномірна межа спостережень). Співвідношення між $\tau$ і $\Delta x$ добирається таким, аби схема була стійкою.

Виходячи 3 різницевої схеми (6) одновимірного рівняння процесів дифузії, переносу й самоочищення (1), помічаємо, що структуру різницевого оператора можна відшукати у вигляді

$$
U_{k, n+1}=a_{-1} U_{k-1, n}+a_{0} U_{k, n}+a_{1} U_{k+1, n}
$$

де

$$
\begin{aligned}
& a_{-1}=\left(\frac{a}{(\Delta x)^{2}}+\frac{V}{2 \Delta x}\right) \tau \\
& a_{0}=\left(\frac{1}{\tau}-\frac{2 a}{(\Delta x)^{2}}+\lambda\right) \tau \\
& a_{1}=\left(\frac{a}{(\Delta x)^{2}}-\frac{V}{2 \Delta x}\right) \tau
\end{aligned}
$$

Якщо швидкість течії на відрізку $A-B$ вважати постійною, умови самоочищення також ідентичними, то синхронними вимірюваннями в моменти $\tau$, $2 \tau, 3 \tau$ у точках $1-3$ концентрацій $U_{k-1, n}^{i} U_{k, n}^{i}, U_{k+1, n}^{i}$ (рис. 1) дістанемо матрицю спостережень $X$ і вектор вихідної величини $Y$ :

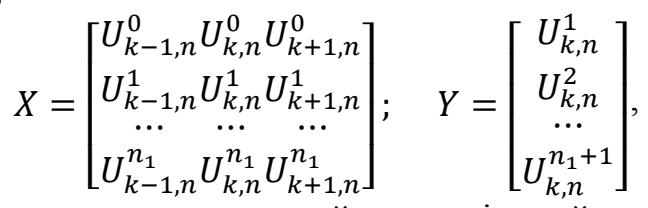

що дає змогу знайти невідомий вектор $\alpha^{T}=\left(\alpha_{-1}, \alpha_{0}, \alpha_{1}\right)$ із системи алгебраїчних рівнянь:

$$
\left(X^{T} X\right) \alpha=X^{T} Y \text {. }
$$

Виходячи $з$ рівнянь (8), (9) і (10) за умови відомих значень $\alpha^{T}$, можна визначити фізичні параметри $a, V, \lambda$.

Окремо треба ідентифікувати «функцію джерела», тобто залежність концентрації забруднювальних речовин у створі повного перемішування (точка 1):

$$
U_{0, n}=b_{0} Q+b_{1} Q M
$$

як функцію викиду стічних вод $M$ за час $\tau, \mu^{3}$; витрат води в річці $Q, M^{3} / c$.

Зауважимо, що схема шаблону (рис. 1) не є оптимальною, коли необхідно мінімізувати число спостережень постійної схеми, оскільки за цих умов спостереження здійснюються в точках $U_{1, n}, U_{2, n}, U_{3}$, ${ }_{n}$ як у початкових умовах, а також у точці $B$ безпосередньо перед водозабором.

Припускаючи, що перенесення речовини за рахунок дифузії є малим порівняно з перенесенням течією річки, дістанемо рівняння:

$$
\frac{d U}{d t}=-V \frac{d V}{d x}+f(x, t)+\lambda(x, t) U
$$

Легко побачити, що тоді можна використати шаблон (рис. 2) і знайти невідомі коефіцієнти рівнянь: 
Результати гідрохіманалізів поверхневої води в річках Хомора та Случ

\begin{tabular}{|c|c|c|c|c|c|c|c|c|c|c|}
\hline Назва створу & $\underset{\text { відбору }}{\text { Дата }}$ & لٍe & 氙 & 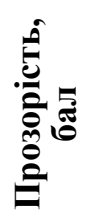 & 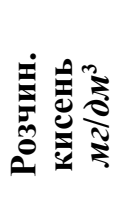 & $\frac{\pi}{2}$ & $\frac{5}{5}$ & $\frac{1}{4} \frac{3}{5}$ & 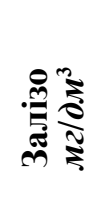 & 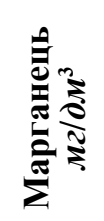 \\
\hline \multicolumn{2}{|c|}{ ГДК за Сан ПиН № 4630-88 } & & 2 & $>20$ & $>4$ & $6,5-8,5$ & 15 & 2,26 & 0,3 & 0,1 \\
\hline \multirow{3}{*}{$\begin{array}{c}\text { Створ 1 } \\
\text { р. Хомора, ліва } \\
\text { притока р. Случ, } \\
7 \text { км від гирла, } \\
\text { межа Житомирської } \\
\text { та Хмельницької } \\
\text { областей } \\
\end{array}$} & 19.04.2016 & 14 & 5 & 19 & 0,16 & 7,76 & 43,97 & 6,12 & 0,550 & 0,441 \\
\hline & 26.04 .2016 & 10 & 5 & 17 & 1,44 & 7,72 & 48,64 & 6,16 & 0,625 & 0,580 \\
\hline & 11.05 .2016 & 17 & 5 & 16 & 0,16 & 7,68 & 78,18 & 9,12 & 0,725 & 0,603 \\
\hline \multirow{3}{*}{$\begin{array}{c}\text { Створ 2 } \\
\text { р. Хомора, } \\
\text { 4 км від гирла, } \\
\text { смт Першотравенськ }\end{array}$} & 19.04 .2016 & 15 & 5 & 17 & 1,04 & 7,29 & 62,28 & 8,16 & 0,850 & 0,580 \\
\hline & 26.04 .2016 & 10 & 5 & 15 & 2,64 & 7,68 & 56,32 & 7,44 & 0,658 & 0,650 \\
\hline & 11.05 .2016 & 17 & 5 & 13 & 1,04 & 7,67 & 80,88 & 9,44 & 0,725 & 0,510 \\
\hline
\end{tabular}

$$
U_{k, n+1}=b_{0} U_{k, n}+b_{1} U_{k-1, n} .
$$

Проведемо розрахунковий аналіз для річки Хомора.

За даними гідрохіманалізу поверхневої води р. Хомора (таблиця 1), є перевищення ГДК марганцю [6].

Також маємо значення:

$\alpha=1,4-$ коефіцієнт турбулентної дифузії;

$V(x, t)=0,75 \partial \mu / c-$ швидкість потоку;

$\lambda(x, t)=1$ - величина, що характеризує швидкість розпаду речовини (самоочищення потоку) [5];

$\tau=1$ год $=3600 c-$ інтервал часу [6].

Ми маємо значення для точок 1 i 2, знайдемо концентрацію марганцю для точки 3, а так як відстань між точками вимірювання повинна бути однакова, то $\Delta x=3 \kappa м=30000 \partial м-$ відстань між точками.

Спочатку знаходимо

$$
\begin{gathered}
a_{-1}=\left(\frac{1,4}{(30000)^{2}}+\frac{0,75}{2 \cdot 30000}\right) \cdot 3600=0,045 ; \\
a_{0}=\left(\frac{1}{3600}-\frac{2 \cdot 1,4}{(30000)^{2}}+1\right) \cdot 3600=0,36 ; \\
a_{1}=\left(\frac{1,4}{(30000)^{2}}-\frac{0,75}{2 \cdot 30000}\right) \cdot 3600=-0,044 .
\end{gathered}
$$

Порівнявши вирази (7) і (15), маємо

$a_{-1} U_{k-1, n}+a_{0} U_{k, n}+a_{1} U_{k+1, n}=b_{0} U_{k, n}+b_{1} U_{k-1, n}$ $a_{1} U_{k+1, n}=b_{0} U_{k, n}+b_{1} U_{k-1, n}-a_{-1} U_{k-1, n}-a_{0} U_{k, n}$ $U_{k+1, n}=\frac{b_{0} U_{k, n}+b_{1} U_{k-1, n}-a_{-1} U_{k-1, n}-a_{0} U_{k, n}}{a_{1}}$ $U_{k+1, n}=\frac{0,81 \cdot 0,441+0,02 \cdot 0,580-0,045 \cdot 0,580-0,36 \cdot 0,441}{0,044}=0,267 \mathrm{Mr} / \partial^{3}{ }^{3}$.

Отже, концентрація марганцю в точці 3 перевищує значення ГДК більше ніж у 2,5 рази за Сан ПіН № 4630-88.

Головні висновки. У статті досліджено, що наявність марганцю в стічних водах спричиняє негативні наслідки для флори і фауни водойм, у які відбувається скид стічних вод паперових підприємств. Марганець виявляє схильність до акумуляції в низькомолекулярних сполуках в організмі.

Перспективи використання результатів дослідження. Використовуючи одновимірну математичну модель трансформації й перенесення забруднюючих речовин, установили перевищення ГДК марганцю на відстані 10 км від місця скидання стічних вод більше ніж у 2,5 рази. Доведено необхідність установлення очисного обладнання і прийняття науково обгрунтованих рішень щодо подолання кризової екологічної ситуації в річках Хомора та Случ.

\section{Література}

1. Черних В.П., Зіменковський Б.С., Гриценко І.С. Органічна хімія / за заг. ред. В.П. Черних. Харків, 2008. С. 530.

2. Мінеральне живлення тварин / за ред. Г.Т. Кліценка, М.Ф. Кулика, М.В. Косенка, В.Т. Лісовенка. Київ: Світ, 2001.576 с.

3. Науменко Д.П., Гребенюк Т.В. Аналіз впливу целюлозно-паперової промисловості на стан водних об’єктів України. Енергетика. Екологія. Людина. 2018. № 10. С. 308.

4. Ковальчук П.І. Моделювання і прогнозування стану навколишнього середовища: навчальний посібник. Київ: Либідь, 2003. $208 \mathrm{c}$.

5. Говорун В.Д., Тимощук О.О. Річки Хмельниччини. Київ, 2010. 78 с.

6. Державна екологічна інспекція України. 2018. URL: https://menr.gov.ua/. 


\title{
ТАКСОНОМІЧНА СТРУКТУРА КААДОЦЕРОЦЕНОЗІВ ГААИЧИНИ ТА ПРИАЕГАИХ ТЕРЕНІВ ЗА МАТЕРІАМАМИ ДОСАІДЖЕНЬ ПРОФЕСОРА БЕНЕДИКТА ДИБОВСЫКОГО
}

\author{
Іванець О.P. \\ Львівський національний університет імені Івана Франка \\ вул. Грушевського, 4, 79005, м. Львів \\ oleh_ivanets@ukr.net
}

\begin{abstract}
У статті наведено результати аналізу таксономічної структури кладоцероценозів Галичини та прилеглих теренів за матеріалами професора Б. Дибовського. Зареєстровано 117 таксонів Cladocera, що належать до 37 родів. Виділено 8 груп родів і встановлено їх значимість у структурі кладоцероценозу. Проведені дослідження є важливими для встановлення динаміки гідроекологічних змін і визначення рівня антропогенної трансформації довкілля. Ключові слова: таксоструктура, Сladocera, гідробіоценози, Б. Дибовський, Галичина.
\end{abstract}

Таксономическая структура кладоцероценозов Галиции и сопредельных территорий по материалам исследований профессора Бенедикта Дыбовского. Иванец О.Р. В статье приведены результаты анализа таксономической структуры кладоцероценозов Галиции и сопредельных территорий по материалам профессора Б. Дыбовского. Зарегистрировано 117 таксонов Cladocera, относящихся к 37 родам. Выделено 8 групп родов и установлено их значимость в структуре кладоцероценоза. Проведенные исследования важны для установления динамики гидроэкологических изменений и определения уровня антропогенной трансформации окружающей среды. Ключевые слова: таксоструктура, Cladocera, гидробиоценозы, Б. Дыбовский, Галиция.

The taxonomic structure of cladocerocenoses of Galicia and surrounding areas on the materials of the researches of professor Benedict Dybowski. Ivanets O. The results of analysis of taxonomic structure of cladocerocenoses of Galicia and surrounding areas on the materials of the researches of professor Benedict Dybowski are presented. 117 cladocera taxa belonging to 37 genera have been registered. 8 groups of genera were identified and their significance in the structure of cladocerocenosis was determined. The conducted studies are important for establishing the dynamics of hydroecological changes and determining the level of anthropogenic environmental transformation. Key words: taxonomic structure, Cladocera, hydrobiocenosis, B. Dybowski, Galicia.

Постановка поблеми. Одним із приорітетних напрямів гідроекологічних досліджень $є$ вивчення різноманітності біосистем різних рівнів складності. Зоопланктон i, зокрема, Cladocera - невід'ємний елемент біоти водойм різного типу. Структурні характеристики гідроекосистем значною мірою детермінують особливості їх функціонування, $є$ одним із критеріїв гідроекологічного моніторингу. Вони визначаються ідентифікацією певних функціональних груп, що зумовлені взаємодіями на популяційному рівні й закономірно реагують на вплив біотичних та абіотичних факторів довкілля. Надвидові таксони кладоцероценозів є більш консервативними. Об'єднання груп видів за особливостями біології, трофічними характеристиками становить особливий інтерес і дає змогу більш формалізовано підійти до вивчення угруповань, які є різноманітними у видовому відношенні $[1 ; 4]$. Проблема біорізноманіття пов'язана, зокрема, з такою властивістю угруповань та екосистем, як еволюційна історія. Водойми і стан їх біоти, зокрема кладоцероценозів, $є$ інтегральним показником змін довкілля загалом, оскільки їх оптимальне функціонування забезпечується надійною взаємодією компонентів у системі водойма-суходіл.
Ретроспективний аналіз таксономічної структури кладоцероценозів поряд із вивченням життєстійкості латентних яєць, які є банком генетичної інформації популяцій Cladocera у водоймах, - надійний складник реконструкції стану водних екосистем [7].

Метою роботи був ретроспективний аналіз таксономічної структури кладоцероценозів Галичини та прилеглих теренів за матеріалами Б. Дибовського й М. Гроховського $з$ урахуванням чинної на той час систематики. Такі роботи є актуальними з огляду на сучасні дослідження регіональних фаун Cladocera [10].

Матеріали та методи. Таксоном уважали таксономічну групу будь-якого рангу, котра достатньо відособлена, щоби їй можна було присвоїти певну категорію. Ураховували, що таксономічна категорія $€$ абстрактним терміном, що становить назву певної групи, а організми, які належать до цих категорій, - конкретні зоологічні об'єкти. Брали до уваги, що поняття таксону має два аспекти: воно належить до конкретних організмів і має бути формально описаним під відповідною назвою [3]. Таксономічну структуру та іï рангування аналізували, враховуючи методичні рекомендації $[5 ; 6]$. 
Виклад основного матеріалу. Бенедикт Дибовський - видатний польський зоолог із багатогранними науковими інтересами, який зробив значний вклад у дослідження фауни Сибіру й, зокрема, 03. Байкал [8; 11]. У 1884-1906 pр. Б. Дибовський разом 3 асистентом М. Гроховським досліджував гіллястовусих раків (Cladocera) водойм Галичини та прилеглих теренів.

Матеріали, отримані Б. Дибовським та М. Гроховським щодо морфолого-таксономічного й екологічного вивчення Cladocera прісних вод Галичини, представлені в низці публікацій, що й сьогодні $є$ актуальними та мають вагоме значення для розвитку таксономії Cladocera. Особливу увагу привертає стаття «Spis systematyczny Wioślarek (Cladocera) krajowych sporządzony na podstawie okazów i preparatów, które oddane były na naszą tegoroczną Wystawę krajową we Lwowie» [9], у якій викладено окремі методологічні аспекти вивчення таксономії Cladocera та подано перелік таксонів водойм Галичини і прилеглих теренів. Ці вчені описали нові для науки таксони, зокрема такі як рід Kurzia Dybowski \& Grochowski, 1894; рід Oxyurella Dybowski \& Grochowski, 1 894; підродина Aloninae Dybowski \& Grochowski, 1894; підродина Chydorinae Dybowski \& Grochowski, 1894; підрід Ctenodaphnia Dybowski \& Grochowski, 1895. Колекція Cladocera, зібрана Б. Дибовським та М. Гроховським, нині зберігається в зоологічному музеї Львівського національного університету ім. І. Франка [2].

У водоймах за матеріалами Б. Дибовського та М. Гроховського виявлено 117 таксонів гіллястовусих раків, що належать до 37 родів [9] (таблиця 1).

За рангуванням і значимістю в ценозі роди можна розділити на вісім груп. У першій групі головну роль відіграє рід Ceriodaphnia, якому притаманний

Таксономічна структура кладоцероценозів Галичини і прилеглих теренів за матеріалами Б. Дибовського та М. Гроховського [9]

\begin{tabular}{|c|c|c|c|c|c|}
\hline $\begin{array}{l}\text { № } \\
\text { 3/II }\end{array}$ & Роди & $\begin{array}{c}\text { Кількість видів } \\
\text { у роді }\end{array}$ & Ранг & $\begin{array}{c}\text { Представленість (\%) роду } \\
\text { в кладоцероценозі за кількістю видів }\end{array}$ & $\begin{array}{l}\text { Група } \\
\text { родів }\end{array}$ \\
\hline 1 & Acantholeberis & 1 & I & 1 & VIII \\
\hline 2 & Alonopsis & 1 & I & 1 & VIII \\
\hline 3 & Harporhynchus & 1 & I & 1 & VIII \\
\hline 4 & Holopedium & 1 & I & 1 & VIII \\
\hline 5 & Kurzia & 1 & I & 1 & VIII \\
\hline 6 & Landea & 1 & I & 1 & VIII \\
\hline 7 & Lathonura & 1 & I & 1 & VIII \\
\hline 8 & Leptodora & 1 & I & 1 & VIII \\
\hline 9 & Peracantha & 1 & I & 1 & VIII \\
\hline 10 & Polyphemus & 1 & I & 1 & VIII \\
\hline 11 & Sida & 1 & I & 1 & VIII \\
\hline 12 & Streblocerus & 1 & I & 1 & VIII \\
\hline 13 & Coronatella & 2 & II & 1,5 & VII \\
\hline 14 & Eurycercus & 2 & II & 1,5 & VII \\
\hline 15 & Hyalodaphnia & 2 & II & 1,5 & VII \\
\hline 16 & Ilyocryptus & 2 & II & 1,5 & VII \\
\hline 17 & Macrothrix & 2 & II & 1,5 & VII \\
\hline 18 & Monospilus & 2 & II & 1,5 & VII \\
\hline 19 & Rhypophilus & 2 & II & 1,5 & VII \\
\hline 20 & Acroperus & 3 & III & 2,5 & VI \\
\hline 21 & Camptocercus & 3 & III & 2,5 & VI \\
\hline 22 & Graptoleberis & 3 & III & 2,5 & VI \\
\hline 23 & Leydigia & 3 & III & 2,5 & VI \\
\hline 24 & Lynceus & 3 & III & 2,5 & VI \\
\hline 25 & Moina & 3 & III & 2,5 & VI \\
\hline 26 & Alona & 4 & IV & 3,5 & $\mathrm{~V}$ \\
\hline 27 & Daphnella & 4 & IV & 3,5 & $\mathrm{~V}$ \\
\hline 28 & Oxyurella & 4 & IV & 3,5 & V \\
\hline 29 & Pleuroxus & 4 & IV & 3,5 & V \\
\hline 30 & Simocephalus & 5 & $\mathrm{~V}$ & 4 & IV \\
\hline 31 & Alonella & 6 & VI & 5 & III \\
\hline 32 & Bosmina & 6 & VI & 5 & III \\
\hline 33 & Chydorus & 7 & VII & 6,5 & II \\
\hline 34 & Ctenodaphnia & 7 & VII & 6,5 & II \\
\hline 35 & Leiodaphnia & 7 & VII & 6,5 & II \\
\hline 36 & Scapholeberis & 7 & VII & 6,5 & II \\
\hline 37 & Ceriodaphnia & 12 & VIII & 8,5 & I \\
\hline
\end{tabular}


найвищий 8 ранг. Він представлений 12 видами: C. echinata, C. fischeri, C. Landei, C. laticaudata, C. leydigii, C. megops, C. polonica var. kromaniana, C. polonica, C. pulchella, C. reticulata, C. rotunda, C. świteziana. За кількістю видів цей рід становить 8,5\% від усього видового складу.

Другу групу становлять роди, що включають по сім видів: Chydorus (Ch. caelatus, Ch. globiformis, Ch. globosus, Ch. latus, Ch. ovalis, Ch. punctatus, Ch. sphaericus); Ctenodaphnia (C. hellichii, C. pulex var. gibbosa, C. pulex var. notodonta, C. pulex var. obtusa, C. pulex var. pennata, C. pulex var. schoedleri, C. pulex); Leiodaphnia (L. aquilina, L. berolinensis, L. caudata, L. dolichocantha, L. gracilis, L. hyalina, $L$. ventricosa); Scapholeberis (S. aurita, S. aurita var. wojnowiensis, S. mucronata var. acera, S. mucronata var. microcera, S. mucronata, S. obtusa, S. świteziana). Для них притаманний дещо нижчий 7 ранг. Ці роди нараховують по 7 видів, що становить по 6,5\% для кожного таксону цього роду. Загалом це становить 26\% у загальній структурі кладоцероценозу.

У третю групу 6 рангу включені два роди: Alonella (A. excisa var. miraticensis, A. excisa, A. excisa, var. szczorsiana, $A$. excisa var. wojnowiensis, A. excisa var. goplana, A. exigua); Bosmina (B. brevirostris, B. cornuta, B. janoviensis, B. kromaniana, B. longirostris, B. varsoviensis). Ці роди включають по 6 видів, що становить по 5\% для кожного роду від загальної кількості видів і $10 \%$ у загальній структурі кладоцероценозу.

Четверта група представлена лише одним родом Simocephalus. Він включає 5 видів: S. wojnowiensis, $S$. congener, $S$. exspinosus, $S$. serrulatus, $S$. vetulus. Це становить $4 \%$ в загальній структурі кладоцероценозу.

П'ята група включає чотири роди, кожен із яких нараховує по чотири види: Alona (A. affinis, A. quadrangularis, $A$. quadrangularis var. delaticiana, $A$. świteziana); Daphnella (D. brachyura, D. brandtiana,

Розподіл таксонів за середньозваженою значимістю в структурі кладоцероценозу

Таблиця 2

\begin{tabular}{|c|c|c|c|c|}
\hline $\begin{array}{l}\text { № } \\
\text { 3/II }\end{array}$ & Таксони & $\begin{array}{c}\text { Сумарний відсоток } \\
\text { у структурі кладоцероценозу }\end{array}$ & $\begin{array}{c}\text { Сумарна кількість } \\
\text { видів у родах } \\
\end{array}$ & $\begin{array}{c}\text { Індекс таксономічної } \\
\text { впорядкованості }\end{array}$ \\
\hline 1 & $\begin{array}{l}\text { Chydorus } \\
\text { Ctenodaphnia } \\
\text { Leiodaphnia } \\
\text { Scapholeberis } \\
\end{array}$ & 26 & 28 & 20,8 \\
\hline 2 & \begin{tabular}{|l|} 
Acroperus \\
Camptocercus \\
Graptoleberis \\
Leydigia \\
Lynceus \\
Moina \\
\end{tabular} & 15 & 18 & 15,6 \\
\hline 3 & $\begin{array}{l}\text { Alona } \\
\text { Daphnella } \\
\text { Oxyurella } \\
\text { Pleuroxus }\end{array}$ & 14 & 16 & 13,0 \\
\hline 4 & \begin{tabular}{|l|} 
Acantholeberis \\
Alonopsis \\
Harporhynchus \\
Holopedium \\
Kurzia \\
Landea \\
Lathonura \\
Leptodora \\
Peracantha \\
Polyphemus \\
Sida \\
Streblocerus \\
\end{tabular} & 12 & 12 & 15,6 \\
\hline 5 & \begin{tabular}{|l} 
Coronatella \\
Eurycercus \\
Hyalodaphnia \\
Ilyocryptus \\
Macrothrix \\
Monospilus \\
Rhypophilus \\
\end{tabular} & 10,5 & 14 & 13,6 \\
\hline 6 & $\begin{array}{l}\text { Alonella } \\
\text { Bosmina }\end{array}$ & 10 & 12 & 9,1 \\
\hline 7 & Ceriodaphnia & 12 & 8,5 & 8,4 \\
\hline 8 & Simocephalus & 5 & 4 & 3,9 \\
\hline
\end{tabular}


D. schaefferi var. eylmanii, D. schaefferi); Oxyurella (O. costata, O. goplana, O. lithuanica, O. tenuicaudis); Pleuroxus (P. aduncoides, P. hastatus, P. kijowiensis, P. trigonellus). Кожен рід становить по 3,5\% від загальної кількості видів, що загалом становить 14\% у загальній структурі кладоцероценозу.

Шоста група включає шість родів: Acroperus (A. angustatus, A. leucocephalus, A. wojnowiensis); Camptocercus (C. biserratus, C. lilljeborgii, C. rectirostris); Graptoleberis ( $G$. reticulata, G. wojnowiensis var. anacanthina, G. wojnowiensis); Leydigia (L. acanthocercoides, L. quadrangularis var. wojnowiensis, L. quadrangularis); Lynceus (L. nargielewiczii, L. piasti, L. rostratus); Moina (M. micrura, M. paradoxa, M. rectirostris). Кожен рід становить по 2,5\% від загальної кількості видів, що загалом становить 15\% у загальній структурі кладоцероценозу.

У сьомій групі зареєстровано сім родів: Coronatella (C. inornata, C. similis); Eurycercus (E. polyodontus var. goplanus, E. polyodontus); Hyalodaphnia (H. cederstroemii, H. kahlbergensis); Ilyocryptus (I. sordidus, I. sowińskii); Macrothrix (M. laticornis, M. rosea); Monospilus (M. kromanensis, M. świtezianus); Rhypophilus (R. kijoviensis, $R$. personatus). Кожен рід становить по 1,5\% від загальної кількості видів, що загалом становить $10,5 \%$ у загальній структурі кладоцероценозу.

Восьма група, найбільш чисельна за представленістю родів, включає 12 таксонів такого рівня. Проте в кожному роді зареєстрований лише один видовий таксон: Acantholeberis (A. lithuanica), Alonopsis (A. Świteziana), Harporhynchus (H. polonicus), Holopedium (H. kotowiczii), Kurzia (K. nalibokiana), Landea (L. syrenopolitana), Lathonura (L. rectirostris), Leptodora (L. hyalina), Peracantha (P. truncata), Polyphemus (P. pediculus), Sida (S. crystallina), Streblocerus (S. serricaudatus). Загалом восьма група становить $12 \%$ у структурі кладоцероценозу.

Аналіз структури кладоцероценозів 3 урахуванням середньозваженої значимості таксонів показує такі закономірності (таблиця 2). Сумарний відсоток у структурі кладоцероценозу відповідних функціональних груп змінюється в межах від 5\% (рід Simocephalus, 4 види) до 26\% (роди Chydorus, Ctenodaphnia, Leiodaphnia, Scapholeberis, сумарно 28 видів). Майже вдвічі меншим рівнем представленості в кладоцероценозі характеризуються друга (Acroperus Camptocercus Graptoleberis Leydigia Lynceus Moina, сумарно 18 видів, 15\%) і третя (Alona Daphnella Oxyurella Pleuroxus, сумарно 16 видів, 14\%) категорії функціональних груп. Проміжне положення займають 4, 5, 6, 7 категорії. Вони мають представленість від 10\% до 12\%.

Для формалізації таксономічних характеристик нами запропоновано інтегральний індекс таксономічної впорядкованості (ITB) угруповань. Він відображає сумарну ієрархічну різноманітність різних таксономічних рівнів. Цей індекс розраховується як відношення таксономічної різноманітності виділених з урахуванням кількості видів у родах груп (сума кількості родів і видових таксонів у них) до суми кількості родів і видових таксонів, що характеризують цілий кладоцероценоз. Для оптимізації отриманих показників їх множать на 100.

3 урахуванням цього показника маємо таку картину (таблиця 2). Для першої групи (Chydorus, Ctenodaphnia, Leiodaphnia, Scapholeberis) цей показник найбільший i становить 20,8. Друга (Acroperus, Camptocercus, Graptoleberis, Leydigia, Lynceus, Moina) і четверта (Acantholeberis, Alonopsis, Harporhynchus, Holopedium, Kurzia, Landea, Lathonura, Leptodora, Peracantha, Polyphemus, Sida, Streblocerus) групи родів характеризуються одинаковими показниками - 15,6. Це свідчить про подібні функціональні характеристики в структурі гідробіоценозу. Дещо нижчі показники (відповідно 13,0 та 13,6) спостерігаємо в третій (Alona, Daphnella, Oxyurella, Pleuroxus) і п'ятій (Coronatella, Eurycercus, Hyalodaphnia, Ilyocryptus, Macrothrix, Monospilus, Rhypophilus) групах. Для шостої (Alonella, Bosmina), сьомої (Ceriodaphnia) і восьмої (Simocephalus) груп родів ці показники найнижчі і становлять, відповідно, 8,4; 9,1; 3,9.

Отже, у водоймах Галичини і прилеглих теренах за матеріалами Б. Дибовського та М. Гроховського виявлено 117 таксонів гіллястовусих раків, що належать до 37 родів. Аналіз таксономічної структури 3 урахуванням кількості видів у родах дав змогу виділити певні функціональні одиниці.

Перша з них включає рід Ceriodaphnia (12 видів). Друга група об'єднує чотири роди: Chydorus, Ctenodaphnia, Leiodaphnia, Scapholeberis (по 7 видів кожного роду, друга група). Менш різноманітні групи родів нижчих рангів відіграють провідну роль у ценозі при стресових ситуаціях і детермінують функціональну стабільність угруповань.

Сумарний відсоток у структурі кладоцероценозу відповідних функціональних груп змінюється в межах від 5\% (рід Simocephalus, 4 види) до 26\% (роди Chydorus, Ctenodaphnia, Leiodaphnia, Scapholeberis, сумарно 28 видів). Майже вдвічі меншим рівнем представленості в кладоцероценозі характеризуються друга (Acroperus Camptocercus Graptoleberis Leydigia Lynceus Moina, сумарно 18 видів, 15\%) і третя (Alona Daphnella Oxyurella Pleuroxus, сумарно 16 видів, 14\%) категорії функціональних груп. Проміжне положення займають 4, 5, 6, 7 категорії. Вони мають представленість від $10 \%$ до $12 \%$.

Індекс таксономічної впорядкованості змінюється загалом у межах від 3,9 до 20,8. На основі цього індексу виділено чотири категорії груп родів. У першій значення ITВ становить 20,8. Друга категорія груп родів характеризується значенням ITB 15,6. У третій ІТВ змінюється в межах від до 13,0-13,6. У четвертій діапазон варіабельності ITВ більш мін- 
ливий: від 3,9 до 9,1. Це свідчить про подібні функціональні характеристики окремих таксонів у структурі гідробіоценозу.

Головні висновки. У подальшому доцільно із застосуванням сучасних методів досліджень опрацювати колекцію Cladocera Б. Дибовського та М. Гроховського, що зберігається в Зоологічному музеї Львівського національного університету ім. I. Франка, провести систематичну ревізію таксонів, зареєстрованих цими науковцями, 3 урахуванням змін у сучасній систематиці. Отримані результати дадуть змогу провести реконструкцію стану гідробіоценозів попередніх періодів існування, встановити динаміку гідроекологічних змін, викликаних антропогенними та мікрокліматичними чинниками. Визначення спектрів таксономічних родів дасть можливість виділити певні регіональні закономірності, що зумовлюють головні риси структури гідробіоценозів різних територій. Порівняльна характеристика таких матеріалів 3 результатами сучасних досліджень дасть можливість установити рівень антропогенної трансформації довкілля.

\section{Література}

1. Іванець О.Р. Таксономічна структура кладоцероценозів Українського Розточчя. Вісн. Львів. ун-ту. Серія «Біологічна». 2014. Вип. 64. С. 260-269.

2. Іванець О.Р. Колекції гіллястовусих раків (Cladocera) Б. Дибовського і М. Гроховського у фондах Зоологічного музею Львівського університету та перспективи їх подальших досліджень. Природничі музеї та їх роль в освіті і науці: матерілили Міжнар. конф. 27-30 жовтня 2015 р. Київ, 2015. С. 84-87.

3. Майр Э. Популяции, виды и эволюция. Москва: Мир, 1974. 460 с.

4. Мегарран Э. Экологическое разнообразие и его измерение. Москва: Мир, 1992. 184 с.

5. Песенко Ю.А. Принципы и методы количественного анализа в фаунистических исследованиях. Москва: Наука, 1982. $287 \mathrm{c}$.

6. Чуйков Ю.С. Методы экологического анализа состава и структуры сообществ водних животных. Экология. 1981. № 3. C. 71-77.

7. Brendonck L., de Meester L. Egg banks in freshwater zooplankton: evolutionary and ecological archives in the sediment. Hydrobiologia 491. 2003. P. 65-84.

8. Brzęk G. Benedykt Dybowski. Życie i dzieło. Wydanie II. Uzupełnione i rozszerzone. Warszawa, Wrocław: Polskie Towarzystwo Ludoznawcze (Biblioteka Zesłańca), 1994. $398 \mathrm{~s}$.

9. Dybowski B., Grochowski M. Spis systematyczny Wioślarek (Cladocera) krajowych sporządzony na podstawie okazów i preparatów, które oddane były na naszą tegoroczną Wystawę krajową we Lwowie. Kosmos, XX, Lwów, 1895. S. 139-165.

10. Ivanets O.R. The fauna of Rotatoria and microcrustaceans (Cladocera, Copepoda) of the Ukrainian Roztocze and its surroundings. Development of natural sciences in countries of the European Union taking into account the challenges of XXI century: Collective monograph. Lublin: Izdevnieciba "Baltija Publishing", 2018. P. 183-196.

11. Kuczyński A. Benedykt Dybowski - badacz "Świętego Morza” i nie tylko / wywiad E. Skrobockiego z A. Kuczyńskim. Magazyn Polski (Grodno). 1998. № 1. S. 6-11. 


\title{
ЗАПОБІГАННЯ ЗАБРУДНЕННЮ ГІДРОЕКОСИСТЕМ ВАЖКИМИ МЕТАААМИ ЯК ОДНА З ФОРМ РЕАМІЗАЦІї ЦІАЕЙ СТАМОГО РОЗВИТКУ В УКРАЇНI
}

\author{
Скиба О.І. ${ }^{1}$, Грубінко В.В. ${ }^{2}$, Федонюк Л.Я. ${ }^{1}$ \\ ${ }^{1}$ ДВНЗ «Тернопільський державний медичний університет \\ імені І.Я. Горбачевського \\ Міністерства охорони здоров'я України» \\ майдан Волі, 1, 46001, м. Тернопіль \\ skyba@tdmu.edu.ua \\ ${ }^{2}$ Тернопільський національний педагогічний університет \\ імені Володимира Гнатюка \\ вул. Словацького, 2, 46001, м. Тернопіль
}

\begin{abstract}
У статті проведено дослідження вмісту й міграції ВМ у воді лівої притоки Дністра - річки Серет, Тернопільська обл., Україна. Довжина річки в межах області - 248 км; уздовж річки розташовано приблизно третину всіх промислових підпри-

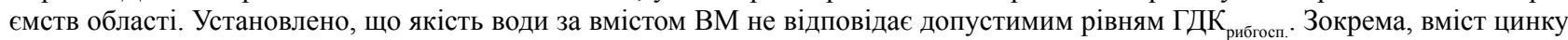
у 2016 р. перевищував показники ГДК у 2,75 раза, мангана - у 6,1 раза, феруму - у 3,7 раза, нікелю - у 3,1 раза, що вказує про зростаюче, порівняно з попередніми (1999-2015) роками, забруднення цієї гідроекосистеми й утрату річкою самоочисної здатності, що в кінцевому підсумку може призвести до забруднення дністровської водної екосистеми регіонального значення. Для покращення екологічної ситуації, яка склалася, запропоновано використання прибережно-водних і водних макрофітів як біологічних фільтрів, що здатні адсорбувати ВМ. Ключові слова: річка Серет, гідроекосистема, важкі метали, забруднення, гранично допустима концентрація.
\end{abstract}

Предупреждение загрязнения гидроэкосистем тяжелыми металлами как одна из форм реализации целей устойчивого развития в Украине. Скиба О.И., Грубинко В.В., Федонюк Л.Я. В статье проведено исследование содержания и миграции ТМ в воде левого притока Днестра - реки Серет, Тернопольская обл., Украина. Длина реки в пределах области 248 км; вдоль реки расположена примерно треть всех промышленных предприятий области. Установлено, что качество воды по содержанию ТМ не соответствует допустимым уровням ПДК показатели ПДК в 2,75 раза, мангана - в 6,1 раза, железа - в 3,7 раза, никеля - в 3,1 раза, что указывает о растущем, по сравнению с предыдущими (1999-2015) годами, загрязнении данной гидроэкосистемы и потери рекой самоочищающейся способности, что в конечном итоге может привести к загрязнению днестровской водной экосистемы регионального значения. Для улучшения сложившейся экологической ситуации предложено использование прибрежно-водных и водных макрофитов как биологических фильтров, способных адсорбировать ТМ. Ключевые слова: река Серет, гидроэкосистема, тяжелые металлы, загрязнение, предельно допустимая концентрация.

Warning of pollution by heavy metals in water ecosystem as one of the forms of the implementation of the sustainable development goals in Ukraine. Skyba O., Hrubinko V., Fedoniuk L. We have conducted a research of content and migration of HM in water left inflows of Dniester - the Seret River, the Ternopil Region, Ukraine. River length within an area - $248 \mathrm{~km}$; along the river, it is located about a third of all industrial enterprises of the region. The content of Zinc, Mangan, Ferrum in the last three years have exceeded indicators with a maximum allowable concentration by 2,75 times, - by 6,1 times, - by 3,7 times, Nickel - by 3,1 times. This specifies about growing pollution of this hydro ecosystem and loss of the river to self-cleaning ability, that finally can lead to pollution of the Dniester ecosystem of regional value. For improvement of an ecological situation, which has developed, we offered to use coastal and water plants as the biological filters capable to adsorb HM, such as Nuphar lutea (L.) Sm., Sagittaria sagittifolia L., Ceratophyllum demersum L. and Ranunculus circinatus Sibth. Key words: Seret river, hydroecosystem, heavy metals, pollution, maximum permissible concentration.

Постановка проблеми. Розвиток суспільства на основі концепції про невичерпність і самовідновлюваність запасів прісної води призвів до значної деградації як світових, так і вітчизняних водних ресурсів, їх дефіциту, виснаження й погіршення якості внаслідок забруднення, що зростає. Нині саме якість водних ресурсів, а не їх кількість є обмежуючим фактором раціонального та екологічно безпечного водокористування на фоні різкого зростання попиту на якісну прісну воду. 3 огляду на цілі сталого розвитку людства, які ухвалені на Саміті $\mathrm{OOH}$ зі сталого розвитку, однією із цілей є забезпечення наявності і сталого управління водними ресурсами й санітарією, що передбачає захист і відновлення водних екосистем, таких як ліси, гори, болота й річки, і має вагоме значення для пом'якшення дефіциту води. Забезпечення загального доступу до безпечної та недорогої питної води для всіх до 2030 року вима- 
гає від нас інвестування у відповідну інфраструктуру, забезпечення санітарно-технічних споруд, а також стимулювання гігієни на всіх рівнях [1, с. 22].

Однією 3 гострих екологічних проблем стає забруднення басейнів малих і середніх річок, які через незначні площі водозборів є найбільш вразливими до впливу антропогенезу й техногенезу. Особливо небезпечними за впливом на екологічну систему водних об'єктів є важкі метали (далі - ВМ), які належать до класу консервативних забруднюючих речовин, що не використовуються та не розкладаються під час міграції по трофічних ланцюгах гідроекосистем, мають мутагенну й токсичну дію, значно знижують інтенсивність проходження біохімічних процесів у водних об'єктах $[14 ; 23 ; 24]$.

У результаті недосконалості технологій дуже велика кількість промислових забруднень потрапляє до поверхневих водойм, у тому числі токсичні сполуки ВМ (свинець, кадмій, марганець, кобальт, нікель, мідь, залізо, цинк тощо). Сумарна кількість забруднень, які потрапляють у водойми й водотоки 3 поверхневим стоком урбанізованих територій, становить близько 15-20\% від показників забруднення господарсько-побутових стічних вод.

Усі вищеописані обставини висувають проблему забруднення вод ВМ на одне з перших за екологічним значенням місць, незважаючи на те що рівень умісту в гідросфері ВМ натепер нижчий, ніж нафтопродуктів, хлорорганічних пестицидів, поліхлорованих біфенілів та інших токсикантів. Моніторинг ВМ, вивчення процесів їх накопичення й міграції, виявлення факторів, якими ці процеси визначаються, є одним із важливих питань як для оцінювання безпеки навколишнього середовища, так і для здоров'я людей [26]. Регіональне забруднення малих і середніх річок ВМ призводить до погіршення якості води у великих річках, що створює серйозну небезпеку для здоров'я населення [21].

3 огляду на зазначене, мета дослідження - здійснити аналіз ступеня забруднення води річки Серет важкими металами, зіставити отримані дані зі значеннями ГДК проблеми забруднення водойм Тернопільської області завдяки поглинальній здатності прибережно-водних і водних макрофітів.

Виклад основного матеріалу. Останніми роками проведено низку досліджень із тематики екологічної безпеки природних водойм, опубліковано низку статей, монографій і захищено кандидатські дисертацій («Закономірності формування вмісту та розподілу сполук фосфору у річках Тернопільщини у зв'язку із ступенем антропогенного навантаження» (О.І. Скиба, 2017 р.), «Екологічна оцінка стану p. Збруч за накопиченням важких металів в умовах зарегулювання стоку та маловоддя» (Т.В. Сорока, 2018 р.). Однак у зв'язку 3 незворотними кліматичними змінами та погіршенням екологічного стану поверхневих водойм вивчення забруднення гідроекосистем потребує подальшого вивчення й дослідження.

Використання як природних біофільтрів водної рослинності відомо ще 3 минулого століття, однак нами вперше здійснена спроба пояснити процес очищення за допомогою рослин-макрофітів і виділити серед них найкращих очисників водойм.

Матеріали й методи дослідження. Річка Серет - найдовша 3 лівих приток Дністра в межах Тернопільської області. Площа іії басейну - 3900 км², що становить майже $1 / 3$ площі області. Довжина річки - 248 км, ширина русла - 10-20 м, середня глибина - 0,5-2,0 м. Основними забруднювачами річки $\epsilon$ комунальне підприємство «Зборівський водоканал», комунальне підприємство «Теребовля» й комунальне підприємство «Чортківське виробниче управління водопровідно-каналізаційного господарства».

Проаналізовано 128 проб води з річки Серет, які відібрані впродовж травня-вересня 2016 р. Методику вибору місць відбору проб викладено в роботах $[8 ; 10 ; 11]$. Воду фільтрували через мембранний фільтр із діаметром пор 0,45 мкм, концентрували до 10 разів і визначали вміст ВМ методом атомноабсорбційної спектрофотометрії на спектрофотометрі C-115 M1, С-600 при відповідних довжинах хвиль, що відповідали максимуму поглинання кожного з досліджуваних металів згідно зі стандартними методиками [15]. Уміст ВМ виражали в мг на 1 дм³ досліджуваних зразків. Отримані дані зіставляли згідно 3 гранично допустимими концентраціями досліджуваних металів [2]: ГДК $(\mathrm{Zn})_{\text {рибгосп. }}=0,01 \mathrm{мг} /$ дм $^{3}$, ГДК $(\mathrm{Mn})_{\text {рибгосп }}=0,01 \mathrm{M} /$ дм $^{3}, \Gamma Д К(\mathrm{Fe})_{\text {рибгосп. }}=0,1 \mathrm{Mг} /$ дм $^{3}$, $\Gamma Д К(\mathrm{~Pb})_{\text {рибгосп. }}=0,01 \mathrm{мг} /$ дм $^{3}, \Gamma Д К(С о)_{\text {рибгосп. }}=0,05 \mathrm{M \Gamma} /$ дм $^{3}$, ГДК(Ni) $)_{\text {рибгосп. }}=0,01 \mathrm{мг} /$ дм $^{3}$.

Для визначення вмісту ВМ у пробах вищих водних рослин їх висушували в сушильній шафі за температури $60-65^{\circ} \mathrm{C}$ до повітряно-сухого стану. Повітряно-суху пробу подрібнювали й просіювали через сито 3 отворами діаметром 2 мм. Залишок на ситі після подрібнення ножицями або в ступці додавали до просіяної частини й ретельно перемішували. Мінералізацію проб рослин проводили методом мокрого озолення, після чого визначали ВМ у зольних розчинах рослинних проб на атомно-абсорбційному спектрофотометрі при відповідних довжинах хвиль, що відповідали максимуму поглинання кожного 3 досліджуваних металів згідно зі стандартними методиками [12-13].

Статистична обробка одержаних експериментальних даних проведена 3 використанням пакета прикладних програм Microsoft Office Excel 2010 і Statistica 6.0.

Результати дослідження й обговорення. Відомо [4; 14; 25; 27], що антропогенними джерелами забруднення поверхневих вод сполуками плюмбуму $\epsilon$ згоряння вугілля, використання тетраетилсвинцю як антидетонатора в моторному паливі, а також винесення у водойми зі стічними водами рудозба- 
гачувальних фабрик, металургійних підприємств, хімічних підприємств і шахт. Сполуки кобальту потрапляють у поверхневі води в результаті вилуговування мідноколчеданних руд, екзогенних мінералів і порід, із грунтів під час розкладання організмів і рослин тощо. Основними джерелами надходження мангану в поверхневі води є залізо-марганцеві руди та деякі інші мінерали, які містять манган, стічні води марганцевих збагачувальних фабрик, металургійних заводів, підприємств хімічної промисловості, шахтні води тощо. Значна кількість феруму надходить у водойми 3 підземним стоком, з виробничими й сільськогосподарськими стічними водами. Одним із найбільш серйозних джерел забруднення нікелем є стічні води цехів нікелювання, заводів синтетичного каучуку, нікелевих збагачувальних фабрик, підприємств хімічної промисловості, спалювання вугілля. Високим умістом цинкку характеризуються стічні води рудозбагачувальних фабрик, гальванічних цехів багатьох підприємств, виробництв пергаментного паперу, мінеральних фарб, штучного волокна тощо [9; 18; 29].

У результаті дослідження встановлено, що якість води в річці Серет за вмістом ВМ не відповідає допустимим рівням ГДК рибгосп. за винятком кобальту, вміст якого не перевищує гранично допустимих концентрацій для рибогосподарських водойм. Статистичні дані щодо вмісту ВМ у водоймі представлені в таблиці 1 .

Концентрація циинку знижувалася 3 травня до червня, зростала в серпні та знижувалася у вересні. Уміст Zn у травні перевищив показник ГДК рибогоп. у 1,2 раза, у серпні - у 2,7 раза, у вересні у 1,3 раза.

У водоймі, порівняно 3 травнем, у червні вміст цинку значно знижувався, що може бути свідченням прискорених процесів вегетації фітогідробіонтів у зв'язку з високими температурами води. У другій половині літа при максимальній температурі води наставав новий період бурхливого розвитку фітопланктону і друге «цвітіння» води, що мало б призвести до наступного зниження концентрації цинку у воді. Однак спостерігалось обернене явище, а саме підвищення вмісту елемента у водоймах області, що, на нашу думку, пов'язано з гідрохімічними особливостями досліджуваних річок, зокрема рівнем $\mathrm{pH}$. У вересні концентрація елемента впала, що пояснюється активним споживанням цинку протягом літа водною біотою та певною мірою його закомплексованістю з гумусовими речовинами.

Щодо мангану, то для водойми було характерним поступове зростання вмісту металу з травня до вересня. У травні показник умісту мангану не перевищував ГДК щив у 2,6; 4,1 і 6,1 раза.

Значне перевищення ГДК невих водах Тернопільщини передусім зумовлено знаходженням цього металу в незначній кількості в усіх гірських породах $[16 ; 19]$. Окрім того, чорноземи опідзолені, які займають значні площі басейну річки, зазнають оглеєння, внаслідок чого виникають токсичні речовини (закисні сполуки заліза, марганцю).

Незначні концентрації мангану у травні можна пояснити залуженням води ( $\mathrm{pH}=8,14-8,94)$ у зв'язку з вегетацією гідробіонтів. У вересні вміст мангану зростав, що зумовлено надходженням елемента в процесі відмирання й розкладу гідробіонтів, особливо синьо-зелених і діатомових водоростей, а також вищих водних рослин (далі - ВВР).

Уміст феруму у воді річки характеризувався поступовим збільшенням 3 травня до вересня $\left(0,371\right.$ мг/дм $\left.{ }^{3}\right)$, що перевищувало ГДК рибгосп. У 3,7 раза. У дослідженні перевищення концентрації феруму у водоймах Тернопільщини до 9,21 ГДК чинене покладами пісковиків у Бучацькому районі, кварцових пісків у Тернопільському районі, гравію в долині та на прибережних схилах Серету, Золотої Липи, які, порівняно з іншими покладами осадового походження, містять у своєму складі значні концентрації сполук феруму [16]. Загалом динаміка вмісту феруму в досліджених водоймах значно нагадує таку, як для мангану, адже ці два елементи близькі як за фізико-хімічними властивостями, так і відношенням до біоти. У всіх водоймах у травні спостерігались високі концентрації елемента, незважаючи на залуженість води, що можна пояснити надходженням феруму 3 донних відкладів і накопиченням у товщі води. У червні зафіксовано зменшення вмісту металу, що, на нашу думку, спричинене комплексоутворенням металу з участю розчинених органічних речовин. У вересні, у процесі відмирання й розкладу гідробіонтів і ВВР, уміст феруму зростає.

Концентрація плюмбуму зростала 3 травня до червня, мінімум у серпні та зростання у вересні. Підвищення елемента у воді можна пояснити його

Показники вмісту важких металів у воді річки Серет з травня по вересень 2016 р.

\begin{tabular}{|c|c|c|c|c|c|c|}
\hline $\begin{array}{c}\text { Метал/ } \\
\text { місяць }\end{array}$ & $\mathrm{Zn}$, мг/дм & $\mathrm{Mn}$, мг/дм $^{3}$ & $\mathrm{Fe}, \mathrm{мг} /$ дм$^{3}$ & $\mathrm{~Pb}, \mathrm{мг} /$ дм $^{3}$ & $\mathrm{Co}, \mathrm{мг} /$ м $^{3}$ & $\mathrm{Ni}$, мг/дм $^{3}$ \\
\hline Травень & $0,012 \pm 0,002$ & $0,003 \pm 0,019$ & $0,338 \pm 0,056$ & $0,091 \pm 0,027$ & $0,013 \pm 0,003$ & $0,024 \pm 0,003$ \\
\hline Червень & $0,006 \pm 0,001$ & $0,026 \pm 0,006$ & $0,223 \pm 0,021$ & $0,105 \pm 0,017$ & $0,017 \pm 0,001$ & $0,032 \pm 0,005$ \\
\hline Серпень & $0,027 \pm 0,005$ & $0,041 \pm 0,017$ & $0,332 \pm 0,132$ & $0,027 \pm 0,0$ & $0,019 \pm 0,000$ & $0,017 \pm 0,000$ \\
\hline Вересень & $0,013 \pm 0,001$ & $0,061 \pm 0,016$ & $0,371 \pm 0,071$ & $0,053 \pm 0,019$ & $0,02 \pm 0,002$ & $0,022 \pm 0,002$ \\
\hline
\end{tabular}


Поглинальної здатність вищих водних рослин ВМ у травні 2016 р.

\begin{tabular}{|c|c|c|c|c|c|c|c|}
\hline $\begin{array}{l}\text { № } \\
\text { 3/II } \\
\end{array}$ & Рослина & $\begin{array}{l}\text { Fe, мг/кг } \\
\text { сухої маси }\end{array}$ & 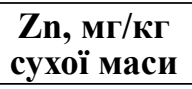 & $\begin{array}{l}\text { Со, Мг/кг } \\
\text { сухої маси }\end{array}$ & $\begin{array}{l}\mathrm{Ni}, \mathrm{Mг} / \mathbf{~} \mathbf{} \\
\text { сухої маси }\end{array}$ & $\begin{array}{l}\text { Мn, Мг/кг } \\
\text { сухої маси }\end{array}$ & $\begin{array}{l}\mathrm{Pb}, \text { Мг/кг } \\
\text { сухої маси }\end{array}$ \\
\hline \multirow{3}{*}{1} & N. lutea (L.) Sm., radix & 458,11 & 5,68 & 9,06 & 10,77 & 4,35 & 4,34 \\
\hline & N. lútea, caulis & 133,77 & 3,80 & 5,78 & 7,93 & 12,48 & 3,44 \\
\hline & N. lútea, folium & 110,00 & 4,87 & 7,31 & 8,29 & 7,31 & 1,54 \\
\hline \multirow{3}{*}{2} & S. sagittifolia L., radix & 333,35 & 8,77 & 10,95 & 12,94 & 10,63 & 8,84 \\
\hline & S. sagittifolia L., caulis & 117,60 & 2,88 & 10,87 & 14,38 & 3,33 & 7,28 \\
\hline & $\begin{array}{l}\text { S. sagittifolia L., } \\
\text { folium }\end{array}$ & 173,33 & 4,63 & 10,83 & 15,41 & 5,01 & 7,73 \\
\hline \multirow{3}{*}{3} & $\begin{array}{l}\text { Ranunculus circinatus } \\
\text { Sibth., radix }\end{array}$ & 107,02 & 4,38 & 5,24 & 3,90 & 7,84 & 2,46 \\
\hline & $\begin{array}{l}\text { Ranunculus circinatus } \\
\text { Sibth., caulis }\end{array}$ & 50,00 & 4,46 & 5,06 & 4,37 & 3,85 & 2,57 \\
\hline & $\begin{array}{l}\text { Ranunculus circinatus } \\
\text { Sibth., folium }\end{array}$ & 73,60 & 6,14 & 5,32 & 4,15 & 4,71 & 4,21 \\
\hline 4 & C. demersum L. & 528,48 & 5,79 & 9,01 & 9,08 & 19,95 & 2,69 \\
\hline
\end{tabular}

надходженням зі стічними водами промислових підприємств м. Тернополя 3 високим умістом поверхнево-активних речовин. На нашу думку, значна концентрація плюмбуму в серпні пов'язана з процесом метилювання неорганічних сполук свинцю в донних відкладах, що сприяє мобілізації елемента з мулу. Як відомо, рослини восени, поглинувши деяку кількість ВМ, за течією води опускаються в нижні ділянки водойми й там, відмираючи, викликають вторинне забруднення води, віддаючи їй ВМ, біогенні елементи та органічні речовини.

Для металу кобальт характерне поступове підвищення елемента 3 травня до вересня. 3 травня до червня у водоймі спостерігалось зростання вмісту кобальту, що можна пояснити таким. Улітку має місце надходження ВМ у водне середовище 3 донних відкладів і їх акумуляція водною рослинністю внаслідок фізичного (хвилі, течії, пониження та підвищення рівня води) чи антропогенного впливів, які призводять до збільшення концентрації вільних іонів елемента [3]. У серпні відзначалось зростання вмісту елемента, що може бути внаслідок як природних, так й антропогенних факторів [9].

Уміст нікелю зростав з травня до червня, зменшення в серпні та незначне зростання у вересні. Концентрація нікелю перевищувала ГДК у 2,2 раза. Підвищення вмісту нікелю в червні, порівняно $з$ травнем, може бути зумовлено невисоким ступенем його закомплексованості. У серпні у водоймі при рН від 6,64 до 7,6 моль/л зафіксовано зниження концентрації елемента, що пов’язано зі зв'язуванням металу в комплекси 3 фульвокислотами. У вересні у воді річки спостерігали підвищення вмісту нікелю, що пояснюємо вивільненням останнього з відмираючої біоти [20].

Згідно 3 нашими дослідженнями, кількісне співвідношення ВМ металів у воді досліджуваної водо- йми можна подати такими рядами:

травень: $\mathrm{Mn}<\mathrm{Zn}<\mathrm{Co}<\mathrm{Ni}<\mathrm{Pb}<\mathrm{Fe}$; червень: $\mathrm{Zn}<\mathrm{Co}<\mathrm{Ni}<\mathrm{Mn}<\mathrm{Pb}<\mathrm{Fe}$;

серпень: $\mathrm{Ni}<\mathrm{Co}<\mathrm{Zn}<\mathrm{Pb}<\mathrm{Mn}<\mathrm{Fe}$; вересень: $\mathrm{Zn}<\mathrm{Co}<\mathrm{Ni}<\mathrm{Pb}<\mathrm{Mn}<\mathrm{Fe}$.

Порівнюючи ряди вмісту ВМ у річці Серет, відмітимо, що забруднення насамперед спричинено біогенними ВМ (ферумом і манганом) і плюмбумом. Якщо в першому випадку можна говорити про природний високий фоновий рівень цих елементів, то наявність плюмбуму у воді - це вплив господарської діяльності людини.

Відомо, що специфічним та ефективним біологічним фільтром для очистки водойм від забруднень $\epsilon$ водна рослинність, зокрема макрофіти $[5 ; 6 ; 28]$. Тому другим етапом дослідження було виявлення прибережно-водних і водних рослин-макрофітів, які здатні адсорбувати важкі метали в різноманітних частинах свого тіла [7]. Результати поглинальної здатності рослин щодо ВМ у мг/кг сухої маси представлені в таблиці 2.

Проведеними дослідженнями (визначався вміст важких металів у рослині, мг/кг сухої маси) встановлено, що найбільша поглинальна здатність для рослин припадає на кореневу систему, за винятком Ranunculus circinatus Sibth., у якого поглинальна здатність найбільша в листковій системі (у поглинанні цинку, кобальту і плюмбуму). Максимальна поглинальна здатність для C. demersum L. характерна для таких металів, як ферум, кобальт і манган. Найбільша здатність до поглинання цинку характерна для кореневих частин S. sagittifolia L. i N. lutea (L.) Sm. Нікелю найбільше поглинає S. sagittifolia L. Листям і стебловою частиною. Щодо плюмбуму, то його найбільше поглинає S. sagittifolia L. кореневою системою [17].

Отже, Nuphar lutea (L.) Sm. (Глечики жовті) найбільше акумулює ферум і цинк, Sagittaria 
sagittifolia L. (Стрілолист стрілолистий) - кобальт, нікель, Ceratophyllum demersum L. (Кушир занурений) - манган, Ranunculus circinatus Sibth. (Водяний жовтець) - плюмбум. Тому нами запропоновано додаткове культивування водних рослин як біологічних фільтрів уздовж річок і в їх прибережній частині з їх подальшою утилізацією.

Головні висновки. Якість води в річці Серет за вмістом важких металів не відповідає допустимим рівням ГДК не перевищує гранично допустимих концентрацій для рибогосподарських водойм. Підвищений уміст мангану й феруму у воді зумовлений знахо- дженням цих елементів в абіотичних складниках долини річки, зокрема в місцях рудопроявів феруму й мангану, алювіальних відкладах, оглеєних грунтах, а також вимиванням елементів із гірських порід, грунту та лісової підстилки. Культивування вищих водних і прибережно-водних рослин сприятиме поступовому очищенню гідроекосистеми від ВМ і відновленню самовідтворювальної здатності річки. Для акумулювання феруму й цинку запропоновано додатково культивувати Nuphar lutea (L.) Sm., кобальту й нікелю - Sagittaria sagittifolia L., мангану - Ceratophyllum demersum L., плюмбуму Ranunculus circinatus Sibth.

\section{Лiтература}

1. Вергун А.М., Тарасенко І.О. Концепція сталого розвитку в умовах глобалізації. Вісник КНУТД. 2014. № 2. С. $207-218$.

2. Гранично допустимі значення показників якості води для рибогосподарських водойм. Загальний перелік ГДК і ОБРВ шкідливих речовин для води рибогосподарських водойм (№ 12-04-11 від 09.08.1990). Київ: Мінрибгосп СРСР, 1990. 45 с.

3. Гуменюк Г.Б. Розподіл важких металів у гідроекосистемі прісної водойми (на прикладі Тернопільського ставу): дис. ... канд. біол. наук: спец. 03.00.16 «Екологія» / Тернопільський нац. пед. ун-т ім. В. Гнатюка; наук. кер. В.В. Грубінко. Тернопіль, 2003. 198 с.

4. Клименко М.О., Бєдункова О.О. Колообіг важких металів у водних екосистемах. Рівне: НУВГП, 2008. 216 с.

5. Клименко М.О., Гроховська Ю.Р., Бєдункова О.О. Накопичення важких металів гідрофітам. Вісник Національного університету водного господарства та природокористування: зб. наук. праць. 2006. № 33 (1). С. 159-164.

6. Кокин К.А. Экология высших водных растений. Москва: Изд-во Моск. ун-та, 1982. 160 с.

7. Крот Ю.Г. Использование высших водных растений в биотехнологиях очистки поверхностных и сточных вод. Гидробиологический журнал. 2006. № 42 (1). С. 49-55.

8. Лейте В. Определение органических загрязнений питьевых, природных и сточных вод/ пер. с нем. Москва: Химия, 1975.200 с.

9. Линник П.Н., Набиванец Б.И. Формы миграции металлов в пресных поверхностных водах. Ленинград: Гидрометеоиздат, 1986. $268 \mathrm{c}$.

10. Лурье Ю.Ю. Унифицированные методы анализа вод. Москва: Химия, 1973. 376 с.

11. Лурье Ю.Ю., Рыбникова А.И. Химический анализ производственных сточных вод. Москва: Химия, 1974. 336 с.

12. Полевой В.В., Максимов Г.Б. Методы биохимического анализа растений: учебное пособие. Ленинград: Изд-во Ленинградского ун-та, 1978. $192 \mathrm{c.}$

13. Методы биохимического исследования растений / под ред. А.И. Ермакова. Ленинград: Изд-во Ленинградского ун-та, 1972.365 с.

14. Мур Дж., Рамамурти В.С. Тяжёлые металлы в природных водах. Контроль и оценка влияния. Москва: Мир, 1987. 285 с.

15. Новиков Ю.В., Ласточкина К.О., Болдина З.Н. Методы исследования качества воды водоемов. Москва: Медицина, 1990. $400 \mathrm{c}$.

16. Природні умови та ресурси Тернопільщини / за ред. М.Я. Сивого. Тернопіль: ТзОВ «Терно-граф», 2011. 512 с.

17. Прокопчук О.І. Застосування вищих водних рослин в очищенні водойм від фосфатів. Наукові засади підготовки фахівців природничого, інженерно-педагогічного та технологічного напрямків: матеріали I Всеукраїнської науково-практичної інтернет-конференції. Бердянськ, 2017. С. 184-185.

18. Прокопчук О.І., Грубінко В.В. Важкі метали у малих річках Тернопільщини з різним рівнем антропічного навантаження. Вісник Дніпропетровського університету. Серія «Біологія, екологія». Дніпропетровськ, 2016. № 24 (1). С. $173-181$.

19. Свинко Й.М. Нарис про природу Тернопільської області: геологічне минуле, сучасний стан. Тернопіль: Навчальна книга - Богдан, 2007. 192 с.

20. Скиба O.І. Закономірності формування вмісту та розподілу сполук фосфору у річках Тернопільщини у зв'язку із ступенем антропогенного навантаження: дис. ... канд. біол. наук: спец. 03.00.16 «Екологія» / Тернопільський нац. пед. ун-т ім. В. Гнатюка; Чернівецький нац. ун-т ім. Ю. Федьковича; наук. кер. В.В. Грубінко. Чернівці, 2017. 180 с.

21. Сніжко С.І. Оцінка та прогнозування якості природних вод. Київ: Ніка-Центр, 2001. 262 с.

22. Стратегія сталого розвитку України на період до 2030 року. Проект. Версія 3.2 станом на 05.12.2016 1. 29 с.

23. Трахтенберг И.М., Колесников В.С., Луковенко В.П. Тяжелые металлы во внешней среде: соврем. гигиен. и токсикол. аспекты. Минск: Навука і тэхніка, 1994. 285 с.

24. Тяжелые металлы как фактор экологической опасности: метод. указ. / сост. Ю.А. Холопов. Самара: СамГАПС, 2003.16 с.

25. Duruibe J., Ogwuegbu M., Egwurugwu J. Heavy metal pollution and human biotoxic effects. International Journal of Physical Sciences. 2007. № 2 (5). P. 112-118.

26. Kar D., Sur P., Mandal S., Saha T., Kole R. Assessment of heavy metal pollution in surface water. Int. J. Environ. Sci. Tech. 2008. № 5 (1). P. 119-124.

27. Nasrabadi T. An index approach to metallic pollution in riverwaters. Int. J. Environ. Res. 2015. № 9 (1). P. $385-394$.

28. Nouri J., Khorasani N., Lorestani B., Karami M., Hassani A., Yousef N. Accumulation of heavy metals in soil and uptake by plant species with phytoremediation potential. Environmental Earth Sciences. 2009. № 59. P. 315-323.

29. Reza R., Singh G. Assessment of heavy metal contamination and its indexing approach for river water. Int. J. Environ. Sci. Tech. 2010. № 7 (4). P. 785-792. 


\title{
ОЦІНЮВАННЯ СТАНУ ВОДНИХ ЕКОСИСТЕМ НА ОСНОВI МЕТОДІВ СИСТЕМНОГО АНАМІЗУ АЕРОКОСМIЧНОÏ Й НАЗЕМНОÏ ІНФОРМАЦIї
}

\author{
Федоровський О.Д. ${ }^{1}$, Зуб Л.М. ${ }^{2}$, Томченко О.В. ${ }^{1}$, Хижняк А.В. ${ }^{1}$, \\ Ходоровський А.Я. ${ }^{1}$, Підгородецька Л.В. ${ }^{3}$ \\ ${ }^{1}$ ДУ «Науковий центр аерокосмічних досліджень Землі \\ Інституту геологічних наук Національної академії наук України» \\ вул. Олеся Гончара, 55-Б, 01601, м. Київ \\ adfedorovsky@ukr.net \\ tomch@i.ua \\ AVSokolovska@i.ua \\ ${ }^{2}$ Інститут еволюційної екології Національної академії наук України \\ вул. акад. Лебедєва, 37, 03143, м. Київ \\ lesyazub@yandex.ru \\ ${ }^{3}$ Інститут космічних досліджень Національної академії наук \\ та Державного космічного агентства України \\ просп. Академіка Глушкова, 40, корп. 4/1, 03680, м. Київ \\ pidgorodetska@ukr.net
}

\begin{abstract}
У статті розглянуто результати аналізу аерокосмічної та наземної інформації під час вирішення різносторонніх тематичних завдань оцінювання стану водних екосистем за методами системного аналізу. Наведено приклади дослідження трансформації водних екосистем, оцінювання якості води, визначення елементів гідрологічного режиму, моніторингу забруднення води, дослідження літоральної міграції донних відкладів і розподілу радіонуклідів на території Київського водосховища, гирлової зони р. Прип'ять та оз. Світязь. Ключові слова: дистанційне зондування Землі (ДЗ3), природні територіальні комплекси (ПТК), вища водна рослинність (ВВР), якість води, метод багатокритеріальної оптимізації, метод фрактального аналізу, метод аналізу ієрархій, метод адаптивного балансу впливів.
\end{abstract}

Оценка состояния водных экосистем на основе методов системного анализа аэрокосмической и наземной информации. Федоровский А.Д., Зуб Л.Н., Томченко О.В., Хижняк А.В., Ходоровский А.Я., Подгородецкая Л.В. В статье рассмотрены результаты анализа аэрокосмической и наземной информации при решении разносторонних тематических задач оценки состояния водных экосистем на основе методов системного анализа. Приведены примеры исследования трансформации водных экосистем, оценки качества воды, определения элементов гидрологического режима, мониторинга загрязнения воды, исследования литоральной миграции донных отложений и распределения радионуклидов на территории Киевского водохранилища, устьевой зоны р. Припять и оз. Свитязь. Ключевые слова: дистанционное зондирование Земли (ДЗ3), природные территориальные комплексы (ПТК), высшая водная растительность (ВПР), качество воды, метод многокритериальной оптимизации, метод фрактального анализа, метод анализа иерархий, метод адаптивного баланса влияний.

The assessment of conditions of aquatic ecosystems based on the methods of system-oriented analysis of aerospace and land information. Fedorovsky A., Zub L., Tomchenko O., Khyzhnyak A., Pidgorodetska L., Khodorovskyi A. The article deals with the results of analysis of aerospace and land information in solving diverse thematic tasks of assessment of conditions of aquatic ecosystems based on the methods of system-oriented analysis. The examples of research of transformation of aquatic ecosystems, assessment of the quality of water, determination of the elements of hydrological regime, monitoring of water contamination, research of littoral migration of sediments and distribution of radionuclides on the territory of the Kiev reservoir and estuarine zone of the river Pripyat and the lake Svitiaz are given in the article. Key words: remote sensing of the Earth (RSZ), natural territorial complexes, higher aquatic vegetation (VVR), water quality, multicriterial optimization method, fractal analysis method, hierarchy analysis method, adaptive balance of influences method.

Постановка проблеми. Оцінювання стану водних екосистем в умовах техногенезу є основною проблемою раціонального використання водних ресурсів, охорони й відновлення їх природного стану. На межі тисячоліть екологічне оздоровлення басейну p. Дніпро стало одним із пріоритетних напрямів природоохоронної діяльності уряду України, адже його водні ресурси становлять $80 \%$ водних ресурсів України та забезпечують водою понад 32 млн. населення і 2/3 господарського потенціалу країни.

Головним завданням міжнародної програми спостереження за кліматом Global Climate Observing System (GCOS) є забезпечення іiі необхідними методиками й комп'ютерними програмами для виявлення 
ресурсів води високої якості; виявлення змін у гідробіологічному різноманітті; аналіз ступеня загрози водним екосистемам тощо. Отже, комплексне застосування аерокосмічних i наземних досліджень у поєднанні з інтерпретацією результатів на основі методів системного аналізу становить значний інтеpec i дає змогу вирішувати численні питання щодо моніторингу водних екосистем [1].

Виклад основного матеріалу. Використання інформації космічного геомоніторингу дає можливість не тільки оперативно отримувати зображення водних об'єктів, що займають великі площі, а й фіксувати зміни їх характеристик у просторі та часі. Так, дешифрування космічних знімків водних об'єктів допомагає за низкою ознак визначити особливості гідрографічної мережі та гідрологічного режиму, типи біотопів, аквальні ландшафти і їх структуру. За супутниковими знімками можна виділити ділянки заболочування і заростання, обчислювати площі, зайняті вищою водною рослинністю (ВВР), і незарослі акваторії, відслідковувати розвиток явищ «цвітіння води» $[2 ; 3 ; 4]$.

Мета статті - обгрунтувати оцінку стану водних екосистем на основі методів системного аналізу аерокосмічної та наземної інформації з використанням знань із суміжних наукових дисциплін - екології, гідробіології, гідрології, гідрохімії та геології.

Водні об'єкти являють собою складні системи, аналіз яких відбувається на різних рівнях абстрактного опису з урахуванням ієрархії їх складників: ландшафтні комплекси, гідрологічні, геологічні, гідробіологічні та гідрохімічні характеристики. При цьому оцінювання екологічного стану водних об'єктів здійснюється на основі узагальненого критерію, що фактично інтегрує результати досліджень у різних наукових напрямах $[5 ; 6]$.

Методи системного аналізу. За допомогою методів системного аналізу обгрунтовуються найбільш раціональні математичні моделі використання космічної інформації під час вирішення різних тематичних завдань, моделюється і прогнозується розвиток процесів, що досліджуються.

Під час вирішення завдань, для яких потрібні одночасні найкращі значення всіх критеріїв, кожний із який характеризує один із боків розглянутої проблеми, використовується метод багатокритеріальної оптимізаціï (Multi-objective optimization) [7]. На основі цього методу здійснюється інтегральне оцінювання стану водних екосистем за всіма їх складниками (біологічні та абіотичні) й оцінюванням змін щодо попередніх років дослідження. У нашому випадку описаний підхід включає обчислення таких функцій [8]:

- близькості $S$, що характеризує близькість окремих значень характеристик складників водного об'єкта за поточний і попередній періоди;

- відповідності $f$, яка показує ступінь відповідності значень кожної характеристики всіх складників об'єкта за поточний і попередній періоди;
- належності $F$, яка показує ступінь належності кожного складника водного об'єкта за поточний і попередній періоди.

Для оцінювання вагових коефіцієнтів складників водних об'єктів $\rho\left(b_{i}, a_{i}\right)$ використовується метод експертних оцінок-аналізу ієрархій (Analytic Hierarchy Process), запропонований Т. Сааті на основі лінгвістичного підходу та експертної інформації. Метод дає можливість на основі експертних оцінок сформувати необхідну цільову функцію і провести рейтинг альтернативних варіантів [9].

Використання фрактального аналізу (Fractal analysis) дає змогу оцінити ступінь упорядкованості і стійкості системи до зовнішнього впливу, що неможливо визначити іншими статистичними методами. Як кількісну міру, яка описує структуру складників об'єкта, прийнято використовувати фрактальну розмірність Ренії $-D_{q}$, що показує, наскільки щільно й рівномірно елементи цієї множини заповнюють евклідовий простір. Значення $D_{q}-$ інваріантне до розміру вибірки, площі, масштабу. При цьому необхідне виконання двох умов: по-перше, степеневої залежності зростання компонентів статистичної суми $Z q$ від розміру вибірки $N$, по-друге, незростаючий вигляд функції спектра узагальнених розмірностей $D_{q}$, динаміка змін яких характеризує закономірності росту й еволюції процесу [10].

Для моделювання інтегральних процесів в екосистемі використовується метод адаптивного балансу впливів (method of adaptive balance of causes $(A B C)$ ), який дає можливість моделювати і прогнозувати розвиток складних систем і виконувати обчислювальні функції з урахуванням взаємодії всіх модулів, кожен із яких перебуває в стані динамічної рівноваги. Рівновага підтримується функціями впливу, які пов'язують цей модуль з іншими модулями системи. Режим динамічного балансу впливів усередині системи зберігається під управлінням зовнішнього впливу на систему [11].

Розглянемо кілька прикладів використання методів системного аналізу для проведення інтегрального аналізу стану водних екосистем із поєднанням даних аерокосмічних і наземних спостережень.

Приклад № 1. Під час дослідження трансформації екосистеми озера Світязь за 20-річний період (1988-2009 рр.), з огляду на постулат, що склад i структурні особливості ВВР визначають структуру мілководних ландшафтів водойми й формують певні природні територіальні комплекси (далі - ПТК) у зарослевій зоні озера з шести виокремлених для водойми і проаналізованих ПТК, лише чотири виділені як індикаторні. На основі обраних складників і проведених мультифрактальних досліджень матеріалів дешифрування космічних знімків як критеріїв оцінювання екологічного стану озера Світязь прийнято фрактальну розмірність $D_{q}$ при $q=-4$, коефіцієнт кореляції якої з експертними оцінками по роках дорівнював $r=0,78$ [12]. 
Результати прогнозу ймовірних екологічних наслідків на основі системного моделювання методом АВС підтвердили можливість побудови динамічних моделей природного середовища для прогнозування впливу розвитку рекреаційного навантаження на екологічній стан водойми [13].

Приклад № 2. Для одержання оцінки якості води верхів'я Київського водосховища обраний критерій на основі методу багатокритеріальної оптимізації. Як індикаторні критерії обрані біотопи - основна класифікаційна одиниця, що характеризує місце існування організмів (у нашому випадку - угруповань ВВР). За результатами дешифрування й аналізу космічних знімків Landsat за період з 1989 по 2013 рр. виділено основні типи біотопи водно-болотних угідь (далі - ВБУ) верхніх ділянок водойми та одержані дані щодо динаміки їх площ через кожні 2 роки. На основі площ виділених біотопів обчислена функція належності, що характеризувала якість води [14].

У процесі аналізу встановлено типи біотопів, які позитивно й негативно впливають на якість води. Так, параметри максимізуються, коли збільшення показника впливає на якість води позитивно, і мінімізуються, коли позитивно на якість води впливає зменшення показника. Заключним етапом розрахунків було отримання функції належності як суми функцій відповідності всіх параметрів складників за кожен рік дослідження порівняно з 1989 р., прийнятим за еталон. У таблиці 1 наведені значення функції належності $F_{(д 33)}$, отримані за результатами дешифрування космічних знімків, які відображають зміну якості води Київського водосховища в бік незначного погіршення за фізико-хімічними характеристиками [15]. Наступним кроком було визначення ступеня взаємозв'язку між динамікою заростання Київського водосховища ВВР і даними гідрохімічних досліджень. У результаті розрахунків виявлено взаємозв'язок функцій належності $F_{\text {дзз }}$ та $F_{\text {назем }}$, що становить 0,7 за коефіцієнтом кореляції Пірсона i $\epsilon$ цілком достатнім аргументом для підтвердження доцільності оперативного контролю якості води на основі матеріалів Д33, на відміну від трудомістких наземних спостережень.

Виконані дослідження у випадку як озера Світязь, так і Київського водосховища свідчать про наявність статистичної залежності між наземними, в тому числі експертними, оцінками екологічного стану водних об'єктів та оцінками, здійсненими за космічними знімками з подальшою обробкою отриманих даних методами фрактального аналізу й багатокритеріальної оптимізації.

Приклад № 3. Функціонування водних екосистем, склад біоти в них і якісні характеристики води насамперед визначаються впливом гідрологічних умов. Зміною внутрішнього й зовнішнього водообмінів, рівня води, швидкості течії можна регулювати самоочисну здатність і біопродуктивність водойм. Для реалізації такої можливості необхідно знайти кількісні залежності показників екологічного стану водойм і якості води від зазначених гідрологічних складників. У цей комплекс входять фізико-географічні характеристики водойм i ïx водозборів, хімічні, біохімічні та біологічні аспекти формування якості вод, антропогенний вплив тощо. Отже, регулювання водного режиму для зміни в потрібному напрямі будь-яких характеристик водних екосистем має погоджуватися із загальною концепцією керування станом екосистеми. При цьому необхідно забезпечити наукову обгрунтованість i доцільність запропонованого рішення, технічну й економічну реальність його реалізації, розрахувати ефективність важелів впливу.

У роботі [8] наведено модель, що описує взаємозв'язок гідрологічних показників (площа водного дзеркала, інтенсивність водообміну, тип мілководь, наявність заплавних водойм тощо) $з$ параметрами, що їх характеризують. Зарахування сукупності гідрологічних параметрів, що характеризують досліджувану ділянку гирла річки, до $j$-ого типу гідрології вироблясться на основі обчислення функції належності $F_{2 л}$ згідно з виразом

$$
F_{\text {гл }}=\exp \left[-\sum_{i=1}^{N}\left(\frac{\bar{R}_{i j}-R_{i}}{2 \cdot \Delta R_{i j}}\right)^{2}\right],
$$

де $R_{i}$ - нормоване (за умовою $\sum_{i=1}^{N} R_{i}=1$ ) значення $i$-го параметра гідрології на ділїнці, наприклад, площа водного дзеркала; $\bar{R}_{i j}$ - середина бального інтервалу $i$-го параметра в $j$-ому типі гідрології; $\bar{R}_{i j}$ - ширина інтервалу $i$-го параметра; $i=1,2, \ldots, N_{1}$; $j=1,2, \ldots, M_{1}$. У тому випадку, коли параметри задаються дискретним рядом, у формулі $F_{2 \pi}$ на заміну $\bar{R}_{i j}$ використовуються вагові коефіцієнти $\bar{b}_{i j}$, а $\bar{R}_{i j}$ буде відповідати значенням ряду.

На основі цієї моделі визначаються елементи гідрологічного режиму. Зарахування досліджуваної ділянки до конкретного типу гідрологічних параметрів проводиться за максимальним значенням функції належності.

Описана методика й розроблена програма апро-

Таблиця 1

Значення узагальненого критерію оцінювання якості води Київського водосховища за даними Д33 та наземних спостережень Держгідрометслужби

\begin{tabular}{|c|c|c|c|c|c|c|c|c|c|c|c|c|c|}
\hline Роки & $\mathbf{1 9 8 9}$ & $\mathbf{1 9 9 1}$ & $\mathbf{1 9 9 3}$ & $\mathbf{1 9 9 5}$ & $\mathbf{1 9 9 7}$ & $\mathbf{1 9 9 9}$ & $\mathbf{2 0 0 1}$ & $\mathbf{2 0 0 3}$ & $\mathbf{2 0 0 5}$ & $\mathbf{2 0 0 7}$ & $\mathbf{2 0 0 9}$ & $\mathbf{2 0 1 1}$ & $\mathbf{2 0 1 3}$ \\
\hline $\mathbf{F}_{\text {Дз3 }}$ & 1,00 & 0,98 & 0,97 & 0,94 & 0,96 & 0,87 & 0,84 & 0,81 & 0,76 & 0,83 & 0,83 & 0,81 & 0,73 \\
\hline $\mathbf{F}_{\text {назем. }}$ & 0,97 & 0,76 & 0,61 & 0,47 & 0,43 & 0,41 & 0,43 & 0,37 & 0,35 & 0,34 & 0,40 & 0,45 & 0,46 \\
\hline
\end{tabular}


бовані на прикладі класифікації ВВР і визначення якості води в гирловій зоні р. Прип'ять [16].

Приклад № 4. Регулярний моніторинг за перерозподілом забруднювачів, насамперед радіонуклідів, має винятково вагоме значення не тільки для контролю функціонування водних екосистем водоймищ, а й для забезпечення належної якості води.

Розподіл радіоактивного забруднення донних відкладень у заростях вищих водних рослин відбувається нерівномірно. Центральна частина прибережних фітоценозів, яка розташована в глибині заростей на відстані до 20 м від його нижньої границі, є зоною підвищеного вмісту радіонуклідів. Так, для Київського водосховища на цих ділянках уміст $\mathrm{Sr}^{90}$ у 4-40 разів, а $\mathrm{Cs}^{134}+\mathrm{Sr}^{90}$ у 2-26 разів перевищував рівень радіоактивного забруднення донних відкладень порівняно $з$ іншими ділянками заростей, а також із такими, де відсутні зарості рослин. У заростях занурених рослин (рдести) радіоактивне забруднення донних відкладень вище, ніж на чистій воді, у 3,5 рази для з $\mathrm{Sr}^{90}$ і в 2,5 рази - для $\mathrm{Cs}^{134}+\mathrm{Cs}^{137}$.

У процесі росту вищі водні рослини, крім радіонуклідів, поглинають із грунту й води біогенні елементи (азот, фосфор, калій тощо), також мікроелементи, у тому числі й ті, що належать до важких металів. Цим поглинанням виконується важлива функція консервації і трансформації забруднювачів та очищення й кондиціонування води. Проте сезонне відмирання рослин чи падіння рівня води водойм, що зумовлює осушення літоралі й одночасне відмирання рослинності, спричиняють залпове повернення у воду (при повторному затопленні) пов'язаних біомасою біогенних елементів.

Найбільш тривалий період пов'язують біогенні елементи повітряно-водних рослин. По-перше, вони розвивають могутню кореневу систему, яка становить 30-60\%, а іноді 70-80\% загальної біомаси, що не відмирає до кінця вегетації. Тому, незважаючи на активний весняний відтік із кореневої системи біогенних елементів для формування надземних пагінців, значна кількість цих речовин залишається в біомасі кореневища й разом із придатковими коренями й старими кореневищами йде в більш глибокі шари донних відкладень, тобто хорониться. Саме ця група рослин найбільш чітко контролюється дистанційними методами під час зйомок у період вегетації.

Для інтегрального оцінювання забруднення води обраний критерій на основі методу багатокритеріальної оптимізації $-F_{\text {назем }}$. При цьому кореляція сумарного показника хімічного забруднення води (ПХЗ-10), отриманого значення функції належності $F_{\text {назем }}$ та обчислених за період з 1989 р. по 2013 р. становить 0,94. Це доводить, що отриманий так узагальнений критерій оцінки хімічного забруднення води може бути використаний на рівні 3 показниками інтегральних індексів, розрахованими загальноприйнятими методами [17].
Приклад № 5. Відомо, що важливу роль у накопиченні донних відкладів водоймищ відіграє рельєф дна, який визначається переважно сучасними вертикальними рухами по розломах. Особливості геологічної будови дна водосховища і його виразність у рельєфі необхідно враховувати під час створення мережі контрольних станцій для проведення моніторингу якості води не тільки поверхневих, а й підземних вод, а також рівня забруднень донних відкладень. Крім того, по зонах розломів відбувається інтенсивна фільтрація води 3 розчинними в неї компонентами на глибину. Ці явища мають особливе значення для Київського водоймища, у якому накопичено багато радіонуклідів, пов'язаних з аварією на Чорнобильській AEC.

З метою дослідження літоральної міграції донних відкладів і розподілу радіонуклідів [18] використані матеріали структурного дешифрування різночасових космічних знімків різної просторової розрізненості («Океан-O», «SPOT» і «Landsat»). Виділені на берегах структури екстрапольовані в межі дна водоймища, виконано аналіз морфології рельєфу зо топографічними картами різних років, ураховано матеріали наземних геофізичних досліджень навколишньої суші, а також дані гідробіологічних, гідроекологічних, радіоекологічних досліджень Київського водоймища й ріки Прип'яті.

У результаті проведених досліджень складена структурна схема району, на якій показані розломи, блоки, кільцеві структури та вузли перетинання розломів, тобто всі структури, що впливають на латеральне переміщення відкладів і вертикальну проникність гірських порід і фільтрацію підземних вод [19].

Виходячи 3 проведених досліджень, найбільш небезпечною структурою з погляду забруднення підземних вод радіонуклідами є північна частина водоймища, де сходяться Прип'ятський і Дніпровський відроги. У цьому районі розташована кільцева структура, що активна на сучасному етапі розвитку.

Три вузли перетинання Одесько-Тальнівскої зони розломів з більш дрібними структурами встановлені в межах Тетерівського, Толокунського та Лютізького плес. Крім того, ще один вузол розломів розташований у районі Чорнобильської АЕС. Найбільш небезпечним із погляду забруднення підземних вод варто вважати вузол у районі Тетерівської затоки. Високий уміст радіонуклідів і важких металів у поверхневих відкладеннях на цій території та підвищена проникність гірських порід роблять цей район особливо небезпечним із погляду забруднення підземних вод.

Використання методу синтезу й екстраполяції результатів дешифрування космічних знімків та аналіз наявних матеріалів з розподілу радіонуклідів у воді, суспензіях і донному геологічному відкладі водоймища дали змогу виокремити в ложі водосховища ділянки з більшим умістом радіонуклідів (правобережна частині водоймища, дно якої відрізняється більш піднесеним і розчленованим рельєфом) 
і припустити, що нерівності дна виявилися «пастками»»» на шляхах переміщення осадів, що містять радіонукліди.

Головні висновки. Результати комплексного оцінювання стану водних екосистем на основі дистанційних і наземних досліджень наочно показали ефективність використання системного аналізу.

Розроблення й апробація алгоритму оцінювання стану водних екосистем на основі методу багатокритеріальної оптимізації та аналізу ієрархій дали можливість сформувати узагальнений критерій - функцію належності - й ієрархічну модель, які поповнили методичну базу дистанційних аерокосмічних досліджень у природокористуванні.

Вивчення загальної картини заростання крупних водних об'єктів із комплексним використанням космічної й наземної інформації дає змогу відстежити зміни площ основних типів рослинних угруповань i, відповідно, біотопів і природно-територіальних комплексів за тривалий період і прогнозувати їх подальший розвиток під дією того чи іншого чинника.
Дослідження взаємозв'язку гідрохімічних параметрів і розвитку угруповань вищих водних рослин у великому рівнинному водосховищі показали наявність залежності між зміною площ зарослих акваторій і вмістом розчиненого у воді діоксиду вуглецю, хлору та показниками біхроматної окислюваності, кольоровості води, вмістом іонів міді й завислих речовин.

За космічними знімками виділені тектонічні блоки, що проявилися в сучасному рельєфі та вплинули на розподіл і перерозподіл радіонуклідів у донних відкладах Київського водосховища. Вивчення розломно-блокових структур, які впливають на перерозподіл придонних водних потоків і седиментів, дало змогу точніше прогнозувати виникнення екстремальних ситуацій.

Перспективи використання результатів дослідження. Набутий у ході досліджень Київського водосховища, понизових ділянок Дніпра та озера Світязь досвід комплексного використання різнодисциплінарних матеріалів може бути використаний як методична основа для оцінювання інших водойм України.

\section{Література}

1. Використання космічної інформації у вирішенні водогосподарських і водоохоронних завдань / В.І. Лялько, О.Д. Федоровський, Л.Я. Сіренко та ін. Космічна наука і технологія. 1997. № 3/4. С. 40-49.

2. Пат. 104662 Україна, Спосіб дешифрування оптичних аномалій на аерокосмічних знімках / О.Д. Федоровський, В.Г. Якимчук, А.В. Соколовська, О.В. Томченко; власник патенту ДУ «Науковий центр аерокосмічних досліджень Землі Інституту геологічних наук НАН України». № a 2012 09156; заявл. 25.07.2012; опубл. 25.02.14, Бюл. № 16-1 с.

3. Макрофиты - индикаторы изменений природной среды / С. Гейны, Д.В. Дубына, К.М. Сытник и др. Киев: Наукова думка, 1993. $433 \mathrm{c}$.

4. Fedorovsky A.D., Dychenko T.N., Sirenko L. A. Use of the remote control for revealing sites of danube with various speed of water stream on the basis of phytoindication. 32. Konferenz der IAD. Wien/Osterreich. 1997. C. 211-215.

5. Оценка экологического состояния водоемов с использованием космической информации / А.Д. Федоровский, Л.А. Сиренко, Э.Л. Звенигородский, И.Ю. Иванова, К.Ю. Суханов, В.Г. Якимчук. Космічна наука і технологія. 1996. № 5-6. C. 103-106.

6. Соколовська А.В., Томченко О.В. Використання системних методів аналізу космічної інформації ДЗ3 для визначення екологічного стану антропогенно змінених ландшафтів. Геоінформатика - теоретичні і прикладні аспекти: матеріали 13-ї Міжнародної конф. (Київ, Україна, 13-16 травня 2013). Київ: Наукова думка, 2013. С. 1-6.

7. Многокритериальная оптимизация: Математические аспекты / Б.А Березовский, Ю.М. Барышников и др. Москва: Наука, 1989. 128 с.

8. К вопросу оценки экологического состояния аквально-наземных ландшафтных комплексов на основе системного подхода / А.Д. Федоровский, Л.Ф. Даргейко, Т.Н. Дьяченко, В.Г. Якимчук. Доповіді Національної академії наук. 2000 . № 5. С. $129-131$.

9. Саати Т. Принятие решений. Метод анализа иерархий. Москва: Радио и связь, 1993. 186 с.

10. Артюшенко М.В., Подгородецкая Л.В., Федоровский А.Д. Фрактальный анализ спектрограмм растительного покрова в задачах природопользования. Доповіді Національної академії наук. 2010. № 8. С. 113-119.

11. Тимченко И.Е., Игумнова Е.М. Системный менеджмент и АВС-технологии устойчивого развития. Севастополь: МГИ НАН Украины, 2000. 225 с.

12. Мультифрактальный анализ биоразнообразия и ценотической структуры сообщества растений по данным дистанционного зондирования / М.В. Артюшенко, Л.Н. Зуб, Л.В. Подгородецкая, А.Д. Федоровский. Доповіді Національної академії наук. 2011. № 9. С. 132-141.

13. Підгородецька Л.В., Зуб Л.М., Федоровський О.Д. Використання інформації космічного геомоніторингу для оцінки екологічного стану водойм на прикладі озера Світязь. Космічна наука і технологія. 2010. Т. 16. № 4. С. 51-56.

14. Томченко O.В. Використання методу багатокритеріальної оптимізації матеріалів Дз3 та наземних даних для оцінки екологічного стану Київського водосховища. Екологічна безпека та природокористування: зб. наук. праць / М-во освіти i науки України, Київ. Нац. ун-т буд-ва і архіт., НАН України, Ін-т телекомунікацій і глобал. інформ. простору; редкол.: О.С. Волошкіна, О.М. Трофимчук (голов. ред.) та ін. Київ, 2014. Вип. 15. С. 31-39.

15. Томченко О.В., Зуб Л.М., Сагайдак А.В. Оцінка екологічного стану акваторій водно-болотних угідь верхніх ділянок Київського водосховища. Екологія водно-болотних угідь і торфовищ: зб. наук. ст. / головний редактор В.В. Коніщук. Київ: ТОВ НВП«Інтерсервіс», 2014. С. 246-251.

16. Романенко В.Д., Сиренко Л.А., Федоровский А.Д. Экологические проблемы Днепра в ретроспективе и на современном этапе. Гидробиол. журнал. 1998. Том 34. № 5. С. 3-10. 
17. Гідрохімічний довідник: Поверхневі води України. Гідрохімічні розрахунки. Методи аналізу / В.І. Осадчий, Б.Й. Набиванець, Н.М. Осадча, Ю.Б. Набиванець. Київ: Ніка-Центр, 2008. 656 с.

18. Использование космической информации для контроля состояния водных объектов чернобыльской зоны / А.Д. Федоровский, Л.А. Сиренко, А.Я. Ходоровский, А.Д. Рябоконенко. Гидробиологический журнал. 1999. Т. 35 . № 4. С. $3-11$.

19. О влиянии разломных структур на распределение радионуклидов в донных отложениях Киевского водохранилища / В.М. Шестопалов, В.И. Лялько, А.Д. Федоровский, Л.А. Сиренко, А.Я. Ходоровский. Доповіді Національної академії наук України. 2000. № 8. С. 131-134. 


\title{
ЕКОАОГІЯ ЗЕМЕАЬНИХ РЕСУРСІВ TA ГРУHTIB
}

УДК 579.262:665.7

DOI https://doi.org/10.32846/2306-9716-2018-4-23-24

\section{РОСАИННО-МІКРОБНІ ВЗАЕМОВІДНОСИНИ ОБАІПИХИ КРУШИНОВИДНОЇ - ОСНОВА ЕФЕКТИВНОї ФІТОРЕМЕДІАЦІї НАФТОЗАБРУДНЕНИХ ГРУНТІВ}

\author{
Шевчик Л.3. ${ }^{1}$, Романюк О.І. ${ }^{1}$, Борсукевич Б.М. ${ }^{2}$ \\ ${ }^{1}$ Відділення фізико-хімії горючих копалин \\ Інституту фізико-органічної хімії і вуглехімії імені Л.М. Литвиненка \\ Національної академії наук України \\ вул. Наукова, 3а, 79053, м. Львів \\ lesyashevchik@gmail.com \\ ${ }^{2}$ Львівський національний університет імені Івана Франка \\ вул. Грушевського, 4, 79005, м. Львів
}

\begin{abstract}
Показано, що в умовах зростання обліпихи крушиновидної на нафтозабруднених грунтах має місце симбіоз ії кореневої системи з азотофіксувальними мікроорганізмами роду Frankia. Інфікування коренів обліпихи мікроорганізмами відбувається ще в молодому віці, що значно покращує приживання й ріст рослин. Установлено, що в процесі фіторемедіації нафтозабруднених грунтів рослинами $H$. rhamnoides оптимізуються умови грунту: відбувається покращення мікробіологічних показників, збільшується кількість гетеротрофів у 10000 разів, деструкторів нафти - у 1000 разів, азотофіксувальних мікроорганізмів у 10 разів; підвищується вміст загального й амонійного азоту. Ключові слова: нафтозабруднені грунти, рослинно-мікробні взаємовідносини, азотофіксувальні мікроорганізми, фіторемедіація, Hippophae rhamnoides L.
\end{abstract}

Растительно-микробные взаимоотношения облепихи крушиновидной - основа эффективной фиторемедиации нефтезагрязненных почв. Шевчик Л.З., Романюк О.І., Борсукевич Б.М. Показано, что в условиях роста облепихи крушиновидной на нефтезагрязненных почвах имеет место симбиоз ее корневой системы с азотофиксирующими микроорганизмами рода Frankia. Инфицирование корней облепихи микроорганизмами происходит еще в молодом возрасте, что значительно улучшает приживаемость и рост растений. Установлено, что в процессе фиторемедиации нефтезагрязненных почв растениями H. rhamnoides оптимизируются условия почвы: происходит улучшение микробиологических показателей, увеличивается количество гетеротрофов в 10000 раз, деструкторов нефти - в 1000 раз, азотофиксирующих микроорганизмов - в 10 раз, повышается содержание общего и аммонийного азота. Ключевые слова: нефтезагрязненные почвы, растительно-микробные взаимоотношения, азотофиксирующие микроорганизмы, фиторемедиация, Hippophae rhamnoides L.

Plant-microbe interaction of Hippophae rhamnoides L. in the conditions of growth on oil-contaminated soils. Shevchyk L., Romaniuk O., Borsukevych B. It is shown that in the conditions of the growth of H. rhamnoides plants in the oil-contaminated soils, there is a symbiosis of its root system with nitrogen-fixing microorganisms of the genus Frankia. Infection of the roots of $H$. rhamnoides by microorganisms occurs at a young age. It greatly improves the survival and growth of plants in the oil-contaminated soils. It is established that in the process of phytoremediation of oil contaminated soils by H. rhamnoides plants the soils conditions are optimized: the microbiological parameters are improved - the number of heterotroph microorganisms is increased by 10,000 times, oil destructive microorganisms - 1000 times and the nitrogen-fixing microorganisms - 10 times, increases content of total nitrogen and ammonia. Key words: oil-contaminated soils, plant-microbe interaction, nitrogen-fixing microorganisms, phytoremediation, Hippophae rhamnoides L.

Постановка проблеми. Нині актуальною залишається проблема очищення грунтів від нафтового забруднення. Серед наявних технологій, розроблених для іiі вирішення, найбільш перспективними вважаються ті, що базуються на біологічних методах очистки, зокрема фіторемедіації, яка приваблює своєю природністю, екологічністю, економічністю, характеризується тривалішим впливом і стабільним покращенням екологічної ситуації $[10 ; 11 ; 13]$.
Однак застосування фіторемедіаційних технологій для нафтозабруднених грунтів стримується високою токсичністю полютанта (нафти) й неможливістю зростання більшості рослин на таких грунтах. Крім цього, нафтозабруднені грунти набувають гідрофобності, у них порушується водно-повітряний баланс, співвідношення між основними елементами живлення $\mathrm{N}: \mathrm{C}$, що ускладнює приживання фіторемедіантів. 
Актуальність дослідження. Для успішного застосування фіторемедіаційних технологій головна увага приділяється відбору рослин, стійких до нафтового забруднення. Ця стійкість забезпечується насамперед кореневою системою рослини. Здатність до симбіотичної взаємодії з мікроорганізмами підвищує адаптацію до стресів завдяки оптимізації мінерального живлення та захисту рослин від патогенів. Перевагу слід віддавати рослинам, які в симбіозі 3 мікроорганізмами здатні трансформувати токсичну частину забруднень у менш рухому форму. Важливу роль у цьому плані відіграють кореневі виділення, що впливають на забруднювач як прямо, так і опосередковано. Пряма дія полягає в солюбілізації, трансформації й деградації забруднювача під впливом ферментів, що виділяються в ризосферу. Опосередкована - у стимуляції кореневими виділеннями грунтових мікроорганізмів-деструкторів, що супроводжується збільшенням їхньої чисельності й оптимізацією фізико-хімічних умов грунту [8; 12].

Відомо про метаболічний потенціал (у контексті біоремедіації) бактерій роду Frankia, здатних розкладати поліароматичні вуглеводні, нафталін, феноли й утворювати симбіотичні азотфіксуючі асоціації з більш ніж 220 видами деревних дводольних рослин [9; 15]. Frankia належать до грампозитивних ниткоподібних азотофіксувальних актинобактерій, які фіксують азот шляхом перетворення атмосферного азоту в біологічно корисний аміак і постачають рослину-господаря джерелом відновленого азоту.

Аналіз останніх досліджень і публікацій. У попередніх наших дослідженнях [6; 16] показана стійкість обліпихи крушиновидної (Hippophae rhamnoides L.) до несприятливих умов техногенних нафтозабруднених грунтів, експериментально доведено, що ця рослина, розмножуючись кореневими паростками, поширюється на забруднені території навіть за високого рівня забруднення (12-15\% нафти в грунті). Обліпиха входить у перелік актиноризних рослин, що вступають у симбіоз з азотофіксувальними бактеріями роду Frankia [5].

Метою роботи було встановити, що в умовах зростання обліпихи крушиновидної на нафтозабруднених грунтах має місце симбіоз з азотофіксувальними мікроорганізмами роду Frankia і відбувається оптимізація властивостей грунту.

Методика досліджень. Дослідження проводили в польових умовах на нафтозабруднених техногенних відвальних грунтах озокеритовидобутку м. Борислава. Закладали дослідні ділянки на грунтах різного рівня забруднення нафтою: 97 г/кг, 123 г/кг, 150 г/кг $(9,7 \%, 12,3 \%, 15 \%)$, в які рано навесні без додаткового внесення добрив, мікроорганізмів чи поливу висаджували двома рядами в шаховому порядку відсадки висотою до 30-40 см обліпихи крушиновидної в лунки глибиною 15-20 см, відстань між рослинами - 1,5 м, відстань між рядами 1 м. Польові дослідження для забруднення грунту нафтою 123 г/кг проводили в трьох повторностях: закладали три фіторемедіаційні ділянки, кожна площею 10 м², на яких висаджували 14 саджанців за вищеописаною схемою. Відстань між ділянками складала 4,5 м. Експерименти проводили 3 2-4-річними саджанцями на ділянках забруднення грунту нафтою у кількості 12,3\%.

Чисельність мікроорганізмів у грунті визначали методом серійних розведень [7]. Мікроорганізмидеструктори нафти виділяли методом накопичувальної культури на середовищі Шишкіної-Троценко 3 нафтою й рідкими парафінами як джерелами вуглецю [14]. Чисельність олігонітрофільних і азотофіксувальних мікроорганізмів визначали на середовищі Ешбі [3]. Вміст загального азоту в грунті визначали колориметрично з реактивом Неслера [1], вміст
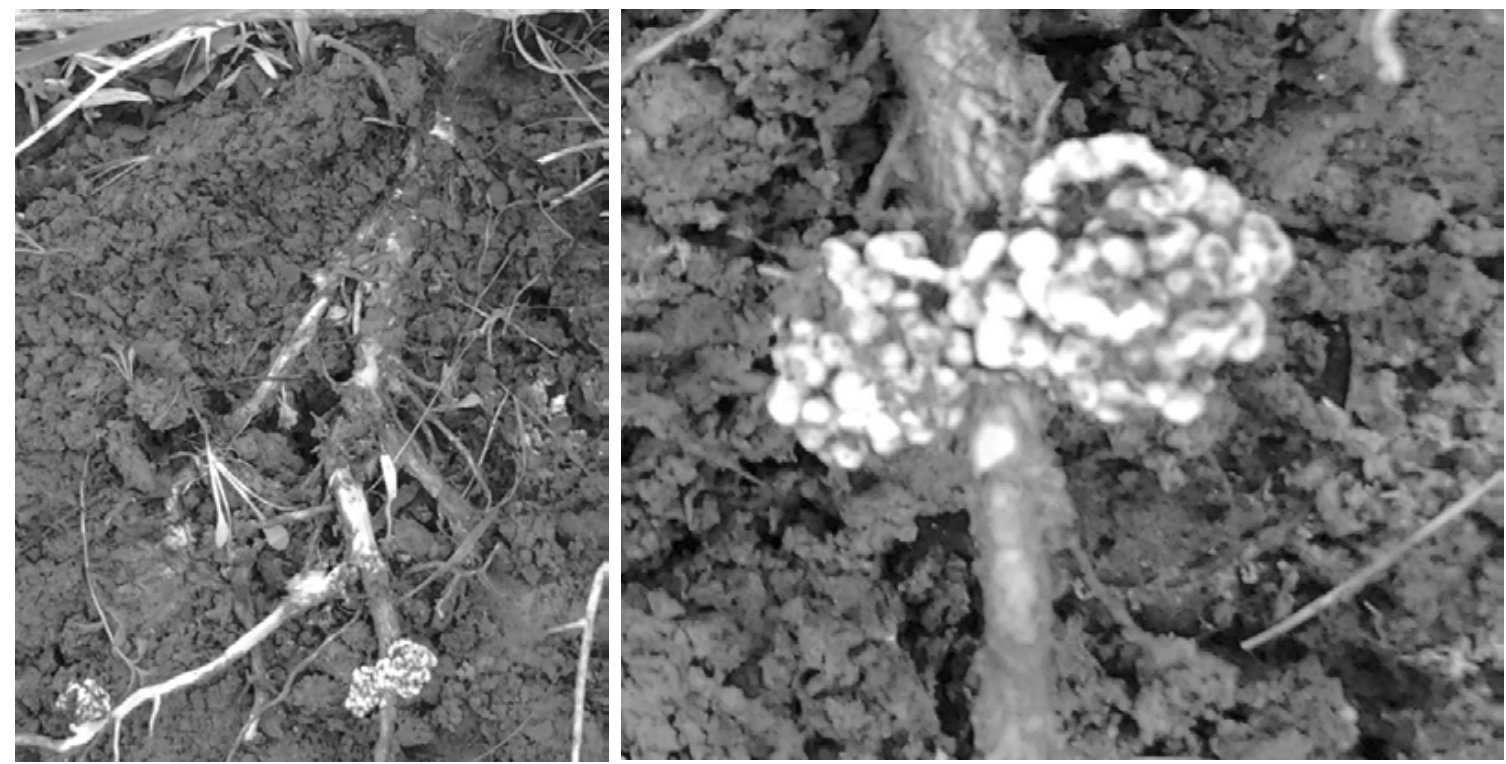

Рис. 1. Корені обліпихи крушиновидної з азотофіксувальними мікроорганізмами в нафтозабрудненому трунті 


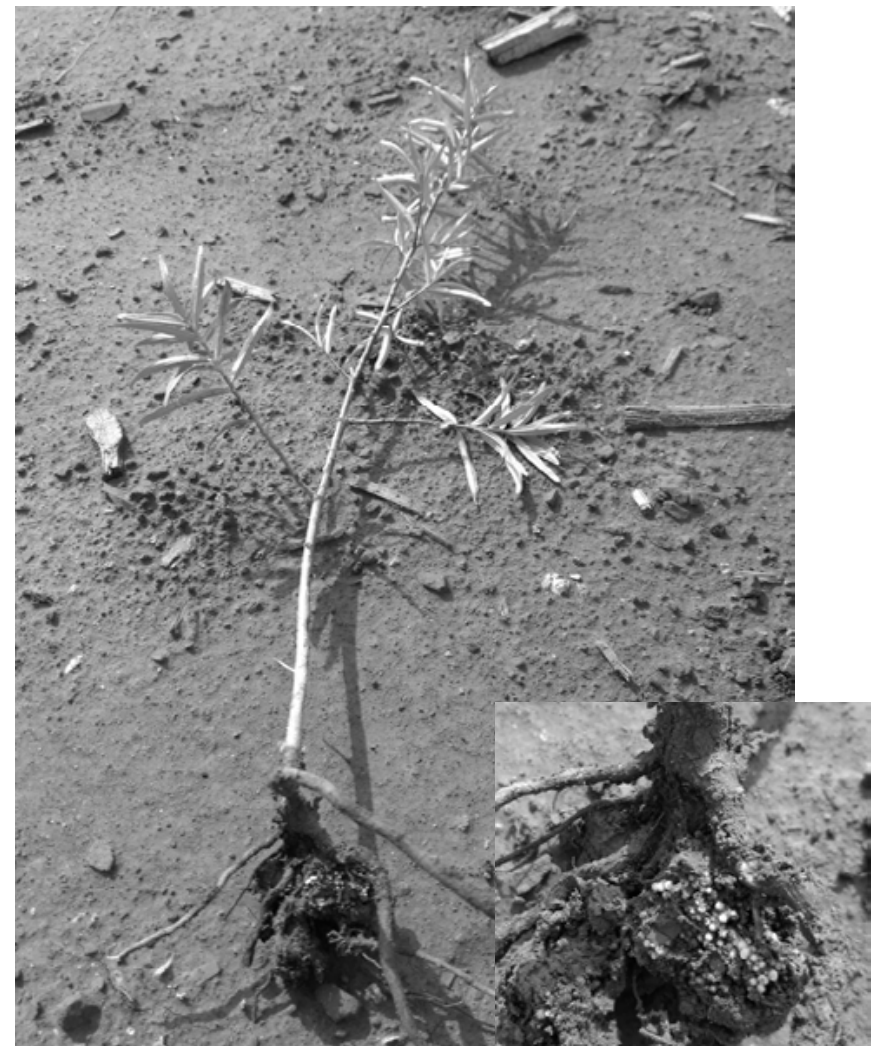

Рис. 2. Бульбочки азотофіксувальних мікроорганізмів на корінні молодих дворічних особин обліпихи крушиновидної

амонійного азоту в грунті - за методом ЦІНАО [2]. Результати досліджень опрацьовували статистично.

Виклад основного матеріалу. Утворення рослиною-живителем спеціалізованих структур, що містять мікробні клітини (бульбочки), є характерною ознакою симбіозу. Ці утворення $є$ екологічною нішею для симбіонта, структурною основою для обміну метаболітами, а також для контролю чисельності й фізіологічної активності симбіонта. У бульбочках створюються оптимальні умови для обміну між партнерами карбонвмісними і нітрогенвмісними сполуками, а також мікроаерофільні умови, необхідні для функціонування нітрогеназного комплексу.

У результаті проведених досліджень установлено, що на корінні рослин обліпихи крушиновидної, яка росла в умовах нафтового забруднення, формуються бульбочки. Це дає можливість говорити про наявність симбіозу обліпихи 3 азотофіксувальними мікроорганізмами роду Frankia. Ці бактерії ініціюють утворення спеціалізованих органів - бульбочок - на коренях H. rhamnoides (рис. 1). Frankia зв'язують молекулярний азот атмосфери, передають його рослині, яка забезпечує мікроорганізми поживними речовинами.

Забезпеченість азотом сприяє виживанню та зростанню рослин на нафтозабрудненому грунті, що призводить до поліпшення екологічного стану грунту. Позитивний вплив азотофіксувальних мікроорганізмів на рослину не обмежується лише поліпшенням азотного живлення. Бактеризація сприяс трансформації важкорозчинних сполук у форми, що легко засвоюються рослинами. При цьому корисні мікроорганізми, заселивши корені, не допускають інфікування рослин патогенними мікроорганізмами, збільшуючи стійкість рослин до хвороб [4].

Варто зазначити, що бульбочки наявні як на корінні дорослих особин, так і на корінні молодих особин дворічної обліпихи, яка розростається, поширюючись на забруднені території (рис. 2).

Таким чином, інфікування коренів обліпихи крушиновидної азотофіксувальними мікроорганізмами

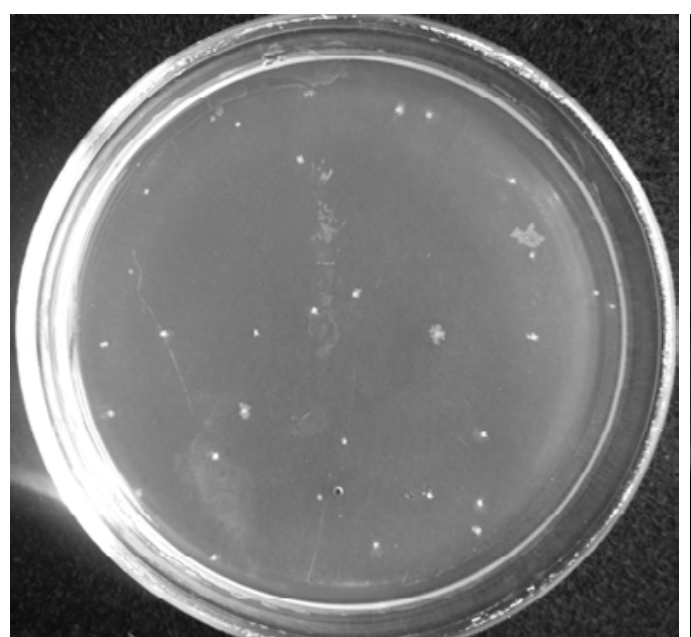

$A$

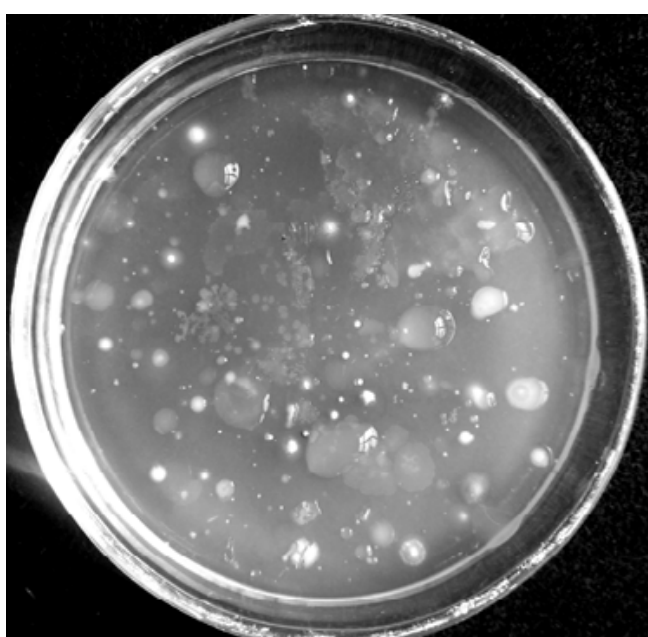

b

Рис. 3. Колонії азотофіксувальних мікроорганізмів на нафтозабруднених грунтах:

(A) - до фіторемедіаціï, (Б) - після фiторемедіаціï H. rhamnoides 
Вплив нафти й Hippophae rhamnoides на чисельність мікроорганізмів у нафтозабрудненому грунті

\begin{tabular}{|l|c|c|}
\hline \multicolumn{1}{|c|}{$\begin{array}{c}\text { Грунтові мікроорганізми, } \\
\text { КОУ/г грунту }\end{array}$} & Нафтозабруднений грунт & $\begin{array}{c}\text { Грунт після ремедіації } \\
\text { H. rhamnoides }\end{array}$ \\
\hline Азотофіксувальні мікроорганізми & $3 \times 10^{8}$ & $2 \times 10^{9}$ \\
\hline Гетеротрофи & $2 \times 10^{4}$ & $2 \times 10^{8}$ \\
\hline Деструктори нафти & $5 \times 10^{2}$ & $3 \times 10^{5}$ \\
\hline
\end{tabular}

Таблиця 2

Вміст азоту в нафтозабруднених грунтах до й після фіторемедіації обліпихою крушиновидною

\begin{tabular}{|c|c|c|}
\hline $\begin{array}{c}\begin{array}{c}\text { Нафтозабруднений грунт } \\
(12,3 \% \text { нафти в грунті) }\end{array} \\
\text { Вміст азоту в грунті }\end{array}$ & до фіторемедіації & $\begin{array}{c}\text { після чотирьох років } \\
\text { фіторемедіації }\end{array}$ \\
\hline $\mathrm{N}-\mathrm{NH}_{4}^{+}, \mathrm{Mг} / к \Gamma$ & $23,6 \pm 0,3$ & $30,00 \pm 0,2$ \\
\hline $\begin{array}{l}\mathrm{N} \text { (мінеральний) } \\
\left(\mathrm{N}-\mathrm{NO}_{3}+\mathrm{N}-\mathrm{NH}_{4}^{+}\right), \text {мг/кг }\end{array}$ & $29,5 \pm 0,2$ & $32,19 \pm 0,2$ \\
\hline N (загальний), \% & $0,05 \pm 0,01$ & $0,15 \pm 0,02$ \\
\hline
\end{tabular}

Таблиця 3

Вплив рослин Нippophae rhamnoides на біодеградацію нафти в грунті впродовж 1-4 років зростання, початкове забруднення грунту 123 г/кг [6]

\begin{tabular}{|l|c|c|c|c|}
\hline \multirow{2}{*}{} & \multicolumn{4}{|c|}{ Часовий період ремедіації } \\
\cline { 2 - 5 } & $0^{\text {-й }}$ рік & $1^{\text {-й }}$ рік & $2^{\text {-й }}$ рік & $4^{\text {-й }}$ рік \\
\hline Вміст нафти в грунті, г/кг & 123 & 26,5 & 13,9 & 9,0 \\
\hline Сумарне очищення грунту, \% & 0 & 77,5 & 88,7 & 92,7 \\
\hline
\end{tabular}

відбувається ще в молодому віці, що значно покращує приживання й ріст рослин на забруднених грунтах. Це робить обліпиху придатною для безпосереднього використання в якості посадкового матеріалу для фіторемедіації грунтів, забруднених нафтою.

У процесі фіторемедіації нафтозабруднених грунтів рослинами $H$. rhamnoides відбувається покращення мікробіологічних показників цих грунтів. Так, на четвертий рік зростання обліпихи на нафтозабрудненому грунті кількість грунтових мікроорганізмів у ньому зростає: гетеротрофів - у 10000 разів, деструкторів нафти - у 1000 разів, азотофіксувальних мікроорганізмів - у 10 разів порівняно 3 нерекультивованим грунтом. Збільшується видова різноманітність азотфіксаторів: для нафтозабрудненого грунту характерні однотипні невеликі колонії, а в грунті після фіторемедіації обліпихою спостерігали колонії різного розміру, форми, кольору, консистенції (рис. 3).

Зокрема, виявлено чималу кількість слизистих пігментованих колоній, які характерні для мікроорганізмів роду Azotobacter, і міцелієподібні колонії, які характерні для актинобактерій, зокрема роду Frankia.
Спостерігається також збільшення загального й амонійного азоту. Так, вміст амонійного азоту в нерекультивованому грунті сягає 23,6 мг/кг, а в нафтозабрудненому грунті, рекультивованому обліпихою, становить 30,00 мг/кг. Збільшується і вміст мінерального азоту, який $є$ сумою нітратного й амонійного та характеризує забезпеченість грунтів азотом, його доступність для рослин (табл. 2).

Завдяки такій фіторемедіації відбувається ефективне очищення нафтозабруднених грунтів: на четвертий рік росту обліпихи ступінь очистки сягає 92,7\% за початкового забруднення грунту нафтою 123 г/кг (табл. 3).

Головні висновки. Проведені дослідження свідчать, що в умовах зростання обліпихи крушиновидної на нафтозабруднених грунтах має місце симбіоз iii кореневої системи з азотофіксувальними мікроорганізмами роду Frankia. Рослинно-мікробні взаємовідносини забезпечують ефективну фіторемедіацію нафтозабруднених грунтів: оптимізуються умови грунту, збільшується чисельність грунтових мікроорганізмів, зростає забезпеченість доступним для рослин мінеральним азотом, відбувається очищення грунту від нафтопродуктів до 92,7\%. 


\section{Література}

1. ГОСТ 26107-84. Почвы. Методы определения общего азота. Москва: Изд-во стандартов, 1984. $11 \mathrm{c.}$

2. ГОСТ 26489-85. Почвы. Определение обменного аммония по методу ЦИНАО. Москва: Изд-во стандартов, 1985.5 с.

3. Гудзь С., Гнатуш С., Яворська Г., Білінська І., Борсукевич Б. Практикум з мікробіології: підручник: для студ. вищ. навч. закл. Львів: ЛНУ імені Івана Франка, 2014. 436 с.

4. Молекулярные основы взаимоотношений ассоциативных микроорганизмов с растениями / отв. ред. В. Игнатов. Москва: Наука, 2005. 262 с.

5. Надкернична О. Азотфіксуючі мікробно-рослинні симбіози. Сільськогосподарська мікробіологія: міжвід. темат. наук. зб. Чернігів, 2005. Вип. 1-2. С. 105-127.

6. Романюк О., Шевчик Л., Терек О. Пат. на корисну модель 86572 UA. Спосіб очищення техногенних грунтів, забруднених нафтою. № u2013 05665; заявл. 30.04.2013; опубл. 10.01.2014; Бюл. № 1.

7. Сэги Й. Методы почвенной микробиологии. Москва: Колос, 1983. С. 107-109.

8. Турковская О., Муратова А. Биодеградация органических поллютантов в корневой зоне растений. Молекулярные основы взаимоотношений ассоциативных микроорганизмов с растениями. Москва: Наука, 2005. С. 180-208.

9. Baker E., Tang Y., Chu F.X., Tisa L.S. Molecular responses of Frankia sp. strain QA3 to naphthalene. Canadian Journal of Microbiology. 2015. 61(4). P. 281-292.

10. Banks M., Kulakow P., Schwab A., Chen Z., Rathbone K. Degradation of crude oil in the rhizosphere of Sorghum bicolor. Intern. J. Phytoremediation. 2003. Vol. 5, № 3. P. 225-234.

11. Cunningham S., Anderson T., Schwab A., Hsu F. Phytoremediation of soils contaminated with organic pollutants. Adv.Agron. 1996. Vol. 56. P. 55-114.

12. Dashti N., Khanafer M., El-Nemr I., Sorkhoh N., Ali N., Radwan S. The potential of oil-utilizing bacterial consortia associated with legume root nodules for cleaning oily soils. Chemosphere. 2009. Vol. 74(10). P.1354-1359.

13. Gerhardt K., Huang X.-D., Glick B., Greenberg B. Phytoremediation and rhizoremediation of organic soil contaminants: Potential and challenges. Plant Science. 2009. 176 (1). P. 20-30.

14. Ilyina A., Castillo Sanchez M., Villarreal Sanchez J., Ramirez Esquivel G. Isolation of soil bacteria for bioremediation of hydrocarbon contamination. Вестн. Моск. ун-та. Сер. 2. Химия. 2003. Т. 44, № 1. С. 88-91.

15. Rehan M., Swanson E., Tisa L. Frankia as a Biodegrading Agent. Biochemistry, Genetics and Molecular Biology. 2016. Chapter 11. P. 271-290.

16. Shevchyk L., Romaniuk O. The optimal way of biological cleaning of oil-contaminated soils. Mediterranean Journal of Biosciences. 2016. № 1(3). P. 109-113. 


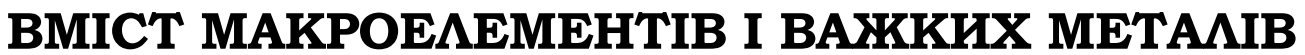 У ПОРОДНИХ ВІДВАМАХ І РОСАИНАХ

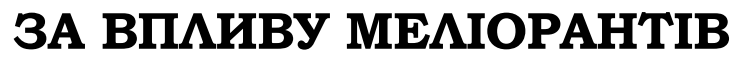

\author{
Шпак Я.В., Баранов В.I., Терек О.I. \\ Львівський національний університет імені Івана Франка \\ вул. Грушевського, 4, 79005, м. Львів \\ yaroslavecofizros@gmail.com
}

\begin{abstract}
У статті досліджено вміст рухомих форм макроелементів (P, K i Ca) й важких металів ( $\mathrm{Pb}$ i Cr) у субстраті породних відвалів Червоноградського гірничопромислового району (ЧГПР) і їх валовий уміст в органах суданської трави Sorghum bicolor subsp. drummondii (Nees ex Steud.) за впливу меліорантів (кам'яновугільного попелу Добротвірської теплоелектростанції та гумату Калію «ГКВ-45»). Знайдено підвищений уміст рухомих форм $\mathrm{P}$ i K на фоні зниженого вмісту рухомих форм $\mathrm{Pb}$ i Cr y субстратах породних відвалів. Також виявлено підвищення валового вмісту Р в органах суданської трави за впливу попелу. У свою чергу, внесення гумату призвело до зниження вмісту рухомих форм $\mathrm{Pb}$ i Cr у субстраті породних відвалів, а також до підвищення валового вмісту Р на фоні зниження валового вмісту $\mathrm{Pb}$ i Cr в органах суданської трави. Установлено, що застосування кам'яновугільного попелу разом із гуматом калію підвищує вміст макроелементів і знижує вміст важких металів у субстраті породних відвалів Червоноградського гірничопромислового району й рослинах суданської трави ефективніше, ніж застосування тільки одного із цих меліорантів. Ключові слова: породні відвали, суданська трава, кам'яновугільний попіл, гумат калію.
\end{abstract}

Содержание макроэлементов и тяжелых металлов в породных отвалах и растениях под воздействием мелиорантов. Шпак Я.В., Баранов В.И., Терек О.И. В статье исследовано содержание подвижных форм макроэлементов (Р, К и $\mathrm{Ca})$ и тяжелых металлов ( $\mathrm{Pb}$ и $\mathrm{Cr}$ ) в субстрате породных отвалов Червоноградского горнопромышленного района (ЧГПР) и их валовое содержание в органах суданской травы Sorghum bicolor subsp. drummondii (Nees ex Steud.) под воздействием мелиорантов (каменноугольного пепла Добротворской теплоэлектростанции и гумата калия «ГКВ-45»). Найдено повышение содержания подвижных форм Р и $\mathrm{K}$ на фоне понижения содержания подвижных форм $\mathrm{Pb}$ и $\mathrm{Cr}$ в субстратах породных отвалов. Также обнаружено повышение валового содержания Р в органах суданской травы под воздействием пепла. В свою очередь, внесение гумата привело к снижению содержания подвижных форм $\mathrm{Pb}$ и $\mathrm{Cr}$ в субстрате породных отвалов, а также к повышению валового содержания Р на фоне понижения валового содержания $\mathrm{Pb}$ и $\mathrm{Cr}$ в органах суданской травы. Установлено, что применение каменноугольного пепла вместе с гуматом калия повышает содержание макроэлементов и понижает содержание тяжелых металлов в субстрате породных отвалов Червоноградского горнопромышленного района и растениях суданской травы эффективнее, чем применение только одного из этих мелиорантов. Ключевые слова: породные отвалы, суданская трава, каменноугольный пепел, гумат калия.

Effect of ameliorants on the content of macronutrients and heavy metals in waste rock dumps and plants. Shpak Y., Baranov V., Terek O. Studied the effect of ameliorants (coal fly ash of the Dobrotvir TPP and potassium humate "ГКВ-45") on contents of mobile macronutrients $(\mathrm{P}, \mathrm{K}$ and $\mathrm{Ca}$ ) and heavy metals $(\mathrm{Pb}$ and $\mathrm{Cr}$ ) in substrate of waste rock dumps from the Chervonohrad coal mining region and their total contents in organs of Sudan grass Sorghum bicolor subsp. drummondii (Nees ex Steud.). Found the effect of ash on increasing of mobile $\mathrm{P}$ and $\mathrm{K}$ in contrast of decreasing of mobile $\mathrm{Pb}$ and $\mathrm{Cr}$ contents in substrates from waste dumps. Also detected increasing of total $\mathrm{P}$ content in organs of Sudan grass under the effect of ash. In turn, the application of humate caused decreasing contents of mobile $\mathrm{Pb}$ and $\mathrm{Cr}$ in substrate of waste rock dumps and increasing of total $\mathrm{P}$ content in contrast of reducing total contents of $\mathrm{Pb}$ and $\mathrm{Cr}$ in organs of Sudan grass. Concluded that application of coal fly ash together with potassium humate increases contents of macronutrients and reduces contents of heavy metals in substrate of waste rock dumps from the Chervonohrad coal mining region and in plants of Sudan grass is more effective than application only one of these ameliorants. Key words: waste rock dumps, Sudan grass, coal fly ash, potassium humate.

Постановка проблеми. Відвали пустої породи, яку вилучили після видобутку чи збагачення кам'яного вугілля, негативно впливають на стан екосистем прилеглих територій через виділення газів, пилу i стічних вод із високими концентраціями токсичних хімічних сполук.

Актуальність дослідження. Фітомеліорація хімічно забруднених територій із поступовим грунтоутворенням призводить до нейтралізації чи зменшення рухомості токсичних сполук. Однак субстрати породних відвалів кам'яновугільної промисловості малопридатні для росту більшості покритонасінних рослин через несприятливі едафічні фактори, зокрема дефіцит макроелементів і високий уміст важких металів $[3 ; 10 ; 18]$. Тому актуально розробляти оптимальні заходи підготовки субстратів породних відвалів для фітомеліорації.

Зв'язок авторського доробку із важливими науковими та практичними завданнями. Дослідження особливостей хімічного складу едафо- 
топів і мінерального живлення рослин за впливу різних факторів необхідні для економії ресурсів у процесі меліорації антропогенно порушених територій.

Виділення не вирішених раніше частин загальної проблеми, котрим присвячується означена стаття. У процесі аналізу літературних джерел не знайдено досліджень сумісного впливу попелу ТЕС iз гуматами на вміст макроелементів і важких металів у породних відвалах гірничої промисловості.

Новизна. У статті вперше досліджено вміст рухомих форм макроелементів і важких металів у відвалах гірничої промисловості за сумісного впливу кам'яновугільного попелу ТЕС і гумату калію.

Підготовка субстратів для проведення фітомеліорації полягає в нейтралізації кислотності промисловими відходами 3 лужною реакцією, внесенні меліорантів, добрив і стимуляторів росту рослин $[10 ; 15 ; 19 ; 20]$. Завдяки лужній реакції, кам'яновугільний попіл ТЕС використовують для зниження кислотності породних відвалів шахт [24; 26]. У свою чергу, гумати різного походження застосовують для меліорації антропогенно порушених територій завдяки здатності підвищувати стресостійкість рослин, рухомість макроелементів і водночас знижувати рухомість важких металів у грунтовому розчині $[6 ; 10 ; 28]$.

Методологічне або загальнонаукове значення. Проведення кореляційного аналізу вмісту рухомих форм макроелементів і важких металів із їх валовим умістом у різних органах рослин у контрольованих експериментальних умовах дає змогу розробити рекомендації щодо проведення польових випробовувань меліоративних заходів.

Свіжовідсипану породу сіро-чорного забарвлення відбирали у 2015 році в межах Червоноградського промислового району (далі - ЧГПР) із відвалу, розташованого на території Сілецької сільської ради Сокальського району Львівської області біля Центральної збагачувальної фабрики (ЦЗФ), а кам'яновугільний попіл 2016 року - 3 відвалу Добротвірської теплоелектростанції (далі - ДТЕС), розташованої в селищі міського типу Добротвір Кам'янка-Бузького району Львівської області. Як еталон використовували субстрат без потенційного впливу едафічних стрес-факторів, який виготовили змішуванням торфу, листового перегною та піску в пропорції 1:2:1. Для виготовлення субстратів контролю породу з відвалу змішали із субстратом еталону в пропорції 9:1 для запобігання ранній загибелі проростків суданської трави. Субстрати досліду виготовляли із субстрату контролю, обробленого тільки одним чи обома дослідними меліорантами. Попіл ДТЕС додавали до субстратів породних відвалів у концентрації 5\% за масою, щоб досягти компромісу між ефективністю підвищення $\mathrm{pH}$ і потенційними фінансовими витратами в разі практичного застосування результатів дослідження. Вплив гуматів на фітотоксичність субстрату перегорілої породи досліджували за допомогою гумату калію «ГКВ-45» виробництва ТзОВ «ПАРК» (Україна, Львівська область), який, за даними виробника, має такий склад: гумінові речовини $-42 \%$; карбон загальний - 166,3 г/л; $\mathrm{N}-2,4$ г/л; $\mathrm{P}_{2} \mathrm{O}_{5}-0,4$ г/л; $\mathrm{K}_{2} \mathrm{O}$ - 69,3 г/л; Mn - 197,99 мг/л; Fe - 132,04 мг/л; $\mathrm{Cu}-3,17$ мг/л; Zn - 19,69 мг/л; В - 2,28 мг/л; Со 3,45 мг/л. Цей меліорант застосовували в концентрації 0,5\% для запобігання плазмолізу рослинних клітин. Субстрати для дослідження готували за схемою: Еталон: грунтосуміш (1500 г); Контроль: порода (1350 г)+грунтосуміш $(150$ г); Дослід 1: порода (1200 г)+грунтосуміш (150 г)+попіл (150 г); Дослід 2: порода (1350 г)+грунтосуміш (150 г)+гумат (150 мл); Дослід 3: порода (1200 г)+грунтосуміш (150 г)+попіл (150 г)+гумат (150 мл). Проростки суданської трави Sorghum bicolor subsp. drummondii (Nees ex Steud.) пророщували в темряві протягом 4-х діб за температури $23^{\circ} \mathrm{C}$. Далі в горщики об’ ємом 2 л висаджували по 15 проростків, які вирощували під відкритим небом на території ЛНУ ім. І. Франка 3 липня по жовтень 2016 року. Актуальну кислотність (рівень рН) субстратів вимірювали на приладі «Иономер универсальный ЭВ-74» за температури води $+18,5{ }^{\circ} \mathrm{C}, \mathrm{pH}$ дистильованої води $-5,5$ і вмісті твердої речовини - 100 г/л [10]. Витяжки для визначення рухомих форм калію, кальцію і фосфору в субстраті одержували методом Кірсанова, а валового вмісту цих макроелементів у рослинному матеріалімокрим озоленням сульфатною кислотою за Піневич у модифікації Куркаєва. Уміст фосфору у витяжках вимірювали фотоколориметричним методом на апараті КФК-3 за методом Деніже, а калію й кальцію методом полум'яної фотометрії на апараті ПФМ $[1 ; 8]$. Визначення рухомих форм важких металів у попелі ДТЕС і субстратах проводили в буферній ацетатно-амонійній витяжці $3 \mathrm{pH} \mathrm{4,8,} \mathrm{а} \mathrm{валового}$ вмісту в органах рослин - у витяжці, одержаній мокрим озоленням нітратною кислотою. Далі вміст плюмбуму і хрому у відповідних витяжках вимірювали на атомно-абсорбційному спектрофотометрі C115 M1 [9]. Морфометричні параметри визначали у 25-, біохімічні у 5-, а кореляцію у 20-кратній повторюваності після 96 діб росту суданської трави. Середнє арифметичне і стандартне відхилення розраховували в програмі MS Excell 2007, а критерій достовірності Стьюдента і кореляційний аналіз здійснювали в програмі Statistica 10. Коефіцієнти кореляції зображені в клітинках парних кореляційних матриць на перетинах стовпчиків і рядків із назвами дослідних параметрів (таблиці 5-7, 10, 11). Для кореляційного аналізу брали тільки значення варіантів із субстратом породних відвалів [4; 5].

Виклад основного матеріалу. 3 літератури відомо, що попіл ТЕС має переважно лужне значення $\mathrm{pH}$ через наявність металів із лужними властивостями у своєму складі $[23 ; 26]$. Нами виявлено достовірне підвищення $\mathrm{pH}$ витяжки субстрату 
породних відвалів ЧГПР за впливу попелу ДТЕС (таблиця 2), яке можна пояснити наявністю калію й кальцію в ньому (таблиця 1), що підтверджено прямим кореляційним зв'язком умісту рухомих форм цих макроелементів із актуальною кислотністю субстратів (таблиці 6, 7).

3 літератури відомо, що внесення гуматів підвищує рН грунтового розчину завдяки утворенню високорухомих сполук із лужними металами [17]. Нами виявлено достовірне підвищення рН субстратів породних відвалів за впливу гумату калію. Установлено, що субстрати, оброблені обома меліорантами, мають вищий $\mathrm{pH}$, ніж тільки одним. Також виявлено підвищення $\mathrm{pH}$ субстратів породних відвалів ЧГПР після вирощування суданської трави (таблиця 2), яке можна пояснити кореневими виділеннями рослин [21].

3 літератури відомо, що нейтралізація кислих грунтів покращує доступність фосфору для рослин $[12 ; 25]$, що підтверджено здійсненим нами кореляційним аналізом, який показав прямий зв'язок умісту рухомого фосфору 3 рівнем $\mathrm{pH}$ субстратів (таблиця 5). Нами виявлено підвищення вмісту фосфору в субстраті до й після вирощування рослин за внесення попелу ДТЕС разом із гуматом калію, що зумовлено підвищенням рН субстратів (таблиці 2, 3).

Відомо, що найбільше фосфору накопичують листки, оскільки в них найактивніший метаболізм серед органів рослин, трохи менше корені, які

Таблиця 1

Уміст рухомих форм макроелементів і важких металів у кам'яновугільному попелі Добротвірської ТЕС, мг/кг сухої маси $(n=5)$

\begin{tabular}{|c|c|c|c|c|}
\hline \multicolumn{3}{|c|}{ Макроелементи } & \multicolumn{2}{c|}{ Важкі метали } \\
\hline$P$ & $K$ & $C a$ & $P b$ & $C r$ \\
\hline $58 \pm 3$ & $22,0 \pm 1,9$ & $237 \pm 14$ & $2,39 \pm 0,08$ & $17,3 \pm 0,2$ \\
\hline
\end{tabular}

Таблиця 2

Актуальна кислотність субстратів (pH) до й після 96 діб росту суданської трави (n=5)

\begin{tabular}{|l|c|c|}
\hline \multirow{2}{*}{ Варіант } & \multicolumn{2}{c|}{ дН } \\
\cline { 2 - 3 } & по & $6,47 \pm 0,05$ \\
\hline Еталон & $6,22 \pm 0,06$ & $4,23 \pm 0,04$ \\
\hline Порода (Контроль) & $3,63 \pm 0,06$ & $4,85 \pm 0,05^{*}$ \\
\hline Порода+Попіл & $4,34 \pm 0,05^{*}$ & $4,52 \pm 0,06^{*}$ \\
\hline Порода+Гумат & $3,95 \pm 0,05^{*}$ & $5,23 \pm 0,05^{*}$ \\
\hline Порода+Попіл+Гумат & $4,44 \pm 0,04^{*}$ & \\
\hline
\end{tabular}

Примітка: «*» (тут і далі) - достовірна відмінність параметрів субстратів чи рослин породних відвалів за впливу меліорантів стосовно значень субстрату чи рослин породних відвалів без впливу меліорантів (контролю) при $p \leq 0,05$.

Таблиця 3

Уміст рухомих форм макроелементів у субстратах до й після 96 діб росту суданської трави за впливу меліорантів, мг/кг сухої маси $(\mathbf{n}=5)$

\begin{tabular}{|c|c|c|c|}
\hline \multirow{2}{*}{$\begin{array}{c}\text { Хімічний } \\
\text { елемент }\end{array}$} & Варіант & \multicolumn{2}{|c|}{ Вирощування суданської трави } \\
\cline { 2 - 4 } & Еталон & $42,6 \pm 2,7$ & Після \\
\hline \multirow{4}{*}{ Р } & Порода (Контроль) & $16,2 \pm 1,4$ & $37,5 \pm 2,5$ \\
\cline { 2 - 4 } & Порода+Попіл & $17,9 \pm 1,6$ & $12,5 \pm 0,9$ \\
\cline { 2 - 4 } & Порода+Гумат & $21,8 \pm 1,8$ & $14,8 \pm 1,2$ \\
\cline { 2 - 4 } & Порода+Попіл+Гумат & $23,7 \pm 2,1^{*}$ & $18,5 \pm 1,8$ \\
\hline \multirow{4}{*}{ К } & Еталон & $43,6 \pm 3,8$ & $19,9 \pm 1,9^{*}$ \\
\cline { 2 - 4 } & Порода (Контроль) & $13,9 \pm 1,9$ & $40,4 \pm 3,5$ \\
\cline { 2 - 4 } & Порода+Попіл & $18,4 \pm 2,9$ & $11,7 \pm 1,9$ \\
\cline { 2 - 4 } & Порода+Гумат & $19,8 \pm 2,9$ & $15,3 \pm 1,9$ \\
\cline { 2 - 4 } & Порода+Попіл+Гумат & $23,6 \pm 2,9^{*}$ & $15,7 \pm 2,2$ \\
\hline \multirow{4}{*}{ Са } & Еталон & $35,5 \pm 5,1$ & $31,9 \pm 5,1$ \\
\cline { 2 - 4 } & Порода (Контроль) & $21,1 \pm 3,8$ & $21,5 \pm 4,0$ \\
\cline { 2 - 4 } & Порода+Попіл & $25,6 \pm 3,8$ & $21,1 \pm 3,9$ \\
\cline { 2 - 4 } & Порода+Гумат & $29,2 \pm 4,5$ & $24,7 \pm 3,2$ \\
\cline { 2 - 4 } & Порода+Попіл+Гумат & $31,0 \pm 4,0$ & \\
\cline { 2 - 4 }
\end{tabular}


поглинають рухомі сполуки цього макроелемента 3 грунтового розчину, а найменше стебла, що виконують переважно опорну і транспортну функції [27]. Ми встановили, що додавання попелу збільшує валовий уміст фосфору в коренях і листках суданської трави, а гумату - тільки в листках. Стебла суданської трави, які виросли на субстраті з унесенням обох меліорантів, містили фосфору достовірно більше, ніж рослини контролю, а вміст цього макроелемента в листках перевищив межу стандартного відхилення стосовно субстратів, оброблених тільки одним із меліорантів, що свідчить про сумісність попелу й гумату (таблиця 4).

3 літератури відомо, що калій активно поглинається, транспортується й накопичується з різною швидкістю, яка залежить від органу і стадії онтогенезу, що спричиняє його нерівномірне накопичення в органах рослин $[11 ; 29]$. Нами виявлено достовірне підвищення вмісту калію в стеблах суданської трави за впливу внесення гумату, а також гумату разом із попелом.

У листках достовірне підвищення вмісту цього макроелемента щодо контролю виявили тільки

Таблиця 4

Валовий уміст макроелементів в органах суданської трави через 96 діб росту за впливу меліорантів, г/кг сухої маси $(\mathbf{n}=5)$

\begin{tabular}{|c|c|c|c|c|}
\hline \multirow{2}{*}{$\begin{array}{l}\text { Хімічний } \\
\text { Елемент }\end{array}$} & \multirow{2}{*}{ Варіант } & \multicolumn{3}{|c|}{ Орган суданської трави } \\
\hline & & Корінь & Стебло & Листок \\
\hline \multirow{5}{*}{$\mathrm{P}$} & Еталон & $1,81 \pm 0,05$ & $1,46 \pm 0,03$ & $2,38 \pm 0,05$ \\
\hline & Порода (Контроль) & $0,99 \pm 0,04$ & $0,72 \pm 0,05$ & $1,24 \pm 0,04$ \\
\hline & Порода+Попіл & $1,27 \pm 0,05^{*}$ & $0,81 \pm 0,04$ & $1,64 \pm 0,05^{*}$ \\
\hline & Порода+Гумат & $1,12 \pm 0,05$ & $0,83 \pm 0,04$ & $1,47 \pm 0,04^{*}$ \\
\hline & Порода+Попіл+Гумат & $1,44 \pm 0,05^{*}$ & $1,07 \pm 0,05^{*}$ & $2,15 \pm 0,07^{*}$ \\
\hline \multirow{5}{*}{$\mathrm{K}$} & Еталон & $3,72 \pm 0,12$ & $6,10 \pm 0,16$ & $6,98 \pm 0,12$ \\
\hline & Порода (Контроль) & $1,85 \pm 0,20$ & $2,09 \pm 0,12$ & $2,70 \pm 0,18$ \\
\hline & Порода+Попіл & $1,91 \pm 0,16$ & $2,25 \pm 0,17$ & $2,90 \pm 0,16$ \\
\hline & Порода + Гумат & $2,02 \pm 0,17$ & $2,79 \pm 0,21^{*}$ & $3,18 \pm 0,25$ \\
\hline & Порода+Попіл+Гумат & $2,28 \pm 0,19$ & $3,02 \pm 0,20^{*}$ & $3,57 \pm 0,21^{*}$ \\
\hline \multirow{5}{*}{$\mathrm{Ca}$} & Еталон & $10,3 \pm 0,3$ & $11,8 \pm 0,3$ & $8,70 \pm 0,32$ \\
\hline & Порода (Контроль) & $6,22 \pm 0,32$ & $7,03 \pm 0,40$ & $4,95 \pm 0,42$ \\
\hline & Порода+Попіл & $7,18 \pm 0,37$ & $7,65 \pm 0,34$ & $5,69 \pm 0,40$ \\
\hline & Порода+Гумат & $6,84 \pm 0,45$ & $7,52 \pm 0,42$ & $5,54 \pm 0,40$ \\
\hline & Порода+Попіл+Гумат & $8,20 \pm 0,45^{*}$ & $9,07 \pm 0,53^{*}$ & $6,28 \pm 0,40^{*}$ \\
\hline
\end{tabular}

Таблиця 5

Коефіціснти кореляції між актуальною кислотністю субстратів (рН) і вмістом Фосфору (Р) в субстратах і органах рослин до і після 96 діб росту суданської трави $(\mathbf{n}=20)$

\begin{tabular}{|c|c|c|c|c|c|c|}
\hline & $\mathbf{p H}$ & $\mathbf{P ~ Д о ~}$ & Р Після & Корінь & Стебло & Листок \\
\hline $\mathrm{pH}$ & & $0,52 \#$ & $0,54 \#$ & $0,91 \#$ & $0,74 \#$ & $0,88 \#$ \\
\hline До & $0,52 \#$ & & $0,84 \#$ & $0,58 \#$ & $0,71 \#$ & $0,69 \#$ \\
\hline Після & $0,54 \#$ & $0,84 \#$ & & $0,62 \#$ & $0,67 \#$ & $0,67 \#$ \\
\hline Корінь & $0,91 \#$ & $0,58 \#$ & $0,62 \#$ & & $0,80 \#$ & $0,94 \#$ \\
\hline Стебло & $0,74 \#$ & $0,71 \#$ & $0,67 \#$ & $0,80 \#$ & & $0,92 \#$ \\
\hline Листок & $0,88 \#$ & $0,69 \#$ & $0,67 \#$ & $0,94 \#$ & $0,92 \#$ & \\
\hline
\end{tabular}

Примітка: «\#» (тут і далі) - наявність достовірного кореляційного зв'язку при $p \leq 0,05$.

Таблиця 6

Коефіцієнти кореляції між актуальною кислотністю субстратів (рН) і вмістом калію (К) в субстратах та органах рослин до й після 96 діб росту суданської трави $(\mathrm{n}=20)$

\begin{tabular}{|c|c|c|c|c|c|c|}
\hline & $\mathbf{p H}$ & $\mathbf{~ К ~ Д о ~}$ & К Після & Корінь & Стебло & Листок \\
\hline $\mathrm{pH}$ & & $0,65 \#$ & 0,43 & $0,45 \#$ & $0,50 \#$ & $0,61 \#$ \\
\hline До & $0,65 \#$ & & $0,75 \#$ & $0,73 \#$ & $0,72 \#$ & $0,65 \#$ \\
\hline Після & 0,43 & $0,75 \#$ & & $0,57 \#$ & $0,70 \#$ & $0,73 \#$ \\
\hline Корінь & $0,45 \#$ & $0,73 \#$ & $0,57 \#$ & & $0,71 \#$ & $0,55 \#$ \\
\hline Стебло & $0,50 \#$ & $0,72 \#$ & $0,70 \#$ & $0,71 \#$ & & $0,77 \#$ \\
\hline Листок & $0,61 \#$ & $0,65 \#$ & $0,73 \#$ & $0,55 \#$ & $0,77 \#$ & \\
\hline
\end{tabular}


в рослин, вирощених на субстраті з додаванням обох дослідних меліорантів, що можна пояснити підвищенням рухомості калію, який містив попіл ДТЕС (таблиця 1) гуміновими речовинами гумату калію [17]. Впливу меліорантів на вміст калію в коренях не виявлено (таблиця 4). Також установлено, що внесення тільки гумату чи попелу не спричиняє достовірного підвищення вмісту калію в субстраті породних відвалів. Натомість виявлено достовірне підвищення вмісту рухомого калію в субстратах породних відвалів за внесення обох меліорантів. У свою чергу, вирощування рослин зменшило вміст цього макроелемента в субстратах за межу стандартного відхилення (таблиця 4), що підтверджено наявністю прямого кореляційного зв'язку вмісту рухомого калію в субстраті з його валовим умістом в органах рослин (таблиця 6).

3 літератури відомо, що злакові рослини із $\mathrm{C}_{4}$ типом фотосинтезу найбільше кальцію накопичують у стеблах для зміцнення клітинних стінок, трохи менше в коренях і найменше в листках [16].

Нами відмічено зниження вмісту кальцію в субстратах за межу стандартного відхилення за впливу вирощування суданської трави, яке можна пояснити

Таблиця 7

Коефіцієнти кореляції між актуальною кислотністю субстратів (рН) і вмістом Кальцію (Са) в субстратах та органах рослин до й після 96 діб росту суданської трави $(\mathbf{n}=20)$

\begin{tabular}{|c|c|c|c|c|c|c|}
\hline & $\mathbf{p H}$ & $\mathbf{C а ~ Д о ~}$ & Са Після & Корінь & Стебло & Листок \\
\hline $\mathrm{pH}$ & & $0,49 \#$ & $0,48 \#$ & $0,80 \#$ & $0,72 \#$ & $0,70 \#$ \\
\hline До & $0,49 \#$ & & 0,22 & $0,54 \#$ & $0,63 \#$ & $0,61 \#$ \\
\hline Після & $0,48 \#$ & 0,22 & & 0,44 & 0,37 & $0,23 \#$ \\
\hline Корінь & $0,80 \#$ & $0,54 \#$ & 0,44 & & $0,79 \#$ & $0,82 \#$ \\
\hline Стебло & $0,72 \#$ & $0,63 \#$ & 0,37 & $0,79 \#$ & & $0,73 \#$ \\
\hline Листок & $0,70 \#$ & $0,61 \#$ & 0,23 & $0,82 \#$ & $0,73 \#$ & \\
\hline
\end{tabular}

Таблиця 8

Уміст рухомих форм важких металів у субстраті до й після 96 діб росту суданської трави за впливу меліорантів, мг/кг сухої маси $(\mathbf{n}=5)$

\begin{tabular}{|c|l|c|c|}
\hline \multirow{2}{*}{ Хімічний елемент } & \multicolumn{1}{|c|}{ Варіант } & \multicolumn{2}{c|}{ Вирощування суданської трави } \\
\cline { 2 - 4 } & & \multicolumn{2}{|c|}{ До } \\
Посля \\
\hline \multirow{3}{*}{$\mathrm{Pb}$} & Еталон & $4,41 \pm 0,32$ & $3,57 \pm 0,26$ \\
\cline { 2 - 4 } & Порода (Контроль) & $14,5 \pm 1,0$ & $11,3 \pm 0,9$ \\
\cline { 2 - 4 } & Порода+Попіл & $12,4 \pm 0,9$ & $10,7 \pm 0,7$ \\
\cline { 2 - 4 } & Порода+Гумат & $10,4 \pm 0,7^{*}$ & $8,17 \pm 0,44^{*}$ \\
\cline { 2 - 4 } & Порода+Попіл+Гумат & $8,30 \pm 0,55^{*}$ & $6,65 \pm 0,47^{*}$ \\
\hline \multirow{3}{*}{$\mathrm{Cr}$} & Еталон & $8,32 \pm 0,49$ & $5,43 \pm 0,40$ \\
\cline { 2 - 4 } & Порода (Контроль) & $44,5 \pm 3,2$ & $32,5 \pm 1,4$ \\
\cline { 2 - 4 } & Порода+Попіл & $30,3 \pm 2,4^{*}$ & $22,1 \pm 1,1^{*}$ \\
\cline { 2 - 4 } & Порода+Гумат & $38,7 \pm 2,7$ & $24,2 \pm 1,2^{*}$ \\
\cline { 2 - 4 } & Порода+Попіл+Гумат & $26,6 \pm 1,1^{*}$ & $19,1 \pm 1,1^{*}$ \\
\hline
\end{tabular}

Таблиця 9

Валовий уміст плюмбуму (Pb) і хрому (Cr) в органах суданської трави через 96 діб росту за впливу меліорантів, мг/кг сухої маси $(\mathbf{n}=5)$

\begin{tabular}{|c|l|c|c|c|}
\hline \multirow{2}{*}{ Хімічний елемент } & \multicolumn{1}{|c|}{ Варіант } & \multicolumn{3}{|c|}{ Орган суданської трави } \\
\cline { 2 - 5 } & & Корінь & Стебло & Листок \\
\hline \multirow{3}{*}{$\mathrm{Pb}$} & Еталон & $1,26 \pm 0,11$ & $0,78 \pm 0,08$ & $0,67 \pm 0,07$ \\
\cline { 2 - 5 } & Порода (Контроль) & $6,44 \pm 0,42$ & $1,76 \pm 0,14$ & $1,38 \pm 0,10$ \\
\cline { 2 - 5 } & Порода+Попіл & $5,72 \pm 0,46$ & $1,25 \pm 0,12$ & $0,68 \pm 0,08^{*}$ \\
\cline { 2 - 5 } & Порода + Гумат & $5,62 \pm 0,35$ & $1,41 \pm 0,18$ & $0,63 \pm 0,05^{*}$ \\
\cline { 2 - 5 } & Порода + Попіл+Гумат & $4,35 \pm 0,32$ & $1,33 \pm 0,12$ & $0,61 \pm 0,05^{*}$ \\
\hline \multirow{3}{*}{$\mathrm{Cr}$} & Еталон & $4,29 \pm 0,32$ & $3,53 \pm 0,30$ & $2,68 \pm 0,25$ \\
\cline { 2 - 5 } & Порода (Контроль) & $14,2 \pm 1,1$ & $8,44 \pm 0,50$ & $11,7 \pm 0,7$ \\
\cline { 2 - 5 } & Порода +Попіл & $12,1 \pm 0,9$ & $6,82 \pm 0,41$ & $7,44 \pm 0,62^{*}$ \\
\cline { 2 - 5 } & Порода+Гумат & $12,4 \pm 0,9$ & $7,52 \pm 0,43$ & $8,34 \pm 0,68^{*}$ \\
\cline { 2 - 5 } & Порода +Попіл+Гумат & $10,4 \pm 0,6^{*}$ & $6,12 \pm 0,37 *$ & $6,63 \pm 0,45^{*}$ \\
\hline
\end{tabular}


Коефіціснти кореляції між актуальною кислотністю субстратів (рН) і вмістом плюмбуму (Рb) у субстратах та органах рослин до й після 96 діб росту суданської трави $(n=20)$

\begin{tabular}{|c|c|c|c|c|c|c|}
\hline & $\mathbf{p H}$ & $\mathbf{P b}$ До & Рb Після & Корінь & Стебло & Листок \\
\hline рН & & $-0,68 \#$ & $-0,52 \#$ & $-0,73 \#$ & $-0,74 \#$ & $-0,79 \#$ \\
\hline До & $-0,68 \#$ & & $0,94 \#$ & $0,83 \#$ & 0,44 & $0,76 \#$ \\
\hline Після & $-0,52 \#$ & $0,94 \#$ & & $0,79 \#$ & 0,35 & $0,63 \#$ \\
\hline Корінь & $-0,73 \#$ & $0,83 \#$ & $0,79 \#$ & & $0,52 \#$ & $0,65 \#$ \\
\hline Стебло & $-0,74 \#$ & $0,44 \#$ & 0,35 & $0,52 \#$ & & $0,75 \#$ \\
\hline Листок & $-0,79 \#$ & $0,76 \#$ & $0,63 \#$ & $0,65 \#$ & $0,75 \#$ & \\
\hline
\end{tabular}

Таблиця 11

Коефіцієнти кореляції між актуальною кислотністю субстратів (рН) і вмістом хрому (Cr) у субстратах та органах рослин до й після 96 діб росту суданської трави (n=20)

\begin{tabular}{|c|c|c|c|c|c|c|}
\hline & $\mathbf{p H}$ & $\mathbf{C r}$ До & Сг Після & Корінь & Стебло & Листок \\
\hline $\mathrm{pH}$ & & $-0,93 \#$ & $-0,92 \#$ & $-0,78 \#$ & $-0,87 \#$ & $-0,91 \#$ \\
\hline До & $-0,93 \#$ & & $0,88 \#$ & $0,74 \#$ & $0,82 \#$ & $0,84 \#$ \\
\hline Після & $-0,92 \#$ & $0,88 \#$ & & $0,88 \#$ & $0,87 \#$ & $0,93 \#$ \\
\hline Корінь & $-0,78 \#$ & $0,74 \#$ & $0,88 \#$ & & $0,86 \#$ & $0,84 \#$ \\
\hline Стебло & $-0,87 \#$ & $0,82 \#$ & $0,87 \#$ & $0,86 \#$ & & $0,85 \#$ \\
\hline Листок & $-0,91 \#$ & $0,84 \#$ & $0,93 \#$ & $0,84 \#$ & $0,85 \#$ & \\
\hline
\end{tabular}

споживанням рослинами [11], що підтверджено наявністю прямого кореляційного зв'язку вмісту рухомих форм цього макроелемента в субстратах із його валовим умістом в органах рослин (таблиця 7). Натомість не виявлено достовірного впливу попелу й гумату на вміст рухомих сполук кальцію в субстратах. Однак виявлено достовірне зростання вмісту цього макроелемента в органах суданської трави за сумісного впливу обох досліджених меліорантів (таблиці 3, 4).

В Україні ГДК для рухомих форм плюмбуму і хрому в грунтах становить 6 мг/кг [28]. У контрольному субстраті породних відвалів ЧГПР ми виявили перевищення цього нормативу (таблиця 8), яке можна пояснити високими концентраціями $\mathrm{Pb}$ i Cr у відходах кам'яновугільної промисловості [18], а також низьким значенням $\mathrm{pH}$, яке підвищує рухомість важких металів у грунтовому розчині [14], що підтверджено наявністю зворотного кореляційного зв'язку вмісту рухомих сполук плюмбуму і хрому 3 актуальною кислотністю субстратів (таблиці 10, 11).

3 літератури відомо, що злакові рослини найбільше концентрують важкі метали в кореневій системі до межі фізіологічного бар'єру між кореневою шийкою і стеблом, а в стеблі й листках набагато менше [7], що підтверджено нами й для випадку вирощування суданської трави на породних відвалах ЧГПР (таблиця 9). Виявлено, що попіл ДТЕС не впливає на вміст рухомих форм плюмбуму в субстраті породних відвалів, але статистично достовірно знижує його валовий вміст у листках. Також установлено, що внесення тільки гумату калію і його внесення $з$ попелом достовірно знижує вміст рухомих форм плюмбуму в субстраті й листках суданської трави (таблиці 8, 9). Також відомо, що сполуки хрому здатні поширюватися на великі відстані разом iз пилом та аерозолями промислового походження, що могло спричинити виявлене нами перевищення ГДК в субстраті еталону (таблиця 8). Нами виявлено зниження вмісту рухомих форм Хрому в субстратах за межу стандартного відхилення, яке зумовлено поглинанням кореневою системою [2; 22], що підтверджено наявністю прямого кореляційного зв'язку вмісту рухомих сполук хрому в субстраті 3 його валовим умістом у коренях рослин (таблиця 11). У свою чергу, додавання попелу ДТЕС спричинило достовірне зниження вмісту рухомих форм хрому в субстраті породних відвалів (таблиця 8) через підвищення рН [14], що підтверджено наявністю зворотного кореляційного зв'язку вмісту хрому з актуальною кислотністю субстратів (таблиця 11).

На основі відсутності перетину межі стандартного відхилення між значеннями вмісту хрому в субстратах породних відвалів за впливу сумісного застосування обох меліорантів і застосування тільки попелу зроблено припущення, що внесення гуматів не впливає на ефективність зниження рухомості хрому попелом ДТЕС (таблиця 8).

Зниження вмісту рухомих форм хрому в субстраті призвело до зниження його валового вмісту в листках, що підтверджено наявністю прямого кореляційного зв'язку вмісту рухомих форм хрому з його валовим умістом у листках рослин (таблиця 11).

Головні висновки. Унесення кам'яновугільного попелу Добротвірської ТЕС разом із гуматом калію підвищує вміст макроелементів і знижує вміст важких металів у субстраті породних відвалів ЧГПР і рослинах суданської трави Sorghum bicolor subsp. drummondii (Nees ex Steud.) ефективніше, ніж застосування тільки одного із цих меліорантів. 
Перспективи використання результатів

дослідження. Досліджені концентрації меліорантів у поєднанні з вирощуванням суданської трави можна використати для польових випробовувань фітомеліорації породних відвалів Червоноградського гірничопромислового району.

\section{Література}

1. Аринушкина Е.В. Руководство по химическому анализу почв. 2-е изд. Москва: МГУ, 1970. 488 с.

2. Бессонова В.В., Иванченко О.Е. Накопление хрома в растениях и его токсичность. Питання біоіндикації та екології. 2011. № 2. T. 16. С. 13-29.

3. Бешлей C.В. Екологічні властивості Calamagrostis epigeios (L.) Roth та його середовищетворна роль на відвалах вугільних шахт (Червоноградський гірничопромисловий район): дис. ... канд. біол. наук: спец. 03.00.16 / Інститут екології Карпат. Львів, 2016. 148 с.

4. Карчевский Е.М., Филиппов И.Е. Excel 2007 в примерах: учебно-методическое пособие. Казань: Казанский федеральный университет, 2010. 75 с.

5. Лакин Г.Ф. Биометрия: учебное пособие для биол. спец. вузов. Москва: Высшая школа, 1990. 352 с.

6. Макеева Н.А. Оценка продукционных процессов овса в условиях внесения гуматов калия и натрия на породный отвал. Современные проблемы науки и образования. 2014. № 6.

7. Окрушко С.С. Вивчення впливу іонів свинцю на проростки ярого ячменю. Корми і кормовиробництво. 2012. Вип. 72. С. 23-28.

8. Практикум по агрохимии: учебное пособие / под ред. академика РАСХН В.Г. Минеева. 2-е изд., перераб. и доп. Москва: Изд-во МГУ, 2001. 689 с.

9. Руденко С.С., Костишин С.С., Морозова Т.В. Загальна екологія: практичний курс: навчальний посібник: у 2 ч. Чернівці: Книги-XXI, 2008. Частина 2: Природні наземні екосистеми. 307 с.

10. Фітотоксичність субстрату породних відвалів кам'яновугільних шахт за впливу попелу теплоелектростанцій і гумату калію / Я. Шпак, I. Запісоцька, В. Баранов, О. Терек. Traektoriâ Nauki/Path of Science. 2017. T. 3. № 3.17 c.

11. Barker A., Pilbeam D. Handbook of Plant Nutrition. Boca Raton: CRC Press, 2015. 773 p.

12. Burtan L., Dumitru M., Sirbu C. et al. The effect of bioremediation technologies on mobile phosphorus content from polluted soil with crude oil. Research Journal of Agricultural Science. 2015. Is. 3. Vol. 3. P. 15-22.

13. Canellas L., Olivares F. Physiological responses to humic substances as plant growth promoter. Chemical and Biological Technologies in Agriculture. 2014. Is. 1. Vol. 3.

14. Caporale A., Violante A. Chemical Processes Affecting the Mobility of Heavy Metals and Metalloids in Soil Environments. Current Pollution Reports. 2016. Is. 1. Vol. 2. P. 15-27.

15. Firpo B., Filho J., Schneider I. A brief procedure to fabricate soils from coal mine wastes based on mineral processing, agricultural, and environmental concepts. Minerals Engineering. 2015. Vol. 76. P. 81-86.

16. Johnson J., Barbour N., Weyers S. Chemical Composition of Crop Biomass Impacts Its Decomposition. SSSAJ. 2007. Vol. 7. P. 155-162.

17. Khaled H., Fawy H. Effect of different levels of humic acids on the nutrient content, plant growth, and soil properties under conditions of salinity. Soil \& Water Res. 2011. Is. 6. Vol. 1. P. 21-29.

18. Knysh I., Karabyn V. Heavy metals distribution in the waste pile rocks of Chervonogradska mine of the Lviv-Volyn coal basin (Ukraine). Pollution Research. 2014. Is. 33. Vol. 4. P. 663-670.

19. Lorestani B., Yousefi N., Cheraghi M. et al. Phytoextraction and phytostabilization potential of plants grown in the vicinity of heavy metal-contaminated soils: a case study at an industrial town site. Environ Monit Assess. 2013. Is. 185. Vol. 12. P. 10217-10223.

20. Malti D., Malti S. Ecorestoration Of Waste Dump By The Establishment Of Grass-Legume Cover. IJSTR. 2014. Is. 3. Vol 3. P. 37-41.

21. Marschner H., Römheld V. In vivo measurement of root-induced $\mathrm{pH}$ changes at the soil-root interface: effect of plant species and nitrogen source. Zeitschrift für Pflanzenphysiologie. 1983. Is. 3. Vol. 111. P. 241-251.

22. Olivera H. Chromium as an Environmental Pollutant: Insights on Induced Plant Toxicity. Hindawi Publishing Corporation Journal of Botany. 2012. Vol. 2012.

23. Pohrebennyk V. Influence of Dobrotvir thermal power plant on environmental specifications. Bulletin of the Lviv Polytechnic National University. Environmental problems. 2016. Is. 1. Vol. 1. P. 83-89.

24. Roy M., Roopali R., Mukherjee P. et al. Phytoreclamation of Abandoned Acid Mine Drainage Site After Treatment with Fly Ash. IntechOpen. 2017. № 69527. P. 101-118.

25. Sanyal S.K., De Datta S.K. Chemistry of Phosphorus Transformations in Soil. Advances in Soil Science. 1991. Vol. 16. P. 1-120.

26. Srivastava A., Chhnkar P. Amelioration of coal mine spoils through fly ash application as liming material. J. Sci. Ind. Res. 2000. Vol. 59. P. 309-313.

27. Taiz L. Zeiger E., Moller I. et al. Plant Physiology and Development. 6th Edition, 2015. Sunderland: Sinauer Associates. 896 p.

28. Tregubova P., Koptsik G., Stepanov A. et al. Application of humic substances in the remediation of heavy-metal-polluted soils of the Subarctic Zone of the Kola Peninsula. Moscow Univ. Soil Sci. Bull. 2017. Is. 72. P. 207-214.

29. Wolf O., Jeschke W. Modeling of Sodium and Potassium Flows via Phloem and Xylem in the Shoot of Salt-stressed Barley. Journal of Plant Physiology. Is. 128. 1987. P. 371-386.

30. Державні санітарні правила та норми / Державна санітарно-епідеміологічна служба України. 1999. URL: http://mozdocs. kiev.ua/view.php?id=4010 (дата звернення: 03.12.2018). 


\title{
ЗБЕРЕЖЕННЯ БIOРIЗНОМАНITТЯ
}

\author{
УДК 597.2/.5
}

DOI https://doi.org/10.32846/2306-9716-2018-4-23-26

\section{CIEPMATOГЕНЕЗ СОНЯЧНОГО ОКУНЯ LEPOMIS GIBBOSUS (LINNAEUS, 1758) В УMOВAX САMAРСЫКОÏ ЗАТОКИ ЗАПОРІЗЫКОГО ВОДОСХОВИЩА}

\author{
Нестеренко О.С., Маренков О.М. \\ Дніпровський національний університет імені Олеся Гончара \\ пр. Гагаріна, 72, 49050, м. Дніпро \\ gidrobions@gmail.com
}

\begin{abstract}
Процес сперматогенезу сонячного окуня в українських водоймах ще не вивчений. Дослідження сперматогенезу має велике теоретичне та практичне значення. Проведено дослідження щодо сперматогенезу сонячного окуня в умовах Самарської затоки Запорізького водосховища. У період із 20 червня по 26 червня 2018 р. гонади всіх експериментальних самців перебували на IV стадії зрілості, а величина гонадо-соматичного індексу (ГСІ) змінювалася в діапазоні від 0,23 до 1,21\% (в середньому $0,73 \pm 0,39 \%)$. На препаратах мазків сім'яної рідини спостерігали статеві клітини трьох фаз розвитку: сперматоцити першого порядку $(12,1 \%)$, сперматоцити другого порядку $(41,0 \%)$ і сперматиди $(46,9 \%)$. Отже, під час нересту в самців сонячного окуня в першій порції сім'яної рідини утворюється до 50\% сперматидів, які формують першу генерацію сперматозоїдів. Згідно з результатами цитометричного аналізу репродуктивних клітин сонячного окуня, сперматоцити першого порядку мали розмір $13,68 \pm 2,21$ мкм² $^{2}$ Сперматоцити другого порядку були на $39,1 \%$ меншими, а їх розміри $-8,32 \pm 1,19$ мкм². Найменшими кліти-

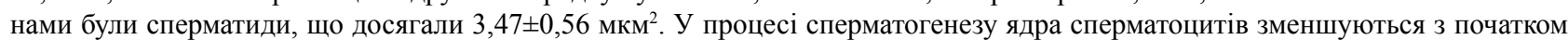
наступної фази розвитку статевих клітин. Отже, у сперматоцитів першого порядку ядра мали розмір $0,61 \pm 0,13$ мкм², а у спер-

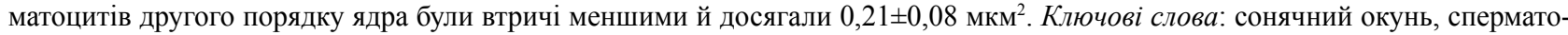
генез, сперматоцити, Запорізьке водосховище, нерест.
\end{abstract}

Сперматогенез солнечного окуня Lepomis gibbosus (Linnaeus, 1758) в условиях Самарского залива Запорожского водохранилища. Нестеренко О.С., Маренков О.Н. Процесс сперматогенеза солнечного окуня в украинских водоемах еще не изучен. Исследование сперматогенеза имеет большое теоретическое и практическое значение. Проведены исследования сперматогенеза солнечного окуня в условиях Самарского залива Запорожского водохранилища. В период с 20 июня по 26 июня 2018 г. гонады всех экспериментальных самцов находились на IV стадии зрелости, а величина гонадо-соматического индекса (ГСИ) изменялась в диапазоне от 0,23 до $1,21 \%$ (в среднем $0,73 \pm 0,39 \%$ ). На препаратах мазков семенной жидкости наблюдали половые клетки трех фаз развития: сперматоциты первого порядка $(12,1 \%)$, сперматоциты второго порядка $(41,0 \%)$ и сперматиды (46,9\%). Таким образом, во время нереста у самцов солнечного окуня в первой порции семенной жидкости образуется до $50 \%$ сперматид, которые формируют первую генерацию сперматозоидов. Согласно результатам цитометрического анализа репродуктивных клеток солнечного окуня, сперматоциты первого порядка имели размер 13,68 2 ,21 мкм². Сперматоциты вто-

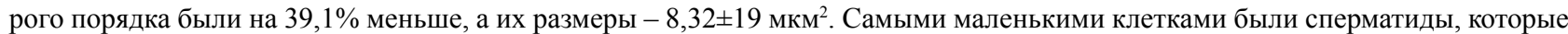
достигали $3,47 \pm 0,56$ мкм²$^{2}$ В процессе сперматогенеза ядра сперматоцитов уменьшаются с началом следующей фазы развития половых клеток. Таким образом, в сперматоцитах первого порядка ядра имели размер $0,61 \pm 0,13$ мкм², а в сперматоцитах

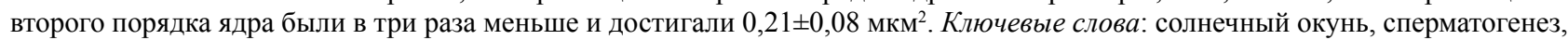
сперматоциты, Запорожское водохранилище, нерест.

Spermatogenesis of the pumpkinseed Lepomis gibbosus (Linnaeus, 1758) in the conditions of the Samara Bay of Zaporizhzhya Reservoir. Nesterenko O., Marenkov O. The process of spermatogenesis of the pumpkinseed in Ukrainian reservoirs has not been studied yet. The study of spermatogenesis has a great theoretical and practical significance. We conducted a study on spermatogenesis of the pumpkinseed in the conditions of the Samara Bay of Zaporizhzhya Reservoir. During the period from June 20 to June 26, 2018, the gonads of all experimental males were in the IV stage of maturity, and the gonado-somatic index (GSI) varied in the range from 0.23 to $1.21 \%$ (on average of $0.73 \pm 0.39 \%$ ). On the preparations of seminal fluid smears, the sexual cells of three phases of development were observed: spermatocytes of the first order (12.1\%), spermatocytes of the second order $(41.0 \%)$ and spermatids (46.9\%). Thus, during spawning in males of the pumpkinseed, in the first portion of the seminal fluid, up to $50 \%$ of the spermatoidis formed, which forms the first generation of spermatozoa. According to the results of cytometric analysis of reproductive cells of the pumpkinseed, it was found that spermatocytes of the first order had a size of $13.68 \pm 2.21 \mu \mathrm{m}^{2}$. Spermatocytes of the second order were $39.1 \%$ smaller, and their sizes were $8.32 \pm 1.19 \mu \mathrm{m}^{2}$. The smallest cells were spermatids and reached $3.47 \pm 0.56 \mu \mathrm{m}^{2}$. During the course of spermatogenesis, the nucleus of spermatocytes decreases with the beginningof the next phase of the development of sexual cells. Thus, in spermatocytes of the first order, the nucleus had a size of $0.61 \pm 0.13 \mu \mathrm{m}^{2}$, and in the spermatocytes of the second order the nucleus were three times smaller and reached $0.21 \pm 0.08 \mu \mathrm{m}^{2}$. Key words: pumpkinseed, spermatogenesis, spermatocytes, Zaporizhzhya reservoir, spawning. 
Постановка проблеми. Одним із нових видів-вселенців водойм України є сонячний окунь Lepomis gibbosus (Linnaeus, 1758) (Centrarchidae, Perciformes), який потрапив до водойм Дніпропетровської області лише 25 років тому, але активно наростив чисельність і біомасу [1]. Стрімке поширення виду пов'язане $з$ особливостями біології та екології виду, особливо $з$ питаннями його відтворення.

Актуальність дослідження. Перебіг сперматогенезу сонячного окуня у водоймах України раніше не вивчався [2; 3]. Вивчення сперматогенезу має вагоме теоретичне і практичне значення. 3 теоретичного погляду сперматогенез являє собою зручну модель для вивчення багатьох питань клітинної та репродуктивної біології риб. Практичне значення вивчення сперматогенезу полягає в тому, що стерильність самців тісно пов'язана 3 порушенням здатності зрілих сперміїв до запліднення або з відхиленням нормального функціонування сперматогенної епітеліальної тканини, що спричиняє масову загибель клітин i, як наслідок, створює умови для розвитку оліго- й азооспермії.

Аналіз останніх досліджень і публікацій. Низка вітчизняних авторів у наукових роботах відзначає, що біологічні дослідження розмноження сонячного окуня у водоймах України комплексно не проводилися $[3 ; 4 ; 5]$. Відсутні повноцінні дані щодо перебігу сперматогенезу чужорідних видів і загалом бракує інформації щодо репродуктивного потенціалу та перебігу фаз розвитку статевих залоз, яка має як фундаментальне, так і прикладне значення для вирішення низки завдань екології.

Виділення не вирішених раніше частин загальної проблеми, котрим присвячується означена стаття. Останні дослідження гідробіонтів на прикладі деяких коропових і окуневих риб дали змогу виявити деякі особливості адаптації репродуктивної системи інвазійних видів до розмноження в нових умовах існування, що дають вселенцям можливість ефективно відтворюватись і нарощувати свою чисельність, створюючи конкуренцію аборигенним видам $[1 ; 2 ; 5]$.

Основною метою роботи було проаналізувати перебіг сперматогенезу сонячного окуня Lepomis gibbosus (Linnaeus, 1758) (Centrarchidae, Perciformes) як виду-вселенця Самарської затоки Запорізького водосховища.

Новизна. Нами детально досліджено репродуктивний цикл сонячного окуня в умовах водойм Придніпров'я, на відміну від зарубіжних досліджень [6], уперше детально описано процеси сперматогенезу з використанням цитологічних і гістологічних методів досліджень.

Матеріали й методи дослідження. Відбір іхтіологічних проб проводили в червні 2018 року (20-26 червня 2018 р.). під час науково-дослідних і контрольних ловів на акваторії Самарської затоки Запорізького водосховища. Вилов риби проводили на контрольно-спостережному пункті, який розташований у Самарській затоці (с. Новоселівка $48^{0} 57354 \mathrm{~N}, 35^{0} 23509$ Е). Науково-дослідні лови здійснювали на підставі дозволів на спеціальне використання водних біоресурсів (від 13 квітня 2016 року № 000031/2016). Вилов сонячного окуня здійснювали стандартними дрібновічковими сітками 3 кроком вічка a=30-36 мм згідно 3 класичними іхтіологічними методиками відповідно до чинного законодавства та на підставі розробленого науково-біологічного обгрунтування застосування дрібновічкових ставних сіток на акваторії Самарської затоки. Матеріалом для іхтіологічних і гістологічних досліджень слугували статевозрілі особини сонячного окуня (віком від 3 до 6 років, довжиною 7,1-14,2 см).

Біологічний аналіз риб проводили згідно 3 класичними методиками в іхтіології [7; 8]. 3 метою дослідження статевих залоз статевозрілих самців риб розтинали, визначали ступінь зрілості гонад за шестибальною шкалою та розраховували величину гонадо-саматичного індексу (далі - ГСІ). Для вивчення сперматогенезу виготовляли мазки сперми сонячного окуня. Відбір сім'яної рідини проводили в риб прижиттєво піпеткою шляхом легкого натиску в районі статевого отвору. Відібрану рідину наносили на скло, виготовляли мазок і висушували за кімнатної температури на повітрі. Отримані мазки фіксували за Май-Грюнвальдом і фарбували за Романовським.

Також виготовляли зрізи гонад для отримання більш інформативних даних щодо співвідношення кількості статевих продуктів, які формуються в поточній порції сім'яної рідини. Гістологічні препарати виготовлялись за допомогою мікротома «Thermo scientific microm HM 325» [9].

Мікрофотографії препаратів робили за допомогою цифрової камери «AmScope MU500 5.1MPix», яка приєднувалась до оптичного мікроскопа «MICROmed» XS-2610. Опис зрізів гонад мазків сперми проводили з використанням робіт М.С. Козія та М.М. Шихшабекова [10; 11]

Для визначення умов перебігу нересту на нерестовищах відбирали проби води для визначення гідрохімічних показників [7]. Загальноприйнятими гідрохімічними методами у воді визначали розчинені гази, біогенні елементи, жорсткість, лужність, кількість розчиненої органічної речовини за показниками перманганатної окислюваності. Показники хімічного складу води порівнювали з нормативними критеріями якості води для рибогосподарських потреб - СОУ 05.01-37-385:2006.

Статистичне опрацювання цифрових матеріалів проводили за допомогою пакетів прикладних програм Microsoft Exel 2007 i STATISTICA 6.0.

Виклад основного матеріалу. Натепер найбільша чисельність сонячного окуня концентрується в Самарській затоці Запорізького водосховища, оскільки вона характеризується слабкою проточні- 


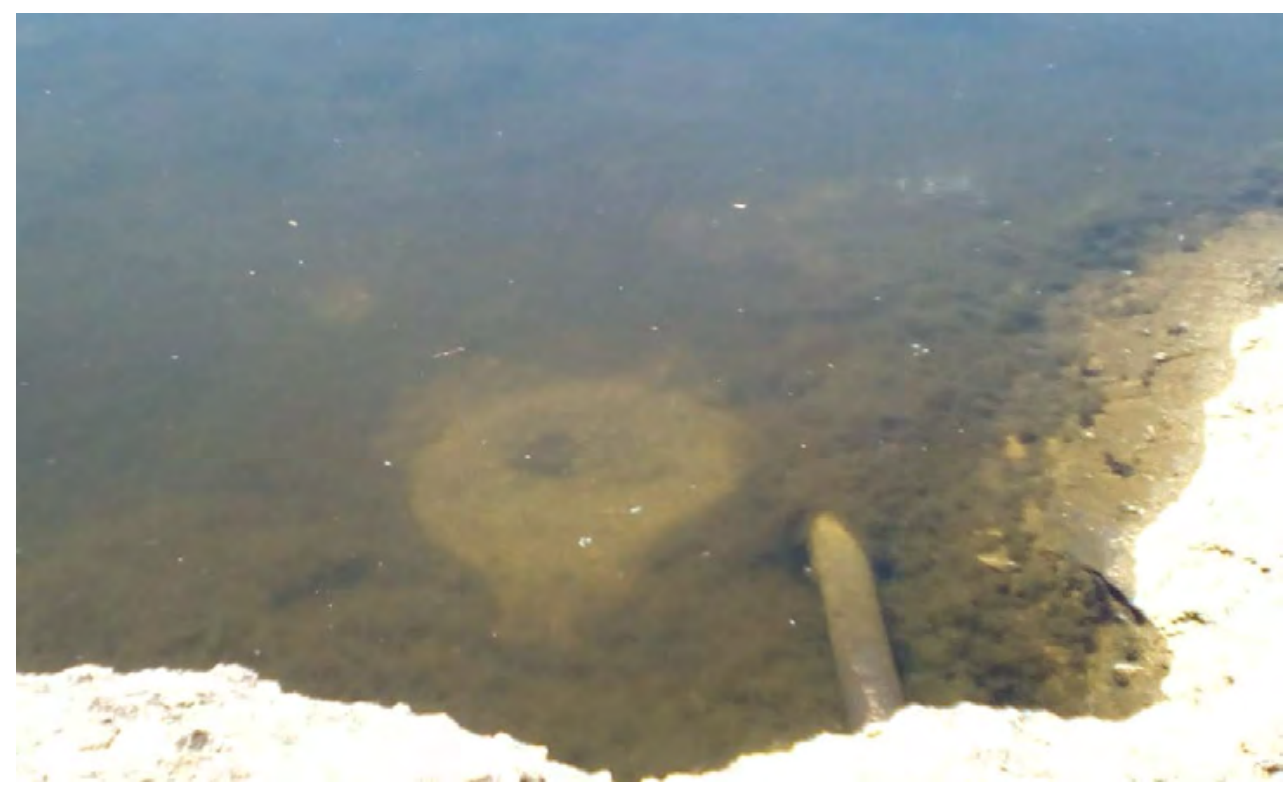

Рис. 1. Типове гніздо сонячного окуня на мілководді

стю й великою площею мілководь, що створює сприятливі умови для репродукції цього виду.

Перебіг нересту. Розмноження сонячного окуня проходить у літоральній зоні серед заростей рослинності на невеликих глибинах (зазвичай до 1 м). Самці використовують свій хвостовий плавець, щоб будувати блюдцеподібне гніздо діаметром від 10 до 38 см (рис. 1). Самці окуня при цьому будують невеликі, круглі гнізда на дні водойми. На деяких ділянках спостерігали масові скупчення нерестових гнізд сонячного окуня (до 7-10 гнізд на $100 \mathrm{~m}^{2}$ ).

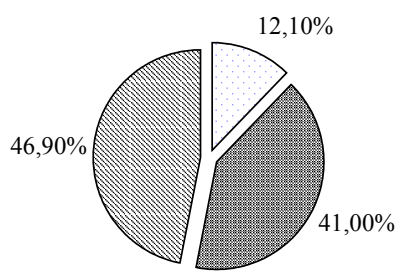

$$
\begin{aligned}
& \square \text { сперматоцити I } \\
& \text { порядку } \\
& \square \text { сперматоцити II } \\
& \text { порядку } \\
& \mathbb{Q} \text { сперматиди }
\end{aligned}
$$

Рис. 2. Мазок сперми сонячного окуня: $S_{1}$ - сперматоцичти I порядку; $S_{2}$ - сперматоцичти II порядку; $S_{t}-$ сперматиди

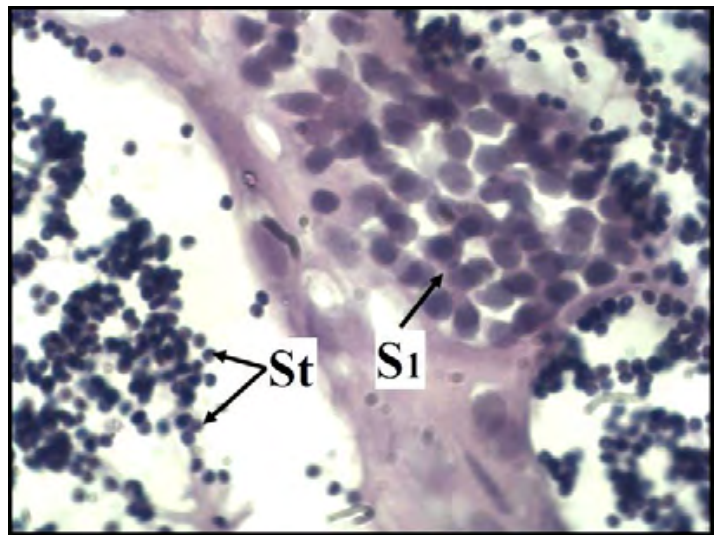

Після того, як гніздо побудоване, самець енергійно захищає його від інших самців. Самки чекають на більшій глибині, поки не будуть побудовані

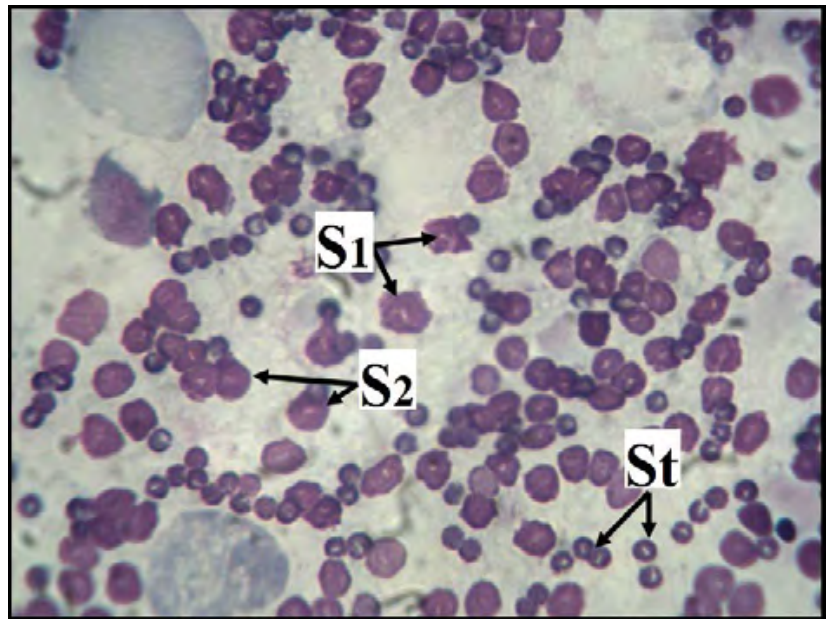

Рис. 3. Відсоткове співвідношення статевих клітин самців сонячного окуня

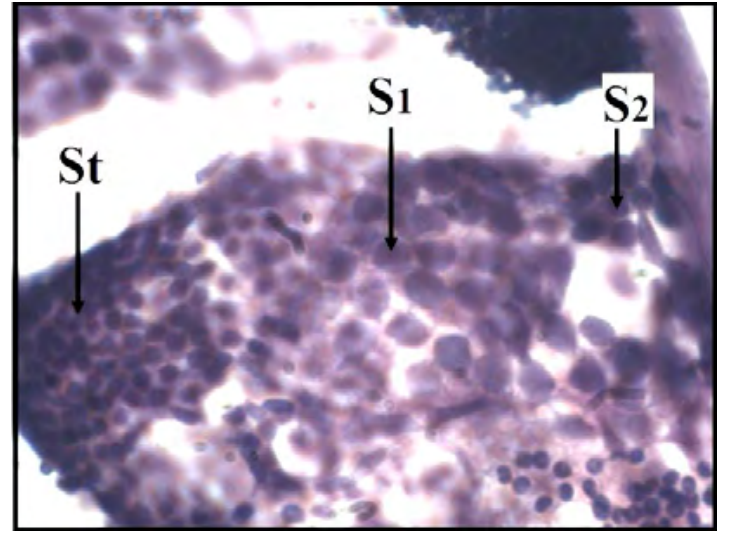

Рис. 4. Гістологічна картина сім'янників сонячного окуня: $S_{1}$ - сперматоцити I порядку; $S_{2}$ - сперматоцити II порядку; $S_{t}-$ сперматиди 
впливає на відтворення гідробіонтів і визначається впливом високомінералізованих шахтних стічних вод, основними забруднюючими компонентами яких $\epsilon$ дрібнодисперсні зважені частки та важкі метали. Тому дослідження гідрохімічних показників і репродуктивних можливостей риб у цих умовах має великий теоретичний і практичний інтерес. Під час дослідження води нами встановлені такі гідрохімічні показники: нітрати - 0,2 мг/кг, нітрити 0,017 мг/кг, кальцій - 234,47\%; аміак - 0,550,1 мг N/дм³ розчинений кисень - 4,46 мг/дм ${ }^{3}$, перманганатна окислюваність - 10,8 мг/дм³ , сульфати - 103,2 мг/дм ${ }^{3}$, фосфати - 0,01 мг $\mathrm{P} /$ дм $^{3}$, хлориди - 450мг/дм³. Отже, Самарська затока Запорізького водосховища за своїми гідрохімічними показниками й гідроекологічним режимом $є$ достатньо придатною для освоєння сонячним окунем іiі біотопів. В умовах затоки вид має високі репродуктивні показники та швидко нарощує свою чисельність.

Перебіг сперматогенезу. Результати досліджень зрілості гонад показали, що сім'янники всіх дослідних самців знаходилися на IV стадії зрілості, а величина ГСІ коливалася в межах від 0,23 до 1,21\% (у середньому становила 0,73 $\pm 0,39 \%$ ). На препаратах мазків сім'яної рідини нами відмічалися статеві клітини трьох фаз розвитку: сперматоцити I порядку, сперматоцити II порядку і сперматиди (рис. 2).

За співвідношенням сперматоцити I порядку становили $12,1 \%$, сперматоцити II порядку - 41\%, а сперматиди $-46,9 \%$. Отже, під час нересту в самців сонячного окуня в першій порції сім'яної рідини формується до 50\% сперматид, які формують першу генерацію сперматозоїдів (рис. 3).

За результатами цитометричного аналізу статевих клітин сонячного окуня нами встановлено, що сперматоцити I порядку мали розміри $13,68 \pm 2,21$ мкм², $^{2}$ сперматоцити II порядку були на $39,1 \%$ меншими, а

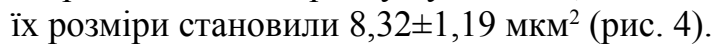

Найменшими клітинами були сперматиди $3,47 \pm 0,56$ мкм² $^{2}$ Під час перебігу сперматогенезу ядра сперматоцитів зменшуються з переходом до наступної фази розвитку статевих клітин. Так, у сперматоцитів I порядку ядра мали розміри $0,61 \pm 0,13$ мкм², а у сперматоцитів II порядку ядра були втричі меншими $-0,21 \pm 0,08$ мкм² $^{2}$
Отже, проведено дослідження сперматогенезу сонячного окуня на акваторії Самарської затоки Запорізького (Дніпровського) водосховища, які розширюють наявну інформацію щодо біології та репродукції сонячного окуня в нових умовах існування.

Головні висновки. Дослідження статевих залоз сонячного окуня має не тільки теоретичний інтерес, а й цінне прикладне значення. Визначення періодів і фаз розвитку статевих клітин, стадій розвитку статевих залоз, перебігу сперматогенезу використовуються для розроблення шкали зрілості гонад, яка необхідна для вирішення низку практичних питань екологічного значення. У результаті проведених досліджень отримані нові матеріали щодо сперматогенезу сонячного окуня як вида-вселенця Самарської затоки Запорізького водосховища.

Перспективи використання результатів дослідження. Оскільки розуміння пристосування риб до умов розмноження та їх адаптація до нових водойм базуються на глибоких знаннях особливостей формування репродуктивної системи, отримані результати мають очевидну теоретичну зацікавленість i практичну значимість для дослідження і прогнозування біоресурсного потенціалу водойм $з$ використанням даних комплексних досліджень репродуктивного потенціалу риб.

Важливим аспектом подальших досліджень є всебічне поглиблене вивчення й дослідження гістологічної будови гонад риб і стадій зрілості статевих продуктів із використанням гістологічних, цитологічних і біохімічних методів.

Проведення біохімічних досліджень, а саме вивчення гормональної регуляції процесу сперматогенезу, можуть дати відповідь на низку питань щодо нормального та патологічного функціонування статевих залоз риб, а також питань механізмів регуляції резорбційних процесів як за нормальних, так і за несприятливих умов існування.

Публікація містить результати досліджень, проведених за грантом Президента України за конкурсним проектом Ф75/142 Державного фонду фундаментальних досліджень «Репродуктивний потенціал інвазійних гідробіонтів водойм Придніпров'я та їх вплив на формування біопродуктивності» (ДР № 0118U006319).

\section{Література}

1. Федоненко О.В., Маренков О.М. Промислове освоєння іхтіофауни Запорізького (Дніпровського) водосховища. Дніпро: ЛІРА, 2018. $154 \mathrm{c}$.

2. Сучасні проблеми гідроекології: Запорізьке водосховище / О.В. Федоненко, Н.Б. Єсіпова, Т.С. Шарамок та ін. Дніпропетровськ: ЛІРА, 2012. 280 с.

3. Біологічне різноманіття України. Дніпропетровська область. Круглороті (Cyclostomata). Риби (Рisces) / В.Л. Булахов, P.О. Новіцький, О.Є. Пахомов, О.А. Христов; за заг. ред. проф. О.Є. Пахомова. Дніпропетровськ: Вид-во Дніпропетр. ун-ту, 2008. $304 \mathrm{c}$.

4. Христенко Д.С., Рудик-Леуська Н.Я., Котовська Г.О. Атлас аборигенної іхтіофауни басейну р. Дніпро. Київ: Фітосоціоцентр, 2011. $192 \mathrm{c}$.

5. Адаптивный потенциал и функциональные особенности репродуктивных систем рыб в экологически трансформированных водоемах / М.М. Шихшабеков, Е.В. Федоненко, О.Н. Маренков, Н.М. Абдуллаева, Н.И. Рабазанов. Днепропетровск: Журфонд, 2014. 224 с. 
6. Annual development of gonads of pumpkinseed, Lepomis gibbosus (Actinopterygii: Perciformes: Centrarchidae) from a heatedwater discharge canal of a power plant in the lower stretch of the Oder River, Poland / J. Domagała, L. Kirczuk, K. Dziewulska, M. Pilecka-Rapacz. Acta Ichthyologica et Piscatoria. 2014. № 44. P. 131-143.

7. Методи гідроекологічних досліджень поверхневих вод/ О.М. Арсан, О.А. Давидов, Т.М. Дьяченко та ін.; за ред. В.Д. Романенка. Київ: Логос, 2006. 408 с.

8. Methods for fish biology / Edited by Carl B. Schreck and Peter B. Moyle. Bethesda, Maryland, USA, 1990. 685 p.

9. Гистология для ихтиологов: Опыт и советы / Е.В. Микодина, М.А. Седова, Д.А. Чмилевский, А.Е. Микулин, С.В. Пьянова, О.Г. Полуэктова. Москва: Изд-во ВНИРО, 2009. 112 с.

10. Общая гистология и эмбриология рыб / М.С. Козий, И.М. Шерман, В.В. Самойлюк, Н.Н. Матвиенко. Херсон: ФЛП Гринь Д.С., 2016. 484 с.

11. Шихшабеков М.М., Рабазанов Н.И. Морфо-экологические исследования размножения рыб в водоемах с нарушенным экологическим режимом: монография. Москва: Юнити-дана, 2009. 327 с. 


\title{
DYNAMICS OF BRADYRHIZOBIUM JAPONICUIM NUMBER ON SOYBEAN SEED
}

\author{
Gumeniuk I.I., Sherstoboeva O.V., Chabanyuk Ya.V. \\ Institute of Agroecology and Environmental Management \\ of the National Academy of Agricultural Sciences of Ukraine \\ 12, Metrologichna str., 03143, Kyiv \\ gumenyuk.ir@gmail.com
}

\begin{abstract}
The culture broth of Bradyrhizobium japonicum LG 2 and LG 5 strains of nodule bacteria were analyzed. The expediency of using pre-sowing treatment with simultaneous use of treaters Maxim, Vitavaks $200 \mathrm{FF}$ and Redigo M, which are popular today, was tested. The dynamics of the nodule bacteria $B$. japonicum abundance on the surface of soybean seeds was estimated at 12 hours of cultivation. Processing the composition of both isolated strains allowed saving $2 \cdot 10^{3} \mathrm{CFU} /$ seed. Key words: soybean, nitrogenfixing bacteria, nodule bacteria, symbiosis Bradyrhizobium japonicum.
\end{abstract}

Динаміка чисельності Bradyrhizobium japonicum на насінні сої. Гуменюк І.І., Шерстобосва О.В., Чабанюк Я.В. У статті проаналізовано культуральні рідини штамів бульбочкових бактерій Bradyrhizobium japonicum LG 2 та LG 5. Перевірено доцільність застосування передпосівної обробки з одночасним застосуванням популярних сьогодні протруйників: Максим, Вітавакс 200 ФФ і Редіго М. Оцінено динаміку чисельності бульбочкових бактерій $B$. japonicum на поверхні насіння сої за умови обробки культуральними рідинами виділених штамів бульбочкових бактерій сої В. japonicum LG 2 та LG 5. Обробка композицією обох виділених штамів дала змогу збереження $2 \cdot 10^{3} \mathrm{KУО/насінину.} \mathrm{Ключові} \mathrm{слова:} \mathrm{соя,} \mathrm{азотфіксувальні} \mathrm{бактерії,}$ бульбочкові бактерії, симбіоз, Bradyrhizobium japonicum.

Динамика численности Bradyrhizobium japonicum на семенах сои. Гуменюк И.И., Шерстобоева Е.В., Чабанюк Я.В. В статье проанализированы культуральные жидкости штаммов клубеньковых бактерий Bradyrhizobium japonicum LG 2 и LG 5. Проверена целесообразность применения предпосевной обработки с одновременным применением популярных на сегодняшний день протравителей Максим, Витавакс 200 ФФ и Редиго М. Оценена динамика численности клубеньковых бактерий B. japonicum на поверхности семян сои на протижении 12 часов культивирования. Обработка композицией обоих выделенных штаммов позволяла сохранить $2 \cdot 10^{3} \mathrm{KOЕ/семя.} \mathrm{Ключевые} \mathrm{слова:} \mathrm{соя,} \mathrm{азотфирующие} \mathrm{бактерии,} \mathrm{клубеньковые} \mathrm{бактерии,} \mathrm{сим-}$ биоз, Bradyrhizobium japonicum.

Introduction. Biological nitrogen is needed to produce environmentally friendly crop products. Thanks to biological nitrogen $\left(\mathrm{N}_{2}\right)$, which is fixed in symbiosis with nodule bacteria, it has become real to obtain significant organic yields. Nearly $40 \%$ of leguminous crops seeds in Ukraine are treated with preparations of nodule bacteria, and the number of national biological preparations is $10 \%$. Very important is the shelf life of the preparation based on living nodule bacteria, which, with complete sterility, continue to grow and function. Their growth and multiplication stop only when they reach a certain concentration in the liquid, lack of nutrients and ageing of the bacteria population. Also there is an accumulation of metabolites and toxins, which can in further use reduce the symbiotic properties of bacteria.

Therefore, it is interesting to create and study bacterial preparations with a long shelf life, which remain activity and stay on the surface of seeds. Modern inoculants increase the rate of symbiosis formation, activate the nitrogenase complex of the bacteria and also contribute increasing plant resistance to adverse environmental conditions. In addition, the preparations contain unique components that contribute to an increase in the adhesive ability of bacteria to be fixed on the surface of seeds and ensure their storage for at least two months.

Literary review. As distinct to the inoculum on a dry carrier, the liquid carrier allows the manufacturer to include a sufficient amount of nutrients, protective agents to improve the characteristics of bacterial cells. In fact, they are microbial cultures or suspensions, supplemented with substances that improve adhesion, contribute stabilization, increase the ability of surfactants [1]. Although the shelf life of conventional inoculants based on solid carriers is about 6 months, another advantage of liquid preparations is that their shelf life can reach 2 years [2]. They have gained popularity in developed countries for the treatment of legumes due to the large titer of microorganisms ( 2 billion cells $/ \mathrm{ml}$ ), which 
makes possible to reduce the rate of inoculum application [3]. In addition, it is argued that these inoculants are not contaminated, have a longer shelf life of the components of the nutrient medium, are more protected from environmental stresses and could increase efficiency in the field compared with peat-based inoculants $[1 ; 4]$. They are easier to use - contribute to even application and keeping on the surface of the seed. The main component of the medium is sucrose or mannose. Glycerin contributes to the preservation of microbial preparations for 6 months (content of significant amount of water allow to protect bacteria from drying). In most cases, high molecular weight polymeric materials are added, such as carboxymethyl cellulose, gum arabic and polyvinylpyrrolidone (PVP). Exactly PVP contributes to the survival of Bradyrhizobium japonicum [1]. With the arabian gum, PVP provides some protection against drying and additional protection against exudates of inhibitory seed shells that are harmful for rhizobia. Thus, liquid inoculants occupy the main niche in the market and their advantages and disadvantages need to be studied and developed.

The aim of the research was to establish the effectiveness of the use of culture fluids of nodule bacteria as the basis of biological preparations with modern protectors and to determine the dynamics of the number of soybean nodule bacteria Bradyrhizobium japonicum on the surface of soybean seeds.

Materials and methods. The experiments were conducted in the laboratory of ecology of microorganisms of the Institute of Agroecology and Nature Management of the NAAS. It was used Moravia soybean, which was grown in the Forest-Steppe of Ukraine and included to the "Register of Plant Varieties of Ukraine" from year 2011.

The objects of research were selected breeds of soybean nodule bacteria and their culture broth of strains Bradyrhizobium japonicum LG 2 and LG 5. The working titer of the preparations was $5-6 \cdot 10^{9} \mathrm{CFU} / \mathrm{ml}$.

The dynamics of the number of nitrogen-fixing microorganisms on the seeds was determined as follows:
$10 \mathrm{~g}$ of inoculated soybean seeds were placed in $100 \mathrm{ml}$ of water at certain intervals of storage time and shaken at $220 \mathrm{vol} / \mathrm{min}$. Within 30 minutes a series of 10 -fold dilutions of the cell suspension was prepared and sown on mannitol yeast agar (MYA). From each flask, a $0.1 \mathrm{ml}$ suspension was taken separately with a sterile pipette and applied to the agar surface and with a Drygalsky sterile spatula, holding the half-open cup near the burner flame, and gently rubbed into the agar plate. The plates were placed in a thermostat for 10 days at a temperature of $26-28^{\circ} \mathrm{C}$. The titer of bacterial cells in the water wash was $1-8$ thousand $/ \mathrm{ml}[5]$.

The determination of the titer of the obtained soybean nodule bacterial strains was carried out by sowing $10^{6}$ dilutions of the suspension of culture broth on MYA. The presence and amount of extraneous microflora was determined by sowing $10 \%$ suspension of culture broth in sterile tap water on Meat extract-peptone medium to detect extraneous bacteria and the presence of micromycetes on Chapek's medium.

Inoculants and culture broth of nodule bacteria Bradyrhizobium japonicum LG 2 and LG 5 were used for presowing treatment of the studied seed samples in combination with the most common seed treatment preparations: Maxim, Vitavaks $200 \mathrm{FF}$, Redigo M, which have protective fungicidal and regulatory properties. Determined the number of colonies forming units (CFU) after storage for 30 and 60 days.

Results of the research and discussion. We determined the dynamics of the titer of viable cells of soybean nodule bacteria of strains Bradyrhizobium japonicum LG 2 and LG 5 on the surface of soybean seeds under monosteam inoculation and combined use of the composition of two strains LG 2 and LG 5 . In both of the variants of Bradyrhizobium japonicum inoculation pressure was $8.27 \cdot 10^{3}$ cells per 1 seed. The control served as seeds treated with water and the titer of epiphytic rhizobia per 1 seed did not exceed 100 cells.

In the study of washed out of inoculated soy seeds, which were obtained by shaking in sterile

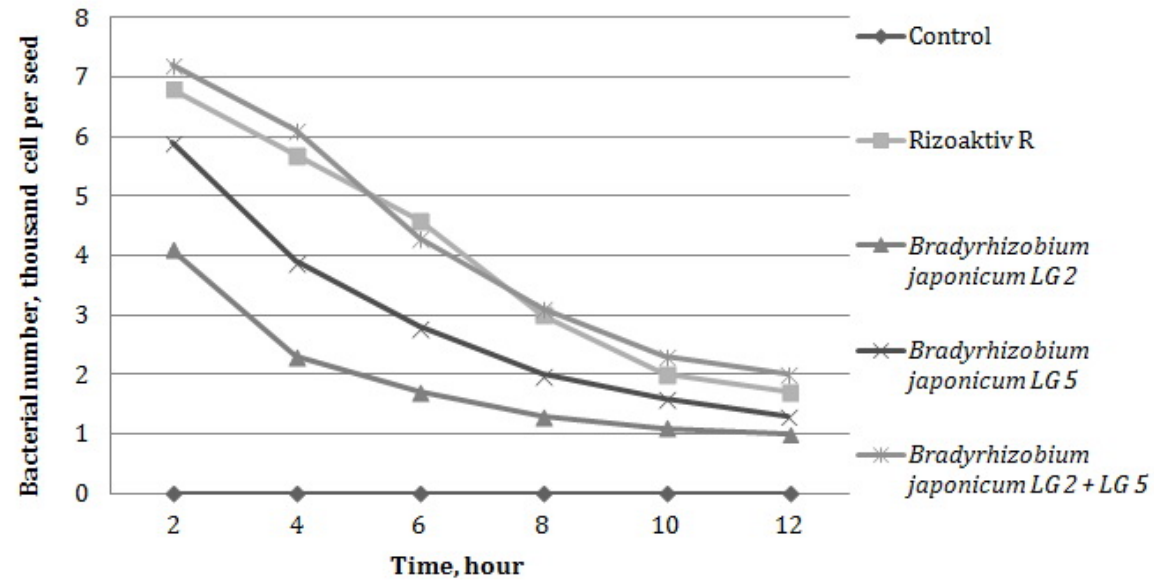

Fig. 1. Dynamics of Bradyrhizobium japonicum numder per seed of soybean 
water for 30 minutes in a shaker at 220 vol per minute, it was shown that in the first 2 hours the number of Bradyrhizobium japonicum decreases in all variants of the experiment. In particular, in the variant with the LG 2 strain, the number was $4.110^{3}$ cells / seed, in variant with the strain LG $5-5.9 \cdot 10^{3}$ cells/seed, and when inoculated with the composition of both strains of nodule bacteria soybeans - up to $7.2 \cdot 10^{3}$ cells/ seed, which is by $5.7 \%$ more compared to the national modern inoculant Rizoaktiv R (Fig. 1).

As the control in these studies we used seeds treated with water and the epiphytic titer of rhizobia existing on 1 seed did not exceed 100 cells. To compare the effectiveness of our existence, we used a modern innovative biological product for treating soybean Rizoaktiv R.

Within 12 hours, the titer of B. japonicum strain during its inoculation decreased in all variants of the experiment. In particular, in the variant with usage strain LG 2, the number of nodule bacteria was $1.0 \cdot 10^{3}$ cells / seed, in the variant with strain LG 5 in monoinoculation - up to $1.3 \cdot 10^{3}$ cells / seed. In another case, when inoculated with the composition of both strains of soybean nodule bacteria, the rhizobia titer decreased only to $2.0 \cdot 10^{3}$ viable cells per 1 seed, which is $15 \%$ more than the modern national inoculants Rizoaktiv R. The similar results have already been obtained and described by Spanish researchers where seeds of legumes were inoculated with including soybean, they differed only in absolute numbers while maintaining the general trend [6]. The delay in reducing the titer of nodule nitrogen-fixing bacteria on soybean seeds when inoculated in the complex of two strains is done, we consider several of the following features, namely, the presence of viscous exopolysaccharides that synthesize strain LG 5 and which in turn protect against the effects of factors damaging bacterial cells, and also helps to keep cells on the surface of seeds, recent studies of these strains have been shown [7].

After conducting research to determine the dynamics of the number of nodule bacteria on the surface of soybean seeds, it will be important to evaluate the culture fluids for a certain period of suitability for further biological development based on them. Therefore, we tested the vital activity of nitrogen-fixing bacteria in the culture broth. For microorganisms, a liquid nutrient medium is not only a source of nutrition and functioning, it also play the protection role against negative environmen- tal factors during storage of the preparations, as well as exposure to the soil. One of the main advantages of the liquid form of inoculants is the high efficiency compared to the dry, due to the combination of several microorganisms, as well as the possibility of $100 \%$ covering of soybean seeds due to the liquid carrier. The effect of the use of biological preparations based on living microorganisms may differ depending on certain criteria, such as the characteristics of bacteria, the method of their application, as well as various environmental factors, infused on them in the process of life activity (biotic, abiotic, anthropogenic). Any of these factors will have an effect on the inoculum, which can provide an inhibitory effect or will lead to increasing the amount of biological agent in the preparation or outdoor microflora in it. One of the important factor in the successful introduction of microorganisms into biogeocenosis is the properties of these microorganisms, their relationship with plants and already existing microorganisms of this biogeocenosis.

The results of determining the dynamics of the bacteria titer during storage of culture broth are the basis of the possible preparation and their own quality indicators during the corresponding storage period are shown (Table 1).

Mature 1-2 day old cultures of strains Bradyrhizobium japonicum LG 2 and LG 5 had a titer of 5-6 billion cells per $1 \mathrm{ml}$ [8]. A rapid fall in cell titer in the first half of the month and a slight increase in its further storage up to 2 months may indicate that the strains of Bradyrhizobium japonicum LG 2 and LG 5 restore the population in the nutrient substrate.

During storage of culture broth for a certain period of the presented options, no contamination from micromycetes was observed, and contamination by extraneous bacteria was 2-3 times lower than allowed by the standard at the end of the storage period [9]. Despite the change in the titer of bacterial cells in the culture broth of both strains of nodule bacteria after 3 months of storage, as well as more than 1.5 billion/g of viable cells up to 6 months is sufficient (for technical requirements) to inoculate seeds per 1 ha.

From the literature it is known that the introduction of large amounts of inoculum into the substrate leads to a rapid loss of titer, which is not updated, because metabolites of bacteria from the suspension interfere with this. Conversely, the introduction of a small amount of inoc-

Table 1

The quality of the culture broth of the nodule bacteria Bradyrhizobium japonicum

\begin{tabular}{|c|c|c|c|c|c|c|c|c|}
\hline \multicolumn{2}{|c|}{ Strain } & \multicolumn{7}{c|}{ Storage terms, months } \\
\cline { 3 - 8 } & $\mathbf{0 . 5}$ & $\mathbf{1}$ & $\mathbf{2}$ & $\mathbf{3}$ & $\mathbf{4}$ & $\mathbf{5}$ & $\mathbf{6}$ \\
\hline \multicolumn{2}{|c|}{ Bradyrhizobium japonicum LG 2, billion/ml } & 3.4 & 3.5 & 3.7 & 3.2 & 2.5 & 2.1 & 1.7 \\
\hline \multirow{2}{*}{ Outdoor microflora, \% } & extraneous bacrteria & 0 & 0 & 0.1 & 0.2 & 0.2 & 0.4 & 0.4 \\
\cline { 2 - 8 } & micromycetes & 0 & 0 & 0 & 0 & 0 & 0 & 0 \\
\hline \multicolumn{2}{|c|}{ Bradyrhizobium japonicum LG 5, billion/ml } & 4.2 & 4.4 & 4.6 & 3.5 & 3.2 & 2.4 & 2.1 \\
\hline \multirow{2}{*}{ Outdoor microflora, \% } & extraneous bacrteria & 0 & 0 & 0.1 & 0.2 & 0.2 & 0.2 & 0.3 \\
\cline { 2 - 9 } & micromycetes & 0 & 0 & 0 & 0 & 0 & 0 & 0 \\
\hline
\end{tabular}


The number of viable microorganisms on soybean seeds when processing the culture broth of nodule bacteria in combination with various treaters

\begin{tabular}{|c|c|c|c|c|}
\hline \multicolumn{3}{|c|}{ Variant } & $\begin{array}{c}\text { Bradyrhizobium japonicum } \\
\text { thousand CFU ( } 30 \text { days) }\end{array}$ & $\begin{array}{c}\text { Bradyrhizobium japonicum } \\
\text { thousand CFU (60 days) }\end{array}$ \\
\hline 1 & \multirow{3}{*}{ Rizoaktiv R } & Treater Maxim & $3.91 \pm 0.2$ & $3.12 \pm 0.2$ \\
\hline 2 & & Treater Vitavaks $200 \mathrm{FF}$ & $3.45 \pm 0.2$ & $2.95 \pm 0.2$ \\
\hline 3 & & Treater Redigo M & $2.31 \pm 0.2$ & $1.92 \pm 0.2$ \\
\hline 4 & \multirow{3}{*}{ Strain LG 2} & Treater Maxim & $3.71 \pm 0.2$ & $2.02 \pm 0.1$ \\
\hline 5 & & Treater Vitavaks $200 \mathrm{FF}$ & $3.23 \pm 0.1$ & $0.96 \pm 0.1$ \\
\hline 6 & & Treater Redigo M & $1.06 \pm 0.1$ & $0.92 \pm 0.2$ \\
\hline 7 & \multirow{3}{*}{ Strain LG 5} & Treater Maxim & $3.15 \pm 0.5$ & $3.06 \pm 0.2$ \\
\hline 8 & & Treater Vitavaks $200 \mathrm{FF}$ & $7.16 \pm 0.3$ & $4.68 \pm 0.2$ \\
\hline 9 & & Treater Redigo M & $2.45 \pm 0.2$ & $2.14 \pm 0.1$ \\
\hline 10 & \multirow{3}{*}{$\begin{array}{l}\text { Strain (LG } 2 \\
\quad+\text { LG 5) }\end{array}$} & Treater Maxim & $2.91 \pm 0.5$ & $3.21 \pm 0.5$ \\
\hline 11 & & Treater Vitavaks $200 \mathrm{FF}$ & $3.69 \pm 0.2$ & $0.83 \pm 0.3$ \\
\hline 12 & & Treater Redigo M & $4.21 \pm 0.2$ & $3.21 \pm 0.5$ \\
\hline
\end{tabular}

ulum with a low titer of cells (biological inoculation) contributes to the adaptation of bacteria to the substrate, which form a new population of the strain [10].

Soybean seeds, which were treated with the most commonly used treaters for today (Maxim, Vitawax 200 FF, Redigo M) and inoculated of culture brothof the nodule bacteria strains selected by us in previous studies [11]. Seed treatment is a complex action aimed at destroying the infection of plant or bacterial origin and suppressing infections in the soil and creating a danger to plants, reducing their density and crops, suppressing their growth and development in general. This allows for treatment to protect against diseases and pests in combination with soybean inoculation, which reduces the chemical load on crops and reduces the number of treatments [12].

Among the variants presented in our research, we can say that when applying culture broth of strains of Bradyrhizobium japonicum LG 2 and LG 5 and protectant Vitavaks $200 \mathrm{FF}$, which has a fungicidal effect and acts as a growth regulator, the number of viable nodule bacteria of all the experience options was $3.23 \cdot 10^{3}$ CFU and $7.16 \cdot 10^{3} \mathrm{CFU}$, and in the composition of both strains $-3.69 \cdot 10^{3} \mathrm{CFU}$ (Table 2).

In the variants with the use of the mentioned strains and the treater Maxim, which has fungicidal properties, the following place was noted in terms of the number of viable nitrogen-fixing bacteria grown on solid MDA $3.15-3.71 \cdot 10^{3} \mathrm{CFU}$ among the variants presented in the studies and $-2.91 \cdot 10^{3} \mathrm{CFU}$ in the composition of both strains.

The lowest in the number of nodule bacteria was characterized by the variants with the use of culture broth Bradyrhizobium japonicum LG 2 and LG 5 and the treater of Redigo M. The number of CFU there was 1.06-2.45 $\cdot 10^{3} \mathrm{CFU}$, and when applying the composition of culture broth (LG $2+$ LG 5) $-4.21 \cdot 10^{3}$ CFU.

Thus, we can conclude that after 30 days from the moment of seed treatment with drugs (inoculum and dis- infectants), a large number of nitrogen-fixing microorganisms are still on the surface of the seeds.

A month later, a similar microbiological seeding of the experimental variants presented in the studies was carried out, that is, in just 60 days. A similar trend was observed in the number of nitrogen-fixing microorganisms of the genus Bradyrhizobium japonicum on the surface of soybean seeds after washing in an aqueous solution. Inoculation increases the storage period of microorganisms on the surface of soybean seeds, where every hour it is extremely important to characterize the practicality of using the drug based on these strains of bacteria. For comparison, the table shows the dynamics of the number of modern soybean inoculum Rizoaktiv R.

Thus, when using culture fluids in a composition with modern disinfectants, it is possible to preserve the quality of seeds, to provide protection against diseases along with the subsequent increase in nitrogen-fixing activity of symbiotic systems, which will be formed due to soybean nodule bacteria. The use of high-quality inoculants with a high content of nitrogen-fixing bacteria for the treatment of seeds of leguminous crops is today a necessary practice, which will ensure good yields for a better return on investment.

Conclusions. Consequently, the presence of viscous exopolysaccharides that synthesize the tuber bacterial strains Bradyrhizobium japonicum LG 2 and LG 5 protects against the effects of factors damaging bacterial cells, as well as contributes to cell retention on the surface of the seed. Based on the conducted research, the effectiveness of the preparation of culture broth of the strains of nitrogen-fixing soybean nodule bacteria Bradyrhizobium japonicum LG 2 and LG 5 for the treatment of soybean seeds using modern disinfectants Maxim, Vitavaks 200 FF, Redigo M with protective fungicidal and regulatory properties for the survival of bacteria of the genus Bradyrhizobium japonicum was established. 


\section{References}

1. Herridge D. Inoculants and Nitrogen Fixation of Legumes in Vietnam. Brisbane: PK Editorial Services, $2002.116 \mathrm{p}$.

2. Stephens J.H.G., Rask H.M. Inoculant production and formulation. Field Crops Research. 2000. Vol. 65. Issue 2/3. P. $249-258$.

3. Schulz T.J., Thelen K.D. Soybean seed inoculant and fungicidal seed treatment effects on soybean. 2008. Crop Science. Vol. 48. P. $1975-1980$.

4. Date R.A. Advances in inoculant technology: a brief review. Australian Journal of Experimental Agriculture. 2001. Vol. 41. Issue 3. P. 321-325.

5. Alternatives to peat as a carrier for rhizobia inoculant: solid and liquid formulations / M. Albareda, D. Rodriguez-Navarro, M. Camacho, F. Temprano. Soil Biol Biochem. 2008. Vol. 40. P. 2771-2779.

6. Synthesis of exopolisaccharides by Bradyrhizobium japonicum isolates / I.I. Gumeniuk, S.Yu. Gruzinskii, I.S. Brovko, Ya.V. Chabanyuk. Ekolohichni nauky. 2018. № 22. P. 153-156.

7. Hotjanovich A.V. Metody kultivirovanija azotfiksirujushhih bakterij, sposoby poluchenija i primenenija preparatov na ih osnove: Methods for cultivating nitrogen-fixing bacteria, methods for preparing and using preparations based on them. Leningrad, $1991.60 \mathrm{p}$.

8. TCC 319.00494456-006. 2002. Preparat bulbochkovych bakterii pid bobovi kultury - Ryzobofit [Preparation of nodule bacteria for legumes - Rizobofit].

9. Biopreparaty azotfiksirujushhih bakterij: problemy i perspektivy primenenija / E.V. Sherstoboeva, I.A. Dudinova, S.N. Kramarenko, N.K. Sherstoboev. Micriobilogy journal. 1997. № 4. P. 109-116.

10. Screening of aboriginal Bradyrhizobium bacteria from soil and their symbiotic properties / I.I. Gumeniuk, S.Yu. Gruzinskii, I.S. Brovko, Ya.V. Chabanyuk. Agroecological journal. № 3. P. 77-81.

11. Ekolohichna ocinka vplyvu pestycydiv ta agrochimikativ na gruntovi mikroorganizmy: metodychni rekomendaciii / Ya.V. Chabanyuk, O.V. Sherstoboeva, V.V. Chaikovska, A.M. Klymenko, V.U. Yashchuk, A.P. Korecky, G.O. Iutynska. Kyiv, 2015. 63 p.

12. Catroux G, Hartmann A, Revellin C. Trends in rhizobial inoculant production and use. Plant Soil. 2001. № 230. P. 21-30. 


\title{
РОЗВИТОК ПРИРОДНО-ЗАПОВІДНОГО ФОНДУ УКРАЇНИ
}

\author{
УДК 502/504:712.252:58 (447.81) \\ DOI https://doi.org/10.32846/2306-9716-2018-4-23-28
}

\section{ЕКОАОГІЧНИЙ І ГЕОГРАФІЧНИЙ АНАМІЗ ДЕНДРОФАОРИ ШТУЧНИХ ЗАПОВІДНИХ ПАРКІВ РІВНЕНСЫКОЇ ОБААСТІ}

\author{
Покотилова К.Г. \\ Національний університет біоресурсів і природокористування України \\ вул. Генерала Родимцева, 19, м. Київ, 03041
}

KamilaPG@ukr.net

\begin{abstract}
У статті наведено результати дослідження екологічної та географічної структур дендрофлори 25 штучних заповідних парків Рівненської області. Досліджена дендрофлора представлена 481 видом деревних рослин. Екологічний аналіз показав значну частку видів світлолюбних рослин (53,64\%). За відношенням до вологи переважають мезофіти (32,02\%) та ксерофіти (28,27\%). Більша кількість видів належить до екогрупи морозостійких рослин $(63,83 \%)$. За відношенням до родючості грунту першою $\epsilon$ екогрупа мезотрофів (47,89\%). Дендрофлору досліджених штучних заповідних парків становлять автохтонні (19,33\%) й екзотичні $(80,67 \%)$ види деревних рослин, які природно поширені в Голарктичному царстві, Циркумбореальній, Східноазійській, Ірано-Туранській, Атлантико-Північноамериканській, Мадреанській, області Скелястих гір, Середземноморській і СахароАравійській флористичних областях. Лише $66,75 \%$ видів-екзотів природно ростуть у межах однієї флористичної області. Найбільша їх кількість в Ірано-Туранській (74 види) і Циркумбореальній (64 види) флористичних областях. Із двох флористичних областей походять 116 видів (29,90\%), з трьох - 13 видів рослин $(3,35 \%)$. В автохтонній фракції дендрофлори переважають види рослин європейського (52 види) та євразійського (17 видів) типів ареалів. Вони представляють 31 геоелемент, із яких до європейського геоелементу належать 20 видів деревних рослин. Ключові слова: види деревних рослин, екофактори, екогрупи, флористичні області, типи ареалів, геоелементи.
\end{abstract}

Экологический и географический анализ дендрофлоры искусственных заповедных парков Ровенской области. Покотилова К.Г. В статье приведены результаты исследования экологической и географической структур дендрофлоры 25 искусственных заповедных парков Ровенской области. Исследованную дендрофлору представляет 481 вид древесных растений. Экологический анализ показал значительную часть видов светолюбивых растений $(53,64 \%)$. По отношению к влаге преобладают мезофиты $(32,02 \%)$ и ксерофиты $(28,27 \%)$. Большее количество видов относится к экогруппе морозостойких растений $(63,83 \%)$. По отношению к плодородию почвы первой является экогруппа мезотроф (47,89\%). Дендрофлору исследованных искусственных заповедных парков составляют автохтонные $(19,33 \%)$ и экзотические $(80,67 \%)$ виды древесных растений, естественно распространены в Голарктическом царстве, Циркумбореальной, Восточноазиатской, Ирано-Туранской, Атлантико-Североамериканской, Мадреанской, области Скалистых гор, Средиземноморской и Сахаро-Аравийской флористических областях. Только $66,75 \%$ видов-экзотов естественно произрастают в пределах одной флористической области. Наибольшее их количество в Ирано-Туранской (74 вида) и Циркумбореальной (64 вида) флористических областях. Из двух флористических областей происходят 116 видов $(29,90 \%)$, из трех - 13 видов растений $(3,35 \%)$. В автохтонных фракциях дендрофлоры преобладают виды растений европейского (52 вида) и евразийского (17 видов) типов ареалов. Они представляют 31 геоелемент, к европейскому геоелемента принадлежат 20 видов древесных растений. Ключевые слова: виды древесных растений, екофакторы, экогруппы, флористические области, типы ареалов, геоелементы.

Ecological and geographical analysis of dendroflora of artificial protected parks in the Rivne region. Pokotylova K. The article presents the results of the study of ecological and geographic structure of dendroflora of 25 artificial protected parks in the Rivne region. The studied dendroflora is represented by 481 species of woody plants. Ecological analysis showed a significant part of light-loving species of plants (53.64\%). In regard to moisture prevail mesophytes (32.02\%) and xerophytes (28.27\%). The larger part of species belongs to the ecological group of frost-resistant plants $(63.83 \%)$. As to the soil fertility, the eco-group of mesotrophs $(47.89 \%)$ is the first one. Dendroflora of the artificial protected parks consists of native (19.33\%) and exotic (80.67\%) species of woody plants, which are naturally widespread in the Holarctic kingdom, Circumboreal, Eastern Asiatic, Irano-Turanian, Atlantic North American, Madrean, Rocky Mounain, Mediterranean and Sahara-Arabic floristic areas. Only $66.75 \%$ of exotic species naturally grow within one floristic region. The largest number is in the Irano-Turanian (74 species) and Circumboreal (64 species) floristic regions. From two floristic regions comes -116 species $(29.90 \%)$, from three -13 species of plants $(3.35 \%)$. In the native fraction, dendroflora is dominated by plant species of European ( 52 species) and Eurasian (17 species) types of habitats. They represent 31 geoelements, 20 species of woody plants belong to the European geoelement. Key words: woody species, ecofactors, ecological groups, floristic regions, types of habitats, geoelements. 
Постановка проблеми. Для стабілізації антропічних змін дендрофлори особливо актуальною є проблема формування й розвитку природно-заповідного фонду, штучні об'єкти ботанічного профілю якого є найбільшими та найважливішими осередками концентрації іiї видів. Структурний аналіз дендрофлори штучних заповідних парків (далі - ШЗП) - надзвичайно важливий напрям у розвитку дендрології. Саме в цих парках зосереджуються дослідження акліматизації, росту й розвитку передусім раритетних видів деревних рослин, що дає можливість їх перспективного використання в озелененні. Тому дослідження екологічної та географічної структури дендрофлори ШЗП є актуальним і важливим аспектом для подальшого збагачення урболандшафтів як одного із сучасних напрямів збереження й оптимізації стану навколишнього природного середовища.

Мета дослідження. Головною метою дослідження було проаналізувати екологічну та географічну структури дендрофлори ШЗП Рівненської області задля подальшого використання отриманих результатів у природоохоронних і парково-господарчих цілях. Об'єктом дослідження стала дендрофлора ШЗП Рівненської області, а предметом дослідження - екологічний і географічний структурний флористичний аналіз видового складу деревних рослин цих парків.

Аналіз останніх досліджень i публікацій. Дендрофлористичні дослідження різних парків проводили як зарубіжні, так і вітчизняні вчені. Із зарубіжних дослідників вивчали дендрофлору різних парків С. Абендрот, І. Коварик, Н. Мюллер (Індонезія) [1], Д. Тафра, М. Пандза, М. Мілович (Хорватія) [2], М. Дудкевич, М. Дабські, В. Дурлак (Польща) [3], А. Ташев, С. Тсавков (Болгарія) [4], Х. Фігеро, С. Кастро, М. Реєс, С. Тельє (Чилі) [5] та інші. Водночас досить часто вчені досліджували дендрофлору ШЗП в різних куточках України. Зокрема, О.М. Попова, В.О. Кузнєцов, Л.П. Осадча проводили спостереження в м. Одесі [6], Н.В. Михайлович у м. Чернівці [7], Н.О. Сиплива - на Вінниччині [8], А.С. Власенко - загалом на території Степу України [9], Т.О. Бойко, О.І. Дементьєва в м. Херсоні [10] та інші. Що стосується території Українського Полісся, то дослідженням аналізу структури дендрофлори ШЗП (зокрема екологічної та географічної) приділяли увагу С.О. Потоцька (м. Чернігів) [11], Л.О. Коцун (Волинська обл.) [12], Ф.Ф. Марков (Житомирщина) [13], А.М. Савоськіна, М.Ю. Шерстюк, С.Ю. Попович (Українське Полісся) $[14 ; 15]$ та інші. Однак досі ніхто не досліджував структуру дендрофлори ШЗП Рівненської області.

Методологічне або загальнонаукове значення. Як відомо, північна частина Рівненської області знаходиться в межах Українського Полісся, а південна в зоні широколистяних лісів (далі - ЗШЛ). У зв'язку 3 цим ми проводили порівняння отриманих результатів дослідження екологічної та географічної струк- тур дендрофлори ШЗП відповідно до двох частин цієї області.

Екологічний аналіз дендрофлори досліджуваної території здійснено на основі традиційного підходу, який полягає в поділі видів рослин на екогрупи стосовно обраного екофактору [16]. Для оцінювання екологічної структури дендрофлори ШЗП Рівненської області оцінювали відношення видів рослин до світла, вологи, температури і трофності грунту. Задля оцінювання географічної структури дендрофлори визначали належність видів рослин до флористичних областей Землі за працею А.Л. Тахтаджяна [17] (для екзотів) і карти ботаніко-географічних районів Земної кулі, розробленої X. Мойзелем $[18 ; 19]$ (для автохтонів).

Виклад основного матеріалу. У результаті проведення польових досліджень нами виявлено, що дендрофлора ШЗП Рівненської області нараховує 481 вид рослин. Для аналізу екологічної структури дендрофлори обраних об'єктів необхідно провести розподіл видів деревних рослин на певні екогрупи стосовно їх потреб до основних екофакторів: світла, вологи, температури, трофності грунту.

За відношенням до освітленості види рослин розподіляються на три екогрупи: геліофіти, геміскіофіти і скіофіти. Виявлено, що переважна частина видів $(53,64 \%)$ належить до екогрупи геліофітів (Juniperus horizontalis Moench., Abies balsamea (L.) Mill., Prunus spinosa L. тощо). Наступною за кількістю видів $є$ екогрупа геміскіофітів, яка становить 26,4\% (Abies concolor Lindl. et Gord., Acer ginnala Maxim., Viburnum opulus L. тощо). Екогрупа скіофітів найменш представлена в дендрофлорі 19,96\% (Acer ginnala Maxim. L., Taxus cuspidata Siebold \& Zucc., Physocarpus opulifolius (L.) Maxim. тощо). За відношенням до цього самого екофактору відсоткове співвідношення видів дендрофлори ШЗП в поліській частині області майже не відрізняється від загальних даних по області: геліофітні види становлять 53,38\% (від кількості видів у цій частині області), геміскіофіти - 26,37\% і скіофіти - 20,25\%. Інша картина спостерігається в ЗШЛ області: на першому місці за кількістю видів також є геліофіти $54,33 \%$, однак друге місце посідають скіофіти $25,98 \%$, найменша кількість геміскіофітів - 19,69\%. Тобто в північних і південних об'єктах дослідження переважають світлолюбні види дендрофлори. Однак у перших найменшу частку становлять скіофіти, а у другій - геміскіофіти.

За відношенням до вологості всі виявлені види деревних рослин розподіляються на сім екогруп і підгруп: ксеро-, ксеромезо-, мезоксеро-, мезо-, мезогігро-, гігромезо- та гігрофіти. У дендрофлорі ШЗП Рівненської області виявлено найбільшу кількість мезофітних видів деревних рослин - 32,02\%. Наступною за кількістю видів $є$ екогрупа ксерофітів - 28,27\%, ксеромезофіти становлять 13,10\%, мезогігрофіти - 9,56\%, гігрофіти - 9,15\%, мезоксе- 
рофіти й гігромезофіти мають найменші частки 5,20\% та 2,70\% відповідно. Майже ідентичні дані отримано за розподілу видів дендрофлори залежно від їх відношення до водного режиму в північній частині області: мезофіти становлять 32,28 \% від кількості видів на цих об'єктах, ксерофіти - 27,64\%, ксеромезофіти - 13,29\%, мезогігрофіти - 9,50\%, гігрофіти - 9,28\%, мезоксерофіти - 5,27\% та гігромезофіти - 2,74\%. Розподіл видів дендрофлори об'єктів дослідження, розташованих у південній частині області, стосовно цього екофактору також незначно відрізняється від загальних показників. Мезофітних видів тут виявлено 34,65\% від кількості видів на цих об'єктах, ксерофітних - 30,71\%, ксеромезофітних - 11,81\%, мезогігрофітних - 10,24\%, гігрофітних - 6,29\%, мезоксерофітних - 3,94\% та гігромезофітних - 2,36\%. Отже, загалом як по всіх об'єктах області, так й окремо по двох іiі частинах найбільше представлена екогрупа мезофітів, а найменша кількість проглядається в екогрупі гігромезофітних видів.

За відношенням видів деревних рослин до температурного режиму розподіляли їх на такі екогрупи: дуже морозостійкі, морозостійкі, відносно морозостійкі, неморозостійкі й теплолюбні. Найбільш репрезентованими виявились екогрупи морозостійких $(63,83 \%)$ та відносно морозостійких видів (26,40\%). Незначна частина видів належить до дуже морозостійких - 4,16\%, теплолюбних - 3,12\% та неморозостійких - 2,49\%. Така сама динаміка спостерігалася під час розгляду дендрофлори південних і північних об'єктів окремо.

За відношенням рослин до трофності грунту всі виявлені види поділено на оліготрофи, мезотрофи та евтрофи. Зазвичай переважна частка належить до мезотрофів - 47,40\%, оліготрофні види становлять $28,48 \%$, евтрофи - 24,12\%. Подібна ситуація спостерігається в поліських об'єктах: мезотрофи становлять $47,89 \%$, оліготрофи - 28,27\%, евтрофи $23,84 \%$. Інша картина виявилась за розподілу досліджуваних видів ШЗП ЗШЛ області щодо вимогливості до родючості грунтових умов. Переважаюча за кількістю видів $є$ екогрупа евтрофів - 36,22\%, мезотрофи становлять $33,07 \%$, найменша частка видів належить до екогрупи оліготрофних - 30,71\%. Тобто переважна частка видів ШЗП області загалом, а також північних об'єктів зокрема середньо вибагливі до родючості грунту. Найменша ж кількість видів вимагає багатих грунтових умов. Дендрофлора досліджуваних парків, розташованих у межах ЗШЛ Рівненської області, представлена більшою мірою евтрофами, найменша кількість видів деревних рослин є оліготрофами.

Підсумовуючи результати дослідження екологічної структури дендрофлори досліджуваних об'єктів, уважаємо, що загалом види рослин дендрофлори ШЗП Рівненської області переважно геліофітні, мезофітні, морозостійкі та мезотрофні. Така сама ситуація в дендрофлорі досліджуваних парків, розташованих у межах Українського Полісся. Проте у видовому складі дендрофлори ШЗП ЗШЛ відмічено деякі відмінності від загальної картини: за рівнем трофності грунту переважають евтрофні види рослин.

Для оцінки географічної структури дендрофлори ШЗП Рівненської області необхідно встановити ареал природного поширення кожного виду рослин. У результаті виявлено, що загалом на території дослідження росте 93 (19,33\%) автохтонні і 388 (80,67\%) екзотичних видів деревних рослин. Дендрофлора поліської частина ШЗП області представлена 90 $(18,99 \%)$ автохтонними та 384 (81,01\%) екзотичними видами, інша південна частина - 55 (43,31\%) автохтонами та $72(56,69 \%)$ екзотами.

У результаті дослідження географічної структури ШЗП установлено, що дендроекзофлору всіх об’єктів області представляють види, які природно зростають у Голарктичному царстві, а саме у восьми флористичних областях: Циркумбореальній, Східноазійській, Ірано-Туранській, АтлантикоПівнічноамериканській, Модреанській, області Скелястих гір, Середземноморській і СахароАравійській областях. Один вид має невідоме походження.

3 усієї фракції екзотів лише 66,75\% природно ростуть у межах однієї флористичної області. Найбільша кількість таких видів представляє ІраноТуранську область - 74 види (18,81\% від загальної кількості екзотів). Це такі види: Pinus wallichiana A.B. Jacks., Cotoneaster horizontalis Decaisne, Malus niedzwetzkyana Diek ex Koehne тощо. Наступна за кількістю видів Циркумбореальна флористична область - 64 види (16,49\%). 3 неї походять Picea omorica (Pancic) Purk., Pinus nigra J. F. Arnold, Malus domestica Borkh. тощо. В АтлантикоПівнічноамериканській флористичній області природно росте 57 виявлених у ШЗП видів (14,69\%): Abies balsamea (L.) Mill., Ribes aureum Pursh, Robinia viscosa Vent. тощо. Східноазійська область представлена 48 видами (12,37\%): Abies holophylla Maxim., Pinus koraiensis Siebold \& Zucc., Kerria japonica (L.) DC. тощо. 3 флористичної області Скелястих гір походять вісім виявлених видів (2,06\%): Picea pungens Engelm., Pseudotsuga menziesii (Mirb.) Franco, Berberis aquifolium Pursh тощо. Мадреанська флористична область - це батьківщина семи досліджуваних видів (1,80\%): Chamaecyparis lawsoniana Parl., Amorpha glabra Desf. ex Poir., Catalpa bignonioides Walt. Середземноморську флористичну область представляє лише один вид (0,26\%) - Abies pinsapo Boiss.

Значно менша кількість дендроекзотів, які природно поширені у двох флористичних областях, - 116 видів (29,90\%). Серед виявлених екзотів, що природно розповсюджені у двох флористичних областях, більша кількість представляє комбінацію Східноазійської та Циркумбореальної 
областей (30 видів, 7,73\% від загальної кількості екзотів) - Larix gmelinii (Rupr.) Kuzen., Cornus alba L., Sorbaria sorbifolia (L.) A. Braun тощо. За кількістю видів деревних рослин комбінація Східноазійської та Ірано-Туранської областей посідає друге місце (26 видів, 6,70\%) - Juniperus squamata Buch.-Ham. ex D. Don, Platycladus orientalis (L.) Franco, Styphnolobium japonicum (L.) Schott та тощо. Водночас Циркумбореальну й АтлантикоПівнічноамериканську область репрезентують 25 видів (6,44\%), зокрема Juniperus virginiana L., Tsuga canadensis (L.) Carriere, Spiraea salicifolia L тощо.

Незначна кількість екзотів (13 видів, 3,35\%) у різних комбінаціях охоплює межі трьох флористичних областей. У межах Циркумбореальної, Ірано-Туранської та Східноазійської флористичних областей природно росте п'ять виявлених видів (1,29\%). Комбінацію Циркумбореальної, Атлантико-Північноамериканської й Мадреанської областей представляють два види (0,52\%). Також два екзоти водночас охоплюють область Скелястих гір, Циркумбореальну й АтлантикоПівнічноамериканську флористичні області. Такі комбінації, як Ірано-Туранська, Судано-Аравійська та Індійська; Східноазійська, Ірано-Туранська й Середземноморська; Циркумбореальна, ІраноТуранська та Сахаро-Аравійська; Циркумбореальна, Сахаро-Аравійська й Середземноморська флористичні області, делегували в ШЗП Рівненської області по одному виду (по 0,26\%). Один вид деревної ліани має невизначену область природного походження Vitis vinifera L.

Дендрофлора ШЗП Українського Полісся регіону дослідження представлена видами, які природно походять із таких флористичних областей: Циркумбореальної, Східноазійської, ІраноТуранської, Атлантико-Північноамериканської,
Мадреанської та області Скелястих гір. Найбільша кількість досліджуваних видів походить 3 ІраноТуранської флористичної області - 73 види, 19,01\% від кількості екзотів на цих територіях. У північних об'єктах дослідження також виявлено види деревних рослин, у яких межі природного поширення охоплюють дві флористичні області в таких самих комбінаціях по області загалом. Переважна кількість таких видів походить зі Східноазійської та Циркумбореальної областей (29 видів). Як по всіх досліджуваних ШЗП області, так і поліських об'єктах зокрема дендрофлора включає види рослин, що поширені у трьох флористичних областях. Більша частина 3 них також характерна для Циркумбореальної, Ірано-Туранської, Східноазійської флористичних областей.

На територіях ШЗП ЗШЛ Рівненської області виявлено види, поширення яких обмежується однією флористичною областю: Циркумбореальною, Східноазійською, Ірано-Туранською, Атлантико-Північноамериканською, Мадреанською, областю Скелястих гір чи Середземноморською. Види Циркумбореальної флористичної області найбільш представлені в південних об'єктах дослідження (14 видів). Дві флористичні області охоплює поширення 25 видів. Ïx поширення комбінуються так: Циркумбореальна та Антлантико-Північноамериканська, Циркумбореальна й Ірано-Туранська, Східноазійська та ІраноТуранська, Східноазійська й Циркумбореальна, Середземноморська та Сахаро-Аравійська, Середземноморська й Циркумбореальна флористичні області. Чотири види комбінують три флористичні області: Циркумбореальну, Атлантико-Північноамериканську та Мадреанську (два види), Східноазійську, Ірано-Туранську, Середземно-морську й Циркумбореальну, Ірано-Туранську та Східноазійську, відповідно по одному виду деревних рослин.

Таблиця 1

Кількісний спектр видів автохтонної дендрофлори ШЗП Рівненської області за регіональними типами ареалів

\begin{tabular}{|c|c|c|c|c|c|c|}
\hline \multirow[t]{2}{*}{ Типи ареалів } & \multicolumn{2}{|c|}{$\begin{array}{l}\text { Кількість видів } \\
\text { частини ЗШЛ }\end{array}$} & \multicolumn{2}{|c|}{$\begin{array}{c}\text { Кількість видів } \\
\text { поліської частини }\end{array}$} & \multicolumn{2}{|c|}{$\begin{array}{c}\text { Кількість видів } \\
\text { по області у цілому }\end{array}$} \\
\hline & IIIT. & $\%$ & IIIT. & $\%$ & IIIT. & $\%$ \\
\hline Східноєвропейсько-азійський & 1 & 1,82 & 1 & 1,11 & 1 & 1,08 \\
\hline Європейсько-західносибірський & 3 & 5,45 & 3 & 3,33 & 3 & 3,22 \\
\hline Європейський & 35 & 63,64 & 50 & 55,56 & 52 & 55,91 \\
\hline Євразійський & 9 & 6,36 & 17 & 18,89 & 17 & 18,28 \\
\hline Свропейсько-центральноазійський & 1 & 1,82 & 2 & 2,22 & 2 & 2,15 \\
\hline Євразійський диз'юктивний & - & - & 3 & 3,33 & 3 & 3,22 \\
\hline Циркумбореальний & 3 & 5,45 & 4 & 4,45 & 4 & 4,30 \\
\hline Східноєвропейсько-західносибірський & - & - & 1 & 1,11 & 1 & 1,08 \\
\hline Середземноморський & - & - & 3 & 3,33 & 3 & 3,22 \\
\hline Субсередземноморський & 2 & 3,64 & 4 & 4,45 & 5 & 5,38 \\
\hline Свропейсько-південносибірський & 1 & 1,82 & 1 & 1,11 & 1 & 1,08 \\
\hline Номадійський & - & - & 1 & 1,11 & 1 & 1,08 \\
\hline Усього & 55 & 100 & 90 & 100 & 93 & 100 \\
\hline
\end{tabular}


Під час аналізу географічної структури автохтонної фракції дендрофлори ШЗП Рівненської області виявлено належність видів до певних типів ареалів. Отже, автохтонні види деревних рослин репрезентують 12 типів ареалів. Зазвичай переважна частина цих видів представляє європейський (52 види) та євразійський (17 видів) типи ареалів. П'ять видів рослин репрезентують субсередземноморський тип ареалу, чотири види - циркумбореальний, по три види - європейсько-західносибірський, євразійський диз'юктивний і середземноморський типи ареалів, два види - європейсько-центральноазійський, а також по одному виду представляють східноєвропейсько-азійський, східноєвропейсько-західносибірський, європейсько-південносибірський і номадійський типи ареалів (таблиця 1).

Автохтонні види деревних рослин поліських об'єктів дослідження репрезентують 12 типів ареалів. Натомістьавтохтониіншоїчастини областіпредставляють вісім типів ареалів. Установлено, що переважання автохтонів дендрофлори європейського типу ареалу характерне для дендрофлори ШЗП обох частин області.

Загалом дендрофлора ШЗП Рівненської області складається 3 автохтонних видів, які представляють 31 геоелемент. Найбільша кількість видів належить до європейського геоелементу (20 видів), по дев'ять видів зараховано до євразійського та неморального геоелементів, вісім видів - до бореального, сім видів - до західноєвропейського неморального, шість видів - до східноєвропейського степового, чотири види - до європейського неморального, по три види - до субсередземноморського гірського і степового, по два види - до монтанного та диз'юктивного неморального. Решту 20 геоелементів представлено по одному виду.
Дендрофлора ШЗП поліської частини області володіє видами, які належать до таких самих геоелементів, як і в загальній картині належності автохтонних видів деревних рослин до геоелементів по області загалом. Однак від цих показників значно відрізняється характер розподілу автохтонів дендрофлори ШЗП частини ЗШЛ у межах області, де виявлені види репрезентують лише 18 геоелементів. Однакову кількість автохтонів зараховано до європейського та неморального геоелементів - по вісім видів. По шість видів представляють західноєвропейський неморальний, бореальний i євразійський геоелементи, п'ять видів - східноєвропейський степовий, три види - степовий, по два види - європейський неморальний i монтанний геоелементи. По одному виду має решта дев'ять геоелементів.

Головні висновки. У мережі штучних природоохоронних територій насамперед необхідно звертати увагу на екологічні особливості кожного виду деревних рослин, а також на його природний і культигенний ареали. Загалом дендрофлору ШЗП Рівненської області здебільшого становлять світлолюбні $(53,64 \%)$, мезофітні $(32,02 \%)$, морозостійкі $(63,83 \%)$ та мезотрофні $(47,40 \%)$ види рослин. Із дослідженого флористичного складу (481 вид) $19,33 \%$ зараховано до фракцій автохтонних і 388 80,67\% - екзотичних видів деревних рослин. Досліджені дендроекзоти представляють переважно Голарктичне царство (вісім флористичних областей). Найбільша кількість видів природно ростуть в Ірано-Туранській $(18,81 \%)$ та Циркумбореальній $(16,49 \%)$ флористичних областях. Виявлені дендроавтохтони репрезентують 12 типів ареалу та 31 геоелемент.

1. Abendroth S., Kowarik I., Muller. N. The green colonial heritage: Woody plants in parks of Bandung, Indonesia. Landscape and urban planning. T. 106. № 1. 2012. P. 12-22.

2. Tafra D., Pandza M., Milovic M. Woody plants of the Omis. The nature of Croatia. № 2. 2012. P. 301-334.

3. Dudkiewicz M., Dabski M., Durlak W. Dendroflora zabytkowego parku w Kijanach. Formatio circumiectus. 2015. № 14. P. $15-25$.

4. Tashev A., Tsavkov E. Dendroflora of calcareous terrains in Bulgaria and its significance for conservation. Nature Conservation Research. 2016. № 1. P. 70-77.

5. Figueroa J., Castro S., Reyes M., Teillier S. Urban park area and age determine the richness of native and exotic plants in parks of a Latin American city: Santiago as a case study. Urban ecosystems. 2012. T. 21. № 4. P. 645-655.

6. Попова Е.Н., Кузнецов В.О., Осадчая Л.П. Дендрофлора парков-памятников садово-паркового искусства города Одессы. Науч. зап. Гос. природоведч. музея. 2007. № 23. С. 145-156.

7. Михайлович Н.В. Структурний аналіз дендрофлори парку-пам'ятки садово-паркового мистецтва «Чернівецький парк культури і відпочинку ім. Т.Г. Шевченка». Науковий вісник Національного університету біоресурсів і природокористування України. Серія «Лісівництво та декоративне садівництво». 2014. № 1. С. 175-180.

8. Сиплива Н.О. Інвентаризаційні дослідження парків-пам'яток садово-паркового мистецтва Вінниччини. Вісник Національного науково-природничого музею. 2014. № 12. С. 116-122.

9. Власенко А.С. Заповідна дендросозофлора EX SITU Степу України: дис. ... канд. біол. наук: спец. 06.03.01. Київ: Національний університет біоресурсів і природокористування України, 2016. 229 с.

10. Boiko T.O., Dementieva O.I. The tree vegetation of the Kherson State Agrarian University Arboretum. Ukrainian journal of ecology. 2018. № 8 (2). P. 120-127.

11. Потоцька С.О. Порівняльний аналіз дендрофлори зелених насаджень міста Чернігова. Науковий вісник Ужгородського університету. 2012. № 33. С. 64-70.

12. Коцун Л.О. Парки-пам’ятки садово-паркового мистецтва Волинського Полісся. Науковий вісник Волинського державного університету імені Лесі Українки. 2007. № 11. С. 162-166. 
13. Марков Ф.Ф. Структура насаджень і територіальна організація старовинних парків-пам'яток садово-паркового мистецтва Житомирщини: автореф. дис. ... канд. с.-г. наук: спец. 06.03.01. Київ: Житомирський державний агроекологічний університет, 2015. 20 c.

14. Савоськіна А.М. Біоморфологічна та екологічна структура екзотичної дендросозофлори штучних заповідних парків Українського Полісся. Науковий вісник Східноєвропейського національного університету імені Лесі Українки. 2016. № 7. C. 59-65.

15. Шерстюк М.Ю., Попович С.Ю. Заповідні дендросозоавтохтони Українського Полісся : монографія. Київ, 2018.272 с.

16. Калініченко О.А. Декоративна дендрологія: навчальний посібник. Київ, 2003. 200 с.

17. Тахтаджян А.Л. Флористические области Земли. Ленинград, 1978. 248 с.

18. Meusel H., Jager E., Rauschertet S. Vergleichende Chorologie der Zentraleuropaischen Flora Karten. Jena. 1978. Bd. 2. 421 p.

19. Meusel H., Jager E., Weinert E. Vergleichende Chorologie der Zentraleuropaischen Flora. Jena. 1965. Bd. 1. 535 p. 


\title{
ЕКОАОГІЧНI ПИТАННЯ В КОНТЕКСТI СВРОІНТЕГРАЦIї УКРАЇНИ
}

\author{
УДК 556.531.3, 556.11 \\ DOI https://doi.org/10.32846/2306-9716-2018-4-23-29
}

\section{ПОРІВНЯАЫНИЙ АНАМІЗ НОРМАТИВНОЇ БАЗИ ЄС ТА УКРАЇНИ ЩОДО ЗАХИСТУ ВОДНИХ РЕСУРСІВ}

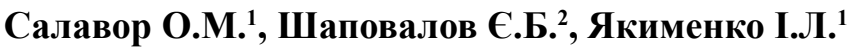 \\ ${ }^{1}$ Національний університет харчових технологій \\ вул. Володимирська, 68, 01601, м. Київ \\ iyakymen@gmail.com \\ ${ }^{2}$ Національний центр «Мала академія наук України» \\ вул. Дегтярівська, 38-44, 04119, м. Київ \\ saloksamir@ukr.net
}

\begin{abstract}
У статті проведено порівняльний аналіз законодавства $Є С$ та України в галузі охорони водних ресурсів і вимог до якості питної води. Показано, що практично в усіх сферах захисту водних ресурсів $\epsilon$ необхідність узгодження українського законодавства із законодавством ЄС. Проаналізовано першочергові заходи і стан речей з імплементації директив і регламентів ЄС у галузі водної політики в законодавчу базу України. Ключові слова: євроінтеграція, Угода про асоціацію між Україною та ЄС, Водна рамкова директива, якість води, охорона водних ресурсів.
\end{abstract}

Сравнительный анализ нормативной базы ЕС и Украины в сфере защиты водных ресурсов. Салавор О.М., Шаповалов Е.Б., Якименко И.Л. В статье проведен сравнительный анализ законодательства ЕС и Украины в области охраны водных ресурсов и требований к качеству питьевой воды. Показано, что практически во всех областях защиты водных ресурсов есть необходимость согласования украинского законодательства с законодательством ЕС. Проведен анализ первоочередных мероприятий и состояние вопроса по имплементации директив и регламентов ЕС в сфере водных ресурсов в законодательную базу Украины. Ключевые слова: евроинтеграция, Договор про ассоциацию между Украиной и ЕС, Водная рамковая директива, качество воды, охрана водных ресурсов.

Comparative analysis of the normative frameworks in the EU and Ukraine for water protection. Salavor O., Shapovalov E., Yakymenko I. Comparative analysis of legislation of the EU and Ukraine on water protection and requirements for drinking water quality was conducted. It is shown that in all spheres of water protection it is necessary to harmonize Ukrainian legislation with EU legislation. Top priority measures and a current situation as for implementation of the EU water directives and regulations into Ukrainian legislation are discussed. Key words: Eurointegration, Ukraine-European Union Association Agreement, Framework Water Directive, water quality, water resources protection.

Постановка проблеми. Адаптація, імплементація та практичне використання законодавчих актів ЄС у законодавчому полі України є важливим складником євроінтеграції України згідно з Угодою про асоціацію між Україною та Європейським Союзом (далі - Угода про асоціацію), що набула чинності 1 вересня 2017 р. [1]. 3 огляду на це, важливим $\epsilon$ проведення глибокого порівняльного аналізу нормативної бази України та ЄС у всіх сферах, у тому числі в галузі захисту довкілля й, зокрема, за таким стратегічним напрямом, як захист водних ресурсів і забезпечення належної якості питної води. Крім того, важливим є критичний аналіз темпів практичної реалізації кроків щодо імплементації норм Європейського Союзу в цій царині в українське законодавство, визначених в Угоді про асоціацію.
Актуальність дослідження. Сьогодні водокористування в Україні здійснюється переважно нераціонально, за високих рівнів непродуктивних витрат води, різкого зменшення об'ємів придатних до використання водних ресурсів унаслідок їх забруднення й виснаження, критично низької якості питної водопровідної води в більшості регіонів країни. За рівнем раціонального використання водних ресурсів і якістю води, включаючи наявність очисних споруд, Україна, за даними ЮНЕСКО, посідає 95-те місце у світі. Водомісткість ВНП у 3-5 разів вища, ніж в індустріально розвинених країнах Європи, що свідчить про нераціональне водокористування та низьку ефективність роботи наявного виробничого устаткування. У різних галузях промисловості й сільського господарства в результаті 
природного зносу інженерних споруд та обладнання, а також низької якості окремих проектів, недотримання правил експлуатації очисних споруд останніми роками збільшилась кількість аварій, що призвело до тяжких екологічних наслідків, отруєння стічними і дренажними водами багатьох річок України [2]. Система державного управління у сфері охорони вод потребує невідкладного реформування та переходу до інтегрованого управління водними ресурсами за басейновим принципом [3].

Сучасний період складних суспільних трансформацій за вкрай низького рівня економічного розвитку підвищив пріоритетність екологічної проблематики в Україні [4].

Аналіз останніх досліджень і публікацій. Сучасний стан розвитку законодавчої бази України щодо процесу реформування системи управління водними ресурсами аналізовано в роботах В.В. Гребінь [5] і В.О. Свдокимова [6]. При цьому автори підтверджують необхідність упровадження інтегрованого підходу до управління водними ресурсами за басейновим принципом. У роботі [7] проведено доволі повний порівняльний аналіз законодавства України та Європейського Союзу щодо забезпечення якості водних ресурсів. Проблемам узгодження національної нормативно-регуляторної бази в галузі управління водними ресурсами з вимогами Рамкової водної директиви ЄС присвячено публікацію А.В. Гриценка та співавторів [8]. Низка авторів проводила порівняльний аналіз нормативів якості питної води в Україні та СС [9-12].

Разом із тим набуття чинності Угоди про асоціацію 31 вересня 2017 року переводить питання узгодження українського законодавства в галузі захисту водних ресурсів і якості питної води з вимогами ЄС у практичну площину, оскільки Угода визначає чіткі часові рамки для імплементації конкретних нормативних документів ЄС до законодавчого поля України. Відповідно, у роботі ми зосереджуємо свій аналіз саме на цьому складникові питання.

Виклад основного матеріалу. Європейська політика регулювання взаємовідносин у водній галузі представлена низкою директив, серед яких до Угоди про асоціацію є такі:

- Водна рамкова директива 2000/60/ЄС, що встановлює рамкові вимоги до дій європейської спільноти в галузі водної політики [13];

- Директива 98/83/СС про якість води, призначеної для споживання людиною [14];

- Директива 2008/56/СС, яка встановлює рамки діяльності Співдружності у сфері політики з морського середовища (Рамкова Директива 3 морської стратегіi) [15];

- Директива 91/271/СЕС про очищення міських стічних вод [16];

- Директива 91/676/СЕС щодо охорони вод від забруднення, викликаного нітратами із сільськогосподарських джерел [17];
- Директива 2007/60/СС про оцінювання й управління ризиками затоплення [18].

Щодо Водної рамкової директиви 2000/60/ЄС зі змінами й доповненнями, внесеними Рішенням № 2455/2001/СС і Директивою 2009/31/СС, то упродовж трьох років 3 дати набрання чинності Угодою про асоціацію мають бути впроваджені такі їі положення [3]:

- прийняття національного законодавства та визначення уповноваженого органу (органів);

- закріплення на законодавчому рівні визначення одиниці гідрографічного районування території країни;

- розроблення положення про басейнове управління 3 покладенням на нього функцій, передбачених ст. 3 Директиви 2000/60/СС;

Упродовж 6 років в Україні необхідно впровадити [3]:

- визначення районів річкових басейнів і створення механізмів управління міжнародними річками, озерами та прибережними водами (ст. 3);

- аналіз характеристик районів річкових басейнів (ст. 5);

- програми моніторингу якості води (ст. 8).

Упродовж 10 років 3 дати набрання чинності Угодою про асоціацію необхідно підготувати плани управління басейнами річок, провести консультації з громадськістю й публікацію цих планів (ст. ст. 13 і 14) [3].

Щодо Директиви 98/83/СС про якість води, призначеної для споживання людиною, зі змінами й доповненнями, внесеними Регламентом (СС) 1882/2003 і Регламентом (СС) 596/2009, то впродовж 5 років $з$ дати набрання чинності Угодою про асоціацію Україні необхідно впровадити в національне законодавство такі її положення:

- прийняття національного законодавства та визначення уповноваженого органу (органів);

- установлення стандартів для питної води (ст. ст. 4 та 5);

- створення системи моніторингу (ст. ст. 6 і 7);

- створення механізму надання інформації споживачам (ст. 13).

У відповідні терміни 3 дати набрання чинності Угодою про асоціацію повинні бути впроваджені положення Директиви 2007/60/СС про оцінювання та управління ризиками затоплення:

- прийняття національного законодавства й визначення уповноваженого органу (органів) (упродовж 2 років);

- проведення попереднього оцінювання ризиків затоплення (ст. ст. 4 і 5) (упродовж 4 років);

- підготовка карт загроз і ризиків затоплення (ст. 6) (упродовж 6 років);

- запровадження планів управління ризиками затоплення (ст. 7) (упродовж 8 років).

Також в Угоді про асоціацію окреслено графік упровадження в національне законодавство 
основних положень Директиви 91/271/СЕС про очистку міських стічних вод зі змінами та доповненнями, внесеними Директивою 98/15/СС, Регламентом (СС) № 1882/2003, Регламентом (СС) № 1137/2008 i Директивою 91/676/СС про захист вод від забруднення, спричиненого нітратами із сільськогосподарських джерел, зі змінами й доповненнями, внесеними Регламентом (СС) № 1882/2003 [3].

Важливо, що ще до набуття чинності Угодою про асоціацію Верховною Радою України ухвалено зміни до Водного кодексу України [19], спрямовані на впровадження Водної рамкової Директиви ЄС, прийнято низку відповідних законодавчих актів:

- Закон України «Про внесення змін до деяких законодавчих актів України щодо впровадження інтегрованих підходів в управлінні водними ресурсами за басейновим принципом» від 04.10.2016 № 1641-VIII;

- Наказ Мінприроди «Про виділення суббасейнів та водогосподарських ділянок у межах встановлених районів річкових басейнів» від 26.01.2017 № 25;

- Наказ Мінприроди «Про затвердження меж районів річкових басейнів, суббасейнів та водогосподарських ділянок» від 03.03.2017 № 103;

- Наказ Мінприроди «Про затвердження Переліку забруднюючих речовин для визначення хімічного стану масивів поверхневих і підземних вод та екологічного потенціалу штучного або істотно зміненого масиву поверхневих вод» від 06.02.2017 № 45;

- Наказ Мінприроди «Про затвердження Типового положення про басейнові ради» від 26.01.2017 № 23;

- Постанову Кабінету Міністрів України «Про затвердження Порядку розроблення плану управління річковим басейном» від 18.05.2017 № 336;

- Закон України «Про ратифікацію Договору між Кабінетом Міністрів України та Урядом Республіки Молдова про співробітництво у сфері охорони і сталого розвитку басейну річки Дністер» від 07.06.2017;

- Постанову Кабінету Міністрів України «Про затвердження Порядку здійснення державного моніторингу вод від 19.09.2018 № 758 (набере чинності з 01.01.2019).

Щодо контролю якості питної води Директива 98/83/ЄС про якість води, призначеної для споживання людиною, визначає основні вимоги ЄС до якості питної води. У роботі [10] проведено порівняльний аналіз вимог цієї Директиви (за кількістю параметрів) з вимогами Всесвітньої організації охорони здоров'я (ВОО3) [21], України та інших країн світу (таблиця 1).

Вочевидь, найбільш детальними є рекомендації BOO3 [21], у яких є такі окремі переліки: неорганічні речовини (переважно важкі метали, нітрати й нітрити); органічні речовини (близько 30); пестициди (більше ніж 40); речовини, що застосовуються для дезінфекції води, в основному різні сполуки брому і хлору (більше ніж 20); речовини, що впливають на смак, колір і запах води. Також перераховані речовини, які не впливають негативно на здоров'я при ГДК у воді, до них належать срібло й олово.

Щодо якості питної води в Україні сьогодні чинний ДСанПіН 2.2.4-171-10 Державні санітарні норми та правила «Гігієнічні вимоги до води питної, призначеної для споживання людиною» [22], який визначає гігієнічні вимоги щодо якості до всіх видів питних вод, що використовуються в Україні, а саме: водопровідних, фасованих (у герметично закритих ємностях), із пунктів розливу (автоцистерн, кіосків), бюветів, колодязів, а також вод питної якості, що використовуються для виробництва продукції на промислових підприємствах. Під час розроблення ДСанПіН 2.2.4-171-10 ураховані рекомендації ВООЗ і положення Директиви 98/83/СС.

У ДСанПіН закладено поетапний підхід до впровадження показників якості питної води. Перелік показників гігієнічної оцінки питної води збільшується через кожні 5 років з часу набуття чинності ДСанПіН 2.2.4-171-10 упродовж 10 років. У водопровідній питній воді обов'язковому контролю підлягають 24-43 показники, з 2015 року додається ще

Таблиця 1

Стандарти якості питної води в різних країнах, Директиві ЄС і рекомендовані ВООЗ [10]

\begin{tabular}{|c|c|c|c|c|c|c|c|c|c|c|}
\hline 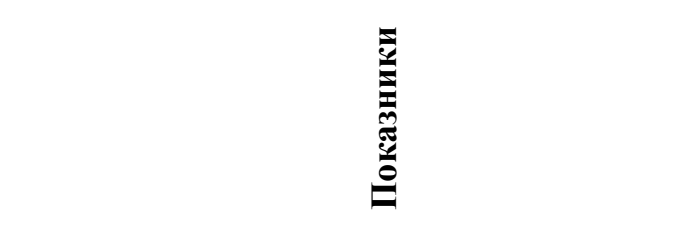 & 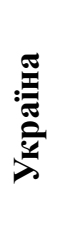 & 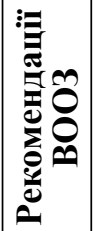 & 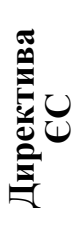 & & $\begin{array}{l}\text { 绨 } \\
\text { 兽 }\end{array}$ & 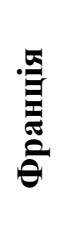 & 㺼 & 遏 & 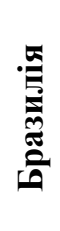 & ב్ \\
\hline Біологічні & 11 & 3 & 8 & 5 & 5 & 5 & 2 & 3 & 3 & 6 \\
\hline Узагальнені фізико-хімічні, органолептичні & 4 & 4 & 8 & 8 & 7 & 7 & 6 & 9 & 5 & 6 \\
\hline Неорганічні забруднення & 41 & 29 & 23 & 22 & 25 & 23 & 24 & 26 & 23 & 32 \\
\hline Органічні забруднення & 17 & 65 & 7 & 19 & 11 & 11 & 86 & 18 & 34 & 40 \\
\hline $\begin{array}{l}\text { Галогеновмісні сполуки (побічні продукти } \\
\text { дезінфекції) }\end{array}$ & 12 & 10 & 3 & 3 & 3 & 2 & 9 & 9 & 8 & 10 \\
\hline Радіологічні & 8 & 2 & 2 & 2 & 3 & 3 & 2 & 2 & 2 & 2 \\
\hline Усього & 93 & 113 & 48 & 59 & 54 & 51 & 129 & 67 & 75 & 96 \\
\hline
\end{tabular}


13 показників (10 із них - за вимогою Свропейського Союзу, 3 - через пріоритетність в Україні), 32020 року додається ще 12 показників (7 із них - за вимогою Європейського Союзу, 5 - через пріоритетність в Україні). У подальшому передбачається посилення вимог до якості питної води: удосконалення традиційної технології підготовки питної води на річкових водопровідних станціях з метою поліпшення ії якості та зменшення утворення обов'язкових до контролю у воді токсичних тригалогенметанів (далі - ТГМ). Нині тільки на поодиноких водопровідних станціях змінили технологію хлорування та хлорування з преамонізацією, що дало змогу мінімізувати утворення й надходження до питної води ТГМ, насамперед канцерогенного хлороформу [11].

Основні проблеми, що виникають під час поетапного впровадження вимог Директиви 98/83/ЄС в Україні, пов'язані з таким:

- унесенням змін у традиційні технології підготовки питної води або будівництво нових сучасних водоочисних споруд. Сьогодні нами визначено найбільш проблемні показники 3 тих, що контролюються в питній воді й не завжди відповідають нормативним вимогам;

- проведення атестації в Україні європейських методик визначення всіх підконтрольних показників якості питної води. Нині із 66 методик, що зазначені в ДСанПіН, тільки 16 відповідають вимогам міжнародних стандартів EN та ISO;

- формування європейської системи моніторингу води питної якості, що використовується для питних, технологічних і господарсько-побутових цілей;

- переоснащення лабораторій і навчання персоналу підприємств питного водопостачання й контролюючих установ;

- заміни застарілих водопровідних мереж;

- створення механізму надання інформації споживачам [11].

Директива 98/83/ЄС містить тільки ті показники, вплив яких на здоров'я людини доведено. Мабуть, саме ця обставина $€$ причиною того, що в Директиві ЄС відсутні будь-які рекомендації щодо фізіологічної повноцінності питної води, які наявні в переліку показників Державних санітарних норм та правил ДСанПіН. ДСанПіН [19] допускають наявність у питній воді нафтопродуктів, фенолів і поверхневоактивних речовин, тоді як у СС ці показники не нормуються. Також у ДСанПіН допускаються в кілька разів більші значення вмісту в питній воді алюмінію, азоту амонію, нітритів (у шість разів), свинцю, срібла, сульфатів, заліза, марганцю, миш'яку та хлоридів. Але в Україні більш жорсткі параметри порівняно з $\mathrm{CC}$ щодо вмісту в питній воді кадмію, міді, ртуті, ціанідів.

3 метою імплементації Директиви 98/83/ЄС прийнято Закон України «Про внесення змін до Закону України «Про питну воду та питне водопостачання» від 18.05.2017 №2047-VIII, пройшов міжвідомче

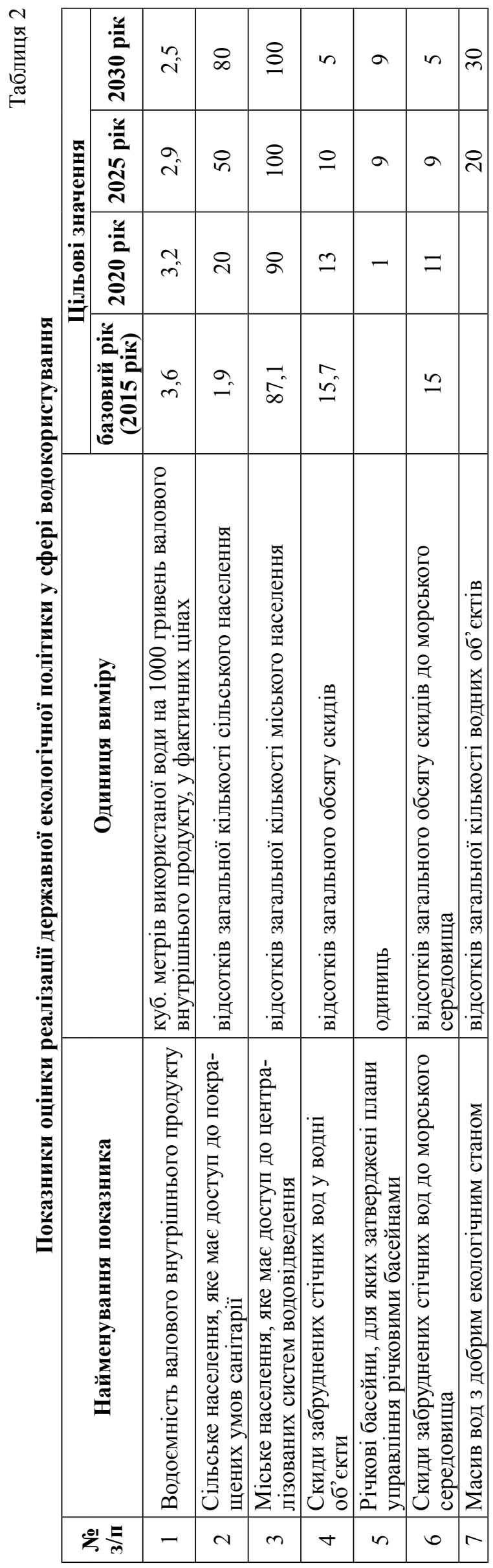


погодження проект Державних санітарних норм i правил «Гігієнічні вимоги до води питної, призначеної для споживання людиною» (на заміну ДСанПіН 2.2.4-171-10).

Що стосується Директиви 2007/60/ЄС про оцінювання й управління ризиками затоплення, то 3 метою впровадження в національне законодавство iii основних положень в Україні прийнято таке:

- Закон України «Про внесення змін до деяких законодавчих актів України щодо впровадження інтегрованих підходів в управлінні водними ресурсами за басейновим принципом» від 04.10.2016 № 1641-VIII (ст. 107-1);

- Наказ Міністерства внутрішніх справ України «Про затвердження Методики попередньої оцінки ризиків затоплення» від 17.01.2018 № 30;

- Наказ Міністерства внутрішніх справ України «Про затвердження Методики розроблення карт загроз і ризиків затоплення» від 28.02.2018 № 153;

- Постанову Кабінету Міністрів України «Про затвердження Порядку розроблення плану управління ризиками затоплення» від 04.04.2018 № 247.

Для імплементації Директиви 91/271/СЕС про очищення міських стічних вод i Директиви 2008/56/ЄС з морської стратегії в Україні також проведена певна законотворча діяльність:

- затверджено Наказ Мінрегіону «Про затвердження Правил приймання стічних вод до систем централізованого водовідведення та Порядку визначення розміру плати, що справляється за понаднормативні скиди стічних вод до систем централізованого водовідведення» від 01.12.2017 № 316

і розроблено проекти:

- Наказу Мінрегіону «Про затвердження Порядку повторного використання очищених стічних вод та осаду за умови дотримання нормативів гранично допустимих концентрацій забруднюючих речовин»;

- Наказу Мінприроди «Про затвердження Порядку визначення популяційного еквівалента населеного пункту та Критеріїв визначення уразливих та менш уразливих зон»;

- Порядку здійснення державного моніторингу вод (надіслано до Секретаріату Кабінету Міністрів України).

В Україні зареєстровано проект Закону про Основні засади (стратегію) державної екологічної політики України на період до 2030 року [24], згідно з яким реалізація державної екологічної політики у сфері водокористування оцінюється низкою показників, що представлені в таблиці 2. Також у цій таблиці наведено цільові значення цих показників, які необхідно досягнути, відповідно, у 2020, 2025 та 2030 роках порівняно з базовим 2015 роком.

Варто зазначити, що під час оцінювання показників реалізації державної екологічної політики поряд iз показниками енергоємності й ресурсоємності валового внутрішнього продукту вагоме значення приділяється показнику водоємності, що вимірюється в кубічних метрах використаної води на 1000 гривень валового внутрішнього продукту [24].

Тобто маємо констатувати достатньо вагому законотворчу активність останніх років в Україні, спрямовану на вирішення нагальних питань покращення стану природних ресурсів і якості питної води шляхом наближення національного законодавства до законодавчих норм Свропейського Союзу. Вочевидь, не менш критичним наступними роками для України буде залишатися належне дотримання законодавчих норм у галузі водної політики в практичній діяльності державних органів влади та місцевого самоврядування, усіх операторів ринку i членів суспільства загалом.

Головні висновки. У зв'язку 3 підписанням Угоди про асоціацію між Україною та Європейським Союзом необхідно забезпечити поетапне наближення (транспозиція, імплементація та забезпечення дотримання) природоохоронного законодавства, зокрема в галузі водної політики, до відповідних законодавчих і регуляторних актів ЄС. Проведений порівняльний аналіз виявив певні відмінності в законодавчій і нормативній базах ЄС та України щодо захисту водних ресурсів і якості питної води, що робить обгрунтованою активну імплементацію норм СС до законодавства України. На сучасному етапі важливим для українського законотворця є чітке дотримання вимог Угоди про асоціацію стосовно часових рамок імплементації окремих регуляторних актів ЄС щодо водної політики в національне законодавство. При цьому зміни та розширення законодавчої бази України в галузі водної політики упродовж останніх років мають позитивну динаміку й можуть сприяти покращенню стану водних ресурсів у країні за умови їх жорсткого дотримання. 


\section{Література}

1. Угода про асоціацію між Україною, з однієї сторони, та Європейським Союзом, Свропейським співтовариством 3 атомної енергії і їхніми державами-членами, з іншої сторони. Документ 984_011, поточна редакція від 30.11.2015. URL: http://zakon.rada.gov.ua/laws/show/984_011.

2. Наукові основи національної стратегії сталого розвитку України / за наук. ред. акад. НААН України, д. е. н., проф. М.А. Хвесика; Державна установа «Інститут економіки природокористування та сталого розвитку Національної академії наук України». Київ: ДУ IЕПСР НАН України, 2013. 40 c. URL: http://ecos.kiev.ua/share/upload/reports/Naukovi_osnovy_ stalogo_rozvytku_2013_1.pdf.

3. Додаток XXX до глави 6 навколишнє середовище Угоди про асоціацію між Україною та ЄC. URL: https://www.kmu.gov.ua/ storage/app/media/ugoda-pro-asociaciyu/30_Annex.pdf.

4. Якименко І.Л. Стратегія сталого розвитку: європейський вимір / Нац. ун-т харч. технол. Київ: НУХТ, 2017.79 с. URL: http://dspace.nuft.edu.ua/jspui/bitstream/123456789/26706/1/February.pdf.

5. Гребінь, В.В., Яцюк М.В., Чунарьов О.В. Гідрографічне районування території України як передумова розробки планів інтегрованого управління річковими басейнами. Гідрологія, гідрохімія і гідроекологія. 2012. Т. 2. С. 8-16.

6. Свдокимов В.О., Жук В.М. Державне регулювання розвитку водогосподарського комплексу шляхом впровадження інтегрованого підходу до управління водними ресурсами за басейновим принципом. Актуальні проблеми державного управління. 2015. № 1 (47). С. 139-145.

7. Дейнега М.А., Шестопалка Р.І. Правове забезпечення якості водних ресурсів за законодавством України та Європейського Союзу. Національний університет біоресурсів і природокористування України. 2013. № 182. Ч. 2. С. 116-123.

8. Гриценко А.В., Васенко О.Г., Кресін В.С. Удосконалення правил охорони поверхневих вод України від забруднення зворотними водами. Проблеми охорони навколишнього природного середовища та екологічної безпеки: зб. наук. пр. / УкрНДІЕП. 2016. Вип. XXVIII. С. 3-13.

9. Салавор О.М. Регулювання ЄС щодо забезпечення якості природної та питної води, порівняльний аналіз із нормативною базою України. Інструменти, політика та кращі практики захисту довкілля у Свропейському Союз: виклики для України: матеріали Літньої Школи проекту Жан Моне Модуль, 7-8 червня 2017 року. URL: http:/ecopro.nuft.edu.ua/index.php.

10. Прибилова В.М. Порівняльна характеристика нормативів якості питної води, що застосовуються в окремих країнах світу. Вісник Харківського національного університету імені В.Н. Каразіна. Серія «Геологія. Географія. Екологія». 2016. Вип. 44. C. 55-62. URL: http://nbuv.gov.ua/UJRN/VKhG_2016_44_9.

11. Зоріна О.В. Імплементація в Україні директиви 98/83/ЄС про якість води, призначеної для споживання людиною. Гігієна населених місць. 2014. № 63. С. 85-93.

12. Проневич О.С. Імплементація європейських стандартів забезпечення якості питної води: інституційно-правовий аспект. Форум права: електрон. наук. фахове вид. 2017. № 3. C. 182-189. URL: http://nbuv.gov.ua/j-pdf/FP_index.htm_ 2017 3 33.pdf.

13. Directive 2000/60/EC of the European Parliament and of the Council of 23 October 2000 establishing a framework for Community action in the field of water policy. URL: https://eur-lex.europa.eu/legal-content/en/TXT/?uri=CELEX:32000L0060.

14. Council Directive 98/83/EC of 3 November 1998 on the quality of water intended for human consumption. URL: https://eur-lex. europa.eu/legal-content/EN/TXT/?uri=CELEX\%3A31998L0083.

15. Directive 2008/56/EC of the European Parliament and of the Council of 17 June 2008 establishing a framework for community action in the field of marine environmental policy (Marine Strategy Framework Directive) (Text with EEA relevance). URL: https://eur-lex.europa.eu/legal-ontent/en/TXT/?uri=CELEX\%3A32008L0056.

16. Council Directive 91/271/EEC of 21 May 1991 concerning urban waste-water treatment. URL: https://eur-lex.europa.eu/ legal-content/EN/ALL/?uri=celex:31991L0271.

17. Council Directive 91/676/EEC of 12 December 1991 concerning the protection of waters against pollution caused by nitrates from agricultural sources. URL: https://eur-lex.europa.eu/legal-content/en/ALL/?uri=CELEX:31991L0676.

18. Directive 2007/60/EC of the European Parliament and of the Council of 23 October 2007 on the assessment and management of flood risks (Text with EEA relevance). URL: https://eur-lex.europa.eu/legal-content/EN/TXT/?uri=celex:32007L0060.

19. Водний кодекс України: офіц. текст: за станом на 06.06.1995 / Верховна Рада України. URL: http://zakon.rada.gov.ua/laws/ show/ru/213/95-\%D0\%B2\%D1\%80.

20. Климчик О.М., Пінкіна Т.В., Пінкін А.А. Впровадження системи інтегрованого управління водними ресурсами за басейновим принципом. Scientific Journal «ScienceRise». 2018. № 4 (45). C. 36-40.

21. Руководство по контролю качества питьевой воды. 3-е изд. Женева: ВОЗ, 2004. Москва: Медицина, 1994. Т. 1: Рекомендации. 62 c. URL: http://www.who.int/water_sanitation_health/dwq/gdwq3ruprelim_1to5.pdf.

22. Державні санітарні норми та правила «Гігієнічні вимоги до води питної призначеної для споживання людиною»: ДСанПіН 2.2.4-171-10: офіц. текст: затверджено Наказом Міністерства охорони здоров’я України від 12.05.2010 № 400 . URL: http://zakon.rada.gov.ua/laws/show/z0452-10.

23. Зацерковний В.І., Плічко Л.В. Аналіз підходів щодо створення бази геоданих геоінформаційних систем моніторингу якості поверхневих вод. Наукоємні технології. 2018. № 1 (37). С. 114-124.

24. Проект Закону про Основні засади (стратегію) державної екологічної політики України на період до 2030 року № 8328 , дата реєстрації 26.04.2018. URL: http://w1.c'.rada.gov.ua/pls/zweb2/webproc4_1?pf3511=63948. 


\title{
СТОРІНКА МОАОДОГО ВЧЕНОГО
}

УДК 004.9

DOI https://doi.org/10.32846/2306-9716-2018-4-23-30

\section{МОДЕАЮВАННЯ ПРОЦЕСУ КООРДИНАЦІЙНОї ВЗАЕМОДІї В СИСТЕМІ ОПЕРАТИВНОГО УПРАВАІННЯ В УМОВАХ ВИНИКНЕННЯ НАДЗВИЧАЙНИХ СИТУАЦИЙ З ВИКОРИСТАННЯМ МУАЬТИАГЕНТНОЇ ПАРАДИГМИ}

\author{
Ложкін P.C. \\ Херсонський національний технічний університет \\ пр. Щорса, 13, 73485, смт. Антонівка, м. Херсон \\ ruslanlozhkin@gmail.com
}

\begin{abstract}
У статті розглянуто процес координаційної взаємодії в системі оперативного управління в умовах виникнення надзвичайної ситуації. Основою системи є інтелектуальні агенти, що моделюють взаємовідносини між представниками органів ліквідації наслідків надзвичайної ситуації, спираючись на характеристики надзвичайної ситуації та обмеження, що накладаються навколишнім середовищем у зоні надзвичайної ситуації, силами й засобами цивільного захисту України. Подано схему мультиагентного управління в умовах виникнення надзвичайної ситуації. Ключові слова: координаційна взаємодія, мультиагентна парадигма, інтелектуальний агент, надзвичайна ситуація.
\end{abstract}

Моделирование процесса координационного взаимодействия в системе оперативного управления в условиях возникновения чрезвычайных ситуаций с использованием мультиагентной парадигмы. Ложкин Р.С. В статье рассмотрен процесс координационного взаимодействия в системе оперативного управления в условиях возникновения чрезвычайной ситуации. Основой системы являются интеллектуальные агенты, которые моделируют взаимоотношения между представителями органов ликвидации последствий чрезвычайной ситуации, опираясь на характеристики чрезвычайной ситуации и ограничения, накладываемые окружающей природной средой в зоне чрезвычайной ситуации, силами и средствами гражданской обороны Украины. Представлена схема мультиагентного управления в условиях возникновения чрезвычайной ситуации. Ключевые слова: координационное взаимодействие, мультиагентная парадигма, интеллектуальный агент, чрезвычайная ситуация.

Modeling of the coordinating interaction process in the operative control system under conditions of emergencies with using multi-agent paradigm. Lozhkin R.S. The process of coordination interaction in the system of operational control under conditions of emergencies is considered. Intelligent agents are the main part of the system modeling relationship between members of emergency response agencies based on the characteristics of the emergency situation and the restrictions imposed by the environment in the emergency area, by the forces and means of Ukrainian civil defense. A scheme of multi-agent control in conditions of emergency situations is presented. Key words: coordination interaction, multi-agent paradigm, intelligent agent, emergency.

Постановка проблеми. Сумна статистика надзвичайних ситуацій (далі - НC), що трапилися на території України, говорить про те, що державна система цивільного захисту (далі - ЦЗ) має низку невирішених проблем.

Ефективність проведення ліквідаційних робіт багато в чому залежить від того, як орган місцевого самоврядування організовує оперативне керування в умовах виникнення НС [1]. Основними завданнями під час ліквідації наслідків НС є прийняття зважених управлінських рішень і координація взаємодії сил і засобів ЦЗ. Процес ліквідації наслідків $\mathrm{HC}$ стикається з проблемами невизначеності, швидкоплинності, нестачі часу та ресурсів. Окрім цього, є проблеми неузгодженості дій сил і засобів ЦЗ, прийняття оперативних управлінських рішень в умовах виникнення НС.
Актуальність дослідження. В умовах виникнення НС у процесі прийняття зважених та ефективних рішень велике значення має координація взаємодії органів управління, що беруть участь у ліквідації наслідків НС. Тому розроблення методів і моделей координації $\epsilon$ важливим науково-практичним завданням.

Зв'язок авторського доробку із важливими науковими та практичними завданнями полягає в моделюванні процесу координаційної взаємодії органів оперативного управління в умовах виникнення НC 3 використанням мультиагентної парадигми. Застосування зазначеної моделі допоможе у вирішенні проблем прийняття управлінських рішень в умовах нестачі часу, ресурсів, динамічної зміни характеристик у зоні НС, людського фактору. 
Аналіз останніх досліджень і публікацій. Аналіз останніх публікацій із цієї тематики показав, що не всі питання моделювання процесу координаційного керування розкрито достатньою мірою.

У роботі Р.І. Шевченка [2] проведено аналіз систем моніторингу і прогнозування НС на державному рівні керування. Також авторами проаналізовано процес взаємодії підрозділів у системі моніторингу i прогнозування НС, здійснено формування різних інформаційних потоків у процесі взаємодії. Визначено системні протиріччя. Розглянуто інформаційно-функціональні, інформаційно-структурні схеми систем, процесів моніторингу і прогнозування НС на державному рівні керування.

У праці Р.Л. Михайлова [3] виконано аналіз способів застосування науково-методичного апарату теорії координації. Розглянуто питання координації в системах воєнного управління, здійснено акцент на проблемах координації в системах воєнного нагляду та впливу.

Питання безпеки життєдіяльності будівель і споруд масового обслуговування проаналізовано в роботі О.Б. Зачко, О.Р. Головатий [4]. Запропоновано концептуальну модель одноканальної системи масового обслуговування 3 використанням мультиагентної парадигми. Розглянуто недоліки у безпеці життєдіяльності сучасних систем масового обслуговування.

У праці Е.Н. Ляшенко, В.Г. Шерстюк [5] запропоновано звести завдання координації в слабко структурованій ієрархічній системі цивільного захисту населення до завдання підтримки цілеспрямованого кооперативного прийняття рішень. Показано, що неявна координація може розглядатися як процес спільного пошуку рішень агентами в багатоагентній моделі з нормативним регулятором, а явна координація - як процес узгодження планів агентів.

У роботі Е.Н. Ляшенко, Д.Л. Кирийчук [6] проведено аналіз робіт у галузі теорії координації. Обгрунтовано актуальність розроблення моделей, які дадуть змогу вирішити завдання координації в багаторівневих ієрархічних системах. Запропоновано структуру багаторівневої ієрархічної системи цивільного захисту населення від НС, виділено рівні керування системи. Наведено формальну постановку завдання координації в цій системі.

У праці [7] детально розглянуто проблему прийняття рішень під час ліквідації НС. Розроблено концепцію підтримки прийняття рішень під час ліквідації НС і їі характеристики. Розглянуто можливі рішення, що приймаються для кожного етапу ліквідації НС. Наведено огляд теорії та методів прийняття рішень у НС з методологічного погляду. Продемонстровано побудову системи підтримки прийняття рішень під час ліквідації НС природного характеру. Наведено схему загальних процесів прийняття рішень під час ліквідації НС природного характеру i схему системи підтримки прийняття рішень під час ліквідації НС природного характеру.
Виділення не вирішених раніше частин загальної проблеми, котрим присвячусться означена стаття. Ефективність роботи органу оперативного управління в умовах виникнення НС багато в чому залежить від злагодженої взаємодії між його представниками. Кожний представник органу оперативного управління в умовах виникнення НС має власні бажання, переконання, наміри, плани, тому їх можна представити як інтелектуальних агентів, що також мають свої бажання, переконання, наміри та бібліотеку планів. Модель процесу координаційної взаємодії в системі оперативного управління ліквідації наслідків НС, де кожний представник цього органу представлений як інтелектуальний агент, згідно з мультиагентною парадигмою, дає змогу приймати ефективні, зважені рішення з огляду на брак часу, ресурсів, швидкоплинність, невизначеність, неузгодженість дій сил і засобів ЦЗ України.

Новизна пропонованого дослідження полягає в моделюванні процесу координаційної взаємодії в системі оперативного управління в умовах виникнення НС 3 використанням мультиагентної парадигми. Розроблені методи та моделі дадуть змогу вирішити науково-практичну проблему оперативного управління в умовах виникнення НС з урахуванням проблем браку часу, ресурсів, швидкоплинності, невизначеності, неузгодженості дій сил і засобів ЦЗ, прийняття оперативних управлінських рішень.

Методологічне або загальнонаукове значення пропонованого дослідження полягає в подальшому розвитку теорії координації в системах оперативного управління в умовах виникнення НС. Запропоновані методи та моделі координаційної взаємодії з використанням мультиагентної парадигми становлять невирішену раніше частину цієї загальної проблеми.

Виклад основного матеріалу. Під час організації оперативного управління силами й засобами ЦЗ України в умовах виникнення НС одним із важливіших завдань є взаємодія відповідних органів і їі членів. Під час організації взаємодії керуються не тільки положеннями, законами, розпорядженнями, інструкціями, а й отриманим досвідом, методичними вказівками, сталими схемами, планами взаємодії, аналізом результатів ліквідації великої кількості НС.

Основою успішної взаємодії оперативного управління силами й засобами ЦЗ України в умовах виникнення НС $є$ особистий вклад кожного члена відповідно до його компетенцій та обов'язків, згідно 3 прийнятим порядком взаємодії та розробленими етапами:

- спільна участь у розробленні відповідних актів і керівних документів;

- взаємний обмін інформацією, яка стосується компетенцій сторін;

- спільне розроблення планів взаємодії;

- визначення, виділення сил і засобів ЦЗ, необхідних для ліквідації НС, відповідно до розроблених планів взаємодії. 
Без розуміння загальних цілей виконуваних робіт із запобігання та ліквідації НС, без методів, порядку організації сил і засобів ЦЗ України взаємодія неможлива. Лише однієї взаємодії оперативного управління силами та засобами ЦЗ України в умовах виникнення НС недостатньо для ліквідації НС iз найменшими збитками й утратами серед населення. Для досягнення оптимального результату, що відповідає цілям виконуваних робіт, доцільним $\epsilon$ використання методів координації в багаторівневих і складних системах. Організації, які створюються під час ліквідації НС, є ієрархічними, складними системами, що мають динамічну структуру.

Координація взаємодії оперативного управління силами та засобами ЦЗ України в умовах виникнення НС - це сумісне здійснення робіт 3 ліквідації $\mathrm{HC}$, які призводять до спільного результату або цілі, з оптимальним поєднанням інтересів в ресурсів, залучених до підготовки та ліквідації НС, з урахуванням усіх обмежень, що накладаються відповідними органами.

Під час запобігання та ліквідації НС місцевою владою створюється орган оперативного управління в умовах виникнення НС. Структура цього органу має три рівні:
1. Комісія з питань техногенно-екологічної безпеки (далі - ТЕБ) і НС.

2. Штаб з ліквідації наслідків НС.

3. Робочі групи штабу.

Комісія з питань ТЕБ і НС виконує контролюючі, координуючі обов'язки роботи штабу 3 ліквідації НС [1]. Штаб з ліквідації НС безпосередньо виконує оперативне управління в умовах виникнення НC i віддає накази робочій групі штабу, яка і є виконувачем ліквідаційних робіт, робіт з порятунку населення та майна й робіт з відновлення інфраструктури і споруд у зоні НС [1]. Комісія з питань ТЕБ і НС складається з голови комісії, секретаря, заступника голови комісії та членів комісії з питань ТЕБ і НС [1]. Штаб 3 ліквідації наслідків НС у своєму складі має керівника штабу, двох заступників керівника штабу та членів штабу з ліквідації наслідків НС [1]. Робоча група складається 3 групи аналізу ситуації й підготовки даних, групи управління резервом сил, організаційної групи, групи представників органів влади, групи організації зв'язку, групи взаємодії з населенням і засобами масової інформації, групи безпосереднього реагування, групи матеріально-технічного забезпечення [1].

Схема оперативного управління в умовах виникнення НС показана на рис. 1.

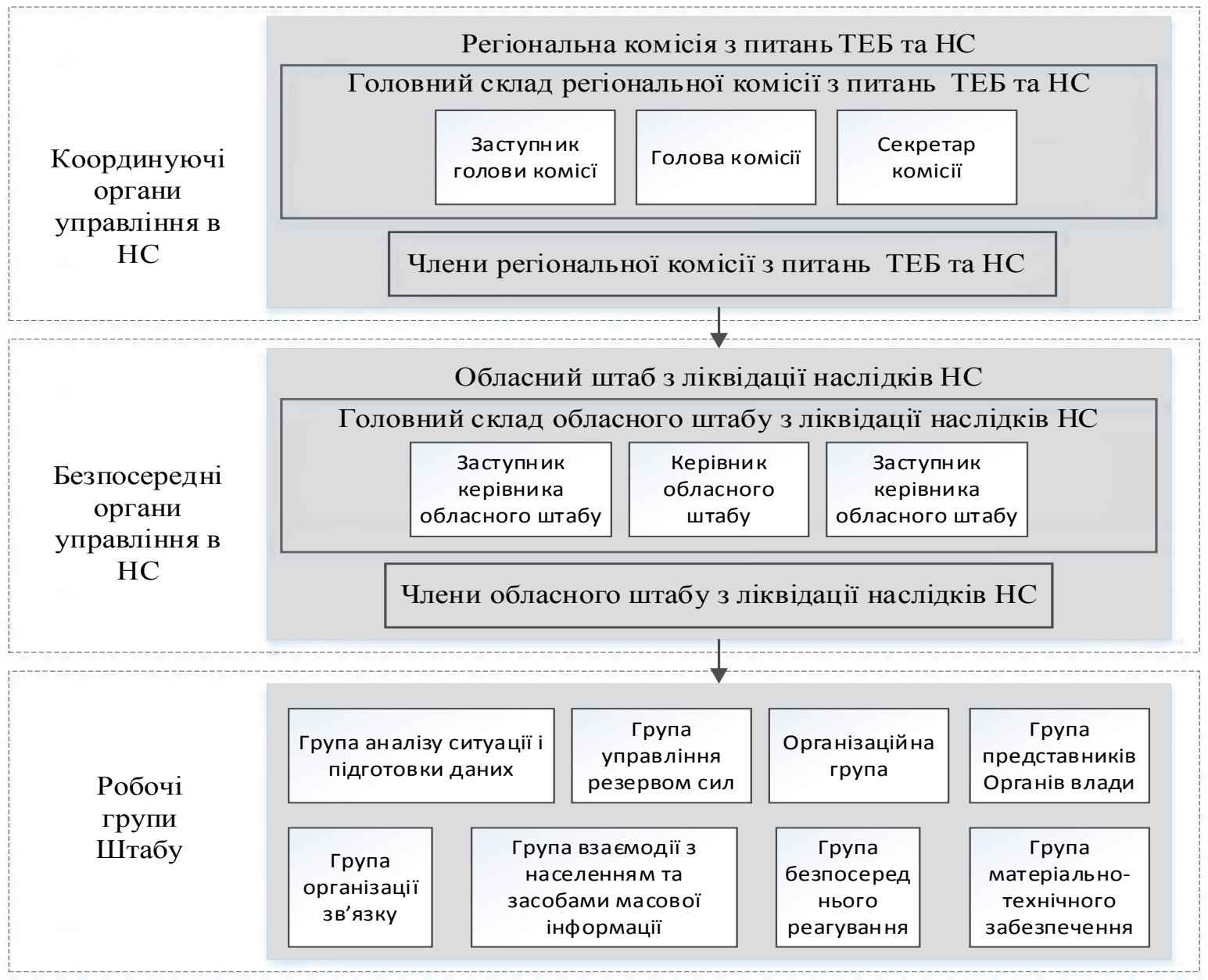

Рис. 1. Схема оперативного управління в умовах виникнення НС 
Комісія з питань ТЕБ і НС виконує роль координуючого органу, аналізує, контролює діяльність штабу з ліквідації наслідків $\mathrm{HC}$ за допомогою координуючих повідомлень як окремого члена штабу, так і штабу загалом [1].

Штаб з ліквідації наслідків НС виступає як безпосередній орган управління [1]. На цьому рівні координація виконується за принципом менеджер і підрядник. Згідно із цим принципом, керівник штабу $\epsilon$ головним менеджером, а члени штабу $є$ водночас менеджерами й підрядниками. На першому етапі головним менеджером оголошується завдання [8]. На другому етапі виконується подання тендерних пропозицій у відповідь на завдання [8]. На третьому етапі головний менеджер виконує вибір підрядника та його субпідрядників за необхідності [8]. Такий самий підхід під час вирішення завдань виконують

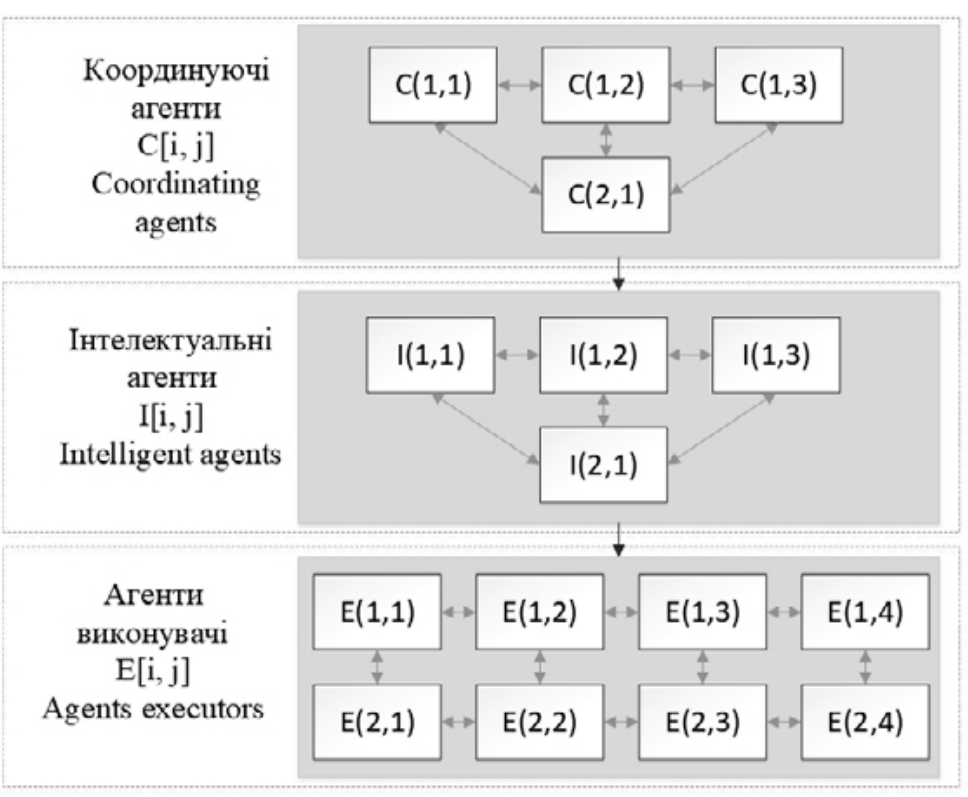
і менеджери на рівні членів штабу, які виступають водночас підрядником для головного менеджера й менеджером для тих, хто подає тендерні пропозиції вже на цьому рівні.

На рівні робочих груп курівники органів управління виконують розпорядження керівника штабу й за необхідності можуть також бути менеджером і підрядником, тобто самі ініціювати завдання, далі за допомогою тендерних пропозицій знаходити підрядників і субпідрядників.

Кожний представник органу оперативного управління в умовах виникнення НС має свої посадові обов'язки та знання вирішуваних завдань разом із бажаннями, переконаннями, намірами й низкою планів, що відповідає головному складникові мультиагентної парадигми - інтелектуальному агенту (далі - IA) [8]. IA також має свої власні бажання, переконання, наміри та бібліотеку планів, що є основними структурами даних, із вирішувачем, який i виконує потрібні розв'язки [8]. Як представники органу оперативного управління IA також мають сенсори, що сприймають інформацію, та актуатори, що виконують відповідні потрібні дії. Саме такий опис і має один із варіантів архітектури переконань-бажань-намірів (Belief Desire Intention - BDI), a саме процедурно-аргументована система (Procedural Reasoning System - PRS), яка використовується в більшості мультиагентних систем [8].

Якщо біля головного агента відповідного рівня схеми оперативного управління в умовах виникнення НС є додаткові агенти, то обов'язково один iз них виконує роль секретаря, що веде системний

журнал, а інший є допоміжним агентом, що може виконувати частину функцій головного агента.

На кожному рівні схеми оперативного управління в умовах виникнення НС представлені агенти свого класу. На рівні комісії з питань ТЕБ та НС - масив координуючих агентів C [i j]. На рівні штабу з ліквідації наслідків НС - масив інтелектуальних агентів I $[\mathrm{i}, \mathrm{j}]$. На останньому рівні робочих груп - масив агентів-виконувачів E $[i, j]$. Координація між рівнями та на рівнях виконується згідно з описаною моделлю, детально схему мультиагентного керування в умовах виникнення НС продемонстровано на рис. 2. Спілкуються інтелектуальні агенти за допомогою мови комунікації агентів FIPA ACL iз використанням транспортного протоколу повідомлень (Message Transport Protocol).

Головні висновки. Отже, процес координаційної взаємодії в системі оперативного управління в умовах виникнення НС із використанням мультиагентої парадигми визначається як система відносин між IA, що змінюються в часі. IA $є$ основою системи, що моделює взаємовідносини між представниками органів ліквідації наслідків НС, спираючись на характеристики НС та обмеження, що накладаються навколишнім середовищем у зоні НС, силами та засобами ЦЗ України.

Перспективи використання результатів дослідження. Отримані результати можуть стати основою для подальшого розроблення інформаційної технології координаційної взаємодії органів оперативного управління в умовах виникнення НC із використанням мультиагентної парадигми. 


\section{Література}

1. Про затвердження Положення про штаб з ліквідації наслідків надзвичайної ситуації та Видів оперативно-технічної і звітної документації штабу з ліквідації наслідків надзвичайної ситуації: Наказ Міністерства внутрішніх справ України від 26 грудня 2014 року № 1406. URL: http://zakon.rada.gov.ua/laws/show/z0047-15.

2. Шевченко P.I. Інформаційно-функціональний аналіз системи моніторингу та прогнозування надзвичайних ситуацій. Системи обробки інформації. 2015. № 8 (133). С. 148-157.

3. Михайлов Р.Л. Анализ научно-методического аппарата теории координации и его использования в различных областях исследований. Системы управления, связи и безопасности. 2016. № 4. С. 1-29.

4. Зачко О.Б., Головатий О.Р. Мультиагентна модель управління безпекою при плануванні проектів створення об’єктів 3 масовим перебуванням людей. Стратегічне управління, управління портфелями, програмами та проектами. 2017. № 2 (1224). C. $46-51$.

5. Ляшенко Е.Н., Шерстюк В.Г. Разработка модели координации сил и средств в иерархической системе гражданской защиты населения. Технологический аудит и резервы производства. 2015. № 4/2 (24). С. 4-10.

6. Ляшенко Е.Н., Кирийчук Д.Л. Постановка задачи координации в системе гражданской защиты населения от чрезвычайных ситуаций регионального уровня управления. Науковий вісник Херсонської державної морської академії. 2015. № 1 (12). C. 270-276.

7. Lei Zhou Xianhua Wu Zeshui Xu Hamido Fujitad. Emergency decision making for natural disasters: An overview. International Journal of Disaster Risk Reduction. 2018. Volume 27. P. 567-576.

8. Bellifemine Fabio, Caire Giovanni, Greenwood Dominic. Developing multi-agent systems with JADE. John Wiley \& Sons Ltd. 2007. C. 303. 


\title{
МОНІТОРИНГ ЕКОАОГІЧНОГО СТАНУ РІЧКИ РИБНИЦЯ, НАЦІОНАМЫНИЙ ПРИРОДНИЙ ПАРК „ГУЦУАЫЩИНА"
}

\author{
Глодова Л.М. \\ Національний природний парк «Гуцульщина» \\ вул. Дружби, 84, 78601, м. Косів, Івано-Франківська область \\ glodova.1.m@gmail.com
}

\begin{abstract}
У публікації представлені результати екологічного моніторингу р. Рибниця (в межах м. Косів, Національний природний парк «Гуцульщина») за 2013-2017 pр. Установлено, що вода в річці є чистою, в період дослідження продемонстровано високу здатність водойми до самовідновлення. Перевищення ГДК з досліджуваних показників (іони амонію, нітрити, залізо, хлориди, сульфати) мало місце тільки для нітритів і заліза в періоди злив. За три тижні мало місце повернення цих показників до норми. Вода в річці м'яка. Ключові слова: Національний природний парк «Гуцульщина», моніторинг, р. Рибниця, хімічний аналіз.
\end{abstract}

Мониторинг экологического состояния речки Рыбница, Национальный природный парк «Гуцульщина». Глодова Л.М. В публикации представлены результаты экологического мониторинга р. Рыбница (в пределах г. Косов, Национальный природный парк «Гуцульщина») за 2013-2017 гг. Установлено, что вода в реке чистая, в период исследования продемонстрирована высокая способность водоема к самовосстановлению. Превышение ПДК за исследуемыми показателями (ионы аммония, нитриты, железо, хлориды, сульфаты) имело место только для нитритов и железа в периоды ливней. Через три недели имело место возвращение этих показателей к норме. Вода в реке мягкая. Ключевые слова: Национальный природный парк «Гуцульщина», мониторинг, р. Рыбница, химический анализ

Monitoring the environment state of the river Ribnitsa, National nature park "Hutsulshchina". Glodova L. The publication presents the results of environmental monitoring of Ribnitsa (within Kosiv, National Natural Park "Hutsulshchyna") for 2013-2017. It was established that the water in the river is clean, during the study the high ability to self-healing of the reservoir has been demonstrated. Excess of MAC from the studied parameters (ammonium ions, nitrites, iron, chlorides, sulphates) occurred only for nitrites and iron during periods of showering. Three weeks later, the return of these indicators to the norm took place. The water in the river is mild. Key words: National natural park "Hutsulshchina", monitoring, Rybnitsa, chemical analysis.

Постановка проблеми. Проблема забруднення прісних водойм як ніколи актуальна в наш час. Малі річки,щоопинилисяв межах населенихпунктів, зазнають антропогенного навантаження, інтенсивність впливу якого залежить від роду людської діяльності.

Територія Косівського району (Івано-Франківська область) не багата на діючі промислові підприємства та об'єкти, основний тип навантаження на водні артерії реалізується за рахунок господарської діяльності (типу малого бізнесу) та рекреаційного арсеналу послуг. Весь Косівський район, на території якого знаходиться Національний природний парк «Гуцульщина» (далі - НПП), належить до басейну Прута. На Косівщині розташовані верхів'я й середня течія таких його великих правих приток, як Лючка, Пістинька та Рибниця, а по межі з Буковиною протікає найбільша притока Прута - ріка Черемош. Близько 70\% території НПП «Гуцульщина» знаходиться в басейнах річки Пістиньки та Рибниця [1]. Річка Рибниця має загальну довжину 54 км, у т. ч. в межах району - 37,5 км. Площа басейну становить 276 км², у т. ч. в межах району - 232 км² $^{2}$ Річка бере початок з-під перевалу Буковець на висоті близько 800 м.

Чисте повітря, чисті річки, водоспади, ліси, привітні жителі здавна є візитівками краю і приваблюють чимало туристів. Зважаючи на активне використання ресурсів, у т. ч. водних, і жителями й гістьми краю, актуальними є дослідження, спрямовані на визначення екологічного стану водойм у часових рамках.

Саме тому у 2005 р. при НПП «Гуцульщина» створена Лабораторія екологічного моніторингу, що систематично проводить контроль якості поверхневих, підземних і зворотних вод на водозаборах Косівщини, які вибрано з урахуванням специфіки гідромережі, ступеня забруднення й антропогенного впливу [2].

У публікації представлені результати аналізу проб, що відбиралися на р. Рибниця на ділянці течії, які знаходиться в межах м. Косів. Відбір проб проводили планово щомісячно (в перших числах місяця) та непланово (після випадання великої кількості опадів, довготривалої посухи, підозри на викиди шкідливих речовин чи інші причини) й аналізували по кварталах. Аналітичний контроль води проводили згідно 3 нормативними документами, рекомендованими службами Міністерства екології та природних ресурсів України, в яких визначені норми - гранично допустимі концентрації (далі ГДК) у воді для кожного з аналізованих нами показників (таблиця 1).

Статистичний аналіз отриманих результатів проводили за допомогою Excel згідно зі Statistica 8.0. 
Аналіз останніх досліджень і публікацій. Якість питної води, стан водних ресурсів України, проблеми й перспективи їх використання та збереження - тема не нова для досліджень, однак від цього не менш актуальна $[3 ; 4 ; 5 ; 6 ; 7]$. Регулярні національні та регіональні доповіді із цієї тематики рясніють повідомлення про систематичне й постійне забруднення поверхневих вод побутовими стоками, господарсько невиправданими та непоправними рішеннями, екологічними катастрофами, застерігають нас від цілком очікуваного екологічного колапсу, що загрожує жителям і мегаполісів, і сільської місцевості відсутністю найбільш необхідного для всіх ресурсу - води.

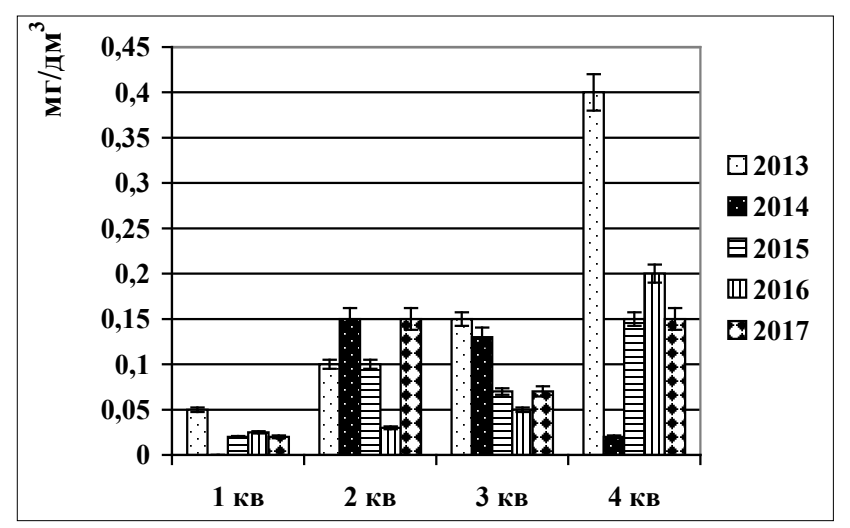

Рис. 1. Рівень амоній-іонів у р. Рибниця в 2013-2017 рр.

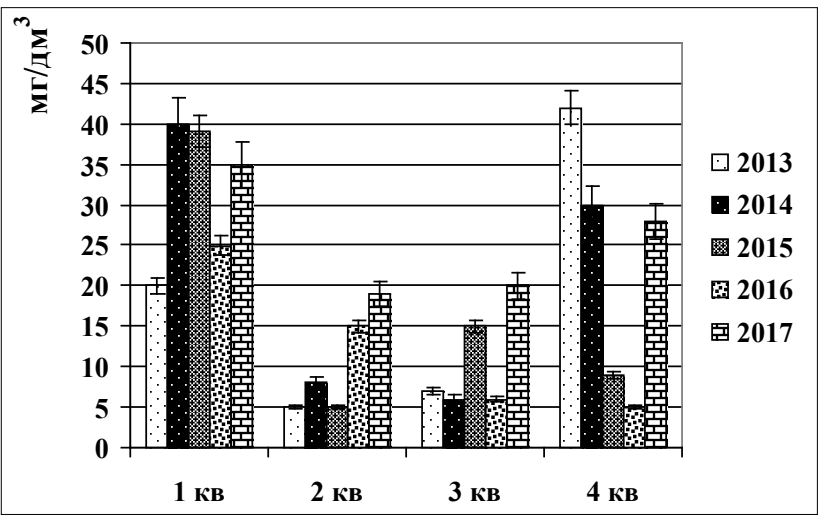

Рис. 2. Рівень хлоридів у р. Рибниця в 2013-2017 рр.

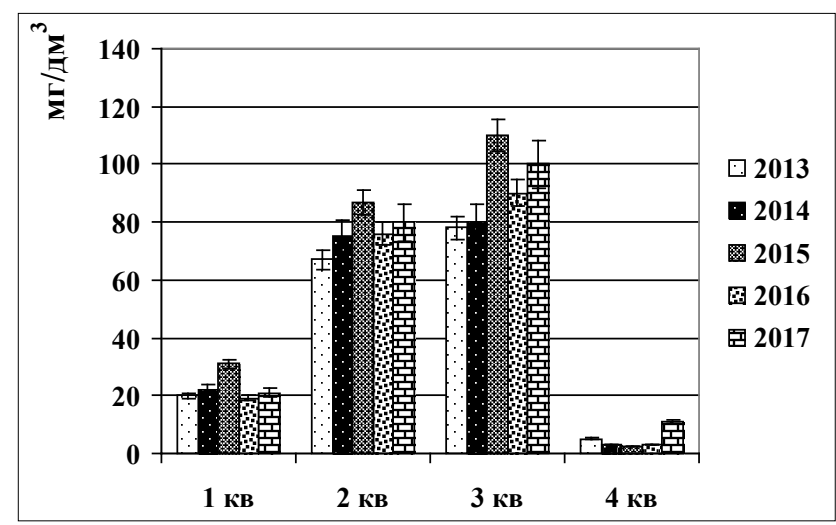

Рис. 3. Рівень сульфатів у р. Рибниия в 2013-2017 рр.
Незадовільний стан водних ресурсів зумовлений недотриманням підприємствами технологічного процесу, екологічних і санітарних норм, низькими темпами впровадження сучасних очисних технологій, відсутністю ефективних очисних споруд. Страждають від людського втручання й гірські річки, де, здавалося б, безпосередній антропогенний вплив зведений до мінімуму внаслідок малодоступності та відсутності великих заводів і підприємств поблизу берегів. Проблема забруднення водойм сьогодні досягла того критичного стану, коли ігнорування факту обходиться собі ж дорожче, ніж іiі визнання. Саме тому, очевидно, на сайті Мінприроди України з'явилася інтерактивна карта забрудненості річок в Україні «Чиста вода» на основі даних Державного агентства водних ресурсів [8]. На картіпонад 400 пунктів контролю річкової води. Наші дослідження доповнюють цю інформацію, адже р. Рибниця не входить у перелік пунктів водозабору, представлених на карті, а найближчий із них знаходиться на р. Прут, на кордоні Івано-Франківської та Чернівецької областей, смт. Неполоківці [8].

Виклад основного матеріалу. Результати моніторингу р. Рибниця за 20013-2017 рр. встановили, що вода в річці є чистою, а перевищення ГДК окремих досліджуваних показників стосуються переважно періодів, коли мали місце зливи чи затяжні дощі. Разом із тим коливання вмісту показників у рамках допустимих концентрацій $є$ постійним, часто залежним від атмосферних явищ. Так, моніторинг умісту амоній-іонів у р. Рибниця за останні п'ять років не виявив перевищення ГДК цього показника (рис. 1).

Іони амонію з'являються у воді внаслідок розчинення в ній аміаку - продукту розкладу органічних азотовмісних речовин. Тому основними джерелами надходження іонів амонію у водойми $\epsilon$ тваринницькі ферми, господарсько-побутові стічні води, поверхневий стік із сільгоспугідь під час використання амонійних добрив. Відсутність цих об'єктів на річці (принаймні в зоні дослідження та вище неї, аж до Буковецького перевалу, звідки бере початок Рибниця), очевидно, є запорукою чистоти водойми в плані забруднення продуктами деградації білкових речовин. Низький уміст амонію свідчить про аеробні умови формування хімічного складу води та іiі задовільну якість.

Максимальний рівень - 0,4 мг/л (при ГДК 0,5 мг/л) фіксували у 4 кварталі 2013 року (рис. 1). Саме в цей період мав місце факт скидання нечистот у р. Рибниця, вище за течією від місця забору проб. Ураховуючи, що ми не фіксували перевищення ГДК іонів амонію навіть за цих обставин, можемо констатувати, що р. Рибниця має високу здатність до самоочищення, що важливо для жителів і гостей краю.

Небажаним показником для води є підвищений уміст у ній хлоридів, оскільки цей компонент знижує їі смакові якості, робить воду непридатною до зрошення сільськогосподарських угідь. Значну роль 
у потраплянні хлоридів у річкові води відіграють стоки промислових і комунально-побутових підприємств. Також ці іони можуть потрапляти атмосферним шляхом і через розчинення у воді хлорумісних мінералів (содаліт, хлорапатит). Допускається вміст хлоридів у воді до 300 мг/л. Тривале споживання води 3 вищою концентрацією цього показника створює ризик захворювання на рак сечового міхура і прямої кишки.

За період моніторингу хімічного стану вод в річці Рибниця відмічено невеликий уміст хлоридів 16,5-43,08 мг/дм ${ }^{3}$ (рис. 2), тобто перевищення ГДК не спостерігали.

Відповідно до наших спостережень, уміст хлоридів залежить від кліматичних умов: під час танення снігу і криги, інтенсивних дощів концентрація хлоридів у річці помітно знижується (наприклад, 2 квартал 2013-2015 рр.). Так, у 2014 р. максимальний рівень опадів фіксували в травні та липні [9; 10], у ці самі квартали реєстрували мінімальні рівні хлоридів у воді. У 2015 р. дощовими були травень і червень, відповідно, реєстрували низький уміст хлоридів. У бездощовий період і під час льодоставу, коли річка живиться тільки грунтовими водами, спостерігається підвищення вмісту хлоридів (1 квартал 2014-2017 pp., 4 квартал 2013, 2014, 2017 рр.). Отже, в наших дослідженнях концентрація хлоридів у p. Рибниця обернено пропорційна до кількості опадів.
Важливим санітарним показником є вміст нітритів у поверхневих водах: підвищення концентрації цих іонів є свідченням забруднення водного об'єкта внаслідок процесів розкладання органічних речовин в умовах повільного окислення $\mathrm{NO}^{2-}$ в $\mathrm{NO}^{3-}$. Оскільки біодеградація активніше відбувається в умовах тепла, то цей показник має сезонний характер, є залежним від температурних умов. Показники рівня нітритів у р. Рибниця доволі нестабільні. Варто відмітити, що перевищення рівня ГДК (3,3 мг/л) має місце тільки в період грозових дощів. Наприклад, у другому кварталі 2013 р. рівень нітритів зростав у 1,4 рази вище за норму, а у 2 кварталі 2014 - у 1,2 рази (таблиця 2).

Разом із тим повторні дослідження через три тижні після грозових дощів реєструють незначні показники нітритів, хоча й увесь період лили затяжні дощі. Отже, для р. Рибниця характерна висока здатність до самоочищення.

Нормавмістузалізауводі-небільшеніж 0,3 мг/дм³ . При цьому безпечною добовою дозою заліза для людини є 0,8 мг на кілограм ваги (згідно з ВООЗ). Отже, зашкодити організму водою з високим умістом заліза практично неможливо в силу фізіологічних потреб людини у воді. Крім цього, не потрібно бути експертом, щоб визначити високий уміст заліза у воді: характерний неприємний запах запобігає споживанню води 3 високим умістом цього елементу.

Таблиця 1

Нормативні документи і гранично допустимі концентрації для визначення якості води

\begin{tabular}{|l|c|c|}
\hline \multicolumn{1}{|c|}{ Показник } & ГДК & Документ \\
\hline Амоній-іони & 0,5 мг/л & МВВ № 081/12-0106-03 \\
\hline Залізо & 0,3 мг/л & МВВ № 081/12-0175-05 \\
\hline Хлориди & 350 мг/л & ГОСТ 4245-72 \\
\hline Нітрити & 3,3 мг/л & КНД 211.1.4.023-95 \\
\hline Сульфати & 500 мг/л & ГОСТ 4389-72 \\
\hline Загальна твердість & Не регламентовано & МВВ № 081/12-0006-01 \\
\hline
\end{tabular}

Таблиця 2

Моніторинг нітритів (мг/л) у річці Рибниця

\begin{tabular}{|c|c|c|c|c|c|c|}
\hline \multirow{2}{*}{$\begin{array}{c}\text { Період } \\
\text { відбору проб }\end{array}$} & \multirow{2}{*}{ ГДК } & \multicolumn{5}{|c|}{ Рік забору зразків } \\
\hline & & 2013 & 2014 & 2015 & 2016 & 2017 \\
\hline 1 квартал & \multirow{4}{*}{$\begin{array}{c}\text { Не більше } \\
\text { ніж } \\
\text { 3,3 мг/л }\end{array}$} & $0,09 \pm 0,01$ & $0,07 \pm 0,01$ & $0,16 \pm 0,01$ & $0,09 \pm 0,01$ & $0,04 \pm 0,01$ \\
\hline 2 квартал & & $4,57 \pm 0,09$ & $4,00 \pm 0,02$ & $1,50 \pm 0,01$ & $1,80 \pm 0,01$ & $2,02 \pm 0,01$ \\
\hline 3 квартал & & $2,80 \pm 0,02$ & $2,50 \pm 0,02$ & $2,00 \pm 0,02$ & $2,12 \pm 0,01$ & $1,50 \pm 0,01$ \\
\hline 4 квартал & & $2,93 \pm 0,03$ & $0,20 \pm 0,02$ & $0,05 \pm 0,02$ & $0,10 \pm 0,01$ & $0,43 \pm 0,01$ \\
\hline
\end{tabular}

Таблиця 3

Моніторинг заліза (мг/л) у річці Рибниця

\begin{tabular}{|c|c|c|c|c|c|c|}
\hline \multirow{2}{*}{$\begin{array}{c}\text { Період } \\
\text { відбору проб }\end{array}$} & \multirow{2}{*}{ гДК } & \multicolumn{5}{|c|}{ Рік забору зразків } \\
\hline & & 2013 & 2014 & 2015 & 2016 & 2017 \\
\hline 1 квартал & \multirow{4}{*}{$\begin{array}{c}\text { Не більше } \\
\text { ніж } \\
\text { 3,3 мг/л }\end{array}$} & $0,010 \pm 0,001$ & $0,120 \pm 0,001$ & $0,020 \pm 0,001$ & $0,150 \pm 0,001$ & $0,120 \pm 0,001$ \\
\hline 2 квартал & & $0,030 \pm 0,001$ & $0,290 \pm 0,001$ & $0,022 \pm 0,001$ & $0,250 \pm 0,001$ & $0,290 \pm 0,001$ \\
\hline 3 квартал & & $0,016 \pm 0,001$ & $0,150 \pm 0,001$ & $0,011 \pm 0,001$ & $0,130 \pm 0,002$ & $0,120 \pm 0,001$ \\
\hline 4 квартал & & $0,028 \pm 0,001$ & $0,260 \pm 0,001$ & $0,025 \pm 0,001$ & $0,290 \pm 0,001$ & $0,450 \pm 0,001$ \\
\hline
\end{tabular}




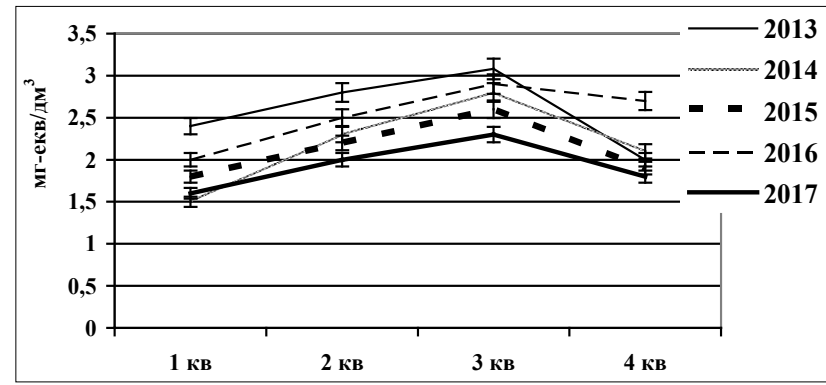

Рис. 4. Динаміка загальної твердості води в р. Рибниця в 2013-2017 pp.

У річці Рибниця концентрація заліза в період досліджень коливалася в межах 0,01-0,3 мг/л, перевищення ГДК заліза спостерігали лише в 4 декаді 2017 р. (таблиця 3).

Імовірною причиною такого явища $є$ зафіксовані в цей період природні відклади залізної руди, які проступили на поверхню вище місця забору проб через проливні дощі та потрапили в річку. Отже, перевищення ГДК заліза у воді в цьому випадку не пов'язано з втручанням людини.

Досліджуючи рівень сульфатів, установили, що за моніторинговий період їх концентрація в Рибниці не перевищувала ГДК (500 мг/л), коливаючись у межах 2,26-100 мг/л (рис. 3).

Основними процесами надходження сульфатів у воду $є$ вивітрювання й розчинення сірковмісних мінералів, в основному гіпсу, а також окислення сульфідів і сірки. Значна частка сульфатів потрапляє у воду внаслідок відмирання організмів, окислення наземних і водних речовин рослинного і тваринного походження. Суттєві коливання вмісту сульфатів дають підстави припустити, що забруднення води спричинене саме органічними речовинами. Це пояснює, чому вміст сульфатів у воді підвищується саме в другому та третьому кварталах року: $з$ потеплінням інтенсифікуються процеси розкладання перезимованої органіки, а восени в річку потрапляє багато опалих листків.

Сульфати - необхідні для людського організму сполуки, у невеликих кількостях позитивно впливають на фізіологічні процеси живих організмів, мають холеретичну, холекінетичну дію, відновлюють структуру печінки, через що запобігають розвитку цирозу, сприяють зменшенню застою жовчі, що дуже важливо під час лікування жовчнокам'яної хвороби.

Досліджуючи загальну твердість води, встановили, що цей показник у р. Рибниця коливається

\section{Типи категорій поверхневих вод залежно} від загальної твердості

\begin{tabular}{|l|c|}
\hline \multicolumn{1}{|c|}{ Категорія } & $\begin{array}{c}\text { Границі загальної } \\
\text { твердості, мг-екв/дм }\end{array}$ \\
\hline Дуже м'яка & $0-1,5$ \\
\hline М'яка & $1,5-3,0$ \\
\hline Середня твердість & $3,0-6,0$ \\
\hline Тверда & $6,0-10,0$ \\
\hline Дуже тверда & $\geq 10,0$ \\
\hline
\end{tabular}

в межах 1,5-3 мг-екв/дм³ (рис. 4), що, згідно $з$ категоріями поверхневих вод, визначає іiї як м'яку воду (таблиця 4).

У природі чистої води не буває. Вона завжди містить домішки яких-небудь речовин. Джерелом потрапляння речовин у воду $є$ природні поклади вапняків, гіпсу й доломітів. Грунти території парку і прилеглі території багаті на прошарки вапняку та гіпсу, тому можуть бути визначальним фактором у наданні твердості води.

Отже, вода в р. Рибниця за проаналізованими нами показниками є чистою, що важливо для Косівського регіону, для жителів і гостей краю. Ця річка викликає зацікавленість, адже асоціюються 3 первозданною природою та, як показано нами, має високу здатність до самоочищення.

Головні висновки. Моніторинг р. Рибниця упродовж 2013-2017 pp. установив, що вода в річці $\epsilon$ чистою ц м'якою згідно 3 категоріями загальної твердості.

Рівень амоній-іонів, хлоридів, сульфатів у жодній із проб не перевищували ГДК. За п'ять років моніторингу мало місце дворазове перевищення ГДК нітритів у період грозових дощів та одноразове заліза (в 4 декаді 2017 р.). Упродовж досліджень мали місце сезонні коливання всіх показників, але в межах ГДК.

Ураховуючи, що навіть у разі несанкціонованого викиду нечистот у річку ми не спостерігали перевищення ГДК амонію, нітритів, можемо констатувати, що р. Рибниця має високу здатність до самоочищення, що важливо для жителів і гостей краю.

Перспективи використання результатів дослідження. Отримані результати важливі для рекреаційно-туристичної галузі краю, можуть бути використані структурами, що займаються питаннями забрудненості річок в Україні.

\section{Література}

1. Національний природний парк «Гуцульщина» / В.В. Пророчук, Ю.П. Стефурак, В.П. Брусак та ін.; за ред. В.В. Пророчука, Ю.П. Стефурака, В.П. Брусака, Л.М. Держипільського. Львів: НВФ «Карти і Атласи», 2013. 408 с.

2. Лабораторія екологічного моніторингу Національного природного парку «Гуцульщина». Kociв, 2010. URL: http://nnph.if.ua/2010/09/24/164/ (дата звернення: 11.12.2018).

3. Бабіч М.Я., Стрілець Б.І. Водні ресурси України і проблеми їх використання та збереження. ДКУ по вод. госп-ву. Київ, 1996. $213 \mathrm{c}$.

4. Израэль Ю.А. Экология и контроль природной среды. Москва: Гидрометеоиздат, 1984. 248 с. 
5. Касьяненко А.А. Контроль качества окружающей среды. Москва: Изд-во РУДМ, 1992. 248 с

6. Концепция построения автоматизированной системы экологического контроля вод Украины / под ред. В.А. Гайского, В.Н. Еремеева. Севастополь, 1997. 159 с.

7. Сурилова О. Актуальные вопросы экологической ответственности за нарушение законодательства об использовании и охране недр. Право Украины. 2001. № 5. С. 81-84.

8. Чиста вода. Інтерактивна карта забрудненості річок в Україні. Київ, 2018. URL: http://texty.org.ua/water/ (дата звернення: 11.12.2018).

9. Літопис Національного природного парку «Гуцульщина»: у 15 т. / за ред. Ю.П. Стефурака. Косів: Писаний камінь, 2015. T. $12.286 \mathrm{c}$.

10. Літопис Національного природного парку «Гуцульщина»: у 15 т. / за ред. Ю.П. Стефурака. Косів: Писаний камінь, 2015. T. $15.346 \mathrm{c}$. 


\section{БIБАIOГРАФІЯ}

Ковшун Н.Е. Система сталого водокористування: механізм та технології управління. - К.: KHT, 2018. - 301 c.

У монографії розглянуто проблему формування системи сталого водокористування. Згідно з існуючими концептуальними уявленнями проаналізовано питання, пов'язані з різними напрямами збереження та розвитку водоресурсного потенціалу, підвищення рівня та якості водозабезпечення, формування інтегрованої структури управління, зменшення екологічного навантаження на водні об'єкти, посилання мотивів і стимулів до раціонального водокористування, удосконалення фінансового забезпечення водогосподарського комплексу, поступовий і послідовний розвиток відповідних інститутів, застосування механізмів підвищення ефективності державного управління екологічною сферою. Монографія буде цікавою для викладачів, аспірантів та широкого кола читачів, що цікавляться проблемами розвитку рекреаційного підприємництва.

Пєтков В.П., Соболь Є.Ю., Пєтков С.В. Екологічна безпека. - К.: КНТ, 2018. - 216 с.

Навчальний посібник присвячений дослідженню проблем екологічної безпеки. Сформульовано низку конкретних пропозицій та рекомендацій щодо вдосконалення чинного законодавства України, яке регулює правовідносини у сфері екологічної безпеки. Адресований науковцям і практикам, а також тим, хто цікавиться проблемами екологічної безпеки.

Жигуц Ю.Ю., Лазарь В.Ф. Інженерна екологія. - К.: Кондор, 2018. - 170 с.

Посібник присвячений методичним і методологічним питанням інженерної екології, встановленню впливу промислових підприємств на навколишнє середовище, визначенню екологічного ефекту та оцінці природоохоронних заходів. Посібник рекомендований для підготовки студентам курсу «Інженерна екологія», для бакалаврів, спеціалістів, магістрів та аспірантів технічних спеціальностей і може бути корисним для керівників дипломних та магістерських робіт. У посібнику вміщено екологічний словник, який дає можливість краще ознайомитись із основними екологічними термінами.

Трус І.М., Флейшер Г.Ю., Гомеля М.Д., Токарчук В.В. - К.: Кондор, 2018. - 164 с.

Робота присвячена розробці наукових підходів і наукових основ процесів знесолення мінералізованих вод, переробки осадів з отриманням розчинів хімічних реагентів, будівельних матеріалів, створення комплексних безвідходних технологій очищення шахтних вод для екологічно безпечних систем водокористування. Розроблено технологію ефективної демінералізації концентратів баромембранного знесолення води при використанні синтезованих доступних алюмініймістких коагулянтів, що дозволяє значно скоротити затрати на очищення води, з подальшою утилізацією даних осадів водоочищення в будівельній індустрії. Для наукових та інженерно-технічних працівників, аспірантів, викладачів та студентів вузів.

Устименко П.М., Дубина Д.В., Мовчан Я.І., Давидов Д.А., Якубенк Б.Є. - К.: Ліра-К, 2018. - 524 с.

У контексті розбудови екомережі Лісостепу України виявлено 52 ключові території національного та 78 регіонального рівнів, проаналізовано їхній сучасний стан рослинного покриву і ступінь природності ландшафтів, узагальнено матеріали щодо представленості раритетних синтаксонів на виділених ключових територіях екомережі та рівня забезпеченості їх охороною, проведено созологічний аналіз раритетного фітоценофонду, встановлено ступінь його трансформації, з'ясовано основні загрози для раритетних угруповань. Розроблено рекомендації щодо режимів їхньої охорони. Наведено картосхеми розміщення ключових територій національного та регіонального рівнів окремих областей регіону. Для широкого кола фахівців у галузі охорони довкілля, екології, фітоценології, органів місцевого самоврядування та виконавчої влади, працівників і студентів вищих навчальних закладів, членів неурядових екологічних організацій, викладачів. 


\section{ВIДОМОСТI ПРО АВТОРІВ}

Азаров Сергій Іванович (Київ) - доктор технічних наук, старший науковий співробітник, Інститут ядерних досліджень наук Національної академії наук України.

Барабаш Олена Василівна (Київ) - кандидат біологічних наук, доцент, Національний транспортний університет.

Баранов Володимир Іванович (Львів) - кандидат біологічних наук, доцент кафедри фізіології та екології рослин біологічного факультету, Львівський національний університет імені Івана Франка.

Білецький Олег Олександрович (Київ) - кандидат технічних наук, доцент кафедри теоретичної електротехніки, Національний технічний університет України «Київський політехнічний інститут імені Ігоря Сікорського».

Борсукевич Богдан Михайлових (Львів) - асистент кафедри мікробіології, Львівський національний університет імені Івана Франка.

Броницький Вадим Олегович (Київ) - асистент кафедри інженерної екології, Національний технічний університет України «Київський політехнічний інститут імені Ігоря Сікорського».

Глібовицька Наталія Ігорівна (Івано-Франківськ) - кандидат біологічних наук, Івано-Франківський національний технічний університет нафти і газу.

Глодова Любов Михайлівна (Косів) - науковий співробітник, Національний природний парк «Гуцульщина».

Гребенюк Тетяна Володимирівна (Київ) - кандидат технічних наук, старший викладач кафедри інженерної екології, Національний технічний університет України «Київський політехнічний інститут імені Ігоря Сікорського».

Гривківська Оксана Василівна (Київ) - доктор економічних наук, професор, Європейський університет.

Григор'сва Людмила Іванівна (Миколаїв) - доктор біологічних наук, професор, Чорноморський національний університет імені Петра Могили.

Грубінко Василь Васильович (Тернопіль) - доктор біологічних наук, професор, Тернопільський національний педагогічний університет імені Володимира Гнатюка.

Гуменюк Ірина Ігорівна (Київ) - аспірант, Інститут агроекології і природокористування Національної академії аграрних наук України.

Гурець Лариса Леонідівна (Суми) - доктор технічних наук, доцент кафедри прикладної екології, Сумський державний університет.

Задунай Олексій Сергійович (Київ) - начальник центру, Державний науково-дослідний інститут спеціального зв'язку та захисту інформації.

Зуб Леся Миколаӥвна (Київ) - кандидат біологічних наук, старший науковий співробітник, Інститут еволюційної екології Національної академії наук України.

Іванець Олег Романович (Львів) - кандидат біологічних наук, доцент, Львівський національний університет імені Івана Франка.

Іщенко Данііл Романович (Херсон) - студент факультету інтегрованих технологій, Херсонський національний технічний університет.

Котова Ірина Ігорівна (Суми) - студент кафедри прикладної екології, Сумський державний університет.

Котовський Віталій Йосипович (Київ) - доктор технічних наук, професор, завідувач кафедри загальної фізики, Національний технічний університет України «Київський політехнічний інститут імені Ігоря Сікорського».

Котолевець Анастасія Сергіївна (Суми) - аспірант кафедри прикладної екології, Сумський державний університет.

Кузнєцов Сергій Іванович (Херсон) - кандидат технічних наук, доцент кафедри хімії і екології, Херсонський національний технічний університет.

Кургузенкова Людмила Анатоліївна (Київ) - кандидат економічних наук, доцент, Європейський університет.

Лисенко Михайло Вікторович (Черкаси) - студент, Черкаський державний технологічний університет.

Ложкін Руслан Сергійович (Антонівка) - аспірант кафедри програмних засобів i технологій, Херсонський національний технічний університет.

Лук'янченко Олекснадр Юрійович (Черкаси) - кандидат технічних наук, доцент, Черкаський державний технологічний університет.

Люльчик Вадим Олександрович (Рівне) - кандидат сільськогосподарських наук, завідувач технічного відділення, ВСП «Рівненський коледж Національного університету біоресурсів і природокористування України». 
Ляшенко Олена Миколаївна (Херсон) - кандидат технічних наук, доцент, Херсонський національний технічний університет, кафедра програмних засобів і технологій.

Маковейчук Олександр Миколайович (Харків) - кандидат технічних наук, Харківський національний університет радіоелектроніки.

Маренков Олег Миколайович (Дніпро) - кандидат біологічних наук, доцент, Дніпровський національний університет імені Олеся Гончара.

Махиня Олександр Миколайович (Київ) - кандидат технічних наук, доцент, Київський національний університет будівництва і архітектури.

Науменко Дар'я Павловна (Київ) - студентка 4 курсу кафедри інженерної екології, Національний технічний університет України «Київський політехнічний інститут імені Ігоря Сікорського».

Нестеренко Олег Станіславович (Дніпро) - технік, Дніпровський національний університет імені Олеся Гончара.

Нечай Михайло Михайлович (Верхній Ясенів) - директор, Національний природний парк «Верховинський».

Нєпєіна Ганна Володимирівна (Миколаїв) - старший викладач кафедри екології, Чорноморський національний університет імені Петра Могили.

Патрушева Лариса Іванівна (Миколаїв) - кандидат географічних наук, доцент, Чорноморський національний університет імені Петра Могили.

Печений Володимир Леонідович (Київ) - провідний спеціаліст, Державна екологічна академія післядипломної освіти та управління.

Підгородецька Людмила Володимирівна (Київ) - кандидат технічних наук, Інститут космічних досліджень наук Національної академії наук України та Державного космічного агентства України.

Плаксій Леся Василівна (Івано-Франківськ) - асистент, Івано-Франківський національний технічний університет нафти і газу.

Покотилова Каміла Георгї̈вна - аспірант, Національний університет біоресурсів і природокористування України.

Поліщук Дмитро Володимирович (Світловодськ) - кандидат технічних наук, головний інженер, ПП «ТД ВО Машинобудівний завод».

Романюк Ольга Іванівна (Львів) - старший науковий співробітник, кандидат хімічних наук, старший науковий співробітник, Відділення фізико-хімії горючих копалин, Інститут фізико-органічної хімії і вуглехімії імені Л. М. Литвиненка Національної академії наук України.

Русіна Неля Григорівна (Рівне) - кандидат педагогічних наук, викладач вищої категорії, викладач-методист, ВСП «Рівненський коледж Національного університету біоресурсів і природокористування України».

Салавор Оксана Мирославівна (Київ) - кандидат технічних наук, доцент, Національний університет харчових технологій.

Селіванов В'ячеслав Володимирович (Київ) - генеральний директор, ООО «Евро-Реконструкция».

Сербулова Надія Алимівна (Миколаїв) - старший викладач кафедри екології, Чорноморський національний університет імені Петра Могили.

Скиба Олена Ігорівна (Тернопіль) - кандидат біологічних наук, асистент, Тернопільський державний медичний університет імені І. Я. Горбачевського.

Смирнов Віктор Миколайович (Миколаїв) - кандидат геологічних наук, ТОВ «ТД «АННОНА».

Смирнова Світлана Михайлівна (Миколаїв) - кандидат геологічних наук, доцент (б.в.з.) кафедри управління земельними ресурсами, Чорноморський національний університет імені Петра Могили.

Соломоненко Юрій Станіславович (Харків) - заступник начальника факультету з навчальної та наукової роботи, Харківський національний університет Повітряних Сил імені Івана Кожедуба.

Суха Наталія Олександрівна (Миколаїв) - аспірант, Чорноморський національний університет імені Петра Могили.

Терек Ольга Іштванівна (Львів) - доктор біологічних наук, професор, академік АН ВШ України, завідувач кафедри фізіології та екології рослин біологічного факультету, Львівський національний університет імені Івана Франка.

Тищенкова Марина Олегівна (Київ) - директор, ООО «НПО «Экоальянс».

Томілін Юрій Андрійович (Миколаїв) - доктор біологічних наук, професор, Чорноморський національний університет імені Петра Могили.

Томченко Ольга Володимирівна (Київ) - науковий співробітник, відділ системного аналізу, ДУ «Науковий центр аерокосмічних досліджень Землі Інституту геологічних наук Національної академії наук України».

Федонюк Лариса Ярославівна (Тернопіль) - доктор медичних наук, професор, Тернопільський державний медичний університет імені І. Я. Горбачевського. 
Федоровський Олександр Дмитрович (Київ) - доктор фізико-математичних наук, професор, член-кореспондент Національної академії наук України, ДУ «Науковий центр аерокосмічних досліджень Землі Інституту геологічних наук Національної академії наук України».

Філін В'ячеслав Миколайович (Кам'янське) - кандидат технічних наук, старший науковий співробітник, науковий консультант, ООО «Экология-Днепр 2004».

Хворов Михайло Михайлович (Київ) - доктор хімічних наук, старший науковий співробітник, Європейський університет.

Хижняк Ірина Анатоліївна (Харків) - начальник групи авіаційного обладнання нвчально-лабораторного комплексу, Харківський національний університет Повітряних Сил імені Івана Кожедуба.

Хижняк Анна Василівна (Київ) - кандидат технічних наук, молодший науковий співробітник, ДУ «Науковий центр аерокосмічних досліджень Землі Інституту геологічних наук Національної академії наук України».

Ходоровський Артур Якович (Київ) - кандидат геолого-мінералогічних наук, старший науковий співробітник, ДУ «Науковий центр аерокосмічних досліджень Землі Інституту геологічних наук Національної академії наук України».

Худов Геннадій Володимирович (Харків) - доктор технічних наук, професор, Харківський національний університет Повітряних Сил імені Івана Кожедуба.

Чабанюк Ярослав Васильович (Київ) - доктор сільськогосподарських наук, старший науковий співробітник, завідувач відділу, Інститут агроекології і природокористування Національної академії аграрних наук України.

Шабалтун Артем Миколайович (Київ) - студент, Київський національний університет будівництва і архітектури.

Шаповалов Євгеній Борисович (Київ) - молодший науковий співробітник, Національний центр «Мала академія наук України».

Шевчик Леся Зеновіївна (Львів) - молодший науковий співробітник, кандидат біологічних наук, Відділення фізико-хімії горючих копалин, Інститут фізико-органічної хімії і вуглехімії імені Л.М. Литвиненка Національної академії наук України.

Шелудченко Леся Сергіївна (Кам'янець-Подільський) - кандидат технічних наук, доцент, Подільський державний аграрно-технічний університет.

Шерстобоєва Олена Володимирівна (Київ) - доктор сільськогосподарських наук, головний науковий співробітник, Інститут агроекології і природокористування Національної академії аграрних наук України.

Шпак Ярослав Васильович (Львів) - аспірант кафедри фізіології та екології рослин біологічного факультету, Львівський національний університет імені Івана Франка.

Якименко Ігор Леонідович (Київ) - доктор біологічних наук, професор, Національний університет харчових технологій. 


\section{ЕКОЛОГГЧНІ НАУКИ}

- Теоретична екологія

- Загальні проблеми екологічної безпеки

- Екологія і виробництво

- Проблеми еколого-збалансованого розвитку

- Екологія водних ресурсів

- Екологія земельних ресурсів та грунтів

- Збереження біорізноманіття

- Біологічна безпека

- Розвиток природно-заповідного фонду України

- Екологічні питання в контексті євроінтеграції України

- Сторінка молодого вченого тел./факс (+38 044) 206-30-34;

www.ecoj.dea.kiev.ua

e-mail: info@ecoj.dea.kiev.ua

Видавничий дім «Гельветика»

E-mail: mailbox@helvetica.com.ua Свідоцтво суб'єкта видавничої справи ДК № 6424 від 04.10.2018 p.

Підписано до друку 15.01.2019. Формат 60x84/16.

Папір офсетний. Гарнітура Times New Roman. Цифровий друк.

Ум.-друк. арк. 18,6. Тираж 100. Замовлення № 0119/19.

Ціна договірна. Віддруковано з готового оригінал-макета 